ALINE LÍCIA KLEIN

\title{
EXERCÍCIO DE ATIVIDADES DE POLÍCIA ADMINISTRATIVA POR ENTIDADES PRIVADAS
}

Tese de Doutorado

Orientadora: Professora Titular Doutora Maria Sylvia Zanella Di Pietro

UNIVERSIDADE DE SÃO PAULO - FACULDADE DE DIREITO

SÃO PAULO

2014 
ALINE LÍCIA KLEIN

\title{
EXERCÍCIO DE ATIVIDADES DE POLÍCIA ADMINISTRATIVA POR ENTIDADES PRIVADAS
}

\begin{abstract}
Tese de doutorado apresentada à Faculdade de Direito da Universidade de São Paulo como requisito parcial à obtenção do título de Doutor em Direito, sob a orientação da Professora Titular Doutora Maria Sylvia Zanella Di Pietro. Área de Concentração: Direito do Estado
\end{abstract}

SÃO PAULO

2014 
BANCA EXAMINADORA 


\section{RESUMO}

O presente estudo foi desenvolvido com o objetivo de identificar os limites e possibilidades do exercício de atividades de polícia administrativa por entidades privadas. Primeiro, analisou-se a atividade de polícia administrativa, procurando-se definir o seu conceito e abrangência no modelo atual do Estado. Em seguida, examinaram-se as diversas configurações utilizadas pelo Estado para o desempenho das suas atividades. Foram identificadas mais detidamente as características do exercício de atividades estatais por meio de entidades da Administração indireta com personalidade jurídica privada e dos contratos de delegação e de colaboração. Após essa análise, demonstrou-se que o dogma da indelegabilidade da atividade de polícia não pode ser tomado como absoluto, de modo a vedar toda e qualquer participação privada no exercício dessa atividade. Delinearam-se os limites e possibilidades do exercício privado de atividades de polícia administrativa. Nesse ponto, constatou-se que a atividade normativa originária e o exercício de coerção não comportam a delegação do seu exercício a particulares. As demais atividades que integram o denominado ciclo das atividades de polícia são passíveis de delegação, observando-se determinados critérios e limites. Uma vez identificados os requisitos a serem observados para a delegação, aplicaram-se esses conceitos a atividades específicas de polícia administrativa. A seguir, examinou-se o regime jurídico a ser observado no exercício de atividades de polícia administrativa por entidades privadas. Demonstrou-se que a observância de determinados aspectos desse regime jurídico consiste em condição para a legitimidade da atribuição do exercício dessas atividades a entidades privadas. Ao final, foram arroladas as conclusões obtidas ao longo do trabalho.

Palavras-chave: privatização - atividades exclusivas do Estado - poder de polícia delegação - entidades privadas - Administração indireta 


\begin{abstract}
This study aimed at identifying the limits and possibilities of the exercise of administrative police activities by private entities. Firstly, the activity of the administrative police was analyzed in order to define its concept and scope in the current model of State. Then, the various settings used by the State for the performance of State activities were examined. The characteristics of the exercise of State activities by means of indirect Government Agencies of private law personality and delegation and collaboration agreements were identified in more detail. After this analysis, it was demonstrated that the dogma of the impossibility to delegate police activity cannot be considered as absolute, as to prohibit any private participation in the exercise of this activity. The limits and possibilities of the private exercise of administrative police activities were outlined. At that point, it was noted that primary normative activity and the exercise of coercion do not accept delegation to individuals. The other activities that integrate the so-called cycle of police activities can be subject to delegation, considering certain criteria and limits. Once the requirements for delegation were identified, these concepts were applied to specific activities of administrative police. Then, the legal regime applicable in the exercise of administrative police activities by private entities was examined. It was demonstrated that compliance with certain aspects of this legal regime is condition for the legitimacy of assigning the exercise of these activities to private entities. At last, the conclusions obtained throughout the study were presented.
\end{abstract}

Key-words: privatization - exclusive Government activities - police power - delegation private entities - indirect Government Agencies 


\section{RIASSUNTO}

Il presente studio fu svolto con l'obiettivo di identificare i limiti e le possibilità dell'esercizio delle attività di polizia amministrativa dalla parte dalle entità private. In un primo momento si analizzò l'attività di polizia amministrativa, cercando di precisare il suo concetto e il suo campo d'applicazione nel modello odierno di Stato. Poi, si esaminarono le diverse forme utilizzate dallo Stato per l'esecuzione delle attività che gli spettano. Furono identificate più accuratamente le caratteristiche dell'esercizio delle attività statali per mezzo delle entità dell'amministrazione indireta dotate di personalità giuridica privata e per mezzo dei contratti di delegazione e di collaborazione. Dopo quest'analisi si dimostrò che il dogma dell'impossibilità di delega dell'attività di polizia non può essere visto come assoluto, in modo che impedisca qualsiasi partecipazione privata nell'esercizio di questa attività. Furono delineati i limiti e le possibilità dell'esercizio privato dell'attività di polizia amministrativa. A questo punto si constatò che l'attività normativa originaria e l'esercizio coercitivo non possono essere delegati ai particolari. Le altre attività che si inseriscono nel cosiddetto ciclo delle attività di polizia sono passibile di delega, osservando certi criteri e limiti. Una volta identificati i requisiti necessari alla delega, si applicono questi concetti alle attività specifiche di polizia amministrativa. Di seguito fu esaminato il regime giuridico che deve essere osservato nell'esercizio dell'attività di polizia amministrativa dalle entità private. Si dimostrò che l'osservanza a certi aspetti di questo regime giuridico consiste nella condizione per la legittimità dell'attribuzione del ezercizio di queste attività alle entità private. Alla fine furono elencate le conclusioni ottenute lungo questo studio.

Parole chiave: privattizzazione - attività esclusive dello Stato - potere di polizia - delega entità private - Amministrazione indiretta. 


\section{SUMÁRIO}

INTRODUÇÃO............................................................................................16

\section{CAPÍTULO I - DEFINIÇÃO DE ATIVIDADE DE POLÍCIA ADMINISTRATIVA 27}

1. A atividade administrativa e o exercício de poderes públicos.

1.1. O exercício da autoridade como instrumento da atuação estatal. 28

1.2. Atividades públicas e poderes públicos de autoridade 30

1.3. A configuração legal do exercício do poder 32

2. O conceito de atividade de polícia

2.1. A construção histórica do conceito de polícia administrativa

2.2. A atividade de polícia no Estado de Direito 36

2.3. A atividade de polícia administrativa e a função pública. 38

2.4. A atividade de polícia administrativa e o poder de polícia 40

3. A finalidade da atividade de polícia administrativa

4. O fundamento da atividade de polícia administrativa......

5. Atividade de polícia administrativa e serviço público

6. A "crise" da noção de atividade de polícia administrativa 52

7. A atividade de polícia administrativa e o princípio da legalidade 54

7.1. A vinculação e a discricionariedade nas competências administrativas 55

7.2. A denominada "discricionariedade técnica" 56

7.3. A vinculação e a discricionariedade nas previsões legais de polícia administrativa.... 59

8. A exigibilidade e a autoexecutoridade dos atos de polícia administrativa 60

9. As diversas manifestações da atividade de polícia administrativa 64

10. A titularidade das atividades de polícia administrativa 66

11. Proposta de classificação das hipóteses de exercício de atividades de polícia administrativa por entidades privadas. 
12. A atividade de polícia administrativa e os poderes privados

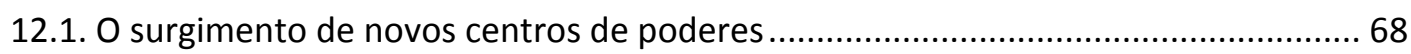

12.2. As manifestações de poderes no âmbito da autonomia privada .............................. 70

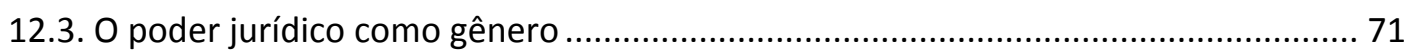

12.4. A delimitação dos poderes privados pelo ordenamento jurídico ................................ 72

12.5. O fundamento dos poderes privados ……….................................................... 73

12.6. O exercício de atividades similares às de polícia administrativa no âmbito de poderes

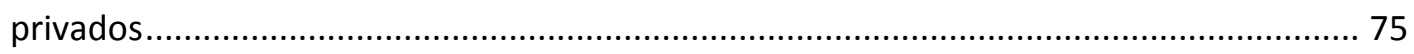

12.7. Exemplos de atos que implicam o exercício de poderes privados ............................ 76

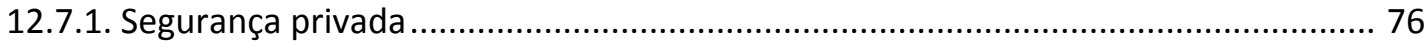

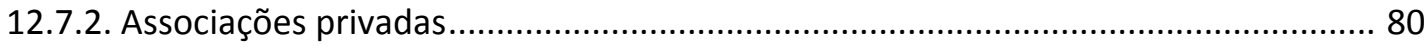

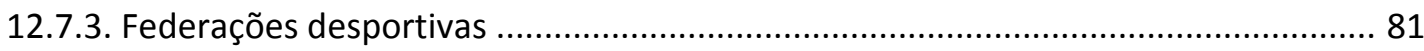

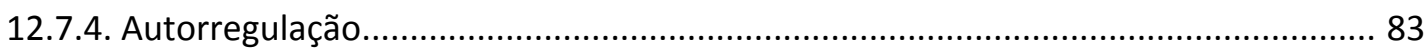

13. A possibilidade de contratualização do exercício de atividades de polícia administrativa .... 84

13.1. A consensualidade na atividade administrativa 84

13.2. A contratualização do exercício de uma competência administrativa em substituição ao ato unilateral.

13.3. A compatibilidade entre a contratualização e o princípio da indisponibilidade do interesse público

13.4. A necessidade de autorização legal para a celebração de acordos substitutivos de atos unilaterais.

13.5. A contratualização e os atos de polícia administrativa

\section{CAPÍTULO II - AS DIVERSAS FORMAS DE ORGANIZAÇÃO DO ESTADO} PARA O EXERCÍCIO DE ATIVIDADES PÚBLICAS .....................................................93

1. A possibilidade de dissociação entre a forma jurídica da entidade e a sua forma de ação ..... 93

1.1. O princípio da subsidiariedade.

1.2. A margem de liberdade para a escolha das formas de organização para o exercício de atividades públicas

2. Exercício de atividades estatais por meio de entidades da Administração indireta 99

2.1. Primeira ressalva prévia: caracterização de desempenho direto das atividades

2.2. Segunda ressalva prévia: risco de fuga do direito público 
2.3. As repercussões da descentralização no regime jurídico de execução da atividade 102

2.4. A distinção entre entidades públicas e privadas...................................................... 102

2.5. A capacidade de direito público nos sentidos formal e material............................... 104

2.6. As entidades públicas da Administração indireta e seu regime jurídico ..................... 104

2.7. As empresas públicas e as sociedades de economia mista e seu regime jurídico..... 106

2.7.1. As atividades desempenhadas.....

2.7.2. A necessidade de diferenciação do regime jurídico de acordo com o objeto social 108

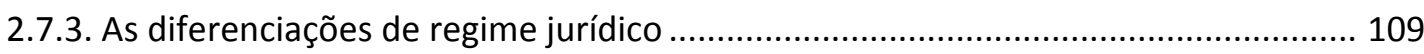

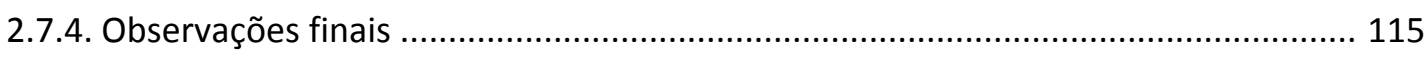

3. Exercício indireto de atividades estatais ...................................................................... 116

3.1. Ressalva prévia: preservação da titularidade pública ............................................... 116

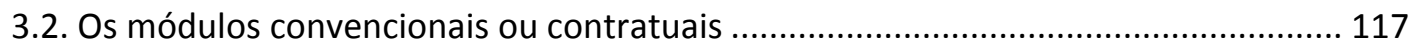

3.3. Contratos de colaboração e contratos de delegação ................................................. 119

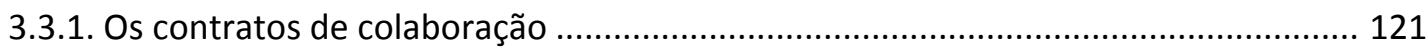

3.3.2. Os contratos de delegação................................................................................ 122

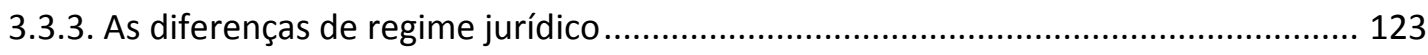

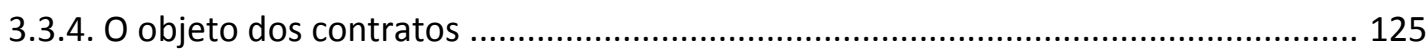

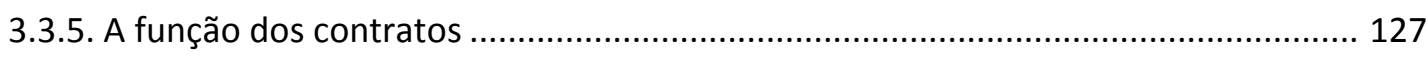

3.3.6. A identificação da atribuição ou não da gestão da atividade ao particular.............. 129

3.4. Os contratos de prestação de serviços e a terceirização ............................................. 133

3.4.1. A terceirização na iniciativa privada ..................................................................... 134

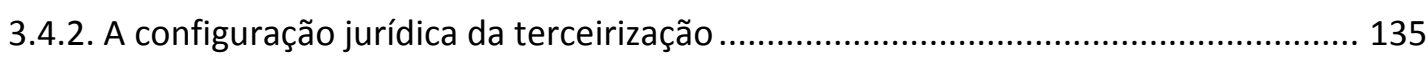

3.4.3. Limites da terceirização nas atividades administrativas ........................................ 137

3.5. A delegação do exercício de atividades de polícia administrativa nos contratos de

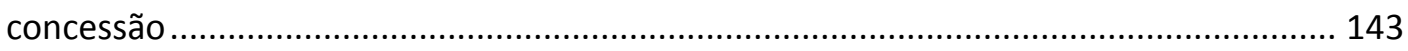

3.5.1. Ausência de tipificação restrita dos contratos de concessão ................................... 144

3.5.2. A concessão como gênero de outorga de direitos a particulares.............................. 144

3.5.3. A concepção tradicional do contrato de concessão no direito nacional ................... 146

3.5.4. A atual configuração do contrato de concessão no direito nacional......................... 147

3.5.5. A concessão administrativa e o exercício privado de atividades de polícia

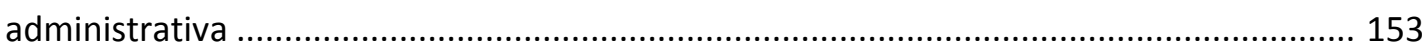

3.6. A delegação do exercício de poderes públicos nos contratos de concessão.............. 158 
3.6.1. A ausência de um instituto específico no direito nacional para designar exclusivamente o exercício privado de poderes públicos. 159

3.6.2. A concessão e a delegação do exercício de poderes públicos 159

3.6.3. A não equiparação necessária entre a concessão e a delegação do exercício de poderes públicos 164

3.6.4. As discussões no direito comparado acerca da utilização do termo "concessão" ... 165

3.6.5. As ressalvas quanto à utilização do termo "delegação" 166

3.6.6. A delegação do exercício de poderes públicos e a delegação de competências administrativas

3.6.7. A delegação do exercício de poderes públicos e a habilitação para o exercício de função pública 168

3.6.8. Observações finais 168

3.7. A delegação do exercício de poderes públicos por ato unilateral 169

3.8. O credenciamento 170

4. Autorregulação e delegação de poderes públicos .

4.1. A autorregulação como manifestação da autonomia privada

4.2. A autorregulação e o movimento de desregulação

4.3. Os elementos e o conteúdo da autorregulação 175

4.4. Os efeitos do descumprimento da autorregulação 177

4.5. A atribuição de efeitos públicos à autorregulação 177

4.6. As modalidades de autorregulação 178

4.7. Autorregulação e exercício de atividades de polícia administrativa 181

4.8. A gestão de mercados de valores mobiliários 182

5. Privatização "de fato" 187

\section{CAPÍTULO III - OS LIMITES E POSSIBILIDADES DO EXERCÍCIO DE} ATIVIDADES DE POLÍCIA ADMINISTRATIVA POR ENTIDADES PRIVADAS

1. A afirmação da indelegabilidade da atividade de polícia administrativa 191

2. Os questionamentos da indelegabilidade da atividade de polícia administrativa ................. 196

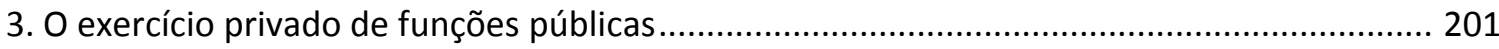

4. A execução de atividades materiais, instrumentais ou acessórias por entidades privadas ... 203

4.1. Os atos materiais, os atos jurídicos e a atividade técnica da Administração 
4.1.1. Os atos materiais e os atos jurídicos da Administração. 204

4.1.2. A atividade técnica da Administração. 206

4.2. Os atos decisórios e os atos preparatórios ou de mera execução. 208

4.2.1. Participação de entidades privadas no processo de formação da decisão administrativa 208

4.2.2. Participação de entidades privadas na implementação da decisão administrativa . 210

4.2.3. O critério do exercício ou não de poder de decisão 210

4.3. A dificuldade de aplicação do critério da delegabilidade de atividades instrumentais, acessórias, materiais e de mera execução.

5. Os limites da delegação de atividades de polícia administrativa a particulares.

5.1. Ressalva prévia: possibilidade de se transferir a particulares o exercício de poderes públicos

5.2. A desnecessidade de autorização expressa no texto constitucional 216

5.3. A delimitação da parcela da função estatal indelegável 219

5.3.1. Definição de atividades públicas 220

5.3.2. Identificação da apropriação pública das atividades desempenhadas por entidades privadas

5.3.3. Atividades essencialmente públicas

5.4. Os critérios e requisitos para a delegação de atividades de polícia administrativa .. 233

5.4.1. A suposta maior aptidão do regime de direito de direito público para a prática de atos de autoridade

5.4.2. Advertência necessária: os riscos do argumento da busca da eficiência 233

5.4.3. Possibilidade de delegação de atividades que não impliquem o uso da coerção ou manifestação de amplo poder decisório.

5.4.4. Necessidade de identificação expressa dos poderes públicos cujo exercício é objeto de delegação

5.4.5. Necessidade de prévia programação dos critérios e procedimentos a serem observados na execução das atividades delegadas

5.4.6. Necessidade de se assegurar a objetividade e impessoalidade na execução das atividades delegadas

5.4.7. Necessidade de retenção dos dados para posterior controle pelo concedente

5.4.8. Delegação do exercício de poderes públicos com caráter temporário e acessório à delegação da atividade principal 
5.4.9. Vedação de delegação de poderes públicos desvinculada do exercício de atividades públicas

5.5. Conclusões parciais

6. A exigência de autorização legislativa para a delegação

6.1. Necessidade de autorização legislativa para a delegação

6.2. Autorização legislativa como mecanismo de legitimação

6.3. A disposição do art. 2ㅇ da Lei $n=9.074 / 95$.

6.4. A autorização legislativa para as entidades da Administração indireta

6.5. Atribuição do exercício de atividades de polícia administrativa diretamente pelo ordenamento jurídico

6.5.1. Conselhos de fiscalização profissional

6.5.2. Comandantes de embarcações e aeronaves

7. As atividades de polícia administrativa e a possibilidade de delegação a particulares

7.1. Primeira ressalva: necessidade de delegação formal das atividades de polícia administrativa a particulares

7.2. Segunda ressalva: natureza pública das atividades objeto de delegação

7.3. O poder de coerção

7.3.1. A necessidade de desempenho direto pelo Estado do poder de coerção. 268

7.3.2. A participação privada na gestão de estabelecimentos prisionais

7.4. O poder sancionatório 276

7.4.1. A sanção administrativa 276

7.4.2. A sanção administrativa e a atividade de polícia administrativa 277

7.4.3. O poder disciplinar 282

7.4.4. Indelegabilidade do exercício da capacidade sancionatória a particulares. 284

7.4.5. Delegabilidade do exercício da capacidade sancionatória a entidades da Administração indireta 288

7.5. A atividade normativa derivada 288

7.5.1. O monismo e o pluralismo jurídico 288

7.5.2. O poder normativo 290

7.5.3. Os atos normativos originários 291

7.5.4. Os atos normativos derivados. 291

7.5.5. A atribuição de efeitos jurídicos a normas privadas 
7.6.1. A fiscalização das normas de polícia 308

7.6.2. A participação privada na atividade de fiscalização. 309

7.6.3. Exemplos de deveres de fiscalização atribuídos pela lei a particulares 311

7.6.4. A fiscalização de trânsito

7.7. A atividade de avaliação da conformidade

7.7.1. A avaliação da conformidade 317

7.7.2. A relevância da avaliação da conformidade para o exercício da função administrativa 319

7.7.3. A delegabilidade da atividade de avaliação da conformidade 319

7.7.4. A natureza jurídica da atividade de controle exercida por particulares 321

7.7.5. As diversas formas de participação privada na atividade de controle 322

7.7.6. O sistema nacional de avaliação da conformidade. 324

7.7.7. A prévia acreditação das entidades privadas que exercem a função de controle ... 325

7.7.8. Os programas de avaliação da conformidade compulsórios 327

7.7.9. Os programas de avaliação da conformidade voluntários. 327

7.7.10. A atividade de certificação 328

7.7.11. Inspeção e vistoria veicular. 336

7.8. A atividade de registro e de declaração que produz efeito de certeza pública ou que é dotada de força probatória especial 340

7.8.1. Atividade notarial e de registro 342

7.9. A privatização de parcela do procedimento administrativo 348

7.10. A capacidade tributária ativa 350

7.10.1. Capacidade tributária ativa e atividade de polícia 350

7.10.2. Competência tributária e capacidade tributária ativa ..................................... 351

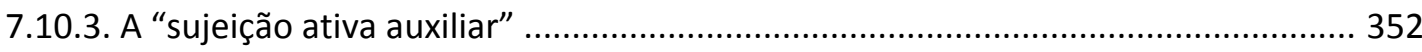

7.10.4. A delegação de capacidade tributária ativa no contexto da parafiscalidade 352

7.10.5. A cobrança de tarifas dos usuários de serviços concedidos: inocorrência de delegação de capacidade tributária

7.10.6. A exigência de autorização legal 354

7.11. Observações finais 355

8. O exercício de atividades de polícia administrativa pelas empresas estatais 356

8.1. A possível reserva do exercício de prerrogativas públicas a entidades com personalidade jurídica pública 
8.2. O monopólio estatal do uso da força e as entidades privadas da Administração indireta

8.3. O controle a que se submetem as entidades privadas da Administração indireta ... 358

8.3.1. O controle interno 359

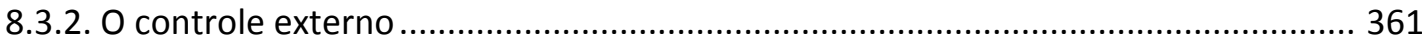

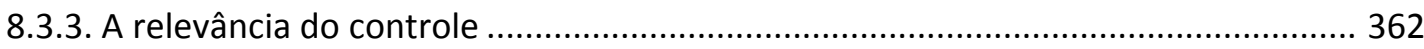

8.4. A possível incompatibilidade entre a execução de atividades de polícia administrativa e a presença de recursos privados no capital da empresa estatal ........................................... 363

8.4.1. Afastamento do conflito em relação às empresas públicas 363

8.4.2. A participação de capital privado nas sociedades de economia mista e os fins lucrativos 364

8.4.3. A necessidade de observância dos critérios legais no exercício da atividade pública 365

8.4.4. As diversas configurações do capital social e da destinação dos valores arrecadados pelas sociedades de economia mista............................................................................ 366

8.4.5. Os mecanismos passíveis de mitigar os potenciais conflitos .................................... 368

8.5. O regime de pessoal das entidades regidas pelo direito privado e o exercício de atividades de polícia administrativa 369

8.5.1. Os requisitos constitucionais para o provimento de cargos públicos e empregos públicos nas empresas estatais 370

8.5.2. Os requisitos para a dispensa de servidores estatutários e empregados públicos das empresas estatais. 371

8.5.3. A reserva do exercício de funções públicas por servidores estatutários 373

8.5.4. Observações finais 377

8.6. A necessidade de autorização legal para a criação das empresas estatais 378

8.7. Conclusões parciais 378

\section{CAPÍTULO IV - REGIME JURÍDICO DO EXERCÍCIO DE ATIVIDADES DE POLÍCIA ADMINISTRATIVA POR ENTIDADES PRIVADAS................................382}

1. A submissão das entidades privadas ao direito administrativo 383

1.1. Aplicação parcial do direito administrativo às entidades privadas 384

1.2. A vinculação ao direito administrativo de acordo com a extensão das atividades atribuídas ao particular

1.2.1. Relações com a Administração

1.2.2. Relações com outros particulares 
2. A vinculação dos particulares aos direitos fundamentais.

2.1. Aplicação dos direitos fundamentais às relações privadas

2.1.1. Eficácia horizontal dos direitos privados

2.1.2. Modo de aplicação dos direitos fundamentais às relações privadas: eficácia mediata ou imediata 391

2.1.3. A jurisprudência do STF 394

2.2. Vinculação direta aos direitos fundamentais dos particulares que exercem atividades de polícia administrativa 395

3. A natureza jurídica dos atos praticados pelas entidades privadas no exercício de poderes públicos

3.1. A produção de efeitos públicos por atos de particulares

3.2. A qualificação de atos de particulares como atos administrativos

3.2.1. A possibilidade de equiparação de atos de particulares a atos administrativos 398

3.2.2. A identificação dos atos que podem ser equiparados a atos administrativos 400

3.2.3. A confirmação da equiparação pelo ordenamento jurídico 400

3.2.4. As consequências da equiparação 404

4. A incidência da garantia do devido processo. 406

4.1. A aplicação da garantia do devido processo no exercício da atividade delegada ..... 406

4.2. A garantia dos direitos dos administrados. 408

4.3. A participação dos usuários na gestão da atividade delegada 409

4.4. A abrangência da incidência da garantia do devido processo em relação a terceiros410

5. O controle a que se submetem os atos praticados por particulares no exercício de atividades de polícia administrativa.

5.1. Os diversos graus de controle.

5.3. Os meios de controle 414

6. A responsabilidade civil das entidades privadas que exercem atividades de polícia administrativa

6.1. A responsabilidade civil pelo exercício de atividade de polícia administrativa

6.2. A responsabilidade civil na ausência de transferência da gestão da atividade ao particular 
6.2.1. Responsabilidade civil do contratado

6.2.2. Responsabilidade civil do poder público

6.3. A responsabilidade civil com transferência da gestão da atividade ao particular..... 420

6.3.1. Responsabilidade civil do delegatário. 420

6.3.2. Responsabilidade civil do poder público 421

7. Observações finais: a publicização das atividades privadas

CONCLUSÕES 


\section{INTRODUÇÃO}

O objeto da tese consiste no exame da participação de entidades privadas no exercício de atividades de polícia administrativa.

Para fins didáticos, as atividades administrativas podem ser divididas em fomento, polícia administrativa, serviço público e intervenção ${ }^{1}$. No exercício dessas atividades, é possível haver a colaboração de entidades privadas. Porém, a extensão da participação privada e os mecanismos empregados para tanto variam em cada uma dessas atividades.

Cabe registrar que a menção a entidades privadas como destinatárias da atribuição de atividades de polícia administrativa abarca todos os sujeitos com personalidade jurídica de direito privado, sejam particulares (pessoas jurídicas ou físicas) sejam entidades administrativas com personalidade jurídica privada.

Trata-se de entidades privadas às quais se atribui o exercício de determinadas atividades de polícia administrativa, que podem implicar, em maior ou menor medida, o desempenho de algumas prerrogativas próprias do poder público. Ressalve-se que não é em todo exercício de atividades públicas por entidades privadas que se verifica o manejo privado de prerrogativas públicas. Várias atividades públicas podem ser desenvolvidas por entidades privadas sem envolver mecanismos autoritativos.

\section{1. $\underline{\text { O exercício privado }} \underline{\text { de }} \underline{\text { atividades }} \underline{\text { de polícia administrativa }}$}

As atividades de polícia administrativa abrangem desde atos meramente materiais, instrumentais ou acessórios ao desempenho da função pública de polícia até o exercício de atos de autoridade, inclusive com a utilização da coerção física. Entre esses extremos, há uma ampla gama de tarefas que podem envolver maior ou menor interferência das entidades privadas no exercício da atividade de polícia.

Assim, cabe analisar quais atividades de polícia administrativa podem ser desenvolvidas por entidades privadas. A questão diz respeito diretamente à problemática do desempenho por entidades privadas de prerrogativas próprias do Estado.

O exercício das atividades de polícia administrativa é usualmente concebido como sendo indelegável a entidades privadas. Pode-se localizar uma grande quantidade de

\footnotetext{
${ }^{1}$ Maria Sylvia Zanella Di Pietro. Direito administrativo, 2013, p. 55.
} 
manifestações doutrinárias no sentido da impossibilidade de se delegar a entidades privadas a função de polícia administrativa por implicar a manifestação de poder de coerção do Estado $^{2}$.

A justificativa para tanto reside no monopólio estatal de violência, consagrado no sistema constitucional, em razão do qual não é possível que o Estado transfira o poder de coerção física a entidades privadas. Apenas o próprio Estado pode impor coercitivamente deveres a particulares. A possibilidade de manifestação coercitiva e imperativa da atividade de polícia pelo Estado está vinculada à legitimidade do poder político e ao princípio da República. Trata-se de poder funcional, necessário ao atendimento dos interesses da coletividade, que, por isso, foi originariamente atribuído ao Estado. Também por essa razão há o monopólio estatal da violência, como instrumento para a persecução de finalidades públicas.

Por outro lado, a doutrina aceita que atos materiais ou de mera verificação ou técnico-instrumentais, preparatórios ou sucessivos do exercício do poder de polícia ${ }^{3}$, ou ainda de mera execução ${ }^{4}$ sejam exercidos por entidades privadas. Justifica-se tal possibilidade porque o ato decisório, de exercício de poder de polícia propriamente dito, continuaria sendo praticado pelo poder público ${ }^{5}$. A classificação dos atos de polícia administrativa em instrumentais ou acessórios e finais e a admissão do exercício privado dos primeiros são utilizadas para justificar a delegação a entidades privadas de diversas atividades de polícia administrativa.

A observação da realidade conduz à constatação do crescente envolvimento de entidades privadas no desempenho da função de polícia administrativa, de modo a interferir decisivamente ou até mesmo a substituir a prática do ato final pela Administração.

\footnotetext{
${ }^{2}$ Restringindo-nos à doutrina nacional, para fins exemplificativos, confiram-se, entre outras, as lições de José Cretella Júnior. Manual de direito administrativo, 1979, p. 256-257; Celso Antônio Bandeira de Mello. Curso de direito administrativo, 2013, p. 855; Marçal Justen Filho. Curso de direito administrativo, 2013, p. 603604; Diogenes Gasparini. Direito administrativo, 2012, p. 187-188; Heraldo Garcia Vitta. Poder de polícia, 2010, p. 136-157; Irene Patrícia Nohara. Direito administrativo, 2013, p. 161-162; Dora Maria de Oliveira Ramos, A terceirização em matéria de poder de polícia, 2013, p. 571; Rafael Aliprandi Mendonça. A indelegabilidade do poder de polícia às sociedades de economia mista, 2011.

${ }^{3}$ Entre outros, podem ser conferidos os ensinamentos de Celso Antônio Bandeira de Mello. Serviço público e poder de polícia: concessão e delegação, 1997, p. 27; Adilson Abreu Dallari. Credenciamento mediante licitação, 1998, p. 100; Dinorá Musetti Grotti. Parcerias na Administração Pública, 2006, p. 300.

${ }^{4}$ Hely Lopes Meirelles. Direito administrativo brasileiro, 2012, p. 138.

${ }^{5}$ Segundo Floriano de Azevedo Marques Neto, o centro das atividades nucleares do Estado (e, por isso, indelegáveis) restringe-se "àquelas atividades para o exercício das quais seja imprescindível o poder político, o poder estatal. Resumem-se elas, ao meu ver, ao exercício último da produção do Direito, do monopólio da força e da imposição dos tributos" (A contratação de particulares para suporte de atividade regulatória estatal, 1999, p. 172). Adiante, o autor assevera que podem ser delegados os meios para o exercício do poder de polícia desde que não seja transferido o poder de polícia em si, a autoridade pública que o caracteriza (ob. cit., p. 174).
} 
Constata-se certo distanciamento entre a afirmação contundente da indelegabilidade das atividades de polícia administrativa e a realidade dos fatos. As aparentes derrogações ao princípio são numerosas.

Como as atividades de polícia repercutem diretamente na esfera subjetiva dos indivíduos e podem limitar o exercício de liberdades individuais, pode-se apresentar como sendo problemático o exercício de tais atividades por entidades privadas em qualquer caso. Mesmo a execução material das atividades de polícia administrativa é apta a determinar o conteúdo da decisão final da Administração ou inclusive substituí-la em termos práticos, interferindo inequivocamente na esfera dos particulares que se submetem a tais atividades.

Por isso, é importante analisar quais são os limites entre a inadmissível imposição coercitiva de deveres por entes privados e o exercício por entidades privadas de atividades acessórias ou instrumentais à função de polícia.

Aliás, no exercício de atividades auxiliares ou instrumentais à polícia administrativa, muitas vezes é até mesmo necessário que as entidades privadas acabem exercendo determinadas prerrogativas públicas em face dos particulares que se submetem às atividades de fiscalização, inspeção, vistoria etc. Caso contrário, em diversas situações, as entidades privadas restariam inviabilizadas de exercer as atividades que lhes foram atribuídas. A própria delegação acabaria perdendo sentido, com a necessidade de intervenção constante da Administração Pública no exercício de tais atividades.

Daí a necessidade de, ao se conferir a realização de determinadas atividades públicas a entidades privadas, atribuírem-se as competências necessárias ao cumprimento dos seus deveres ${ }^{6}$. No entanto, o exercício de tais competências envolve determinadas prerrogativas públicas e poderá acarretar, em alguma medida, restrições sobre a esfera privada dos beneficiários daquela atividade.

Disso decorre a preocupação em se diferenciarem as atividades de polícia que podem ser exercidas por entidades privadas daquelas que não são passíveis de qualquer forma de privatização.

Por um lado, a solução não está em se admitir uma ampla privatização de atividades que implicam o exercício de soberania, afastando-se princípios solidamente

\footnotetext{
${ }^{6}$ Para ilustrar, pode-se recorrer ao exemplo exposto por Marçal Justen Filho: “cabe apenas ao poder concedente a competência para proibir que os passageiros fumem no interior de veículos de transporte. No entanto, caberá ao concessionário exercitar a fiscalização concreta. Se não existisse a competência do concessionário para a prática dos atos materiais de execução das determinações do concedente, eles seriam ineficazes e irrelevantes” (Teoria geral das concessões de serviço público, 2003, p. 322).
} 
estabelecidos no sistema jurídico. Faz-se necessário um exame mais detido de quais seriam as competências e poderes que não podem ter o seu exercício atribuído a particulares.

Por outro, o Estado não tem condições de exercer diretamente todas as atividades necessárias para o desempenho da função de polícia administrativa. Com o incremento dos fatores de risco, a atividade de imposição de controles e restrições para assegurar a ordem social adquiriu maior complexidade.

Assim, a questão que se coloca diz respeito aos critérios que devem ser utilizados para se proceder à diferenciação entre as atividades de polícia administrativa passíveis de exercício privado daquelas que não o são ${ }^{7}$. A afirmação de que a atividade de polícia não comporta qualquer delegação não é apta a justificar diversas das atividades que têm sido exercidas por entidades privadas. Porém, se essa afirmação for aplicada com rigor, a consequência seria o reconhecimento da ilegitimidade do exercício privado de uma grande quantidade de atividades que ora se encontram nas mãos de entidades privadas.

\section{A privatização}

O objeto do estudo diz respeito à privatização de atividades públicas, investigando os seus limites no que diz respeito à atividade de polícia administrativa.

Referimo-nos ao sentido amplo de privatização, que "abrange todas as formas pelas quais se busca uma diminuição do tamanho do Estado”. Isso inclui desde a transferência do controle acionário de empresas estatais para a iniciativa privada até as diversas formas de desregulação, delegação da prestação de serviços públicos, contratações de terceiros, parcerias etc.. Em sentido restrito, o vocábulo “privatização” indica apenas a privatização de empresa estatal, com a transferência do seu controle acionário para o setor privado $^{8}$.

Analisaremos especialmente as diversas formas de participação privada no exercício de atividades de polícia administrativa, que continuam sendo de titularidade pública. Examinam-se especialmente os mecanismos de delegação e de colaboração de terceiros.

Gaspar Ariño Ortiz aparta as diversas modalidades de privatização em dois grandes grupos. O primeiro deles agregaria aquelas que consistiriam nas verdadeiras

\footnotetext{
${ }^{7}$ Como acentua Pedro Gonçalves, ao tratar da delegação de poderes públicos a particulares: "o centro atual do debate reside menos na questão de saber se a delegação é constitucionalmente possível do que na definição do âmbito, na determinação dos limites e no estabelecimento das condições constitucionais da delegação" (Entidades privadas com poderes públicos, 2008, p. 932).

${ }^{8}$ Maria Sylvia Zanella Di Pietro. Parcerias na Administração Pública, 2012, p. 215.
} 
privatizações, nas quais se altera o regime de propriedade ou a titularidade da atividade. Já no segundo tipo de privatização há alteração do regime jurídico, que o autor insere no fenômeno da fuga do direito público porque usualmente ocorre mediante a conversão formal de regime público em entidade sujeita ao regime privado ${ }^{9}$.

Em relação às modalidades de privatização que são objeto do presente estudo, o risco que se apresenta é o de indevida fuga do direito público. Essa é uma das principais preocupações ao se examinar a participação privada na execução de atividades de polícia administrativa.

\section{3. $\underline{\text { A dicotomia }} \underline{\text { entre o público }} \underline{\text { e o privado }}$}

Premissa necessária a ser considerada no presente estudo é a impossibilidade de se compreender a dicotomia entre as esferas pública e privada tal como originariamente concebida.

O nascimento do direito administrativo foi marcado pela pretensão de se separar com rigidez o público e o privado.

O direito administrativo surgiu no contexto do Estado liberal, em que a intervenção estatal visava especialmente os fins de ordenação e de polícia, utilizando-se de poder e autoridade. Para submeter o exercício de tais poderes a regras jurídicas, surgiu o direito administrativo ${ }^{10}$. O nascimento do direito administrativo foi marcado então pela regulação de relações que envolvem poder-sujeição. Sob esse aspecto, o direito administrativo contrapunha-se ao direito privado, que era o ordenamento a que se submetiam os cidadãos, nas relações com os seus iguais.

Os desenvolvimentos posteriores do Estado conduziram a uma maior aproximação entre Estado e sociedade, com a intensificação da participação dos particulares no exercício de atividades de interesse público.

\footnotetext{
${ }^{9}$ El ámbito privado del sector público, 2002, p. 580.

${ }^{10}$ Cabe ressalvar que há intensa controvérsia na doutrina acerca dos motivos que conduziram ao surgimento do direito administrativo. Para a maioria da doutrina, o nascimento do direito administrativo decorreu do intento de se subordinar o exercício do poder à lei. Nesse sentido, podem ser conferidos, entre outros, Maria Sylvia Zanella Di Pietro. Direito administrativo, 2013, p. 1-4; Caio Tácito. Evolução histórica do direito administrativo, 1997, p. 2; e Celso Antônio Bandeira de Mello. Curso de direito administrativo, 2013, p. 4749. A partir dessa concepção, Prosper Weil descreve o surgimento do direito administrativo como sendo um milagre, pois "resulta estranho que o Estado aceite voluntariamente considerar-se obrigado pela Lei" (Derecho administrativo, 1994, p. 35). Já para outros doutrinadores, tal narrativa do surgimento do direito administrativo seria um equívoco pois permitiu que o juiz administrativo se substituísse ao legislador na definição das normas aplicáveis à Administração. Pretendeu-se, assim, afastar a intervenção do Parlamento sobre a atividade do Executivo bem como a possibilidade de os Tribunais julgarem a Administração. É o que sustentam, por exemplo, Paulo Otero. Legalidade e Administração Pública, 2003, p. 269-282 e Gustavo Binenbojm. Uma teoria do direito administrativo, 2008, p. 9-17.
} 
Etapa relevante nessa discussão foi a constatação de que se faz necessária a participação privada no desempenho de atividades que buscam a satisfação de interesses coletivos, à medida que a persecução dos fins públicos é uma missão compartilhada entre os setores público e privado. Reconheceu-se também que, na ampla maioria dos casos, não há atividades puramente privadas, sem qualquer interferência estatal. Verificou-se a existência de forte interdependência entre o público e o privado.

Pedro Gonçalves propõe a delimitação do espaço do Estado, em contraposição ao espaço privado, de duas formas, conforme os objetivos que se pretende alcançar. Trata-se de identificar o espaço que o Estado pode ocupar ou o espaço que o deve ocupar $^{11}$. As premissas são distintas. No primeiro caso, reconhece-se que há limites à intervenção do Estado. No segundo, afirma-se que há limites à privatização. Para o autor, uma teoria das responsabilidades públicas deve considerar quais missões e tarefas o Estado tem que assumir (o que pressupõe que ele pode assumi-las).

Por isso, caberia a rejeição de definições meramente formais de atividades públicas, como sendo aquelas que são assumidas por entes públicos. Demarcações a partir de tais critérios sugerem a ausência de limites para a intervenção estatal e a possibilidade de soluções casuísticas. Há limites materiais a serem considerados.

Nesse sentido, a “competência-competência” do Estado para definir suas próprias atribuições não é ilimitada, pois há restrições constitucionais à publicização. Podese cogitar da vedação do exercício pelo Estado, de modo permanente, de atividades que não apresentem relevância pública ou social ou que não guardem relação com a persecução das finalidades atribuídas ao Estado pelo ordenamento jurídico. Trata-se de questão diretamente relacionada ao princípio da subsidiariedade, que é objeto de exame adiante.

Logo, a definição de uma atividade como sendo pública deve considerar a conjugação de critérios legais, definidos pelo ordenamento jurídico, e teleológicos, no sentido da sua vinculação à realização de fins constitucionalmente atribuídos ao Estado.

A significativa permeabilidade dos setores público e privado não implica a superação da distinção entre essas duas áreas. Há aspectos relevantes a serem extraídos de tal diferenciação, apesar de ser inequívoca a interpenetração entre os dois setores.

O ordenamento jurídico consagra expressamente determinadas missões como sendo estatais, atribuindo-as preferencial ou exclusivamente ao Estado. Delimita também uma esfera de autonomia privada dos indivíduos em face do Estado. Porém, o ordenamento também admite a participação privada na persecução dos fins públicos bem

\footnotetext{
${ }^{11}$ Pedro Gonçalves. Entidades privadas com poderes públicos, 2008, p. 238.
} 
como estipula determinadas regras para o exercício da autonomia privada, revelando que também nessa esfera existe intervenção estatal.

Nesse ponto, cabe aludir às diversas propostas de um sistema ternário, com a inserção de um setor intermediário entre o público e o privado. A doutrina sugere diversas nomenclaturas para essa terceira esfera - zona mista ou intermediária, setor público nãoestatal etc. $^{12}$

\subsection{A distribuição de tarefas entre os setores público e privado}

O objeto do presente estudo vincula-se diretamente às transformações verificadas na intensidade e nas modalidades de intervenção pública. No âmbito dessa mutação, destaca-se a redistribuição de atividades entre os setores público e privado, com ênfase na cooperação e conjugação de esforços dos atores públicos e privados na persecução de finalidades de interesse coletivo.

Há maior estímulo para a participação de particulares na realização das incumbências públicas. Constata-se a redução do tamanho do Estado e a redefinição das funções por ele desempenhadas. O Estado afasta-se da execução direta de determinadas atribuições e passa a se valer de instrumentos de regulação e ativação da intervenção da própria sociedade para a execução de tais atividades.

Para tanto, o Estado utiliza-se especialmente de duas estratégias: a privatização de responsabilidades públicas e a ativação de responsabilidades privadas ${ }^{13}$. Disso resulta a atribuição de maiores responsabilidades aos atores privados e o incremento da intervenção pública em determinadas atividades privadas. É nesse contexto que se insere a delegação do exercício de funções administrativas a particulares.

Verifica-se também uma alteração em relação às atividades que passaram a ser delegadas a particulares. No século XX, utilizou-se amplamente a delegação a particulares da gestão e da exploração de serviços públicos em sentido estrito. Atualmente, constata-se a intensificação da participação de particulares na execução de tarefas nucleares do Estado, que poderiam ser consideradas públicas por natureza, tais como a gestão de prisões, a manutenção da segurança e o controle de condições de segurança técnica.

\footnotetext{
12 Sobre o tema, pode-se consultar, entre outros, Luiz Carlos Bresser-Pereira; Nuria Cunill Grau (Org.). $O$ público não-estatal na reforma do Estado, 1999; Vital Moreira. Administração autónoma e associações públicas, 2003, p. 88-89.

${ }^{13}$ Pedro Gonçalves. Entidades privadas com poderes públicos, 2008, p. 14.
} 


\subsection{O Estado policêntrico}

Outro aspecto a ser considerado é a nova organização da estrutura estatal.

O Estado moderno assentava-se na hierarquia e na ideia de unidade orgânica. Com o advento do Estado pós-moderno, verifica-se a desintegração dessa grande máquina, com maior diversificação e autonomia das estruturas administrativas. Como anota Jacques Chevallier, “a ordem burocrática, fundada sobre a hierarquização, é desestabilizada pela proliferação de estruturas de um novo tipo, colocadas fora do aparelho de gestão clássico e escapando ao poder da hierarquia” ${ }^{14}$. Os liames verticais de subordinação, constituídos como pirâmide, são substituídos por estruturas transversais de controle, em forma de rede.

Gilles Deleuze detecta essa transformação do Estado na forma de passagem das sociedades disciplinares para as sociedades de controle ${ }^{15}$. As sociedades disciplinares foram objeto de intenso estudo por Foucault, que assim designou o modelo predominante nos séculos XVIII e XIX e que atingiu seu auge no início do século XX. Tratava-se da sociedade que organizava os indivíduos em espaços fechados de confinamento, comandados em moldes rígidos. Especialmente a partir da Segunda Guerra Mundial, novas forças sociais foram se instalando, com a instituição de diferentes modos de controle que são moduláveis, autodeformantes, em variação contínua. Na expressão de Deleuze, a sociedade de disciplina é caracterizada como uma toupeira, que representaria os meios de confinamento com seus túneis estruturais, enquanto que a sociedade de controle seria representada pela serpente, de movimento ondulado, contínuo, que se entranha por toda a extensão da sociedade.

A delegação a particulares da execução de atividades de polícia administrativa insere-se nesse contexto de pluralização da Administração. As principais motivações que conduziram à multiplicação de entidades administrativas e à criação de diversos centros de imputação de competências também justificam a atribuição de execução de determinadas atividades de polícia a particulares. Entre tais justificativas, destacam-se a maior complexidade das tarefas, que demandam domínio de conhecimentos especializados, maior especialização e agilidade, por um lado, e o aspecto estritamente material, de mera execução, de outras tantas atividades voltadas ao exercício da polícia administrativa, por outro. Em diversos casos, essas necessidades podem ser satisfeitas de modo mais eficiente pela iniciativa privada.

\footnotetext{
${ }^{14}$ O Estado pós-moderno, 2009, p. 99.

15 "Post-scriptum" sobre as sociedades de controle, 1992, p. 219-226.
} 


\subsection{Os setores público e privado no controle de riscos}

O desenvolvimento científico e tecnológico repercutiu nas funções desempenhadas pelo Estado.

Atribui-se à sociedade de hoje a caracterização de "sociedade de risco"16 . O risco mencionado relaciona-se com a noção de perigo, de ocorrência futura de um dano ou de uma lesão. Vincula-se à contingência decorrente da complexidade da sociedade contemporânea, que deu ensejo à multiplicação dos riscos derivados da atividade humana. A substituição da produção artesanal pela atividade industrial em larga escala e o incentivo ao consumo demandam constante inovação tecnológica, que é acompanhada de riscos até então não conhecidos. Em alguma medida, trata-se de riscos e incertezas fabricadas.

A crescente complexidade da vida social e o elevado grau de desenvolvimento tecnológico verificado nas atividades econômicas conduziram a uma ampliação da necessidade de regulamentação específica e técnica. Isso implicou o aumento da demanda pelo exercício da atividade de polícia pelo Estado, ao mesmo tempo em que se verificou uma maior especialização e diferenciação destas atividades. A adequada proteção da saúde, do meio ambiente, da segurança etc. atualmente exige a permanente vigilância estatal. A verificação do cumprimento de normas cada vez mais complexas determina o controle contínuo de diversos aspectos da vida dos cidadãos, fazendo-se necessária uma maior colaboração privada para que o Estado possa exercer a função de polícia administrativa.

O controle adequado dos riscos da ciência e da técnica requer uma estrutura complexa. Constata-se que as estruturas material e de pessoal da Administração não dão conta do exercício do controle necessário. A dificuldade não é só da Administração mas também do legislador, que não detém o conhecimento necessário para a formulação das regras aplicáveis aos setores da ciência e da tecnologia. No âmbito da sociedade de risco, é relevante prevenir e administrar os riscos por ela criados. E o Estado não tem condições de desenvolver tais atividades sem a colaboração privada.

A solução para isso foi recorrer-se a entes privados, que detêm a capacidade e o conhecimento necessários para o exercício das funções tais como as de controle, inspeção e certificação.

Com isso, a participação privada no exercício da atividade de polícia administrativa ganhou destaque, enfatizando-se a atribuição a particulares do controle dos

\footnotetext{
${ }^{16}$ O termo "sociedade de risco" pode ser atribuído a Ulrich Beck e foi desenvolvido especialmente na sua obra Sociedade de risco, 2011.
} 
riscos da técnica. Parcela da reestruturação do Estado deve-se à complexidade tecnológica e à necessidade do seu controle.

A colaboração de entidades privadas na realização de tarefas de polícia administrativa não é um fenômeno novo. Tradicionalmente, tais entidades dedicavam-se precipuamente à gestão e à execução de decisões públicas. Mais recentemente, foram atribuídas outras funções a tais entidades, às quais cabe inclusive a tomada de decisões vinculantes relacionadas à gestão dos riscos tecnológicos.

Constata-se um crescente exercício de atividades de polícia administrativa por entidades privadas, tanto em termos quantitativos quanto qualitativos. Deixou de ser uma colaboração simplesmente preparatória ou executiva para ser uma colaboração declaratória e, em alguma medida, decisória. A Administração reconhece sua incapacidade não apenas por não dispor dos meios materiais para executar as intervenções necessárias mas também porque não detém os conhecimentos especializados imprescindíveis para adotar as decisões em tais setores ${ }^{17}$.

Assim, o sistema de controle da técnica e de seus riscos é integrado por agentes privados que exercem funções que até então cabiam exclusivamente ao Estado.

Em alguma medida, a atuação dos particulares, legitimada tecnicamente, passa a ser revestida de legitimação jurídica.

Essa circunstância é apta a gerar diversos questionamentos, inclusive sob o ponto de vista da legitimação democrática. Não apenas a função administrativa mas também a própria função legislativa encontra-se limitada frente aos avanços da ciência e da técnica. Isso demanda não apenas uma colaboração excepcional dos particulares mas também a atribuição do exercício de funções públicas a entidades privadas, inclusive de conteúdo decisório. À medida que a legitimidade da transferência de funções públicas não pode se apoiar na presumível autoridade técnica desses particulares, é imprescindível a legitimação democrática de tal processo, o que ocorre com a lei. É necessária a legitimação jurídica.

É nesse contexto que nos propomos a analisar o exercício de atividades de polícia administrativa por entidades privadas.

\footnotetext{
${ }^{17}$ No contexto europeu, o direito comunitário exerceu grande influência para a transferência a particulares das funções de controle, inspeção e certificação. Isso pode ser atribuído a dois motivos principais: a grande complexidade técnica da tarefa de assegurar a segurança industrial e a proteção do meio ambiente e a necessidade de se superarem obstáculos técnicos para se garantir a livre circulação de mercadorias no mercado comum (Dolors Canals i Ametller. El ejercicio por particulares de funciones de autoridad, 2003, p. 102-103).
} 


\section{Estrutura do $\underline{\text { trabalho }}$}

No Capítulo I, analisamos a atividade de polícia administrativa, procurandose definir o seu conceito e abrangência no modelo atual do Estado. Identificaram-se os poderes nela abrangidos, inclusive para diferenciá-los das situações em que particulares exercem poderes privados.

No Capítulo II, examinamos as diversas configurações utilizadas pelo Estado para o desempenho das suas atividades. São identificadas mais detidamente as características do exercício de atividades estatais por meio de entidades da Administração indireta com personalidade jurídica privada e de contratos de delegação e de colaboração. A autorregulação também é objeto de exame específico, à medida que o exercício de atividades públicas por particulares também pode aparecer nessa manifestação regulatória da sociedade.

Após essa análise, no Capítulo III, demonstramos que o dogma da indelegabilidade da atividade de polícia não pode ser tomado como absoluto, de modo a vedar toda e qualquer participação privada no exercício dessa atividade. Delineiam-se os limites e possibilidades do exercício privado de atividades de polícia administrativa. Procura-se identificar o núcleo da atividade estatal que não comportaria qualquer tipo de delegação. Após, são delineados os requisitos a serem observados para a delegação. Esses conceitos operacionais são então aplicados a atividades específicas de polícia administrativa, para se concluir em relação a cada uma delas acerca da possibilidade ou não de delegação.

A seguir, no Capítulo IV, examinamos algumas questões relacionadas ao regime jurídico a ser observado no exercício de atividades de polícia administrativa por entidades privadas. Demonstra-se que a observância de determinados aspectos desse regime jurídico consiste em condição para a legitimidade da atribuição do exercício dessas atividades a entidades privadas.

Ao final, são arroladas as conclusões obtidas ao longo do trabalho. 


\section{CAPÍTULO I - DEFINIÇÃO DE ATIVIDADE DE POLÍCIA ADMINISTRATIVA}

Para o desenvolvimento do presente trabalho, é necessário inicialmente determinar em que consiste a atividade de polícia administrativa e quais são os seus fundamentos, no contexto de um Estado Democrático de Direito. Trata-se de premissas necessárias para a avaliação dos limites e possibilidades da atribuição a entidades privadas do exercício de atividades de polícia administrativa.

\section{1. $\underline{\text { A }}$ atividade $\underline{\text { administrativa }} \underline{\text { e o exercício }} \underline{\text { de }}$ poderes públicos}

Pode-se constatar que o direito administrativo desenvolveu-se precipuamente a partir da concepção da função administrativa como exercício de poder público. Em alguma medida, considerou-se o exercício de poder que o desempenho da função administrativa implica mais relevante do que a atribuição de determinadas incumbências à Administração. A autoridade da Administração foi inicialmente mais vinculada aos meios de que se utiliza do que aos fins perseguidos com a sua atuação. Disso decorre a própria designação das atribuições estatais como poderes, tal como o denominado poder de polícia.

Empregamos os termos “atividade de polícia” e “poder de polícia” por se tratar de uso consagrado na doutrina e na legislação. Como se examina adiante, os referidos termos são objeto de severas críticas por alguns doutrinadores, porque não refletiriam adequadamente o conjunto de atividades que representam. A doutrina sugere outras nomenclaturas para designar esse setor de atividades estatais, tais como "limitações administrativas à liberdade e à propriedade”"18 e “administração ordenadora”19 .

No entanto, não se pode deixar de reconhecer a continuidade da ampla utilização de tal terminologia. Por isso, empregamos o termo "polícia” para indicar o setor da atividade administrativa a que se refere o presente estudo.

\footnotetext{
${ }^{18}$ Celso Antônio Bandeira de Mello. Curso de direito administrativo, 2013, p. 837-838.

${ }^{19}$ Carlos Ari Sundfeld. Direito administrativo ordenador, 1997, p. 16-17.
} 


\subsection{O exercício da autoridade como instrumento da atuação estatal}

O direito administrativo francês foi construído em torno da figura da puissance publique ${ }^{20}$, do poder de autoridade que foi exercido de diversas formas, acompanhando as transformações do Estado. Era a presença ou não da puissance publique que justifica, por exemplo, a distinção propugnada entre atos de império e atos de gestão. Separava-se, então, uma parcela da atividade estatal que não se submetia ao direito administrativo, qualificada como sendo a dos atos de gestão.

Com o surgimento da denominada Escola do Serviço Público, a noção de puissance publique ${ }^{21}$ deixou de significar apenas o emprego de prerrogativas exorbitantes pela Administração mas também a submissão de seus atos a normas derrogatórias do direito comum.

A disputa entre Duguit e Hauriou, no início do século XX, não chegou a vulnerou a noção de poder de autoridade como caracterizador da atividade administrativa. Os doutrinadores debateram acerca daquele que poderia ser considerado o critério a ser empregado para a definição do direito administrativo. Para a Escola do Serviço Público, capitaneada por Duguit, o critério estruturante do direito administrativo era o conceito de serviço público. A atuação do Estado justificava-se para a oferta de utilidades fruíveis pela população. Já para a Escola Institucionalista, que teve como principal expoente Hauriou, o núcleo estaria no conceito de puissance publique, no poder exercido pelo Estado. O direito administrativo estaria diretamente vinculado ao uso da força, como instrumento para a satisfação das necessidades coletivas. Ou seja, a puissance publique seria o meio utilizado pelo Estado para cumprir as suas atribuições.

Com a superação do impasse e a elevação do serviço público à condição de conceito fundamental do direito administrativo, decaiu a distinção entre ato de autoridade e ato de gestão ${ }^{22}$. O serviço público é que passou a ser adotado para definir a competência da jurisdição administrativa. Os atos praticados pela Administração na prestação de serviço

\footnotetext{
${ }^{20}$ Optou-se pela utilização da expressão em francês, considerando-se que a sua tradução mais recorrente para o português, como "poder público", não refletiria adequadamente o seu conteúdo.

${ }^{21}$ Duguit faz uma crítica bastante firme ao conceito de puissance publique: "O conceito de puissance publique é um conceito metafísico emprestado do direito romano e defendido pelos homens no poder e seus legisladores para dar um fundamento de aparência jurídica à força que eles detêm; é um conceito que todo espírito positivo deve rejeitar" (De la situation des particuliers à l'égard des services publiques, 1907, p. 422). Diante disso, propõe a utilização dos termos atos de autoridade e atos de gestão para designar os atos unilaterais e os contratos da Administração, respectivamente (ob. e loc. cit.).

${ }^{22}$ A jurisprudência francesa, especialmente pelo Conselho de Estado e pelo Tribunal de Conflitos, adotou a noção de serviço público como critério determinante para a definição da jurisdição administrativa e superou a distinção entre atos de autoridade e atos de gestão especialmente a partir dos famosos "ârrets" Blanco (Tribunal de Conflitos em 8 de fevereiro de 1873), Terrier (Conselho de Estado em 6 de fevereiro de 1903) e Feutry (Tribunal de Conflitos em 28 de fevereiro de 1908).
} 
público, antes reputados atos de gestão, passaram a ser considerados atos administrativos. Os fins visados pelo Estado passaram a ser mais importantes do que os meios por ele utilizados para qualificar os atos como sendo administrativos ${ }^{23}$.

Em qualquer caso, garantia-se à Administração uma posição de superioridade em relação aos administrados, utilizando-se de instrumentos que não se encontram à disposição de particulares. Logo, o direito administrativo foi concebido como o direito próprio do exercício da função pública.

Mas isso não implicou a submissão da integralidade da atividade estatal ao direito público. Procurou-se separar uma parcela da atividade do Estado que não se sujeitaria ao direito administrativo, sendo regida pelo direito privado. Assim se passou, por exemplo, com a teoria do fisco do direito alemão, com a qual se pretendeu submeter parcela da atividade estatal ao direito privado. Mais recentemente, ampliaram-se as atividades estatais sujeitas, em maior ou menor medida, ao direito privado, empregando-se os mais variados mecanismos de privatização. Parcela da doutrina qualifica esse fenômeno como sendo de "fuga para o direito privado".

De todo modo, sempre se resguardou um núcleo essencial que necessariamente deveria ser regido pelo direito administrativo. Esse núcleo usualmente está relacionado ao exercício de poderes de autoridade pelo Estado. Ainda que exista uma variação entre as tarefas atribuídas aos setores público e privado nas diversas formas de organização estatal, reconhece-se a necessidade de se manter a submissão ao direito administrativo das atividades que implicam o exercício de poderes autoritativos.

O desenvolvimento do direito administrativo foi marcado então pela vinculação entre o exercício de poderes públicos por formas organizativas de direito público. Porém, tal concepção foi sendo aos poucos revista para abarcar também formas privadas de gestão da Administração. O recurso da Administração a institutos de origem privada, tais como os contratos, e a diversas formas de colaboração de particulares, ainda que sujeitando-as a regime jurídico que conjuga aspectos de direito público e de direito privado, evidenciam a impossibilidade de haver relação necessária entre Administração, poder público e direito administrativo em todas as circunstâncias.

\footnotetext{
${ }^{23}$ Almiro do Couto e Silva. Autoridade pública e mandado de segurança, 2003, p. 244-245.
} 


\subsection{Atividades públicas e poderes públicos de autoridade}

No contexto do exercício de atividades públicas, é relevante para o objeto do presente estudo identificar quais delas implicam o manejo de poderes públicos de autoridade.

Assim se passa porque o exercício privado da atividade de polícia administrativa ganha especial relevância e dá ensejo a questionamentos mais complexos quando envolve o exercício de poder público de autoridade. São as hipóteses em que, para o exercício da função administrativa, o ordenamento jurídico atribui à Administração uma capacidade superior para formular juízos, em posição de supremacia jurídica em relação aos particulares que se submetem ao exercício desse poder.

A autoridade indica a possibilidade de o titular do poder produzir unilateralmente efeitos jurídicos que incidem sobre a esfera jurídica de terceiros. Como define Freitas do Amaral, poderes públicos de autoridade são “aqueles que denotam supremacia das pessoas coletivas públicas sobre os particulares e, nomeadamente, consistem no direito que essas pessoas têm de definir a sua própria conduta ou a conduta alheia em termos obrigatórios para terceiros, independentemente da vontade destes, o que naturalmente não acontece com as pessoas coletivas privadas”24.

Para Giannini, a característica autoritativa da função administrativa seria uma decorrência dos sistemas positivos de direito administrativo, das normas legais que assim determinam $^{25}$. Portanto, não seria o caráter autoritativo que caracterizaria a função administrativa em si mesma, isso seria uma configuração histórica e positivada.

O poder de autoridade não se restringe ao poder de coação. Consiste em poder conferido a um sujeito pelo ordenamento jurídico para praticar atos unilaterais aptos a provocar efeitos imediatos na esfera jurídica de terceiros, atos estes que podem ser normativos, declaratórios com força probatória especial etc.

Cabe notar que o poder de autoridade não está presente no exercício de todas as atribuições públicas. Trata-se de um atributo conferido pelo ordenamento jurídico ao exercício de determinadas competências públicas. Sobre o tema, Giannini pondera que “nem toda atividade administrativa é manifestação do momento de autoridade"26. Por isso, o ato administrativo não pode ser, por definição, um ato de autoridade. Os atos de

\footnotetext{
${ }^{24}$ Curso de direito administrativo, v. I, 2006, p. 758. No conceito apresentado pela Lei $\mathrm{n}^{\circ}$ 9.784/99, a autoridade é vinculada ao exercício de poder decisório. O art. $1^{\circ}$, $\S 2^{\circ}$, inc. III daquela lei define que "autoridade" é "o servidor ou agente público dotado de poder de decisão".

${ }^{25}$ Corso di diritto amministrativo, 1965, p. 84.

${ }^{26}$ Lezioni di diritto amministrativo, v. I, 1950, p. 78.
} 
autoridade são apenas uma das categorias do ato administrativo, considerando-se que a atividade administrativa substancialmente não se impõe como atividade imperativa ${ }^{27}$.

A esse respeito, é elucidativa a classificação, proposta por parcela da doutrina, dos atos administrativos em autoritativos ${ }^{28}$ e não autoritativos ou ainda a distinção, já em desuso, em atos de império e atos de gestão ${ }^{29}$.

Tais diferenciações enfatizam que nem todos os atos da Administração são unilaterais e de autoridade. Trata-se de diferenciar as hipóteses em que a Administração atua com poder de império, emanando atos dotados de imperatividade, independentemente do consentimento do particular, daquelas em que seus atos não têm carga decisória ou apenas produzem efeitos se houver a aquiescência do particular ${ }^{30}$.

O que determinaria o caráter autoritativo do ato seria a presença do poder de constituir ou declarar uma situação unilateralmente, poder este conferido pelo ordenamento jurídico ao aplicador da norma. Os efeitos propriamente ditos do ato não seriam determinantes para se identificar a presença de poder de império. O resultado produzido por um ato de autoridade pode até ser desejado pelo particular interessado. O ponto decisivo seria o fato de a produção daquele efeito desejado depender exclusivamente do agente público ou da concorrência de vontades entre a Administração e o particular ${ }^{31}$.

Porém, não há unanimidade na doutrina. Para outra corrente, os atos cuja produção pressupõe o consentimento do particular não seriam destituídos de autoridade. A relação de subordinação que a autoridade revela não seria necessariamente vinculada a uma situação não desejada ou contrária aos interesses do administrado. Nos casos em que a produção do ato depende de manifestação do seu destinatário, não deixaria de haver poder e autoridade. O exercício dessa autoridade é que dependeria de um ato do destinatário. Em

\footnotetext{
${ }^{27}$ Ob. cit., p. 79.

${ }^{28}$ Pelas razões expostas por Marçal Justen Filho, prefere-se o emprego do termo “autoritativo” para identificar o exercício de autoridade ao termo "autoritário”: “A expressão autoritativo é utilizada na ausência de outra mais adequada e para evitar o uso de autoritário. Existem poderes que traduzem o exercício de autoridade, ou seja, de uma posição jurídica reforçada e protegida. Esses poderes devem ser exercitados de modo democrático. Portanto, não cabe um uso autoritário. Em suma, autoritativo se refere a autoridade, enquanto autoritário indica uma conduta não democrática e arbitrária” (Curso de direito administrativo, 2013, p. 268, nota 4).

${ }^{29}$ A distinção entre atos de autoridade e atos de gestão foi amplamente utilizada pela doutrina francesa do século XIX, para diferenciar os campos de aplicação do direito administrativo e do direito privado. Essa doutrina foi sendo progressivamente substituída pela teoria do serviço público, com a resistência de Hauriou.

${ }^{30}$ Nesse sentido, entre outros, Eugenio Bruti Liberati. Consenso e funzione nei contratti do diritto pubblico, 1996, p. 89 e Stefano Civitarese. Contributo allo studio del principio contrattuale nell'attività amministrativa, 1997, p. 78-90.

${ }^{31}$ Para Mário Aroso de Almeida, o que caracteriza o exercício de poderes de autoridade é a "emissão de pronúncias às quais o ordenamento jurídico confere a capacidade de definirem - e, porventura, de modificarem - a situação jurídica de pessoas ou de coisas por formal unilateral e, portanto, sem contar com o concurso de outras vontades que não a do próprio autor da declaração" (Anulação de actos administrativos e relações jurídicas emergentes, 2002, p. 89).
} 
qualquer caso, deve haver um ato unilateral da Administração para a produção do efeito jurídico desejado ${ }^{32}$.

Já para Vasco Pereira da Silva, seriam destituídos de autoridade os diversos atos administrativos de prestação e de constituição, que contam, em alguma medida, com a manifestação de vontade dos particulares, ainda que não seja necessária a sua concordância para que o ato produza seus efeitos ${ }^{33}$.

Para o presente estudo, cabe assentar a noção de que nem todos os atos praticados no exercício da função administrativa implicam a definição da situação jurídica de terceiros. Há casos em que são produzidos apenas efeitos materiais, sem determinar a conduta de terceiros de modo obrigatório.

O conjunto das atividades públicas que implicam o manejo do poder de autoridade pela Administração é especialmente enquadrado, no direito nacional, na função estatal de polícia administrativa ${ }^{34}$.

\subsection{A configuração legal do exercício do poder}

Como enunciam Eduardo García de Enterría e Tomás-Ramon Fernández, o poder da Administração vincula-se estritamente ao ordenamento jurídico à medida que "a legalidade atribui poderes à Administração”35. Ou seja, é o direito que outorga os poderes à Administração, que os delimita e disciplina seu exercício. Os poderes não podem ser compreendidos tal como se pertencessem aprioristicamente ao Estado ${ }^{36}$, à medida que são concebidos pelo direito positivo.

Assim, ao se tratar de poder público e legalidade, o principal aspecto a ser destacado é o de que cabe ao direito determinar o exercício do poder, estipulando os limites do seu exercício. Esse é o núcleo essencial do exercício do poder em um Estado Democrático de Direito.

\footnotetext{
32 Esse é o posicionamento de Pedro Gonçalves (Entidades privadas com poderes públicos, 2008, p. 597612).

${ }^{33}$ Em busca do acto administrativo perdido, 1996, p. 562-566. A colaboração do particular na produção do ato pode se manifestar de diversas formas: a produção do ato ser desencadeada a seu pedido, haver participação privada, em alguma medida, na definição do conteúdo ato mediante negociações, sugestões etc.

${ }^{34}$ Isso não significa que as atividades exercidas pela Administração Pública nas outras modalidades de função administrativa não possam também envolver o uso da autoridade. Por exemplo, Maria Sylvia Zanella Di Pietro propõe como uma das modalidades de função administrativa a intervenção que, em sua parcela sujeita ao regime jurídico de direito público, “compreende a regulamentação e fiscalização da atividade econômica de natureza privada” (Direito administrativo, 2013, p. 56). O exercício destas atividades também pode envolver o manejo da autoridade.

${ }^{35}$ Curso de derecho administrativo, v. I, 2002, p. 443.

${ }^{36}$ Agustín Gordillo. Tratado de derecho administrativo, t. 2, 2009, p. V-5.
} 
Cabe ao ordenamento jurídico a atribuição de poderes jurídicos à Administração ${ }^{37}$. Cabe também à lei (em sentido amplo) a definição do regime jurídico a que se submete o seu exercício e rege as situações em que a Administração atua manejando poder extroverso na persecução de fins públicos.

Referido regime jurídico é identificado como sendo o de direito público.

Extrapola os limites do presente estudo a definição do regime jurídico de direito público. Em linhas bastante gerais, o regime jurídico de direito público consiste no conjunto de princípios e regras que disciplinam o desempenho das atividades desempenhadas na consecução de fins comuns. As principais características do regime de direito público atribuem-se à realização de fins coletivos e à natureza indisponível dos interesses tutelados.

Uma das principais manifestações de poder público de autoridade é o exercício do denominado poder de polícia. Ao se falar em atividade de polícia e poder de polícia estamos nos referindo a uma das formas de exercício do poder estatal.

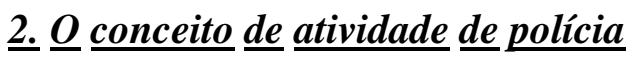

Como conceito operacional, adotaremos a noção de que a atividade de polícia consiste na imposição de restrições à liberdade e à propriedade dos cidadãos, necessárias para se assegurar a manutenção da ordem pública.

Porém, esse conceito comporta várias especificações e depurações para se compreender a sua abrangência.

\subsection{A construção histórica do conceito de polícia administrativa}

A função estatal de polícia administrativa esteve presente em diversas concepções de Estado. Ao longo do tempo, houve variações quanto à abrangência e aos instrumentos empregados no exercício da referida função. Trata-se de expressão que propiciou diversos abusos e equívocos na sua aplicação, sendo invocada como suposto fundamento para a violação de direitos individuais.

\footnotetext{
37 “Como consequência dessa origem legal e não negocial, os poderes são inalienáveis, intransmissíveis e irrenunciáveis, justamente porque são indisponíveis pelo sujeito enquanto criação do Direito objetivo supraordenado ao mesmo. O titular do poder pode exercê-lo ou não, mas não pode transferi-lo; a própria Lei pode, no máximo, permitir sua delegação de exercício (...) Os poderes são também imprescritíveis, ainda que seu exercício possa estar submetido a caducidade ou decadência. Os poderes são, enfim, inesgotáveis e idênticos através do seu exercício, que mais do que consumi-los os confirma. São também insuscetíveis de modificação pelo titular; apenas a Lei, na qual têm sua origem, pode alterá-los ou extingui-los” (Eduardo García de Enterría e Tomás-Ramón Fernández. Curso de derecho administrativo, v. I, 2002, p. 445).
} 
Ainda nos dias de hoje emprega-se amplamente o termo “polícia” para designar uma das formas da atividade do Estado, o que justifica, inclusive, a manutenção da locução, apesar de não mais refletir adequadamente o instituto no Estado Democrático de Direito.

“Polícia” tem origem no latim “politia” e no grego “politeia”. Denota, assim, a referência à “polis”, como comunidade política.

A atividade de polícia é tão antiga quanto o surgimento da sociedade organizada. Reportando-nos à teoria de Hobbes, pode-se dizer que a polícia teria sido o motivo de saída do estado de natureza e a razão de ser do surgimento do Estado. Na concepção hobbesiana, o poder soberano originou-se de um pacto pelo qual o soberano apropria-se dos poderes privados. Retiram-se dos particulares, com seu consentimento, os poderes que lhes eram assegurados no estado de natureza ${ }^{38}$.

O surgimento da polícia como função estatal pode ser demarcado no século XVIII, mais precisamente na França e nos países germânicos ${ }^{39}$. Com o nome Estado-polícia (terminologia introduzida pelo direito alemão, de "Polizeistaat"), designa-se a etapa do Estado moderno em que a forma de governo era a monarquia absoluta. Caracteriza-se pela concentração de poderes no monarca, que os exercia de modo arbitrário. Vincula-se, portanto, ao nascimento do absolutismo.

Antes do surgimento do direito administrativo como ramo autônomo, entre o fim do século XVIII e o início do século XIX, a atividade de polícia dissolveu-se nas demais funções desempenhadas pelo Estado. Nesse período, o termo “polícia” referia-se ao conjunto de ações das autoridades públicas, compreendendo a função de governo, legislativa, a administração no sentido de fornecimento de prestações e de manutenção da ordem, a apuração de crimes e a justiça ${ }^{40}$. Não havia interesse em se identificar, no conjunto de atividades estatais, o sentido de polícia. Toda a atividade administrativa se confundia com a polícia administrativa.

A atividade de polícia inseria-se entre as prerrogativas reconhecidas ao soberano, que não se submetia à lei. Tratava-se de um poder juridicamente ilimitado, que compreendia a emissão de ordens e o exercício de coação de acordo com a conveniência do soberano. Autorizava-se a imposição de limitações à liberdade e à propriedade por qualquer

\footnotetext{
${ }^{38}$ Thomas Hobbes. Leviatã, 2003, p. 147-148. Sobre as construções teóricas de Hobbes, consultem-se, entre outros, Michel Villey. O direito e os direitos humanos, 2007, p. 142-163 e Francisco C. Weffort. Os clássicos da política, v. 1, 2006, p. 51-77.

${ }^{39}$ Jacques Chevallier. Science administrative, 2007, p. 10.

${ }^{40}$ Francis-Paul Bénoit. Le droit administratif français, 1968, p. 739.
} 
finalidade pública que viesse a ser invocada, abrigada na noção genérica de "ordem pública”.

O núcleo do poder de polícia nessa época era o de intervir, mediante a utilização de coação, onde fosse necessário para a preservação da ordem pública. Mas essa intervenção tinha a sua abrangência limitada, tal como era restrita a atuação estatal. O poder de polícia manifestava-se essencialmente por meio de medidas de caráter proibitivo e repressivo, com a imposição de obrigações de não fazer.

Não estava abrangida na função de polícia a promoção do bem estar da população, a adoção de medidas positivas pelo Estado. A atividade de polícia incidia sobre os efeitos das violações à ordem pública e não sobre as suas causas. Como define Gordillo, nessa etapa do processo evolutivo do conceito “o objeto da polícia é limitado e preciso; ilimitados são, no entanto, os meios que pode utilizar”41.

Já nessa época, a polícia não deixa de ser uma função do Estado, ainda que não fosse diferenciada das demais. Mas essa característica de poder absoluto deixou de existir com a submissão do exercício do poder ao direito.

A formação do direito administrativo como ramo autônomo está vinculada ao surgimento do Estado Moderno e do conceito de Estado de Direito.

Com a submissão dos poderes estatais ao ordenamento jurídico, institucionalizou-se o monopólio da violência estatal sob a forma de poder de polícia. Apenas depois da limitação do poder de coerção estatal pelo direito é que foi possível cogitar da obtenção de utilidades concretas fornecidas pelo Estado em benefício da população.

No Estado de Direito, reconheceu-se que o indivíduo é titular de uma esfera de liberdade, que é protegida pelo direito contra as intervenções estatais. A justificativa para a existência de uma atividade estatal de limitação e restrição da liberdade e da propriedade privada passou a ser a de que o exercício desses direitos de liberdade, conferidos aos cidadãos, é passível de gerar perigos para os interesses coletivos protegidos pelo ordenamento jurídico.

Isso se refletiu na evolução do Estado de Polícia para o Estado de Bem-Estar Social e na diferenciação das atividades estatais, quando menos, em dois grandes grupos, a polícia e o serviço público.

\footnotetext{
${ }^{41}$ Tratado de derecho administrativo, t. 2, 2009, p. V-7.
} 


\subsection{A atividade de polícia no Estado de Direito}

Depreende-se que a atividade de polícia consiste em um instituto legado pelo Estado absolutista que foi recondicionado pelo direito. Com o advento do Estado de Direito, essa função púbica foi readequada para ser utilizada de acordo com a nova forma de exercício do poder político.

Em linhas gerais, a doutrina define a atividade de polícia, no contexto do Estado de Direito, a partir dos seguintes elementos: imposição de restrições, limitações ou condicionamentos à atividade privada, que foram previamente estipulados pela lei. Trata-se de delimitar a atividade privada, inclusive mediante o emprego da coerção, com o objetivo de preservação da ordem pública.

Para Otto Mayer, a definição de polícia envolveria a combinação de um fim especial com determinadas formas que lhe servem de meio: “a polícia é a atividade do Estado que tem por fim a defesa da boa ordem da coisa pública, mediante os recursos do poder de autoridade, contra as perturbações que as existências individuais podem ocasionar" ${ }^{42}$.

Como destaca Garrido Falla, na construção do conceito, especialmente no direito alemão, identificou-se a atividade de polícia com a coerção ${ }^{43}$. Diante do descumprimento de uma ordem de polícia, a consequência poderia ser a aplicação de uma sanção. Daí que se reputou ser a coerção essencial para a definição de polícia, de modo a diferenciá-la das outras atividades estatais, desenvolvidas com o emprego de meios não coercitivos.

As principais diferenças da noção atual de atividade de polícia em relação àquela existente no período do Estado absoluto são a instituição e limitação das competências pela lei e a abrangência da noção de ordem pública. São diferenças nucleares, com grandes repercussões no significado a ser atribuído à atividade de polícia e nos meios de que esta se utiliza.

Apesar de o exercício da coerção sempre ter estado presente na noção de polícia, verificaram-se variações em relação aos condicionamentos e limites para o emprego da coerção. No Estado Democrático de Direito, a polícia manifesta-se especialmente por ordens, proibições e autorizações. A coerção apenas pode ser empregada eventualmente, na medida em que for estritamente necessária e observando os limites legais

\footnotetext{
${ }^{42}$ Derecho administrativo alemán, t. II - parte especial, 1982, p. 8. Cabe ressalvar que o objetivo aludido pelo autor, de "defesa da boa ordem da coisa pública", deve ser interpretado de forma adequada em face da configuração atual do Estado.

${ }^{43}$ Tratado de derecho administrativo, v. II, 1992, p. 127.
} 
e o princípio da proporcionalidade. A proporcionalidade entre o condicionamento imposto pela Administração e o benefício coletivo que se procura obter consiste em requisito específico de validade da medida de polícia ${ }^{44}$.

No intento de se afastar eventual vinculação do termo "poder de polícia” à sua origem histórica, associaada ao Estado liberal clássico e exercício autoritário do poder, independentemente da lei, a doutrina propõe a sua substituição por outras expressões, tais como “Administração Ordenadora” e "limitações administrativas”. A esse respeito, um marco fundamental na doutrina nacional é a obra de Carlos Ari Sundfeld ${ }^{45}$.

Nesse contexto, Diogo de Figueiredo Moreira Neto propõe abandonar-se a concepção do "poder de polícia” como sendo um “poder do Estado” para associá-lo a uma função estatal:

é necessário iniciar-se, assim, com uma reflexão sobre o próprio conceito de poder de polícia, propondo-se o abandono em definitivo da ideia de que se está diante de um tipo especial de poder do Estado próprio ou exclusivo da Administração Pública, para aceitar a visão mais moderna e mais ampla, que vem tomando fôlego doutrinário, de que se trata apenas de um tipo de função estatal a ser exercida por quem receba a necessária competência da Constituição e das leis ${ }^{46}$.

Podem-se diferenciar um sentido amplo e um sentido restrito de poder de polícia $^{47}$. Em acepção ampla, corresponderia ao conjunto de atividades estatais condicionadoras da liberdade e da propriedade, atividades estas retratadas em atos praticados tanto pelo Legislativo quanto pelo Executivo. Já o sentido restrito do termo diria respeito exclusivamente aos atos praticados pelo Executivo, disciplinando e limitando os atos dos particulares. Este sentido restrito corresponde à polícia administrativa. Como ensina Maria Sylvia Zanella Di Pietro, a polícia administrativa "se rege pelo Direito

\footnotetext{
${ }^{44}$ Hely Lopes Meirelles. Direito administrativo brasileiro, 2012, p. 147. Como sugere Floriano de Azevedo Marques Neto, a proporcionalidade das medidas de polícia consiste em um dos seus principais aspectos inclusive para fins de controle. Assim se posiciona ao tratar do controle da atividade de polícia pelo Judiciário: "Este controle, hoje, não se prende apenas à legalidade. Talvez a dimensão mais importante desse controle se dê sob a égide do princípio da proporcionalidade, que permite - e, mais que isso, exige - que se controle se a medida de polícia se mostra: (i) adequada àquele interesse público residente em sua finalidade; (ii) necessária tendo em vista a situação concreta em que a proporcionalidade é aplicada e as outras possíveis formas de disciplinar o caso menos onerosas; e (iii) ponderado em intensidade com os fins buscados" (Poderes da Administração Pública, 2012, p. 235).

${ }^{45}$ Carlos Ari Sundfeld designa, sob o rótulo de "administração ordenadora”, as diversas atividades administrativas cujo exercício envolve o manejo de poder extroverso. Na definição do doutrinador, "Administração ordenadora é a parcela da função administrativa, desenvolvida com o uso do poder de autoridade, para disciplinar, nos termos e para os fins da lei, os comportamentos dos particulares no campo de atividades que lhes é próprio" (Direito administrativo ordenador, 1997, p. 20).

${ }^{46}$ Mutações do direito administrativo, 2001, p. 131 - grifos no original.

${ }^{47}$ Como ensinam Maria Sylvia Zanella Di Pietro. Direito administrativo, 2013, p. 123-124; Adilson Abreu Dallari. Inspeção de segurança veicular - credenciamento - desnecessidade de autorização legislativa, 1996, p. 433; e Celso Antônio Bandeira de Mello. Curso de direito administrativo, 2013, p. 838-839, entre outros.
} 
Administrativo, incidindo sobre bens, direitos ou atividades" e seu exercício "se reparte entre diversos órgãos da Administração"48.

Considerando-se que no presente estudo pretende-se analisar o exercício por entidades privadas de atividades de polícia de competência do Executivo, relativas à aplicação da lei ao caso concreto, ocupamo-nos especificamente das atividades de "polícia administrativa" 49 .

A polícia administrativa consistiria então no exercício de competências pela Administração voltadas à imposição de restrições e limitações às atividades privadas, que objetivam a preservação da ordem pública.

\subsection{A atividade de polícia administrativa e a função pública}

Uma noção clássica da atividade de polícia determina o seu enquadramento como função pública. No entanto, essa afirmação pode não ser a mais adequada para refletir a atividade de polícia à medida que o conceito de função pública é controverso.

A investigação acerca do papel desempenhado pela Administração Pública foi objeto de amplos estudos doutrinários. Questionou-se especialmente se a Administração exerceria uma função típica, adotando como ponto de partida a teoria da separação de poderes. O debate dizia respeito principalmente à existência ou não de um critério apto a definir a função administrativa, de modo a diferenciá-la das funções típicas dos demais poderes estatais.

Como constata Manuel Izquierdo Carrasco, esse debate foi evidenciado especialmente nos estudos que tinham por objeto a colaboração de particulares na execução de atividades administrativas ${ }^{50}$. Procurava-se identificar em que consistiria a função administrativa para então se avaliar a possibilidade de a sua execução ser realizada, ainda que parcialmente, por entidades privadas.

Para parcela da doutrina, a função pública seria equivalente à atividade estatal, no sentido de abranger todas as atividades atribuídas ao Estado.

Já para outros, a função pública estaria indissociavelmente vinculado ao exercício do poder soberano. Apenas as atividades realizadas mediante o emprego de poderes públicos seriam enquadradas no conceito de função pública.

${ }^{48}$ Direito administrativo, 2013, p. 119 - grifos no original.

49 A polícia administrativa pode ser diferenciada da denominada polícia judiciária, que age diante da ocorrência do ilícito penal. A polícia judiciária é regida pelo direito processual penal e é exercida pelas polícias civil e militar (Maria Sylvia Zanella Di Pietro. Direito administrativo, 2013, p. 119).

${ }^{50}$ Algunas cuestiones generales a propósito del ejercicio privado en el ámbito de la seguridad industrial, 2001, p. 375. 
Esta seria uma concepção restrita de função pública, de modo a abarcar apenas algumas das atividades desempenhadas pelo Estado, especificamente aquelas que envolvem o exercício de prerrogativas e poderes próprios do Estado.

Assim, não haveria equivalência entre as atividades assumidas pelo Estado e a função estatal. Apenas algumas das atividades estatais retratariam o exercício de função pública - mais especificamente, aquelas que compreenderiam a prerrogativa de puissance publique.

Guido Zanobini, por exemplo, sustenta que a função pública não retrata uma atividade estatal qualquer, devendo apresentar uma natureza jurídica diferenciada: “a atividade deve, além disso, ser pública não apenas pelo fim a que serve, mas também pela sua eficácia jurídica: essa pode compreender a emanação de regulamentos, de atos de polícia, a formação de certificados e de atos em geral dotados de fé pública”51.

Também para Santamaría Pastor o conceito de função pública em sentido estrito não é equivalente ao de atividade estatal de interesse público, sendo necessário que “os atos concretos em que se desenvolva possuam eficácia jurídico-pública (por exemplo, a atribuição de fé pública por um notário) ou sejam objeto de um serviço público em sentido estrito (por exemplo, o serviço de segurança)" ${ }^{\text {"52. }}$.

No mesmo sentido, Sainz Moreno define que a caracterização como função pública não decorre apenas do reconhecimento de interesse público na atividade. É utilizada para “designar certas atividades que gozam de uma especial eficácia reconhecida pelo Direito ou que são exercitadas fazendo uso de poderes que, em princípio, correspondem aos poderes públicos”, ${ }^{33}$.

O critério de função pública em sentido estrito foi utilizado especialmente para diferenciá-la do serviço público. O serviço público, por envolver principalmente o fornecimento de prestações materiais, não tem por objeto principal o exercício de poderes soberanos, ainda que estes possam também encontrar-se associados ao serviço público, como instrumentos necessários à sua prestação adequada.

É relevante ter ciência da diferenciação proposta por parcela da doutrina, especialmente estrangeira, entre os conceitos de atividade estatal e função pública, para se interpretar adequadamente a produção doutrinária alienígena.

De todo modo, essa distinção não será adotada no âmbito do presente estudo. O conceito de função pública será utilizado para se referir tanto às atividades que envolvem

\footnotetext{
${ }^{51}$ Corso di diritto amministrativo, v. III, 1946, p. 303.

52 Principios de derecho administrativo, v. I, 1998, p. 431.

${ }^{53}$ Ejercicio privado de funciones publicas, 1983, p. 1781.
} 
quanto às que não implicam o manejo de poderes públicos. Quando se pretender restringir a função pública à parcela da atividade estatal que é realizada fazendo-se uso de poderes públicos, a delimitação será expressamente indicada.

Adota-se, assim, o conceito que prevalece no direito nacional acerca da atividade administrativa, para o qual o manejo de poderes públicos não é essencial para toda e qualquer atividade administrativa.

Como define Maria Sylvia Zanella Di Pietro, a atividade desempenhada pela Administração Pública consiste na "atividade concreta e imediata que o Estado desenvolve, sob regime jurídico total ou parcialmente público, para a consecução dos interesses coletivos" ${ }^{54}$.

\subsection{A atividade de polícia administrativa e o poder de polícia}

Conceitualmente, pode ser diferenciada a atividade desempenhada pela Administração, que é a de polícia, do poder envolvido no seu exercício, que é o poder de polícia. Como define Otto Mayer, “a polícia é uma espécie particular de atividade administrativa; o poder de polícia é a manifestação do poder público próprio de tal atividade" ${ }^{55}$.

Nesse sentido, parcela da doutrina propõe a distinção entre o poder de polícia, como sendo aquele manejado pelo Legislativo, da atividade de polícia, que é aquela desempenhada no exercício da função administrativa e manifestada em atos de polícia.

O objetivo dessa diferenciação é destacar a necessidade de os atos restritivos da liberdade e da propriedade encontrarem-se previstos em lei. Nas palavras de José Afonso da Silva, poder de polícia “é manifestação do poder legislativo, único competente para impor limitações aos direitos individuais, mediante lei formal”56. Já a atividade de polícia é a função administrativa exercida mediante a prática de atos administrativos, subordinados ao princípio da legalidade, voltados à implementação e verificação do cumprimento das normas 57 .

\footnotetext{
${ }^{54}$ Direito administrativo, 2013, p. 57.

${ }^{55}$ Derecho administrativo alemán, t. II, 1982, p. 3.

${ }^{56}$ Poder de polícia, 1978, p. 243.

${ }^{57}$ Ob. e loc. cit. No direito nacional, essa distinção também é adotada, por exemplo, por Adilson Dallari. Credenciamento, 1997, p. 48 e Andreas Joachim Krell. As competências administrativas do artigo 23 da CF, sua regulamentação por lei complementar e o "poder-dever" de polícia, 2003.
} 
Portanto, ao se referir à função administrativa, o termo mais adequado a ser empregado seria atividade de polícia e não poder de polícia ${ }^{58}$. A polícia é a atividade estatal na qual o poder de polícia é empregado. No que diz respeito à função administrativa, a polícia é uma atividade e não uma faculdade ou prerrogativa ${ }^{59}$.

Essa diferenciação também é importante para destacar que a atividade de polícia é manifestada de diversas formas, que são necessárias para a realização do objeto principal mas que não envolvem sempre o exercício de prerrogativas de autoridade e o emprego de mecanismos de coação ${ }^{60}$.

No presente trabalho, adota-se o termo atividade de polícia administrativa tanto para se referir aos atos que implicam o exercício do poder de polícia propriamente dito quanto aos atos acessórios e instrumentais à efetivação do poder de polícia, incluindo os atos preparatórios e sucessivos ao exercício do poder de polícia.

\section{A finalidade $\underline{\text { da atividade }} \underline{\text { de }}$ polícia administrativa}

É usual a afirmação de que o objetivo visado com o exercício da polícia é a preservação da ordem pública. Como define Garrido Falla, “a finalidade peculiar da polícia é a ordem pública”,61.

Alguns autores chegam a visualizar semelhança entre serviço público e atividade de polícia justamente por esse aspecto. Pierre Delvolvé afirma, por exemplo, que “a missão de manutenção da ordem corresponde ela mesma a um serviço público”62.

\footnotetext{
${ }^{58}$ Ao se propor a distinção entre polícia e poder de polícia nos termos acima expostos, não se está adotando a diferenciação feita por alguns doutrinadores no sentido de que o "poder de polícia” seria mais amplo do que a "polícia” em termos de objeto. Para alguns doutrinadores, tais como Bielsa e Villegas Basavilbaso, o poder de polícia teria por objeto a promoção do bem estar geral. Já a atividade de polícia, atribuída precipuamente à Administração, teria por objeto apenas a proteção da segurança, moralidade e salubridade públicas - ou seja, retoma a noção do direito francês da atividade de polícia, sem levar em consideração o surgimento das denominadas "polícias especiais" naquele regime, para dar conta da ampliação da noção de ordem pública. Confira-se o exame do posicionamento desses doutrinadores e a crítica à distinção entre poder de polícia e atividade de polícia, a partir desses critérios, em Agustín Gordillo. Tratado de derecho administrativo, t. 2, 2009, p. V-18-19.

${ }^{59}$ Ao rejeitar a noção segundo a qual o poder de polícia conferiria um poder próprio à Administração, sujeito a um regime jurídico diferenciado, Diogo de Figueiredo Moreira Neto afasta "a ideia da existência de uma faculdade ou poder diferenciado como atributo da Administração Pública” e sustenta ser o poder de polícia "uma específica manifestação do poder estatal, que caracteriza um tipo de atividade administrativa em que se executa a limitação e o condicionamento de direitos fundamentais” (Mutações do direito administrativo, 2001, p. 132-133).

${ }^{60}$ Nesse sentido, Jean-Paul Négrin diferencia as atividades de polícia em si daquelas que têm um objeto de polícia mas que não se exercem com o emprego de meios de polícia, que seriam as ações prestacionais (L'intervention des personnes morales de droit prive dans l'action administrative, 1971, p. 99).

${ }^{61}$ Las transformaciones del régimen administrativo, 1962, p. 117; Francis-Paul Benoit. Le droit administratif français, 1968, p. 741.

${ }^{62}$ Le droit administratif, 1994, p. 29. Sobre a distinção entre serviço público e atividade de polícia, v. item I.5.
} 
Para atingir o objetivo de preservação da ordem pública é que se concentraria no Estado o exercício legítimo da violência, a ser utilizada quando o particular não observar as restrições impostas à sua atividade. O emprego dos meios de coerção seria justificado pelo objetivo a ser atingido, a manutenção da ordem pública.

A definição de ordem pública é contingente e variável de acordo com o contexto histórico. O seu conteúdo depende das concepções dominantes em cada momento acerca dos fins do Estado. Garrido Falla registra que as alterações do conceito de ordem pública é que consistem no aspecto fundamental para se compreender as transformações da noção de polícia administrativa ${ }^{63}$.

No âmbito do Estado liberal, a ordem pública restringia-se à manutenção da segurança interna e externa. Na esfera municipal, abrangia também a preservação da tranquilidade e salubridade públicas ${ }^{64}$. Em linhas gerais, tratava-se de proteger a propriedade e a liberdade, apenas em relação ao que era estritamente necessária a intervenção estatal.

A delimitação do âmbito da atividade de polícia pela doutrina francesa à defesa da ordem pública, da segurança e da salubridade decorre da influência legislativa. A competência da autoridade municipal em matéria de polícia foi delimitada a esses três aspectos pela Lei de 5 de abril de 1884, art. $97^{65}$. Para superar essas limitações, ainda antes do início do século XX, foram criadas diversas “polícias especiais” - dos minérios, das águas, florestal, da pesca, das máquinas a vapor etc. - para abranger medidas estabelecidas para atender a necessidades específicas, não incluídas na denominada “polícia geral”, ainda restrita à polícia de segurança ${ }^{66}$.

Outro aspecto a ser considerado na ampliação do conceito de ordem pública é o fato de que as ameaças deixam de provir apenas do poder público para ter sua origem também na atividade dos outros cidadãos. Nesse sentido, Ranelletti destaca na sua conceituação de polícia a necessidade de proteção da sociedade em face da atuação dos riscos provocados pela atuação dos cidadãos, no exercício da sua liberdade: “o escopo da

\footnotetext{
${ }^{63}$ Tratado de derecho administrativo, v. II, 1992, p. 129-130.

${ }^{64}$ Charles-Édouard Minet. Droit de la police administrative, 2007, p. 34.

${ }^{65}$ Caio Tácito. O poder de polícia e seus limites, 1952, p. 4.

${ }^{66}$ As polícias especiais do direito francês são consideradas apenas "forças de polícia” e não "autoridades de polícia”. Apenas as autoridades podem editar regras de polícia. As forças podem apenas desempenhar atribuições materiais de controle e vigilância (Jean-Paul Négrin. L'intervention des personnes morales de droit privé dans l'action administrative, 1971, p. 107).
} 
polícia é garantir o todo social e as suas partes contra os danos que podem provir da atividade humana"67.

Com o Estado de Bem-Estar Social, o conceito de ordem pública foi ampliado. A função do Estado passou a ser também a de promoção de interesses coletivos. O conceito de ordem pública teve seus contornos expandidos e adquiriu maior complexidade, para abranger o incremento das condições sociais da população, a intervenção do Estado na economia bem como a inclusão da proteção de outros aspectos, tais como a moralidade e a dignidade da pessoa humana. Como ensina Maria Sylvia Zanella Di Pietro,

o próprio conceito de ordem pública, antes concernente apenas à segurança, passou a abranger a ordem econômica e social, com medidas relativas às relações de emprego, ao mercado dos produtos de primeira necessidade, ao exercício das profissões, às comunicações, aos espetáculos públicos, ao meio ambiente, ao patrimônio histórico e artístico nacional, à saúde e tantas outras ${ }^{68}$.

Ou seja, além da ampliação do conceito de ordem pública, passou a ser incluída na sua abrangência também a promoção do bem estar comum, inclusive mediante a adoção de medidas positivas. Em termos práticos, uma mesma medida de prevenção de danos à ordem pública usualmente implica também a promoção da ordem pública. Quando são impostos limites à construção de um imóvel, está-se promovendo a preservação da ordem pública no local. A imposição de medidas restritivas para se evitar a propagação de doenças também implica promover a saúde pública da população.

Uma questão interessante relacionada ao conceito de ordem pública diz respeito aos seus limites. Na sua concepção tradicional, excluíam-se da ordem pública as relações estritamente privadas. No entanto, não é de fácil delimitação o marco onde não mais se aplica a noção de ordem pública e se iniciam as relações estritamente privadas, nas quais não seria cabível a intervenção estatal.

A esse respeito, Paulo Otero registra que uma das características assumidas pela função administrativa mais recentemente consiste na sua intervenção para o que denomina "arbitragem de conflitos entre privados” “9 . A intervenção da Administração passa a ter como propósito também a resolução de conflitos de interesses entre particulares. Da relação tradicionalmente bilateral, em que a Administração se colocava em oposição aos particulares, passa-se a uma relação trilateral, em que a Administração disciplina e controla

\footnotetext{
${ }^{67}$ La polizia di sicurezza, 1904, p. 233.

${ }^{68}$ Direito administrativo, 2013, p. 122 - grifos no original.

${ }^{69}$ Legalidade e Administração Pública, 2003, p. 325-329.
} 
relações entre particulares, não assumindo a posição de parte mas aplicando as condições estabelecidas pelo próprio Estado para essas relações ${ }^{70}$.

Outra questão ainda diz respeito à proteção do indivíduo contra si mesmo, como estando compreendida na noção de ordem pública.

Sobre esse tema, o exemplo paradigmático, apresentado em diversas obras de direito administrativo, é o do arremesso de anões ${ }^{71}$. Tratava-se de uma atividade de diversão, geralmente realizada em discotecas, à qual os anões submetiam-se voluntariamente e eram remunerados para tanto. Diante de normas municipais vedando tal atividade, o Conselho de Estado posicionou-se favoravelmente a tais interdições. Para tanto, assentou que “o respeito da dignidade da pessoa humana é um dos componentes da ordem pública”72. A autoridade local encontrava-se autorizada a interditar a realização de atividades violadoras da dignidade e, portanto, imorais, apesar de os anões submeterem-se livremente a tal exibição e serem adotadas as medidas de segurança necessárias.

Logo, a noção atual de proteção da ordem pública abrange também a moralidade, incluindo a dignidade da pessoa humana.

\section{4. $\underline{\text { O fundamento }} \underline{\text { da }} \underline{\text { atividade }} \underline{\text { de }}$ polícia administrativa}

A questão do fundamento da atividade de polícia encontra-se diretamente relacionada às razões pelas quais se faz necessária a imposição de restrições à liberdade e à propriedade dos particulares. Vincula-se à necessidade de limitação e, ao mesmo tempo, de proteção da liberdade e propriedade privada para a vida em sociedade. Logo, o fundamento da polícia é também aquele que justifica as limitações e restrições impostas à liberdade e à propriedade.

Também por isso, o fundamento da polícia sofre o impacto do conceito atribuído à “ordem pública” em determinado momento histórico ${ }^{73}$. Como já se analisou,

\footnotetext{
${ }^{70}$ Em alguma medida, é o que ocorre com as regras de proteção da concorrência, em que o Estado intervém, pelos seus órgãos e entes responsáveis, para evitar que o abuso do livre exercício da atividade econômica por alguns acabe violando esse mesmo direito dos demais. Cabe registrar que a atividade de defesa da concorrência não consiste propriamente em exercício de polícia administrativa, sendo mais adequadamente enquadrada nas funções administrativas de intervenção ou de regulação, ressalvando-se haver diversidade na doutrina quanto à classificação das funções administrativas.

${ }^{71}$ René Chapus. Droit administratif général, t. 1, 1999, p. 676-678; Charles Debbasch. Droit administratif, 2002, p. 450-451; Georges Dupuis, Marie-José Guédon e Patrice Chrétien. Droit administratif, 2009, p. 524.

72 CE Ass. 27 de outubro de 1995, Comm. de Morsang-sur-Orge e Ville d'Aix-en-Provence, p. 372, concl. Patrick Frydman.

${ }^{73}$ Fernando Garrido Falla. Los medios de la policia y la teoria de las sanciones administrativas, 1959, p. 14.
} 
atualmente, os bens a serem tutelados com o emprego das medidas de polícia são muito mais amplos do que a preservação da segurança interna e externa.

São recorrentes as manifestações doutrinárias que associam a atividade de polícia ao exercício da soberania estatal e ao emprego de determinados instrumentos jurídicos para atingir certo fim (realização da ordem pública) ${ }^{74}$. Sob outra perspectiva, os administrados teriam a sua liberdade e propriedade restringidas e limitadas porque se encontram em posição de submissão em relação ao Estado.

Essa situação de supremacia estatal e de submissão do administrado seria consequência do fato "de que nem o direito de liberdade pode ser absoluto nem a propriedade pode ser utilizada contrariamente aos interesses da comunidade”75.

No entanto, essa supremacia estatal apenas pode ser exercida tendo em vista determinadas finalidades. Em um Estado Democrático de Direito, deve ter por objetivo a concretização dos direitos fundamentais dos cidadãos ${ }^{76}$.

Nesse sentido, Alexandre Santos de Aragão define como fundamento da atividade de polícia a "soberania que o Estado exerce sobre todas as pessoas e coisas no seu território, que faz com que toda atividade ou propriedade esteja, observado o ordenamento jurídico-constitucional, condicionado ao bem-estar da coletividade e à conciliação com os demais direitos fundamentais"77.

Essa supremacia pode se revelar de modos distintos. A esse respeito, o direito estrangeiro concebeu a distinção entre supremacia geral e supremacia especial. Esta daria ensejo à existência de relações especiais de poder entre Administração e certos administrados.

Renato Alessi destaca que a Administração pode se encontrar em posição de supremacia em relação a determinados particulares, com fundamento diverso da simples titularidade do poder de império ${ }^{78}$. São situações em que se faz necessária uma disciplina

\footnotetext{
${ }^{74}$ Para Garrido Falla, a atividade de polícia consiste na manifestação mais típica e imediata da situação de supremacia do Estado (ob. cit., p. 16).

${ }^{75}$ Fernando Garrido Falla. Tratado de derecho administrativo, v. II, 1992, p. 131.

${ }^{76}$ A releitura do princípio da supremacia do interesse público é essencial para a sua compreensão no contexto do Estado Democrático de Direito. Para ilustrar o amplo debate travado na doutrina acerca do referido princípio, podem ser consultados, entre outros, Marçal Justen Filho. Curso de direito administrativo, 2013, esp. p. 143-160, e Conceito de interesse público e a "personalização" do direito administrativo, 1999, p. 115136; Floriano de Azevedo Marques Neto. Regulação estatal e interesses públicos, 2002; Maria Sylvia Zanella Di Pietro e Carlos Vinícius Alves Ribeiro (Coord.). Supremacia do interesse público e outros temas relevantes do direito administrativo, 2010; Romeu Felipe Bacellar Filho e Daniel Wunder Hachem (Coord.). Direito administrativo e interesse público, 2010; Daniel Sarmento (Coord.). Interesses públicos versus interesses privados, 2007; Gustavo Binenbojm. Uma teoria do direito administrativo, 2008.

${ }^{77}$ Curso de direito administrativo, 2012, p. 187.

${ }^{78}$ Principi di diritto amministrativo, v. I, 1978, p. 281.
} 
especial, mais acentuada, do comportamento pessoal de particulares, para o melhor desenvolvimento das atividades compreendidas na relação jurídico-administrativa.

Seria com fundamento no poder disciplinar que a Administração aplicaria sanções aos indivíduos que se encontram em relação de sujeição especial em face da Administração. Já a atividade de polícia encontrar-se-ia vinculada à normal supremacia geral exercida pela Administração ${ }^{79}$.

Nessa mesma linha, Guido Zanobini destaca que a aplicação de uma sanção administrativa e de uma sanção disciplinar, apesar de terem a mesma função, representariam manifestação e aplicação de duas ordens de poderes distintas. A sanção disciplinar estaria inserida precisamente nas relações de sujeição especial que o Estado mantém com determinados particulares ${ }^{80}$.

A diferenciação entre as manifestações de soberania derivaria de uma qualidade especial do administrado, que o colocaria em contato mais direto e imediato com a Administração. Alguns dos exemplos recorrentes são os do funcionário público, do detento, do que presta serviço militar obrigatório e do aluno de escola pública. Esses sujeitos submetem-se não apenas às regras gerais mas também às normas específicas da instituição à qual se encontram vinculados. O vínculo que dá ensejo a essa relação especial de poder pode tanto ser formado voluntariamente quanto compulsoriamente.

Com a teoria das situações de supremacia estatal, procurou-se identificar as situações em que os cidadãos poderiam submeter-se a maiores restrições em sua liberdade e propriedade. Nas relações especiais de poder, seriam aplicados limites diferenciados em relação àqueles decorrentes da lei, aplicável à generalidade dos cidadãos.

Celso Antônio Bandeira de Mello foi um dos principais doutrinadores nacionais a adotar a diferenciação entre as diversas formas de exercício da soberania estatal. No exercício da supremacia geral, cabe à lei estabelecer seus contornos. Quanto à supremacia especial, o autor afirma que o seu fundamento último é a lei. Porém, reconhece que a lei, de modo explícito ou implícito, pode conferir à Administração a possibilidade de expedir regras a serem aplicadas às relações de supremacia especial. Assim, o fundamento imediato da supremacia especial é o vínculo que se estabelece entre o Estado e o particular, que deve observar os limites estabelecidos pela lei ${ }^{81}$.

\footnotetext{
${ }^{79}$ Renato Alessi. Ob. cit., p. 283-287. No mesmo sentido, Heraldo Garcia Vitta. Soberania do Estado e poder de polícia, 2011, p. 94.

${ }^{80}$ Corso di diritto amministrativo, v. III, 1946, p. 52-53.

${ }^{81}$ Curso de direito administrativo, 2013, p. 841-843. O autor expõe aqueles que reputa serem os requisitos que devem ser observados no exercício de poderes nas relações de sujeição especial. Os condicionamentos expostos pelo doutrinador enfatizam a necessidade de observância do princípio da legalidade. Como limite
} 
Nesse sentido, Celso Antônio Bandeira de Mello sustenta que

não se confundem com a polícia administrativa as manifestações impositivas da Administração que, embora limitadoras da liberdade, promanam de vínculos ou relações específicas firmadas entre o Poder Público e o destinatário de sua ação. Desta última espécie são as limitações que se originam em um título jurídico especial, relacionador da Administração com terceiro ${ }^{82}$.

Aplicando esse entendimento, o doutrinador exclui das relações de polícia administrativa os atos que atingem, por exemplo, os usuários de serviços públicos. Os atos de polícia administrativa apenas seriam aqueles exercidos no âmbito das relações da denominada "supremacia geral”

A maior problemática relacionada à teoria da sujeição especial diz respeito às suas origens históricas. Trata-se de concepções no sentido de que, para aqueles que se vinculam de um modo estável com a Administração, poderiam ser impostas restrições mais intensas, à margem da lei.

Já ao se conceberem as relações de sujeição especial apenas como situações regidas por estatutos especiais, editados em conformidade com a lei ${ }^{84}$, é possível aplicá-las de modo compatível com os princípios do Estado Democrático de Direito. O relevante a se destacar é que a observância do princípio da legalidade, com todas as suas decorrências, não pode ser vulnerada em qualquer caso.

Considerando-se que o princípio da legalidade deve ser sempre observado, seja nos casos de relações gerais seja nas relações específicas que vinculam a Administração aos particulares, não se adota a teoria da sujeição especial no presente trabalho. As denominadas situações de sujeição especial, em que se verifica uma relação peculiar entre a Administração e o particular, não se submetem propriamente a um regime jurídico diferenciado à medida que essa relação deverá ser disciplinada pela lei, observando-se os limites de discricionariedade que eventualmente a lei conferir ao administrador.

positivo, destaca-se o de que os poderes a serem exercidos "tenham que encontrar seu fundamento último em lei que, explícita ou implicitamente, confira aos estabelecimentos e órgãos públicos em questão atribuições para expedir ditos regulamentos, os quais consistirão em especificações daqueles comandos” (ob. cit., p. 843 grifos no original). Como condicionamento negativo, é relevante destacar o de que os poderes "não podem infirmar qualquer direito ou dever, ou seja, não podem contrariar ou restringir direitos, deveres ou obrigações decorrentes de norma (princípio ou regra) de nível constitucional ou legal, nem prevalecer contra a superveniência destes” (ob. cit., p. 844).

${ }^{82}$ Curso de direito administrativo, 2013, p. 839 - grifos no original.

${ }^{83}$ Ob. cit., p. 839-840.

${ }^{84}$ Nesse sentido, Luís S. Cabral de Moncada propõe substituir a expressão “relações especiais de poder” por "estatutos especiais”, para evidenciar que se trata de relações igualmente sujeitas ao princípio da legalidade (As relações especiais de poder no direito português, 2001, p. 227). 
Porém, cabe ressaltar um aspecto da teoria da relação de sujeição especial que apresenta especial interesse para o objeto do presente estudo. Trata-se das constatações, retratadas nas lições de Zanobini e Alessi, no sentido de que a conduta dos cidadãos em geral submete-se à atividade administrativa de polícia. Já no que diz respeito aos que se encontram em relação de sujeição especial, aplica-se o poder disciplinar. Como se analisa adiante, a origem diferenciada do poder disciplinar em relação à atividade de polícia é relevante para se identificar a presença ou não do exercício de poderes públicos delegados ${ }^{85}$.

\section{Atividade de polícia administrativa $\underline{\text { e serviço público }}$}

É possível localizar os fundamentos da distinção entre serviço público e atividade de polícia na célebre polêmica da doutrina francesa acerca do critério do direito administrativo.

Aqueles que defendiam que o direito administrativo regia os atos de manifestação de "puissance publique", tal como Hauriou, aproximam-se dos que reconduzem toda atividade estatal à manifestação de poder de império e do monopólio da violência, ainda que limitados pelo direito. Em Hauriou, a noção de polícia não é oposta à de serviço público e sim complementar. A polícia seria o fim do serviço público porque seu objetivo seria prestar um serviço ao público. Já no serviço público também há poderes de restrição e de coação, necessários para a organização dos serviços. Por isso, Hauriou coloca indiferentemente um e outro na base da sua teoria do direito público ${ }^{86}$. Todo o serviço público deveria ser motivado por um pensamento de polícia e toda atividade de polícia seria um serviço público. A polícia seria o fim visado e o serviço público, o procedimento adotado para se atingir essa finalidade.

Já os que sustentavam ser o critério do serviço público aquele que definia o direito administrativo, como Duguit, reputavam que a existência do Estado justificava-se pela prestação de utilidades essenciais para a satisfação de interesses coletivos. Na Escola do Serviço Público, a polícia não era concebida como uma das funções do Estado porque a sua única função seria a prestação de serviço público. O conceito de serviço público compreendia tanto as atividades cujo exercício demandava a utilização de poderes de

\footnotetext{
${ }^{85}$ V. item III.7.4.3.

${ }^{86}$ Etienne Picard. La notion de police administrative, t. I, 1984, p. 88.
} 
autoridade quanto as atividades que deles prescindiam. A polícia é então concebida como um serviço público, entre outros.

Pode-se dizer que a superação da polêmica ocorreu com o reconhecimento de que o Estado tem por finalidade a prestação de serviço público mas que também concentra em si o monopólio da violência legítima.

A distinção entre atividade de polícia e serviço público resulta bastante clara ao se conceber a primeira como sendo exclusivamente prescritiva e o segundo, prestacional. Para Vedel e Delvolvé, a polícia destinava-se a regular o âmbito no qual os particulares exerciam as atividades para satisfazer suas necessidades enquanto que o serviço público tinha por objetivo satisfazer diretamente essas necessidades. Daí a concepção de que a polícia operava por prescrições e o serviço público, por prestações. Mas os autores ressalvam que a oposição não é absoluta à medida que a polícia em si poderia ser considerada um serviço público, tanto no sentido orgânico quanto funcional ${ }^{87}$.

Atualmente, não há maiores controvérsias quanto à distinção teórica entre os conceitos de atividade de polícia, como desempenho de atos de imposição de restrições, limitações ou condicionamentos à atividade privada, e de serviço público, como fornecimento de utilidades essenciais aos cidadãos ${ }^{88}$. A atividade de polícia é usualmente definida como sendo uma atividade estatal negativa, no sentido de restringir, limitar a atividade dos particulares. Sob esse aspecto, opor-se-ia à atividade de prestação de serviço público, que envolve a oferta de utilidades aos usuários.

Na realidade, a aplicação concreta dos conceitos não propicia a distinção tão nítida entre as duas atividades.

Ainda que em termos abstratos a diferença entre as atividades não seja apta a gerar maiores dúvidas, em termos concretos elas podem não se apresentar tão distintas entre si. Em primeiro lugar, constata-se uma crescente integração das diversas atividades estatais, que se utilizam de diversos meios para atingir seus fins. Em segundo lugar, observa-se uma nítida ampliação do conceito de ordem pública e da intervenção estatal necessária para a

\footnotetext{
${ }^{87}$ Droit administratif, 1984, p. 1062-1063. Também para Charles Debbasch a polícia seria um serviço público em sentido orgânico e funcional, por ser integrada por um conjunto de pessoas especializadas e desempenhar uma função de interesse geral. Mas a polícia se distingue do serviço público quanto à suas finalidades, procedimentos e efeitos (Droit administratif, 2002, p. 447).

${ }^{88}$ A distinção nítida dos conceitos é assim apresentada por Celso Antônio Bandeira de Mello: "Enquanto o serviço público visa a ofertar ao administrado uma utilidade, ampliando, assim, o seu desfrute de comodidades, mediante prestações feitas em prol de cada qual, o poder de polícia, inversamente (conquanto para a proteção do interesse de todos), visa a restringir, limitar, condicionar, as possibilidades de sua atuação livre, exatamente para que seja possível um bom convívio social. Então, a polícia administrativa constitui-se em uma atividade orientada para a contenção dos comportamentos dos administrados, ao passo que o serviço público, muito ao contrário, orienta-se para a atribuição aos administrados de comodidades e utilidades materiais” (Curso de direito administrativo, 2013, p. 700-701 - grifos no original).
} 
sua preservação. Em terceiro lugar, há uma tendência de as atividades materiais de polícia serem qualificadas como serviço público. Por fim, a prestação de serviço público implica também, ainda que com caráter acessório, o manejo de poderes estatais para restringir a liberdade e a propriedade na medida necessária para se garantir a prestação de utilidades essenciais à coletividade.

Portanto, não é incomum que atividade de polícia e serviço público se manifestem conjuntamente. Uma determinada estrutura estatal ou concessionária de serviço público pode desempenhar tanto atividade de polícia quanto prestar serviço público. Como constata Marçal Justen Filho, "há uma tendência a que toda a atividade estatal apresente natureza complexa, de modo que não apenas haja a limitação à autonomia privada, mas, concomitantemente, verifique-se a satisfação de necessidades coletivas”,

A distinção entre serviço público e atividade de polícia, em alguma medida, pode ser reportada à diferenciação feita pelo direito francês entre os serviços públicos administrativos e os serviços públicos industriais e comerciais. Os serviços públicos industriais e comerciais do direito francês aproximam-se do que é considerado atividade econômica em sentido estrito no direito nacional ${ }^{90}$.

Note-se que, na França, significativa parcela das atividades estatais são qualificadas como sendo serviço público. Há quase que uma equiparação entre os serviços públicos e atividade administrativa. O instituto do serviço público acaba por abranger atividades que, no direito nacional, não são consideradas serviço público. Ainda que os serviços públicos administrativos do direito francês não possam ser equiparados às atividades de polícia no direito nacional, pode-se afirmar que o seu exercício envolve o manejo de poderes de autoridade em proporção bastante mais elevada do que se passa em relação aos serviços públicos industriais e comerciais.

Mesmo assim, admite-se a delegação dos serviços públicos administrativos, desde que essa transferência não implique o exercício de poder de coação por particulares ${ }^{91}$. A possibilidade de concessão de serviços administrativos foi reconhecida expressamente

\footnotetext{
${ }^{89}$ Curso de direito administrativo, 2013, p. 597.

${ }^{90}$ Para a diferenciação, aplicam-se os critérios do objeto do serviço, do modo de organização, das condições de funcionamento e da origem dos recursos, sendo que os serviços industriais e comerciais devem apresentar semelhança com as empresas privadas em relação a todos estes aspectos, operando em condições similares às das empresas privadas. Sobre o tema, podem ser conferidos, entre outros, André de Laubadère. Direito público económico, 1985, p. 456-458 e René Chapus. Droit administratif général, t. 1, 1999, p. 565-576. Como destaca Jean Rivero, o juiz pode considerar equivocada a qualificação dada pelo texto legal a determinado serviço como sendo industrial e comercial e restitui o seu caráter administrativo (Direito administrativo, 1981, p. 499).

${ }^{91}$ Claudie Boiteau. Les conventions de délégation de service public, 1999, p. 61.
} 
pelo Conselho de Estado, em parecer de 7 de outubro de 1986 ${ }^{92}$ : “o caráter administrativo de um serviço público não impede a coletividade territorial de confiar a sua execução a pessoas privadas, sob a reserva no entanto de que o serviço não se encontre entre aqueles que, por sua natureza ou pela vontade do legislador, não possam ser assegurados a não ser pela própria coletividade territorial”93.

Mais recentemente, com a utilização pelo Estado dos mais diversos mecanismos de parceria com a iniciativa privada, por vezes menciona-se que a diferença entre serviço público e atividade de polícia seria a delegabilidade do primeiro e a indelegabilidade do segundo.

A questão é apta a dar ensejo a várias controvérsias. Uma das problemáticas que têm sido enfrentadas pelo direito francês consiste em certa tendência em se autorizar a privatização de determinadas prestações de polícia sustentando-se que teriam sido transformadas em serviços públicos ${ }^{94}$. Sob esse argumento, campos inteiros das atividades de polícia administrativa foram transferidos para a área dos serviços públicos, tornando-se, com isso, atividades sujeitas às técnicas de privatização ${ }^{95}$.

No entanto, a diferença entre serviço público e atividade de polícia também não reside no fato de que apenas a segunda envolveria o exercício de poderes de coerção. Como conclui Marçal Justen Filho:

a distinção entre serviço público e poder de polícia, atinente à delegação a particulares, pode ser identificada como meramente quantitativa. Talvez se possa dizer que o serviço público comporta margem significativa de delegabilidade aos particulares na medida em que abrange inúmeras competências e atividades não vinculadas ao poder de coerção estatal. Já o poder de polícia se constitui, quase integralmente, de competências relacionadas com poder coercitivo estatal ${ }^{96}$.

Como se analisa adiante, os limites à delegação da atividade de polícia residem, em linhas bastante gerais, no monopólio estatal da violência e do poder político de decisão. Esses limites incidem sobre todas as atividades estatais, não sendo uma restrição aplicável apenas às atividades de polícia administrativa. Toda e qualquer atividade estatal que implicar o manejo de poderes institucionalizados de coerção para utilização em face dos indivíduos não será passível de delegação a particulares.

\footnotetext{
${ }^{92}$ Grands avis du Conseil d’État, p. 245.

93 A afirmação de François Llores é categórica, no sentido de que nada mais impede o recurso à concessão para assegurar a gestão dos serviços públicos administrativos (La définition actuelle de la concession de service public en droit interne, 1992, p. 23).

${ }^{94}$ Nesse sentido, confira-se Elina Lemaire. Actualité du principe de prohibition de la privatisation de la police, 2009, p. 767.

${ }^{95}$ Exemplos de atividades de polícia que passaram a ser consideradas serviço público no direito francês são a remoção de veículos estacionados em local proibido e a televigilância de edifícios e equipamentos públicos.

${ }^{96}$ Teoria geral das concessões, 2003, p. 29.
} 
Logo, se a prestação do serviço público envolver algum tipo de manifestação de poder de coerção sobre os seus usuários ou terceiros, o exercício dessa competência não poderá ser delegado a particulares. Por outro lado, se as atividades de polícia administrativa não implicarem a exteriorização de poder de coerção e de poder político de decisão, serão passíveis de delegação. Competências de cunho coercitivo, estejam elas compreendidas em atividade denominada serviço público ou de polícia, não são passíveis de delegação a particulares.

Portanto, a diferença entre atividades de polícia e serviço público não pode se restringir à nomenclatura atribuída à atividade, para se decidir pela sua delegabilidade ou não. Faz-se necessário identificar precisamente cada uma das atividades que será exercida por entidades privadas, para se avaliar a presença ou não de prerrogativas de soberania.

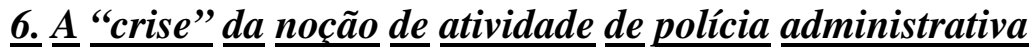

Diante das características da concepção atual da atividade de polícia administrativa, parcela da doutrina menciona a "crise" de tal conceito.

Com a noção atual de polícia, a atividade teria deixado de apresentar as características que a diferenciavam das demais atividades estatais. Como afirma Gordillo, “não existe hoje em dia uma 'noção’ autônoma e suficiente de 'poder de polícia'; não existe porque essa função distribuiu-se amplamente dentro de toda a atividade estatal”97.

Ainda segundo Gordillo, o principal aspecto da crise seria o fato de a atividade de polícia ter deixado de ser apenas uma atividade administrativa, ainda que distribuída entre os três poderes. O seu conceito passou a abranger também parcela da atividade legislativa, de edição de normas de limitação da atividade privada e de regulação do exercício dos direitos pelos particulares ${ }^{98}$.

Também para Lúcia Valle Figueiredo não haveria uma atividade da Administração, sujeita a regime jurídico distinto, que pudesse ser caracterizada como atividade de polícia ${ }^{99}$.

Para esses doutrinadores, continua existindo o exercício de coação e de poderes de autoridade sobre os particulares. Mas não haveria aspectos que diferenciariam essa atividade em relação às demais atividades estatais.

\footnotetext{
${ }^{97}$ Tratado de derecho administrativo, t. 2, 2009, p. V-14.

${ }^{98}$ Ob. cit., p. V-16.

${ }^{99}$ Curso de direito administrativo, 2008, p. 310-313.
} 
A principal preocupação dos doutrinadores residiria no uso indevido da noção de polícia para justificar restrições impostas às atividades privadas, tal como se a invocação do exercício da atividade de polícia pudesse dispensar a devida motivação do ato $^{100}$. Ainda segundo essa parcela da doutrina, a invocação indevida da atividade de polícia propiciaria a prática de atos antijurídicos, com suposto fundamento nessa atividade estatal. Porém, a simples menção à atividade de polícia não é apta a justificar toda e qualquer limitação que o Estado pretenda impor à autonomia privada. Isso implicaria o retorno ao Estado absoluto.

Parece-nos que a problemática apontada pelos doutrinadores quanto à aplicação do conceito de polícia não está relacionada à suposta ambiguidade ou imprecisão do conceito. Tratar-se-ia de um problema de legalidade. O exercício da atividade de polícia sempre deverá observar os limites previstos no ordenamento. A invocação do conceito jamais poderá autorizar a desconsideração dos limites legais para a atuação da Administração ${ }^{101}$.

A diferenciação da atividade de polícia em relação às demais continua tendo relevância especialmente no que diz respeito aos meios empregados. Como destaca Carlos Ari Sundfeld, a administração ordenadora é caracterizada pelo seu desempenho envolver a utilização do poder de autoridade ${ }^{102}$. Isso não significa que todas as atividades de polícia sejam executadas mediante o emprego do poder de autoridade mas não deixa de ser uma distinção relevante em relação às demais atividades estatais.

Ainda que não se trate propriamente de “crise” da atividade de polícia, é evidente a ampliação do campo de incidência dessa atividade nas últimas décadas.

O objetivo geral de preservação da ordem pública, tradicionalmente reconhecido como sendo a finalidade da atividade de polícia, demanda atualmente uma atuação intensa do Estado, nas mais diversas áreas da vida social.

Passou a existir uma nova dimensão dos bens protegidos pelo Estado. Superou-se a exclusividade da esfera do indivíduo e os bens a serem protegidos foram

\footnotetext{
${ }^{100}$ Nesse sentido, Agustín Gordillo. Tratado de derecho administrativo, t. 2, 2009, p. V-14.

${ }^{101}$ Odete Medauar assim se manifesta sobre as críticas à atividade de polícia: "Parece que o ponto nuclear no entendimento de quem prega essa eliminação é a preocupação com um poder de polícia indeterminado, independente de fundamentação legal, baseado num suposto dever geral dos indivíduos de respeitar a ordem ou baseado num 'domínio eminente' do Estado. Essa louvável preocupação perde consistência ante a realidade presente de mais solidez na concepção de Estado de direito, ante o princípio da legalidade regendo a Administração e ante a maior valoração dos direitos fundamentais” (Direito administrativo moderno, 2008, p. 333).

${ }^{102}$ Direito administrativo ordenador, 1997, p. 25-26. Como se indicou anteriormente, isso não significa que o exercício de outras modalidades da função administrativa não possa implicar também o manejo de poderes de autoridade. Isso varia especialmente de acordo com a classificação das funções administrativas proposta por cada doutrinador.
} 
coletivizados e universalizados. A saúde pública e a tutela do meio ambiente, por exemplo, passaram a ser consideradas como direitos que são objeto de proteção específica.

Um dos fatores que implicou significativo incremento das atividades de polícia é o controle dos diversos riscos. Trata-se de área que envolve significativa complexidade técnica, que a Administração deve enfrentar para o atendimento dos interesses gerais. Essa atividade costumava ser desempenhada diretamente pelo Estado, utilizando-se de estrutura própria.

O controle dos riscos nos campos da ciência e da técnica passou a demandar uma estrutura cada vez mais complexa. Os recursos materiais e humanos da Administração não são suficientes para atender diretamente a todas as demandas. A dificuldade não é só da Administração mas também do Legislativo.

O atendimento a essas demandas implica a necessidade de entidades privadas concorrerem para a prática desses atos, ao lado da atuação estatal. Essa reestruturação do Estado consiste em processo inverso daquele que se verificou no surgimento do Estado moderno, que se caracterizou pela concentração do poder no Estado diante da sua incapacidade de manter os equilíbrios necessários através dos mecanismos de autorregulação ${ }^{103}$.

\section{7. $\underline{\text { A atividade }} \underline{\text { de }}$ polícia $\underline{\text { administrativa }} \underline{\text { e o princípio }} \underline{\text { da }}$ legalidade}

É inerente à noção atual de polícia administrativa a sua limitação pelo direito. A Administração apenas pode proteger os bens compreendidos na noção de ordem pública mediante a imposição de limitações e restrições à autonomia privada se o direito assim permitir. É pressuposto para o exercício da atividade de polícia administrativa a sua prévia regulamentação pelo direito.

Portanto, os limites da atividade de polícia são os mesmos limites que incidem sobre as demais atividades da Administração em um Estado Democrático de Direito.

A atividade de polícia administrativa tem natureza infralegal. Não pode apresentar caráter inovador, devendo todas as restrições e constrangimentos envolvidos no seu exercício encontrarem-se previstos em lei.

${ }^{103}$ Dolors Canals I Ametller. El ejercicio por particulares de funciones de autoridad, 2003, p. 52. 
Os direitos e liberdades fundamentais apenas podem ser restringidos se houver previsão legal que atribua essa competência à Administração. Portanto, o exercício da função de polícia deve estar fundado em lei.

No entanto, isso não afasta a possibilidade de ser atribuída determinada margem para avaliação das circunstâncias concretas pela Administração, mediante a outorga de competências discricionárias.

\subsection{A vinculação e a discricionariedade nas competências administrativas}

O tema da discricionariedade dos atos administrativos já foi amplamente tratado pela doutrina ${ }^{104}$. No presente estudo, cabe fazer apenas alguns apontamentos, necessários para o delineamento dos conceitos operacionais a serem utilizados no desenvolvimento do trabalho.

O legislador pode determinar previamente todos os aspectos envolvidos na prática de determinado ato pela Administração. Nesse caso, diz-se que a competência atribuída à Administração é vinculada.

Mas a previsão legislativa pode não atingir todos os aspectos relacionados à atuação administrativa, deixando determinada margem de liberdade de decisão para o caso concreto. Caberá à Administração optar pela decisão a ser adotada, apreciando as alternativas disponíveis. Haverá então competência discricionária da Administração.

A discricionariedade somente existe porque o legislador assim optou por disciplinar normativamente determinada situação. Também por isso, a discricionariedade apenas existe nos espaços intencionalmente deixados pelo legislador. O seu exercício deverá observar os limites previstos em lei. Como ensina Maria Sylvia Zanella Di Pietro, “a fonte da discricionariedade é a própria lei; aquela só existe nos espaços deixados por esta”105.

Parcela da doutrina sustenta ser mais adequado tratar da dicotomia entre atos vinculados e atos discricionários sob a perspectiva de diversos graus de vinculação dos atos administrativos à legalidade ${ }^{106}$. A discricionariedade comporta graus de autonomia, que variam em cada caso. Por isso, propõe-se a substituição das expressões “ato discricionário" e “ato vinculado” para se referir a aspectos discricionários e aspectos vinculados do ato.

\footnotetext{
${ }^{104}$ Entre outras, confiram-se as obras de Maria Sylvia Zanella Di Pietro. Discricionariedade administrativa na Constituição de 1988, 2012 e Celso Antônio Bandeira de Mello. Discricionariedade e controle jurisdicional, 2000.

${ }^{105}$ Direito administrativo, 2013, p. 221.

106 Nesse sentido, Marçal Justen Filho. Curso de direito administrativo, 2013, p. 261-262 e Gustavo Binenbojm. Uma teoria do direito administrativo, 2008, p. 38-42.
} 
Segundo esses doutrinadores, não é propriamente o ato que é discricionário ou vinculado. Existiria um conteúdo variável de discricionariedade e de vinculação em cada caso.

Gustavo Binenbojm propõe uma escala decrescente de densidade normativa vinculativa $^{107}$. O mais alto grau de vinculação detêm os atos vinculados por regras (constitucionais, legais ou regulamentares). Em grau inferior, há os atos vinculados por conceitos jurídicos indeterminados, que demandam a realização de valorações ou avaliações técnicas por seus aplicadores. O último grau seria o dos atos vinculados diretamente por princípios, que correspondem aos atos tradicionalmente concebidos como discricionários. Ou seja, quando menos, o exercício de competências discricionárias pela Administração encontra-se restringida pela incidência dos princípios. A incidência dos princípios poderá até mesmo reduzir a margem de discricionariedade a zero, apontando uma única solução possível em determinado caso concreto.

Como afirmou de modo precursor no direito administrativo nacional Maria Sylvia Zanella Di Pietro, “a discricionariedade é liberdade de apreciação limitada pelo Direito e também pela Moral (desde que se reconheça a esta um campo não absorvido por aquele)”108. A Administração deve obrigatoriamente observar os princípios jurídicos, sob pena de invalidade do ato que os contrarie. Isso implica evidente restrição à margem de livre apreciação conferida pela lei à Administração:

em vez de afirmar-se que a discricionariedade é liberdade de ação limitada pela lei, melhor se dirá que a discricionariedade é liberdade de ação limitada pelo Direito. O princípio da legalidade há de ser observado, não no sentido estrito, concebido pelo positivismo jurídico e adotado no chamado Estado legal, mas no sentido amplo que abrange os princípios que estão na base do sistema jurídico vigente, e que permitem falar em Estado de Direito propriamente dito ${ }^{109}$.

\subsection{A denominada "discricionariedade técnica”}

Designa-se como sendo de discricionariedade técnica as hipóteses em que a lei recorre ao conhecimento técnico-científico para disciplinar determinada situação.

A doutrina registra que a expressão foi cunhada no direito austríaco. Bernatzik utilizou-a para se referir a casos de extrema complexidade técnica, em relação aos quais se apresentam diversas opiniões e possibilidades de solução. No entanto, haveria dificuldade em se identificar a decisão mais acertada. Por isso, a proposta inicial era a de que esses atos não se submetessem a controle jurisdicional, pois deveriam ser orientados

\footnotetext{
${ }^{107}$ Uma teoria do direito administrativo, 2008, p. 229-241.

${ }^{108}$ Discricionariedade administrativa na Constituição de 1988, 2012, p. 160.

109 Ob. cit., p. 162 - grifos no original.
} 
por critérios exclusivamente técnicos. Caberia ao Judiciário uma intervenção residual, para a verificação da ocorrência de erro material na escolha feita pelo administrador. Já Tezner criticou a posição da Corte Administrativa da Áustria, que reputava as questões que envolviam conceitos indeterminados como inseridas na esfera de discricionariedade da Administração ${ }^{110}$.

Porém, as premissas adotadas por essa teorização podem ser facilmente refutadas $^{111}$. A identificação daquelas que seriam as “decisões altamente técnicas” nem sempre é fácil e pacífica. O juiz também pode dispor de elementos técnicos para decidir, ao recorrer a peritos. Por fim, a própria identificação do que seria erro manifesto, a permitir a sindicabilidade do ato, remete a avaliação a ser desenvolvida com alguma margem de subjetividade.

Portanto, rejeita-se a possibilidade de se conceber uma categoria apartada de atos que, por envolverem questões altamente técnicas, não estariam sujeitos ao controle judicial.

Isso não afasta as discussões que possa haver em torno da denominada discricionariedade técnica. Um dos principais debates diz respeito à configuração da discricionariedade técnica como verdadeira discricionariedade administrativa.

Parcela da doutrina sustenta que a denominada discricionariedade técnica não consiste na discricionariedade propriamente dita. Nas situações em que haveria margem de discricionariedade técnica, a lei não autoriza que o administrador faça uma escolha de natureza política, devendo ser aplicados juízos técnico-científicos.

Nesse sentido, Maria Sylvia Zanella Di Pietro sustenta que, em determinadas hipóteses, não há margem para escolha discricionária pela Administração porque não se admitem soluções alternativas:

diante da manifestação do órgão técnico, a Administração não pode valorar em que medida o fato afeta o interesse público; a ela caberá decidir em consonância com as condições técnicas previamente definidas pela lei. Por exemplo, quando a lei determina a destruição de mercadorias deterioradas, à Administração cabe apenas constatar a ocorrência de deterioração e determinar sua destruição; não lhe cabe valorar a medida em face do interesse público ${ }^{112}$.

\footnotetext{
110 Almiro do Couto e Silva. Poder discricionário no direito administrativo brasileiro, 1990, p. 57-58; António Francisco de Souza. “Conceitos indeterminados” no direito administrativo, 1994, p. 105-106.

111 Tal como o faz António Francisco de Souza, ob. cit., p. 107-109.

${ }^{112}$ Discricionariedade administrativa na Constituição de 1988, 2012, p. 108. Em outra oportunidade, a autora consignou o seguinte, ainda a respeito da discricionariedade técnica: “também chamada de imprópria, exatamente por não envolver escolha de diferentes opções postas pelo legislador. Na discricionariedade técnica, a lei usa conceitos técnicos, cuja interpretação cabe a órgãos especializados. A discricionariedade pode existir abstratamente na lei, mas desaparece no momento de sua aplicação nos casos concretos, com base em manifestação de órgãos técnicos.” (Limites do controle externo da Administração Pública, 2013).
} 
É possível que a discricionariedade técnica apareça de modo aliado à discricionariedade propriamente dita. Trata-se de situações em que os critérios técnicos não fornecem certeza, mas meras probabilidades. Nesses casos, para se adotar a decisão a partir das possibilidades oferecidas pelos critérios técnicos, caberá o exercício de juízos de oportunidade.

Ainda seguindo os ensinamentos de Maria Sylvia Zanella Di Pietro, constata-se que se trata das hipóteses em que os conceitos técnicos encontram-se ligados a critérios administrativos. Nestes casos, apesar da aplicação de critérios técnicos, caberá também à Administração a apreciação da situação em face do interesse público. Com base nos ensinamentos de Renato Alessi, a doutrinadora menciona duas hipóteses em que há a conjugação de critérios técnicos e de critérios administrativos: (a) quando, com base em dados técnicos, cabe à Administração decidir de acordo com os critérios administrativos de oportunidade e conveniência, e (b) quando, considerando dados técnicos e aplicando critérios administrativos, cabe à Administração escolher os meios técnicos mais adequados para a satisfação do interesse público ${ }^{113}$.

Assim, é possível que reste certa margem de autonomia para o administrador decidir mesmo em se tratando de decisão fundada em critério técnico-científico. O elemento técnico poderá reduzir as alternativas disponíveis mas não conduzirá necessariamente a apenas uma solução válida. Ainda que o conhecimento técnico não reduza sempre a uma única solução para o caso concreto, a sua aplicação implica a redução da margem de apreciação pelo administrador, restringindo-a às opções técnicas válidas disponíveis.

A questão da discricionariedade técnica é relevante para o presente estudo porque significativa parcela das atividades de polícia administrativa que têm a sua execução atribuída a entidades privadas apresenta caráter técnico.

Como se analisa adiante, a diferenciação das hipóteses de discricionariedade técnica daquelas de discricionariedade propriamente dita fornece elementos úteis para se justificar a atribuição de atividades que envolvem a aplicação de critérios técnicocientíficos a entidades privadas. O fato de não dispor de ampla margem de livre escolha e ser passível de controle com a aplicação de critérios objetivos permite justificar que uma parcela da atividade administrativa de cunho técnico seja exercida por entidades privadas.

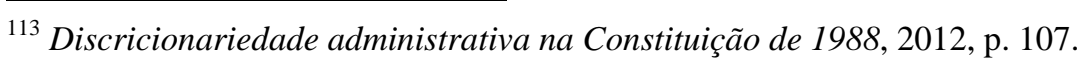




\subsection{A vinculação e a discricionariedade nas previsões legais de polícia administrativa}

A previsão legal acerca do exercício da atividade de polícia pode resultar na atribuição de competência tanto vinculada quanto discricionária. Não é viável que o Legislativo esgote toda a regulação necessária para o exercício das atividades de polícia, determinando previamente todas as circunstâncias e mecanismos a serem utilizados.

A outorga de competência discricionária em matéria de polícia administrativa é, inclusive, bastante frequente. Como registra Pietro Virga, diante da extrema variedade de situações sobre as quais a atividade de polícia incide, não é possível prever detalhadamente as medidas a serem adotadas em cada caso. Usualmente a norma jurídica atribui à autoridade competente a decisão sobre como intervir e quanto aos meios a serem adotados em cada caso concreto ${ }^{114}$.

Por tal razão, alguns autores chegaram a incluir o aspecto discricionário na própria definição da atividade de polícia, tal como se fosse inerente a essa atividade. É o que se encontra, por exemplo, na definição de Cretella Júnior: "É a faculdade discricionária da Administração de limitar as liberdades individuais em prol do interesse coletivo”"115. Themístocles Brandão Cavalcanti também definiu as medidas de polícia como sendo discricionárias: "mesmo que revestidas do caráter discricionário, as medidas de polícia não precisam estar predeterminadas pela lei. Elas se compreendem perfeitamente dentro de uma certa maneira de agir, limitada apenas pelos direitos e garantias asseguradas expressamente pela legislação". 116

O entendimento desses autores vincula-se à concepção da literatura administrativa tradicional, que inseria a polícia entre os denominados poderes do Estado. Consistiria em um dos poderes de que a Administração seria dotada para a persecução das finalidades que lhe foram atribuídas. Nesse contexto, o exercício da atividade de polícia seria considerado uma "faculdade" da Administração Pública ${ }^{117}$.

Atualmente, a atividade de polícia insere-se entre as funções estatais, a serem exercidas pela Administração nos limites que são definidos pela lei. Não se concebe a atividade de polícia como uma faculdade ou poder diferenciado conferido à Administração. Trata-se do exercício, pela Administração, de competências que implicam

\footnotetext{
${ }^{114}$ La potestà di polizia, 1954, p. 41.

${ }^{115}$ Direito administrativo do Brasil, v. IV, 1961, p. 54.

${ }^{116}$ Tratado de direito administrativo brasileiro, v. III, 1964, p. 10.

${ }^{117}$ Nesse sentido, por exemplo, pode ser conferida a definição de Hely Lopes Meirelles: “Poder de polícia é a faculdade de que dispõe a Administração Pública para condicionar e restringir o uso e gozo de bens, atividades e direitos individuais, em benefício da coletividade ou do próprio Estado” (Direito administrativo brasileiro, 2012, p. 137).
} 
restrições e limitações à autonomia privada e que lhe foram atribuídas pela lei, com ou sem margem de discricionariedade. Portanto, a referência à discricionariedade no exercício da atividade de polícia não significa nenhuma virtude adicional dessa atividade em relação à aplicação geral do princípio da legalidade nas atividades da Administração.

Diante desse contexto, parece-nos superado o entendimento de que a discricionariedade seria inerente à atividade de polícia. Cabe ao legislador avaliar se deverá ser outorgada uma competência discricionária ao administrador ou se é possível serem estabelecidas previamente todas as condições em que o administrador deverá atuar, vinculando a sua ação futura. Um dos exemplos da possibilidade de convivência da atividade de polícia com a vinculação é a licença administrativa, que é definida como ato administrativo vinculado ${ }^{118}$.

Assim, da possibilidade de a polícia administrativa ser uma atividade discricionária “não decorre, evidentemente, ser a discricionariedade peculiar à natureza jurídica dessa atividade, já que a conveniência do legislador de outorgá-la ou não, ao administrador é questão de política legislativa, e como tal, é questão metajurídica, não se podendo traduzi-la como peculiaridade dessa atividade” ${ }^{119}$.

\section{8. $\underline{\text { A exiqibilidade }} \underline{\text { e }} \underline{\text { autoexecutoridade }} \underline{\text { dos }} \underline{\text { atos }} \underline{\text { de }}$ polícia administrativa}

Como se indicou anteriormente, a atividade de polícia administrativa com frequência é caracterizada pela utilização de um meio específico, que é a $\operatorname{coerção~}^{120}$. A possibilidade de utilização desse mecanismo consistiria em um dos principais elementos de diferenciação da atividade de polícia administrativa em relação às demais funções estatais.

A coerção manifesta-se especialmente na forma de exigibilidade e autoexecutoriedade dos atos de polícia.

\footnotetext{
${ }^{118}$ Nesse sentido, entre outros, Maria Sylvia Zanella Di Pietro. Direito administrativo, 2013, p. 236; Celso Antônio Bandeira de Mello. Curso de direito administrativo, 2013, p. 444; Hely Lopes Meirelles. Direito administrativo brasileiro, 2012, p. 196.

${ }^{119}$ Clóvis Beznos. Poder de polícia, 1979, p. 35.

${ }^{120}$ Para os fins do presente estudo, adotam-se os termos "coerção" e "coação" como sendo sinônimos. No entanto, cabe registrar que parcela da doutrina diferencia os conceitos. Para Tercio Sampaio Ferraz Junior, as normas jurídicas são coercivas mas nem sempre coativas: "A coercibilidade seria uma característica que diz respeito à suscetibilidade de aplicação da coação. Ora, isto nem sempre ocorre - há normas, por exemplo, de direito internacional que não são coercivas naquele sentido - o que faz pensar que não há relação automática entre coercibilidade e sanção-castigo. A coercibilidade tem antes a ver com a relação de autoridade institucionalizada" (Introdução ao estudo do direito, 1994, p. 121-122). Em sentido próximo, Miguel Reale define a coercibilidade como sendo "a possibilidade lógica da interferência da força no cumprimento de uma regra de direito” (Lições preliminares de direito, 1984, p. 69). Já a coação seria verificada quando "a força se organiza em defesa do cumprimento do Direito" ou "o próprio Direito quando se arma da força para garantir o seu cumprimento" (ob. cit., p. 71-72).
} 
Disso não decorre que todos os atos de polícia administrativa consistam em manifestação de coerção. O grau de autoridade e de coerção que cada uma das competências de polícia implica é diverso. Em diversos casos, a autoridade do ato manifesta-se exclusivamente em termos de exigibilidade, revelando-se no caráter imperativo dos atos produzidos pela Administração.

Nem sempre a Administração dispõe da competência para executar materialmente os seus próprios atos, sem a necessidade de recorrer previamente ao Judiciário. Essa questão é evidenciada ao se analisar a distinção entre a exigibilidade (ou imperatividade) e a autoexecutoriedade como atributos dos atos de polícia administrativa.

A exigibilidade do ato administrativo retrata o "atributo pelo qual os atos administrativos se impõem a terceiros, independentemente de sua concordância”121 ${ }^{\text {. Trata- }}$ se da competência de instaurar relações jurídicas, criando direitos e deveres para terceiros, observando os limites da lei, e de exigir o seu cumprimento ${ }^{122}$.

Parcela da doutrina utiliza a expressão autotutela declarativa para identificar a característica dos atos administrativos de obrigarem de imediato a sua observância, ainda que o outro sujeito discorde da sua legalidade ${ }^{123}$. Indica que o ato ou declaração produzidos pela Administração são de cumprimento obrigatório, independentemente da intervenção do Judiciário. Por esse efeito reconhecido aos seus atos, a Administração pode modificar unilateralmente as situações jurídicas.

A exigibilidade situa-se no âmbito dos atos ou declarações. Já a autoexecutoriedade vai além, para ingressar no campo dos fatos.

A autoexecutoriedade é o "atributo pelo qual o ato administrativo pode ser posto em execução pela própria Administração Pública, sem necessidade de intervenção do Poder Judiciário”. ${ }^{124}$ Consiste na possibilidade de a Administração fazer diretamente a execução forçada das suas decisões e praticar atos materiais para compelir o administrado a cumprir a obrigação por ela imposta ${ }^{125}$.

\footnotetext{
${ }^{121}$ Maria Sylvia Zanella Di Pietro. Direito administrativo, 2013, p. 208.

${ }^{122}$ Alguns doutrinadores diferenciam os atributos da imperatividade e da exigibilidade. Nesse sentido, para Celso Antônio Bandeira de Mello, a imperatividade “é a qualidade pela qual os atos administrativos se impõem a terceiros, independentemente de sua concordância” (Curso de direito administrativo, 2013, p. 423). Já a exigibilidade "é a qualidade em virtude da qual o Estado, no exercício da função administrativa, pode exigir de terceiros o cumprimento, a observância, das obrigações que impôs” (ob. e loc. cit.).

123 Eduardo García de Enterría e Tomás-Ramón Fernández. Curso de derecho administrativo, v. I, 2002, p. 513-515.

${ }^{124}$ Maria Sylvia Zanella Di Pietro. Direito administrativo, 2013, p. 208.

125 Como expõem Eduardo García de Enterría e Tomás-Ramón Fernández, o ato apto a ser executado forçadamente deve consistir em um ato administrativo formal, que estipule uma obrigação certa e contenha a indicação precisa do seu conteúdo e destinatários, de modo a dispensar a sua prévia submissão ao Judiciário para definir o seu alcance e extensão. Para a execução desse ato, a obrigação deve se encontrar vencida ou
} 
Alguns denominam a autoexecutoriedade de autotutela executiva. Essa autotutela permite o uso direto da própria coerção pela Administração, sem necessidade de solicitar apoio ao Judiciário. Manifesta-se por comportamentos ou operações materiais, fazendo uso concreto da coerção frente a terceiros ${ }^{126}$.

A autoexecutoriedade como execução forçada não está presente em todos os atos administrativos, inclusive nos de polícia. A esse respeito, a doutrina tende a restringir a sua incidência, em princípio, apenas às hipóteses expressamente previstas em lei ${ }^{127}$. A sua aplicação deve ser antecedida da observância do devido processo, assegurando-se ao interessado o exercício do contraditório e da ampla defesa.

Outra possibilidade de autoexecutoriedade decorre da necessidade de adoção de medidas urgentes, imprescindíveis à tutela dos fins atribuídos à Administração, se não for viável aguardar-se a apreciação da questão pelo Judiciário e oferecer-se previamente ao interessado a possibilidade de cumprimento voluntário ${ }^{128}$.

Ou seja, a autoexecutoriedade pode também dizer respeito à utilização direta da coerção pela Administração, sem consistir na execução forçada de um ato formal prévio. Trata-se das hipóteses - excepcionais - em que se faz necessária a atuação da Administração a título emergencial, sem um título formal prévio ${ }^{129}$. O controle dessas medidas é feito posteriormente, para se verificar a presença das circunstâncias legitimadoras para a utilização da coerção e se foram observados os requisitos e limites legais. Essas restrições para a aplicação da autoexecutoriedade são aceitas amplamente pela doutrina $^{130}$.

inadimplida pelo seu devedor. Os autores comparam, assim, o título da execução forçada pela Administração ao título executivo judicial, do processo civil de execução (Curso de derecho administrativo, v. I, 2002, p. 777-778).

${ }^{126}$ Eduardo García de Enterría e Tomás-Ramón Fernández. Curso de derecho administrativo, v. I, 2002, p. 516-517.

${ }^{127}$ Maria Sylvia Zanella Di Pietro. Direito administrativo, 2013, p. 126.

${ }^{128}$ Como pondera Maria Sylvia Zanella Di Pietro, "No caso de medidas preventivas de perigos previsíveis mas não iminentes, fica mais difícil a autoridade de polícia auto-executar a sua decisão (sem recurso ao Poder Judiciário), quando não haja previsão legal expressa. Nesse caso, não há a justificativa da urgência para dispensar a autorização judicial” (Poder de polícia, 1991, p. 91).

${ }^{129}$ Mais especificamente, o uso da coerção pela Administração não é antecedido de um procedimento formal, em razão da urgência da situação. A intimação para cumprimento voluntário (se este for possível), a ordem de execução e a execução em si acabam sendo exteriorizadas em um mesmo momento. Isso não significa que não existam condicionantes ou limites. Por exemplo, a ordem de execução deve ser proferida por autoridade competente. As medidas a serem adotadas devem observar os direitos e garantias fundamentais dos cidadãos bem como o princípio da proporcionalidade.

${ }^{130}$ Nesse sentido, entre outros, Maria Sylvia Zanella Di Pietro. Direito administrativo, 2013, p. 126-127; Celso Antônio Bandeira de Mello. Curso de direito administrativo, 2013, p. 425-426; Marçal Justen Filho. Curso de direito administrativo, 2013, p. 417-418 e 608; Hely Lopes Meirelles. Direito administrativo brasileiro, 2012, p. 144. 
Nestes casos excepcionais, em que se admite o exercício da autotutela executiva pela Administração, os atos a serem praticados deverão observar estritamente o princípio da proporcionalidade, devendo-se buscar a alternativa menos lesiva para se atingir o fim visado.

Uma leitura contemporânea da atividade de polícia não pode deixar de considerar a necessidade de que seu exame seja feito sob a perspectiva dos direitos fundamentais. Além dos limites expressamente previstos na Constituição e na lei, o exercício da atividade de polícia submete-se a diversos outros limites implícitos no ordenamento jurídico e que decorrem fundamentalmente da necessidade de se respeitar o núcleo essencial dos direitos fundamentais. Esse aspecto determina uma redução ainda maior do aspecto coercitivo da atividade de polícia.

Diante disso, a execução forçada dos atos pela própria Administração é considerada uma forma subsidiária de execução ${ }^{131}$, a ser aplicada quando não houver a possibilidade de emprego de outros meios eficazes para afastar a resistência ao cumprimento da medida, tais como as sanções administrativas e penais ${ }^{132}$.

Como diferencia com precisão Maria Sylvia Zanella Di Pietro, a partir do atributo da exigibilidade, a Administração pode se utilizar de meios indiretos de coerção, tais como a imposição de multas e a suspensão do exercício de determinados direitos até o adimplemento da obrigação ${ }^{133}$. Já a autoexecutoridade pode implicar a adoção de medidas materiais em face do administrado, com o emprego de meios diretos de coerção ${ }^{134}$ - tais como a apreensão de bens e a interdição de estabelecimentos.

Portanto, o exercício das atividades de polícia nem sempre é acompanhado da coerção.

Uma das consequências disso é a possibilidade de se atribuir a determinadas entidades o exercício de certas atividades de polícia administrativa, mesmo que tais entidades não estejam legitimadas para o exercício da coerção.

\footnotetext{
${ }^{131}$ Eduardo García de Enterría e Tomás-Ramón Fernández. Curso de derecho administrativo, v. I, 2002, p. 516.

132 “O acesso à coação só é facultado ao agente público quando não há outro meio eficaz para o alcance do cumprimento da pretensão jurídica e só é legítima quando além de compatível é proporcional ao resultado pretendido e tutelado pela norma" (Farlei Martins Riccio de Oliveira e Alexandra Cerqueira Campos. Poder de polícia, 2007, p. 191).

${ }^{133}$ Direito administrativo, 2013, p. 126. A utilização de meios indiretos encontra limites, especialmente porque não pode comprometer o desempenho de atividades lícitas pelos particulares. A esse respeito, são elucidativas as Súmulas do STF: Súmula $\mathrm{n}^{\circ}$ 70: É inadmissível a interdição de estabelecimento como meio coercitivo para cobrança de tributo; Súmula $n^{\circ}$ 323: É inadmissível a apreensão de mercadorias como meio coercitivo para pagamento de tributos; Súmula ${ }^{\circ}$ 547: não é lícito à autoridade proibir que o contribuinte em débito adquira estampilhas, despache mercadorias nas alfândegas e exerça suas atividades profissionais.

${ }^{134}$ Ob. e loc. cit.
} 


\section{As $\underline{\text { diversas }} \underline{\text { manifestações }} \underline{\text { da atividade }} \underline{\text { de polícia administrativa }}$}

O exercício da atividade de polícia administrativa compreende um conjunto de manifestações diversas. Essa constatação, apesar de óbvia, determina a necessidade de se avaliar a possibilidade de exercício privado das atividades de polícia administrativa considerando cada um dos tipos de atividade compreendidos no desempenho dessa função.

Considerando-se os tipos de providência jurídica que podem estar envolvidos, as atividades de polícia administrativa podem se manifestar de três formas: a regulamentação (edição de normas gerais), a emissão de decisões particulares e a coerção fática propriamente dita ${ }^{135}$. Comportam não apenas deveres de não fazer bem como os de fazer ou de dar e os de suportar ${ }^{136}$.

Para impor limitações administrativas à liberdade e à propriedade, o Estado dispõe de diversos mecanismos, que podem incidir tanto preventiva quanto repressivamente. Seguindo a sistemática apresentada por Carlos Ari Sundfeld, o Estado pode exercer competências distintas ao condicionar o exercício de direitos pelos particulares: a) impor os condicionamentos, observando o princípio da legalidade, b) expedir autorizações e licenças, c) fiscalizar a observância dos condicionamentos, d) reprimir a inobservância dos condicionamentos, e e) executar materialmente os atos administrativos, constrangendo os particulares a observá-los, sem a necessidade de recorrer previamente ao Judiciário $^{137}$.

Não existe no direito nacional um elenco normativo abrangendo todas as manifestações possíveis da atividade de polícia. Há uma grande quantidade de disposições normativas atribuindo competências ao Estado cujo exercício envolve, a título principal ou acessório, a competência de polícia. O funcionamento do Estado e a preservação da ordem pública cada vez mais demandam restrições à autonomia, à liberdade e à propriedade dos cidadãos.

\footnotetext{
${ }^{135}$ Marçal Justen Filho. Curso de direito administrativo, 2013, p. 604.

${ }^{136}$ Seabra Fagundes destaca que a obrigação de suportar consistiria em um diferencial do direito público: "Enquanto no direito privado só se conhecem as obrigações de dar, de fazer ou de não fazer, no direito público aparecem com particular relevo, as obrigações de suportar. Nelas se exige, sem dúvida, alguma abstenção ou ação, como nas obrigações de fazer e de não fazer, mas, ao mesmo tempo, se impõe ao obrigado uma carga, que lhe cabe aceitar passivamente. A prestação em tais casos reveste, portanto, um duplo feitio: fazer ou não fazer e suportar, ou seja, praticar algum ato ou dele se abster, e ainda aceitar certo ônus que o sujeito ativo da obrigação imponha com a sua atividade. O ônus é o seu elemento característico. Constituem exemplos desta modalidade de obrigação pública: a obrigação de isolamento imposta ao doente de moléstia infecto-contagiosa; a obrigação do funcionário público de submeter-se, em determinados casos, à inspeção de saúde; a obrigação do residente de receber e admitir a visita da polícia sanitária; a obrigação do comerciante de franquear o seu estabelecimento à inspeção fiscal; a obrigação de vacinar-se etc.” ( $O$ controle dos atos administrativos pelo Poder Judiciário, 2010, p. 257, nota 8).

${ }^{137}$ Direito administrativo ordenador, 1997, p. 74-84.
} 
Para o exame dos diversos tipos de atividades compreendidos na polícia, pode-se utilizar a categorização do ciclo de exercício da atividade de polícia, tal como exposta por Diogo de Figueiredo Moreira Neto ${ }^{138}$. Trata-se de conceito operacional a ser empregado no exame das atividades de polícia passíveis de delegação ou não. A teoria do “ciclo” da polícia divide em quatro grupos as atividades compreendidas no exercício dessa função:

a) ordem de polícia: previsão legal a partir da qual vai ser exercida a atividade administrativa;

b) consentimento de polícia: ato administrativo que manifesta a aquiescência da Administração com a conduta do particular, a ser produzido nos casos em que a lei estipula ser necessário;

c) fiscalização de polícia: verificação da observância das regras de polícia administrativa bem como a manutenção das condições que determinaram a manifestação do consentimento de polícia, nos casos em que este for cabível; e d) sanção de polícia: imposição de medidas punitivas.

Importa ressalvar que, muitas vezes, não é possível distinguir com precisão uma atividade da outra. O desempenho da atividade de polícia demanda a prática de vários atos, logicamente encadeados entre si, em que se sucedem as diversas atividades compreendidas no denominado "ciclo de polícia”.

Mas a sistematização das atividades em quatro grandes grupos não deixa de desempenhar importante função no contexto do presente estudo. Trata-se de evidenciar que a diversidade das funções compreendidas no exercício da atividade de polícia impede que seja fornecida uma resposta única a respeito da possibilidade ou não de seu exercício por entidades privadas.

O principal aspecto a ser identificado é o de que nem todas as atividades envolvem o exercício do poder de coerção. A viabilidade de determinadas funções serem desempenhadas por particulares depende das especificidades da atividade considerada. Não existe a necessidade de todas as atividades do “ciclo de polícia” serem exercitadas por um mesmo órgão ou entidade. Elas podem ser dissociadas e apresentam características $\operatorname{distintas~}^{139}$.

\footnotetext{
${ }^{138}$ Curso de direito administrativo, 2009, p. 444-447.

139 Em sentido diverso, Dora Maria de Oliveira Ramos sustenta que todas as atividades que integram o denominado “ciclo de polícia” apresentam as mesmas características: “a segmentação do poder de polícia (...) pode ser admitida apenas para fins de compreensão didática da atividade do Estado. Isso não significa que, assim considerado, o poder de polícia perde sua unidade de atuação ou que cada fração da atividade deixa de deter a característica que delineia o todo. O poder de império, inerente à atividade de polícia, está presente em
} 
Portanto, nem toda atividade de polícia administrativa implica o exercício de coerção. De todo modo, pode-se identificar que as atividades administrativas cujo exercício privado apresenta-se como sendo mais problemático consistem na imposição de sanções. Essa questão é analisada detalhadamente adiante ${ }^{140}$.

\section{0. $\underline{\text { A titularidade }} \underline{\text { das }} \underline{\text { atividades }} \underline{\text { de polícia }} \underline{\text { administrativa }}$}

O titular principal das atividades de polícia administrativa e do poder de polícia a elas vinculado é o Estado. A competência para o exercício da atividade de polícia “é, em princípio, da pessoa federativa à qual a Constituição federal conferiu o poder de

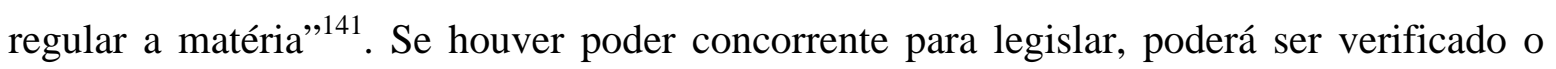
exercício conjunto de atividade de polícia por entes de nível federativo diverso.

Ainda que as atividades de polícia administrativa encontrem-se concentradas no Executivo, quando o Legislativo e o Judiciário encontram-se no exercício de função administrativa também poderão ser titulares de atividades de polícia administrativa.

A situação usual é o exercício das atividades de polícia administrativa no âmbito da Administração direta do Estado. Isso não impede a distribuição interna de competências entre os vários órgãos públicos, em processo de desconcentração do poder.

No entanto, é possível que entidades da Administração indireta tenham o direito de exercer determinadas competências de polícia administrativa ${ }^{142}$. Verifica-se também a atribuição do exercício de atividades de polícia administrativa a particulares, observando-se determinados condicionamentos e limites.

\section{Proposta de $\underline{\text { classificação }} \underline{\text { das }} \underline{\text { hipóteses }} \underline{\text { de }} \underline{\text { exercício }} \underline{\text { de }} \underline{\text { atividades }} \underline{\text { de polícia }}$ administrativa por entidades privadas}

Em alguns ordenamentos jurídicos, foram criadas figuras específicas de pessoas privadas às quais são atribuídos poderes públicos. Podem-se mencionar, por

cada um dos segmentos apontados. O poder de polícia é um todo, ordenado pela supremacia do interesse público, sendo exercido pelo detentor do poder nos limites da lei e em nome da coletividade. Não se concebe, portanto, que qualquer uma dessas facetas possa ser inteiramente delegada a ente privado" (A terceirização em matéria de poder de polícia, 2013, p. 571).

${ }^{140}$ V. capítulo III.

141 José dos Santos Carvalho Filho. Manual de direito administrativo, 2012, p. 76.

142 Como ensina Maria Sylvia Zanella Di Pietro, as “empresas públicas e as sociedades de economia mista são criadas por lei e adquirem o direito à prestação do serviço, direito esse oponível até mesmo à pessoa jurídica que as criou, pois esta somente pode interferir na vida da empresa nos limites previstos em lei” (Parcerias na Administração Pública, 2012, p. 57). 
exemplo, a Beleihung do direito alemão e as entidades colaboradoras do direito espanhol. Já o texto constitucional português faz expressa referência às entidades privadas que exercem poderes públicos, indicando que são sujeitas à fiscalização administrativa ${ }^{143}$. Apesar de apresentarem alguns traços em comum, há significativas diferenças entre os regimes jurídicos aplicáveis a cada uma dessas figuras.

No direito brasileiro, não há figuras jurídicas similares, no sentido de não haver uma designação específica para as entidades privadas às quais sejam atribuídas prerrogativas públicas. Porém, a ausência dessa categoria específica não significa que a discussão não seja pertinente. O que se verifica é a atribuição de atividades de polícia administrativa a diversas figuras já existentes no nosso sistema, tais como entidades da administração indireta, empresas privadas em geral e associações.

Zanobini classifica o exercício privado de funções públicas de acordo com a sua fundamentação, dividindo-o em a) os que têm por título a existência de normas jurídicas gerais, que impõem determinados deveres aos cidadãos (tais como as obrigações vinculadas a determinadas profissões) ou concedem determinadas faculdades (atuação em legítima defesa, prisão em flagrante etc.) e b) os que têm por título um ato administrativo especial (tal como a concessão de serviços públicos) ${ }^{144}$.

Optamos por desdobrar essas categorias, considerando a significativa variação que apresentam internamente. A nossa proposta de classificação das hipóteses de exercício, por entidades privadas, de atividades de polícia administrativa seria a seguinte:

a) Contratos de concessão e figuras análogas, pelas quais se atribuem a particulares funções públicas que compreendem atividades de polícia, a serem exercidas sob controle e direção estatal.

b) Empresas estatais e associações civis que desenvolvem atividades de polícia administrativa, que lhes são atribuídas pela lei.

c) Profissões cujo objeto consista especificamente no exercício de uma função pública, tais como os titulares de serviços notariais e de registro, práticos de portos, leiloeiros, tradutores e intérpretes públicos etc. Estes profissionais exercem a função pública, em nome próprio e sem vínculo empregatício com o poder público. São remunerados pelos beneficiários diretos dos serviços prestados e não pelo poder público.

\footnotetext{
${ }^{143}$ Art. 267\%6: “As entidades privadas que exerçam poderes públicos podem ser sujeitas, nos termos da lei, a fiscalização administrativa”.

${ }^{144}$ L'esercizio privato delle funzioni e dei servizi pubblici, 1935, p. 256-257.
} 
d) Profissões cujo objeto seja o desempenho de uma atividade privada, à qual se encontra associada uma função pública: é o que se verifica em relação aos capitães de navios e comandantes de aeronaves, a cujas atividades privadas associa-se o exercício eventual de atos com eficácia jurídico-pública.

e) Particulares que exercem temporariamente o exercício de funções públicas, sem manter vínculo empregatício com o poder público e usualmente sem perceberem remuneração. Incluem-se nessa categoria a requisição estatal para o exercício de função pública temporária (jurados, particulares convocados para a prestação de serviço militar ou eleitoral) e os gestores de negócio, particulares que, sponte propria, assumem o exercício de funções públicas em situações emergenciais, para dar atendimento a necessidades públicas urgentes.

A classificação proposta já evidencia um dos pressupostos adotados no âmbito do presente estudo.

Adota-se como premissa que atividades de polícia administrativa apenas são legitimamente desempenhadas por entidades não integrantes da Administração direta na hipótese de a lei atribuir-lhes diretamente o exercício dessa função ou de haver delegação expressa pelo Estado ou outro tipo de autorização pelo poder público para o exercício da função pública. Na ausência de um desses instrumentos, não há o exercício de função pública por particulares e sim o exercício de poderes privados. Essa atuação privada pode até mesmo ter os seus efeitos reconhecidos pelo Estado mas não representa o exercício privado de função pública.

\section{2. $\underline{\text { A atividade }} \underline{\text { de }}$ polícia administrativa $\underline{\text { e os }}$ poderes privados}

É relevante diferenciar a atividade de polícia administrativa dos denominados poderes privados, especialmente porque as manifestações de um e de outro podem se apresentar de modo similar em termos fáticos, ainda que os fundamentos jurídicos sejam diversos.

\subsection{O surgimento de novos centros de poderes}

A construção do Estado moderno, na figura do Estado-nação, foi marcada pela pretensão de se separar, com rigidez, as esferas pública e privada.

O surgimento do constitucionalismo, a partir das Revoluções francesa e norte-americana, marcou o estabelecimento de um novo sistema político, propositalmente 
desvinculado das formas anteriores de exercício do poder. O constitucionalismo assentouse especialmente em duas contraposições: público-privado e externo-interno ${ }^{145}$.

$\mathrm{Na}$ sua forma originária, o constitucionalismo não reconhece poderes legítimos fora da Constituição ou outras formas de exercício do poder. Propõe uma regulação abrangente, no sentido de que não haveria instâncias extraconstitucionais de poder, nem reconheceria outros meios ou modos de exercício de poder ${ }^{146}$. Todo o poder tem a sua origem na Constituição e é exercido pelo Estado. A identidade entre o poder público e o poder estatal foi uma das bases em que se fundaram os Estados nacionais.

Os desenvolvimentos posteriores do Estado conduziram a uma maior aproximação com a sociedade, com a intensificação da participação dos atores privados no exercício de atividades de interesse público. Acentuou-se a incidência da regulação setorial especializada, exercida principalmente sob a forma de autorregulação. Também foi relativizada a fronteira existente entre as relações internas e externas do Estado, com a crescente influência de organizações internacionais e transnacionais nos Estados nacionais.

Além disso, o ambiente regulatório cada vez mais é definido pelo entrelaçamento e sobreposição de conjuntos de normas de origem pública e privada. A regulação estatal deixou de ser suficiente para dar conta da crescente complexidade social.

Considerando-se esses aspectos, constata-se a inequívoca interpenetração entre os setores público e privado. As fronteiras entre o Estado e a sociedade civil deixaram de ser nítidas, verificando-se a redistribuição de algumas das funções entre essas duas esferas. Com a proliferação de entidades com influência global, com poder de decisão especialmente no campo da técnica, cogita-se do surgimento de um direito administrativo global para organizar o exercício desses poderes ${ }^{147}$.

Disso decorreu a formação de determinados centros de poderes na esfera social e econômica, cuja atuação é apta a determinar o comportamento dos demais atores privados $^{148}$. A força reconhecida a diversos grupos sociais e o poderio exercido por grandes

\footnotetext{
${ }^{145}$ Dieter Grimm. The achievement of constitutionalism and its prospects in a changed world, 2010, p. 13-14. 146 Ob. cit., p. 9.

147 Sobre o tema, podem ser consultadas, entre outras, as obras de Sabino Cassese (Il diritto amministrativo globale, 2005, p. 331-357 e La funzione costituzionale dei giudici non statali. Dallo spazio giuridico globale all'ordine giuridico globale, 2007, p. 609-626), Stefano Battini (Organizzazioni internazionali e soggetti privati: verso un diritto amministrativo globale?, 2005, p. 359-388) e Giacinto della Cananea (I pubblici poteri nello spazio giuridico globale, 2003, p. 1-34).

${ }^{148}$ Um dos problemas que se coloca na atualidade é o do controle dos poderes privados. Como anota José Esteve Pardo, há certo consenso social acerca da necessidade de seu controle, sendo que a autorregulação é um dos mecanismos preferenciais para esse controle. Apenas quem opera nesses setores é que detém a capacidade e os instrumentos necessários para controlá-los (Autorregulación, 2002, p. 22-25).
} 
empresas multinacionais evidenciam que o Estado não exerce mais o poder com exclusividade $^{149}$.

\subsection{As manifestações de poderes no âmbito da autonomia privada}

Relações de poder, com assimetria entre as partes, não são exclusividade das relações existentes entre Estado e particulares. Também nas relações que se estabelecem entre privados pode-se verificar que alguns detêm a capacidade de exercer sobre outros particulares uma posição dominante ou de impor unilateralmente condições ${ }^{150}$.

Trata-se da incidência dos denominados "poderes privados" ou "poderes sociais”.

O direito privado também abriga o fenômeno do poder, no sentido da capacidade de alguns de determinar ou condicionar o comportamento dos outros. Foi o reconhecimento da existência de assimetria nas relações entre particulares e da ameaça que isso implica para a liberdade e autonomia privadas que deu ensejo ao desenvolvimento da teoria da vinculação dos particulares a direitos fundamentais ${ }^{151}$.

Como destaca Juan María Bilbao Ubillos, não se pode afirmar ser horizontal a relação existente entre particulares que não dispõem efetivamente do mesmo grau de liberdade. Faz-se uma analogia entre a desigualdade e a supremacia verificadas nas relações entre o poder público e particulares e aquelas existentes em determinadas relações entre particulares:

São evidentes, com efeito, as analogias entre o poder público e o privado, um poder que aflora como tal naquelas situações caracterizadas por uma disparidade substancial

\footnotetext{
${ }^{149}$ A influência de entidades internacionais nos Estados nacionais é relevante inclusive para fins de exercício de atividade de polícia administrativa. Basta verificar o domínio exercido pelas federações desportivas internacionais, estipulando uma grande quantidade de normas a serem observadas para que os Estados possam sediar eventos esportivos internacionais. Outro exemplo é a gestão global da internet, que foi atribuída à ICANN - Internet Corporation for Assigned Names and Numbers. Trata-se de entidade privada, instituída segundo a lei americana. Foi investida de funções de autoridade global, cabendo-lhe a gestão da infraestrutura da internet no âmbito mundial. Esta entidade é responsável pela gestão do sistema comum de endereços na rede e pela atribuição dos endereços para aqueles que têm interesse em ter uma página na rede mundial. Sobre o tema, pode-se consultar Pedro Gonçalves. Regulação administrativa da internet, 2003, p. 177-199.

150 "Há muito o Estado não é o único detentor de poder - talvez nunca tenha sido o único. No mundo contemporâneo, pessoas e grupos privados não só detêm poder político, econômico e ideológico como também desenvolvem lutas de e pelo poder (...) Portanto, o poder não é somente fenômeno político em sentido estrito, cuja manifestação se dá nas relações intra-estatais e entre Estado e particulares. O poder é fenômeno social em sentido amplo, porque se manifesta nas múltiplas relações sociais, sejam elas verticais, sejam elas horizontais" (Wilson Steinmetz. A vinculação dos particulares a direitos fundamentais, 2004, p. 85 e 89).

${ }^{151}$ Sobre o tema, entre outros, consultem-se as obras monográficas de Claus-Wilhelm Canaris. Direitos fundamentais e direito privado, 2009; Virgílio Afonso da Silva. A constitucionalização do direito, 2011; Wilson Steinmetz. A vinculação dos particulares a direitos fundamentais, 2004; Daniel Sarmento. Direitos fundamentais e relações privadas, 2006; Benedita Ferreira da Silva Mac Crorie. A vinculação dos particulares aos direitos fundamentais, 2005.
} 
entre as partes. Esta falta de 'simetria' permite que a parte que por razões econômicas ou sociais se encontra em 'posição dominante' condicione a decisão da parte 'débil'. O que se exerce nesses casos é um poder formalmente privado (no que concerne à sua fonte e aos sujeitos implicados), mas que se exerce com formas de coação e autoridade assimiláveis substancialmente às próprias dos poderes públicos. As decisões desses poderes de supremacia privada, aos quais se atribuem com frequência amplas faculdades de autotutela, são muitas vezes tão imperativas e imediatamente executivas como aquelas adotadas por um órgão administrativo. Produz-se, em suma, uma aproximação substancial entre as relações públicas e privadas de dominação ${ }^{152}$.

As ameaças desencadeadas pela supremacia de um dos indivíduos em relação a outro nas relações entre particulares demandam a proteção daqueles que se encontram sujeitos a tais relações de poder ou de domínio ${ }^{153}$. Não é por acaso que a origem e o desenvolvimento mais profundo da análise dos poderes privados tenha sido verificada no âmbito do direito do trabalho, especialmente no que diz respeito aos poderes exercidos pelo empregador.

Uma das dificuldades é a identificação da intensidade ou grau de assimetria a partir do qual se pode cogitar da configuração de poder privado. A desigualdade sempre esteve presente nas relações humanas. A grande diversificação das relações sociais e os vários condicionamentos impostos à autonomia privada na vida social dificultam a clara identificação das situações em que há propriamente uma situação de dominação de uma das partes sobre a outra que possa ser, de algum modo, assimilada ao poder público.

A possível similitude das manifestações de poderes públicos e privados, em termos fáticos, consiste em uma das principais consequências da proximidade entre eles. Ao se considerarem os atos em si, constata-se que aqueles decorrentes do exercício de poderes privados guardam muita semelhança com os atos praticados no exercício de poderes públicos.

\subsection{O poder jurídico como gênero}

A aproximação entre as manifestações de atividade de polícia e o exercício de poderes privados decorre do fato de a categoria "poder jurídico" poder ser concebida como um gênero, que tem como espécies os poderes titularizados pelo Estado e os poderes privados.

Na definição de Max Weber, “Poder significa toda probabilidade de impor a própria vontade numa relação social, mesmo contra resistências, seja qual for o fundamento

\footnotetext{
${ }^{152}$ La eficacia frente a terceros de los derechos fundamentales en el ordenamiento español, 2007, p. 167-168.

153 Jorge Reis Novais. A intervenção do provedor de Justiça nas relações entre privados.
} 
dessa probabilidade"154. Em seguida, esclarece que o “conceito de 'poder' é sociologicamente amorfo. Todas as qualidades imagináveis de uma pessoa e todas as espécies de constelações possíveis podem por alguém em condições de impor sua vontade, numa situação dada”155.

Adotando a noção de poder como gênero no sistema jurídico, García de Enterría e Tomás-Ramon Fernández destacam que o poder conferido à Administração pelo ordenamento jurídico não consiste em uma figura jurídica distinta dos poderes de titularidade privada ${ }^{156}$. Tanto os poderes públicos quanto os denominados poderes privados consistem em espécies do gênero poder jurídico, que compreende as "faculdades de querer e de agir conferidas pelo ordenamento jurídico aos sujeitos”"157.

Nessa acepção, o poder jurídico diferencia-se do direito subjetivo pois não gera uma relação jurídica específica e não corresponde a um dever atribuído a um sujeito passivo. O poder jurídico é genérico, aplicável a situações não previamente definidas, e decorre diretamente do ordenamento jurídico. A ele corresponde a simples sujeição ou submissão dos outros sujeitos, que suportam os efeitos do exercício do poder jurídico.

Vasco Pereira da Silva reconhece que também existem atos unilaterais privados, que “correspondem ao exercício de poderes jurídicos de que tanto goza a Administração Pública nas relações administrativas, como os particulares no seu relacionamento interprivado"158. Como destaca Jean-Claude Venezia, a natureza desses poderes privados “não é em nada alterada pelo fato de existir uma convenção que colocou os sujeitos numa posição de superior para inferior"159.

\subsection{A delimitação dos poderes privados pelo ordenamento jurídico}

As diversas modalidades e manifestações de poder na sociedade são objeto de amplos estudos pelas ciências sociais.

Os poderes privados podem ser diferenciados em jurídicos e fáticos. Os considerados jurídicos são aqueles cuja supremacia é conferida pelo ordenamento jurídico. Já os poderes de fato são aqueles reconhecidos por outros sistemas que não o jurídico, tais como o social e o econômico.

\footnotetext{
${ }^{154}$ Economia e sociedade, v. 1, 1994, p. 33.

155 Ob. e loc. cit. De modo similar, Floriano de Azevedo Marques Neto ensina que o "conceito de poder nos remete à ideia de capacidade de alguém comandar a conduta alheia, de se fazer obedecer, ou seja, de, em última instância, determinar o comportamento de outrem” (Poderes da Administração Pública, 2012, p. 223).

${ }^{156}$ Curso de derecho administrativo, v. I, 2002, p. 443.

${ }^{157}$ Ob. e loc. cit.

${ }^{158}$ Em busca do acto administrativo perdido, 1996, p. 556.

${ }^{159}$ Puissance publique, puissance privée, 1975, p. 370.
} 
Para o âmbito do presente estudo, interessam-nos apenas os poderes privados reconhecidos pelo direito. São aqueles presentes, por exemplo, nas relações entre instituições privadas de ensino e professores e estudantes, nas relações entre associações e seus respectivos membros e nas relações decorrentes de contratos de trabalho.

Os poderes privados jurídicos não são originários ou soberanos. São conferidos por uma norma superior e apenas podem ser exercidos nos limites nela previstos. Trata-se, portanto, de poderes derivados. São poderes fundados no poder estatal e por ele limitados ${ }^{160}$.

Mas a atuação realizada com base na autonomia privada não consiste na mera aplicação do direito estatal. Ainda que não seja a autonomia privada o fundamento para a criação de normas próprias e para a regulação das relações internas, as entidades privadas dispõem de autonomia para exercer tais funções, que lhe é conferida pela lei e que deve ser exercida dentro dos limites estabelecidos pela lei.

Os poderes privados não são dotados de autoridade no sentido de que permitem dar ordens aos membros da associação mas carecem de força suficiente para obrigar, por seus próprios meios, a execução de tais ordens. Os meios de que as associações dispõem para executar suas ordens são apenas os de caráter disciplinar.

Jellinek diferencia o poder disciplinar do poder de dominação ${ }^{161}$. O meio mais forte de fazer valer as suas ordens de que o poder disciplinar dispõe é a dissolução da relação pessoal, com a supressão do vínculo de associação. Aquele que se submete ao poder disciplinar pode, a qualquer tempo, separar-se da associação se não houver obrigação legal de se manter vinculado a ela. Já o poder de dominação, que pertence originariamente ao Estado, é irresistível. Implica o uso da coação para obter o cumprimento das suas ordens, não havendo como se subtrair ao poder de imperium.

\subsection{O fundamento dos poderes privados}

O fundamento mediato dos poderes privados reconhecidos pelo direito é a lei. À medida que a lei reconhece a determinado sujeito privado a titularidade desses poderes, diz-se ser o ordenamento jurídico o fundamento mediato do exercício desses poderes.

O fundamento imediato está diretamente vinculado ao exercício da autonomia privada.

\footnotetext{
${ }^{160}$ Luigi Ferri. La autonomía privada, 2001, p. 42-45.

${ }^{161}$ Teoría general del Estado, 1958, p. 349.
} 
No direito privado, diz-se que a subordinação é consentida e que a sua justificativa encontra-se na própria autonomia privada. A relação de desigualdade no direito privado apenas pode existir em relações jurídicas constituídas voluntariamente, resultando de um ato de adesão voluntária. Nesse contexto, a lei não pode suprir o ato livre necessário para a constituição da relação privada de poder.

No entanto, disso não decorre que a adesão voluntária constitua o fundamento desse poder autoritativo privado. A livre adesão consiste apenas em condição necessária para o exercício do poder privado. A fonte mediata da autoridade que um particular exerce sobre o outro é a própria lei. Isso decorre do reconhecimento da natureza jurídica dos poderes privados.

No direito público, o fundamento do poder exercido também é a lei. Porém, a livre submissão dos cidadãos não consiste em pressuposto necessário para a sua participação nessa relação de poder. Nas hipóteses em que não se configura a livre adesão, faz-se necessária a delegação de poderes públicos para que as associações privadas possam exercer autoridade sobre os seus associados ${ }^{162}$.

O fundamento dos direitos privados foi analisado com mais detenção em relação ao poder diretivo exercido pelo empregador, no âmbito do contrato de trabalho.

O poder diretivo manifesta-se por força do contrato de trabalho e corresponde ao risco da atividade econômica que é assumido pelo empregador. O poder diretivo exercido pelo empregador implica a capacidade de fazer prevalecer determinadas normas de conduta no âmbito da empresa ${ }^{163}$. Consiste no instrumento utilizado pelo empregador para introduzir determinadas inovações, consideradas necessárias para a consecução dos seus objetivos. Tais mudanças compreendem desde alterações nas condições de trabalho até a dispensa do trabalhador.

O exercício do poder diretivo não é ilimitado. Como poder reconhecido pelo direito $^{164}$, apenas pode ser exercido dentro dos limites previstos no ordenamento jurídico. São várias as limitações aplicáveis, instituídas em um processo de funcionalização do poder diretivo. De um direito potestativo do empregador transmudou-se em um direito-função, a ser exercido não no interesse exclusivo do empregador e sim no da coletividade implicada pelas medidas $^{165}$.

\footnotetext{
${ }^{162}$ Vital Moreira. Administração autónoma e associações públicas, 2003, p. 561.

${ }^{163}$ Octavio Bueno Magano. Do poder diretivo na empresa, 1982, p. 29.

${ }^{164} \mathrm{O}$ fundamento legal do poder diretivo pode ser localizado no art. $2^{\circ}$ da CLT, que atribui ao empregador a direção na relação de emprego.

${ }^{165}$ Octavio Bueno Magano. Do poder diretivo na empresa, 1982, p. 30.
} 
Há duas correntes principais de justificativas para o poder diretivo: a contratual e a institucionalista ${ }^{166}$.

Em linhas gerais, a teoria contratual propugna ser o acordo de vontades entre o empregado e o empregador que determina o surgimento da relação de trabalho entre ambos, com todas as suas decorrências. O empregado, espontaneamente, coloca-se em posição de subordinação e aceita que o empregador exerça a direção da sua atividade. Para a teoria institucionalista, a disciplina da relação de trabalho decorreria da organização interna da empresa. A empresa, como instituição, teria o seu próprio ordenamento, para a tutela dos interesses dos seus membros e disciplina das relações internas. Ao se inserir nessa instituição, o empregado deve obedecer as suas regras ${ }^{167}$.

Em qualquer caso, encontra-se na esfera das relações privadas o fundamento do poder diretivo, ainda que este seja reconhecido pelo direito. Sob esse aspecto, não se confunde, portanto, com as atividades de polícia administrativa.

\subsection{O exercício de atividades similares às de polícia administrativa no âmbito de poderes privados}

A temática dos poderes privados é mencionada no presente trabalho em razão da possível similitude entre manifestações de poderes públicos, quando são exercidos por particulares, e de poderes privados.

Tanto no âmbito do exercício do poder público quanto no do poder privado podem existir situações jurídicas semelhantes, tais como as de emissão de autorizações ou de aplicação de sanções, que se apresentam, inicialmente, como situações subjetivas juridicamente neutras. Para diferenciá-las, é necessário analisar qual é o seu fundamento jurídico.

Isso significa que a sua caracterização como sendo de natureza pública ou privada depende da verificação da natureza da função desempenhada no exercício do referido poder ou da natureza da relação existente entre o titular do poder e aquele que se encontra a ele sujeito. Como se examina adiante, o exercício de funções públicas por particulares depende de delegação estatal. Em alguns casos, o ordenamento jurídico pode

\footnotetext{
166 Ob. cit., p. 50-58.

167 Trata-se da aplicação da noção proposta por Santi Romano, do direito como instituição. Para o autor, o conceito de instituição pressupõe o de direito. O direito apenas poderia se concretizar no âmbito de uma instituição. Por isso, o autor afirma que instituição e direito seriam um mesmo fenômeno. Disso resulta uma pluralidade de ordenamentos jurídicos - há tantos ordenamentos jurídicos quantas são as instituições. Mas esses ordenamentos jurídicos da sociedade organizada seriam derivados, subordinados ao ordenamento estatal (O ordenamento jurídico, 2008, p. 92).
} 
até atribuir efeitos públicos a determinados atos praticados por particulares mas não se trata do exercício de função delegada.

\subsection{Exemplos de atos que implicam o exercício de poderes privados}

Para demonstrar o que se mencionou acima, apresentam-se alguns exemplos de atividades que envolvem apenas o exercício de poderes privados. Apesar disso, a sua exteriorização poderá apresentar feições similares às das situações em que há exercício de funções públicas por particulares.

\subsubsection{Segurança privada}

O primeiro exemplo é o da segurança privada.

A contratação de segurança privada por particulares para a defesa pessoal e de seu patrimônio apenas pode envolver o manejo de poderes privados. Não envolve a delegação de poderes públicos para o exercício de segurança privada ${ }^{168}$.

As empresas de segurança privada atuam no âmbito do direito privado e exercem poderes privados. Daí que os poderes de defesa que podem exercer são apenas aqueles tolerados pelo direito privado e que têm o seu uso conferido a qualquer pessoa em circunstâncias específicas, tais como os de uso da força no contexto de legítima defesa e de flagrante delito.

Isso significa que os atos praticados no âmbito da segurança privada são atos privados, que apenas podem envolver o manejo dos poderes a todos reconhecidos para fins de autodefesa e para afastar dano iminente. Os atos praticados devem, assim, observar os limites previstos na lei para o afastamento da ilicitude dos atos praticados em legítima defesa ${ }^{169}$.

A ampliação da participação da segurança privada é um fenômeno verificado nos mais diversos países. Chega-se a afirmar que a segurança não é mais concebida apenas em termos de agentes do Estado ${ }^{170}$. A participação privada assumiu uma dimensão significativa especialmente nos espaços qualificados como semi-públicos, tais como centros

\footnotetext{
${ }^{168} \mathrm{O}$ fato de a segurança privada acabar, em alguma medida, colaborando para a segurança pública e o estímulo estatal conferido à primeira atividade podem significar a instrumentalização dos poderes privados para a persecução de finalidades públicas de segurança. Assim se passa porque a segurança privada auxilia reflexamente no exercício da segurança pública. Na definição dada por Jean-Paul Négrin, consiste em manifestação de colaboração exterior à função de polícia, que propicia o reforço da polícia pública (L'intervention des personnes morales de droit prive dans l'action administrative, 1971, p. 99). Porém, isso não implica mutação da natureza jurídica destes poderes privados.

${ }^{169}$ Código Civil, art. 188.

${ }^{170}$ Joanna Shapland e Lode Van Outrive. Police et securité, 1999, p. 7.
} 
de compras, hospitais e escolas, nos quais a população acaba convivendo até mesmo mais do que nos espaços públicos propriamente ditos.

A questão adquire maior complexidade quando aquele que contrata a segurança privada é o próprio Estado, para fins de controle e vigilância de bens públicos e exercício de determinadas atividades de fiscalização ${ }^{171}$.

Nesse tipo de contratação, a questão reside em diferenciar quais tarefas podem ser exercidas no âmbito da segurança privada e quais integram necessariamente a segurança pública. Em princípio, como se indicou acima, as empresas de segurança privada atuam no âmbito do direito privado e exercem poderes privados. Nesse contexto, poderão se utilizar da força apenas nos casos em que isso for autorizado para qualquer particular (por exemplo, nas hipóteses de legítima defesa e de flagrante delito).

Pode ser constatada uma conexão entre exercício privado de atividades de polícia administrativa e exercício de poderes privados quando a Administração for usuária dos serviços de segurança privada ${ }^{172}$.

Com frequência, a Administração recorre à privatização de atividades de vigilância, atribuindo sua execução a empresas privadas. O Estado permanece sendo titular da atividade, mas ela é executada por particulares. Porém, disso decorrem vários questionamentos. Por exemplo, pode-se indagar se os agentes privados podem exercer o controle de entrada, saída e presença de pessoas em bens públicos de uso comum ou de uso especial abertos ao público, o que implica decidir, em última análise, quem pode entrar ou não no local.

Ou seja, a questão que se coloca é se a Administração pode e, caso positivo, em quais termos, atribuir a uma empresa privada a execução de tarefas de segurança e vigilância com o emprego de meios privados. Trata-se de empregar poderes privados no exercício de uma função pública, uma vez que os poderes públicos de segurança, que implicam o emprego de coerção, não são passíveis de delegação.

A contratação de segurança privada pela Administração é utilizada principalmente para atuação em recintos públicos, de acesso controlado ou restrito.

\footnotetext{
${ }^{171}$ Como observa Vinicius Marins, não deixa de ser paradoxal que a própria Administração tenha sido uma das principais responsáveis pelo incremento das atividades de segurança privada, seja recorrendo constantemente a esses serviços (conforme dados apresentados pelo autor, estima-se que o poder público concentra a contratação de cerca de $40 \%$ dos vigilantes do mercado) seja impondo a sua contratação aos particulares que desempenham certas atividades - tal como se passa em relação às instituições financeiras, que apenas podem funcionar se possuírem sistema de segurança com parecer favorável à sua aprovação, elaborado pelo Ministério da Justiça (Lei $\mathrm{n}^{\circ}$ 7.102/83, art. $1^{\circ}$ ) (Contratação de serviços de segurança privada pela Administração Pública, 2010).

${ }^{172}$ Como autoriza o art. 10, §2, da Lei n ${ }^{\circ} 7.102 / 83$.
} 
O acesso aos imóveis públicos pode ser livre, sujeito a restrições ou vedado. Quando o acesso for vedado, a contratação de segurança privada não é apta a causar maiores problemas, considerando-se que a vedação da entrada é generalizada e decorre de ato normativo. Podem ocorrer maiores controvérsias quando se tratar de imóveis de acesso livre ou restrito. Em tais casos, os agentes privados exerceriam atividades de controle de entrada, saída e presença de pessoas. O grau de interferência da atividade do agente privado na esfera dos cidadãos depende das circunstâncias de verificação das condições de ingresso no recinto. Se forem condições de constatação simplesmente mecânica, tal como a apresentação de determinado documento, a atividade será pautada por critérios predeterminados e objetivos.

Porém, o questionamento que se coloca é se o agente privado poderia adotar comportamentos ativos em face de alguma situação fora da rotina, tal como autorizar o ingresso de pessoas que, em princípio, não poderiam ser autorizadas ou expulsar pessoas que adotem comportamentos inconvenientes ${ }^{173}$.

Parece-nos que as atividades que demandem adotar decisões que não observem estritamente critérios objetivos previamente programados ou impedir acesso de pessoas implicam a assunção de uma posição de soberania e de domínio naquele recinto e o exercício de poderes públicos de coerção. Portanto, não são passíveis de exercício por particulares.

No caso dos bens públicos, o direito de autorizar o ingresso e de expulsar é conferido pelo ordenamento jurídico e deve ser exercido com o objetivo de garantir as condições necessárias para a realização da função pública naquele espaço. Parece-nos que o seu fundamento não é propriamente o direito de propriedade e sim a necessidade de se propiciar as condições para o exercício das funções públicas. O mesmo se passa em relação aos poderes de revista de pessoas, exercidos, por exemplo, nos aeroportos. Trata-se do exercício de poderes de autoridade.

Desse modo, os atos de autorização de ingresso, de expulsão e de revista consistiriam em atos administrativos. A decorrência disso é que o exercício de tais atos por particulares implicaria a delegação de exercício de poderes públicos e não a simples prática de atos materiais. Mesmo que a Administração determine previamente todos os critérios

\footnotetext{
${ }^{173}$ Pedro Gonçalves anota que a prática de tais atos diria respeito ao exercício de competências integradas no "Hausrecht" que, segundo a doutrina germânica, consiste no "direito de uma pessoa decidir livremente quem pode entrar e permanecer num espaço definido sobre o qual tenha uma posição soberana e de domínio” (Entidades privadas com poderes públicos, 2008, p. 379).
} 
das decisões, faz-se necessária, em face das circunstâncias específicas, a interpretação das condições e a adoção da decisão concreta, que consiste em ato administrativo.

Reputamos ser possível a atribuição de algumas dessas atividades a particulares desde que todos os aspectos e critérios do seu exercício sejam previamente determinados pela Administração, de modo objetivo, e não envolvam o exercício de coerção $^{174}$. Particulares podem, por exemplo, autorizar o ingresso de pessoas em determinado prédio público, mediante a conferência dos documentos necessários para se verificar se estão presentes os requisitos, previamente estabelecidos pela Administração, para a entrada no estabelecimento.

No entanto, em caso de não preenchimento dos requisitos e de resistência do particular que não teve a sua entrada autorizada, faz-se necessária a intervenção do poder público, único legitimado para o exercício da coerção ${ }^{175}$. Após a tomada de decisão pela autoridade ou pelo particular no exercício da atividade pública, se houver resistência, será imprescindível a intervenção da segurança pública. Em nenhuma hipótese poderá ser transferida a particulares a execução coerciva das decisões.

Cabe ressalvar que apenas nas hipóteses em que não se atribuir ao agente privado a possibilidade de adotar qualquer tipo de decisão é que se verifica a transferência de simples atividades materiais, instrumentais ou acessórias.

Em tais casos, os particulares poderão adotar medidas ativas compreendidas no “direito de todos”, no direito privado, consistentes especialmente na atuação em legítima defesa e na detenção em flagrante. No entanto, os institutos de direito privado não podem ser desnaturados, passando a ser aplicados sistematicamente. Trata-se de medidas excepcionais de legítima defesa. Se o exercício da atividade de segurança em favor da

\footnotetext{
${ }^{174}$ Algumas atividades podem se colocar em uma zona limítrofe entre o exercício de atividades de fiscalização e o manejo da coerção. Nesses casos, a constatação de que se trata de atividades previamente determinadas, desempenhadas com a aplicação de critérios objetivos e uniformes em relação a todos os que a ela se submetem é essencial para se autorizar o seu desempenho por particulares, ainda que possam implicar algum grau de constrangimento aos cidadãos. Como ensina Pedro Gonçalves: "Desde que se torne viável determinar antecipadamente, em termos rigorosos, o âmbito da intervenção agressiva, a possibilidade de delegação não se encontra liminarmente excluída. Alguma doutrina refere-se, neste domínio, à viabilidade da delegação que tenha por objeto a adoção de medidas coativas enumeradas, estandardizadas e de aplicação rotineira: assim sucede, por ex., com o controle e a revista de pessoas nos aeroportos ou noutros locais públicos de acesso condicionado. Com efeito, nesta hipótese, a intensidade da ingerência que representa a ação pública encontra-se predefinida e legalmente balizada, dando origem a uma atuação esperada, com contornos definidos e que se manifesta através de medidas que se aplicam, nos mesmos termos, a todos os cidadãos abrangidos” (Entidades privadas com poderes públicos, 2008, p. 965 - grifos no original).

175 "É fundamental que o agente de segurança privada, diante de situações excepcionais, que demandem uma decisão gravosa com impacto direto/imediato sobre a esfera jurídica do cidadão, solicite a presença de um responsável pelo estabelecimento, ou demande a intervenção das forças de segurança pública - legitimados que estão, ambos, à prática de atos administrativos com feições de autoridade” (Vinicius Marins. Contratação de serviços de segurança privada pela Administração Pública, 2010).
} 
Administração demandar o emprego usual, frequente, de mecanismos de defesa, isso implicaria a indevida delegação de poderes públicos de coerção aos agentes privados, pois tal atuação não é compatível com a natureza excepcional dos direitos privados de defesa.

\subsubsection{Associações privadas}

Outro exemplo de exercício de poderes privados pode ser encontrado nas atividades das associações.

O CC/2002 tratou separadamente das associações civis, sem fins lucrativos, em relação às sociedades comerciais.

Em relação às associações, os seus estatutos correspondem às suas normas orgânicas. Ao ingressarem na associação, os associados aderem ao seu estatuto ${ }^{176}$.

Os poderes que as associações privadas exercem sobre os seus associados consistem em poderes privados. Uma das principais manifestações desses poderes é a aplicação de medidas disciplinares em relação aos associados. Assim, em princípio, as sanções aplicadas por associações privadas não consistem em exercício de poder punitivo do Estado. Trata-se de manifestação de poderes privados, que também devem observar as garantias constitucionais do devido processo, do contraditório e da ampla defesa.

Voluntariamente, ao ingressar na associação, o indivíduo submete-se ao poder disciplinar exercido pela instituição sobre aqueles que se encontram a ela vinculados. O poder disciplinar das associações apresenta a mesma natureza dos poderes exercidos pelo empregador sobre seus empregados, que foi objeto de análise acima.

Uma das manifestações mais intensas do poder exercido pelas associações consiste na possibilidade de exclusão do associado. O art. 57 do CC/2002 estabelece que a exclusão apenas poderá ocorrer se houver justa causa. Estipula também que deverá ser assegurado ao associado o exercício do direito de defesa e de recurso, na forma prevista no estatuto. Em relação à aplicação das garantias do devido processo, essa questão já decorre do próprio texto constitucional. Trata-se de hipótese de eficácia dos direitos fundamentais nas relações privadas. Aliás, a exclusão de associado é um dos exemplos mais recorrentes da vinculação de particulares aos direitos fundamentais.

Nas associações, existe também a possibilidade de os associados destituírem os dirigentes, revogando os mandatos que lhes foram conferidos. Em qualquer caso, os procedimentos internos devem assegurar a observância das garantias constitucionais, em especial as do contraditório e da ampla defesa.

\footnotetext{
${ }^{176}$ Os requisitos obrigatórios dos estatutos das associações encontram-se previstos no art. 54 do CC/02.
} 
A CF/88 consagrou expressamente a liberdade de associação entre os direitos e garantias fundamentais. Esse aspecto é relevante para a identificação da natureza dos poderes exercidos pelas associações sobre os seus associados. Se a adesão à entidade privada for obrigatória, ainda que se trate de associação civil, os poderes por ela praticados deverão ser de origem estatal, exercidos mediante delegação.

Configuram-se poderes privados de disciplina apenas se forem aplicáveis exclusivamente aos associados, que aderiram voluntariamente à instituição. Na hipótese de os poderes disciplinares atingirem terceiros, não associados, ou se a vinculação à associação for compulsória, verifica-se a delegação do exercício de poderes públicos.

Em relação à garantia de liberdade de associação, uma questão que se coloca é até que ponto seria possível estimular - ou, eventualmente, até mesmo pressionar - os interessados para que se associem, sem comprometimento do caráter voluntário da associação. O fomento à participação é admitido. Porém, a adoção de medidas mais rígidas, que possam configurar algum tipo de constrangimento para que se promova a associação, devem ser examinadas com cautela. Se for afastada a voluntariedade na formação do vínculo, os poderes de supremacia apenas poderão ser exercidos caso sejam expressamente atribuídos pelo ordenamento jurídico à associação. Deverão consistir em poderes públicos, com fundamento na ordem legal e não na autonomia privada.

\subsubsection{Federações desportivas}

Ao se tratar do exercício de poderes privados, podem ser mencionadas também as federações desportivas.

As federações desportivas são usualmente constituídas como associações de direito privado. No entanto, tais entidades são de utilidade pública e, em alguns países, exercem funções regulamentares e disciplinares, que envolvem o manejo de prerrogativas de autoridade. Cabe analisar se os poderes que exercem são exclusivamente privados, decorrentes da relação associativa, ou se haveria algum tipo de delegação de poderes públicos.

Na sua origem, o direito desportivo surgiu sob a forma de autorregulação privada, no sentido de dispensar a intervenção estatal. Por isso, em diversos ordenamentos, inclusive o nacional ${ }^{177}$, existe cláusula de vedação ou limitação de acesso à justiça estatal para a resolução de conflitos desportivos.

${ }^{177} \mathrm{CF} / 88$, art, 217, $\S 1^{\circ}$. 
Posteriormente, passou a haver maior ingerência estatal no direito desportivo em alguns países. Nos ordenamentos jurídicos francês, espanhol e português, por exemplo, há expressa delegação de poderes para as federações desportivas ${ }^{178}$.

No direito francês, o desporto é considerado serviço público administrativo. Naquele ordenamento jurídico, há expressa previsão legal de delegação de poder disciplinar às federações responsáveis pela organização e promoção de atividades físicas e desportivas $^{179}$.

Reconhece-se a natureza pública da atividade exercida pelas federações por lhes caber a expedição das licenças, que são obrigatórias para todos os esportistas participantes de atividades competitivas. Ainda que não seja compulsória a adesão à federação, os desportistas deverão obter as licenças por elas emitidas para que possam participar de competições. Por isso, o Estado exerce controle sobre a atividade das federações no que diz respeito à expedição das licenças.

A esse respeito, cabe mencionar importantes decisões do Conselho de Estado francês a respeito de confrontos entre torcidas de times de futebol. O Conselho de Estado afirmou a obrigação atribuída aos organizadores dos campeonatos de assegurar a segurança da área e de tomar todas as medidas para evitar a ocorrência de conflitos antes, durante e após os jogos ${ }^{180}$. Com esses julgamentos, como constata Elina Lemaire, o Conselho de Estado reconheceu a legalidade da disposição que atribui o exercício de atividades de polícia a entidades privadas ${ }^{181}$.

Na Espanha, as federações desportivas também consistem em associações de caráter privado, às quais são atribuídas funções públicas de natureza administrativa por delegação. Entre essas funções, está previsto o exercício de poder sancionatório.

Portanto, nos sistemas espanhol e francês, cada federação desportiva dispõe de competência para o estabelecimento e aplicação de um código de disciplina próprio. Considera-se que essa função disciplinar é exercida mediante delegação do poder público.

\footnotetext{
${ }^{178}$ José Bermejo Vera relata a intensa controvérsia existente na Espanha acerca do caráter público ou privado das federações desportivas, considerando que o legislativo delegou-lhes expressamente o exercício de determinadas funções de caráter administrativo. Para o autor, não haveria como qualificá-las como entidades públicas, considerando tratar-se de associações constituídas exclusivamente por associações privadas. Mas menciona o posicionamento de Parada Vázquez, para quem as federações teriam inequívoco caráter público, ao ponto de enquadrá-las como "corporações públicas representativas de interesses setoriais” (Privatización y el nuevo ejercicio de función pública por particulares, p. 419).

179 Código do Esporte, art. L232-21.

${ }^{180}$ CE, avis, 29 de outubro de 2007, Société sportive professionnelle LOSC Lille Métropole, Lebon 431 e CE 20 de outubro de 2008, Fédération Française de Football, req. n 320111. No mesmo sentido, o Código do Esporte, art. L332-1, atribui aos organizadores de manifestações desportivas com fins lucrativos o dever de garantir a segurança e a ordem nos eventos.

${ }_{181}$ Actualité du principe de prohibition de la privatisation de la police, 2009, p. 767.
} 
Já nos sistemas alemão e britânico, por exemplo, as federações desportivas não exercem poderes públicos. Porém, em todos esses sistemas, tais entidades exercem poderes de supremacia sobre aqueles que se submetem à sua atividade. Há de se considerar também a organização de tais entidades no âmbito internacional, em grandes entidades privadas tais como a FIFA e o COI.

No direito brasileiro, as federações desportivas também não exercem poderes públicos.

$\mathrm{O}$ art. 217, inc. I, da CF/88 consagra "a autonomia das entidades desportivas dirigentes e associações, quanto à sua organização e funcionamento”. Já o art. 24, inc. IX, prevê a competência concorrente da União, dos Estados e do Distrito Federal para legislar sobre desporto.

Assegura-se expressamente a prática do desporto, independentemente da associação à entidade do setor ${ }^{182}$.

Constata-se que as associações desportivas não dispõem da mesma autonomia reconhecida às associações civis pelo Código Civil. Trata-se de uma autonomia especial, sujeita a determinadas regras cogentes (tais como as previstas na Lei no 9.615/98).

As funções disciplinares são de competência exclusiva da Justiça Desportiva $^{183}$. Assim, diferentemente do que se passa nos modelos espanhol e francês, por exemplo, em que cada federação dispõe de um código de disciplina próprio, toda a função disciplinar, para os diversos esportes, observa regras e procedimentos comuns ${ }^{184}$ e encontra-se unificada na Justiça Desportiva.

No regime anterior à $\mathrm{CF} / 88$, o poder disciplinar em relação à prática dos desportos também era exercido pela Justiça Desportiva. Reconhecia-se que os poderes exercidos pelas entidades desportivas tinham natureza privada ${ }^{185}$.

\subsubsection{Autorregulação}

Outra hipótese de atividade que pode envolver o exercício de poderes é a autorregulação.

\footnotetext{
${ }^{182}$ Lei n ${ }^{\circ} 9.615 / 98$, art. $2^{\circ}$, incs. II, III e IV. No art. $4^{\circ}, \S 2^{\circ}$, reitera-se a liberdade de associação como fundamento da organização desportiva nacional.

${ }^{183}$ Lei no 9.615/98, art. 50. O art. 90-C da mesma lei exclui expressamente a possibilidade de utilização da arbitragem para a resolução de litígios que tenham por objeto a disciplina desportiva.

184 As regras e procedimentos comuns estão previstos especialmente no Código Brasileiro de Justiça Desportiva - Resolução n ${ }^{\circ} 29$ do Conselho Nacional do Esporte (aprovado em 10.12.09, DOU de 31.12.09).

${ }^{185}$ Decreto n 80.228, de 25.8.77: “Art. 67 - Não exercem função delegada pelo Poder Público os dirigentes, órgãos e poderes de entidades desportivas de natureza privada, assim classificadas as associações, ligas, federações e confederações desportivas, centro de desportos classistas e o Comitê Olímpico Brasileiro”.
} 
Como se examina adiante ${ }^{186}$, em algumas hipóteses os poderes exercidos pelas entidades de autorregulação foram-lhes delegados pelo poder público. Os poderes que exercem têm, portanto, natureza pública.

Já em outros casos de autorregulação, os poderes exercidos são de natureza privada. Nesse caso, a autorregulação pode até mesmo ser induzida ou ter alguns dos seus efeitos reconhecidos pelo poder público. No entanto, a origem dos poderes exercidos é privada, não havendo delegação estatal.

A autorregulação pode, portanto, configurar-se como exercício de poderes de natureza pública ou exclusivamente privada.

\section{3. $\underline{\text { A possibilidade } \underline{\text { de }} \underline{\text { contratualização }} \underline{\text { do }} \underline{\text { exercício }} \underline{\text { de }} \text { atividades } \underline{\text { de }} \text { polícia }}$ administrativa}

Uma questão interessante a ser analisada em relação às atividades de polícia administrativa diz respeito à possibilidade da contratualização do seu exercício. Trata-se das situações em que a Administração exerce a atividade de polícia não unilateralmente mas de forma concertada com o particular.

Note-se que se trata de temática distinta daquela que é objeto do presente estudo, que é o exercício de atividades de polícia administrativa por entidades privadas. No exercício privado de função pública, a Administração transfere ao particular o exercício de determinada atividade, que permanece sendo de titularidade estatal. Já no exercício contratualizado, a Administração exerce diretamente a atividade de polícia mas o faz mediante a celebração de acordos com particulares.

Por comum acordo com a Administração, o particular compromete-se a cessar determinada conduta ou a adotar determinada providência. Em contrapartida, a Administração restringe, condiciona ou afasta o exercício da competência de polícia administrativa no caso concreto.

\subsection{A consensualidade na atividade administrativa}

Não cabe no âmbito do presente estudo discorrer amplamente acerca da consensualidade no direito administrativo. Apresentam-se apenas breves notas, de modo a contextualizar a contratualização do exercício de atividades de polícia administrativa.

${ }^{186}$ V. item II.4. 
O direito administrativo, como instrumento de concretização do Estado de Direito, foi marcado, na sua origem, pela transferência ao Estado de prerrogativas em alguma medida análogas àquelas detidas pelo monarca nos regimes absolutistas. Esse viés de autoridade acompanhou várias das construções teóricas do direito administrativo. Nesse contexto, o consenso não encontrava maior espaço na ação administrativa.

Odete Medauar, ao discorrer sobre as linhas de transformação das matrizes clássicas do direito administrativo, ressalta a importância da figura do contrato administrativo. Aponta duas vertentes pelas quais a atenção sobre o tema foi renovada em meados da década de 70, especialmente a partir da década de $90^{187}$.

A primeira vertente diz respeito à concepção clássica do contrato administrativo como sendo aquele cujo regime se caracteriza pela possibilidade de exercício de prerrogativas especiais pelo contratante público. Propugnou-se (i) maior simplificação do procedimento de contratação e outorga de maior liberdade à Administração de escolha dos contratados, (ii) a tendência à paridade ou à menor desigualdade entre as partes, revelando preocupação sobretudo com a posição do particular contratado, (iii) o questionamento da suposta inaplicabilidade absoluta da exceptio non adimpleti contractus, e (iv) o reconhecimento do particular contratado como um parceiro, um colaborador da Administração.

O outro ângulo diz respeito à atenuação do caráter unilateral e impositivo da atividade administrativa, com o incremento do emprego dos módulos convencionais, contratuais ou consensuais. A sua utilização insere-se no âmbito da Administração concertada. Essa nova forma de agir da Administração é motivada pela multiplicidade de interesses em jogo, que exigem a ampliação do debate e discussão nos mecanismos democráticos, de modo a obter maior aproximação entre Estado e sociedade.

O emprego da consensualidade na atividade administrativa relaciona-se com diversos fenômenos convergentes ${ }^{188}$. A doutrina apresenta vários fundamentos para a busca da consensualidade, no sentido de limitação da autoridade do Estado, incremento da

\footnotetext{
${ }^{187}$ O direito administrativo em evolução, 2003, p. 206-215.

${ }^{188}$ Sobre o tema, confiram-se, entre outros, Alexandre Santos de Aragão. A consensualidade no direito administrativo, 2006; Carlos Ari Sundfeld e Jacintho Arruda Câmara. Acordos substitutivos nas sanções regulatórias, 2011; Floriano de Azevedo Marques Neto e Tatiana Matiello Cymbalista. Os acordos substitutivos do procedimento sancionatório e da sanção, 2010; Maria Sylvia Zanella Di Pietro. A participação popular na Administração Pública, 1993; Juliana Bonacorsi de Palma. Atuação administrativa consensual, 2010; Mark Bobela-Mota Kirkby. Contratos sobre o exercício de poderes públicos, 2011; Luciano Parejo Alfonso. Los actos administrativos consensuales en el derecho español, 2003; Alejandro Huergo Lora. Los contratos sobre los actos y las potestades administrativas, 1998; Luciano Ferraz. Termos de ajustamento de gestão (TAG), 2010; Vitor Rhein Schirato e Juliana Bonacorsi de Palma. Consenso e legalidade, 2011.
} 
participação dos cidadãos na atividade administrativa e emprego de outras formas de exercício do poder de autoridade pelo Estado que não a unilateral.

Como enumera Juliana Bonacorsi de Palma, em aprofundado estudo sobre o tema, os fundamentos encontrados com maior frequência na doutrina seriam os seguintes: (i) a busca pela democracia substantiva, com maior envolvimento direto dos cidadãos no exercício das atividades administrativas, (ii) a crescente contratualização da atividade administrativa, com o recurso a módulos contratuais diversos para o exercício das competências administrativas, e (iii) a busca pela eficiência, enaltecendo as externalidades positivas obtidas com a celebração de acordos administrativos ${ }^{189}$.

\subsection{A contratualização do exercício de uma competência administrativa em substituição ao ato unilateral}

Podem ser diferenciadas a disposição em tese da titularidade de determinada competência da negociação do seu exercício em determinado caso concreto.

A esse respeito, Santi Romano destaca que um poder não pode ser objeto de disposição pelo seu titular: “ele não pode nem modificá-lo substancialmente, nem aliená-lo, nem renunciar-lhe. No entanto se admite, em tais casos, que o seu titular possa, mediante ato bilateral ou unilateral, comprometer-se a não exercitá-lo ou a exercitá-lo de tal modo e dentro de certos limites”,

Importa distinguir o direito do seu exercício ${ }^{191}$. O direito deve necessariamente preexistir ao seu exercício e permanece exatamente o mesmo após o desempenho das competências a ele vinculadas, independentemente da quantidade de vezes em que isso ocorrer. Alguém pode exercer direito de outrem, por meio de diversos mecanismos previstos no direito (representação, substituição etc.) mas isso não implica qualquer transferência do direito a outrem.

Esse ato de disposição não atinge o direito em si, não comprometendo a sua existência nem a titularidade estatal, mas apenas o seu exercício em relação a determinada pessoa e caso específico. Também por isso a negociação do exercício do direito não compromete o princípio da irrenunciabilidade.

A esse respeito, Fernando Dias Menezes de Almeida analisa os módulos convencionais substitutivos de decisão unilateral da Administração entre os diversos módulos convencionais que propõe para sistematizar a ampliação do fenômeno contratual

\footnotetext{
${ }^{189}$ Atuação administrativa consensual, 2010, fl. 82-84.

${ }^{190}$ Frammenti di un dizionario giuridico, 1947, p. 200.

${ }^{191}$ Santi Romano. Ob. cit., p. 199.
} 
da Administração. Trata-se dos casos em que a Administração teria o poder de criar unilateralmente a situação jurídica pretendida, independentemente da concordância da outra parte, mas opta por substituir o exercício unilateral da competência pelo acordo de vontades: “a Administração possui o poder unilateral de impor à outra parte - privada ou pública - a situação jurídica que pretende estabelecer, independentemente do acordo de vontades; contudo decide substituir o exercício desse poder por um acordo de vontades”,192.

\subsection{A compatibilidade entre a contratualização e o princípio da indisponibilidade do interesse público}

A principal questão que se coloca é se celebrar um acordo em substituição à prática de um ato unilateral não implicaria disponibilização do interesse público.

Pode-se afirmar que celebrar acordos não implica disponibilizar o interesse público e sim adotar um mecanismo mais apto para se satisfazerem as necessidades coletivas.

A celebração de acordos não implica ofensa ao princípio da indisponibilidade do interesse público. Não determina a perda, pela Administração, da sua faculdade de resolução unilateral. Deixar de empregar as prerrogativas públicas no caso concreto não implica necessariamente renúncia às competências administrativas.

Isso se verifica inclusive quando, mediante acordo, a Administração deixa de aplicar determinada sanção ou reduz o montante da penalidade inicialmente aplicada. Esses atos poderiam ser praticados unilateralmente pela Administração. Não existe um dever da Administração, por exemplo, de sempre aplicar sanção administrativa. Faz-se necessária a avaliação das circunstâncias do caso concreto para se concluir pelo cabimento ou não da sanção ${ }^{193}$.

Logo, a celebração de acordos não implica renúncia ao exercício de competências administrativas nem omissão no desempenho de poderes. Trata-se apenas da adoção de determinado procedimento para se chegar à decisão final. A eventual vulneração ao interesse público decorrerá do próprio conteúdo da decisão, tenha sido ela formalizada como ato unilateral ou acordo.

\footnotetext{
${ }^{192}$ Fernando Dias Menezes de Almeida. Contrato administrativo, 2012, p. 297.

193 Apesar disso, no passado era recorrente a afirmação da impossibilidade de celebração de acordos pela Administração. Por exemplo, o Conselho de Estado francês, com o precedente Ville de Castelnaudary (CE 17 juin 1932), firmou o entendimento no sentido da incompatibilidade entre o exercício da atividade de polícia e o contrato, com fundamento no princípio de que uma autoridade administrativa não pode abrir mão de sua competência de decisão unilateral, o que ocorreria com a celebração de acordos. No precedente Valet (CE 23 octobre 1974), o Conselho de Estado decidiu pela "impossibilidade para a Administração de celebrar uma convenção sobre o exercício dos poderes de polícia”.
} 
Um conteúdo que não poderia legitimamente constar de decisão unilateral não poderá também ser o teor de acordo celebrado pela Administração em substituição ao ato unilateral. A relação jurídica consensual formada em substituição ao ato unilateral apenas pode ser aquela sobre a qual a Administração poderia exercer a sua atividade jurídica unilateral.

Como regra geral, o conteúdo de um acordo está limitado àquele que seria o conteúdo possível para o ato unilateral que está sendo substituído. Isso não significa que o conteúdo do ato unilateral cabível não possa ser superado em nenhum caso. Essa ampliação dos limites do ato unilateral poderia ocorrer ao menos em dois casos $^{194}$.

No direito administrativo também há normas dispositivas, que tutelam exclusivamente o interesse dos particulares. Nesse caso, a concordância do particular poderia permitir o afastamento ou a modificação do alcance da incidência da regra dispositiva ${ }^{195}$. Outra hipótese em que o teor do acordo poderia superar o do ato unilateral seria aquele do ato favorável ao administrado, praticado no exercício de competência discricionária da Administração, no qual são previstas determinadas contraprestações pelo administrado. Tais contraprestações não se encontram previstas na norma que atribui a competência discricionária à Administração mas a sua estipulação consensual permite a adoção de soluções mais adequadas ao interesse público.

\subsection{A necessidade de autorização legal para a celebração de acordos substitutivos de atos unilaterais}

Em alguns ordenamentos jurídicos, a possibilidade de substituição da decisão unilateral por atos convencionais é prevista na forma de regra geral. Podem ser mencionados os exemplos dos direitos alemão, italiano e espanhol.

No direito alemão, uma das espécies de contrato público é o contrato decisório, substitutivo de decisão unilateral. Nos termos de Lei de Processo Administrativo de 1976, esses contratos podem ser de transação, para pôr fim a uma situação de incerteza, mediante concessões recíprocas, e contratos de intercâmbio, que criam obrigações recíprocas.

No direito italiano, a Lei de Processo Administrativo (de $n^{\circ}$ 241/90) prevê a figura dos acordos administrativos, que podem ser substitutivos de decisão ou integrativos da decisão. Os primeiros assumem o lugar da decisão unilateral que seria adotada pela

\footnotetext{
${ }^{194}$ Alejandro Huergo Lora. Los contratos sobre los actos y las potestades administrativas, 1998, p. 329-344.

195 Exemplo disso seria o acordo celebrado sobre o valor da indenização devida pela Administração ao particular pela expropriação de determinado bem.
} 
Administração. Já os segundos não eliminam a necessidade de se proferir a decisão unilateral mas o seu conteúdo, desde que discricionário, é previamente determinado no acordo. Ou seja, em qualquer caso, o conteúdo da decisão é decidido de modo convencional. Ao final do processo, produz-se um ato unilateral ou um ato convencional, sem consequências juridicamente distintas.

No direito espanhol, a Lei $n^{\circ}$ 30/92 (Regime Jurídico das Administrações Públicas e do Procedimento Administrativo Comum) prevê a possibilidade de a Administração celebrar acordos tanto na fase de decisão administrativa quanto na de julgamento de eventual impugnação à decisão, ressalvando as matérias não suscetíveis de transação.

No Brasil, não há norma geral prevendo a possibilidade de a Administração celebrar acordos em substituição à decisão unilateral. Porém, também não há uma regra que vede. Há previsões normativas esparsas que dispõem sobre a celebração de acordos administrativos em substituição à decisão unilateral ${ }^{196}$.

Parcela da doutrina nacional reputa ser necessária a expressa previsão normativa autorizando a celebração de acordos em substituição à prática de atos unilaterais.

Esse é o entendimento, por exemplo, de Carlos Ari Sundfeld e Jacintho Arruda Câmara ${ }^{197}$. Segundo os doutrinadores, o poder de negociar, modulando em concreto as normas definidoras de deveres, proibições e sanções, deve ser atribuído por norma de hierarquia igual ou superior àquela cuja incidência tenha que ser modulada para viabilizar o acordo. Por exemplo, se a detalhada especificação das infrações e das sanções correspondentes constar da lei, quando menos deverá também ser prevista em lei a possibilidade de celebrar ajustes. Já se as infrações e as sanções não forem especificadas em lei e sim em regulamento, a previsão de celebração de acordos pode constar de regulamento.

O posicionamento de Fernando Dias Menezes de Almeida inclina-se pela desnecessidade de autorização legal expressa. Sustenta que, no poder de decidir unilateralmente, está implícito o poder de decidir de modo consensual com o destinatário da decisão. Ao ter a competência para praticar o ato unilateral, a Administração também

\footnotetext{
${ }^{196}$ Em termos exemplificativos, podem ser mencionadas as seguintes previsões legislativas que autorizam a celebração de acordos em substituição à decisão unilateral: a) acordo extrajudicial para fins de desapropriação (DL 3.365/41, art. 10), b) celebração de TAC no âmbito da Lei de Ação Civil Pública (Lei n ${ }^{\circ} .347 / 85$, art. $5^{\circ}$, $\left.\S 6^{\circ}\right)$, c) celebração de TAC pela ANEEL (Resolução Normativa $n^{\circ} 63 / 2004$, art. 21), d) celebração de TAC pela ANS (Lei ${ }^{\circ} 9.656 / 98$, art. 29, $\S 1^{\circ}$ ), e) celebração de compromisso de cessação da infração à ordem econômica sob investigação (Lei nº 12.529/11, art. 85).

${ }^{197}$ Acordos substitutivos nas sanções regulatórias, 2011, p. 133-134.
} 
estaria autorizada a impor a si mesma determinados condicionamentos à sua ação, podendo chegar a esse mesmo resultado pela via consensual ${ }^{198}$.

De todo modo, diversos doutrinadores reconhecem que a Lei da Ação Civil Pública (Lei $\mathrm{n}^{0}$ 7.347/85) conteria um fundamento que se aproximaria de um permissivo genérico para a celebração de acordos sobre as matérias passíveis de tutela mediante o emprego da referida ação pelos legitimados para a sua propositura. Trata-se do disposto no art. $5^{\circ}, \S 6^{\circ}$ : “Os órgãos públicos legitimados poderão tomar dos interessados compromisso de ajustamento de sua conduta às exigências legais, mediante cominações, que terá eficácia de título executivo extrajudicial”.

Segundo Carlos Ari Sundfeld e Jacintho Arruda Câmara, tratar-se-ia de autorização legal aberta, que não delimita o conteúdo do acordo a ser celebrado mas apenas a sua finalidade, que deve ser de “adequação da situação jurídica às ‘exigências legais””'199. O dispositivo autoriza a transigir sobre o modo de cumprimento das exigências legais, ou seja, previstas em lei, inclusive daquelas relativas à aplicação de sanções.

Juliana Bonacorsi de Palma ressalva que o termo de ajustamento de conduta previsto na Lei de Ação Civil Pública apenas pode ser utilizado se o seu objeto tiver pertinência temática com os objetos tutelados pela referida lei ${ }^{200}$.

No Estado de São Paulo, há permissão genérica para a Administração, direta e indireta, celebrar termos de ajustamento de conduta. Trata-se do Decreto $n^{0} 52.201 / 07$. O referido decreto não define previamente as matérias que poderão ser objeto de TAC nem quais seriam as obrigações que o compromissário poderia assumir. No entanto, condiciona a celebração do TAC à prévia manifestação da Procuradoria Geral do Estado (art. $3^{\circ}$ ). Determina que o processo relativo à celebração do TAC, contendo a demonstração da conveniência de firmá-lo e dos estudos que embasaram a elaboração da minuta do termo, seja encaminhado à Procuradoria Geral do Estado para a sua apreciação (art. $4^{\circ}$ ).

\footnotetext{
198 Confiram-se as palavras do doutrinador: “mesmo ante ausência de expressa previsão, é sustentável a possibilidade da celebração desses acordos no Direito brasileiro. Isso porque está implícita no poder de decidir unilateralmente e de ofício, a opção por se decidir de modo consensual com o destinatário da decisão. Numa situação assim, sempre restará, em potência, o poder unilateral, que, circunstancialmente, não é exercido. Por outras palavras, está implícita no poder de decidir unilateralmente e de ofício, a opção da Administração por impor a si própria certos condicionantes de sua ação, importando obrigação para com o destinatário da decisão. É lícito que se chegue a essa opção por uma via consensual de formação da convicção" (Contrato administrativo, 2012, p. 302).

${ }^{199}$ Acordos substitutivos nas sanções regulatórias, 2011, p. 139.

${ }^{200}$ Atuação administrativa consensual, 2010, p. 280-281.
} 


\subsection{A contratualização e os atos de polícia administrativa}

Entre os atos unilaterais da Administração que podem ser substituídos por acordos com particulares, há aqueles que refletem o exercício de atividades de polícia.

O principal exemplo é a celebração de acordos substitutivos da aplicação de sanção.

Como enunciam Floriano de Azevedo Marques Neto e Tatiana Matiello Cymbalista, podem ocorrer as seguintes situações em relação ao processo sancionatório:

(i) o abandono do procedimento sancionatório, entendido como o iter estabelecido pela norma jurídica de apuração da verdade com vistas à aplicação de uma sanção; (ii) o abandono da própria prerrogativa de punir em favor de providências mais efetivas para consecução do interesse público; ou ainda (iii) a renúncia parcial à aplicação de uma sanção, seja em natureza, seja ainda em volume (montante) $)^{201}$.

Além da aplicação da sanção, outros atos de polícia administrativa podem ser também bilaterais ${ }^{202}$. A outorga de licença, autorização ${ }^{203}$ ou outro ato que permita o exercício de determinada atividade pelo particular pode ser antecedida da celebração de acordo entre a Administração e o particular, no qual serão estabelecidos consensualmente os possíveis condicionamentos para a prática do ato. Poderá ser estipulada a adoção de certas condutas como condição para a outorga de autorização ou licença, usualmente mediante a celebração de acordo prévio à expedição do ato ${ }^{204}$, que continuará sendo uma decisão unilateral.

É importante aludir ao entendimento de Alexandre Aragão, que delimita as situações em que poderá haver a criação de obrigações para o particular que não se encontrem previstas em lei ${ }^{205}$. O autor ressalva as situações em que não está presente a efetiva voluntariedade do particular. Como exemplo, menciona o caso da autorização requerida pelo particular, necessária para o exercício de determinada atividade privada. O particular não tem opção a não ser solicitar a autorização para o desempenho da atividade. O assentimento que ele manifesta, ao requerer a autorização, não pode ser considerado

\footnotetext{
${ }^{201}$ Os acordos substitutivos do procedimento sancionatório e da sanção, 2010, p. 53.

${ }^{202}$ Fernando Dias Menezes de Almeida. Contrato administrativo, 2012, p. 305-306.

${ }^{203}$ Tradicionalmente a doutrina distingue a autorização da licença pelo caráter discricionário da primeira e vinculado da segunda. Mas a legislação nacional não é uniforme ao empregar esses termos. A esse respeito, confira-se a crítica de Maria Sylvia Zanella Di Pietro ao instituto da autorização do serviço de telecomunicações, prevista na Lei $\mathrm{n}^{\circ}$ 9.472/97 como ato vinculado (Parcerias na Administração Pública, 2012, p. 140-144). Cabe registrar que o fato de o ato ser praticado no exercício de competência vinculada não impede a celebração de acordos relacionados ao seu exercício. Em qualquer caso, a decisão final deverá observar os limites estipulados pela lei.

${ }^{204}$ Esse acordo prévio aproxima-se da noção de acordos integrativos, endoprocedimentais ou preliminares do direito italiano. Tais acordos antecedem o provimento administrativo final, sem substitú́-lo. Objetivam modelar o ato final, o qual continua sendo um ato unilateral da Administração. Para uma análise dos acordos integrativos, confira-se Juliana Bonacorsi de Palma. Atuação administrativa consensual, 2010, p. 197-200.

${ }^{205}$ A consensualidade no direito administrativo, 2006, p. 170-171.
} 
título jurídico hábil para a criação de obrigações, independente da previsão em lei. Já em um contrato de delegação de serviço público, o particular manifesta livremente sua concordância e, por isso, pode legitimamente consistir em título criador de obrigações não previstas em lei. 


\section{CAPÍTULO II - AS DIVERSAS FORMAS DE ORGANIZAÇÃO DO ESTADO PARA O EXERCÍCIO DE ATIVIDADES PÚBLICAS}

Para desempenhar as diversas atividades que lhe são atribuídas, o Estado pode adotar configurações organizativas distintas.

Podem-se conceber três grandes modelos de organização de que o Estado pode se utilizar para o exercício das suas atribuições: desempenho de modo centralizado, através dos órgãos que integram a Administração direta, descentralização para entidades que integram a Administração indireta do Estado e descentralização em favor de terceiros, que não integram a estrutura do Estado.

No que diz respeito ao exercício de atividades de polícia administrativa, os questionamentos surgem acerca dos limites e das possibilidades de utilização de modelos de organização que envolvem tanto entidades da Administração indireta quanto terceiros alheios ao aparato estatal.

São estes os mecanismos que são analisados mais detidamente nesse capítulo. Nestes dois casos, há entidades com personalidade jurídica de direito privado e, portanto, o exercício privado de atividades de titularidade do Estado. Porém, à medida que se trata de entidades privadas sujeitas a regimes jurídicos distintos, os limites e possibilidades da atribuição do exercício de atividades de polícia administrativa também são diferenciados.

\section{1. $\underline{\text { A possibilidade }} \underline{\text { de }} \underline{\text { dissociação }} \underline{\text { entre }} \underline{\text { a forma }}$ jurídica da entidade $\underline{\text { e }} \underline{\text { a }} \underline{\text { sua }} \underline{\text { forma }} \underline{\text { de }}$ ação}

Encontra-se subjacente à viabilidade de entidades privadas exercerem atividades públicas a noção de que pode haver dissociação entre a forma jurídica da entidade e a sua forma de ação. Trata-se da hipótese de uma entidade com personalidade jurídica de direito privado, em maior ou menor medida, ter capacidade jurídica de direito público.

Porém, há determinados limites para a atribuição de funções típicas e materialmente administrativas a entidades de natureza privada.

Um dos temas a ser discutido é o da existência ou não de liberdade para o legislador e o administrador escolherem as formas de organização administrativa a serem utilizadas para o exercício de atividades públicas. Por um lado, o princípio da 
subsidiariedade propugna a não concentração excessiva de atividades no Estado. Por outro, há atividades que necessariamente devem ser executadas pelo Estado.

\subsection{O princípio da subsidiariedade}

A definição do grau de protagonismo do Estado na execução das incumbências que lhe foram atribuídas pela Constituição implica considerar em que medida a intervenção estatal pode ser norteada pelo princípio da subsidiariedade ${ }^{206}$.

Em linhas gerais, o princípio da subsidiariedade propugna que a intervenção direta do Estado deve ser excepcional ou supletiva, preferindo-se mecanismos indiretos de intervenção pública. Sempre que os particulares pudessem exercer determinada atividade por conta própria, o Estado deveria omitir-se. O Estado, na sua forma subsidiária, deve intervir apenas para suprir possíveis falhas na atuação privada.

Pode-se localizar o princípio da subsidiariedade nos discursos de Aristóteles, São Tomás de Aquino e Althusius. Mas a noção moderna do princípio surgiu apenas com a doutrina social da Igreja Católica. A partir do final do século XIX é que encontrou a sua formulação mais precisa ${ }^{207}$.

Nas encíclicas, o principal fundamento do princípio da subsidiariedade residia na dignidade da pessoa humana. A Igreja procurava difundir princípios da ordem econômica e social voltados à consagração da justiça social e não à implantação de um modelo econômico ou político específico ${ }^{208}$. A Encíclica Quadragesimo anno (de 1931) contemplou a fórmula da subsidiariedade como "solene princípio da filosofia social”. Tratase da enunciação de subsidiariedade como estímulo, ajuda a ser prestada pelas entidades maiores às menores. A noção de subsidiariedade foi reiterada pelo Papa João XXIII na encíclica Mater et Magistra, de 1961, aplicando-a mais diretamente às relações entre poder público e iniciativa privada. Na Encíclica Pacem in Terris (de 1963) consta a aplicação do princípio da subsidiariedade de forma mais ampla, para abranger as relações do poder público com os cidadãos, as famílias e os corpos intermédios. Já a Encíclica Centesimo Anno menciona expressamente o dever do Estado de suprir a atuação daqueles que não puderem fazê-lo, para atender o bem comum.

\footnotetext{
${ }^{206}$ Sobre o tema, confiram-se, entre outros: José Alfredo de Oliveira Baracho. O princípio de subsidiariedade, 2000; Silvia Faber Torres. O princípio da subsidiariedade no direito público contemporâneo, 2001; Fausto de Quadros. O princípio da subsidiariedade no direito comunitário após o Tratado da União Europeia, 1995. ${ }^{207}$ Silvia Faber Torres. O princípio da subsidiariedade no direito público contemporâneo, 2001, p. 23-24. ${ }^{208}$ Ob. cit., p. 26.
} 
O princípio foi expressamente formulado no direito comunitário europeu, como critério para limitar a competência comunitária, que apenas pode exercer os poderes e atribuições que lhe foram expressamente atribuídos e cedidos pelos Estados. É o que consta do art. 3B do Tratado de Maastricht, que prevê, fora da área de atuação exclusiva, apenas a ação subsidiária, desde que os objetivos visados não possam ser satisfatoriamente atingidos pela ação dos Estados membros. No tratamento comunitário europeu do princípio, são evidenciadas as suas duas vertentes, o sentido vertical e o horizontal.

O princípio é utilizado no direito comunitário no aspecto vertical como critério de distribuição das competências entre a União Europeia e os Estados-membros, "no sentido de que a comunidade intervém apenas se e na medida em que os objetivos da ação não possam ser suficientemente realizados pelos Estados-membros”209. A mesma lógica é adotada na relação entre União e Estados membros.

Já o aspecto horizontal da subsidiariedade diz respeito às relações entre as esferas pública e privada, de modo a se conferir caráter residual à atuação da primeira.

Como destaca Maria Sylvia Zanella Di Pietro, a subsidiariedade desempenha papel fundamental na definição do Estado Democrático de Direito ${ }^{210}$, ainda que o seu conceito tenha sido formulado anteriormente. O Estado subsidiário tem por diretriz a promoção e o desenvolvimento do indivíduo, como sujeito titular de direitos fundamentais. O ser humano passa a ocupar o papel central, devendo Estado e sociedade atuarem conjuntamente para que os cidadãos possam desenvolver as suas potencialidades.

Em seguida, a autora apresenta várias tendências que são decorrências do princípio da subsidiariedade: (a) o propósito de diminuição do Estado, mediante a privatização; (b) a liberalização dos serviços, com a entrega, ao setor privado, de atividades que eram assumidas pelo Estado em caráter de exclusividade; (c) a multiplicação dos interesses a serem tutelados, à medida que deixa de existir um único interesse público, de titularidade do Estado, para dar lugar a vários interesses públicos, representativos dos setores da sociedade civil; (d) para propiciar o atendimento a esses vários interesses, há a intensificação da atividade estatal de fomento e da utilização dos diversos instrumentos de parceria do setor público com o privado; (e) a desregulamentação, com o propósito de ampliar a liberdade de atuação dos particulares; (f) a noção de interesse público deixa de

\footnotetext{
209 Odete Medauar. O direito administrativo em evolução, 2003, p. 245.
}

${ }^{210}$ Parcerias na Administração Pública, 2012, p. 15. 
refletir os interesses da máquina administrativa (interesse público secundário) para expressar os interesses dos cidadãos (interesse público primário) ${ }^{211}$.

O art. 173 da CF/88 não deixa de retratar a consagração do princípio da subsidiariedade da intervenção estatal no domínio econômico. A atuação do Estado no exercício direto de atividade econômica propriamente dita é excepcional e somente pode ocorrer quando for necessária aos imperativos da segurança nacional, a relevante interesse coletivo e nos casos previstos no texto constitucional.

A questão que se coloca é a de que, do fato de a atuação pública ser subsidiária, não decorre haver completa fungibilidade ou alternatividade entre a atuação das esferas pública e privada. Não há intercambialidade plena entre a atuação de uma e de outra. Logo, o princípio da subsidiariedade é insuficiente, por si só, para delinear as esferas de intervenção dos setores público e privado.

\subsection{A margem de liberdade para a escolha das formas de organização para o exercício de atividades públicas}

A doutrina analisa o tema procurando delimitar qual seria a margem de liberdade para configurar a organização subjetiva do Estado. Para tanto, enuncia-se o "princípio da liberdade de escolha das formas jurídicas", nos termos do qual "a Administração Pública, enquanto organização, terá o poder de, motu proprio, definir e alterar, a cada momento, a estrutura e modo de prestação de determinadas atividades que

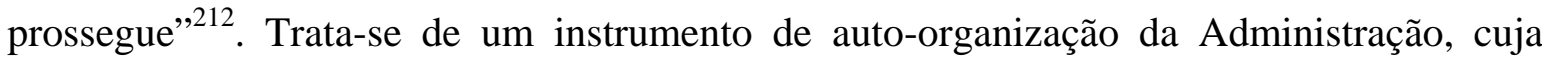
aplicação demanda observar as limitações decorrentes de um Estado Democrático de Direito $^{213}$.

Faz-se necessário analisar em que medida tal princípio poderá ser aplicado às atividades administrativas.

\footnotetext{
${ }^{211}$ Ob. cit., p. 18-23.

212 Sofia Tomé D’Alte. A nova configuração do setor empresarial do Estado e a empresarialização dos serviços públicos, 2007, p. 214. O princípio da liberdade de escolha da forma de atuação pela Administração é defendido pela doutrina alemã, segundo a qual tal princípio implicaria dupla liberdade de escolha, tanto das formas de atuação quanto das formas de organização do direito privado (Maria João Estorninho. A fuga para o direito privado, 1999, p. 190).

213 Paulo Otero assim se manifesta sobre o enunciado princípio da liberdade de escolha das formas de organização do Estado: "Sucede, porém, que uma tal concepção, pensada exclusivamente em relação ao direito alemão, mostra-se ainda na sua origem tributária de um entendimento de que o poder de organização administrativa é um espaço de liberdade insuscetível de penetração legislativa, verdadeiro feudo absolutista herdado pelo Estado liberal e transmitidos às gerações presentes, envolvendo uma realidade interna sem qualquer projeção exterior à própria Administração (...) A verdade, no entanto, é que, (...) num Estado social de Direito, estando toda a Administração subordinada à juridicidade, também o poder de organização administrativa se subordina à legalidade, fundamentando-se, direta ou indiretamente, na Constituição” (Vinculação e liberdade de conformação jurídica do setor empresarial do Estado, 1998, p. 231).
} 
Há limites que impedem a livre atuação da Administração sob o direito privado. Como se analisa adiante ${ }^{214}$, há um determinado núcleo em relação ao qual haveria uma reserva de atuação direta, referente às atividades exclusivas do Estado. Em outros casos, não é possível recorrer a entidades com personalidade jurídica privada, ainda que integrantes da estrutura estatal.

Exatamente porque o enunciado princípio da liberdade de escolha das formas jurídicas não pode ser aplicado de forma ampla e irrestrita, de modo a se conferir larga margem ao legislador para deliberar sobre o tema, parcela da doutrina rejeita a existência desse princípio. É o que sustenta, por exemplo, Gaspar Ariño Ortiz:

devemos rechaçar o princípio de liberdade de eleição de formas: o Estado não pode eleger, em nome de uma pretendida eficácia, a forma que mais cômoda lhe resulte para o exercício de suas funções. Esta é uma justificativa errônea. As 'formas' escolhidas para a realização de suas atividades devem adequar-se ao conteúdo destas, sabendo que, se a forma jurídico-mercantil (sociedades) impõe um regime jurídico dessa natureza, esta não deverá ser utilizada quando tais atividades devam ser submetidas às exigências básicas de Direito Público ${ }^{215}$.

No mesmo sentido, Ricardo Rivero Ortega defende que "se faz necessária uma negação expressa da 'liberdade de formas' que corresponde à Administração ou, dito em termos mais comuns em nosso Direito, da ampla discricionariedade de que desfruta a Administração no exercício do poder organizatório”216.

De todo modo, admitindo-se ou não a existência de um princípio de livre eleição das formas, cabe registrar que o exercício privado de funções públicas

assenta numa divergência entre a natureza de uma entidade e a natureza dos poderes de que aparece investida: há nela uma contradição institucional e uma tensão interna que estão na origem de um dilema permanente entre, por um lado, o estatuto privado e, por outro, a função pública e os poderes públicos ${ }^{217}$.

É importante, assim, estabelecer a partir de qual ponto tal divergência passa a determinar uma vedação a que tais atividades sejam desempenhadas por entidades de natureza privada.

Em linhas gerais, os limites para o legislador encontram-se estritamente vinculados às atividades que não são passíveis de ter o seu exercício atribuído a entidades privadas.

Os limites usualmente enunciados pela doutrina são os de que poderiam ser exercidas apenas pelo Estado as atividades relacionadas à sua organização, às funções

\footnotetext{
${ }^{214}$ V. item III.5.3.

${ }^{215}$ El ámbito privado del sector público, 2002, p. 597-598.

${ }^{216}$ Administraciones públicas y derecho privado, 1998, p. 71.

${ }^{217}$ Pedro Gonçalves. Entidades privadas com poderes públicos, 2008, p. 27 - grifos no original.
} 
políticas e que envolvam o manejo de coerção em face de particulares. Trata-se de limitações extraídas do próprio texto constitucional, ainda que de modo implícito.

Em linhas gerais, incluem-se nesse conceito as atividades legislativa, jurisdicional e de polícia. No que diz respeito à Administração Pública, a consequência usualmente enunciada é a de que haveria vedação de exercício privado das atividades de polícia administrativa. O tema é detalhado adiante, no capítulo III, no qual se procura esclarecer quais seriam os limites e possibilidades de exercício privado de atividades de polícia administrativa.

A possível autorização outorgada pelo legislador para a atribuição de missões públicas a entidades privadas não pode ser empregada em qualquer caso. A decisão concreta quanto à escolha sobre as formas, pública ou privada, de execução de atividades públicas deve levar em consideração várias circunstâncias. Uma das questões a serem ponderadas é se a gestão privada da atividade específica a ser atribuída a particulares é a forma mais adequada de sua execução no caso concreto.

$\mathrm{Na}$ avaliação da forma a ser empregada no exercício de determinada atividade, além do princípio da legalidade, deve ser levado em consideração o princípio da adequação. Como enuncia Sofia Tomé D’Alte, “só será legítima a escolha de uma forma que, além de legalmente prevista, se revele, em concreto, ser a mais adequada à prestação da atividade em causa”218. Faz-se necessário avaliar se a forma jurídica privada oferece maiores benefícios concretos em relação à sua configuração pública.

Outro ponto a ser destacado consiste no fato de que mesmo a atribuição temporária de poderes de autoridade a uma entidade privada não pode se apresentar em potencial conflito com as outras atribuições desta entidade.

O exemplo mais evidente é a inviabilidade de uma mesma entidade ser incumbida da atividade de regulação de determinado setor, exercendo função de autoridade pública, e ao mesmo tempo explorar aquela mesma atividade econômica, objeto da regulação por ela realizada ${ }^{219}$. É bastante nítido o potencial conflito de interesses e a

\footnotetext{
${ }^{218}$ A nova configuração do setor empresarial do Estado e a empresarialização dos serviços públicos, 2007, p. 229. Ricardo Rivero Ortega sustenta que, na aplicação do princípio da adequação, para a escolha de uma forma organizacional privada há de se constatar que "as vantagens reais e legítimas oferecidas por esta modalidade organizativa devem ser maiores que as que se observam na forma pública” (Administraciones públicas y derecho privado, 1998, p. 70).

${ }^{219}$ A concentração das funções de regulador e de prestador do serviço verificava-se em algumas concessões no Brasil. Essa situação foi superada com a criação das agências reguladoras, que institucionalizou a obrigatoriedade de dissociação das funções: "A implantação do modelo de agência conduz a uma diferenciação no âmbito da organização administrativa. A competência regulatória é dissociada da competência operativa propriamente dita. Isso significa que mesmo serviços públicos prestados diretamente
} 
possível violação aos princípios da isonomia e da imparcialidade no que diz respeito aos demais agentes econômicos que atuam no mesmo mercado, concorrendo com a entidade que exerce a regulação. Este aspecto também consiste em um dos limites da liberdade de organização da estrutura subjetiva do Estado.

Logo, ainda que o caso concreto possa apresentar margens de escolha pelo administrador acerca do modo de desempenho das suas atividades, há limitações cogentes que devem ser observadas.

Em seguida, são analisadas as principais formas jurídicas a que o Estado pode recorrer para o exercício das suas funções, com destaque para as atividades de polícia administrativa.

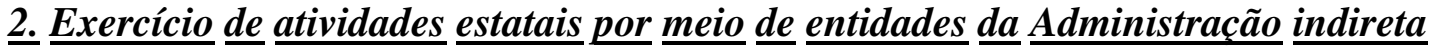

Ao se tratar da viabilidade de exercício de atividades de polícia administrativa por entidades da Administração indireta, a principal questão que se coloca é a possibilidade de tais atividades serem exercidas apenas por entidades de direito público ou se poderiam também ser desempenhadas por entidades de direito privado (especialmente empresas públicas e sociedades de economia mista).

\subsection{Primeira ressalva prévia: caracterização de desempenho direto das atividades}

Cabe indicar inicialmente que reputamos que a execução de atividades de polícia administrativa por entidades da Administração indireta consiste em execução direta da atividade pelo Estado.

Podem-se adotar para a exposição do tema os pressupostos já desenvolvidos pela doutrina acerca da prestação de serviço público por entidades integrantes da Administração.

A doutrina analisa o tema sob a denominação de concessões impróprias.

Ao longo dos anos, criaram-se tanto autarquias quanto sociedades de economia mista e empresas públicas para desempenhar serviços públicos. Várias dessas entidades eram expressamente denominadas “concessionárias” de serviços públicos. Porém, na verdade, o fenômeno de que se tratava era o da descentralização por serviços ${ }^{220}$. A

pelo próprio Estado estariam subordinados à competência regulatória de um organismo administrativo independente” (Marçal Justen Filho. Teoria geral das concessões de serviço público, 2003, p. 292).

${ }_{220}$ Maria Sylvia Zanella Di Pietro diferencia três modalidades de descentralização administrativa. A descentralização territorial ou geográfica indica uma entidade local, com capacidade administrativa genérica e 
Administração cria uma nova entidade, dotada de patrimônio e de personalidade jurídica próprios, mas que integra a estrutura da Administração Pública e se submete ao seu controle. Ao atribuir a essa entidade a prestação do serviço, o Estado não retira o desempenho dos serviços da sua esfera jurídica, pois não há a efetiva atribuição a terceiros.

Maria Sylvia Zanella Di Pietro destaca que o prestação de serviço público por empresa estatal consiste em hipótese de descentralização por serviços e não de concessão, que é uma das formas de descentralização por colaboração ${ }^{221}$.

Marçal Justen Filho também diferencia as situações:

na descentralização, o titular do serviço continuará a controlar sua prestação, ainda quando seu desempenho seja atribuído a outra entidade, dotada formalmente de personalidade jurídica própria. E, por outro lado, o insucesso na gestão dos serviços recairá sobre o patrimônio da própria pessoa titular do serviço. Não haverá, portanto, nem delegação a terceiros do poder de controle sobre a organização dos serviços nem transferência dos riscos acerca do empreendimento ${ }^{222}$.

No mesmo sentido, ao examinar o vínculo existente entre sociedade de economia mista criada para prestar serviços de saneamento e os municípios para os quais presta serviço, Geraldo Ataliba e Rosolea Folgosi concluem que “não é mera ‘concessão’ e não pode ser tratado como se o fora"223.

Portanto, o emprego de técnicas de descentralização por serviços para a prestação de serviço público não se equipara à concessão ${ }^{224}$.

Cabe ressalvar que as conclusões acima expostas não se aplicam quando estiverem envolvidas esferas distintas da federação, notadamente quando a empresa estatal não for controlada pelo ente federativo competente para a prestação dos serviços que constituem o objeto social da empresa.

Há hipóteses em que uma entidade administrativa dedica-se à exploração de serviço público tal como se fosse uma atividade econômica, em concorrência com outras

geograficamente delimitada, com personalidade jurídica de direito público. A descentralização por serviços, funcional ou técnica refere-se à criação de uma entidade pelo poder público, de personalidade jurídica de direito público ou privado, à qual se atribui a prestação de serviço público. Por fim, na descentralização por colaboração, a Administração transfere a execução de determinado serviço público a pessoa jurídica de direito privado, mediante contrato ou ato unilateral (Direito administrativo, 2013, p. 471-475).

${ }^{221}$ Parcerias na Administração Pública, 2012, p. 47-48.

222 Teoria geral das concessões de serviço público, 2003, p. 120.

223 Saneamento básico - serviço público estadual e municipal - contrato administrativo entre Sabesp e município - concessão não ordinária, 1995, p. 116.

${ }^{224}$ A respeito desse tema, cabe registrar o posicionamento parcialmente divergente de Celso Antônio Bandeira de Mello. Segundo o autor, não haveria concessão apenas quando o serviço for prestado por (i) empresa pública, cujo capital for constituído exclusivamente por recursos de titularidade do sujeito que é competente para a prestação do serviço ou por capital dele em conjugação com o de pessoa da sua Administração indireta ou (ii) sociedade de economia mista em que houver participação apenas simbólica de recursos privados na formação do seu capital social, sendo os recursos públicos provenientes da mesma órbita governamental competente para a prestação do serviço. Nas demais hipóteses, segundo o autor, as empresas estatais atuariam como concessionárias de serviço público (Curso de direito administrativo, 2013, p. 203-204). 
entidades, públicas ou privadas. Nesse caso, haverá a configuração de verdadeira concessão, que deverá ser antecedida de licitação e a entidade prestadora do serviço submeter-se-á ao regime jurídico das concessionárias de serviço público ${ }^{225}$.

É possível também a formação de convênios entre os entes estatais, pelos quais serão conjugados esforços e recursos para a prestação de serviço público de interesse comum aos diversos entes. Também nesse caso não haverá concessão de serviço público propriamente dita. Como registra Marçal Justen Filho, a Lei no 11.107/05 reconheceu tratarse de execução direta quando a prestação do serviço é desempenhada por consórcio público, ao prever um mecanismo específico e diferenciado - o contrato de programa - para a sua atribuição ${ }^{226}$.

\subsection{Segunda ressalva prévia: risco de fuga do direito público}

Cabe destacar também que a doutrina dá especial ênfase ao risco de utilização indevida do direito privado pela Administração quando se trata do exercício de atividades estatais por entidades administrativas de personalidade jurídica privada. Tratarse-ia da interposição indevida de entidade privada com o objetivo de elidir a incidência do regime jurídico de direito público.

Para que a participação de entidades administrativas privadas no exercício de atividades de polícia não implique uma forma indevida de administração privada, faz-se necessário avaliar adequadamente a qual regime jurídico tais entidades se submetem em tal circunstância.

A indisponibilidade do interesse público e a necessidade de as orientações do ente estatal prevalecerem nas entidades da Administração indireta de personalidade jurídica privada, para se assegurar o atingimento dos fins para os quais foram constituídas, não permitem que se afastem todas as regras de direito público. Como pondera Maria Sylvia Zanella Di Pietro, o direito público confere determinadas prerrogativas e restrições legais aos seus entes justamente para assegurar a consecução dos seus fins. Essas características do regime jurídico público não podem ser completamente afastadas, sob pena de comprometimento da consecução das finalidades para as quais as entidades da Administração indireta foram criadas $^{227}$.

\footnotetext{
${ }^{225}$ Isso ocorre com empresas estaduais de saneamento básico, que prestam os serviços para diversos municípios.

${ }^{226}$ Curso de direito administrativo, 2013, p. 768-769.

${ }^{227}$ Direito administrativo, 2013, p. 485.
} 


\subsection{As repercussões da descentralização no regime jurídico de execução da atividade}

O fato de a atividade exercida por uma entidade integrante da Administração indireta não deixar de ser execução direta pelo Estado não significa que não apresente repercussões quanto ao regime jurídico.

Em primeiro lugar, há alterações decorrentes da própria modificação da estrutura administrativa. As entidades da Administração indireta não apresentam vínculo hierárquico direto com a Administração central. A entidade administrativa de direito privado é dotada de certa autonomia e é titular de interesses próprios, ainda que estritamente vinculados à Administração direta.

Em segundo lugar, as entidades da administração indireta submetem-se a controle diferenciado em relação àquele incidente sobre a Administração direta. O controle pode se apresentar mais problemático quando não existir um contrato ou instrumento análogo disciplinando as relações entre a Administração direta e a entidade administrativa privada no que diz respeito ao exercício da função pública que lhe foi atribuída. A influência pública exercida no âmbito interno através dos mecanismos de direito societário, em decorrência da detenção do poder de controle da sociedade, pode não ser suficiente para garantir a persecução dos fins públicos.

Por isso, não há completa identidade do regime jurídico a que se submete a atividade quando é realizada pela Administração direta ou pela Administração indireta. Como se analisa adiante, a diferenciação de regime jurídico é mais significativa quando se trata de entidade com personalidade jurídica de direito privado ${ }^{228}$.

\subsection{A distinção entre entidades públicas e privadas}

Na Administração Pública indireta, há tanto entidades com personalidade jurídica de direito público quanto com personalidade jurídica de direito privado.

A constituição formal de uma entidade como sendo pública ou privada não deixa de dar ensejo a consequências relevantes. Como assevera Maria Sylvia Zanella Di Pietro, "as pessoas públicas (autarquias e fundações de direito público) têm praticamente as mesmas prerrogativas e sofrem as mesmas restrições que os órgãos da Administração Direta, e as pessoas de direito privado só possuem as prerrogativas e sujeitam-se às restrições expressamente previstas em lei”,229.

\footnotetext{
${ }^{228}$ V. item II.2.7.

${ }^{229}$ Direito administrativo, 2013, p. 485.
} 
A distinção tradicional entre as entidades públicas e privadas vincula-se à estrutura em que uma entidade e outra estão enquadradas. Nesse sentido, as entidades públicas estariam inseridas na estrutura estatal e seriam destinadas à persecução de fins públicos enquanto que as entidades privadas surgiriam na própria sociedade, visando fins privados. As primeiras seriam regidas pelo direito público e as segundas, pelo direito privado.

Porém, a incidência desses critérios não é tão simples na atual configuração da estrutura administrativa. A primeira razão é a impossibilidade de se delimitar, com rigor, que as entidades públicas apenas seriam regidas pelo direito público e que apenas a elas caberia a persecução de fins públicos. Por outro lado, especialmente em relação às empresas estatais de natureza privada, não se pode afirmar que se submetem exclusivamente ao regime de direito privado. Aplica-se-lhes parcialmente o regime de direito público, em maior ou menor grau, de acordo com as atividades que tais empresas exercem.

René Chapus analisa os critérios que podem ser utilizados para se identificar o caráter público de uma instituição, a serem aplicados especialmente nos casos em que a lei silencia a respeito da natureza jurídica da entidade. Nessas hipóteses, devem ser analisadas as regras de funcionamento e organização da entidade para se identificar a possível presença de indícios de pessoa pública ${ }^{230}$. O autor ressalva que nenhum desses indícios é suficiente por si só para determinar a natureza jurídica, devendo ser analisados conjuntamente $^{231}$. Nas situações em que os indícios não permitem concluir nem por uma nem por outra qualificação, caberia ao juiz aplicar considerações de oportunidade. Trata-se da conveniência de se analisarem as consequências da aplicação do regime público e do regime privado àquela entidade específica, para se concluir se é preferível submeter-se a um ou a outro ${ }^{232}$.

\footnotetext{
${ }^{230}$ O conjunto de indícios a ser verificado, segundo o autor, seria o seguinte: a) a origem da entidade: se tiver sido criada por uma pessoa pública, por lei ou ato administrativo, consistiria em um indício de seu caráter público; b) a finalidade para a qual a sua atividade deve ser exercida: um fim de interesse geral, tal como um fim de serviço público, indicaria pela sua qualificação como entidade pública; c) a organização das suas relações com a autoridade pública: se os seus dirigentes forem nomeados pelo governo ou se os seus nomes devem ser aprovados por entidades governamentais, haveria indícios de sujeição a um controle público na sua gestão e, consequentemente, do seu caráter público; d) a investidura de prerrogativas públicas, exorbitantes do direito privado: o fato de a entidade poder adotar decisões imperativas, aptas a modificar unilateralmente a situação jurídica de terceiros, indicaria a sua natureza pública (Droit administratif général, t. 1, 1999, p. 173 e s.).

${ }^{231}$ Por exemplo, uma entidade que tem por objeto a prestação de serviço público mas que não se submete à intervenção da autoridade pública na sua gestão e não exerce prerrogativas de poder público seria uma entidade privada (ob. cit., p. 180).

${ }^{232}$ Ob. cit., p. 185.
} 


\subsection{A capacidade de direito público nos sentidos formal e material}

Em princípio, apenas as entidades públicas é que detêm a denominada capacidade de direito público.

Pedro Gonçalves apresenta distinção entre capacidade de direito público em sentido formal e material ${ }^{233}$.

Em sentido formal, trata-se da capacidade de utilizar os instrumentos formais de ação do direito público - especialmente, praticar atos administrativos e celebrar contratos administrativos. A capacidade formal decorre diretamente da personalidade jurídica.

Já a capacidade em sentido material diz respeito aos instrumentos necessários à realização dos direitos e obrigações que foram atribuídos a determinada entidade. A capacidade em sentido material é sempre parcial à medida que se encontra delimitada pelas competências atribuídas a determinada entidade pública ou às atividades delegadas a uma pessoa privada.

As entidades privadas apenas poderão deter a capacidade de direito público em sentido material, à medida que lhe forem atribuídos os instrumentos necessários para exercer determinados direitos e obrigações.

O reconhecimento da capacidade de direito público a determinada entidade indica que ela pode utilizar as formas específicas de ação do direito público, tais como praticar atos administrativos e celebrar contratos administrativos. Isso não significa que os atos e contratos de pessoas privadas não possam vir a receber tal qualificação. Isso ocorrerá à medida que lhes seja atribuída capacidade de direito público em sentido material. Disso decorre que os atos e contratos de particulares apenas serão administrativos caso praticados no âmbito da lei que lhes conferiu tais poderes ${ }^{234}$.

\subsection{As entidades públicas da Administração indireta e seu regime jurídico}

As autarquias, as fundações de direito público e os consórcios públicos são as entidades da Administração indireta com personalidade jurídica de direito público. No tocante ao objeto do presente estudo, cabe aludir a alguns aspectos do regime jurídico das autarquias.

\footnotetext{
${ }^{233}$ Entidades privadas com poderes públicos, 2008, p. 253-256.

${ }^{234}$ Sobre a possibilidade de caracterização como administrativos dos atos praticados por entidades privadas que exercem atividades de polícia administrativa, v. item IV.3.
} 
As autarquias são pessoas jurídicas com personalidade de direito público, criadas por lei para o desempenho de funções próprias e inerentes ao Estado.

Têm por vocação o exercício de atividades que devem se submeter ao regime jurídico de direito público. Na conceituação do art. $5^{\circ}$, inc. I, do Decreto-lei $n^{\circ} 200$, cabe às autarquias a execução de “atividades típicas da Administração Pública, que requeiram, para seu melhor funcionamento, gestão administrativa e financeira descentralizada”. Como define Celso Antônio Bandeira de Mello, as autarquias têm capacidade exclusivamente administrativa $^{235}$.

Em processo de descentralização, são atribuídas determinadas competências administrativas às autarquias, que as exercem sob regime de direito público. Não cabe às autarquias desenvolver atividades que devem ser desenvolvidas sob o regime de direito privado, tal como a exploração de atividade econômica em sentido estrito.

Em primeiro plano, a personalidade jurídica de direito público é que diferencia as autarquias das empresas estatais, que são entidades de personalidade jurídica privada. Apenas as autarquias podem ser titulares de atividades públicas. Às empresas estatais pode ser atribuído o exercício de atividades públicas mas elas não detêm a sua titularidade ${ }^{236}$.

As autarquias gozam de autonomia financeira e administrativa nos limites estabelecidos na lei que as criou. Cabe à lei de criação da autarquia definir as suas regras de organização, funcionamento e grau de autonomia em relação à Administração direta.

A atuação das autarquias é desenvolvida em nome próprio, sendo titulares de direitos e deveres bem como de patrimônio próprios. As autarquias são responsáveis pelos próprios atos, podendo o Estado ser chamado a responder por tais atos apenas em caráter subsidiário. A responsabilidade das autarquias por seus atos é da mesma natureza da responsabilidade do Estado, nos termos do art. 37, §6º , da CF/88. Ou seja, em linhas gerais, trata-se de responsabilidade objetiva.

Nas suas relações com terceiros, as autarquias ocupam posição equivalente à da Administração Pública direta. Isso é decorrência da sua personalidade jurídica de direito público. Os atos praticados pelas autarquias são atos administrativos, dotados dos mesmos atributos verificados nos atos praticados pela Administração direta. Ou seja, gozam de presunção de legitimidade, exigibilidade e executoriedade. As autarquias submetem-se também às mesmas restrições e sujeições aplicáveis à Administração direta.

\footnotetext{
${ }^{235}$ Curso de direito administrativo, 2013, p. 164.

${ }^{236}$ Celso Antônio Bandeira de Mello. Curso de direito administrativo, 2013, p. 164-165.
} 
Do mesmo modo, os contratos das autarquias têm natureza administrativa e devem observar os requisitos para a celebração dessas avenças, tal como a necessidade de serem precedidos de licitação pública, na forma prevista na legislação específica.

Podem ter recursos próprios, obtidos a partir do exercício das suas atividades, ou serem dependentes da transferência de recursos pelo ente da Administração direta a que se vinculam. O vínculo existente entre as autarquias e seus servidores é de natureza estatutária, ocupando os servidores cargos públicos ${ }^{237}$.

O vínculo existente entre a autarquia e o ente da Administração direta, manifestado sob a forma de controle exercido sobre a autarquia, é identificado como tutela. Não há relação hierárquica entre a Administração direta e a autarquia. O exercício do controle não implica a detenção de competência para revisão direta de todos os atos praticados pela autarquia. Trata-se de verificação da regularidade da atuação da autarquia, especialmente em vista dos fins para os quais foi criada ${ }^{238}$.

Pela vocação exclusivamente administrativa das autarquias, admite-se que exerçam atividades que impliquem o manejo de poderes de coerção. A personalidade pública dessas entidades revela que são dotadas de um status jurídico diferenciado em relação às entidades privadas. Elas detêm capacidade administrativa específica, reputandose ser a sua atuação equivalente à própria ação da Administração direta.

Ou seja, não se opõem óbices ao exercício de atividades de polícia administrativa pelas autarquias.

Como não há controvérsias acerca da possibilidade de as autarquias exercerem poderes públicos, diante da sua personalidade jurídica de direito público, não cabe aprofundar o exame do seu regime jurídico no âmbito do presente estudo.

\subsection{As empresas públicas e as sociedades de economia mista e seu regime jurídico}

As empresas públicas e as sociedades de economia mista são entidades da Administração indireta com personalidade jurídica de direito privado e fins econômicos ${ }^{239}$.

\footnotetext{
${ }^{237}$ Cabe ressalvar que, em relação às agências reguladoras, consideradas "autarquias especiais", inicialmente foi previsto o regime de pessoal de emprego público, de natureza contratual. Isso é o que constava da Lei ${ }^{\circ}$ 9.986/00. No entanto, como se analisa adiante (v. item III.8.5.3), a eficácia do regime de emprego público foi liminarmente suspensa pela liminar deferida pelo STF na ADI ${ }^{\circ}$ 2.310-1. Posteriormente, os dispositivos da Lei ${ }^{\circ}$ 9.986/00 que estipularam o regime de emprego público para as agências foram expressamente revogados pela Lei $n^{\circ} 10.871 / 04$.

${ }^{238}$ Sobre o poder de tutela da Administração direta sobre as entidades da Administração indireta, v. item III.8.3.

${ }^{239}$ Cabe ressalvar que, além das empresas públicas e das sociedades de economia mista, há outras entidades com personalidade jurídica privada que se encontram sob o controle do Estado. As fundações e os consórcios públicos, por exemplo, podem ter personalidade jurídica de direito público ou privado.
} 
Utiliza-se a designação genérica “empresas estatais” ${ }^{240}$ para se referir aos dois tipos de entidades indistintamente ${ }^{241}$.

As empresas públicas são pessoas jurídicas com personalidade privada, criadas mediante autorização legal e cujo capital social é formado exclusivamente por recursos de entidade ou entidades estatais, de direito público ou privado.

As empresas públicas podem adotar qualquer uma das formas societárias previstas na legislação.

As sociedades de economia mista são pessoas jurídicas com personalidade privada, criadas mediante autorização legal e cujo capital social é constituído por recursos tanto de entidades estatais, integrantes da Administração direta ou indireta, quanto privados, com prevalência acionária votante de titularidade pública.

As sociedades de economia mista devem ser constituídas sob a forma de sociedade anônima.

\subsubsection{As atividades desempenhadas}

Tanto as empresas públicas quanto as sociedades de economia mista são instrumentos de ação estatal. Ou seja, as empresas estatais não são constituídas para a persecução de interesses privados. A condução do seu destino deverá ser decidida pela entidade da Administração direta ou indireta que detém a integralidade ou a maioria das ações com direito a voto.

Cabe à lei de autorização da sua criação estabelecer as atividades que serão por elas desempenhadas. É recorrente a afirmação de que as empresas estatais poderiam atuar tanto na prestação de serviço público quanto na exploração de atividade econômica.

Pode-se questionar então se seria possível a constituição de empresas estatais para exercer atividades de polícia administrativa. Por um lado, não há restrições no ordenamento jurídico em relação às atividades públicas que poderiam ser desempenhadas pelas empresas estatais. Por outro, há uma grande quantidade de exemplos concretos de leis

\footnotetext{
${ }^{240}$ A expressão “empresa estatal” não tem definição positivada mas foi consagrada pelo uso. O anteprojeto de Lei Orgânica da Administração Pública Federal, elaborado pela Comissão constituída nos termos da Portaria $n^{0}$ 426, de 6.12.2007 e que objetiva a substituição do marco legal estabelecido pelo Decreto-lei $n^{\circ}$ 200, propôs a positivação da definição de empresa estatal nos seguintes termos: "Empresa estatal é a pessoa jurídica de direito privado, de fins econômicos, controlada direta ou indiretamente por entidade ou entidades estatais, que executa serviços públicos ou explora atividade econômica caracterizada pela produção ou comercialização de bens ou pela prestação de serviços em geral” (art. 15, caput, do Anteprojeto).

${ }^{241}$ Maria Sylvia Zanella Di Pietro propõe que também integram o conceito de “empresa estatal” as empresas sob controle acionário do Estado, que são pessoas jurídicas de direito privado às quais "falta um dos requisitos essenciais para que seja considerada empresa pública ou sociedade de economia mista” (Direito administrativo, 2013, p. 487). São empresas que, com frequência, prestam serviços públicos sob o regime de concessão.
} 
que autorizaram a constituição de empresas estatais especificamente para o desempenho de atividades de polícia administrativa. Podem ser mencionadas as várias entidades instituídas pelos municípios para atuar na área da ordenação do trânsito.

Outro aspecto a ser considerado é a proximidade existente entre as categorias de serviço público e de polícia administrativa, como se procurou demonstrar acima. Ainda que os conceitos possam ser diferenciados em termos teóricos, na prática é usual que essas suas atividades públicas se apresentem de modo entrelaçado ${ }^{242}$. Também por esse motivo há de se concluir não só pela possibilidade de se constituírem empresas estatais para o desenvolvimento de atividades de polícia administrativa bem como pela proximidade do regime jurídico a que estas se submetem em relação ao regime aplicável às que têm por objeto a prestação de serviço público.

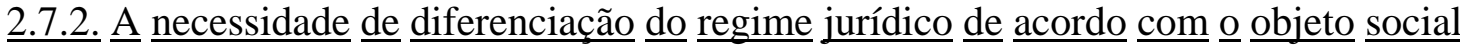

Em princípio, o texto constitucional determinou a incidência de regime jurídico uniforme para as empresas estatais, independentemente da atividade por elas exercida. Como destaca Maria Sylvia Zanella Di Pietro, “o constituinte brasileiro foi muito infeliz, porque, além de não distinguir as que prestam serviços públicos e as que exercem atividade econômica com base no art. 173, ainda deu às mesmas um tratamento em quase tudo semelhante ao da Administração Direta"243.

No entanto, a diversidade das atividades exercidas não recomenda que o regime jurídico seja idêntico. As empresas estatais que desempenham atividade econômica submetem-se ao regime jurídico de direito privado quase que em sua integralidade. Já as que exercem atividade de natureza pública submetem-se principalmente ao regime jurídico de direito público ${ }^{244}$.

\footnotetext{
${ }^{242}$ Como conclui Rodrigo Pagani de Souza: "Tivesse que ser encaixada em alguma das duas alternativas prestadora de serviço público ou exploradora de atividade econômica - a empresa estatal constituída para exercer polícia administrativa estaria mais próxima da prestadora de serviço público. É que, na atividade de polícia ou ordenação administrativa, existe, por certo ângulo, um 'serviço público'. As missões de ordenar o trânsito de uma cidade, ou proteger o seu patrimônio ambiental, envolvem, elas mesmas, prestação de 'serviços públicos' em amplo sentido” (Empresas estatais constituídas para o exercício de poder de polícia, 2014, p. 161).

${ }^{243}$ Parcerias na Administração Pública, 2012, p. 58 - grifo no original.

${ }^{244}$ Isso não significa que não possam existir casos concretos heterogêneos, tais como entidades da Administração indireta que têm por objeto a prestação de serviço público mas que passaram a desenvolver também atividades econômicas em sentido estrito, aproveitando novas oportunidades de negócios. Não são poucas as ocorrências concretas de empresas estatais que ampliaram o seu objeto de atuação, gerando novos desafios para a definição do regime jurídico a que se submetem. Por exemplo, no julgamento do RE $n^{\circ}$ 229.696, que discutia a penhorabilidade dos bens da Empresa Brasileira de Correios e Telégrafos - ECT, o STF chegou a cogitar da possibilidade de dividir as operações da empresa estatal para fins de submissão a regime jurídico distinto de acordo com a natureza específica da atividade considerada em cada caso. Essa tese acabou não prevalecendo naquela oportunidade e decidiu-se pela impenhorabilidade dos seus bens. Sobre as
} 
Para se atingir essa conclusão e determinar-se o regime jurídico adequado das empresas estatais, Marçal Justen Filho propõe a leitura do texto constitucional em consonância com as atividades desempenhadas ${ }^{245}$.

O art. 173 da CF/88 estipula que o Estado poderá exercer diretamente atividades econômicas em sentido estrito apenas em situações especiais. Em tais hipóteses, o Estado deverá se subordinar ao regime próprio das empresas privadas (art. 173, §1º). Logo, para a exploração de atividade econômica o Estado deverá se utilizar de pessoas jurídicas de direito privado.

Já nas hipóteses em que a empresa estatal exerce função de natureza pública, não se aplica a vedação do art. $173, \S 1^{\circ}$, podendo ser-lhes reconhecidos privilégios e vantagens não extensíveis à iniciativa privada e não previstos no regime reservado às pessoas privadas.

Logo, cabe reconhecer que as entidades da Administração indireta com personalidade jurídica de direito privado devem se submeter a regime jurídico distinto, de acordo com a atividade que exercem. Trata-se de dividir as entidades da Administração indireta dotadas de personalidade jurídica de direito privado em dois grandes grupos, daquelas que desempenham atividade econômica em sentido estrito e das que exercem função pública.

Nesse ponto do estudo, as indicações acerca do regime jurídico das estatais que exercem atividades de natureza pública prestam-se a ilustrar que não é incompatível com a personalidade de direito privado a incidência do regime de direito público. O que determina o regime jurídico a que a entidade se submete é precipuamente a atividade que desempenha e não a sua personalidade jurídica. Este aspecto apresenta-se como sendo de maior relevância ao se identificar o regime jurídico aplicável do que a caracterização formal atribuída à entidade.

\subsubsection{As diferenciações de regime jurídico}

Como se procurou demonstrar acima, mesmo que se afirme que as entidades da administração indireta de personalidade privada submetem-se ao regime de direito privado, este regime não se aplica de modo uniforme a todas elas. A gradação da incidência do regime de direito privado depende precipuamente das atividades por elas desempenhadas.

situações híbridas das empresas estatais prestadoras de serviço público e exploradoras de atividade econômica, confira-se o estudo de Marçal Justen Filho. O regime jurídico das empresas estatais e a distinção entre "serviço público" e "atividade econômica", 2006.

${ }^{245}$ Curso de direito administrativo, 2013, p. 298-302. 
O exercício de atividade pública ou de atividade econômica em sentido estrito pelas entidades privadas da Administração indireta apresenta relevância no que diz respeito ao regime jurídico a que se submetem.

Reitere-se que a doutrina e a jurisprudência adotam usualmente a dicotomia entre atividade econômica em sentido estrito e serviço público para diferenciar as entidades estatais que têm por objeto o desempenho de uma ou de outro. Foi sob esse enfoque que as discussões sobre o tema desenvolveram-se com maior profundidade. Não se faz referência expressa às entidades estatais que exercem outras funções de natureza pública, que não são qualificadas como serviço público. Esse seria precisamente o caso das entidades estatais dedicadas ao exercício de atividades de polícia administrativa.

Como já se indicou, o regime jurídico de atuação das entidades estatais que exercem atividades de polícia administrativa deverá ser bastante próximo ao das entidades prestadoras de serviço público. Diante disso, poderão ser aplicadas ao exercício de atividades de polícia administrativa as manifestações doutrinárias e jurisprudenciais que fazem referência à prestação de serviço público como contraposição ao desempenho de atividade econômica em sentido estrito.

2.7.3.1. Regra geral: aplicação de regime jurídico similar ao incidente sobre o exercício da atividade pela Administração direta

O texto constitucional não prevê expressamente as regras a serem observadas no exercício de função pública pelo próprio Estado, quando isso ocorre por meio de entidades que integram a Administração indireta. Coube à doutrina e à jurisprudência a identificação do regime jurídico aplicável.

É praticamente pacífica a aceitação, pela doutrina nacional, de que o regime jurídico a que se submetem as empresas estatais deve ser definido de acordo com a atividade por elas desempenhada.

Disso decorre que, em relação àquelas que exercem atividade econômica de natureza privada, aplica-se-lhes o regime de direito privado, como regra geral. Trata-se de regime o mais próximo possível daquele aplicável às demais pessoas de direito privado. A incidência do direito público sobre as atividades dessas entidades é excepcional e depende de derrogação expressa do direito privado, a ser interpretada restritivamente.

Essas são as regras que se extraem do art. $173, \S 1^{\circ}$, da CF. Ainda que a impressão da leitura do dispositivo constitucional possa ser diversa, não são poucas as derrogações do regime de direito privado aplicáveis às empresas estatais. 
Note-se que derrogações parciais do regime de direito privado necessariamente deverão ocorrer, à medida que as empresas estatais consistem em mecanismo de que se utiliza o Estado para atingir as suas finalidades. O vínculo com a Administração direta sempre deverá existir, de modo a assegurar a persecução dos fins públicos pela empresa estatal. A entidade da Administração indireta não pode se desvincular da atuação da Administração Pública como um todo. É um dos instrumentos de ação da Administração, devendo ter a sua ação coordenada pelas mesmas diretrizes que informam a orientação política geral do Estado.

Já em relação às empresas estatais que exercem atividade de natureza pública, o regime jurídico que lhes é aplicável é o de direito público.

Essa é a conclusão exposta por Maria Sylvia Zanella Di Pietro: nas hipóteses em que “o Estado fizer a gestão privada do serviço público, ainda que de natureza comercial ou industrial, aplicam-se, no silêncio da lei, os princípios de direito público, inerentes ao regime jurídico administrativo" ${ }^{246}$.

Ao analisar o regime jurídico da SABESP, constituída como sociedade de economia mista e encarregada da prestação de serviço público, Geraldo Ataliba assentou o seguinte:

A forma, roupagem e revestimento de 'sociedade' não lhe retira a essencial e substancial natureza pública de 'instrumentalidade' do Estado, assim implicitamente qualificada por toda a legislação. Deveras, a circunstância de assumir a forma de sociedade por ações não altera nem nega as precedentes afirmações. Todas as considerações que - a respeito desta forma escolhida pelo legislador - possam ser desenvolvidas não enfraquecem, nem retiram a plenitude das consequências da afirmação de que ela é entidade pública (substancialmente), prestadora de nítido, rigoroso e indiscutível serviço público ${ }^{247}$.

Ainda no mesmo sentido, Marçal Justen Filho propõe que o exercício de função pública pelo Estado, seja por meio da Administração direta seja por via de entidades da Administração indireta, inclusive com personalidade jurídica de direito privado, deverá submeter-se ao mesmo tratamento jurídico ${ }^{248}$

Ressalvamos que isso não significa afirmar a absoluta equivalência entre o regime jurídico aplicável às entidades da Administração indireta que prestam serviço público e àquelas que exercem atividades de polícia administrativa.

\footnotetext{
${ }^{246}$ Direito administrativo, 2013, p. 506.

${ }^{247}$ SABESP - Serviço público - Delegação a empresa estatal - Imunidade a impostos - Regime de taxas, 1989, p. 71

${ }^{248}$ O regime jurídico das empresas estatais e a distinção entre "serviço público" e "atividade econômica", 2006, p. 122.
} 
Como se indicou acima, não deixa de haver desempenho direto dessas atividades pelo Estado quando são prestadas por via de entidades da Administração direta. Como regra geral, deverá ser aplicado o mesmo regime jurídico incidente sobre essas atividades quando são exercidas pela Administração direta. E o regime jurídico da prestação de serviços públicos e o do exercício de atividade de polícia administrativa não são equivalentes. São essas mesmas diferenças, existentes quando as atividades são desempenhadas pela Administração direta, que serão verificadas entre as entidades da Administração indireta que têm por objeto o desempenho dessas atividades.

\subsubsection{Aplicações concretas}

No que diz respeito aos atos praticados pelas empresas estatais que exercem atividade pública nas suas relações com terceiros, se tais atos forem diretamente vinculados ao próprio exercício da atividade que lhes foi atribuída, reconhece-se que serão regidos pelo direito público. Serão caracterizados como atos administrativos, aplicando-se-lhes as consequências decorrentes $^{249}$.

Já em relação às empresas estatais que exploram atividade econômica, os atos praticados nas suas relações com terceiros serão regidos pelo direito privado.

A regra geral é a de que as empresas estatais submetem-se à exigência de prévia licitação para as suas contratações. O texto constitucional (art. 22, inc. XXVII) previu a incidência de um regime diferenciado para as licitações a serem realizadas pelas sociedades de economia mista e empresas públicas. Esse dispositivo não foi regulamentado até o momento, reputando-se que continuam sujeitas às regras comuns de licitação.

No entanto, em relação às empresas estatais que exploram atividade econômica, a submissão de todas as suas contratações à prévia licitação consistiria em mecanismo apto a obstaculizar a persecução das suas finalidades. Poderia inviabilizar a adequada exploração do negócio e o aproveitamento das oportunidades negociais que surgem na atuação rotineira da empresa e demandam a atuação rápida e ágil da entidade estatal. Mas isso não se aplica a todas as suas contratações. Há casos em que a realização de licitação não compromete a exploração da atividade econômica, não havendo necessidade de ser aplicado o regime correspondente às empresas privadas.

Por isso, o TCU delineou a incidência da exigência de prévia licitação de acordo com o objeto a ser contratado pelas entidades que desempenham atividade econômica em sentido estrito. Assentou o entendimento de que não é obrigatória a

\footnotetext{
${ }^{249}$ Sobre as consequências da caracterização de determinados atos praticados por entidades privadas como sendo atos administrativos, v. item IV.3.
} 
realização de licitação para a celebração de contratos relacionados às atividades-fim dessas entidades $^{250}$. Ou seja, em relação às atividades-fim, equiparou-se o regime aplicável às entidades da administração indireta ao mesmo regime a que se submetem as empresas privadas.

Já o STF reconheceu, por exemplo, que as execuções contra a empresa pública ECT - Empresa Brasileira de Correios e Telégrafos deveriam observar o regime de precatórios $^{251}$. Em relação a sociedades de economia mista, reconheceu a sua submissão ao regime comum de execução judicial, não lhe sendo aplicável o de precatórios ${ }^{252}$. Reconheceu, portanto, que os bens das empresas públicas não são penhoráveis.

Marçal Justen Filho destaca que o aspecto essencial desse entendimento não é o de se considerar que a prestação de serviço público é que determinaria a impenhorabilidade dos seus bens. Esse raciocínio conduziria à aplicação da mesma solução inclusive para concessionárias de serviço público. O aspecto relevante é o de que a empresa pública não retrata a associação de capital público e privado e não é constituída objetivando a obtenção de lucro. Por isso, não poderia receber o mesmo tratamento jurídico das sociedades de economia mista, ainda que as duas possam ter por finalidade a prestação de serviço público ${ }^{253}$.

Em relação ao regime orçamentário e financeiro, a diferenciação decorre não propriamente da atividade desempenhada pelas empresas estatais e sim do fato de serem entidades dependentes ou não dependentes. Trata-se de critério instituído pela Lei de Responsabilidade Fiscal ${ }^{254}$.

As entidades dependentes são aquelas que dependem do repasse de recursos orçamentários da entidade estatal a que se vinculam para cobrir despesas de pessoal ou de custeio. Já as entidades não dependentes suportam essas despesas com recursos próprios.

As empresas estatais, ainda que tenham por objeto o exercício de atividade pública, em princípio não se beneficiariam da imunidade tributária prevista no art. 150, inc. VI, "a” do texto constitucional. Assim se passa especialmente em razão do disposto no $\S 3^{\circ}$ daquele dispositivo: “As vedações do inciso VI, "a", (...) não se aplicam ao patrimônio, à renda e aos serviços, relacionados com exploração de atividades econômicas regidas pelas

\footnotetext{
${ }^{250}$ O desenvolvimento desse entendimento consta especialmente do Acórdão n n 121/1998 - Plenário (j. 26.8.1998), que analisou a adequação do Manual Geral de Contratações da PETROBRÁS à Lei no 8.666/93.

${ }^{251}$ RE n $^{\circ}$ 220.906/DF, Rel. Min. Maurício Corrêa, Plenário, j. 16.11.2000, DJ 14.11.2002.

${ }^{252}$ RE n $^{0}$ 599.628/DF, Pleno, Rel. Min. Ayres Britto, rel. p/ acórdão Min. Joaquim Barbosa, DJe 17.10.2011.

${ }^{253}$ Curso de direito administrativo, 2013, p. 301-302.

${ }^{254}$ Lei Complementar no $101 / 00$, art. $1^{\circ}$, $\$ 3^{\circ}$, inc. I, “b” e art. $2^{\circ}$, inc. III.
} 
normas aplicáveis a empreendimentos privados, ou em que haja contraprestação ou pagamento de preços ou tarifas pelo usuário (...)”.

Assim, à medida que fossem remuneradas por contraprestações pagas pelos usuários do serviço, as empresas estatais não estariam abrangidas pela referida imunidade.

No entanto, o exame da jurisprudência do STF evidencia a relativização na aplicação da referida regra.

O STF decidiu, por exemplo, que as empresas públicas que prestam serviço público beneficiam-se da imunidade tributária recíproca, desde que sejam observados determinados requisitos, tal como a não distribuição de lucros ou resultados a particulares $^{255}$.

Em outro julgado, decidiu de modo mais amplo que "as empresas prestadoras de serviços públicos que não exercem atividade econômica em sentido estrito, sujeitam-se ao regime jurídico das empresas públicas, inclusive quanto às obrigações trabalhistas e tributárias”256.

Como observa Marçal Justen Filho, "rigorosamente, o entendimento professado pelo STF equivale a identificar as empresas públicas prestadoras de serviço público às autarquias”257. No entanto, isso significaria submetê-las a todos os condicionamentos e limites aplicáveis às autarquias, como entes de personalidade jurídica pública. Não poderiam ser destacados apenas alguns dos aspectos do regime de direito público para serem aplicados às estatais de natureza privada que prestam serviço público, de acordo com critérios de conveniência.

\subsubsection{O possível maior grau de incidência do regime jurídico de direito público às} empresas estatais que exercem atividades de polícia administrativa

Em relação às estatais que exercem atividades de polícia, pode-se indicar que possivelmente serão submetidas ao regime jurídico de direito público em maior grau em relação às que prestam serviço público.

Essa constatação não decorre de uma submissão propriamente diferenciada das estatais que exercem atividades de polícia administrativa ao direito público. O que se verifica é que, para o desempenho da atividade que lhes foi atribuída, provavelmente será demandada a prática de uma maior quantidade de atos que impliquem o exercício de

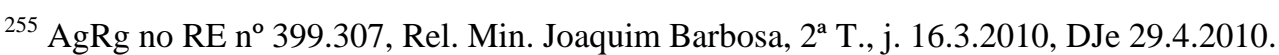

${ }^{256}$ AgRg no RE no 433.666, Rel. Min. Eros Grau, 2 ${ }^{\mathrm{a}}$ T., j. 3.11.2009, DJe 26.11.2009.

${ }^{257}$ Curso de direito administrativo, 2013, p. 300.
} 
prerrogativas e privilégios públicos por essas empresas estatais. A diferença constatada decorreria de fatores quantitativos e não qualitativos.

Em qualquer caso, a constatação do grau de submissão ao regime jurídico de direito público dependerá da análise do caso concreto, considerando-se especificamente as atividades a serem desempenhadas pela entidade. É o objeto da sua atuação que determinará a necessidade de incidência do regime jurídico público em maior ou menor grau.

\subsubsection{A impossibilidade de equiparação das entidades privadas às entidades públicas}

Isso não significa também que as estatais de natureza privada que desempenham atividade pública possam ser simplesmente equiparadas às autarquias para fins de se reconhecer que podem exercer prerrogativas públicas. A natureza privada apresenta diversas decorrências, que podem inclusive configurarem-se como conflitantes com o manejo de competências caracteristicamente estatais.

Não seria cabível autorizar-se a criação de uma sociedade de economia mista, por exemplo, para a execução de uma atividade pública, para pretender aplicar-lhe integralmente o regime jurídico das autarquias. A natureza distinta dos entes impede a equiparação completa e artificial dos regimes jurídicos. Há determinadas decorrências da personalidade de direito privado, especialmente relacionadas à gestão da entidade, que não poderão ser afastadas.

Assim, ainda que se trate de regime jurídico próximo ao de direito público, não se pode pretender equiparar, para todos os fins, as estatais que exercem atividade pública às autarquias.

\subsubsection{Observações finais}

A incidência de vários aspectos do regime jurídico de direito público faz-se necessária para assegurar o adequado exercício da atividade pública pela empresa estatal.

Vitor Rhein Schirato menciona que a prevalência do regime de direito público asseguraria à empresa estatal uma posição de supremacia em relação às pessoas privadas, especialmente pela incidência dos princípios da supremacia do interesse público e da indisponibilidade do interesse público ${ }^{258}$. Parece-nos não ser necessário propriamente que a empresa estatal ocupe uma posição de supremacia. Deve sim ser dotada dos instrumentos necessários para a persecução das finalidades para as quais foi constituída.

${ }^{258}$ Novas anotações sobre as empresas estatais, 2005, p. 229. 
Assim, as empresas estatais que desenvolvem atividades públicas submetemse a regime jurídico mais próximo ao de direito público por exigência do seu objeto social. Faz-se necessária a incidência de um regime jurídico no qual sobressaem aspectos de direito público de modo que sejam propiciados os instrumentos e garantias imprescindíveis para o adequado desempenho da missão que lhe foi atribuída.

No item III.8, analisam-se outros aspectos que diferenciam as entidades com personalidade de direito público das de direito privado, com o propósito de se verificar se consistem em fundamentos suficientes para determinar a inviabilidade do exercício de atividades de polícia administrativa por entidades privadas.

\section{Exercício $\underline{\text { indireto }} \underline{\text { de }} \underline{\text { atividades }} \underline{\text { estatais }}$}

Neste ponto, cabe analisar a possibilidade de exercício indireto de atividades estatais, em especial no que diz respeito às atividades de polícia administrativa, mediante sua atribuição a particulares.

Para tanto, serão apresentadas inicialmente as diversas modalidades de exercício indireto de atividades estatais, com alguns apontamentos sucintos para se diferenciar a extensão das atribuições do particular em cada caso.

\subsection{Ressalva prévia: preservação da titularidade pública}

Ressalva-se inicialmente que o exercício indireto de atividades estatais ora analisado não implica alteração da titularidade da atividade.

Cabe ressalvar que a titularidade estatal não significa necessariamente haver reserva exclusiva para o poder público, com interdição de acesso privado a determinada atividade. A equiparação entre o objeto do trespasse a particulares e o domínio exclusivo do Estado, o monopólio estatal, prevaleceu em períodos anteriores, tal como o do Estado liberal, mas não mais se verifica na atualidade. Como bem pondera Floriano de Azevedo Marques Neto, a titularidade pública indica que a atividade é de responsabilidade do poder público, com ou sem caráter de exclusividade ${ }^{259}$.

No exercício indireto de atividades públicas, não há abdicação ou renúncia do poder público em relação a tais competências. O Estado permanece sendo o titular dos poderes e deveres envolvidos. Transfere-se apenas o exercício de determinadas atividades

${ }^{259}$ A concessão como instituto do direito administrativo, 2013, p. 87-90. 
para entidades privadas. Não há disposição da titularidade da atividade, que continua sendo estatal. Não deixa de existir a publicatio ${ }^{260}$ da atividade.

A manutenção da titularidade estatal manifesta-se especialmente com o exercício de controle e autoridade pelo poder público sobre o particular que se encontra no exercício de atividades públicas. O poder público reserva-se o direito, inclusive, de retomar o exercício da atividade a qualquer tempo, observando-se os requisitos e pressupostos previstos em lei e no contrato ou ato de atribuição.

A seguir, examinam-se os mecanismos de trespasse do exercício de atividades estatais a particulares.

\subsection{Os módulos convencionais ou contratuais}

A Lei $n^{\circ}$ 8.666/1993 consagra definição bastante ampla de contrato. Nos termos do art. $2^{\circ}$, parágrafo único, considera-se “contrato todo e qualquer ajuste entre órgãos ou entidades da Administração Pública e particulares, em que haja um acordo de vontades para a formação de vínculo e a estipulação de obrigações recíprocas, seja qual for a denominação utilizada”.

Disso se extrai a intenção do legislador de aplicar o regime jurídico previsto na Lei $n^{\circ}$ 8.666/1993 como lei geral para todo e qualquer ajuste entre Administração e particulares, independente da nomenclatura que lhe for dada. No entanto, a Lei $n^{\circ}$ 8.666/1993 trata especificamente de alguns tipos de contratos administrativos, que são, em linhas gerais, os contratos de obras, serviços, compras e alienações.

A doutrina tem utilizado o termo "módulos convencionais" para se referir ao conjunto de figuras convencionais de que a Administração pode se utilizar ${ }^{261}$.

Fernando Dias Menezes de Almeida emprega o termo “módulo convencional” para se referir aos casos em que uma nova situação jurídica, subjetiva ou objetiva, é criada mediante o emprego de acordos de vontades ${ }^{262}$. Uma nova situação jurídica pode tanto ser necessariamente criada pelo módulo convencional celebrado pelas

\footnotetext{
${ }^{260}$ Utilizamos o termo publicatio para fazer referência às situações em que existe um ato estatal formal qualificando determinada atividade como pública. Isso poderá ocorrer tanto com ou sem reserva de exclusividade do Estado em relação àquela atividade.

${ }^{261}$ A precursora na utilização da expressão “módulos convencionais” no direito brasileiro é Odete Medauar (Convênios e consórcios administrativos, 1995). O tema foi amplamente desenvolvido por Fernando Dias Menezes de Almeida (Contrato administrativo, 2012, p. 198 e s.).

${ }^{262}$ Contrato administrativo, 2012, p. 237.
} 
partes bem como a Administração pode optar pela via consensual, utilizando-se do acordo de vontades em casos nos quais poderia exercer o poder unilateral de decisão.

De acordo com a classificação proposta pelo autor, aplicam-se os “módulos convencionais necessários para a criação de situação jurídica” quando o surgimento de uma nova situação jurídica depende necessariamente do acordo de vontades. A Administração não dispõe do poder de impor unilateralmente a nova situação jurídica pretendida.

As hipóteses em que a Administração recorre a módulos convencionais sem que estes sejam necessários para a criação de uma nova situação jurídica são qualificadas por Fernando Dias Menezes de Almeida como “módulos contratuais substitutivos de decisão unilateral da Administração" 263 . Trata-se dos casos em que a Administração dispõe do poder de impor unilateralmente a situação jurídica pretendida à outra parte. Porém, opta por substituir a decisão unilateral pela celebração de um acordo de vontades ${ }^{264}$.

A primeira situação, de emprego necessário de acordos de vontade para a constituição de uma situação jurídica, é a que abrange a maioria dos acordos celebrados pela Administração e nela se enquadra a noção de contrato administrativo ${ }^{265}$.

Ainda seguindo a sistemática proposta por Fernando Dias Menezes de Almeida ${ }^{266}$, os módulos convencionais cuja utilização é necessária para a criação de uma nova situação jurídica podem ser divididos em três grandes grupos:

a) módulos convencionais de cooperação: são aqueles empregados para a persecução de fins comuns da Administração e de particulares. Alguns de seus exemplos são as figuras do convênio e do consórcio.

b) módulos convencionais de concessão: são utilizados para a transferência temporária pela Administração do exercício de atividade ou de utilização de elemento que lhe são próprios, ainda que não exclusivos, e continuarão sendo de titularidade pública;

c) módulos convencionais instrumentais: são aqueles pelos quais a Administração recorre a particulares para satisfazer suas necessidades instrumentais para a realização da função pública.

\footnotetext{
${ }^{263}$ Contrato administrativo, 2012, p. 297-298.

${ }^{264}$ Foram feitas algumas referências à utilização do acordo de vontades em substituição à prática de ato unilateral no item I.13.

${ }^{265}$ Fernando Dias Menezes de Almeida. Contrato administrativo, 2012, p. 238.

${ }^{266}$ Ob. cit., p. 239-240.
} 


\subsection{Contratos de colaboração e contratos de delegação}

No âmbito do presente estudo, serão considerados mais especificamente os ajustes compreendidos nos módulos convencionais de concessão e nos módulos convencionais instrumentais, que são aqueles mais aptos para a atribuição do exercício de atividades de polícia administrativa a particulares ${ }^{267}$.

São possíveis várias classificações dos contratos administrativos, utilizandose os mais diversos critérios. Analisa-se a separação entre módulos convencionais de concessão e instrumentais por ser aquela que apresenta maior pertinência em relação ao objeto do presente estudo.

Em alguma medida, a distinção entre esses dois módulos retrata outras classificações possíveis para os contratos administrativos em sentido estrito, como mecanismos utilizados pela Administração para satisfazer as suas necessidades e desempenhar suas funções.

Uma dessas classificações é exposta por Marçal Justen Filho. O autor propõe a divisão entre contratos de colaboração e contratos de delegação a particulares do exercício de competências administrativas ${ }^{268}$, considerando que se submetem a regimes jurídicos distintos.

Os contratos de colaboração “se caracterizam pela assunção por um particular da obrigação de realizar prestação destinada a satisfazer, de modo direto e imediato, necessidades da Administração"269. Não implicam a atribuição de poderes e competências próprias da Administração e os “direitos e obrigações produzidos pelo contrato exaurem-se no relacionamento direto entre as partes”270.

Já os contratos de delegação do exercício de competência têm por objeto “a atribuição de título jurídico para que um terceiro desempenhe funções tipicamente estatais, desencadeando relações jurídicas de direito público perante os administrados”271. O

\footnotetext{
${ }^{267}$ Isso não significa que não possa ser atribuído o exercício de atividades de polícia administrativa mediante o emprego de módulos convencionais de cooperação. Por exemplo, no contexto de um consórcio público, poderá haver a prestação de serviços de forma associada, por entidade da administração direta ou indireta de um dos entes consorciados (nos termos previstos na Lei $\mathrm{n}^{0}$ 11.107/05). Nesse caso, a atribuição do serviço também é regulada pelo contrato de programa e poderá implicar o desempenho de atividades de polícia administrativa, instrumentais à prestação do serviço. No entanto, reputamos que as situações de atribuição do exercício de polícia administrativa no âmbito dos módulos convencionais de cooperação não apresentam diferenças substanciais em relação às situações verificadas nos outros dois módulos convencionais, os de concessão e os instrumentais, de modo que não justificam o seu exame apartado.

${ }^{268}$ Curso de direito administrativo, 2013, p. 476 e ss.

${ }^{269}$ Ob. cit., p. 476.

${ }^{270}$ Ob. cit., p. 480.

${ }^{271}$ Ob. cit., p. 481.
} 
particular assume a posição jurídica de prestador da atividade, ainda que de modo indireto (como ocorre na concessão administrativa) ${ }^{272}$.

Em sentido similar, Diogo de Figueiredo Moreira Neto propõe a distinção dos diversos instrumentos contratuais utilizados pela Administração, para o cometimento do exercício de atividades estatais a entidades privadas, entre aqueles que envolvem a transferência com ou sem delegação dos serviços ${ }^{273}$. Em alguma medida, trata-se também da diferenciação entre os contratos de concessão e os demais contratos administrativos em sentido estrito ${ }^{274}$.

Essas possíveis classificações mencionadas não são idênticas entre si. Porém, a lógica subjacente a essas diferenciações é a mesma. Em linhas gerais, o principal aspecto que aparta esses dois tipos de contrato administrativo que ora estão sendo especialmente considerados é a existência de mera contribuição auxiliar do particular ou a transferência da responsabilidade pela execução da atividade em si, com a assunção de obrigações perante terceiros.

Nessas várias sistematizações possíveis, enfatiza-se que os contratos de transferência de competências administrativas submetem-se a regime jurídico diverso daquele incidente sobre os contratos de colaboração ou instrumentais, voltados à contratação de obrigações de dar ou fazer de particulares e que se submetem precipuamente à Lei $n^{\circ} 8.666 / 93$.

\footnotetext{
${ }^{272}$ Ob. cit., p. 477. Como esclarece Fernando Dias Menezes de Almeida, a sua proposta para os "módulos convencionais de concessão" é mais ampla do que a dos "contratos de delegação de exercício de competência" porque não abrangem apenas a atribuição de "funções tipicamente estatais". Podem ter por objeto outras atribuições do poder público, tais como aquelas relacionadas ao uso de bens públicos. Já os módulos convencionais instrumentais adotam como critério principal o fato de serem instrumentais em relação às atividades-fim da Administração. $\mathrm{O}$ aspecto de exaurimento das obrigações contratuais nas relações diretas entre as partes contratantes pode diferenciá-los dos contratos de delegação ou dos módulos convencionais de concessão. No entanto, ainda segundo Fernando Dias Menezes de Almeida, o exaurimento das obrigações contratuais nas relações entre os contratantes também se aplica ao que denomina "módulos convencionais de cooperação" (Contrato administrativo, 2012, p. 240, nota 478).

${ }^{273}$ Mutações do direito administrativo, 2001, p. 129-140.

${ }^{274}$ Note-se, no entanto, que há classificações que utilizam nomenclaturas próximas para identificar objetos distintos. Esse é o caso da classificação apresentada por Sérvulo Correia, que divide os contratos administrativos em contratos de colaboração e contratos de atribuição. Nos contratos de colaboração, o particular desempenha temporariamente atribuições administrativas, mediante remuneração. O objeto principal é a prestação realizada pelo contratado, em atendimento ao interesse público. Já os contratos de atribuição têm por objeto a atribuição de certa vantagem ao contratado da Administração. O seu aspecto essencial é a prestação por parte da Administração, consistente na outorga de uma vantagem ao particular, e não a contrapartida recebida. A ampla maioria dos contratos administrativos do direito nacional, inclusive os de concessão de serviços públicos, pode ser qualificada como contratos de colaboração, nos termos da sistemática proposta por Sérvulo Correia. O exemplo típico dos contratos de atribuição são os contratos econômicos, celebrados pela Administração para fins de intervenção econômica - tais como os contratos de fomento. Mas são também exemplos dos contratos de atribuição os contratos de concessão de uso de bens públicos (Legalidade e autonomia contratual nos contratos administrativos, 2003, p. 420-428).
} 


\subsubsection{Os contratos de colaboração}

Os contratos de colaboração destinam-se à satisfação de necessidades instrumentais da Administração mediante a contratação de compras, obras, serviços e alienações com particulares.

Na execução das obrigações contratuais, o particular exercita as suas próprias competências, de direito privado, para cumprir as obrigações que the foram atribuídas no contrato celebrado com a Administração. Não são transferidos ao particular poderes e competências próprios da Administração.

No âmbito dos contratos de colaboração, encarrega-se o particular da preparação ou implementação de determinada atividade mas não se lhe atribui a responsabilidade pela sua execução. O particular apenas produz um resultado que atende às necessidades da Administração mas o faz no exercício de uma atividade privada. Há o auxílio de particulares na execução de atividades públicas mas a responsabilidade em relação a tais atividades continua sendo exclusiva do Estado.

O particular atua como representante do Estado, em nome e por conta do Estado. O contratado da Administração mantém uma relação jurídica apenas com o poder público, não se apresentando perante os usuários como titular de posição jurídica própria. Ainda que o contratado atue diretamente perante terceiros, a sua atuação será atribuída à Administração, tal como se ela estivesse exercendo diretamente as atividades.

O Estado mantém a responsabilidade pela realização da atividade, cabendo ao particular executar apenas determinadas tarefas que lhe tenham sido expressamente atribuídas. Não se outorga margem de decisão ao particular acerca do modo de exercício da atividade que lhe foi atribuída.

O interesse visado imediatamente pelo particular é obter a sua remuneração e não o atingimento de determinado resultado - tal como é a prestação do serviço público adequado para o concessionário ${ }^{275}$.

A não assunção da execução da atividade pelo particular "por sua conta e risco”276 é refletida especialmente no controle a ser desempenhado pela Administração ${ }^{277}$. O controle deverá ser exercido em relação a uma maior quantidade de aspectos nos contratos de colaboração para se assegurar que a atividade será desenvolvida com a qualidade necessária para satisfazer a necessidade coletiva a ela vinculada.

\footnotetext{
${ }^{275}$ Marçal Justen Filho. Teoria geral das concessões, 2003, p. 160.

${ }^{276}$ As ressalvas necessárias para a compreensão da expressão "por sua conta e risco”, usualmente associada aos contratos de concessão, são apresentadas no item II.3.5.4.1.

${ }^{277}$ Marçal Justen Filho. Teoria geral das concessões, 2003, p. 136.
} 
São hipóteses de contratos de colaboração, por exemplo, os contratos de compras, serviços e obras da Administração.

\subsubsection{Os contratos de delegação}

Nos contratos de delegação, transfere-se ao particular o exercício de competências administrativas para o desempenho de atividades estatais.

Como define Marçal Justen Filho, “o objeto da contratação é a atribuição de título jurídico para que um terceiro desempenhe funções tipicamente estatais, desencadeando relações jurídicas de direito público perante os administrados”278.

Floriano de Azevedo Marques Neto identifica a concessão como “instrumento de delegação aos particulares de atribuições do poder público”279, pois implica o trespasse de função ou utilidade do concedente ao concessionário. A concessão consiste, assim, em vínculo de atribuição do exercício de funções públicas a particulares.

O particular recebe a atribuição de executar a atividade estatal que é objeto do contrato em nome próprio, “por sua conta e risco”. Apresentam-se adiante as ressalvas a serem consideradas ao se indicar que o particular exerce a atividade estatal por sua conta e risco. De todo modo, em linhas muito gerais, significa que o particular assume a responsabilidade, inclusive perante terceiros, pela realização da atividade que lhe foi transferida.

Nessa modalidade de contrato administrativo, o particular fica encarregado da gestão de uma função pública, a ser exercida com certa autonomia. Atribui-se ao particular inclusive a responsabilidade pela execução da atividade.

A esse respeito, Pierre Delvolvé constata que o único critério distintivo entre a concessão de serviço público e os outros contratos administrativos seria o papel desempenhado pelo contratado da Administração na execução da prestação. Há delegação da gestão de serviço público quando o contratado é encarregado ele mesmo da execução da atividade de interesse coletivo que lhe foi atribuída ${ }^{280}$.

A transferência da gestão do serviço implica a sua organização pelo particular. A participação privada não se restringe ao fornecimento de alguns dos seus elementos ou a colaborar apenas com a obtenção do resultado final. O delegatário assume uma função própria, a ser desempenhada com autonomia e responsabilidade.

\footnotetext{
${ }^{278}$ Curso de direito administrativo, 2013, p. 481.

${ }^{279}$ A concessão como instituto do direito administrativo, 2013, p. 160.

${ }^{280}$ Les contradictions de la délégation de service public, 1996.
} 
Mas isso não significa a transferência integral da atividade, à medida que o Estado preserva a sua titularidade e responsabilidade final pelo seu exercício.

Nos contratos de delegação, o particular atua na posição de Administração nas suas relações com os administrados. Pode, inclusive, exercer poderes públicos vinculados à tarefa que lhe foi atribuída, desde que exista amparo legal e contratual para tanto.

Outro aspecto que caracteriza o contrato de delegação é a convergência e composição de interesses das partes contratantes. Diferencia-se, sob esse aspecto, dos contratos de colaboração, em que os interesses das partes são contrapostos ${ }^{281}$.

Tais características dos contratos de delegação demandam a submissão a um regime jurídico mais rigoroso no que diz respeito à incidência de aspectos do direito público. Há uma vinculação mais intensa do particular ao direito público em razão das competências públicas que exerce.

O exemplo típico dos contratos de delegação é o de concessão de serviço público. Compete usualmente ao particular conceber determinados aspectos do empreendimento e adotar as medidas necessárias para a prestação satisfatória do serviço. Por isso, a concessão envolve também a transferência de determinados poderes ao particular, à medida que sejam necessários ao desempenho da atividade que lhe foi delegada. Mas o instituto da concessão teve o seu uso ampliado no direito nacional, comportando outros objetos além da prestação de serviço público.

\subsubsection{As diferenças de regime jurídico}

A principal repercussão da distinção dos contratos administrativos em contratos de colaboração e contratos de delegação diz respeito ao regime jurídico a que se submetem. Cada um dos tipos de contratos submete-se a um regime jurídico distinto, diante da necessidade de se atingirem objetivos diversos com a contratação.

Essa distinção de regime jurídico está diretamente vinculada às diferenças entre as obrigações conferidas aos contratados em cada um dos tipos de contratos administrativos.

\footnotetext{
281 “No âmbito da concessão, os interesses do poder público e do concessionário são distintos, mas convergentes. Se os móveis são originalmente diversos, no ambiente contratual eles são compostos para convergir a um resultado (a consecução do objeto que, por diversas razões, interessa a ambas as partes. Esse traço demarca sua complexidade. Não existe composição a priori. Esse equilíbrio de interesses varia a cada manifestação do pacto concessório" (Floriano de Azevedo Marques Neto. A concessão como instituto do direito administrativo, 2013, p. 237 - grifos no original).
} 
A evidência da necessidade de distinção de regime jurídico no direito nacional é a disciplina dos contratos administrativos de colaboração, em linhas gerais, pela Lei $\mathrm{n}^{0}$ 8.666/93, e dos contratos de concessão, em sentido amplo, especialmente pelas Leis $\mathrm{n}^{0} 8.987 / 95$ e $11.079 / 04$.

Extrapola os limites do presente estudo analisar detidamente os diversos aspectos que diferenciam o regime jurídico dos contratos de concessão daquele aplicável aos outros contratos administrativos. Cabe registrar também que o regime jurídico da concessão sofre significativas variações de acordo com as especificidades do seu objeto. Daí a dificuldade de se definir um regime jurídico único ${ }^{282}$.

De todo modo, a regulação distinta e a função diversa atribuídas aos contratos de colaboração e aos de delegação é que acabam sendo os critérios determinantes para a escolha, pela Administração, entre a celebração de um contrato de concessão e um contrato de prestação de serviços, por exemplo ${ }^{283}$. São esses os fatores que influenciam a seleção por um ou outro contrato.

Em primeiro lugar, a concessão implica a realização de um volume maior de investimentos pelo particular. Sob esse aspecto, pode-se dizer ser a concessão um mecanismo de financiamento de obras e serviços, com a possibilidade de combinação de mecanismos de pagamento pelos usuários e de aportes e contraprestações pela Administração. Permite a diluição do impacto do custo financeiro do Estado na realização de seus projetos.

Com isso, viabiliza-se a execução de empreendimentos de grande porte, para os quais o Estado não dispõe da totalidade de recursos necessários para pagamento imediato ou a curto prazo.

Estritamente vinculado ao primeiro aspecto, constata-se a duração, tendencialmente mais longa, dos contratos de concessão.

No contrato de delegação, atribui-se ao particular a responsabilidade pela gestão da atividade concedida, durante determinado período. Já nos contratos de colaboração, a responsabilidade pela gestão da atividade permanece na esfera da Administração. $\mathrm{O}$ fato de $\mathrm{o}$ contrato de delegação implicar a atribuição dessa responsabilidade ao particular não significa que a Administração simplesmente abandone a

\footnotetext{
${ }^{282}$ Por esse motivo, como propõe Floriano de Azevedo Marques Neto, é mais relevante atribuir maior margem de normatividade contratual do que se procurar definir uma normatividade geral e abstrata em texto legal, aplicável a todos os objetos possíveis de serem delegados (A concessão como instituto do direito administrativo, 2013, p. 158).

${ }^{283}$ David Soldini, La délégation de service public, sa fonction, ses critères, 2010.
} 
atividade. Esta continua sendo de titularidade pública e a Administração deve garantir a sua prestação, exercendo a sua direção. No entanto, a atribuição da gestão ao particular permite-lhe maior liberdade de decisão em relação à organização da forma de exercício da atividade para o cumprimento das obrigações contratuais.

Em síntese, como conclui David Soldini, o contrato de prestação de serviços amolda-se para adquirir um serviço e a delegação de serviço público, a financiar uma atividade de serviço público ${ }^{284}$. Ou seja, essas diferenças são muito mais de ordem prática, não se encontrando com clareza assim estabelecidas no ordenamento jurídico.

Além disso, em linhas bastante gerais, como se indicou acima, aquele que exerce uma atividade que lhe foi delegada submete-se a um regime jurídico que sofre maiores inflexões do direito público ${ }^{285}$. Já em relação às atividades exercidas mediante transferência sem delegação, o seu caráter privado não sofre alterações tão significativas.

No capítulo IV do presente estudo, dedicado ao exame do regime jurídico aplicável ao exercício de atividades de polícia administrativa por particulares, apontam-se concretamente algumas das diferenças de regime jurídico existentes entre as hipóteses de transferência com e sem delegação.

\subsection{4. $\underline{\text { O objeto }} \underline{\text { dos contratos }}$}

Em estudo aprofundado, Floriano de Azevedo Marques Neto demonstra que, na sua construção histórica, o instituto da concessão foi utilizado como mecanismo de trespasse de privilégios e prerrogativas, que eram de titularidade exclusiva do Estado. O particular apenas poderia exercer tais atividades mediante concessão ${ }^{286}$.

Mais recentemente, especialmente por influência do direito comunitário europeu, a concessão deixou de estar necessariamente vinculada à delegação de atividade exclusiva do Estado. Como constata o autor:

Segue daí que, na concepção que adotamos para o instituto da concessão, hodiernamente, a concessão segue mais como um instrumento de delegação do exercício de competências públicas (poderes e deveres voltados ao atendimento de um direito fundamental) e menos como um veículo de trespasse de privilégios ${ }^{287}$.

\footnotetext{
${ }^{284}$ La délégation de service public, sa fonction, ses critères, 2010.

${ }^{285}$ Sérvulo Correia comenta que a doutrina portuguesa tradicional não se preocupava com a classificação dos vários tipos de contratos administrativos, incluindo-os em uma única categoria ampla, a do contrato de prestação de serviços, que instrumentaliza a colaboração temporária e remunerada do particular na execução de atividades administrativas. Freitas do Amaral é que teria chamado a atenção para o fato de os contratos de uso de domínio público terem natureza necessariamente administrativa. Separaram-se, então, os contratos de prestação de serviços dos contratos de gozo de bens públicos, especialmente em razão da diferença de regime jurídico a que se submetem (Legalidade e autonomia contratual nos contratos administrativos, 2003, p. 417418).

${ }^{286}$ A concessão como instituto do direito administrativo, 2013, p. 51-87.

${ }^{287}$ Ob. cit., p. 91.
} 
Podem, assim, ser objeto de delegação atividades não apenas de setores de atuação exclusiva do Estado mas também de áreas nas quais pode haver atuação de particulares, em regime privado - como meros agentes econômicos ou mediante autorização ou licença outorgada pelo poder público para a exploração de determinada atividade, por exemplo.

Adotando-se essa premissa, cabe examinar se existe diferença em relação ao objeto que é passível de contrato de colaboração em relação àquele que pode ser objeto de contrato de delegação. Trata-se de verificar se determinado objeto, que não poderia ser acomodado em um dos tipos de contrato, poderia constar como objeto de outro tipo.

Ao analisar o contrato de concessão, Vera Monteiro constata inicialmente que o texto constitucional não delimita o que pode ser executado nos contratos previstos no art. 37, inc. XXI - que, em linhas gerais, podem ser reconduzidos aos contratos de colaboração, disciplinados pela Lei n 8.666/93 - e o que ser executado mediante delegação a particulares - no caso, via contrato de concessão ${ }^{288}$.

Daí a conclusão da autora no sentido de que não haveria restrições em relação ao que poderia ser objeto de um tipo de contrato mas não de outro. Compete ao ente titular da atividade decidir o modo como vai exercê-la, de acordo com o que for mais adequado considerando-se as peculiaridades locais. Para tanto, poderá optar pelo seu exercício direto ou indireto, seja com o emprego de contratos de colaboração seja com mecanismos de delegação.

As restrições existentes em relação ao objeto diriam respeito à utilização da técnica contratual como um todo, abrangendo os seus diversos tipos, não sendo específico quanto a um tipo contratual determinado. Ou seja, as restrições existentes em relação às atividades que devem ser exercidas diretamente pelo Estado, não sendo passíveis de delegação, aplicam-se a todos os tipos de contrato.

Como conclui Vera Monteiro: “Toda atividade estatal de interesse público é potencialmente delegável (serviço público, serviço econômico, serviço social e serviço administrativo). Eventual indelegabilidade decorre de vedação expressa na Constituição ou

\footnotetext{
${ }^{288}$ Concessão, 2010, p. 122-123. Cabe também mencionar que o texto constitucional não consagra um conceito de concessão. Aliás, encontra-se o termo “concessão” utilizado nas mais diversas acepções no texto constitucional, tais como a concessão de aposentadoria (art. 40, $\S \S 2^{\circ}, 3^{\circ}$ e $4^{\circ}$ ), a concessão de pensão (art. 40, $\S \S 2^{\circ}$ e $7^{\circ}$ ), a concessão de anistia (art. 48, inc. VIII), a concessão de asilo público (art. $4^{\circ}$, inc. X), a concessão do uso de bem público (arts. 176, 183 e 188) bem como a concessão de exploração de serviço público (art. 21, incs. XI e XII, e art. 175).
} 
norma local, ou com relação a eventual núcleo de autoridade existente para o exercício de atividade concedida"289.

Logo, não haveria um objeto típico da concessão, em razão do qual esta se diferenciaria dos demais contratos administrativos.

\subsection{5. $\underline{\text { A função }} \underline{\text { dos }} \underline{\text { contratos }}$}

A ausência de diferenciação em relação ao objeto possível para os contratos de colaboração e de delegação não significa que esses contratos sejam equivalentes ${ }^{290}$.

Um dos traços característicos da concessão é a transferência da gestão da atividade atribuída ao particular. Ou seja, o particular assume a responsabilidade temporária pela atividade, submetendo-se ao controle e à orientação da Administração.

A esse respeito, pode-se aludir aos diversos sentidos da expressão "modos de gestão”, em lição formulada por Gilles Guglielmi e difundida no direito nacional por Maria Sylvia Zanella Di Pietro ${ }^{291}$. A referida classificação propõe a distinção entre gestão estratégica, gestão operacional e gestão executiva.

A gestão estratégica diz respeito às funções de orientação, direção e controle. Pertence necessariamente a uma pessoa jurídica de direito público e é exteriorizada mediante o poder final de decisão acerca dos objetivos a serem perseguidos. A gestão operacional compreende as tarefas relacionadas à regulação e à otimização da atividade, compreendendo o seu funcionamento, com a organização dos meios de produção e dos modos de execução. Já a gestão executiva é retratada essencialmente na execução material das prestações. Não abrange a prática de atos jurídicos, restringindo-se ao fornecimento material de prestações.

Ainda que não exista coincidência absoluta, pode-se constatar que a gestão executiva seria aquela transferida ao particular nos contratos de prestação de serviços. Já nos contratos de concessão, além da gestão executiva, seria transferida também a integralidade ou significativa parcela da gestão operacional. A gestão estratégica deve ter o seu exercício preservado na pessoa jurídica de direito público titular do serviço, que deve exercer o controle e a direção da atividade atribuída ao particular.

O contrato de delegação, na forma de contrato de concessão, contém determinadas características especiais que impedem a sua utilização em todos os casos. A

\footnotetext{
${ }^{289}$ Concessão, 2010, p. 157.

${ }^{290}$ A eventual equiparação entre eles pode ser ainda mais tentadora diante da concessão administrativa, em face da aparente similitude do seu objeto em relação ao contrato de prestação de serviços, disciplinado na Lei $\mathrm{n}^{\circ}$ 8.666/93. Sobre a concessão administrativa, consulte-se o item II.3.5.5.

${ }^{291}$ Parcerias na Administração Pública, 2012, p. 229-230.
} 
delegação da gestão da atividade ao particular implica uma participação distinta do contratado na execução da atividade pública. Este deixa de ser um mero executor de atos materiais, que são objeto de estrita e prévia determinação pela Administração, para assumir um papel mais amplo, participando da concepção do modo de gestão.

Disso é possível extrair um cunho organizacional da concessão. Cabe ao concessionário providenciar e organizar os meios necessários, incluindo mão-de-obra, recursos e infraestrutura, para a gestão da atividade pública.

Pedro Gonçalves faz uma ampla análise para identificar qual seria a diferença entre o contrato de concessão e o contrato de prestação de serviços. Assenta, inicialmente, a identidade de objeto à medida que esse consiste na realização de prestações. A diferença estaria no fato de a concessão implicar a atribuição ao concessionário da gestão do serviço, o que diferencia os dois tipos de contrato em termos funcionais:

O interesse funcional da concessão é o de proceder à alienação, ou a disposição da gestão do serviço público, enquanto atividade 'própria' da Administração - ao concessionário é confiada a gestão do serviço público. Diferentemente, o contrato de prestação de serviços não altera a responsabilidade pela gestão do serviço, que se mantém na Administração; o contratado apenas colabora na execução de 'determinadas condições da realização daquele ${ }^{, 292}$.

Diogo Freitas do Amaral e Lino Torgal também destacam que o fator distintivo do contrato de concessão daquele de prestação de serviços em favor da Administração consiste em que o primeiro implica a atribuição ao concessionário da responsabilidade temporária pela gestão da atividade pública. Ou seja, “por ela transfere-se da esfera do público para a do privado o essencial o poder decisório relativo à organização e ao modus faciendi de certa atividade” ${ }^{, 293}$.

Pode-se afirmar, assim, que o contrato de concessão pressupõe que o particular exerça as atividades que lhe foram atribuídas com certa autonomia. Essa autonomia está diretamente relacionada aos riscos assumidos pelo particular. À medida que se atribuem determinados riscos ao particular na execução da atividade, deve ser-lhe conferida certa margem de autonomia para que possa adotar as medidas que reputar adequadas para evitar a ocorrência desses fatores de risco ou minimizar o seu impacto.

Disso decorre que, no contrato de concessão, a função de colaboração do contratado é muito mais evidente do que se passa em relação aos contratos de prestação de serviços. Nos contratos de concessão, o contratado não pratica determinadas atividades

\footnotetext{
${ }^{292}$ A concessão de serviços públicos, 1999, p. 161 - grifos no original.

${ }^{293}$ Estudos sobre concessões e outros actos da Administração, 2002, p. 476 - grifos no original.
} 
apenas como meio para a Administração atingir determinado resultado mas também assume a responsabilidade pela obtenção do próprio produto final.

Essa maior autonomia do concessionário demanda também maior controle estatal sobre a gestão da atividade pública. Como titular da atividade, a Administração preserva a sua responsabilidade pela obtenção dos resultados finais pretendidos. Para tanto, deve não apenas exercer o controle sobre as atividades do concessionário mas assume também a posição de garante, de modo a assegurar que os interesses coletivos serão efetivamente atendidos.

Vera Monteiro adota as lições de Pedro Gonçalves e também destaca o papel diferenciado do particular no contrato de concessão e afirma que a diferenciação entre contrato de prestação de serviços e concessão deve "levar em consideração o nível de colaboração do privado na realização de tarefas administrativas. Quanto mais longe se estiver de uma relação em que o privado é mero executor das mencionadas tarefas, mais próximo se estará de uma concessão, cujo 'interesse funcional' é o de 'proceder à alienação, ou à disposição da gestão de um serviço público,”294.

Diante dessas características diferenciadas da concessão, pode-se dizer que ela implica um vínculo mais durável e mais firme entre a Administração e o contratado, tendo em vista a realização de uma atividade de interesse público. Já em relação ao contrato de colaboração, a relação entre a Administração e o contratado estaria mais próxima a uma simples técnica de aquisição de serviços ${ }^{295}$.

Portanto, um dos principais propósitos do contrato de delegação é a atribuição ao contratado da responsabilidade pela gestão da atividade concedida, durante determinado período.

3.3.6. A $\underline{\text { identificação da atribuição }} \underline{\text { ou não }} \underline{\text { da gestão da atividade ao particular }}$

A diferenciação entre a ocorrência ou não da delegação da gestão da atividade ao particular pode ser bastante difícil na prática. Os arranjos contratuais concretos podem não deixar evidente se houve essa delegação ou não. Além disso, há determinados contratos de prestação de serviços com tal complexidade e amplitude de encargos atribuídos ao contratado que acabam se assemelhando aos contratos de delegação.

\footnotetext{
${ }^{294}$ Concessão, 2010, p. 180.

295 David Soldini. La délégation de service public, sa fonction, ses critères, 2010.
} 
Há alguns aspectos que podem auxiliar na distinção entre os dois tipos de contratos $^{296}$. Esses critérios são especialmente relevantes considerando-se a possibilidade de a nomenclatura conferida a determinado contrato não refletir adequadamente o seu conteúdo.

\subsubsection{Atribuição do risco econômico pela execução da atividade}

Uma questão a ser observada é quem assume o risco associado ao exercício da atividade. Caso esse risco seja atribuído à entidade privada, trata-se de indício de que houve delegação do exercício da própria função, acompanhado da responsabilidade pela sua gestão.

Note-se que o critério do risco econômico encontra aplicação especialmente no âmbito comunitário europeu, para se identificar se se trata de contrato de concessão ou de prestação de serviços. Reputa-se que a concessão deve implicar a assunção do risco econômico do empreendimento pelo particular. Já no direito francês, o critério utilizado é mais diretamente associado à remuneração. Se esta for substancialmente vinculada aos resultados da exploração da atividade, considera-se haver uma concessão.

Laurent Richer detecta a evolução da jurisprudência dos tribunais franceses, encaminhando-se para a aproximação desses dois critérios ao aceitar, em determinados precedentes, que o fato de a remuneração encontrar-se substancialmente vinculada aos resultados deve estar associado à transferência de uma parcela significativa do risco de exploração para o contratado ${ }^{297}$. Com isso, afastam-se da caracterização de contratos de concessão aqueles que envolvem tecnologias em que, apesar de o contratado ser remunerado substancialmente pela exploração da atividade, ele não assume propriamente o risco pelo sucesso ou não do empreendimento, havendo, por exemplo, a garantia de receita mínima pelo contratante.

Porém, o critério do risco econômico não seria o mais adequado para o direito nacional.

Em primeiro lugar, cabe reconhecer que, no direito nacional, não há vedação absoluta para que se atribua à entidade privada o risco econômico da execução da tarefa quando se tratar de simples contratação de atividades instrumentais ou acessórias.

Nos contratos firmados sob a égide da Lei $n^{0}$ 8.666/93, reconhece-se a incidência da garantia de equilíbrio econômico-financeiro, de manutenção da relação entre

\footnotetext{
${ }^{296}$ Seguimos a sistematização proposta por Pedro Gonçalves. Entidades privadas com poderes públicos, 2008, p. 352 e s.

${ }^{297}$ Délégation de service public: le critère du risque financier, 2008.
} 
encargos e retribuições estabelecida inicialmente. Isso significa que parcela dos riscos envolvidos na execução do objeto licitado é assumida pelo contratante público. Ressalte-se que se trata de parcela dos riscos, pois não significa que se atribui à Administração todo o risco econômico.

Nos termos do art. 37, inc. XXI, do texto constitucional, a garantia é de manutenção dos termos da proposta do licitante. Os riscos que foram assumidos pelo particular, ao elaborar a sua proposta, não poderão ser transferidos posteriormente à Administração.

Em consonância com tal disposição, o art. 65, inc. II, al. “d”, da Lei ${ }^{0}$ 8.666/93 afasta a possibilidade de modificação do contrato se o evento causador do desequilíbrio era previsível e o contratado deixou de considerá-lo na sua proposta ou no cumprimento das suas obrigações contratuais. Excluem-se, assim, as hipóteses em que o particular atuou de modo culposo, pois estariam abrangidas pela álea econômica ordinária.

Logo, pode-se constatar que é possível fazer-se uma distribuição diferenciada de riscos entre as partes nos contratos administrativos em geral. Essa repartição de riscos deve constar expressamente da lei e do contrato, quando a lei assim autorizar, de modo que as condições originais da proposta do licitante a leve em consideração. É o que se passa, por exemplo, nos contratos de parceria público-privada, em que a lei prevê expressamente a possibilidade de o contrato dispor sobre a distribuição dos riscos entre as partes (Lei $\mathrm{n}^{0} 11.079 / 04$, art. 5º , III) e na contratação com remuneração variável no âmbito do Regime Diferenciado de Contratações Públicas - RDC (Lei $n^{\circ}$ 12.462/11, art. 10), que permite disciplinar os riscos atribuídos às partes no tocante à remuneração.

Assim, a identificação de distribuição diferenciada de riscos não permite concluir, por si só, que se teria promovido a atribuição da responsabilidade pela gestão do serviço à entidade privada. De todo modo, pode consistir em indício de que isso tenha ocorrido à medida que a atribuição de parcela do risco econômico ao particular é mais adequada às contratações em que o particular assume maior responsabilidade pelos resultados da sua atuação.

\subsubsection{Atribuição do exercício de poderes públicos}

A atribuição do exercício de poderes públicos consiste em outro indício de que houve a delegação da responsabilidade pela gestão da tarefa pública. Implica atribuir ao delegatário mecanismos de direito público para o desempenho da sua missão, conferindo- 
lhe status diferenciado em relação a um simples colaborador da Administração na execução de atividades específicas ${ }^{298}$.

Em princípio, apenas os contratos de delegação comportam o trespasse do exercício de poderes e prerrogativas públicas ao paryicular.

\subsubsection{Extensão das incumbências transferidas}

A extensão das incumbências transferidas também é um critério relevante para se identificar se houve delegação do exercício da própria função pública ou apenas a atribuição de atividades instrumentais ou acessórias.

A esse respeito, Pedro Gonçalves recorre ao critério exposto por Christoph Gramm, que assim analisa as incumbências a serem desempenhadas pelos particulares: “quando não lhes caiba definir nem o 'local', nem o 'momento', nem a 'duração' do controle, haverá mera colaboração auxiliar. A incumbência da mera medição, aliás feita pela máquina, não constitui delegação de uma tarefa pública”299.

Esse critério encontra ampla aplicação prática. Por exemplo, pode ser empregado para se avaliar se as atividades relacionadas à fiscalização de trânsito atribuídas a particulares consistem ou não em delegação de exercício de função pública. Pode-se considerar que a aferição de velocidade dos veículos mediante aparelhos eletrônicos não consistiria na delegação de função pública. Já se o particular for incumbido do planejamento e da gestão do sistema de radares, decidindo, por exemplo, os locais onde serão instalados e o modo de funcionamento, haveria delegação de função pública ${ }^{300}$.

\subsubsection{Autonomia de execução da atividade}

A autonomia reconhecida ao particular para executar as atividades que lhe foram atribuídas vincula-se diretamente ao exposto no item anterior, em relação à extensão das suas incumbências. Trata-se de avaliar o grau de programação ou de definição prévia dos termos de execução da tarefa pelo particular. Este também consiste em critério relevante para se aferir se houve delegação ou não do exercício de função pública.

A atribuição de atividades meramente instrumentais ou acessórias implica a Administração manter o gerenciamento integral da atividade púbica, definindo a programação detalhada daquilo que o particular deve executar. Não se delega ao particular

\footnotetext{
${ }^{298}$ A delegação do exercício dos poderes públicos necessários ao desempenho da missão pública atribuída ao particular é analisada no item II.3.6.

${ }^{299}$ Entidades privadas com poderes públicos, 2008, p. 355.

${ }^{300} \mathrm{O}$ tema do exercício privado de atividades relacionadas à fiscalização de trânsito é tratado especificamente no item III.7.6.4.
} 
a responsabilidade pelas escolhas acerca do modo de executar a atividade que lhe foi atribuída.

Já nas hipóteses em que o particular tem a possibilidade de tomar decisões acerca de aspectos relevantes da execução da atividade, é possível que tenha ocorrido a transferência do exercício da própria função pública, atribuindo-se ao particular a responsabilidade pela sua execução e pelos resultados obtidos ${ }^{301}$.

\subsubsection{Observações finais}

A dificuldade concreta de aplicação dos critérios distintivos dos contratos de concessão, aliada à insuficiência desses critérios para resolverem-se adequadamente os casos concretos, acabam evidenciando a proximidade cada vez maior entre esses dois tipos de contrato. Justamente por esse motivo, parcela da doutrina chega a apontar como sendo uma das tendências da delegação de serviço público a sua eventual unificação com o contrato de prestação de serviços ${ }^{302}$.

De todo modo, a distinção entre os contratos de colaboração e os de concessão é relevante para os propósitos do presente estudo. Apenas os contratos de delegação podem implicar o manejo de poderes públicos por particulares, o que dá ensejo aos questionamentos acerca dos limites de delegabilidade das atividades de polícia administrativa.

\subsection{Os contratos de prestação de serviços e a terceirização}

Em alguma medida, pode-se identificar a transferência sem delegação à noção de “terceirização” tal como é correntemente empregada no direito brasileiro.

\footnotetext{
${ }^{301}$ Pedro Gonçalves ressalva que esse critério só se aplica quando se tratar de atividades materiais ou de mera execução, em relação às quais a Administração determine previamente, de forma minuciosa, toda a atividade a ser realizada pelo particular. Quando não se tratar de meras atividades materiais, a programação prévia não consiste em fator determinante para se identificar a delegação ou não da atividade porque ela sempre deverá estar presente: "Se o contratante da Administração for investido de um poder de tomar decisões externas (com relevo na esfera jurídica de terceiros), a programação e a antecipação rigorosa dos critérios de decisão não podem ser interpretados como um fator a apontar no sentido da privatização funcional. Com efeito, sempre que uma entidade privada está autorizada a tomar decisões externas no contexto da execução de uma tarefa que lhe foi confiada pela Administração, estamos diante de um caso de privatização orgânica” (Entidades privadas com poderes públicos, 2008, p. 356). Importa esclarecer os conceitos de privatização funcional e privatização orgânica. Trata-se de sistematização proposta pelo doutrinador alemão Martin Burgi que é adotada por Pedro Gonçalves. A privatização funcional implica a mera contribuição de particulares na execução de tarefas específicas, preservando-se a responsabilidade pública pela gestão e direção da atividade. A privatização orgânica implica a atribuição da responsabilidade pela execução de uma tarefa pública ao particular, conferindo-lhe os poderes públicos necessários para o desempenho da missão (ob. cit., p. 345-349). Os aspectos utilizados para diferenciar as duas categorias são próximos daqueles empregados para distinguir os contratos de colaboração dos de delegação.

${ }^{302}$ David Soldini, La délégation de service public, sa fonction, ses critères, 2010.
} 
Os diversos mecanismos de terceirização utilizados pela Administração Pública podem ser enquadrados nos contratos de colaboração, nos termos expostos acima $^{303}$. Implicam a atribuição da execução material de determinada atividade, sem a transferência da sua gestão, que continua sendo de responsabilidade estatal. Ou seja, utilizamos o vocábulo “terceirização” para fazermos referência às diversas modalidades dos contratos de prestação de serviço que não implicam a sua delegação ao particular ${ }^{304}$.

A denominada “terceirização” na Administração Pública pode assumir várias formas, sendo as mais usuais a empreitada e a prestação de serviços. Mais recentemente, tem sido utilizada para o fornecimento de mão-de-obra, o que deu ensejo a questionamentos jurídicos no âmbito trabalhista e administrativista.

A terceirização apresenta relevância para o objeto do presente estudo especialmente sob dois aspectos.

O primeiro deles é o de que o desenvolvimento por particulares de tarefas instrumentais ou acessórias à função de polícia administrativa, retratadas em atos exclusivamente materiais, com frequência é abrigado nos denominados contratos de terceirização da Administração Pública.

O outro ponto de conexão é que um critério exposto com frequência para se definirem os limites possíveis da terceirização seria o da diferenciação entre atividadesmeio e atividades-fim, para se sustentar que apenas as primeiras poderiam ser transferidas a particulares. Disseminou-se a noção de que não poderiam ser trespassadas a particulares atividades-fim da Administração. Por vezes, pretende-se utilizar essa distinção entre atividade-meio e atividade-fim para se estabelecer a indelegabilidade das atividades de polícia.

Por isso, faz-se necessário o exame mais aprofundado do instituto da terceirização na Administração Pública.

\subsubsection{A terceirização na iniciativa privada}

Na iniciativa privada, o termo terceirização surgiu no âmbito da ciência da Administração.

As definições apresentadas para a terceirização usualmente se reportam à contratação de terceiro para o desempenho de atividades-meio da empresa. É nesse sentido, por exemplo, a definição de Sérgio Pinto Martins:

\footnotetext{
${ }^{303}$ V. item II.3.4.

${ }^{304}$ Nesse sentido, Marçal Justen Filho. Curso de direito administrativo, 2013, p. 851.
} 
Consiste a terceirização na possibilidade de contratar terceiro para a realização de atividades que não constituem o objeto principal da empresa. (...) Envolve a terceirização uma forma de contratação que vai agregar a atividade-fim de uma empresa, normalmente a que presta os serviços, à atividade-meio de outra. ${ }^{305}$

No entanto, o recurso à terceirização não se restringe apenas às atividadesmeio. Há vários exemplos em que toda a produção de determinada empresa é realizada em fábricas de terceiros, geralmente por ofertarem mão-de-obra de custo mais baixo ${ }^{306}$. Como se analisa adiante, os conceitos de atividade-meio e atividade-fim não são precisos, o que impede o seu discernimento em vários casos concretos.

A terceirização poderia então ser definida como sendo a transferência a terceiro de atividades específicas e determinadas, necessárias à obtenção do produto final visado.

Dora Maria de Oliveira Ramos destaca a relação de parceria existente entre o que contrata o terceiro e o terceirizado, à medida que é necessária a atuação coordenada e a coparticipação para a obtenção do resultado final mediante o emprego eficiente dos recursos disponíveis. Por isso, a autora define a terceirização como sendo "um método de gestão em que a execução de uma série de atividades é delegada a outrem, que fornece bens ou serviços a partir de uma relação de parceria”307.

A terceirização propicia a redução da estrutura organizacional com a preservação do âmbito de atuação da empresa ${ }^{308}$. O objetivo visado é precipuamente a eficiência, com a possibilidade de emprego de menos recursos para a obtenção do resultado visado.

\subsection{2. $\underline{\text { A configuração jurídica da terceirização }}$}

Segundo Maria Sylvia Zanella Di Pietro, a terceirização pode assumir formas diversas, tais como a empreitada de obra e de serviço, a locação de serviços por meio de uma pessoa interposta bem como a franquia ${ }^{309}$. Trata-se de uma acepção ampla de

\footnotetext{
305 A terceirização e o direito do trabalho, 1997, p. 22.

${ }^{306}$ Como observa Sergio Pinto Martins, a definição das atividades a serem terceirizadas é uma decisão empresarial: "Em função do princípio da livre iniciativa, previsto no artigo 170 da Constituição, cabe ao empresário definir quais as áreas que pretende fazer a terceirização, inclusive na atividade-fim, se assim entender. Cabe a ele escolher, portanto, a área que pretende terceirizar” (ob. cit., p. 121).

${ }^{307}$ Terceirização na Administração Pública, 2001, p. 54.

${ }^{308}$ Como define Marçal Justen Filho, a terceirização é muito mais um instituto econômico do que uma figura jurídica diferenciada e específica. Em termos econômicos, a terceirização permite a obtenção dos seguintes efeitos: “a) redução da dimensão das atividades econômicas desenvolvidas por um sujeito, intensificando sua especialização; b) transferência para um terceiro autônomo dos encargos referentes à produção ou circulação de bens e (ou) serviços determinados; c) manutenção pelo sujeito, perante o mercado, da titularidade da prestação integral dos bens e (ou) serviços, de molde a que a terceirização permaneça como fenômeno interno à empresa” (Curso de direito administrativo, 2013, p. 851).

${ }^{309}$ Parcerias na Administração Pública, 2012, p. 216.
} 
terceirização, de modo a abranger os diversos mecanismos pelos quais a Administração recorre a terceiros para o desempenho das suas competências.

Em sentido restrito, a terceirização das atividades administrativas corresponderia à transferência a particulares, de modo formal e contínuo, o desempenho material de determinadas atividades, sob a forma de contrato de prestação de serviços ${ }^{310}$. Transfere-se apenas a execução material de certas atividades. Na sua acepção restrita, a terceirização não pressupõe a transferência da gestão da atividade. Não se atribui ao terceirizado margem de poder decisório sobre a atividade a ser desempenhada nem o exercício de prerrogativas de poder público ${ }^{311}$.

Parece-nos ser essencial para a caracterização da terceirização em sentido estrito o fato de que ela não produz efeitos externos mas apenas internos. O terceirizado não desempenha as atividades em nome próprio.

As repercussões da terceirização restringem-se à esfera do que recorre à terceirização e do terceirizado. Disso decorre que aquele que contrata o produto final da empresa que se utiliza da terceirização trava relações jurídicas apenas com esta e não com o terceirizado. Sob o ponto de vista externo, as atividades terceirizadas se desenvolvem tal como se tivessem sendo prestadas diretamente por aquele que contrata o terceiro.

Haveria duas relações jurídicas distintas: a existente entre o cliente final e a empresa que se utiliza da terceirização e a que se verifica entre a empresa que contrata o terceiro e o terceirizado. Em face dos clientes finais, a empresa que terceiriza aparece como titular e responsável pelo conjunto de relações jurídicas necessárias pela obtenção do resultado final. Não há vínculo jurídico direto entre o cliente e o terceirizado. Sob pena de burla às normas trabalhistas, não pode haver subordinação direta pelo que recorre à terceirização sobre os empregados da empresa terceirizada.

\footnotetext{
${ }^{310}$ Como bem pondera Maria Sylvia Zanella Di Pietro, “o que é perfeitamente possível no âmbito da Administração Pública é a terceirização como contrato de prestação de serviços. Na realidade, isto sempre foi feito, sem que se empregasse o termo terceirização, o que permite reafirmar que o direito administrativo moderno foi invadido por termos novos para designar institutos antigos, apenas com a diferença de que hoje vêm carregados de nova ideologia” (Parcerias na Administração Pública, 2012, p. 225 - grifos no original).

311 Dora Maria de Oliveira Ramos. Terceirização na Administração Pública, 2001, p. 55 e 120-121. No mesmo sentido, Diogo de Figueiredo Moreira Neto assim define a terceirização: "modalidade de transferência de atividades materiais da Administração a terceiros, sempre que estas não demandem o exercício de poder estatal" (Mutações do direito administrativo, 2001, p. 138 - grifo no original).
} 


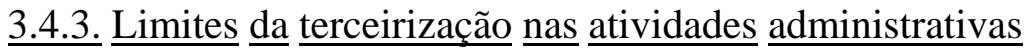

É recorrente a tentativa de se aplicarem os mesmos critérios para determinar a possibilidade de terceirização tanto para o setor público quanto para o setor privado, recorrendo-se especialmente aos conceitos de atividade-meio e atividade-fim.

Por um lado, esse critério não se apresenta adequado para a determinação da possibilidade ou não de se utilizar a terceirização.

Por outro, o recurso à terceirização pela Administração apresenta limites diferenciados em relação àqueles aplicados às empresas privadas. A terceirização, como um dos mecanismos de exercício de atividades de polícia administrativa por particulares, submete-se aos mesmos limites de delegação deste. Trata-se das diversas decorrências da natureza inerentemente estatal da atividade.

\subsubsection{A inadequação do critério de distinção entre atividade-meio e atividade-fim}

Nas relações atuais entre as empresas, nos mais diversos arranjos de terceirização da produção, não é possível definir com segurança em que consiste a atividade-meio e a atividade-fim em cada caso. Em diversas situações, não se pode afirmar ser a atividade terceirizada apenas uma atividade-meio, acessória da atividade principal.

A relação entre atividade acessória e atividade principal também é contingente, em face das constantes alterações das tecnologias produtivas empregadas. Diante do dinamismo da atividade industrial e da evolução das técnicas de produção, não há como se estabelecerem critérios rígidos e engessados para se delimitar a fronteira entre atividade-meio e atividade-fim. Uma atividade que poderia ser enquadrada como atividadefim de determinada empresa poderá passar a ser atividade-meio, deixando de integrar os objetivos finais da empresa $^{312}$.

Outro aspecto a ser observado é que, muitas vezes, a terceirização atinge apenas parcela daquela que é considerada atividade-fim e não a sua integralidade. Isso é relevante porque a preocupação que transparece, especialmente na jurisprudência, é com a

\footnotetext{
${ }^{312}$ A questão é tratada com bastante precisão por Floriano de Azevedo Marques Neto: "No mundo hodierno, pautado pela especialização e sinergia das atividades econômicas e, de outro lado, pela sofisticação tecnológica, coloca-se praticamente impossível distinguir o que seja e o que não seja atividade-meio. Ninguém desconhece que a atividade-fim de uma instituição financeira seja a captação e venda de disponibilidades financeiras. Porém, cada vez mais, os bancos (principalmente os seus ramos de investimentos) passam a oferecer novos produtos, financiamentos sofisticados que envolvem a participação da sua instituição na gestão da empresa financiada. Assim, a avaliação e posterior coadministração de companhias com os escopos mais diversos tornam-se atividade indissociável dos objetivos principais das instituições financeiras. Em uma palavra, confundem-se com as tais ‘atividades-fim’ dos bancos” ( $A$ contratação de particulares para suporte de atividade regulatória estatal, 1999, p. 170).
} 
transferência da integralidade de atividades-fim, de modo a que o Estado se afastasse completamente do desenvolvimento direto daquela atividade ${ }^{313}$.

Por tudo isso, há de se constatar a relativização do critério atividade-meio e atividade-fim. Não é possível traçar-se uma distinção precisa entre aquelas que seriam atividades-meio e as que se caracterizariam como atividades-fim.

\subsubsection{A Súmula $n^{\circ} 331$ do TST}

No âmbito trabalhista, surgiu a preocupação de se evitar que a existência de duas relações jurídicas distintas pudesse ser utilizada para frustrar o adimplemento dos direitos dos trabalhadores.

Diante do grande risco de ser utilizada para se transferirem obrigações trabalhistas com a interposição de terceiros entre a empresa e o trabalhador, mascarando a relação de emprego existente, a terceirização é objeto especial de estudo pelo direito do trabalho.

Note-se que não existem no ordenamento jurídico regras que determinem que a terceirização seria cabível apenas em relação às atividades-meio.

Esse critério foi lançado pela Instrução Normativa do Ministério do Trabalho $\mathrm{n}^{\circ}$ 7, de 21 de fevereiro de 1990, que definia a prestação de serviços a terceiros como sendo a execução de serviços excluídos "do âmbito das atividades essenciais e normais para que se constituiu” a contratante (item I.10).

Aquela norma foi revogada, tendo sido substituída pela Instrução Normativa $\mathrm{n}^{\mathrm{o}} 3$, de $1^{\mathrm{o}}$ de setembro de 1997 . Essa norma indica expressamente que a prestação de serviços a terceiros não pode abranger as atividades-fim da empresa contratante ${ }^{314}$ e que não pode haver coincidência entre as atividades-fim da empresa contratante e da contratada $^{315}$. A IN n ${ }^{\circ}$ 3/1997 estipula que as atividades-fim da empresa contratante e contratada serão identificadas a partir do exame dos respectivos contratos sociais ${ }^{316}$. A ausência de precisão e especificidade com que usualmente é definido o objeto da empresa

\footnotetext{
${ }^{313}$ Essa questão é observada por Flávio Amaral Garcia. A relatividade da distinção atividade-fim e atividademeio na terceirização aplicada à Administração Pública, 2009, p. 152.

${ }^{314} \mathrm{O}$ art. $2^{\circ}$ da $\mathrm{IN} \mathrm{n}^{\circ}$ 3, de 1997, assim define as atividades da empresa de prestação de serviços a terceiros: "Para os efeitos desta Instrução Normativa, considerando-se empresa de prestação de serviços a terceiros a pessoa jurídica de direito privado, de natureza comercial, legalmente constituída, que se destina a realizar determinado e específico serviço a outra empresa fora do âmbito das atividades-fim e normais para que se constitui essa última”.

${ }^{315}$ Art. $^{\circ}$, § $1^{\circ}$, da IN no 3, de 1997: "A contratante e a empresa prestadora de serviços a terceiros devem desenvolver atividades diferentes e ter finalidades distintas."

${ }^{316} \mathrm{IN} \mathrm{n}^{\circ} 3 / 97$, art. 50, “d”.
} 
no seu contrato social confirma a inviabilidade de utilização desse critério para se identificar a ocorrência de terceirização.

Atualmente, a questão encontra-se disciplinada pela Súmula $\mathrm{n}^{0} 331$ do $\operatorname{TST}^{317}$

Como regra geral, no âmbito trabalhista, reconhece-se a existência de vínculo entre o tomador do serviço e o trabalhador terceirizado, salvo se configurada uma das situações excepcionais indicadas na Súmula $n^{\circ}$ 331. Além de se aplicar ao setor privado, a Súmula faz referências também à terceirização na Administração Pública ${ }^{318}$.

A redação da Súmula foi significativamente alterada em 2011, para compatibilizá-la com o teor do art. $71, \S 1^{\circ}$, da Lei $n^{\circ}$ 8.666/93, em decorrência do julgamento da Ação Declaratória de Constitucionalidade nº 16/DF, pelo STF. Passou a prever que, em relação à Administração direta e indireta, apenas pode haver responsabilidade subsidiária como tomador de serviços de empresa terceirizada e que a responsabilização depende da verificação de conduta culposa quanto à fiscalização do cumprimento das obrigações contratuais e legais do terceirizado.

No âmbito do presente estudo, importa outro aspecto da Súmula $n^{\circ} 331$.

Um dos requisitos mencionados na Súmula nº 331 para a não caracterização da relação de emprego é o de que apenas poderiam ser objeto de terceirização atividadesmeio. No caso de atividades-fim, deveria ser reconhecido o vínculo entre o tomador do serviço e o trabalhador. A partir disso, difundiu-se o entendimento de que a referida Súmula

\footnotetext{
${ }^{317}$ O texto da Súmula no 331 do TST é o seguinte: “CONTRATO DE PRESTAÇÃO DE SERVIÇOS. LEGALIDADE (nova redação do item IV e inseridos os itens V e VI à redação) - Res. 174/2011, DEJT divulgado em 27, 30 e 31.05.2011

I - A contratação de trabalhadores por empresa interposta é ilegal, formando-se o vínculo diretamente com o tomador dos serviços, salvo no caso de trabalho temporário (Lei no 6.019, de 03.01.1974).

II - A contratação irregular de trabalhador, mediante empresa interposta, não gera vínculo de emprego com os órgãos da Administração Pública direta, indireta ou fundacional (art. 37, II, da CF/1988).

III - Não forma vínculo de emprego com o tomador a contratação de serviços de vigilância (Lei $\mathrm{n}^{\circ} 7.102$, de 20.06.1983) e de conservação e limpeza, bem como a de serviços especializados ligados à atividade-meio do tomador, desde que inexistente a pessoalidade e a subordinação direta.

IV - O inadimplemento das obrigações trabalhistas, por parte do empregador, implica a responsabilidade subsidiária do tomador dos serviços quanto àquelas obrigações, desde que haja participado da relação processual e conste também do título executivo judicial.

V - Os entes integrantes da Administração Pública direta e indireta respondem subsidiariamente, nas mesmas condiç̃ões do item IV, caso evidenciada a sua conduta culposa no cumprimento das obrigações da Lei $n$. ${ }^{\circ}$ 8.666, de 21.06.1993, especialmente na fiscalização do cumprimento das obrigações contratuais e legais da prestadora de serviço como empregadora. A aludida responsabilidade não decorre de mero inadimplemento das obrigações trabalhistas assumidas pela empresa regularmente contratada.

VI - A responsabilidade subsidiária do tomador de serviços abrange todas as verbas decorrentes da condenação referentes ao período da prestação laboral.”

${ }^{318}$ Uma primeira objeção a ser apresentada diz respeito à própria incompetência da Justiça do Trabalho para fixar os critérios para a admissibilidade da terceirização, em especial em relação à Administração Pública. Se necessário, caberia ao Poder Legislativo identificar as hipóteses em que haveria vedação para a terceirização.
} 
teria vedado o recurso à terceirização em relação às atividades-fim, inclusive para a Administração.

No entanto, a Súmula não veda propriamente a terceirização de atividadesfim. O texto da Súmula indica apenas que as contratações de atividades-meio, que não impliquem pessoalidade ou subordinação direta, não geram vínculo empregatício. A Súmula nada dispõe acerca das atividades-fim.

\subsubsection{A possibilidade de transferência do exercício de atividades-fim da Administração}

Além da inadequação do emprego da distinção entre atividade-meio e atividade-fim para se admitir ou não a terceirização, cabe registrar que esse critério não poderia ser aplicado à Administração Pública.

O art. 37, inc. XXI, da CF/88 não restringe a aplicação da técnica contratual às atividades-meio da Administração ${ }^{319}$. A regra geral extraível do dispositivo é a autorização da utilização do contrato administrativo, com exceção das matérias não passíveis de técnica contratual, assim ressalvadas pelo ordenamento jurídico.

Pode-se agregar ainda o argumento de que o texto constitucional admite expressamente a concessão de serviço público (especialmente nos arts. 21 e 175). Permite, assim, a delegação da gestão de atividade-fim do Estado. No que diz respeito às concessões de serviço público, o art. 25, $\S 1^{\circ}$, da Lei $n^{\circ} 8.987 / 95$ prevê expressamente a possibilidade de a concessionária contratar com terceiros a execução de atividades inerentes, acessórias ou complementares ao serviço concedido ${ }^{320}$.

Nem mesmo foi consagrada legislativamente a distinção entre atividades administrativas meio e atividades administrativas fim $^{321}$. Os limites à delegação do exercício de funções públicas a particulares não se vinculam ao fato de se tratar de atividade-meio ou atividade-fim e sim aos aspectos intrínsecos da atividade, mais especificamente, se implica manifestação de poderes que não podem ser exercidos por particulares ou não.

\footnotetext{
${ }^{319}$ Fernando Vernalha Guimarães. As parcerias público-privadas e a transferência de atividades de suporte ao poder de polícia - em especial, a questão dos contratos de gestão privada de serviços em estabelecimentos prisionais, 2007, p. 378-379.

${ }^{320}$ Há regra similar na Lei no 9.472/97 - Lei Geral de Telecomunicações: “Art. 94. No cumprimento de seus deveres, a concessionária poderá, observadas as condições e limites estabelecidos pela Agência: (...) II contratar com terceiros o desenvolvimento de atividades inerentes, acessórias ou complementares ao serviço, bem como a implementação de projetos associados”.

${ }^{321} \mathrm{O}$ Decreto federal $\mathrm{n}^{\circ}$ 2.271/97, que trata da execução indireta de atividades materiais acessórias, instrumentais ou complementares no âmbito da Administração Pública federal direta, autárquica e fundacional não faz referência a atividades-meio e atividades-fim.
} 
Além disso, como se indicou acima, caracterizou-se a terceirização em sentido estrito como sendo hipótese de contrato de colaboração. Nesse caso, não há transferência da gestão da atividade ao contratado. Os atos são praticados pelo terceirizado tal como se o tivessem sido pela própria Administração, a qual assume a responsabilidade por tais atos perante terceiros.

Logo, trata-se de hipótese de exercício mais restrito de atividades públicas por particulares, na qual se evidencia a simples colaboração do particular na realização de tarefas instrumentais ou acessórias ao exercício da função pública propriamente dita.

\subsubsection{Impossibilidade de utilização da terceirização para substituição de relação de} emprego própria da Administração

Um dos argumentos usualmente levantados contra a terceirização na Administração Pública consiste no risco de ser utilizada para infringir o princípio do concurso público (CF/88, art. 37, inc. II).

A terceirização não pode se restringir ao fornecimento de mão-de-obra para o Estado, em substituição à relação de emprego própria da Administração. Como pondera Maria Sylvia Zanella Di Pietro, o "que a Administração Pública não pode fazer é contratar trabalhador com intermediação de empresa de prestação de serviços a terceiros, porque nesse caso o contrato assume a forma de fornecimento de mão-de-obra, com burla à exigência de concurso público”322.

A vedação de contratação de particulares para o desempenho de atividade inerente a determinada categoria funcional foi objeto de expressa vedação pelo Decreto federal $n^{\circ}$ 2.271/97, que disciplina a contratação de prestação de serviços pela Administração. $\mathrm{O}$ art. $1^{\circ}$, $\S 2^{\circ}$ do Decreto vedou a execução indireta de "atividades inerentes às categorias funcionais abrangidas pelo plano de cargos do órgão ou entidade, salvo expressa disposição legal em contrário ou quando se tratar de cargo extinto, total ou parcialmente, no âmbito do quadro geral de pessoal”.

Mas disso não decorre a vedação da contratação da prestação de serviços em qualquer caso. A celebração de contrato administrativo para a prestação temporária de serviços será cabível quando for necessário para 0 atendimento de necessidades diferenciadas da Administração, que não podem ser adequadamente satisfeitas mediante a utilização de ocupantes de cargos e empregos públicos.

${ }^{322}$ Parcerias na Administração Pública, 2012, p. 222. 
Daí que a contratação de serviços é cabível, ainda que em hipóteses excepcionais e para atendimento de necessidades específicas da Administração.

Celso Antônio Bandeira de Mello também pondera as especificidades que devem estar presentes para justificar o recurso da Administração ao contrato de terceirização. Segundo o autor, considerando-se que a Administração deve ter o seu próprio corpo de servidores, o contrato de prestação de serviços apenas teria cabimento nos casos em que

a atividade pretendida só poderá ser feita adequadamente por terceiros, estranhos ao organismo estatal, ou melhor se fará por meio deles, seja porque menores serão os custos, seja porque distintas circunstâncias desaconselham recorrer aos próprios servidores ou manter, em seus quadros, profissionais da área requerida ${ }^{323}$.

Como observa Flávio Amaral Garcia, a circunstância de um mesmo serviço ser prestado por servidores e por terceirizados ser admitida apenas em situações excepcionais, temporárias e devidamente justificadas aplica-se tanto às atividades-meio quanto às atividades-fim ${ }^{324}$. Em qualquer caso não se admitirá a terceirização ampla e permanente para o desenvolvimento de atividades inerentes às categorias funcionais abrangidas pelo plano de cargos.

Situação diversa é verificada quando, com o recurso à terceirização, objetiva-se a obtenção de determinado resultado, acompanhado da gestão e organização da atividade pela empresa contratada, e não apenas a pessoa executante da prestação.

Nesse sentido, Maria Sylvia Zanella Di Pietro sustenta que seria cabível apenas a terceirização com parceria, situação em que a empresa contratada exerce efetivamente uma função de agenciamento e organização da mão-de-obra. Em qualquer caso, é vedado o recurso à terceirização para mascarar relação de emprego sem observância dos requisitos específicos para contratação de mão-de-obra pela Administração ${ }^{325}$.

\footnotetext{
${ }^{323}$ Regime dos servidores da Administração direta e indireta, 1991, p. 87-88.

324 Flávio Amaral Garcia. A relatividade da distinção atividade-fim e atividade-meio na terceirização aplicada à Administração Pública, 2009, p. 154. Isso é evidenciado no Decreto $n^{\circ} 2.271 / 97$, art. $1^{\circ}$, §2 ${ }^{\circ}$, que não diferencia a contratação de serviços para o desenvolvimento de atividades-meio ou de atividades-fim: "Não poderão ser objeto de execução indireta as atividades inerentes às categorias funcionais abrangidas pelo plano de cargos do órgão ou entidade, salvo expressa disposição legal em contrário ou quando se tratar de cargo extinto, total ou parcialmente, no âmbito do quadro geral de pessoal”.

${ }^{325}$ A doutrinadora assim define a terceirização com parceria, que seria a única apta ao atendimento do interesse coletivo: “a empresa contratada é legalmente constituída para atuar no ramo da atividade terceirizada e deve possuir capacidade técnica e administrativa para executar o serviço, sem a necessidade de interferência da empresa contratante; a mão-de-obra operacional é especializada, adequadamente remunerada, subordina-se exclusivamente à empresa contratada, com os direitos trabalhistas respeitados, atua motivada e produz com a qualidade esperada” (Parcerias na Administração Pública, 2012, p. 217). Admitem também a terceirização quando se trata de contratar a efetiva gestão de mão-de-obra e não apenas a pessoa executante da prestação, entre outros, Carlos Pinto Coelho Motta. Terceirização e funcionalização: conflito ou complementariedade, 1997, p. 802 e Marcos Juruena Villela Souto. Desestatização, 2001, p. 376.
} 


\subsubsection{Observações finais}

Constata-se a inadequação do critério atividade-meio e atividade-fim para diferenciar as hipóteses em que a prestação de serviços poderá ser objeto ou não de contratação pela Administração.

Além de não haver previsão legal para a aplicação desse critério, a dificuldade prática de diferenciação dos conceitos inviabiliza a sua utilização.

O critério a ser utilizado para a definição das matérias passíveis ou não de contratação é se o exercício da atividade implica o manejo de poderes públicos que não podem ser exercidos por particulares. Esse é o núcleo das atividades estatais exclusivas, não passíveis de trespasse a particulares por decorrência, entre outros, do princípio republicano $^{326}$.

Mas esse critério não guarda qualquer semelhança com o de atividades-meio e atividades-fim. Determinadas atividades-meio poderão não ser passíveis de delegação por pressuporem, por exemplo, o exercício de coerção. Por outro lado, há várias atividades-fim que não envolvem manifestação de coerção e que são passíveis de ter o seu exercício transferido a particulares. Esses temas são aprofundados no Capítulo III.

\subsection{A delegação do exercício de atividades de polícia administrativa nos contratos de concessão}

O principal instrumento contratual empregado para a delegação do exercício de atividades públicas a particulares é a concessão. Há ainda outros instrumentos contratuais que podem envolver a delegação do serviço, tais como a permissão, a autorização e a franquia.

No entanto, além das grandes disputas doutrinárias existentes acerca da conceituação e delimitação desses outros institutos, o exercício de atividades de polícia administrativa com delegação que eventualmente se desenvolva sob esses outros rótulos não apresentará regime jurídico significativamente distinto em relação àquele aplicável ao contrato de concessão, no que diz respeito aos aspectos relevantes ao presente estudo.

Portanto, o contrato de concessão é utilizado nesse contexto como exemplificativo de mecanismo contratual de delegação de atividades públicas, sem que se exclua a possibilidade de que isso ocorra no contexto de outros arranjos contratuais.

${ }^{326}$ Sobre a definição das matérias não passíveis de contratação, v. item III.5.3. 


\subsubsection{Ausência de tipificação restrita dos contratos de concessão}

A ampliação da atividade contratual da Administração, que assume variadas configurações, deu ensejo ao surgimento de diversos mecanismos contratuais, sendo que muitos deles não se encontram expressamente previstos na legislação.

Na acepção clássica, a Administração apenas poderia celebrar os tipos de contrato previstos em lei. Partia-se da premissa da necessidade de autorização específica em lei para o Estado contratar. Porém, a disciplina legislativa nacional dos contratos é genérica, prevendo apenas algumas cláusulas que devem obrigatoriamente constar dos pactos.

Vera Monteiro propõe que há uma variação do conteúdo mínimo da legalidade conforme o setor do direito público de que se trata. A legalidade pode se apresentar ora sob a forma de compatibilidade ora como conformidade. Defende a autora que deve haver alguma flexibilidade na matéria de contratos do Estado para se admitir que a Administração celebre contratos ainda que não tenham sido tipificados pela lei, desde que estejam em conformidade com o direito ${ }^{327}$.

Essas premissas aplicam-se também aos contratos de delegação, que podem assumir configurações diversas. Os contratos de delegação não se restringem aos de concessão, nas suas diversas espécies. Como anota Maria Sylvia Zanella Di Pietro, “outras formas de delegação vêm surgindo, por meio de atos unilaterais ou acordos de vontade que não se enquadram como concessão ou permissão, mas que também podem ser consideradas como formas de descentralização por colaboração”328.

\subsection{2. $\underline{\text { A concessão como gênero de outorga de direitos a particulares }}$}

Maria Sylvia Zanella Di Pietro apresenta os vários sentidos atribuídos pela doutrina para a concessão ${ }^{329}$.

$\mathrm{Na}$ acepção amplíssima, a concessão abrange “qualquer tipo de ato, unilateral ou bilateral, pelo qual a Administração outorga direitos ou poderes ao particular”330. Como registra a doutrinadora, não conta com significativa aceitação no direito brasileiro.

\footnotetext{
${ }^{327}$ Concessão, 2010, p. 66.

${ }^{328}$ Parcerias na Administração Pública, 2012, p. 60. Também para Floriano de Azevedo Marques Neto é admissível que a Administração celebre contratos de outras espécies de concessão, a partir de autorizações previstas de forma genérica pelo legislador, não sendo necessário - nem mesmo apropriado, segundo o autor que a lei contenha um regime minucioso da concessão. Deve-se deixar "uma maior margem para a normatividade no âmbito do contrato, de modo que o regime de adapte a cada situação e a cada objeto de outorga concessória” (A concessão como instituto do direito administrativo, 2013, p. 230).

${ }^{329}$ Direito administrativo, 2013, p. 297.

${ }^{330}$ Ob. cit., p. 297.
} 
Em uma acepção menos ampla, a concessão pode ser translativa ou constitutiva e apresentar-se sob três tipos: de serviço público, de obra pública e de uso de bem público ${ }^{331}$. Essa seria a acepção adotada majoritariamente pela doutrina nacional.

Por fim, em uma acepção bastante restrita, a concessão poderia apenas designar a delegação a particulares da prestação de serviços públicos ${ }^{332}$.

Pedro Gonçalves propõe como sendo o ponto comum às diversas espécies de concessão a ampliação da esfera jurídica do concessionário ${ }^{333}$. Para o autor, a essência da concessão seria a de que "um sujeito vê a sua esfera jurídica alargada pela integração nela de um direito que deriva da esfera jurídica Administração"334.

Floriano de Azevedo Marques também caracteriza a concessão como mecanismo de associação dos particulares na implementação, execução e gestão de bens, serviços e atividades de interesse coletivo, mediante a delegação de um direito ou prerrogativa ao particular: “cremos ser possível extrair um núcleo do instituto, qual seja, o fato de que ele se presta a estabelecer um vínculo obrigacional pelo qual o poder público atribui a um particular a execução de uma tarefa cuja efetivação interessa a ambos, não necessariamente pelas mesmas razões”335.

Em sentido estrito, a concessão é a atribuição ao particular do desempenho de deveres de poder público, atribuindo-lhe os direitos e prerrogativas a eles vinculados, necessários para o cumprimento das obrigações assumidas em face do objeto delegado. Nas palavras do autor, "é um instrumento jurídico voltado a atribuir a um privado direitos ou poderes próprios da Administração" ${ }^{336}$, sendo que as “prerrogativas somente são transpassadas na medida do essencial para viabilizar o cometimento"337.

Ainda segundo o autor, a concessão pode ter os mais diversos objetos. Não precisa ser um direito do qual o poder público seja titular exclusivo, bastando que seja uma atribuição do poder público, no sentido de lhe caber a sua efetivação ${ }^{338}$.

Vera Monteiro também propõe uma acepção ampla de concessão de modo a abranger diversos arranjos utilizados para disponibilizar bens e serviços à sociedade.

\footnotetext{
331 Ob. cit., p. 287.

${ }^{332}$ Ob. cit., p. 297

${ }^{333} \mathrm{O}$ autor refere-se à "concessão administrativa” para abranger as diversas modalidades de concessão de que a Administração se utiliza. Não consiste, portanto, em instituto equivalente à "concessão administrativa" prevista na Lei $\mathrm{n}^{\circ}$ 11.079/04, que é uma das espécies do gênero concessão no direito nacional (A concessão de serviços públicos, 1999, p. 45 e s.).

${ }^{334}$ Ob. cit., p. 61 - grifos no original.

${ }^{335}$ A concessão como instituto do direito administrativo, 2013, p. 157.

${ }^{336}$ Ob. cit., p. 165.

${ }^{337}$ Ob. cit., p. 231.

${ }^{338}$ Ob. cit., p. 158
} 
Define-a pela perspectiva funcional, por ter como função "viabilizar a realização de investimentos significativos para promover a disponibilização de bens e serviços à sociedade»339. Admite que o seu objeto não seja apenas serviço público ou bem público mas também qualquer atividade administrativa.

\subsubsection{A concepção tradicional do contrato de concessão no direito nacional}

Apesar de a concessão ser um instituto tradicional do direito administrativo, empregada há bastante tempo, a sua utilização foi retomada no Brasil no final de década de 1980, no conjunto de transformações da estrutura do Estado englobadas genericamente no termo “privatizações”. Nesse momento histórico, a concessão foi utilizada principalmente para a delegação a particulares da gestão de serviços públicos.

No entanto, já havia uma conceituação assente na doutrina nacional quanto ao instituto da concessão.

Vera Monteiro desenvolveu um estudo aprofundado acerca do conceito da concessão no direito nacional ${ }^{340}$. Ao analisar detidamente diversos estudos de direito administrativo da década de 30 e seguintes do século passado, a autora constata que não havia uma restrição do objeto da concessão à prestação de serviços públicos:

O que se nota é que há certo consenso doutrinário envolvendo a palavra 'concessão' quando se trata de reconhecer seu uso para designar ocupações privativas do domínio público e para viabilizar a outorga de direitos próprios do Estado a terceiros - como, por exemplo, a promoção de desapropriações, o recolhimento de tarifas e o exercício do poder de polícia ${ }^{341}$.

A partir disso, conclui que o sentido comum, o vetor que conectaria todas as espécies de concessão seria o da transferência e outorga a terceiros de poderes, vantagens ou utilidades que são de titularidade do concedente.

Esse aspecto de outorga de poderes e deveres da Administração a terceiros como sendo o traço distintivo da concessão é evidenciado também no conceito de concessão apresentado por Oswaldo Aranha Bandeira de Mello: “atos administrativos de delegação a terceiro, por parte da Administração Pública, de poderes e deveres que lhe competem, para, em seu lugar e sob sua fiscalização, desempenhar certos cometimentos, em nome e conta própria”342.

\footnotetext{
${ }^{339}$ Concessão, 2010, p. 176.

${ }^{340}$ Concessão, 2010.

${ }^{341}$ Ob. cit., p. 32.

${ }^{342}$ Princípios gerais de direito administrativo, v. I, 2010, p. 556. Cabe registrar que, segundo o autor, esse é o conceito restrito de concessão, adotado especialmente pela doutrina francesa e alemã. Ainda segundo Oswaldo Aranha Bandeira de Mello, o conceito de concessão em sentido amplo, geralmente adotado pela doutrina italiana, é de “outorga pela Administração Pública de qualquer direito ao particular” (ob. e loc. cit.).
} 
No entanto, como constata Vera Monteiro, é inequívoco o desenvolvimento do contrato de concessão juntamente com a prestação de serviço público. O estudo do contrato de concessão centrava-se naquele que era o seu objeto usual, a concessão de serviço público. Ainda que o conceito de concessão apresentado pelos doutrinadores não reflita essa vinculação necessária, há de se reconhecer que a prestação de serviços públicos é um elemento essencial no contrato de concessão, à medida que "a teoria do contrato de concessão tradicionalmente inclui o objeto da relação na sua caracterização"343.

\subsection{4. $\underline{\text { A atual configuração }} \underline{\text { do contrato }} \underline{\text { de concessão no direito nacional }}$}

Pode-se considerar ter sido superada a noção de que a concessão teria por objeto exclusivo a prestação de serviço. Especialmente com o advento da Lei no 11.079/04, consolidou-se a concepção de que o contrato de concessão consiste em um gênero, que abriga, quando menos, três espécies: (a) a concessão comum; (b) a concessão patrocinada e (c) a concessão administrativa.

É relevante avaliar alguns aspectos que caracterizam as diversas concessões no direito nacional.

\subsubsection{Ressalvas quanto à expressão "por sua conta e risco"}

Em relação aos contratos de delegação, é usual indicar-se que o particular desempenha a atividade pública em nome próprio, por sua conta e risco. É o que consta, inclusive, da definição legal de concessão de serviço público ${ }^{344}$.

A expressão "por sua conta e risco", inclusive em decorrência da definição legal, foi bastante disseminada especialmente em face dos contratos de concessão de serviço público. No entanto, trata-se de noção empregada também quando se analisa o exercício de outras atividades públicas por particulares, mediante contrato de concessão. Também nesses casos indica-se que o particular assume os riscos do exercício da atividade pública que lhe foi delegada pelo Estado ${ }^{345}$.

Mas a indicação de que o particular prestaria o serviço por conta e risco próprios acaba dizendo mais do que realmente poderia significar em face do regime jurídico dos contratos de concessão.

\footnotetext{
343 Concessão, 2010, p. 37.

344 “A delegação de sua prestação, feita pelo poder concedente, mediante licitação, na modalidade de concorrência, à pessoa jurídica ou consórcio de empresas que demonstre capacidade para seu desempenho, por sua conta e risco e por prazo determinado" (Lei $\mathrm{n}^{\circ} 8.987 / 95$, art. $2^{\circ}$, inc. II).

${ }^{345}$ Oswaldo Aranha Bandeira de Mello. Natureza jurídica dos corretores oficiais: os corretores oficiais não são funcionários públicos. São comerciantes, 1943, p. 8.
} 


\subsubsection{A execução da atividade "por conta" do delegatário}

Ao se indicar que a atividade seria executada "por conta” do delegatário, alude-se ao fato de ser desempenhada em nome próprio pelo particular.

Porém, a rigor, não é o que se verifica em relação a todos os aspectos da execução do objeto contratado. O Estado preserva a sua titularidade. A atividade continua sendo pública e é com essa característica que ela se revela perante os administrados.

Ainda que o delegatário desempenhe a atividade pública tal como se fosse um negócio privado seu, ele não pode exercê-la livremente. A sua execução deverá observar os requisitos e critérios que disciplinam a sua delegação. O delegatário sujeita-se a diversos deveres e obrigações, que restringem a sua autonomia na condução da atividade.

Além disso, o regime de responsabilização civil a que se submete o delegatário, em linhas gerais, será o mesmo que se aplica às atividades públicas ${ }^{346}$.

\subsubsection{A execução da atividade "por risco" do delegatário}

A preservação da titularidade pública da atividade e a redução da margem de autonomia do delegatário no seu desempenho, em decorrência da regulação legislativa e contratual do objeto contratado, não permitem que o risco do empreendimento seja assumido exclusivamente pelo delegatário.

\subsection{A natureza pública da atividade e os fins de interesse público perseguidos}

Diante da natureza pública da atividade, o insucesso do negócio do delegatário não é indiferente para o Estado. O próprio atingimento dos objetivos visados com a contratação será comprometido. As necessidades coletivas deixarão de ser satisfeitas e o interesse público, que justifica a atribuição de natureza pública e a assunção da sua titularidade pelo Estado, não será atendido do modo previsto.

Por esses motivos, os riscos atribuídos ao delegatário devem ser limitados. Uma modelagem de exercício de atividade pública na qual todos os riscos fossem atribuídos ao delegatário não seria adequada, diante do elevado grau de possível comprometimento da realização dos fins visados. $\mathrm{O}$ aumento da probabilidade de insucesso do delegatário implica também maior risco de não atendimento das necessidades coletivas vinculadas à atividade pública delegada.

O fato de o sucesso do empreendimento transcender a esfera jurídica do delegatário é evidenciado com a concepção dos “efeitos trilaterais da concessão”. Trata-se de noção desenvolvida tendo em vista a concessão de serviço público mas que pode ser

${ }^{346}$ Sobre o tema, v. item IV.6.3. 
aplicada ao exercício de outras atividades públicas por particulares mediante delegação estatal.

Como enuncia Maria Sylvia Zanella Di Pietro, o contrato de concessão, apesar de ser celebrado entre o poder concedente e o concessionário, produz efeitos também sobre os usuários dos serviços concedidos $^{347}$. Em decorrência de normas regulamentares ou contratuais, o concessionário assume deveres também perante os usuários ${ }^{348}$.

Para o usuário, a sua posição deve ser a mesma, seja na execução direta da atividade pelo Estado seja na execução privada mediante delegação estatal. Os efeitos do contrato celebrado entre o Estado e o delegatário repercutem sobre a esfera jurídica do usuário, que é titular de direitos e obrigações em relação à utilização, efetiva ou potencial, da atividade objeto da delegação.

Portanto, o usuário igualmente está sujeito aos efeitos da delegação da atividade. O sucesso ou não do empreendimento do delegatário é apto a atingir o usuário do serviço. Também por isso os riscos assumidos pelo delegatário devem ser limitados.

\subsection{A natureza comutativa do contrato}

Marcos Augusto Perez menciona outro aspecto a ser considerado para que os riscos sejam compartilhados ${ }^{349}$. Trata-se do reconhecido caráter comutativo do contrato de concessão, que pressupõe a existência de relativa equivalência entre as prestações e a possibilidade de prévio dimensionamento do seu montante pelas partes.

Daí a conclusão do autor: "a noção de equivalência entre os encargos contratuais das partes, bem como de prévio conhecimento destes, opõe-se francamente à ideia de transferência de todos os riscos da contratação para uma única parte: o concessionário”350.

\subsection{O risco em relação à remuneração do delegatário}

A menção à atribuição do risco ao delegatário usualmente refere-se ao fato de caber-lhe perceber a sua remuneração por meio da exploração da atividade que lhe foi delegada.

\footnotetext{
${ }^{347}$ Parcerias na Administração Pública, 2012, p. 96.

${ }^{348}$ Extrapola o objeto do presente estudo o exame da caracterização da natureza da situação jurídica do usuário, se seria contratual ou estatutária. Sobre o tema, consulte-se a obra de Cesar A. Guimarães Pereira. Usuários de serviços públicos, 2008, p. 85-136.

${ }^{349}$ O risco no contrato de concessão de serviço público, 2006, p. 104.

${ }^{350}$ Ob. e loc. cit.
} 
Incumbe ao delegatário realizar os investimentos previstos e remunerar-se mediante a cobrança de tarifas dos usuários e arrecadação de outras receitas vinculadas à exploração da atividade. Se a receita arrecadada for insuficiente para cobrir os investimentos realizados, as consequências da atuação deficitária seriam atribuídas ao delegatário. A atuação por conta e risco próprios significaria então que ao delegatário caberia arcar com os eventuais prejuízos que viessem a ser verificados.

Ocorre que essa é uma forma bastante simplificada de se interpretar a questão dos riscos atribuídos aos delegatários e das suas consequências, podendo conduzir a conclusões equivocadas.

A delegação do exercício de atividade pública não implica necessariamente que todos os investimentos demandados sejam assumidos pelo particular.

Por exemplo, a configuração da concessão de serviço público no direito nacional admite a sua remuneração com recursos públicos. O fato de o particular ser remunerado mediante a exploração do empreendimento nunca impediu o aporte de recursos públicos $^{351}$.

A utilização de recursos públicos para a remuneração do delegatário foi reforçada com as concessões patrocinada e administrativa, instituídas pela Lei $\mathrm{n}^{0}$ $11.079 / 2004$.

Nos termos do art. $2^{\circ}$ da Lei $n^{\circ} 11.079 / 04$, art. $2^{\circ}, \S 1^{\circ}$, a remuneração do concessionário na concessão patrocinada abrange a tarifa cobrada dos usuários e a contraprestação pecuniária do parceiro público. Já na concessão administrativa, o concessionário é remunerado preponderantemente pela contraprestação paga pela Administração. Nos dois casos, não está descartado que o concessionário receba recursos de outras fontes de receitas complementares, acessórias, alternativas ou decorrentes de projetos associados.

As duas modalidades de parcerias público-privadas envolvem a contraprestação pecuniária do parceiro público ao parceiro privado, consistindo esta em acréscimo à tarifa paga pelos usuários ou na forma básica de remuneração do concessionário. Isso confirma não ser algo inerente à concessão a atribuição do risco de remuneração exclusivamente ao concessionário.

Há ainda outros mecanismos pelos quais pode se configurar a solidariedade financeira entre o concedente e o concessionário. Pode-se cogitar da atribuição de

${ }^{351}$ Essa constatação já era feita pela doutrina a partir da leitura do art. 11 da Lei no 8.987/95, ainda antes da edição da Lei n ${ }^{\circ}$ 11.079/04. Nesse sentido, confira-se Marçal Justen Filho. Teoria geral das concessões, 2003, p. 103 e 334-340. 
determinadas obrigações ao poder concedente, tais como as de realização de obras e de custeio de desapropriações. Note-se que esse aporte de recursos pelo Estado não implica o afastamento do risco do concessionário, que continuará tendo a sua remuneração vinculada à utilização pelos usuários dos serviços prestados.

\subsection{O risco em relação a fatores imprevisíveis e não imputáveis ao concessionário}

Outra evidência da limitação dos riscos dos delegatários do exercício das atividades públicas é a incidência da garantia de equilíbrio econômico-financeiro.

Como expõe Maria Sylvia Zanella Di Pietro, a garantia de equilíbrio econômico-financeiro presta-se justamente a conciliar duas noções aparentemente opostas no que diz respeito à concessão de serviço público. A primeira delas é a de que a prestação dos serviços correria por conta e risco do concessionário. A outra é a de que a atividade exercida pelo concessionário atende a necessidades da coletividade e não pode ter a sua prestação comprometida $^{352}$.

Segundo a doutrinadora, o mecanismo de conciliação dessas duas ideias é justamente a incidência da garantia de equilíbrio econômico-financeiro, com a atribuição dos riscos compreendidos nas áleas ordinárias ao concessionário e aqueles das áleas extraordinárias ao poder concedente ${ }^{353}$. Desse modo, limitam-se os riscos assumidos pelo concessionário.

Além dessa divisão entre álea ordinária e álea extraordinária, é possível constatar uma tendência de se diminuírem os riscos atribuídos ao concessionário, com a estipulação de mecanismos que amenizam o impacto dos fatores que podem desestabilizar o contrato. Consistem especialmente em garantias do cumprimento das obrigações das partes, tais como a previsão de diversos tipos de garantias das obrigações pecuniárias contraídas pela Administração, inclusive com a possibilidade de utilização de fundo garantidor ou de empresa estatal para essa finalidade ${ }^{354}$, e a autorização pelo parceiro público para transferência do controle da sociedade de propósito específico para os financiadores, com o objetivo de promover a sua reestruturação financeira e assegurar a continuidade da prestação dos serviços ${ }^{355}$.

Com isso, afasta-se também a noção de que o concessionário assumiria todos os riscos relacionados à prestação dos serviços.

\footnotetext{
${ }^{352}$ Parcerias na Administração Pública, 2012, p. 100-101.

${ }^{353}$ Ob. e loc. cit.

${ }^{354}$ Lei $n^{\circ} 11.079 / 04$, art. $8^{\circ}$.

${ }^{355}$ Lei $^{\mathrm{o}} 11.079 / 04$, art. $5^{\circ}$, §2 ${ }^{\circ}$, inc. I.
} 
3.5.4.3.5. A precificação dos riscos assumidos pelo delegatário

Outro aspecto que não pode ser olvidado é o de que os riscos que são assumidos pelo delegatário na gestão do negócio são precificados.

A decisão do particular de exercer determinada atividade pública mediante delegação envolve uma prévia avaliação de todos os custos envolvidos. Tais custos refletem não apenas os insumos e a mão-de-obra a serem diretamente empregados mas também os riscos envolvidos. Como constata Marçal Justen Filho, disso "se segue que a ampliação dos riscos de um empreendimento qualquer se traduz na ampliação de seus custos” ${ }^{\text {„356. }}$.

O aumento dos custos do delegatário repercute diretamente nos valores que serão cobrados, da Administração ou dos usuários, pelo exercício das atividades públicas. Uma modelagem de concessão que implique a atribuição de todos ou a maior parte dos riscos ao delegatário poderá repercutir na cobrança de tarifas elevadas pela prestação dos serviços.

Daí a evidente incompatibilidade entre a prestação dos serviços "por risco” do delegatário e o princípio da modicidade tarifária, expressamente previsto no art. $6^{\circ}, \S 1^{\circ}$, da Lei $n^{\circ}$ 8.987/95. A concretização do princípio da modicidade tarifária apenas poderá ser atingida com a redução dos riscos atribuídos ao concessionário.

\subsection{A delimitação dos riscos do particular pela lei e pelo contrato}

$\mathrm{Na}$ delegação de atividades públicas, não se atribui exclusivamente ao particular todos os riscos decorrentes do seu desempenho. Pelo menos, não se trata de consequência necessária da delegação. O que vai determinar quais são os riscos assumidos pelo particular é o regime jurídico e as disposições do contrato, se houver, acerca do exercício privado daquela atividade. É a lei e o contrato que definem os riscos pelos quais o particular deverá responder.

É nesse sentido a conclusão atingida por Marcos Augusto Perez, ao constatar que a expressão "por sua conta e risco"

não importa em transferência ao concessionário de todos os riscos inerentes ao empreendimento. Importa, sim, transferência ao concessionário dos riscos que o contrato indicar. Melhor dizendo, são por conta e risco do concessionário aqueles riscos que o contrato, expressa ou implicitamente, lhe transferir ${ }^{357}$.

Portanto, não existe uma fórmula genérica e abstrata, aplicável a todos os casos, que impute todos os riscos ao particular. Em face das peculiaridades de cada

\footnotetext{
${ }^{356}$ Teoria geral das concessões, 2003, p. 334.

${ }^{357}$ O risco no contrato de concessão de serviço público, 2006, p. 130 - grifos no original.
} 
atividade, cabe analisar as previsões legais aplicáveis e a alocação de riscos que é compatível.

A repartição de riscos pelo contrato não se aplica apenas aos contratos regidos pela Lei $\mathrm{n}^{\mathrm{0}}$ 11.079/04, na qual há previsão expressa nesse sentido ${ }^{358}$. Em relação aos contratos regidos precipuamente pela Lei $n^{0}$ 8.987/95, ainda que não exista previsão legal expressa atribuindo à disciplina contratual a matriz de riscos, existe ampla margem para a distribuição de obrigações entre as partes contratantes no próprio contrato. $\mathrm{O}$ conjunto de obrigações, deveres e direitos do concessionário, associado às garantias contratuais, é que vai determinar os riscos que estão sendo por ele assumidos.

\subsubsection{Observações finais}

A expressão "por conta e risco" do delegatário não é adequada para traduzir as responsabilidades que lhe são atribuídas. Por isso, é muito mais apta a gerar controvérsias do que a refletir a realidade da delegação de gestão de atividade pública.

Mantem-se o seu uso por já ser consagrado, mas apenas para diferenciar as situações em que a gestão da atividade, cujo exercício é objeto da delegação, é transferida ao particular dos casos em que isso não se verifica.

3.5.5. $\underline{\text { A concessão }}$ administrativa $\underline{\text { e }} \underline{\text { exercício privado }} \underline{\text { de }} \underline{\text { atividades de polícia }}$ administrativa

Entre as diversas modalidades de concessão, cabe dar especial destaque à concessão administrativa no que diz respeito às atividades de polícia administrativa.

A concessão administrativa deu conformação jurídica para a delegação do exercício de outras atividades públicas que não sejam serviço público em sentido estrito (assim considerados os serviços divisíveis e de natureza econômica).

\subsubsection{O objeto da concessão administrativa}

A concessão administrativa foi introduzida no direito nacional pela Lei $\mathrm{n}^{\mathrm{o}}$ 11.079/04. Uma das suas principais inovações diz respeito ao seu objeto, à medida que permite "a aplicação da lógica econômico-contratual da concessão tradicional a outros objetos que não a exploração de serviços públicos econômicos”359. Com isso, abriu-se a possibilidade de utilização da concessão para os serviços administrativos em geral ${ }^{360}$.

\footnotetext{
${ }^{358} \mathrm{O}$ art. $4^{\text {o }}$, inc. VI, e o art. $5^{\circ}$, inc. III, da Lei $\mathrm{n}^{\circ} 11.079 / 04$ estipulam que os contratos de parceria públicoprivada deverão dispor acerca da "repartição de riscos entre as partes".

${ }^{359}$ Carlos Ari Sundfeld. Guia jurídico das parcerias público-privadas, 2007, p. 21.

${ }^{360}$ No direito comparado, utiliza-se o instituto da concessão para serviços públicos administrativos há bastante tempo. É o que identificam, por exemplo, Diogo de Freitas Amaral e Lino Torgal. Estudos sobre concessões e
} 
A concessão administrativa comporta uma gama mais ampla de possibilidades em relação ao seu objeto. Além dos serviços públicos de natureza econômica, em relação aos quais, por uma opção da Administração, decide-se pela estruturação do contrato de modo que os serviços sejam custeados diretamente pela Administração, desonerando os usuários, a concessão administrativa pode ter por objeto: a) serviços públicos sociais, tais como saúde, educação, cultura e lazer; b) atividades relacionadas à polícia administrativa que sejam passíveis de delegação; e c) serviços de natureza administrativa, consistentes em atividades internas da Administração, das quais o beneficiário direto é o próprio Estado ${ }^{361}$.

Sob essa perspectiva, a concessão administrativa representa uma alternativa em relação à contratação de prestação de serviços, disciplinada pela Lei nº 8.666/93 ${ }^{362}$. A concessão administrativa permitiu a concessão de serviços ou que não são passíveis de individualização, sendo usufruídos apenas coletivamente, ou que, embora individualizáveis, não possibilitam a cobrança dos usuários por razões técnicas, econômicas ou jurídicas ${ }^{363}$. Permitiu também a concessão dos serviços que não são usufruídos diretamente pelos usuários e sim pela Administração.

O objeto principal da concessão administrativa é a realização de investimentos privados para a criação, reforma ou ampliação de estrutura pública, que será utilizada para a prestação de serviços, dos quais a Administração Pública seja usuária direta ou indireta. Associado a esse objeto principal, há a execução de obra ou o fornecimento e instalação de bens. Mais especificamente, a concessão administrativa é caracterizada pela conjugação de prestações distintas, de modo a viabilizar o seu financiamento. Recorrendo à expressão utilizada por Carlos Ari Sundfeld, o objeto da concessão administrativa é caracterizado pela sua complexidade ${ }^{364}$.

O contratado é responsável pela realização de investimentos de, no mínimo, R\$20 milhões na criação, ampliação ou recuperação de infraestrutura ou no fornecimento de bens. Cabe ao concessionário prestar serviços de modo associado à infraestrutura na qual foram realizados os investimentos ou aos bens fornecidos. Confere-se ao contratado certa margem de liberdade para detalhar a concepção da infraestrutura e da prestação dos

outros actos da Administração, 2002, p. 474-475 e François Llorens. La définition actuelle de la concession de service public en droit interne, 1992, p. 22-23).

${ }^{361}$ Alexandre Santos de Aragão. As PPPs e as concessões administrativas, 2011, p. 36-37.

${ }^{362}$ Daí a definição de Carlos Ari Sundfeld de que a "concessão administrativa é uma nova fórmula contratual para a Administração obter serviços” (Guia jurídico das parcerias público-privadas, 2007, p. 23).

${ }^{363}$ Floriano de Azevedo Marques Neto. A concessão como instituto do direito administrativo, 2013, p. 381.

${ }^{364}$ Guia jurídico das parcerias público-privadas, 2007, p. 31. 
serviços, inclusive em relação aos meios a serem utilizados, observando as diretrizes contratuais.

Com a exploração da infraestrutura que forneceu ou construiu, o particular será remunerado pelo poder público pelos resultados obtidos com os investimentos realizados e a prestação de serviços. A amortização dos investimentos ocorre a longo prazo, com a percepção de remuneração pelos resultados apresentados. Daí a estipulação de prazo mínimo para a prestação dos serviços (cinco anos).

Esse ajuste implica também a transferência ao particular do risco pela manutenção da obra executada ou bem fornecido, pois eventuais defeitos identificados no curso do prazo contratual reverterão em custos adicionais para a prestação dos serviços.

Ou seja, em princípio, há uma diversidade de prestações que podem ser objeto de concessão administrativa, desde que não se restrinjam ao fornecimento de mãode-obra e observem os limites gerais de delegabilidade ${ }^{365}$. Pela ampliação do objeto, a concessão administrativa apresenta maiores desafios quanto à delimitação dos direitos e prerrogativas transferidos ao concessionário. Isso é evidenciado, por exemplo, em relação à concessão administrativa da gestão de presídios, em que há significativa aproximação entre a atuação do concessionário e as atividades coercitivas do Estado ${ }^{366}$.

\subsubsection{A vedação do fornecimento de mão-de-obra como objeto exclusivo da concessão administrativa}

$\mathrm{O}$ art. $2^{\circ}, \S 4^{\circ}$, inc. III da Lei $\mathrm{n}^{\circ} 11.079 / 04$ veda que o contrato de parceria público-privada tenha por objeto exclusivo "o fornecimento de mão-de-obra, o fornecimento e instalação de equipamentos ou a execução de obra pública”. Vetou-se expressamente a utilização do contrato de parceria público-privada em substituição ao contrato de locação de serviços.

A interpretação do dispositivo pode gerar alguma dúvida especialmente em relação à concessão administrativa, à medida que esta é definida na própria Lei $\mathrm{n}^{\circ}$ 11.079/04 como sendo um “contrato de prestação de serviços” (art. $2^{\circ}, \S^{\circ}$ ).

A prestação de serviços passível de ser objeto de contratação mediante concessão administrativa não pode ser equivalente à contratação para fornecimento de mãode-obra. O fornecimento de mão-de-obra mencionado pela Lei $n^{0} 11.079 / 04$ pode ser

\footnotetext{
${ }^{365}$ Note-se que, apesar de haver a expressa ressalva acerca da indelegabilidade do exercício do poder de polícia na Lei $\mathrm{n}^{\circ}$ 11.079/04 (art. $4^{\circ}$, inc. III), esse é um limite aplicável aos diversos mecanismos contratuais e, em sentido mais amplo, a todas as formas de parceria da Administração Pública com a iniciativa privada - os limites do exercício de atividades de polícia administrativa por entidades privadas são analisados no Capítulo III.

${ }^{366}$ A privatização da gestão de estabelecimentos prisionais é analisada adiante, no item III.7.3.2.
} 
interpretado como sendo uma das espécies de terceirização. Consistiria apenas em uma das espécies da contratação de serviços disciplinada pela Lei no $8.666 / 93^{367}$.

O fornecimento de mão-de-obra implica a simples disponibilização de mãode-obra para a Administração, a ser administrada pelo próprio contratante. O produto entregue pelo contratado resume-se à disponibilização da mão-de-obra, não envolvendo a organização dos recursos humanos para a produção de determinado resultado, o serviço. Essa organização do trabalho é feita pelo próprio contratante - que, no caso, é a Administração.

Em razão disso, o fornecimento da mão-de-obra é uma solução questionável tanto em face dos princípios da Administração Pública, por possível burla ao princípio do concurso público, quanto aos princípios do direito do trabalho, que tem reconhecido a existência de vínculo trabalhista diretamente com o tomador ${ }^{368}$.

Mas a concessão administrativa também deve ser diferenciada do contrato de prestação de serviços disciplinado pela Lei no 8.666/93.

\subsubsection{Diferenciação da concessão administrativa em relação à empreitada ou locação de serviços disciplinadas pela Lei $n^{\circ} 8.666 / 93$}

A contratação de serviços disciplinada pela Lei $n^{0}$ 8.666/93, usualmente designada como empreitada ou locação de serviços, objetiva a obtenção de determinado serviço, considerado este como o resultado final, sendo que a mera disponibilização de mão-de-obra é apenas o meio para a obtenção desse resultado.

Mas o objeto da concessão administrativa não pode se resumir à obtenção de determinado serviço pela Administração. Há diferenças significativas entre a estruturação desses dois tipos de contratos.

Em primeiro lugar, a concessão administrativa representa um contrato de maior complexidade. $\mathrm{O}$ art. $2^{\circ}, \S 4^{\circ}$, da Lei ${ }^{\circ}$ 11.079/04 veda a celebração de contrato de parceria público-privada que tenha valor inferior a vinte milhões de reais, com período de prestação do serviço inferior a cinco anos e que tenha como objeto único o fornecimento de mão-de-obra, o fornecimento e instalação de equipamentos ou a execução de obra pública.

\footnotetext{
${ }^{367}$ Importa destacar que o próprio conceito de serviço previsto na Lei no ${ }^{8} .666 / 93$ é muito mais amplo do que o simples fornecimento de mão-de-obra. Nos termos do art. $6^{\circ}$, inc. II, serviço consiste em "toda atividade destinada a obter determinada utilidade de interesse para a Administração, tais como: demolição, conserto, instalação, montagem, operação, conservação, reparação, adaptação, manutenção, transporte, locação de bens, publicidade, seguro ou trabalhos técnico-profissionais”. O rol de atividades apresentado evidencia que se objetiva a obtenção de determinado resultado final e não o simples fornecimento de meios. Cabe ao contratado da Administração entregar esse produto final, sendo de sua responsabilidade a obtenção desse resultado.

${ }^{368}$ É esse o significado da Súmula no 331, analisada anteriormente.
} 
As previsões legais objetivam evitar a banalização da utilização da técnica contratual da PPP, reservando essa modalidade de concessão para as hipóteses em que for necessária uma engenharia financeira diferenciada para o adequado atendimento da necessidade coletiva.

Note-se também que a utilização de ajustes tais como os previstos nas concessões administrativas encontravam-se, em princípio, inviabilizados antes da entrada em vigor da Lei $n^{0} 11.079 / 04^{369}$. O art. $7^{\circ}$ da Lei $n^{\circ}$ 8.666/93 veda a inclusão, no objeto da licitação, da obrigação de “obtenção de recursos financeiros para sua execução, qualquer que seja a sua origem” (art. $\left.7^{\circ}, \S 3^{\circ}\right)$. O dispositivo ressalva apenas os empreendimentos explorados no regime de concessão. E os modelos de concessão então previstos no ordenamento jurídico não consagravam como objeto principal a prestação de serviços e a execução de obras.

Logo, a concessão administrativa pressupõe a conjugação de objetos contratados, à medida que há vedação legal para a contratação para execução de obra ou fornecimento de bens desacompanhados da prestação de serviços. Portanto, não pode se limitar à execução da obra. Nas hipóteses em que o seu objeto único é a prestação de serviços, não se restringe ao fornecimento de mão-de-obra. Carlos Ari Sundfeld assim identifica o diferencial em relação aos serviços:

quando se fala de serviços como objeto da concessão administrativa, está-se referindo à execução autônoma de prestações, para alcançar resultados determinados. A Lei das PPPs não considera como tal o mero fornecimento de força de trabalho humano (isto é, de “mão-de-obra”) para atuar sob a direção da Administração (art. $\left.2^{\circ}, \S 4^{\circ}, \mathrm{III}\right)^{370}$.

Ainda que não seja exata a comparação, pode-se invocar a obrigação de resultados para evidenciar a diferença entre os contratos. Diz-se ser a comparação imprópria porque, em alguma medida, o contratado da Administração sempre tem o dever de obter determinado resultado. No entanto, no contrato de prestação de serviços, a colaboração do particular está mais voltada à execução de prestações previamente definidas pela Administração, necessárias à obtenção de determinado resultado, a ser produzido pela própria Administração.

Já na concessão atribui-se ao concessionário a entrega do próprio resultado pretendido pela Administração, conferindo-lhe certa independência e autonomia quanto à escolha dos meios a serem utilizados para a obtenção do produto final. Transfere-se ao

\footnotetext{
369 Essa afirmação deve ser compreendida com ressalvas. Como se expôs acima, não há no ordenamento jurídico nacional a definição do contrato de concessão nem dos objetos possíveis para esses contratos.

${ }^{370}$ Guia jurídico das parcerias público-privadas, 2007, p. 32.
} 
concessionário a responsabilidade pela organização dos recursos humanos e materiais necessários para a obtenção do resultado final.

O controle exercido pela Administração nos dois casos também é diferenciado. Nos contratos de serviços disciplinados pela Lei $\mathrm{n}^{\circ}$ 8.666/93, o controle incide diretamente sobre as prestações isoladas desempenhadas pelo contratado. O pagamento é realizado usualmente a partir de medições parciais. Já na concessão administrativa, o controle é realizado especialmente em relação ao resultado final entregue pelo contratado. Não existe propriamente um controle sobre os meios utilizados, especialmente em face da autonomia atribuída ao concessionário em relação à escolha e organização destes.

Isso se reflete diretamente na responsabilidade assumida pelo contratado em cada caso. Nas contratações regidas pela Lei $n^{\circ}$ 8.666/93, a responsabilidade é limitada ao cumprimento das obrigações contratuais, mediante a execução das prestações na forma previamente estabelecida pela Administração. Na concessão, a responsabilidade é mais ampla. O art. 25 da Lei ${ }^{\circ}$ 8.987/95, expressamente aplicável às concessões administrativas (Lei $n^{0}$ 11.079/04, art. $3^{\circ}$ ), estipula que o concessionário responde amplamente, inclusive perante usuários e terceiros, por todos os prejuízos decorrentes da sua atuação.

Há ainda as diferenças relacionadas ao valor dos investimentos a serem realizados pelo contratado da Administração e aos prazos contratuais, mencionadas acima.

Essas diversas características da concessão administrativa evidenciam a complexidade dessa técnica contratual e impedem que seja utilizada em simples substituição aos contratos regidos pela Lei nº 8.666/93.

\subsection{A delegação do exercício de poderes públicos nos contratos de concessão}

A delegação do exercício de poderes públicos é verificada com frequência no âmbito dos contratos de concessão, apresentando-se de forma associada à atribuição do desempenho de uma atividade pública a particulares.

Cabe ressalvar inicialmente que, ao se fazer referência à delegação de poderes públicos, indica-se a atribuição do seu exercício e não dos poderes em si. A esse respeito, Cretella Júnior assim diferencia as situações, ao definir a concessão:

É um dos clássicos exemplos do chamado exercício privado de função ou de serviço público, transferindo da pessoa pública para a pessoa privada, dando como consequência a criação, no particular, de condições para o exercício da função ou para ao exercício dos poderes públicos correspondentes. Cumpre lembrar que 'funções', 'serviços' e 'poderes' são inerentes à pessoa jurídica pública ao Estado, não podendo, em hipótese alguma, ser transferidos para pessoas de direito privado. O que se transfere é tão-só o exercício correspondente às funções e poderes. Pela concessão, o Estado 
possibilita ao particular o direito a tais exercícios o que lhe possibilita a prática de várias operações, típicas dos entes públicos, como, por exemplo, a de promoção de desapropriações, a de recolhimento de taxas e impostos, a de exercício do poder de polícia” ${ }^{371}$.

3.6.1. $\underline{\text { A }}$ ausência de um instituto específico no direito nacional para designar exclusivamente o exercício privado de poderes públicos

Em alguns ordenamentos jurídicos, há institutos específicos para designar o exercício de poderes públicos por entidades privadas. É o caso, por exemplo, da "Beleihung” do direito alemão, sendo que "Beliehene” consistem nas entidades privadas às quais foram transferidas competências públicas de autoridade e que as exercem em nome próprio.

No direito nacional, o que se verifica é que a operação de transferência a entidades privadas do exercício de certas competências e poderes públicos ocorre especialmente nos contratos de concessão, ainda que não seja uma exclusividade destes.

\subsubsection{A concessão e a delegação do exercício de poderes públicos}

Apesar de a delegação do exercício de poderes públicos ser verificada, com frequência, em contratos de concessão, importa destacar a diferenciação das situações.

Ainda que se opte por designar como “delegação” a atribuição do exercício de poderes públicos a particulares, o cerne da questão não é terminológico. O que se procura destacar é que a delegação do exercício de poderes públicos é sempre instrumental à execução de uma tarefa ou cometimento público atribuído ao particular, que é o objeto principal do contrato de concessão.

O exercício de poderes públicos por concessionários de serviço público consiste em uma das principais manifestações do exercício privado de poderes públicos tratada nas obras de direito administrativo. O exercício de poderes públicos por concessionários é instrumental ao desempenho da atividade pública que lhes foi concedida.

Entre os atos praticados pelos concessionários, alguns consistem no exercício de poderes públicos, por delegação expressa da lei, e outros são caracterizados como atos de direito privado. Em termos históricos, pode-se constatar um decréscimo das prerrogativas públicas transferidas aos concessionários em razão da dissociação das funções de regulação e de prestação do serviço. Antes transferidas em bloco para os concessionários, tais funções foram separadas institucionalmente de modo a permitir que

\footnotetext{
${ }^{371}$ Direito administrativo brasileiro, v. 1, 1983, p. 421-422 - grifos no original.
} 
apenas a segunda seja delegada a particulares, com a consequente redução dos poderes públicos a serem exercidos pelo concessionário.

Atribuem-se ao concessionário poderes à medida que sejam estritamente necessários para o cumprimento efetivo das suas obrigações. Podem ser delegados poderes instrumentais à execução de encargos do concessionário.

Logo, a concessão de serviço público e a delegação de poderes públicos, em determinados casos, aparecem como realidades inseparáveis entre si, à medida que o exercício de poderes públicos é imprescindível para a adequada gestão do serviço concedido. Para que o particular desempenhe as atribuições públicas que lhe são transferidas, recebe também prerrogativas, necessárias ao desempenho integral das suas incumbências.

A esse respeito, Maria Sylvia Zanella Di Pietro reputa que a outorga de prerrogativas públicas ao particular seria uma das características da concessão, decorrente do fato de ter por objeto a prestação de serviço público ${ }^{372}$. Como define Floriano de Azevedo Marques Neto, o concessionário “passa a exercitar essas prerrogativas nos limites do necessário para dar cabo da contrapartida de obrigações que assume em face do objeto delegado" 373 .

A outra face das prerrogativas e privilégios de que o particular dispõe por serem necessários ao cumprimento da missão pública que lhe foi atribuída é o dever de exercê-los. Ao trespassar essas prerrogativas, o Estado transfere também o dever de implementar as finalidades públicas a elas vinculadas ${ }^{374}$. O particular não dispõe de livre escolha quanto ao exercício ou não das prerrogativas que lhe são atribuídas.

O contrato deve prever as atribuições e prerrogativas a serem exercidas pelo delegatário para desempenhar a atividade pública que lhe foi trespassada. Algumas dessas prerrogativas já se encontram expressamente previstas, por exemplo, na Lei $n^{0}$ 8.987/95. Alguns exemplos são as prerrogativas para fiscalizar os serviços e exigir dos usuários a observância das regras de fruição (art. 31, IV), interromper a fruição do serviço em caso de inadimplência (art. $6^{\circ}, \S 3^{\circ}$, inc. II) e de mau uso do serviço (art. $6^{\circ}, \S^{\circ}$, inc. I).

Usualmente reconhece-se que os concessionários exercem poder de autoridade ao se analisar a sua participação nos processos de desapropriação. A Lei n ${ }^{\circ}$ 8.987/95 prevê expressamente a possibilidade de serem outorgados poderes aos

\footnotetext{
${ }^{372}$ Parcerias na Administração Pública, 2012, p. 78.

${ }^{373}$ A concessão como instituto do direito administrativo, 2013, p. 231.

${ }^{374}$ Ob. cit., p. 520.
} 
concessionários para promover desapropriação e instituir servidão administrativa (art. 29, incs. VIII e IX, e art. 31, inc. VI).

A declaração de utilidade pública ou de interesse social de determinados bens, para fins de desapropriação, apenas pode ser promovida pelo Estado ${ }^{375}$. Implica o exercício de potestas expropriandi, de titularidade e exercício exclusivos das pessoas jurídicas de direito público. Portanto, não pode ser atribuída a particulares ${ }^{376}$.

No entanto, a promoção da desapropriação em si, a partir do ato de declaração do Executivo, pode ser realizada por concessionários de serviço público ou outras entidades às quais tenham sido delegados poderes públicos, pela lei ou pelo contrato $^{377}$. Trata-se da delegação da execução das atividades posteriores à declaração estatal, que se destinam a efetivar a desapropriação. É a atividade de condução do processo de desapropriação, a partir da declaração de utilidade pública emitida pela Administração ${ }^{378}$. É a essa atividade que se refere o art. 31, inc. VI, da Lei no 8.987/95 e o art. $3^{\circ}$ do Decreto-lei no $3.365 / 41$.

O mesmo se passa em relação às servidões administrativas. A servidão consiste na imposição de um regime jurídico peculiar, que altera o regime jurídico da propriedade. É imposta diretamente pela lei ou a partir de ato de declaração de utilidade pública $^{379}$ e implica a imposição de deveres ao proprietário do imóvel.

Confirmando o exposto acima, a Lei n 8.987/95 prevê, como sendo dever do poder concedente, a declaração de utilidade pública dos bens necessários à execução do serviço ou obra pública (art. 29, inc. VIII) e a declaração de necessidade ou utilidade pública, para fins de instituição de servidão administrativa (art. 29, inc. IX). Em seguida, os dispositivos mencionam que a Administração poderá promover diretamente a desapropriação ou instituição da servidão ou outorgar poderes à concessionária para que desempenhe estas atividades.

Portanto, apenas o poder de expropriação em si, demandado para a emissão de declaração de utilidade pública, é que consiste em poder de autoridade que não pode ser

\footnotetext{
${ }^{375}$ Decreto-lei $n^{\circ} 3.365 / 41$, art. $6^{\circ}$.

${ }^{376}$ Segundo Marçal Justen Filho, a "competência para declarar bens privados de utilidade pública ou de interesse social, para fins de desapropriação é inerente ao Estado. Não pode ser delegada. Trata-se de um daqueles deveres-poderes cujos efeitos são tão graves e cuja natureza é tão intrinsecamente pública que apenas pode ser exercitada pelo povo ou por seus representantes" (Teoria geral das concessões, 2003, p. 266). ${ }^{377}$ É que consta do art. $3^{\circ}$ do Decreto-lei n ${ }^{\circ} 3.365 / 41$.

${ }^{378}$ Como aponta Zanobini, ainda que o poder de expropriação não seja delegado, a condução do processo de expropriação para fins de utilidade pública também representa o exercício privado de função pública porque os particulares expropriante e expropriado não ocupam posições idênticas perante o juiz. O expropriante não defende apenas um interesse privado mas também um interesse do Estado, substituindo este no processo de desapropriação (L'esercizio privato delle funzioni e dei servizi pubblici, 1935, p. 441-442).

${ }^{379}$ Maria Sylvia Zanella Di Pietro. Direito administrativo, 2013, p. 158.
} 
objeto de delegação. Os demais atos praticados pelo particular, a partir da declaração de utilidade pública, tais como a condução do processo de expropriação e o pagamento da indenização, podem ser desempenhados pelos particulares, ainda que isso implique a assunção de posição diferenciada em face de outros particulares.

Vários dos poderes que têm o seu exercício atribuído aos concessionários dizem respeito a atividades de polícia administrativa. Devem ser atribuídas ao concessionário algumas competências instrumentais ou acessórias ao exercício de atividade de polícia sob pena de inviabilizar o concessionário de dar cumprimento aos seus deveres.

Em alguma medida, faz-se necessária a transferência ao concessionário da competência para a prática de atos materiais de fiscalização do cumprimento de deveres pelos usuários, sob pena de se inviabilizar a verificação da observância das determinações do poder concedente.

Cabe ao concessionário, por exemplo, cobrar a tarifa fixada pelo poder concedente em cumprimento às disposições contratuais. No entanto, diante da eventual recusa do usuário em pagar a tarifa, o concessionário não poderá empregar a coerção física. Para tanto, deverá acionar as autoridades públicas competentes. O concessionário de rodovias, por exemplo, não poderá praticar atos que são de competência exclusiva da polícia rodoviária, tal como a lavratura de autos de infração.

Porém, admite-se que o concessionário possa praticar determinados atos destinados a verificar a regularidade da conduta dos usuários e inclusive aplicar determinadas consequências, tal como a interrupção do serviço.

Um exemplo desse tipo de atuação do concessionário diz respeito à verificação e apuração de irregularidades por parte do usuário ao usufruir dos serviços, tal como adulterações destinadas a evitar ou reduzir o faturamento dos serviços prestados.

No setor de energia elétrica, a Resolução Normativa $n^{\circ}$ 414/2010, da ANEEL, que estabelece as condições gerais de fornecimento de energia elétrica, regula a forma de atuação do concessionário em relação aos usuários. Em caso de suspeita de irregularidade na distribuição de energia elétrica, o art. 129 da Resolução atribui à distribuidora a coleta de evidências para a caracterização de eventual irregularidade, com a emissão de Termo de Ocorrência e Inspeção e elaboração de relatório de avaliação técnica. Por solicitação do usuário, poderá ser realizada perícia técnica no medidor e demais equipamentos, a ser desenvolvida por laboratórios e pessoal acreditados e certificados.

Há a previsão de desenvolvimento de um processo destinado à apuração de eventuais irregularidades no faturamento, a ser realizado exclusivamente na esfera da 
distribuidora e do usuário. Ainda que a análise da questão no âmbito da distribuidora não afaste a possiblidade de o usuário recorrer à agência reguladora se discordar da solução adotada, atribui-se um poder de decisão significativo à distribuidora para deliberar acerca da existência ou não de irregularidades. Trata-se da aplicação de poderes atribuídos ao concessionário para apurar o mau uso do serviço e determinar a incidência das consequências cabíveis.

A doutrina destaca inclusive a maior eficiência que resulta do exercício de determinadas atividades de polícia administrativa vinculadas à prestação do serviço público pela própria concessionária, de modo a compensar a suposta ausência de "vocação ontológica” das pessoas de natureza privada para o exercício de tal função ${ }^{380}$.

Outro exemplo de exercício de poderes públicos por concessionários seria a possibilidade de suspensão da prestação dos serviços por questões de segurança, por exemplo. Mas isso não se aplicaria propriamente ao corte do fornecimento por ausência de pagamento. Como destaca Pedro Gonçalves, o corte por inadimplemento não implica o manejo de poderes públicos, por encontrar amparo no direito privado, na exceção de contrato não cumprido ${ }^{381}$. Mas disso não decorre que o fornecimento do serviço possa ser interrompido em qualquer caso de inadimplemento. É relevante que a regulamentação da prestação do serviço e o contrato de delegação prevejam expressamente a possibilidade de corte por falta de pagamento e os requisitos formais a serem observados para a suspensão.

Ainda no contexto do exercício de poderes públicos no âmbito dos contratos de concessão, cabe aludir à concessão portuária.

A atividade portuária caracteriza-se pela conjugação de aspectos de serviço público e de atividade de polícia administrativa ${ }^{382}$. As atividades desenvolvidas nos portos demandam a intervenção do poder público, mediante o exercício de atividades de polícia, de modo a ordenar e regular a conduta dos agentes públicos e privados que participam das operações portuárias. Por isso, em se tratando de delegação da atividade portuária, constata-

\footnotetext{
380 "Uma empresa pública prestadora de serviços públicos pode se beneficiar sinergicamente do exercício do poder de polícia, de modo tal que a eficiência agregada final na prestação do serviço público compense o exercício subótimo do poder de polícia. (...) a Cedae só teria a ganhar se pudesse imediatamente lacrar 'gatos' e autuar infratores, sem depender da cooperação da Polícia Militar. A extinta Rede Ferroviária Federal (RFFSA) só teria benefícios se o serviço público que prestava fosse acompanhado, por hipótese, da possibilidade do exercício do poder de polícia, sem depender dos batalhões ferroviários constituídos pelas polícias militares” (José Vicente Santos de Mendonça. Estatais com poder de polícia: por que não?, 2009, p. 113-114).

${ }^{381}$ Entidades privadas com poderes públicos, 2008, p. 761-762.

${ }^{382}$ Marçal Justen Filho. O regime jurídico dos operadores de terminais portuários no direito brasileiro, 2006, p. 93.
} 
se que "talvez seja a concessão de serviços públicos que mais acentuadamente importa na transferência, ao particular, de atribuições próximas às de poder público”383.

As atividades delegáveis na concessão portuária aproximam-se bastante daquelas tipicamente caracterizadas como atividades de polícia administrativa ${ }^{384}$. Mas se trata de um exercício de prerrogativas que se submete às determinações dos órgãos ou entes públicos competentes, como consta expressamente dos incisos VIII, IX e X do art. 17 da Lei $\mathrm{n}^{\circ} 12.815 / 13$, por exemplo. Já o art. 18 da Lei $n^{0} 12.815 / 13$ prevê que as atividades de administração do porto delegadas devem ser exercidas sob a coordenação das autoridades marítima e aduaneira.

Portanto, os concessionários de serviço público exercem, com frequência, atividades de polícia administrativa por serem instrumentais e necessárias à execução do objeto principal da delegação.

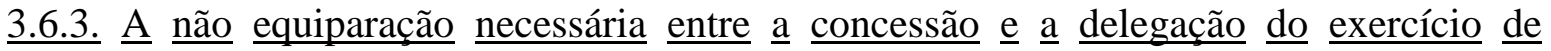 poderes públicos}

Tanto na concessão, compreendida em sentido amplo, quanto na delegação do exercício de poderes públicos há atribuição de uma nova posição ao particular, que deriva de posição ocupada pela Administração, da qual ela continua sendo titular. Trata-se da integração de novos direitos à esfera jurídica do particular, considerando-se a inviabilidade de simples transferência da posição ocupada pela Administração.

\footnotetext{
${ }^{383}$ Floriano de Azevedo Marques Neto. A concessão como instituto do direito administrativo, 2013, p. 344.

${ }^{384}$ Nos termos do art. 17 da Lei $n^{\circ} 12.815 / 13$, a administração do porto é objeto da concessão portuária (art. $2^{\circ}$, inc. IX) e compreende diversas atribuições, previstas no art. $17, \S 1^{\circ}$, da Lei: “§ 10 Compete à administração do porto organizado, denominada autoridade portuária: I - cumprir e fazer cumprir as leis, os regulamentos e os contratos de concessão; II - assegurar o gozo das vantagens decorrentes do melhoramento e aparelhamento do porto ao comércio e à navegação; III - pré-qualificar os operadores portuários, de acordo com as normas estabelecidas pelo poder concedente; IV - arrecadar os valores das tarifas relativas às suas atividades; V - fiscalizar ou executar as obras de construção, reforma, ampliação, melhoramento e conservação das instalações portuárias; VI - fiscalizar a operação portuária, zelando pela realização das atividades com regularidade, eficiência, segurança e respeito ao meio ambiente; VII - promover a remoção de embarcações ou cascos de embarcações que possam prejudicar o acesso ao porto; VIII - autorizar a entrada e saída, inclusive atracação e desatracação, o fundeio e o tráfego de embarcação na área do porto, ouvidas as demais autoridades do porto; IX - autorizar a movimentação de carga das embarcações, ressalvada a competência da autoridade marítima em situações de assistência e salvamento de embarcação, ouvidas as demais autoridades do porto; $\mathrm{X}$ - suspender operações portuárias que prejudiquem o funcionamento do porto, ressalvados os aspectos de interesse da autoridade marítima responsável pela segurança do tráfego aquaviário; XI - reportar infrações e representar perante a Antaq, visando à instauração de processo administrativo e aplicação das penalidades previstas em lei, em regulamento e nos contratos; XII - adotar as medidas solicitadas pelas demais autoridades no porto; XIII - prestar apoio técnico e administrativo ao conselho de autoridade portuária e ao órgão de gestão de mão de obra; XIV - estabelecer o horário de funcionamento do porto, observadas as diretrizes da Secretaria de Portos da Presidência da República, e as jornadas de trabalho no cais de uso público; e XV - organizar a guarda portuária, em conformidade com a regulamentação expedida pelo poder concedente.”
} 
Além disso, como se mencionou acima, os dois institutos aparecem combinados em uma única manifestação com certa frequência. É usual que ao concessionário de serviços públicos sejam transferidos determinados poderes públicos, instrumentais e acessórios, necessários à gestão do serviço concedido.

De todo modo, cabe destacar que a concessão e a delegação do exercício de poderes públicos refletem situações jurídicas distintas. A legislação pode até mesmo agrupá-los em um mesmo instituto, mas não se trata necessariamente da mesma realidade jurídica.

Nesse sentido, Celso Antônio Bandeira de Mello diferencia os concessionários dos delegados de função ou ofício público de acordo com a atividade que desempenham. Para o doutrinador, a atividade desempenhada pelos concessionários (e permissionários) de serviço público é material. Já os delegatários de função pública exercem atividade jurídica ${ }^{385}$. O exemplo típico de agentes delegados de função pública considerado pelo doutrinador é o dos notários e registradores.

\subsubsection{As discussões no direito comparado acerca da utilização do termo "concessão"}

No direito comparado, localizam-se diversas discussões acerca da adequação ou não do instituto da concessão para abarcar a atribuição do exercício de poderes públicos por particulares. Cabe destacar que o referencial utilizado pelos autores é o da concessão de serviço público, não considerando geralmente o contrato de concessão com objeto distinto.

Especialmente para a doutrina espanhola e portuguesa, o traço característico da concessão de serviço público seria a transferência da gestão do serviço e não propriamente a atribuição de poderes ao particular, ainda que isso possa ocorrer de modo acessório e conjuntamente.

Como adverte Pedro Gonçalves, a concessão de serviço público atribui ao ente privado o direito de gerir um serviço público. Já a delegação do exercício de poderes públicos, estejam eles compreendidos entre as atribuições do concessionário de serviço público ou na delegação específica do exercício de atividades de polícia administrativa, implica a atribuição de uma capacidade de direito público à entidade privada ${ }^{386}$. De todo modo, o autor não vê problemas em se conceber uma “concessão de poderes públicos”, ao lado dos demais objetos passíveis de serem concedidos ${ }^{387}$.

\footnotetext{
${ }^{385}$ Curso de direito administrativo, 2013, p. 256.

${ }^{386}$ A concessão de serviços públicos, 1999, p. 158.

${ }^{387}$ Entidades privadas com poderes públicos, 2008, p. 681.
} 
Também para Esteve Pardo o termo “concessão” não seria adequado para refletir a transferência do exercício de poderes públicos e explicar a posição ocupada pelos delegatários ${ }^{388}$. As delegações de poderes iriam além da concessão de gestão de um serviço. Segundo o autor, haveria uma verdadeira "transferência de faculdades decisórias, de autoridade”. Ou seja, o delegatário do exercício de poderes públicos exerceria funções mais amplas e complexas do que a gestão material de um serviço, pois seria detentor inclusive de poderes de decisão ${ }^{389}$.

Por sua vez, Tomas-Ramon Fernandez Rodriguez propõe a qualificação de particulares que exercem poderes públicos tanto como “delegatários” quanto como "agentes descentralizados da Administração”. Sugere que, mais relevante do que o título, é a definição do regime jurídico aplicável a esse exercício privado de funções públicas ${ }^{390}$.

Marcello Caetano vai além para destacar que o exercício de poderes públicos pelo concessionário não seria uma simples delegação de poderes e sim uma verdadeira transferência de exercício, considerando-se que “durante o prazo da concessão ou enquanto esta subsistir a titularidade dos direitos e poderes continua na entidade concedente, mas a faculdade de os exercer passa a ser exclusivamente do concessionário”391.

3.6.5. As ressalvas quanto à ut utilização do termo “delegação”"

É relevante indicar não ser pacífica a caracterização do ato de atribuição do exercício de atividades públicas a particulares, por sua conta e responsabilidade, como sendo delegação.

A definição clássica de “delegação” remete à noção de procuração, significando o poder que uma pessoa dá a outra de agir em seu nome ${ }^{392}$.

Pierre Delvolvé aponta aquelas que seriam as contradições na utilização do termo “delegação” para a concessão da prestação de serviço público ${ }^{393}$.

O termo “delegação” era utilizado apenas para se referir ao instituto da delegação de competências administrativas. O autor registra sua perplexidade diante da utilização mais recente do instituto da delegação para a prestação de serviço público especialmente por dois motivos.

\footnotetext{
${ }^{388}$ Autorregulación, 2002, p. 151-152, especialmente nota 148.

${ }^{389}$ Izquierdo Carrasco também afirma não haver no ordenamento jurídico espanhol uma fórmula jurídica para retratar a transferência a particulares do exercício de poderes públicos (Algunas cuestiones generales a propósito del ejercicio privado en el ámbito de la seguridad industrial, 2001, p. 401-402).

${ }^{390}$ Derecho administrativo, sindicatos y autoadministración, 1972, p. 129-131.

${ }^{391}$ Manual de direito administrativo, v. II, 2010, p. 1100.

${ }^{392}$ David Soldini. La délégation de service public, sa fonction, ses critères, 2010.

${ }^{393}$ Les contradictions de la délégation de service public, 1996.
} 
O primeiro deles é o de que a prestação de serviço público por particulares não implicaria a transferência de competência. O ente público exerceria justamente a sua competência ao atribuí-lo a uma pessoa privada e preservaria a competência, ao exercer os poderes de controle e de fiscalização sobre a concessão. Para o autor, nem mesmo seria concebível uma "transferência" de competência em face das suas características de irrenunciabilidade e indisponibilidade.

O segundo motivo é que não se trata de um mandato. O concessionário atua em nome e por conta próprios. Não atua como mandatário do poder público.

Por isso, o autor pondera que o que é objeto de delegação é a gestão do serviço público e não o serviço público em si, devendo-se falar em “delegação da gestão de serviço público” e não em “delegação de serviço público”.

Em relação ao termo delegação, seria possível argumentar que se refere, em geral, a ocorrências entre órgãos públicos (ou entre órgãos e agentes públicos). No caso da atribuição de funções públicas a particulares, tratar-se-ia de uma delegação atípica. Por isso, a doutrina norte-americana denomina-a de “private delegation”, para diferenciá-la da “public delegation”, verificada no âmbito interno da Administração.

Porém, na ausência de outro termo, adota-se a delegação para identificar o ato pelo qual se transfere a entidade privada o exercício de atividade pública. Eventualmente, a delegação do exercício da tarefa pública poderá estar associada a uma das modalidades de concessão.

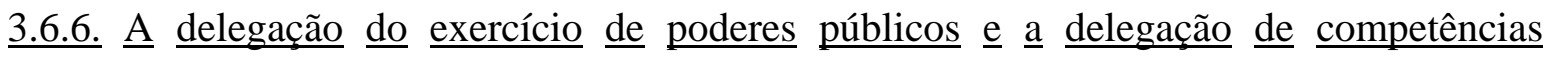
administrativas

A delegação do exercício de poderes públicos, vinculada ao contrato de concessão, aproxima-se do instituto da delegação de competências administrativas.

A delegação de competências do direito administrativo refere-se à transferência temporária e precária de competências específicas entre órgãos da Administração ou para entes distintos, tendo em vista a realização de determinados objetivos $^{394}$.

Seguindo a sistematização proposta por Pedro Gonçalves, os pontos de proximidade entre a delegação do exercício de poderes públicos e a delegação de competências administrativas seriam os seguintes ${ }^{395}$ : (a) a aplicação dos dois institutos

\footnotetext{
${ }^{394}$ No direito nacional, a delegação de competências encontra-se disciplinada especialmente na Lei $n^{\circ}$ 9.784/99, arts. 11 a 14 .

${ }^{395}$ A concessão de serviços públicos, 1999, p. 158-159, nota 168.
} 
depende de autorização legal; (b) as duas medidas refletem decisões acerca do modelo organizatório do Estado, como modelos de desconcentração da atividade administrativa; (c) consistem em atos de habilitação, por legitimarem a atuação dos destinatários, e em atos translativos, por transferirem poderes próprios do delegante; e (d) dão ensejo ao exercício de poder de controle do delegante sobre o delegatário.

Mas há diferenças significativas entre os dois institutos, que impedem a sua equiparação.

Uma das principais diferenças estaria nos objetivos visados com uma delegação e outra. Na delegação do exercício de poderes públicos, procura-se municiar o particular dos instrumentos necessários para a adequada gestão da atividade pública que lhe foi atribuída. O particular assume uma posição distinta daquela ocupada pelo Estado, exercendo a atividade em nome próprio.

Pode-se dizer que haveria uma diferenciação entre os interesses perseguidos pelo delegante e pelo delegatário em cada caso. O interesse do delegatário de competências administrativas é exatamente o mesmo que seria perseguido pelo delegante. Já o delegatário do exercício de poderes públicos procura produzir um resultado mais amplo, que é a gestão de determinada atividade pública, para a qual a delegação de poderes públicos é instrumental, bem como busca satisfazer também interesses próprios, ao fazer a gestão por conta e risco próprios.

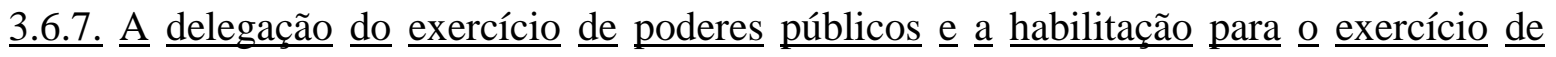
função pública

Pode ser diferenciada também a delegação do exercício de determinados poderes públicos da habilitação para o exercício de uma função pública, na qual serão utilizados os poderes delegados.

Essa distinção é traçada com precisão por Celso Antônio Bandeira de Mello:

A delegação - justamente por sê-lo - não se confunde com uma simples habilitação, ou seja, com um ato meramente recognitivo de atributos pessoais para o desempenho de funções de tal gênero (...) A delegação, propriamente dita, é ato sucessivo ao concurso e seu alcance, seu significado, é precisamente o de adjudicar um determinado 'serviço' (em rigor, o exercício dele) - ou seja, aquela unidade que o consubstancia - à cura de um dado sujeito ${ }^{396}$.

\subsubsection{Observações finais}

Parece-nos que as diferenças existentes entre a delegação de competências administrativas e a delegação de poderes públicos não são suficientes para afastar a

\footnotetext{
${ }^{396}$ Curso de direito administrativo, 2013, p. 256-257 - grifos no original.
} 
possibilidade de se caracterizar como delegação a transferência do exercício de poderes públicos a particulares.

O aspecto principal da delegação é a retenção pelo delegante da titularidade da competência delegada, a qual pode fazer valer a qualquer momento ${ }^{397}$. Considerando-se isso, a transferência do exercício de poderes públicos pode ser enquadrada na noção de delegação.

Por outro lado, ao se mencionar a delegação de poderes públicos no âmbito dos contratos de concessão, procura-se evidenciar que não há nenhuma anormalidade no desempenho de poderes públicos por particulares mediante atribuição contratual. Logo, o fato de a delegação de atividades de polícia administrativa implicar o trespasse do exercício de determinados poderes públicos a particulares não pode ser invocado como óbice absoluto à delegabilidade dessa atividade. O que é necessário examinar é quais poderes podem ter o seu exercício atribuído a particulares, de modo acessório ao desempenho da atividade pública que lhes foi atribuída. Essa temática é analisada no capítulo III.

\subsection{A delegação do exercício de poderes públicos por ato unilateral}

Há hipóteses em que o exercício da função pública delegada decorre de ato unilateral da Administração, praticado com fundamento em lei. É o que se passa, por exemplo, em relação às atividades dos notários e registradores, cujo exercício privado encontra-se previsto no art. 236 da CF/88 ${ }^{398}$.

Note-se que, ainda que se trate de delegação a particulares expressamente previstas no texto constitucional, a outorga não decorre diretamente da previsão normativa. Esta contém apenas a autorização para a delegação. Faz-se necessário o ato administrativo concreto de adjudicação da atividade, de aplicação da previsão normativa de delegação. Em relação aos notários e registradores, promove-se a outorga e a delegação propriamente dita aos candidatos aprovados em concurso público, que consiste na habilitação exigida para o exercício da atividade ${ }^{399}$.

\footnotetext{
${ }^{397}$ Tomas-Ramon Fernández Rodrígues. Derecho administrativo, sindicatos y autoadministración, 1972, p. 180.

${ }^{398}$ A atividade desempenhada pelos notários e registradores é objeto de exame específico no item III.7.8.1.

${ }^{399}$ Há casos em que se constata a delegação legal, promovida diretamente pelo texto legal de modo a dispensar qualquer ato posterior para a concretização da delegação. Assim se passa em relação aos poderes conferidos aos comandantes de navios e aeronaves, examinada no item III.6.5.2. Trata-se de delegação prevista em favor de sujeitos indeterminados, aplicando-se a todos que se encontrem na situação prevista na lei - no caso, desempenhando as referidas profissões.
} 


\section{8. $O$ credenciamento}

Ainda no âmbito do exercício indireto de atividades estatais, cabe considerar também a possibilidade de utilização do credenciamento. Esse instituto é relevante para o objeto do presente estudo porque diversas atividades de polícia administrativa são exercidas por particulares mediante credenciamento. Para a realização de exames e inspeções, por exemplo, a Administração utiliza com frequência o credenciamento de particulares para a execução dessas atividades.

$\mathrm{O}$ instituto do credenciamento não é recente no direito brasileiro ${ }^{400}$. Por exemplo, a Lei de Diretrizes e Bases da Educação Nacional (Lei $n^{0} 4.024 / 61$ ) aludia ao credenciamento de instituições de educação superior, inclusive universidades (art. $9^{\circ}, \S 2^{\circ}$, “c”). A Lei de Execução Penal (Lei no 7.210/84) menciona a designação de entidade ou programa comunitário, devidamente credenciado, para a prestação de serviços à comunidade pelo condenado (art. 149, inc. I).

No entanto, não existe previsão normativa contendo o conceito de credenciamento. O termo credenciamento é empregado em circunstâncias variadas, referindo-se a atos de natureza distinta ${ }^{401}$.

Não há uniformidade também quanto à definição doutrinária de credenciamento.

Como define Adilson Dallari, credenciamento “é uma outorga ou atribuição. O credenciado recebe do poder público uma qualificação, uma situação jurídica ou uma prerrogativa que, sem isso, não lhe assistiria”402.

A definição proposta por Weida Zancaner reflete a imprecisão do termo no direito nacional:

credenciamento é um termo vago utilizado ora para designar atos praticados pelo Estado, ampliativos da esfera jurídica dos particulares, com a concordância destes, pelo qual o Poder Público habilita alguém à prática de atos de prestação de serviços públicos, serviços sociais ou atos materiais, sejam eles preparatórios ou não de atos de polícia, ora para designar atos de habilitação que poderão ou não propiciar atos ampliativos de direito ${ }^{403}$.

\footnotetext{
${ }^{400}$ Adilson Abreu Dallari. Credenciamento, 1997, p. 38; Dinorá Musetti Grotti. Parcerias na Administração Pública, 2006, p. 298-299.

${ }^{401}$ Weida Zancaner apresenta os seguintes exemplos de utilização do termo credenciamento para se reportar a situações distintas: “(1) o ato de credenciamento de estagiários para a Procuradoria do Estado; (2) o ato de credenciamento de médicos e clínicas para atendimento na área da Saúde para os servidores do Tribunal X ou para o atendimento da população do município Y; (3) o credenciamento de tradutores públicos para a prestação de Serviços de Tradução Juramentada para o Supremo Tribunal Federal; (4) ou, ainda, o credenciamento de empresas para averiguação técnica de veículos para o DETRAN" ( $O$ perfil jurídico do credenciamento, 2013, p. 789).

402 Credenciamento, 1997, p. 52.

${ }^{403}$ O perfil jurídico do credenciamento, 2013, p. 793.
} 
Em linhas gerais, pode-se afirmar ser mecanismo de atribuição formal de uma atividade a particulares. Porém, essa definição indica, na verdade, a semelhança do credenciamento com diversos outros instrumentos jurídicos, tais como os contratos de colaboração. Outra característica do credenciamento consiste no fato de o particular ser remunerado diretamente pelos próprios usuários da atividade pública ${ }^{404}$. Mas o credenciamento também não se confunde com o contrato de concessão.

Segundo Adilson Dallari, o credenciamento pode ser ato unilateral ou bilateral, sendo possível formalizá-lo como ato ou contrato ${ }^{405}$. Em relação às formas de atribuição do ato de credenciamento, Weida Zancaner propõe três mecanismos distintos: os atos-condição, os contratos administrativos e os contratos regidos pelo direito privado ${ }^{406}$. Já Diogo de Figueiredo Moreira Neto propõe uma conceituação mais restrita ao instituto, aplicando-o apenas a atos unilaterais e precários de atribuição de atividades de interesse público $^{407}$.

Marçal Justen Filho alude à adoção do credenciamento quando todos os possíveis interessados em exercer certa atividade podem ser satisfeitos concomitantemente, não sendo necessário escolher apenas um determinado particular. Assim se passa quando for possível estabelecer-se uma quantidade ilimitada de contratações ou se a escolha do contratado não couber à Administração. O credenciamento operaria então como um cadastro de fornecedores que preenchem os requisitos necessários para fornecer determinada prestação ${ }^{408}$. Nesta hipótese de credenciamento, a licitação seria inexigível, pela inviabilidade de competição diante da não excludência dos diversos interessados em contratar com a Administração ${ }^{409}$.

\footnotetext{
${ }^{404}$ Adilson Abreu Dallari. Credenciamento mediante licitação, 1998, p. 101.

${ }^{405}$ Credenciamento, 1997, p. 52.

${ }^{406}$ O perfil jurídico do credenciamento, 2013, p. 794.

${ }^{407}$ Segundo o autor, pelo ato de credenciamento "a Administração Pública delega unilateral e precariamente, por atos administrativos, a credenciados, atividades de interesse público, reconhecendo-lhes a produção de eficácia administrativa pública e dando-lhes assentimento para que sejam remunerados por seus serviços diretamente pelos administrados beneficiários ou por ela própria” (Curso de direito administrativo, 2009, p. 313 - grifo no original).

${ }^{408}$ Comentários à lei de licitações e contratos administrativos, 2012, p. 48-49. Em sentido similar, Luciano Ferraz define que o credenciamento "funcionará como procedimento administrativo, pelo qual a Administração convoca os prestadores do serviço de telefonia (quando haja mais de um) para, segundo condições por ela - Administração - previamente definidas e divulgadas, credenciarem-se, deixando a critério dos próprios servidores públicos do órgão ou entidade (que em última instância são os verdadeiros usuários) a escolha da prestadora. Os valores a serem cobrados pelos eventuais credenciados deverão ser uniformes e constantes do edital de credenciamento" (Contratação de prestadoras de serviço de telefonia pelos órgãos e entidades da Administração à luz da Lei no 8.666/93, 2000, p. 370).

${ }_{409}$ Dinorá Musetti Grotti. Parcerias na Administração Pública, 2006, p. 303. Em sentido diverso, encontra-se na obra de Carlos Pinto Coelho Motta a referência ao credenciamento como instrumento auxiliar da licitação: "A nosso ver, o processo de credenciamento seria uma hipótese híbrida, um instrumento auxiliar da licitação, pois não se traduz na inexigibilidade, propriamente dita, regida sob seu aspecto procedimental pelo art. 26
} 
Assim, nas hipóteses em que for possível a prestação simultânea dos serviços por vários interessados, que comprovaram o preenchimento dos requisitos mínimos exigidos, a forma adequada de delegação pode ser o credenciamento ${ }^{410}$. Nesse caso, caberá à Administração a prévia definição dos valores passíveis de serem cobrados pelos credenciados.

Outra circunstância a ser considerada é a eventual necessidade de se restringir o número de credenciados bem como delimitar a área de sua atuação geográfica, de modo a propiciar a fiscalização dos serviços pelo poder público bem como assegurar a viabilidade econômica da atuação dos credenciados. Neste caso, será cabível a realização de licitação para a escolha dos credenciados, pela impossibilidade de contratação conjunta de todos os interessados ${ }^{411}$.

Alice Gonzalez Borges assim sistematiza as circunstâncias em que o credenciamento é recomendado: “tem por finalidade atender duas situações ou solucionar dois problemas: a) quando o interesse público enseja o oferecimento do objeto pretendido pela Administração a uma pluralidade de prestadores; b) quando a pluralidade de prestadores impõe a necessidade de tratamento isonômico em razão da limitação quantitativa do objeto"412.

Por outro lado, o credenciamento poderá não ser adequado para as hipóteses em que for necessária a realização de investimentos significativos em infraestrutura e equipamentos específicos para a prestação dos serviços delegados. Em tais casos, os serviços poderão ser prestados por um custo inferior apenas por um ou alguns interessados, para os quais seja possível garantir o atendimento de uma demanda mínima, suficiente para a amortização dos investimentos sem a cobrança de tarifas excessivas dos usuários. Nesse caso, será cabível a realização de licitação para a seleção dos interessados.

Para os fins do presente estudo, menciona-se o credenciamento por ser um dos títulos jurídicos utilizados para o exercício de determinadas atividades de polícia administrativa por particulares. É o caso, por exemplo, do credenciamento de profissionais

LNL. Isto porque se desenvolve de forma similar à licitação, mediante instauração do processo, em atendimento às formalidades inerentes à fase interna (PB e outras providências), além da fixação de fase externa com previsão das respectivas regras procedimentais em instrumento convocatório - Edital — de que constem os pressupostos limítrofes à habilitação ao credenciamento, com observância dos princípios que informam a atividade licitatória comum" (Delimitação conceitual e finalidade do instituto do credenciamento, 2008, p. 15).

${ }^{410}$ Nesse sentido, a Lei Geral de Telecomunicações (Lei $\mathrm{n}^{\circ}$ 9.472/97) prevê entre as hipóteses de inexigibilidade de licitação quando a disputa for desnecessária, o que se verifica "nos casos em que se admita a exploração do serviço por todos os interessados que atendam às condições requeridas” (art. 91, §2).

${ }^{411}$ Essa situação é analisada por Adilson Abreu Dallari. Credenciamento mediante licitação, 1998, p. 101105.

${ }^{412}$ O credenciamento de inspeções de segurança veicular na legislação de trânsito, 2004. 
para a realização de exames físicos necessários para a obtenção e renovação da carteira de habilitação para condutores de veículos. No entanto, não se faz necessário o exame em apartado do credenciamento no que diz respeito aos limites e requisitos para a delegação de atividades de polícia, à medida que incidem os mesmos critérios aplicáveis aos demais mecanismos de contratação pela Administração.

\section{Autorrequlação $\underline{\text { e delegação de poderes públicos }}$}

Ao serem identificados os mecanismos que podem ser utilizados para a delegação de atividades de polícia administrativa a particulares, cabe analisar se o exercício da autorregulação pode implicar o exercício de poderes públicos delegados ou não.

Além da privatização (em sentido amplo) da execução de atividades públicas, de modo explícito ou implícito, o exercício de atividades de polícia administrativa por particulares pode ser verificado também na ativação de responsabilidades privadas. O plano principal dessa ativação de responsabilidades privadas encontra-se no próprio âmbito privado, mas isso não afasta por completo a possibilidade de haver intervenção estatal na atividade dos particulares de gestão dos seus próprios interesses.

\subsection{A autorregulação como manifestação da autonomia privada}

Uma das manifestações da alteração das relações entre Estado e sociedade é a maior organização dos particulares em organismos estruturados pela autonomia da vontade, que funcionam mediante autorregulação e estabelecem códigos de ética, de conduta e outras normas internas para determinados setores profissionais ou econômicos.

A autorregulação consiste em uma das principais manifestações da autonomia privada. Na lição de Santi Romano, a autonomia, no seu sentido mais específico, indica, subjetivamente, o poder de se dar um ordenamento jurídico. É o poder de autorregulamentação dos próprios interesses. Em termos objetivos, a autonomia indica o caráter próprio de um ordenamento jurídico que os indivíduos ou entidades autodeterminam, em contraposição aos ordenamentos constituídos por terceiros ${ }^{413}$. É a característica de um ordenamento ao qual se submete a própria entidade que o instituiu.

Tal fenômeno é incentivado e reconhecido pelo Estado. A possível maior adequação da percepção pelos próprios agentes acerca das atividades que desenvolvem é

\footnotetext{
${ }^{413}$ Frammenti di un dizionario giuridico, 1947, p. 14.
} 
um dos fatores a serem considerados ao se atribuir a função de regulação aos próprios interessados ${ }^{414}$.

O ambiente de autorregulação é mais propício para a rápida percepção das mudanças no ambiente e a imediata implantação das mudanças regulatórias necessárias. Procura-se elaborar normas mais adequadas à realidade do setor, com o possível aumento da adesão e aceitação da regulação pelos interessados e redução da necessidade de intervenção estatal. As entidades de autorregulação podem inclusive exercer determinados poderes, de origem pública ou privada, sobre aqueles que se submetem à sua regulação, inclusive disciplinares e sancionatórios.

Para Vital Moreira, a administração autônoma, exercida por organismos representativos ou associativos que se autoadministram e desenvolvem funções públicas em nome próprio, consiste em uma das modalidades do exercício privado de atividades administrativas $^{415}$.

\subsection{A autorregulação e o movimento de desregulação}

Especialmente nas últimas décadas do século $\mathrm{XX}$, intensificaram-se as críticas em face da intensidade e concentração da regulação estatal.

Marçal Justen Filho registra que a situação verificada era de desordenação da regulação estatal ${ }^{416}$. Não havia coordenação de conteúdo e finalidade da grande quantidade de regras produzidas. A existência de regulação anacrônica, irracional e contraditória restringia o desenvolvimento das atividades pela iniciativa privada. A dinâmica própria do funcionamento do Legislativo, sujeito às mais diversas pressões, acabava desnaturando a regulação que deveria ser estabelecida a partir de critérios eminentemente técnicos.

Essa crítica contra a regulação conduziu à desregulação, com a supressão de parcelas da regulação estatal. Mas a insurgência dirigiu-se não apenas contra os efeitos da regulação mas também o sistema regulador adotado. Como anota Vital Moreira, a resposta para tanto foi a parcial substituição da regulação estatal pela autorregulação pelos próprios

\footnotetext{
414 "Uma entidade autorreguladora, ao obter adesão dos participantes do mercado, está mais próxima das atividades que propõe regular, dispondo, portanto, de maior sensibilidade e destreza para avaliar as condições e normatizá-las. Esses aspectos favoreceriam a condução de políticas de custos mais moderados e com maior grau de previsibilidade de seus efeitos" (Luiz Roberto Calado. Regulação e autorregulação do mercado financeiro, p. 58).

${ }^{415}$ Administração autónoma e associações públicas, 1997, p. 287 e ss. O autor adota um conceito bastante amplo para administração autônoma, de modo a abranger entidades com suporte institucional público criadas por lei ou por iniciativa pública e dotadas de personalidade jurídica de direito público - bem como entidades privadas que exercem tarefas públicas, tais como as concessionárias de serviço público.

${ }^{416} \mathrm{O}$ direito das agências reguladoras independentes, 2002, p. 41-42.
} 
interessados $^{417}$. A autorregulação consiste em uma das principais reivindicações dos próprios setores sociais, que pretendem autorregularem-se e excluírem-se da regulação pública $^{418}$.

A autorregulação não deixa de ser uma forma de regulação ${ }^{419}$. A desregulação não conduz necessariamente à ausência de regulação, à medida que pode se manifestar mediante recurso a sistemas de autorregulação. O movimento verificado foi mais de desregulação estatal do que desregulação propriamente dita.

Nesse contexto, a desregulação não significa que o Estado tenha se desocupado completamente da função regulatória. Em alguns casos, deve exercer a supervisão sobre o desempenho da autorregulação. Em outros, os próprios sujeitos autorregulados são responsáveis pela sua regulação. Mas se não a exercerem, há o risco de retomada da regulação pelo Estado.

Portanto, a desregulação não significa supressão da regulação. Os espaços de atividade regulatória liberados pelo Estado são "privatizados": "O movimento de desregulação estadual conduziu, portanto, à transferência da regulação do Estado para os grupos sociais organizados, ou seja, à devolução de áreas ocupadas pela regulação pública à autonomia dos sujeitos e dos grupos ${ }^{\text {420. }}$.

Note-se que a desregulação não foi levada a extremos. Atingiu determinados setores e segmentos específicos, sendo uma das suas consequências a ativação de responsabilidades privadas mediante autorregulação.

\subsection{Os elementos e o conteúdo da autorregulação}

A autorregulação é produzida por sujeitos privados, no âmbito privado. Esse é o seu elemento subjetivo.

Ou seja, a autorregulação propriamente dita consiste no desenvolvimento de atividades privadas. Quando há o exercício privado de função que é de titularidade pública, não há propriamente autorregulação (ainda que, em algumas classificações de autorregulação, apareçam formas que implicam a delegação pública de poderes). Em se tratando de autorregulação, mesmo nos casos em que a Administração assume os seus

\footnotetext{
${ }^{417}$ Auto-regulação profissional e Administração Pública, 1997, p. 76-77.

418 José Esteve Pardo. Autorregulación, 2002, p. 36.

419 Como constata M. Mercè Darnaculleta I Gardella, a autorregulação é uma nova técnica de regulação: "mediante esta técnica se procura corresponsabilizar a sociedade na diminuição dos riscos por ela gerados, com o objetivo de facilitar a função de garante que é atribuída ao Estado" (Autorregulación y derecho público, 2005, p. 25).

${ }^{420}$ Vital Moreira. Auto-regulação profissional e Administração Pública, 1997, p. 77.
} 
resultados, estes não são imputáveis a ela. A Administração também não assume a responsabilidade decorrente desses atos praticados pelos sujeitos que se autorregulam quando muito, a sua responsabilidade é limitada, do tipo “in vigilando"421.

A autorregulação pode apresentar graus distintos, conforme seus resultados adquirem relevância perante a Administração. O grau máximo seria o da assunção pela Administração desses atos como sendo próprios, para todos os efeitos. A partir desse ponto, deixa de haver autorregulação propriamente dita.

Quanto aos conteúdos possíveis da autorregulação, destacam-se o normativo e o declaratório ${ }^{422}$.

A autorregulação de conteúdo normativo é representada especialmente pela produção de normas técnicas. Como se analisa adiante ${ }^{423}$, as normas técnicas produzidas no âmbito privado não retratam exercício de poder normativo público. Estas normas não integram, em princípio, o ordenamento jurídico e não são vinculantes nem para os particulares. Em termos práticos, como a autorregulação tende a ser unitária - ou seja, com a existência de uma única entidade especializada na matéria -, as normas técnicas adquirem grande força pela ausência de outros critérios que possam substitui-las ${ }^{424}$.

Quando as normas jurídicas fazem remissões às normas técnicas, estas passam a integrar o ordenamento jurídico e a ter os mesmos efeitos das normas jurídicas. A partir desse momento, a força das normas técnicas deixa de ser atribuída às instâncias privadas autorreguladoras para decorrer da decisão do próprio Estado de incorporar essa norma ao sistema jurídico.

As manifestações de autorregulação de conteúdo declaratório também não produzem efeitos públicos vinculantes por si sós. Consistem em informações qualificadas e referências técnicas que são levadas em consideração para a tomada de decisão pelas instâncias públicas. A sua relevância está diretamente vinculada ao procedimento empregado para a sua elaboração e aos conhecimentos especializados detidos pelos agentes que se autorregulam.

\footnotetext{
421 José Esteve Pardo. Autorregulación, 2002, p. 107.

422 José Esteve Pardo. Autorregulación, 2002, p. 114-126.

${ }^{423}$ V. item III.7.5.5.

${ }^{424}$ As instâncias autorreguladoras submetem-se a processos de racionalização que muitas vezes são voltados à emissão da única referência daquele setor, com pretensão de validade universal. Assim se passa porque a validade e a aceitação geral dependem da uniformização de métodos. Em alguns casos, é possível a convivência entre diversos critérios de avaliação técnica para fins de certificação, por exemplo. Já em outros, é necessária a unificação, tal como na área de segurança. Para Esteve Pardo, quando a autorregulação é a única referência com pretensão de validade universal, verifica-se uma publicização implícita (Autorregulación, 2002, p. 162-166). Caso se atinja essa validade universal, é difícil afirmar que o elemento privado ainda seja predominante. Há nítida interconexão entre público e privado.
} 


\subsection{Os efeitos do descumprimento da autorregulação}

A principal consequência para o descumprimento da autorregulação, quando se trata de atividade privada, consiste no efeito rescisório ${ }^{425}$.

A autorregulação funda-se na adesão e confiança existente entre aqueles que a produzem e os que a ela se submetem. Não se lhe atribui efeito vinculante por si só, a não ser que seus resultados sejam recebidos pelo poder público. Diante da inobservância da autorregulação, a única consequência possível seria a rescisão da relação - representada pela retirada da certificação conferida ou do direito de utilização de determinado selo, por exemplo - e a perda da confiança.

Com isso, perdem-se todos os efeitos e a valoração positiva que a autorregulação poderia atribuir. Isso pode significar repercussões mais ou menos graves, de acordo com a relevância assumida pela autorregulação naquele setor específico.

\subsection{A atribuição de efeitos públicos à autorregulação}

Uma das novidades identificadas mais recentemente em relação à autorregulação diz respeito à aquisição de uma dimensão pública.

A autorregulação continua sendo desenvolvida no âmbito privado, mas em alguns casos os seus resultados vão além dos sujeitos que os produziram, sendo adotados como referências por terceiros e também levados em consideração ou até mesmo assumidos pelo poder público. Não são todas as manifestações de autorregulação que têm relevância pública e, entre as que adquirem tal relevância, nem todas produzem os mesmos efeitos, com a mesma intensidade ${ }^{426}$.

Uma questão a ser destacada e que assume maior relevância à medida que são atribuídos efeitos públicos à autorregulação, em maior ou menor grau, é a de que, em se tratando de atividade privada, não se pode exigir dos sujeitos que se autorregulam que atuem permanentemente de modo objetivo, em atenção aos interesses gerais. Isso é dever inerente aos poderes públicos.

\footnotetext{
${ }^{425}$ José Esteve Pardo. Autorregulación, 2002, p. 156-158.

${ }^{426}$ A atribuição de determinados efeitos públicos à autorregulação é um dos desafios que se apresenta na atualidade. Multiplicaram-se os códigos de condutas elaborados no exercício de autorregulação bem como as normas que a eles se reportam, determinando a sua observância. Os problemas que se apresentam dizem respeito especialmente ao controle de legalidade desses códigos e à sua publicidade, que ainda não são objeto de regulação legal. O tema é analisado na obra de Diego Vigil de Quiñones Otero. Autorregulación y publicidade registral, 2010.
} 
A autorregulação privada não deixa de atender também aos interesses gerais. Mas não se impõe aos seus integrantes o dever de atendimento de interesses gerais, ainda que estes possam coincidir com os seus próprios interesses.

Por isso, a autorregulação apenas pode produzir efeitos públicos caso preencha determinados requisitos, que lhe confiram legitimidade e assegurem a objetividade necessária para que tenha efeitos vinculantes.

Um dos requisitos a serem observados é a reserva de lei para que se verifique o reconhecimento público da autorregulação. É necessária a previsão legal para que determinadas declarações procedentes da autorregulação produzam efeitos idênticos aos das declarações emitidas pelo poder público. Como incide reserva legal para o deslocamento do exercício de competências - para a delegação, avocação etc. - entre órgãos administrativos, com muito mais razão exige-se para habilitar sujeitos privados para que, em regime de autorregulação e sob sua própria responsabilidade, decidam sobre matérias que são de competência da Administração ${ }^{427}$.

A atribuição de efeitos públicos à autorregulação depende também da observância de determinados requisitos no curso da sua produção, de modo a assegurar a sua objetividade. Cabe à regulação pública a fixação de condições e critérios para o desempenho das atividades pelos sujeitos autorreguladores. No desenvolvimento das atividades, pode haver intervenções de supervisão e controle pelo poder público. Por fim, a Administração deve proceder ao recebimento controlado do produto da autorregulação, com a possibilidade de revisão e recusa na hipótese de não terem sido observados os condicionamentos previamente estabelecidos.

A incidência desses diversos mecanismos de controle do poder público sobre a autorregulação varia de acordo com a modalidade de autorregulação de que se trata.

\subsection{As modalidades de autorregulação}

Há várias modalidades de autorregulação. Como define Esteve Pardo, a “autorregulação juridicamente relevante é aquela que resulta inteligível e aceitável pelo sistema do Direito, chegando inclusive em certos casos a incorporá-la como se tratasse de uma referência própria”428, tornando-se uma referência válida para o direito.

\footnotetext{
427 José Esteve Pardo. Autorregulación, 2002, p. 176-177.

${ }^{428}$ Autorregulación, 2002, p. 35.
} 
Floriano de Azevedo Marques Neto diferencia três espécies de autorregulação ${ }^{429}$.

As duas primeiras espécies retratam processos de autorregulação impulsionados pelo Estado. Este pode tanto impor quanto estimular formas de autorregulação privada para os particulares atuarem em determinado sentido adequado à realização de interesses públicos.

A primeira espécie é a autorregulação delegada, em que se verifica a delegação legislativa de competências regulatórias. Seria o caso das ordens profissionais.

Na autorregulação imposta, há a cominação legislativa de deveres. Esta abrange dois grandes grupos de atribuições: 1) pode ser a transferência de missões públicas a particulares (privatização material) ou a atribuição da sua execução (privatização funcional), exigindo-se uma colaboração “forçada” dos particulares; e 2) pode significar a imposição aos particulares do dever de contratar determinadas entidades privadas que exercem funções de controle e certificação.

A segunda espécie é a autorregulação induzida, que é a regulação exercida com incentivo ou recomendação estatal. Nesse caso, a lei não transfere competências mas admite e reconhece o seu exercício por determinadas entidades, o que poderia configurar uma transferência tácita de atribuições. O produto da autorregulação adquire força obrigatória porque a lei assim estipula. É a hipótese das entidades de certificação que atuam mediante convênio ou parceria com o Estado e dos códigos de deontologia elaborados pelas categorias interessadas.

Na autorregulação incentivada ou induzida, o Estado utiliza mecanismos de persuasão e estímulo para obter uma contribuição voluntária dos cidadãos para a realização de fins de interesse público. Em determinados casos, o Estado promove a autorregulação, através de incentivos à adesão pelos particulares aos sistemas de autorregulação.

Há também a autorregulação privada organizada pelo Estado, que conta com intervenção estatal mais intensa. O Estado fornece o enquadramento jurídico e o procedimento de organização da autorregulação privada, definido as condições em que ela será desenvolvida. Usualmente enquadram-se nessa categoria os sistemas de gestão de bolsas e de mercados de valores.

Por fim, há a autorregulação espontânea, que independe da ação estatal e é instituída por instrumentos associativos. As normas editadas no contexto de autorregulação

${ }^{429}$ Regulação econômica e suas modulações, 2009, p. 38-39. 
espontânea são desprovidas de efeitos jurídicos obrigatórios. Nesse caso, há apenas poderes privados nas relações entre a associação e seus membros ${ }^{430}$.

Odete Medauar apresenta também a categoria da autorregulação dirigida, na qual "ocorre uma troca entre o Estado e os grupos privados; estes aceitam limitar sua liberdade de ação sob dupla condição: a) garantia de não haver imposição de regulação autoritária; b) o Poder Público lhes conferir o poder de fixar normas para si próprios”431.

Constata-se, assim, que pode haver diversos graus de interferência pública na autorregulação. Inicia-se no mais forte, no qual há delegação de função pública e fixação dos fins, objetivos, procedimentos de atuação e estatuto jurídico que devem observar os entes de autorregulação - o que determina a publicização da autorregulação e sua aproximação com o regime de direito público ${ }^{432}$. Passa pela atribuição de efeitos públicos à autorregulação até chegar à forma mais fraca de todas, que é o fomento público à autorregulação, mediante estímulos.

As duas primeiras espécies de autorregulação que mencionamos autorregulação imposta e induzida - podem ser reconduzidas ao conceito de “autorregulação privada publicamente regulada”. Nestas hipóteses de transferência de incumbências para os particulares e de ativação de responsabilidades privadas, à medida que o Estado mantém o dever de supervisão e regulação da atuação privada, não resulta uma atividade privada desregulada mas sim uma atividade publicamente regulada.

O campo da atuação por excelência da autorregulação é o da gestão privada de atividades que, apesar de serem de interesse coletivo, não são objeto de apropriação pública formal. Por isso, a autorregulação é induzida pelo Estado.

Essas entidades privadas atuam com os seus próprios meios, ou seja, exclusivamente com os mecanismos de direito privado. Não há diferenciação do regime jurídico que lhes é aplicável em relação ao direito comum.

No entanto, o Estado intervém na atividade dessas organizações privadas de diversas formas. Um desses mecanismos consiste na atribuição de relevância pública a

\footnotetext{
${ }^{430}$ Essa classificação aproxima-se do conceito anglo-saxão de autorregulação, que abrange várias estruturas desde a autoimposição voluntária de padrões de conduta por indivíduos ou organizações até a delegação de poderes públicos em favor de associações privadas representativas dos sujeitos que desempenham certa atividade. Já na Europa continental, o conceito de autorregulação prevalecente é o que a limita às manifestações da sociedade que são levadas em consideração ou assumidas como referência pelos poderes públicos, excluindo do âmbito da autorregulação as atividades originalmente atribuídas ao Estado e posteriormente delegadas a particulares (Luis Arroyo Jiménez. Introducción a la autorregulación, 2008, p. 20).

${ }^{431}$ O direito administrativo em evolução, 2003, p. 258. O exemplo de autorregulação dirigida citado pela autora é o dos bancos na Suíça.

${ }^{432}$ M. Mercè Darnaculleta I Gardella. Autorregulación y derecho público, 2005, p. 26.27.
} 
determinados resultados produzidos no âmbito da autorregulação, para utilizá-los como pressuposto de outras atividades revestidas de natureza propriamente administrativa. Essa atribuição de efeitos públicos aos atos praticados por entidades privadas pode ocorrer, por exemplo, com a incorporação de normas privadas pelo ordenamento estatal, mediante a utilização de mecanismos de remissão ${ }^{433}$.

Como indica Tomas-Ramon Fernández Rodrígues, essa situação não envolve o exercício privado de função administrativa. É uma questão de relação entre ordenamentos jurídicos. Cabe ao ordenamento administrativo, como ordenamento preeminente, determinar as condições e circunstâncias em que serão atribuídos efeitos públicos aos atos das entidades privadas ${ }^{434}$.

Portanto, os poderes envolvidos no exercício da autorregulação podem tanto ter origem pública quanto privada. O problema do exercício de prerrogativas públicas por particulares pode se apresentar nas duas primeiras espécies de autorregulação.

Na autorregulação delegada, há expressa delegação de competências pelo poder público. O Estado transfere-lhes parcela da sua função de regulação, por via legislativa, sem transformar estas entidades em órgãos do Estado. O Estado pode também determinar o desempenho de determinadas funções por entidades de autorregulação, com exclusividade $^{435}$.

No caso das ordens profissionais, como se analisa especificamente adiante $^{436}$, reconhece-se em nosso sistema jurídico que tais entidades devem ter personalidade de direito público para que possam exercer poderes regulatórios e de polícia.

Em relação à autorregulação induzida, não há, em princípio, o exercício de poderes públicos. Porém, apesar de não haver expressa delegação de poderes, estes podem se encontrar implícitos nas atividades exercidas por tais entidades. Por isso, faz-se necessário identificar a origem dos poderes desempenhados pelos particulares nesses casos.

\subsection{Autorregulação e exercício de atividades de polícia administrativa}

Há hipóteses em que a autorregulação aparece conjugada com o exercício de atividades de polícia administrativa.

\footnotetext{
${ }^{433}$ Exemplo disso é a previsão do art. $8^{\circ}$, inc. IX, da Lei no 9.478/97 (Lei do Petróleo), que estabelece, entre os deveres da ANP, o de "fazer cumprir as boas práticas de conservação e uso racional do petróleo, gás natural, seus derivados e biocombustíveis e de preservação do meio ambiente”. As "boas práticas” mencionadas no dispositivo legal deverão ser buscadas em normas técnicas privadas.

434 Tomas-Ramon Fernández Rodrígues. Derecho administrativo, sindicatos y autoadministración, 1972, p. 36.

${ }^{435}$ Exemplos são as previsões dos arts. 207 e 217, inc. I, da CF/88.

${ }^{436}$ V. item III.6.5.1.
} 
No caso da autorregulação imposta, pode ser atribuído o exercício de competências de polícia administrativa a entidades de autorregulação, tal como se passa em relação às ordens profissionais.

Pode-se também verificar a relação entre autorregulação e atividades de polícia administrativa mediante a assunção pelo Estado de determinados resultados produzidos pelas entidades de autorregulação.

É o que se passa quando determinadas normas elaboradas por segmentos da sociedade que, apesar de não terem sido elaboradas por instâncias democráticas, são recepcionadas pelo poder público e passam a ser vinculantes para todos os sujeitos atingidos, por força de lei. Outro processo diz respeito aos controles de qualidade industrial, tais como de certificação e inspeção, originalmente de natureza privada mas que podem inclusive liberar as empresas de se submeterem a controles e autorizações públicas, o que pressupõe a assunção pelo poder público de determinados controles privados, atribuindolhes efeitos jurídico-públicos.

Nesses casos, as atividades desenvolvidas pelas entidades de autorregulação são de natureza privada. Não desempenham atividades de polícia administrativa mediante delegação. Porém, ao assumir os resultados produzidos por essas entidades, o Estado acaba se liberando do desempenho de determinadas atividades de polícia, que são substituídas pela atuação privada, à qual atribuem-se determinados efeitos públicos.

Podem ser mencionadas ainda entidades de regulação setorial às quais se atribui o exercício de atividades tais como as de fiscalização e normativa que se aplicam não apenas aos seus membros mas também a terceiros. No entanto, em relação a terceiros, o fundamento pelo qual se submetem à atuação destas entidades não é meramente privado, não se justificando pela livre associação.

Essa distinção é bastante clara em relação às entidades de gestão de mercados de valores mobiliários, que são analisadas mais detidamente a seguir. Algumas das entidades do setor exercem conjuntamente atividades nos regimes de autorregulação e de delegação pelo poder público.

\subsection{A gestão de mercados de valores mobiliários}

No mercado financeiro, há a conjugação do controle e da supervisão estatal, que correspondem, em linhas gerais, ao modelo latino, com a autorregulação, do modelo 
anglo-saxão $^{437}$. Aplica-se o sistema de autorregulação regulada especialmente em relação aos agentes intermediários, que são as corretoras e as bolsas de valores.

A questão que se coloca é se as diversas funções de regulação do mercado financeiro, desempenhadas por entidades privadas, consistem no exercício de função pública ou de autorregulação privada organizada pelo Estado.

Há várias entidades de autorregulação no mercado financeiro, que atuam em diversos aspectos das atividades dos operadores do mercado de valores mobiliários.

A BM\&F Bovespa Supervisão de Mercados é uma associação civil, sem fins lucrativos $^{438}$. É responsável pela fiscalização e supervisão dos agentes do mercado e da própria BM\&FBOVESPA, competindo-lhe inclusive a instauração de processos administrativos disciplinares e a aplicação de sanções.

A CETIP S.A. - Balcão Organizado de Ativos e Derivativos é responsável pela fiscalização e supervisão das operações realizadas nos mercados compreendidos no seu âmbito de atuação. Cabe-lhe a emissão de normas e a fiscalização da sua observância, inclusive com a instauração de processos disciplinares relativos a infrações verificadas em relação ao cumprimento dessas normas.

A ANBIMA - Associação Brasileira das Entidades dos Mercados Financeiros e de Capitais resultou da fusão entre a ANBID (Associação Nacional dos Bancos de Investimento) e a ANDIMA (Associação Nacional das Instituições do Mercado Financeiro). Compete à ANBIMA especialmente a elaboração de códigos de conduta em relação aos setores em que atua, tais como as ofertas públicas e a distribuição de valores mobiliários.

Todas essas entidades são de direito privado. Cada qual exerce a autorregulação em relação a alguns aspectos específicos do mercado financeiro. Não existe a concentração das atividades em uma única entidade, tal como se verifica em outros setores.

\footnotetext{
${ }^{437}$ Esteve Pardo formula lição a partir do direito espanhol, que também se aplica, em linhas gerais, ao sistema brasileiro. Segundo o autor, o mercado de valores mobiliários encontra-se organizado em três níveis. O primeiro nível é o das normas de conduta de origem estatal, que integram o ordenamento jurídico. O segundo nível é ocupado pelos códigos de conduta, que não têm natureza de norma jurídica. Trata-se de recomendações para as empresas, de observância voluntária, mas cujo grau de observância deve ser periodicamente informado pelas empresas que têm ações negociadas na bolsa de valores. O terceiro nível pode ser considerado como sendo o da autorregulação mais primária, das normas internas de conduta adotadas pelas próprias empresas e entidades que operam no mercado (Autorregulación, 2002, p. 79-82).

${ }^{438}$ Estatuto disponível em http://www.bsm-autorregulacao.com.br/InstDownload/BSM-Estatuto-Social.pdf, acesso em 5.9.2013.
} 
Há controvérsia mais significativa em relação às funções desempenhadas pelas bolsas de valores, à medida que podem exercer poderes disciplinares inclusive em relação a terceiros, que não são seus associados.

As bolsas de valores são pessoas jurídicas de direito privado, constituídas pelas corretoras de valores. Consistem em associações civis, que precisam da prévia autorização para CVM para funcionar. A CVM é uma agência reguladora (autarquia especial), vinculada ao Ministério da Fazenda (Lei $n^{\circ}$ 10.411/02). A Lei $n^{\circ}$ 6.385/76 estipula serem as bolsas “órgãos"439 auxiliares da CVM e integrantes do sistema de distribuição de valores mobiliários ${ }^{440}$.

Cabe às bolsas a manutenção do local e dos sistemas necessários para as operações de compra e venda de sistemas mobiliários. As bolsas também auxiliam a CVM na fiscalização do mercado ${ }^{441}$. Incumbe, ainda, às bolsas fiscalizar o cumprimento das disposições legais pelos operadores de mercado e aplicar as penalidades cabíveis ${ }^{442}$.

Por isso, diz-se que há autorregulação do mercado. A regulação do mercado surge de modo voluntário, com a criação das bolsas pelos próprios agentes privados para que sejam preservados determinados padrões de conduta necessários ao desenvolvimento dos negócios. Como definem Arnoldo Wald e Nélson Eizirik, “por autorregulação do mercado compreende-se a normatização e fiscalização, pelo órgão corporativo (a Bolsa de Valores), das atividades de seus membros, com vistas à manutenção de elevados padrões éticos na prática dos negócios”443.

Entre as funções desempenhadas pelas bolsas, destaca-se o poder disciplinar que lhes é atribuído para investigar, julgar e aplicar sanções aos membros do mercado de capitais $^{444}$. Os poderes disciplinares das bolsas são mais amplos no que diz respeito às

\footnotetext{
${ }^{439}$ A definição das bolsas de valores como "órgãos" auxiliares da CVM é criticada pela doutrina (Ary Oswaldo Mattos Filho. Natureza jurídica das atividades das bolsas de valores, 1986, p. 9; Arnoldo Wald e Nélson Eizirik. O regime jurídico das bolsas de valores e sua autonomia frente ao Estado, 1986, p. 15).

${ }^{440}$ Lei 6.385/76, art. 15, inc. IV.

${ }^{441}$ Lei $n^{\circ}$ 6.385/76, art. 17.

${ }^{442}$ Maria Fernanda Calado de Aguiar Ribeiro Cury e Roberto Codorniz Leite Pereira destacam o significativo risco de conflitos de interesses que podem surgir no âmbito das bolsas de valores. Uma bolsa apresenta "dois escopos fundamentais e, em primeira análise, colidentes, quais sejam: (i) o fato de visar ao lucro, já que é uma sociedade anônima e com esse propósito atua no mercado; e (ii) o fato do exercício da regulação não apenas de si própria, mas de todos os outros participantes desse mercado. Desse modo, é fácil perceber que o surgimento do conflito de interesses se dá quando a atividade regulatória das bolsas pode retardar as suas fontes de lucratividade ou, ainda, quando a atividade regulatória requer obrigatoriamente determinado investimento por parte da bolsa, o qual não poderá ser internalizado antes de um longo período de tempo" (Desafio ao desenvolvimento do mercado de valores mobiliários brasileiro: conflito de interesses na autorregulação, 2009, p. 55-56).

${ }^{443} \mathrm{O}$ regime jurídico das bolsas de valores e sua autonomia frente ao Estado, 1986, p. 5.

${ }^{444} \mathrm{O}$ exercício do poder disciplinar pelas bolsas é especialmente regulado no capítulo VII do Regulamento anexo à Resolução CMN 2.690/00.
} 
entidades que as compõem, incluindo a aplicação de penalidades ${ }^{445}$. Já em relação às empresas cujas ações são negociadas na bolsa e aos investidores, os poderes exercidos pelas bolsas são mais restritos, não incluindo a aplicação de penalidades ${ }^{446}$. Portanto, não se verifica o exercício de poderes sancionatórios pelas bolsas de valores sobre entidades que não a integram ${ }^{447}$.

Diante de tais características, é relevante analisar se os poderes exercidos pelas bolsas são poderes privados ou se são poderes públicos, que lhes foram delegados pelo Estado.

Pode-se identificar certa divergência da doutrina acerca das funções exercidas pelas bolsas de valores.

$$
\text { Para Arnoldo Wald, Nélson Eizirik }{ }^{448} \text { e Ary Oswaldo Mattos Filho }{ }^{449} \text {, por }
$$

exemplo, as bolsas exercem função privada, em modelo de autorregulação privada ${ }^{450}$. O controle estatal sobre elas incidente - no caso nacional, exercido especialmente pela CVM e pelo Banco Central - não desnaturaria as funções por ela exercidas. O fato de a legislação prever serem as bolsas auxiliares da CVM permitiria apenas qualificá-las como entidades de cooperação e não como prestadoras de serviço público.

\footnotetext{
${ }^{445}$ Nos termos do art. 64 da Resolução CMN 2.690/00, as bolsas de valores poderão aplicar penalidades aos integrantes do Conselho de Administração da própria bolsa, às sociedades membros e aos administradores e prepostos de sociedades membros, da própria bolsa de valores e do sistema de registro de operações. Já o poder sancionatório da CVM é mais amplo, aplicando-se, em termos gerais, "aos infratores" das disposições legais (Lei $n^{\circ}$ 6.385/76, art. 11).

${ }^{446}$ Em relação aos agentes em geral que operam nas bolsas de valores, os poderes por elas exercidos apresentam especialmente caráter acautelatório e não propriamente sancionatório. $\mathrm{O}$ art. 62 do Regulamento anexo à Resolução CMN 2.690/00 prevê, por exemplo, que as bolsas de valores têm competência para "suspender a negociação, em seu recinto, de títulos e de valores mobiliários" (inc. III), "impedir a realização de negociações que estejam realizando em bolsa de valores, quando existirem indícios de que possam configurar infrações a normas legais e regulamentares, ou consubstanciar práticas não equitativas” (inc. IV) e "cancelar os negócios realizados em bolsas de valores, ou solicitar às entidades de compensação e liquidação de operações com títulos e valores mobiliários a suspensão da sua liquidação, nos casos de operações onde haja indícios que possam configurar infrações a normas legais e regulamentares, ou que consubstanciem práticas não equitativas, modalidades de fraude ou manipulação” (inc. V). Essas competências são exercidas pelas bolsas de valores sem prejuízo dos poderes atribuídos por lei à CVM, a quem cabe a aplicação de sanções propriamente ditas a entidades que não integram as bolsas de valores.

447 "Em respeito ao princípio da legalidade, o poder disciplinar das bolsas somente pode atingir as companhias, seus administradores e acionistas através da limitação à negociação em seus recintos dos papeis emitidos pelas companhias, não podendo haver a delegação do poder disciplinar geral que detém o Estado" (Bruno Dário Werneck. A auto-regulação da atividade econômica no Brasil, 2003, p. 637).

${ }^{448}$ O regime jurídico das bolsas de valores e sua autonomia frente ao Estado, 1986, p. 6-7.

${ }^{449}$ Natureza jurídica das atividades das bolsas de valores, 1986, p. 12.

${ }^{450}$ Ary Oswaldo Mattos Filho sustenta que as bolsas não exercem poderes delegados e sim funções que lhes são próprias, de origem privada: “as Bolsas de Valores não são exercentes de função delegada do Estado, em qualquer das três modalidades, pelo simples motivo que ao Estado não foi dada a competência originária para o exercício da prestação de tal serviço. De outro lado, é impossível a delegação de poder que não se possui. Desta feita, temos que as Bolsas de Valores não são exercentes de serviços delegados pelo Estado” (ob. e loc. cit.).
} 
Segundo Arnoldo Wald e Nélson Eizirik, as bolsas são entidades privadas, que gozam de determinadas prerrogativas. Consistiriam em mecanismo de colaboração de particulares com a Administração. Não prestam serviço público propriamente dito mas desempenham função de utilidade pública. Algumas das funções que exercem foram-lhes delegadas pelo poder público e outras consistem em funções próprias ${ }^{451}$.

Já para Fabio Konder Comparato ${ }^{452}$ e Celso Antônio Bandeira de Mello ${ }^{453}$, apesar de criadas sob a forma de associações civis, as bolsas de valores exercem função pública, mediante delegação estatal. São prestadoras de serviço público, que lhes foi atribuído diretamente pela lei. Para Fabio Konder Comparato, seria a incumbência, pela lei, da gestão de serviço público a pessoa privada, não integrante da Administração Pública, atribuindo-lhe prerrogativas e sujeições ${ }^{454}$.

Ainda seguindo os ensinamentos de Fábio Konder Comparato, parte dos poderes exercidos pelas bolsas foi-lhes delegada pelo poder público e parte consiste em poderes próprios. Assim, o autor diferencia os poderes das bolsas de fiscalização dos seus associados como sendo um poder interno, similar aos poderes disciplinares que qualquer associação exerce sobre os seus associados, dos poderes de fiscalização das operações realizadas dentro da bolsa, que se caracterizariam como autênticos poderes de polícia ${ }^{455}$.

Já para Celso Antônio Bandeira de Mello, a atividade pública exercida pelas bolsas, mediante delegação estatal, caracteriza-se como serviço público se for utilizado o conceito muito amplo deste, para abranger atividades públicas tanto materiais quanto jurídicas $^{456}$.

Assim, ainda que exista alguma divergência em relação à terminologia empregada, a maior parte da doutrina concorda quanto à natureza privada das bolsas de valores, que exercem funções públicas mediante delegação. Logo, parcela dos poderes que exercem tem natureza pública e são recebidos mediante delegação.

Entre os poderes que lhes são delegados, não se inclui o poder sancionatório, considerando-se que apenas podem aplicar penalidades às entidades que as integram e não a terceiros. Sobre os seus membros, exercem também poder disciplinar, com fundamento em poderes privados, decorrentes da sua natureza associativa.

\footnotetext{
${ }^{451}$ O regime jurídico das bolsas de valores e sua autonomia frente ao Estado, 1986, p. 15-16.

${ }^{452}$ Natureza jurídica das bolsas de valores e delimitação do seu objeto, 1985, p. 47-50.

${ }^{453}$ Natureza jurídica das bolsas de valores, 1987, p. 221.

${ }^{454}$ Natureza jurídica das bolsas de valores e delimitação do seu objeto, 1985, p. 49-50.

455 Ob. cit., p. 45.

${ }^{456}$ Natureza jurídica das bolsas de valores, 1987, p. 221.
} 


\section{Privatização “de fato”}

Como se procura demonstrar adiante, a delegação de atividades públicas a particulares encontra-se sob reserva de lei. Isso significa que pode ser realizada diretamente por lei ou por ato ou contrato administrativo celebrados com base na lei.

Quando não houver ato formal de delegação, cabe avaliar se seria possível cogitar da imposição de fato de deveres a particulares, no âmbito da privatização de fato ou implícita. Consistiriam nas situações em que os particulares são colocados em posição de ter de cumprir determinadas funções cuja responsabilidade de execução é do Estado. Sobre essa questão, Pedro Gonçalves alude à imposição não formal de deveres a particulares, no âmbito de uma privatização de fato ${ }^{457}$.

Um dos principais exemplos pode ser extraído das áreas de segurança e de preservação da ordem pública. O Estado afasta-se da prestação direta de determinadas atividades em certos ambientes mas não as atribui expressamente a particulares. São impostos indiretamente aos particulares deveres jurídicos de autoproteção ${ }^{458}$.

Outra modalidade de privatização “de fato” de função pública seria aquele em que se atribui a particulares o exercício de atividades que seriam meramente materiais ou acessórias mas que acabam sendo determinantes para a decisão da Administração. Exemplo disso seria a contratação de particulares para auxiliar a Administração na fase de preparação de decisões públicas. Porém, pode acabar existindo uma vinculação da Administração aos resultados propostos pelo particular.

Em tais casos, se a Administração não tiver condições de avaliar e receber de forma orientada os resultados obtidos pelo particular, deve-se evitar a atribuição de tal função a particulares pois implicaria indevida privatização de fato do poder público de decisão. Note-se que o ato que atribui tais tarefas pode até ser legítimo, com amparo no

\footnotetext{
${ }^{457}$ Entidades privadas com poderes públicos, 2008, p. 177 e ss.

458 Por exemplo, nos grandes espaços comerciais abertos ao público, a vigilância e o policiamento interno podem ser confiados aos proprietários das áreas sem que exista imposição nesse sentido. Há a pressuposição de que os particulares se encarregarão da vigilância e da segurança em tais áreas. No entanto, em determinados casos, tem-se verificado a imposição direta de deveres de autoproteção aos cidadãos. Como narra Florence Nicoud, a partir da lei n ${ }^{\circ}$ 95-73 de 21 de janeiro de 1995, teria sido instalada na França uma verdadeira parceria público-privada para a execução da política de segurança do Estado, para coibir a violência crescente. A lei atribui encargos específicos a alguns particulares. Por exemplo, estabelece a obrigação de estabelecimentos ou comerciantes que atuam em determinadas áreas (bancos, estádios, grandes lojas etc.) a providenciarem a vigilância privada do local, por sua conta. Como consequência, houve o desengajamento da atuação do Estado na segurança nessas áreas (La participation des personnes privées à la sécurité publique, 2006, p. 1258-1260). No direito nacional, também há exemplos de imposição formal de contratação de segurança privada, tal como se passa em relação às instituições financeiras (Lei $n^{0}$ 7.102/83, art. $\left.1^{\circ}\right)$.
} 
ordenamento jurídico. O problema está localizado no embasamento de tal ato, da sua caracterização como delegação fática do poder de decisão.

As entidades privadas podem também assumir tais funções atuando em espaços que foram deixados em aberto pela falta de preparo técnico do Estado, tal como se verifica com as funções de certificação e de inspeção no âmbito do direito comunitário europeu. Houve uma retração do Estado, que deixou de titularizar tais atividades, e os controles privados passaram a substituir os controles públicos, em uma manifestação do princípio da subsidiariedade da organização administrativa.

Em princípio, a privatização “de fato” apenas será legítima se consistir em hipótese de ativação de responsabilidades privadas, ou seja, de reforço da autorresponsabilidade privada em áreas que sempre corresponderam a atribuições e domínios próprios dos particulares ou em áreas nas quais o Estado foi formalmente liberado de atuar pelo legislador, ao retirar o caráter público da atividade. Em tais casos, a atividade a ser desempenhada pelos particulares será necessariamente privada. Não consistirá no exercício de atividades públicas.

No que diz respeito ao exercício privado de poderes públicos, reputamos que apenas poderá ocorrer mediante prévia habilitação da entidade privada.

Na lição de Bernard Geny,

o princípio da separação traçada entre atividades públicas e atividades privadas, apesar do enfraquecimento que sofre, (...) permanece no entanto em vigor como um dogma teórico, e ele se manifesta, hoje, senão por uma interdição absoluta dirigida aos particulares de se misturar em qualquer medida nos serviços públicos, quando menos pela necessidade imperativa de uma autorização formal autorizando-os a prestar seu auxílio à Administração ${ }^{459}$.

A necessidade de a habilitação prévia encontrar-se prevista em lei é analisada adiante, no item III.6.

A situação de delegação de fato acima mencionada pode ser diferenciada de possíveis delegações implícitas.

São praticamente inexistentes na lei referências expressas à delegação de prerrogativas públicas de polícia administrativa a entidades privadas. Na maioria dos casos, tem-se delegação implícita, que não é expressamente qualificada pelo legislador. Trata-se

\footnotetext{
${ }^{459}$ La collaboration des particuliers avec l'administration, 1930, p. 211. Como registra Jean-Paul Négrin, a autorização prévia seria dispensada apenas em casos excepcionais, delineados pela jurisprudência: atuação benéfica pelo particular (situação em que não há propriamente ausência de título, porque há a solicitação, aceitação implícita ou não oposição pela Administração), a teoria do funcionário de fato, a gestão de negócios e o enriquecimento sem causa (L'intervention des personnes morales de droit prive dans l'action administrative. 1971, p. 54-56).
} 
de poderes públicos cujo exercício está abrangido no plexo de atividades atribuídas às entidades privadas e que é necessário para o desempenho dos encargos transferidos.

Em princípio, a delegação implícita não deixa de ser uma verdadeira delegação se as atividades públicas que a entidade privada exercer resultarem inequivocamente do contrato e a sua delegação for autorizada pela lei. Porém, em qualquer caso, sempre é recomendável a especificação e enumeração das competências atribuídas ao particular, para que não pairem dúvidas acerca da efetiva ocorrência de delegação. 


\section{CAPÍTULO III - OS LIMITES E POSSIBILIDADES DO EXERCÍCIO DE ATIVIDADES DE POLÍCIA ADMINISTRATIVA POR ENTIDADES PRIVADAS}

Neste capítulo, identificam-se os limites intransponíveis para o exercício privado de atividades de polícia administrativa para depois se investigar as suas possibilidades, tanto no que diz respeito a particulares quanto a entidades privadas integrantes da Administração.

Procura-se inicialmente demonstrar a insuficiência do critério que diferencia atividade instrumental da atividade final da Administração, bem como de outros critérios similares, para delimitar as atividades compreendidas na polícia administrativa passíveis de serem exercidas por entidades privadas.

Depois, pretende-se propor os delineamentos dos limites e possibilidades do exercício de atividades de polícia administrativa por entidades privadas, a partir do exame dos argumentos usualmente invocados para justificar a vedação do exercício privado de tais atividades.

Por fim, examinam-se as possibilidades de delegação em relação a atividades específicas desenvolvidas no âmbito da polícia administrativa.

Neste ponto do estudo, cabe ressalvar que se optou por abordar mais especificamente os limites e possibilidades do exercício de atividades de polícia administrativa no âmbito dos contratos de delegação.

Como se procurou examinar no capítulo anterior, os contratos de delegação, em regra, implicam a transferência de atribuições mais amplas aos particulares. A delegação caracteriza-se pelo transpasse a particulares da gestão de uma atividade pública e envolve, com frequência, a transferência do exercício de poderes e prerrogativas públicas.

Já os contratos de colaboração têm objeto mais restrito, consistindo mais especificamente na execução material de determinadas prestações previamente estabelecidas, que não implicam o manejo de poderes públicos. Os contratos de colaboração não consistem em instrumento adequado para a transferência do exercício de poderes públicos a particulares. As atividades a serem desempenhadas são restritas, não demandando a assunção pelo particular da posição ocupada pela Administração perante terceiros. Portanto, em princípio, a problemática do exercício de prerrogativas e privilégios públicos por particulares apresenta-se especialmente em relação aos contratos de delegação. 
De todo modo, os limites existentes para o objeto dos contratos de delegação aplicam-se também aos contratos de colaboração. Aquilo que o particular não pode executar no âmbito de um contrato de delegação também não o poderá mediante a simples contratação de serviços, por exemplo. Determinadas atividades de polícia administrativa também poderão ser desempenhadas no âmbito de contratos de colaboração, submetendo-se aos mesmos limites aplicáveis ao objeto dos contratos de delegação.

Assim, por comportar uma amplitude maior de atribuições conferidas aos particulares, analisa-se especialmente no presente capítulo a delegação de atividades de polícia administrativa a particulares. Ao final, são traçadas considerações aplicáveis exclusivamente às entidades privadas da Administração indireta, considerando as suas especificidades.

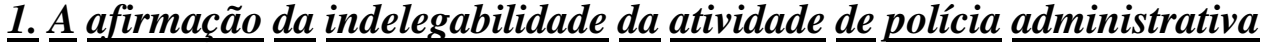

É recorrente a afirmação da indelegabilidade do exercício das atividades de polícia administrativa como sendo um princípio solidamente estabelecido no âmbito do direito administrativo.

O exercício das atividades de polícia administrativa é usualmente concebido como sendo indelegável a entidades privadas. Pode-se tomar como sendo assente na doutrina a impossibilidade de se delegar a entidades privadas funções que implicam a manifestação de poder de império do Estado. Trata-se de afirmar que a autoridade de polícia deve ser exercida diretamente pelo Estado, não sendo possível atribuí-la a uma entidade privada.

As justificativas invocadas usualmente mencionam o fato de a atividade de polícia atingir o cerne da soberania. A soberania deve ser essencialmente manifestada por atos unilaterais praticados diretamente pelo Estado. Há uma grande quantidade de manifestações doutrinárias categóricas nesse sentido ${ }^{460}$.

\footnotetext{
${ }^{460}$ Confiram-se, entre outras, as lições de José Cretella Júnior. Manual de direito administrativo, 1979, p. 256-257; Celso Antônio Bandeira de Mello. Curso de direito administrativo, 2013, p. 855; Marçal Justen Filho. Curso de direito administrativo, 2013, p. 603-604; Diogenes Gasparini. Direito administrativo, 2012, p. 187-188; Heraldo Garcia Vitta. Poder de polícia, 2010, p. 136-157; Irene Patrícia Nohara. Direito administrativo, 2013, p. 161-162; Dora Maria de Oliveira Ramos, A terceirização em matéria de poder de polícia, 2013, p. 571; Rafael Aliprandi Mendonça. A indelegabilidade do poder de polícia às sociedades de economia mista, 2011. Encontra-se referência ao "poder de polícia delegado" na obra de Hely Lopes Meirelles, que assim diferencia o poder originário do delegado: “aquele nasce com a entidade que o exerce e este provém de outra, através de transferência legal. O poder de polícia originário é pleno no seu exercício e consectário, ao passo que o delegado é limitado aos termos da delegação e se caracteriza por atos de execução. Por isso mesmo, no poder de polícia delegado não se compreende a imposição de taxas, porque o
} 
No entanto, especialmente ao se analisarem os precedentes jurisprudenciais, constata-se a existência de várias ressalvas e exceções à suposta premissa da indelegabilidade.

Para ilustrar as nuances da doutrina e da jurisprudência de acordo com as especificidades dos casos concretos, utiliza-se como exemplo a evolução do entendimento do direito francês. No curso das pesquisas realizadas, identificou-se a existência no direito francês de discussões bastante próximas daquelas que se verificam na doutrina e jurisprudência nacionais. O exercício privado de poderes públicos, especialmente no âmbito da atividade de polícia, é objeto de intensos debates pela doutrina e jurisprudência francesas $^{461}$.

Encontram-se várias referências à decisão do Conselho de Estado francês Ville de Castelnaudary ${ }^{462}$, de 1932, como sendo o precedente em que o princípio da interdição da delegação das atividades de polícia administrativa teria sido explicitamente formulado.

Nesse precedente, reputou-se ser ilegal a deliberação de um conselho municipal que ratificou a transferência da atividade de vigilância das propriedades rurais a uma associação local, que desempenharia a função por guardas privados. Reputou-se que tal atividade apenas poderia ser realizada diretamente pela Administração. Após isso, seguiram-se diversas outras decisões vedando a atribuição de atividades de polícia a entidades privadas, mediante ato unilateral ou contrato ${ }^{463}$.

poder de tributar é intransferível da entidade estatal que o recebeu constitucionalmente. Só esta pode taxar e transferir recursos para o delegado realizar o policiamento que lhe foi atribuído. Mas no poder de polícia delegado está implícita a faculdade de aplicar sanções aos infratores, na forma regulamentar, pois que isto é atributo de seu exercício" (Direito administrativo brasileiro, 2012, p. 138). Ainda que não conste expressamente da lição do autor, a menção à delegação do poder de polícia parece referir-se apenas à delegação administrativa, entre órgãos da Administração, e não para entidades privadas. Por isso, deve ser considerada com essa cautela a afirmação, por exemplo, de que a faculdade de aplicar sanções encontrar-se-ia implícita na delegação de atividades de polícia.

${ }^{461}$ Como constata Vital Moreira: “A verdade é que a figura do exercício privado de funções administrativas se tornou inerente à doutrina administrativa francesa, multiplicando-se as suas manifestações. Primeiramente aplicada aos comitês de organização das atividades econômicas criados durante a II Guerra Mundial pelo Governo de Vichy e às ordens profissionais, vieram depois juntar-se-lhes as federações desportivas, as escolas privadas reconhecidas oficialmente, os organismos interprofissionais agrícolas (sobretudo os vinícolas), entre outros” (Administração autónoma e associações públicas, 1997, p. 551).

${ }^{462}$ C.E., Ass. 17 de junho de 1932, Lebon, p. 595. Naquela oportunidade, decidiu-se que o "serviço de polícia rural por sua natureza apenas poderia ser confiado aos agentes colocados sob a autoridade direta da Administração".

${ }^{463} \mathrm{O}$ Conselho de Estado decidiu, por exemplo, a ilegalidade da atribuição a uma entidade privada da gestão do estacionamento pago em via pública (CE $1^{\circ}$ de abril 1994, Commune de Menton, Lebon 175), de serviços de vigilância e segurança de usuários de serviços públicos (CE, ass., 30 de outubro 1996, Mme Wajs et M. Monnier, Lebon 387) e de serviços de segurança e socorro nas pistas de esqui (CE, sect., 28 de abril 1967, Sieur Lafont, Lebon 182). 
Outros precedentes importantes do Conselho de Estado francês sobre a matéria são os arestos Monpeurt (1942) e Bouguen (1943), relacionados a entidades que exercem autorregulação ${ }^{464}$. Nesses casos, o Conselho de Estado reconheceu que tais entidades exerciam serviço público e desempenhavam uma missão pública, inclusive com o manejo de poderes de autoridade. Por isso, decidiu ser de competência da jurisdição administrativa o conhecimento de medidas relacionadas aos atos praticados por essas entidades. Indicou também que não consistiam em estabelecimentos públicos. No entanto, não afirmou expressamente que se tratava de entidades privadas ${ }^{465}$.

Outro precedente invocado pela doutrina é o "Amoudruz",466. O caso versou sobre a delegação dos serviços de banhos e da atribuição ao contratado de adotar diversas medidas de proteção dos usuários. Decidiu-se que essa transferência ao particular não poderia liberar a Administração da sua responsabilização em face de possível acidente ou de falta grave na execução dessas atividades pelo particular. Pode-se identificar que o eixo central da decisão não foi propriamente a indelegabilidade da atividade e sim a impossibilidade de se afastar a responsabilidade da Administração em relação à atividade exercida pelo particular.

Laubadère, ao comentar o precedente “Amoudruz”, assentou que “o poder de polícia não pode ser concedido a um particular e a Administração não pode se liberar de suas responsabilidades nesse domínio” ${ }^{, 467}$. No entanto, o mesmo autor reconhece a natureza privada das entidades e dos agentes que exercem a função de polícia sobre as atividades de caça e pesca, por exemplo ${ }^{468}$. Ou seja, não admite o exercício por particulares de atividades de polícia administrativa geral mas o admite em relação às atividades das polícias especiais e econômicas, nos termos da divisão das atividades de polícia adotada no direito francês ${ }^{469}$.

Jean-Paul Négrin esclarece que essa aparente contradição, encontrada em Laubadère e em outros autores, pode ser justificada no direito positivo francês. A ausência

\footnotetext{
${ }^{464} \mathrm{O}$ primeiro diz respeito a um comitê de organização da indústria e o segundo, ao conselho superior da ordem dos médicos.

${ }^{465}$ René Chapus. Droit administratif général, t. 1, 1999, p. 169.

${ }^{466}$ C.E., 28 de maio de 1958, Rec. 301.

${ }^{467}$ Traité de droit administratif, t. 1, 1999, p. 851. Chapus comenta o precedente "Amoudruz" da seguinte forma: "o fato de uma comuna conceder a exploração de uma praia não pode ter como consequência a transferência da autoridade comunal de polícia ao concessionário do poder de garantir a ordem pública sobre a praia” (Droit administratif général, t. 1, 1999, p. 668).

${ }_{468}^{4}$ Traité de droit administratif, t. 1, 1999, p. 852-853. Essa análise é apresentada por Jean-Paul Négrin. L'intervention des personnes morales de droit prive dans l'action administrative, 1971, p. 100-101.

469 Às associações de pesca e caça, por exemplo, constituídas como entidades privadas, foi atribuída a participação no exercício da função de polícia especial, mediante a organização da vigilância da exploração da atividade, recolhimento de taxas, imposição de regras e desempenho de atividades repressivas (J. M. Garrigou-Lagrange. Recherches sur les raports des associations avec les pouvoirs publics, 1970, p. 120-122).
} 
de previsão legal de delegação para as atividades de polícia administrativa geral conduziu à negativa dessa possibilidade. No que diz respeito às polícias especiais e econômica, há previsões legais ou regulamentares admitindo a sua transferência a particulares ${ }^{470}$. Chapus identifica como sendo uma das particularidades das polícias especiais a possibilidade de serem atribuídas pela lei a quem não exerce normalmente poder de polícia, tais como associações privadas ${ }^{471}$.

Logo, em relação às polícias especiais, o seu exercício por particulares seria mais especificamente um problema de presença ou não de autorização legal e não de

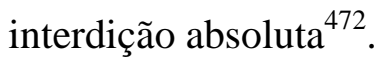

Etienne Picard também concebe a possibilidade de as atividades de polícia especial serem transferidas a particulares porque a competência é, por definição, instituída pela lei. No caso da polícia geral, a competência seria intrinsecamente vinculada ao Estado e existiria anteriormente à designação formal de seu titular pela lei. Portanto, não comporta o exercício por particulares, seja mediante atribuição pela lei ou por via contratual. Em relação às competências de polícia especial, admite-se tanto que a própria lei atribua-as a um particular quanto que, posteriormente, o titular transfira o exercício dessa competência a um particular, por via contratual, desde que a lei assim o autorize expressamente ${ }^{473}$.

Confirmando essa constatação, podem ser encontrados vários precedentes da justiça administrativa francesa que destacam a inviabilidade de delegação de atividades de

\footnotetext{
${ }^{470}$ Jean-Paul Négrin. L'intervention des personnes morales de droit prive dans l'action administrative, 1971, p. 102-103. O autor registra que podem ser localizadas previsões legais que atribuem o exercício de prerrogativas de autoridade às polícias especiais e econômica desde a metade do século XIX. Menciona diversas previsões legais que atribuem prerrogativas de autoridade de polícia a particulares no âmbito das denominadas polícias especiais (controle de estradas, ferrovias, máquinas a vapor etc.) e da polícia econômica (colaboração de sindicatos, comitês e associações na repressão a fraudes, no controle de políticas de preços ou com o poder de estabelecer regulações profissionais de observância obrigatória, por exemplo) (ob. cit., p. 107111).

${ }_{471}$ Droit administratif général, t. 1, 1999, p. 686.

${ }^{472}$ Louis Rolland teceu comentários sobre o art. 65 da lei de finanças de 27 de fevereiro de 1912, que previa a possibilidade de os sindicatos agrícolas e comerciais indicarem agentes para realizarem as funções de fiscalização e constatação de infrações à lei de repressão a fraudes. Esses agentes seriam aprovados pelo ministro competente e remunerados diretamente pelos sindicatos interessados. Essa previsão legal decorreu da solicitação dos sindicatos, que demandavam reforço na fiscalização das fraudes. O autor sustenta que esses agentes são verdadeiros servidores, apesar da sua forma de nomeação e remuneração. Rolland não reputa haver propriamente ilegalidade na atribuição dessas funções a particulares mas destaca alguns riscos envolvidos nessa sistemática, especialmente em relação à possível parcialidade no exercício da função ( $L a$ collaboration des agentes des syndicats à la repression des fraudes, 1912, p. 500-504).

${ }^{473}$ La notion de police administrative, t. II, 1984, p. 682. O autor ressalva a necessidade de se assegurar que a Administração mantenha o controle sobre tais atividades, inclusive estipulando cláusulas contratuais que estabeleçam "um controle que seja da mesma natureza estatutária daquele exercido pela autoridade de tutela ou pela autoridade hierárquica sobre a autoridade inferior” (ob. cit., p. 683).
} 
polícia administrativa pela ausência de autorização legal, sem mencionar propriamente uma interdição absoluta para a delegação ${ }^{474}$.

Em 1961, ao julgar o caso Magnier ${ }^{475}$, o Conselho de Estado assumiu um posicionamento mais claro acerca da possibilidade de entidades privadas exercerem poderes públicos delegados, na hipótese de se encontrarem na gestão de um serviço público, sob o controle da Administração. Nessa condição, o particular agiria como autoridade administrativa e produziria atos administrativos.

Com essas referências ao direito francês, exemplifica-se que o debate da questão comporta várias nuances e especificações, demandando a análise da atividade específica a ser delegada e das circunstâncias concretas da sua atribuição.

No direito nacional, ao lado da proclamação da indelegabilidade, é corrente na doutrina a afirmação de que, no que diz respeito ao exercício de atividades de polícia, poderia ser objeto de delegação a particulares o desempenho de atividades instrumentais ou acessórias.

A doutrina aceita que atos materiais ou de mera verificação ou técnicos instrumentais preparatórios ou sucessivos do exercício do poder de polícia ${ }^{476}$ ou ainda de mera execução ${ }^{477}$ sejam exercidos por entidades privadas. Justifica-se tal possibilidade porque o ato decisório, de exercício de poder de polícia propriamente dito, continuaria sendo praticado pelo poder público.

Cabe assentar não existir na legislação nacional uma vedação geral expressa à delegação a particulares de atividades compreendidas na função de polícia administrativa. Aquilo que mais se poderia aproximar de interdição legislativa à delegação é a previsão do art. $4^{\circ}$, inc. III, da Lei 11.079/04, que enuncia a "indelegabilidade das funções de regulação, jurisdicional, do exercício do poder de polícia e de outras atividades exclusivas do Estado”.

No entanto, reputamos ser necessário interpretar o dispositivo nos termos da sua locução final, que se refere às atividades exclusivas do Estado. Assim, apenas à medida que as atividades de polícia administrativa caracterizarem-se como exclusivas do Estado é que não seriam passíveis de delegação. Com isso, reafirma-se a premissa de que não são

\footnotetext{
${ }^{474}$ No precedente TA Versailles, 17 de janeiro 1986, Commissaire de la République du département de Seineet-Marne, Lebon 303, afirmou-se ser necessária a expressa autorização legal não apenas para que fosse celebrado contrato que tenha por objeto o exercício de atividades normativas de polícia, transferindo o exercício de tais competências para entidade privada, mas também para o exercício de atividades materiais de polícia.

${ }^{475}$ C.E. 13 de janeiro 1961, Rec. p. 33.

${ }^{476}$ Celso Antônio Bandeira de Mello. Serviço público e poder de polícia, 1997, p. 27; Adilson Abreu Dallari. Credenciamento mediante licitação, 1998, p. 100.

${ }^{477}$ Hely Lopes Meirelles. Direito administrativo brasileiro, 2012, p. 138.
} 
todas as atividades compreendidas na função de polícia administrativa que implicam a manifestação de poderes públicos que não sejam passíveis de exercício por particulares ${ }^{478}$.

\section{Os questionamentos $\underline{\text { da }} \underline{\text { indelegabilidade }} \underline{\text { da atividade }} \underline{\text { de }} \underline{\text { polícia administrativa }}$}

As afirmações contundentes acerca da indelegabilidade das atividades de polícia administrativa foram objeto de diversos questionamentos, ainda que nem sempre formulados diretamente.

A questão diz respeito principalmente ao fato de que as matérias ditas indelegáveis comportam parcelas que são passíveis de exercício privado. Por isso, a formulação de um conceito abstrato e amplo de indelegabilidade apresenta-se como sendo excessivo.

Em texto de 1907, Léon Duguit já afirmava que não há nenhuma função do Estado que seja insuscetível de gestão, ao menos parcialmente, por entidades privadas ${ }^{479}$. O autor rejeita qualquer distinção que se pretenda fazer entre atividades que envolvam o exercício de autoridade e aqueles em que esta não se faz presente. Por isso, nada exigiria que serviços públicos em geral, inclusive os de polícia e justiça, sejam prestados pelo Estado com exclusividade.

Contratos celebrados pela Administração, previsões legais e decisões judiciais mais recentes colocam em dúvida a permanência da ideia clássica de incompatibilidade entre polícia e contrato ${ }^{480}$. Um dos setores em que isso tem sido mais evidenciado é o da segurança. Como anota Florence Nicoud, o "princípio do monopólio da preservação da segurança pelo Estado tende a ser questionado pelo efeito de uma transferência discreta - mas progressiva e constante - de missões de segurança a cargo de operadores privados”,481.

Utilizaremos novamente exemplos do direito francês, de modo a demonstrar a evolução do seu entendimento. Apesar da afirmação contundente da indelegabilidade das

\footnotetext{
${ }^{478}$ Marcos Augusto Perez extrai do art. 10, $\S 7^{\circ}$, do Decreto-lei 200 um fundamento geral para a delegação de atividades de polícia administrativa, à medida que o dispositivo menciona as atividades de controle entre aquelas passíveis de delegação. A redação do dispositivo é a seguinte: "Para melhor desincumbir-se das tarefas de planejamento, coordenação, supervisão e controle e com o objetivo de impedir o crescimento desmesurado da máquina administrativa, a Administração procurará desobrigar-se da realização material de tarefas executivas, recorrendo, sempre que possível, à execução indireta, mediante contrato, desde que exista, na área, iniciativa privada suficientemente desenvolvida e capacitada a desempenhar os encargos de execução" (Delegação das atividades chamadas de polícia administrativa ou poder de policía, 2010, p. 43).

${ }^{479}$ De la situation des particuliers à l'égard des services publics, 1907, p. 422-423.

${ }^{480}$ Elina Lemaire. Actualité du principe de prohibition de la privatisation de la police, 2009, p. 767.

${ }^{481}$ La participation des personnes privées à la sécurité publique, 2006, p. 1249.
} 
atividades de polícia pelo Conselho de Estado, analisada acima, verifica-se uma participação cada vez mais acentuada da iniciativa privada nas atividades de segurança. Ainda que sempre tenham sido reconhecidas exceções ao exercício privado de funções de segurança, tal como a legítima defesa, sempre em caráter excepcional e subsidiário, a partir da década de 70 estaria sendo verificado um movimento sistematizado de incremento de participação privada na área de segurança ${ }^{482}$.

Um dos principais exemplos de atuação privada na área de segurança no direito francês é o da segurança aeroportuária. A sua privatização teve início com a aprovação da Lei no 89-467 de 10 de julho de 1989, que autorizava agentes particulares a promoverem a fiscalização de bagagens e outros bens, excluindo a revista de pessoas. Com a Lei $\mathrm{n}^{\circ}$ 96-151 de 26 de fevereiro de 1996, os agentes privados foram investidos de poderes de controle também em relação às pessoas. Tratava-se de uma fiscalização limitada à operação de dispositivos automáticos de controle e à revista da bagagem de mão, atividades realizadas sempre sob a supervisão de um oficial da polícia.

A substituição da segurança pública pela privada foi acentuada pela Lei $\mathrm{n}^{\circ}$ 2001-1062, de 15 de novembro de 2001, cuja edição foi motivada pelos atentados terroristas aos Estados Unidos. Esta lei ampliou os controles de agentes privados sobre pessoas, com a possibilidade de inspeção e palpação. De todo modo, a revista apenas pode ser realizada com a prévia concordância daquele que a ela se submete e supervisão de autoridade policial $^{483}$.

O Conselho Constitucional analisou a Lei no 2005-357, de 20 de abril de 2005, que transformou o estabelecimento público Aéroports de Paris em sociedade anônima, sem opor óbice à disposição que atribui a essa entidade o exercício das missões de polícia administrativa nas instalações aeroportuárias, a serem realizadas sob a autoridade dos titulares do poder de polícia ${ }^{484}$.

Dados da Confederação Europeia de Serviços de Segurança e do Instituto Nacional de Estudos de Segurança revelam que o número de agentes de segurança privada na Europa, em constante crescimento, já ultrapassou, em alguns países, o dos efetivos da segurança pública $^{485}$. A Lei francesa $n^{\circ}$ 2003-239, de 18 de março de 2003, art. 96, por

\footnotetext{
${ }^{482}$ Florence Nicoud. La participation des personnes privées à la sécurité publique, 2006, p. 1249-1251.

${ }^{483} \mathrm{O}$ Conselho constitucional reputou legítimos os poderes atribuídos às empresas privadas de segurança especialmente por se encontrarem expressamente delimitados na lei e não atentarem contra a liberdade individual (Decisão 2003-467, 13 de março de 2003).

${ }^{484}$ Loi relative aux aéroports, decisão n² 2005-513 DC de 14 de abril de 2005.

${ }^{485}$ Mandraud, La sécurité privée empiète de plus en plus sur la police en Europe, Le Monde, edição de 16 de dezembro de 2008.
} 
exemplo, autoriza expressamente a revista de pessoas por agentes privados, na entrada de recintos em que são realizados grandes eventos. Com isso, promoveu-se ampla substituição da segurança pública por agentes privados.

O exemplo do direito francês apenas ilustra uma tendência que tem sido verificada nos diversos países.

No direito nacional, a questão foi debatida com maior intensidade pelo Judiciário em relação aos conselhos profissionais. Como se analisa adiante ${ }^{486}$, o STF decidiu que a personalidade de direito público é requisito essencial para que um ente possa exercer poderes de autoridade pública. Na ADI nº 1717-6, reputou inconstitucional o art. 58 da Lei $\mathrm{n}^{0}$ 9.649/98, que pretendeu atribuir personalidade jurídica de direito privado às corporações profissionais ${ }^{487}$. Já no julgamento da ADI $n^{\circ} 3.026^{488}$, o STF reconheceu que a OAB não integra a organização administrativa estatal, direta ou indireta, e está apenas parcialmente sujeita ao regime jurídico administrativo, apesar de ser dotada de personalidade jurídica de direito público e exercer poder de polícia sobre seus membros.

O debate foi relançado com a apreciação da legitimidade do exercício de atividades de fiscalização de trânsito e aplicação de penalidades por entidades integrantes da administração indireta com personalidade jurídica privada. O STJ decidiu que a BHTRANS, sociedade de economia mista, somente poderia exercer as funções de consentimento e de fiscalização e não as de legislação e de sanção. Apenas as primeiras seriam delegáveis, por serem compatíveis com a personalidade privada ${ }^{489}$.

Ainda para exemplificar o cenário nacional, pode-se mencionar a ampla atuação da iniciativa privada nas atividades de segurança dos aeroportos, apesar de não haver legislação dispondo expressamente sobre a matéria, a exemplo do que se verificou na França. Além da operação dos equipamentos de vistoria de bagagens, as atividades de controle de passaportes e entrevistas de imigração também são desenvolvidas por

\footnotetext{
${ }^{486}$ V. item III.6.5.1.

${ }^{487}$ Rel. Min. Sydney Sanches, Pleno, j. 7.11.2002, v.u., DJ 28.3.2003.

${ }^{488}$ Rel. Min. Eros Grau, Pleno, j. 8.6.2006, maioria, DJ 29.9.2006.

${ }^{489}$ REsp n⿳0 817.534/MG, Rel. Min. Mauro Campbell Marques, 2 ${ }^{\mathrm{a}}$ T., j. 10.11.2009, v.u., DJ 10.12.2009. Em face dessa decisão, foi interposto recurso extraordinário (de $n^{\circ}$ 633.782), ainda não decidido. No STF, foi reconhecida a repercussão geral da matéria, que será apreciada no julgamento do ARE ${ }^{\circ}$ 662.186/MG, tema 532. O agravo em recurso extraordinário com repercussão geral também envolve a BHTRANS e volta-se contra a não admissão de recurso extraordinário interposto contra acórdão do TJMG que adotou entendimento similar ao exposto pelo STJ no julgamento do REsp n ${ }^{\circ} 817.634$, ou seja, de que não poderiam ser aplicadas multas de trânsito por sociedades de economia mista, sendo admitida a delegação apenas das atividades de consentimento e fiscalização. A questão constitucional identificada pelo STF foi a dos limites para a delegação, pelo município, do exercício do poder de polícia, à luz do art. 24 do Código de Trânsito Brasileiro e art. 30 da CF/88. Reconheceu que a questão constitucional subjacente extrapola o interesse das partes.
} 
particulares $^{490}$. O TCU analisou a qualidade e segurança dos controles migratório e aduaneiro nos aeroportos nacionais e determinou a substituição dos terceirizados que exercem atividades típicas de Estado por servidores de carreira ${ }^{491}$.

A crescente atribuição de atividades que envolvem o manejo de poderes públicos a particulares tem motivado a doutrina a analisar o tema mais detidamente, de modo a superar o suposto dogma da indelegabilidade. A constatação da doutrina é de que a interdição da delegação de atividades de polícia administrativa apresenta exceções cada vez mais numerosas. Nesse sentido, há doutrinadores que admitem uma delegabilidade mais ampla da atividade de polícia administrativa.

Diogo de Figueiredo Moreira Neto parte da sistematização do “ciclo de poder de polícia” por ele proposto, abrangendo as fases de ordem de polícia, consentimento de polícia, fiscalização de polícia e sanção de polícia ${ }^{492}$. Para o autor, apenas não seriam passíveis de delegação a parcela de ordem de polícia que se sujeita à reserva de lei e a atividade sancionatória, em relação à qual se aplicaria a reserva estatal de exercício da coerção. A sua conclusão é a seguinte:

Assim, tanto a delegação legal da normatividade secundária discricionária (regulática) de polícia quanto a delegação legal do exercício das atividades de consentimento e de fiscalização de polícia são compatíveis com o Estado de Direito Democrático, em que se reconhece a necessária origem popular do poder político ${ }^{493}$.

Floriano de Azevedo Marques Neto, ao analisar especificamente o tema dos limites da delegabilidade, constata que a “fórmula de que o poder de polícia é indelegável padece de dois problemas de origem: delimitar o que é exatamente, hoje em dia, poder de polícia e compreender os diversos aspectos envolvidos no exercício desse tipo de função pública” $^{\text {494. }}$.

\footnotetext{
490 “Polícia Federal S/A”, Revista Isto É, edição no 2167, 20 de maio de 2011.

${ }^{491}$ No acórdão $\mathrm{n}^{\circ}$ 1.449/2012 - Plenário, Rel. Min. Raimundo Carreiro, DOU de 13.6.2012, o TCU determinou a adoção das seguintes providências, entre outras: "9.1 determinar ao Departamento de Polícia Federal que, na qualidade de órgão responsável pela função de polícia aeroportuária, fixada no art. 144, $\S 1^{\circ}$, inciso III, da Constituição Federal: 9.1.1 elabore e encaminhe a este Tribunal, no prazo de 180 (cento e oitenta) dias a contar da ciência, plano de ação para regularizar a terceirização de serviços relacionados diretamente ao controle migratório, de modo a substituir, gradualmente e sem prejuízo à continuidade do serviço, os terceirizados que executam tarefas típicas de controle migratório por servidores do seu quadro permanente, porquanto se trata de atividade tipicamente finalística desse órgão, cuja terceirização é vedada nos termos do art. $1^{\circ}$, §2 , do Decreto 2271/97; 9.1 .2 enquanto perdurarem os contratos de terceirização que envolvam, direta ou indiretamente, serviços de controle migratório, adote as providências necessárias para garantir níveis mínimos razoáveis de supervisão dos terceirizados, por servidores de carreira, nas tarefas de controle migratório nos aeroportos internacionais, conforme os critérios definidos por esse órgão, informando a este Tribunal sobre as medidas adotadas e resultados alcançados no prazo de 90 (noventa) dias, a contar da notificação"

492 V. item I.9.

${ }^{493}$ Mutações do direito administrativo, 2001, p. 133.

${ }^{494}$ A concessão como instituto do direito administrativo, 2013, p. 564.
} 
O primeiro problema está vinculado à evolução e transformação da atividade de polícia, que se ampliou para atender as mais diversas áreas, em termos bastante abrangentes. O exercício da polícia administrativa implica não apenas medidas de constrição por comandos de abstenção mas também a disciplina dos vários aspectos da vida social e inclusive obrigações de fazer ${ }^{495}$.

Em relação à segunda questão, constata-se que a atividade de polícia envolve o desempenho de diversas funções, que não se limitam ao exercício de poderes de coerção:

Ora, se era plenamente justificável dizer, no passado, que as prerrogativas de limitar ou suprimir direitos individuais, mediante vedação de condutas e prescrição de sanções aos comportamentos discrepantes, não poderiam ser exercidas fora do ambiente do Estado-poder, hoje em dia a complexidade e a multiplicidade das funções ordenadoras torna mais difícil de se sustentar formulações tão peremptórias. Em muitos casos, a atividade ordenadora compreende o exercício de atribuições que, dentro de certos parâmetros, podem ser exercidas pelos particulares. É o que ocorre, por exemplo, com a inspeção de emissão de poluentes ou de segurança veicular ${ }^{496}$.

Ainda seguindo os ensinamentos de Floriano de Azevedo Marques Neto, o autor adota a separação das atividades do ciclo de polícia, nos termos propostos por Diogo de Figueiredo Moreira Neto, para analisar a possibilidade de delegação em relação a cada uma delas. Ao final, conclui que os particulares não podem exercer o poder normativo primário nem atividades coercitivas. Constata que podem ser objeto de delegação a atividade normativa infralegal e as atividades adjudicatórias e de acompanhamento ou fiscalização ${ }^{497}$.

Em sentido similar, Marçal Justen Filho afirma a inviabilidade de transferência a terceiros do exercício da competência normativa e da coerção física em face de terceiros ${ }^{498}$.

Portanto, ainda que seja recorrente a afirmação da indelegabilidade da atividade de polícia, encontram-se, cada vez com maior frequência, ressalvas e exceções, admitindo a delegação de várias atividades. Constata-se, assim, a inviabilidade de se tratar a matéria a partir da enunciação de um princípio geral de indelegabilidade, sendo necessário analisar separadamente os limites e possibilidades de delegação em relação às atividades específicas.

\footnotetext{
495 Ob. cit., p. 564-565.

${ }^{496}$ Ob. cit., p. 565.

${ }^{497}$ Ob. cit., p. 566-568.

${ }^{498}$ Teoria geral das concessões, 2003, p. 102.
} 


\section{3. $\underline{\text { exercício privado de funções públicas }}$}

Ainda no contexto da admissão do exercício de poderes públicos por particulares, cabe registrar que esse tema é objeto de tratamento pela doutrina administrativista há bastante tempo ${ }^{499}$. O tema é usualmente analisado sob a forma de atuação de particulares em colaboração com a Administração, no exercício privado de funções públicas.

Na lição de Zanobini, o exercício privado de funções e serviços públicos é “toda forma de atividade privada, através da qual venham a realizar fins próprios do Estado, ou em geral de um ente público" ${ }^{500}$. Consiste em atividade privada, desenvolvida por particulares, e tal qualidade dos sujeitos não muda, ainda que os fins perseguidos sejam públicos. Ou seja, a atividade é privada, sob o ponto de vista do sujeito que a desenvolve ${ }^{501}$. No exercício privado de função pública, o sujeito que persegue um fim público age em nome próprio. Não é, portanto, representante nem órgão do Estado ${ }^{502}$.

O exame do exercício privado de funções públicas demonstra que não se trata de fenômeno recente na organização administrativa. No período anterior ao Estado moderno, admitia-se o desempenho da função administrativa também por entidades privadas, que exerciam poderes de autoridade. Guido Zanobini ${ }^{503}$ e Almiro do Couto e Silva $^{504}$ identificam a realização de tarefas públicas por particulares, de natureza administrativa e jurisdicional, no período romano. A partir do período feudal, todas as atividades do Estado passaram a ser transferidas a pessoas e associações privadas sob a forma de concessão. Essa possibilidade de transferência era considerada um direito privado e pessoal do príncipe. Exemplo disso são as amplas competências atribuídas às companhias de colonização ${ }^{505}$.

\footnotetext{
${ }^{499}$ A esse respeito, são obrigatórias as referências às obras precursoras de Guido Zanobini. L'esercizio privato delle funzioni e dei servizi pubblici, 1935, p. 235-682 e Bernard Geny. La collaboration des particuliers avec l'administration, 1930.

${ }^{500}$ L'esercizio privato delle funzioni e dei servizi pubblici, 1935, p. 235.

${ }^{501}$ Fernando Garrido Falla. Tratado de derecho administrativo, v. I, 1994, p. 366.

${ }^{502}$ Guido Zanobini. L'esercizio privato delle funzioni e dei servizi pubblici, 1935, p. 236.

${ }^{503} \mathrm{O}$ autor menciona que um dos exemplos mais antigos do exercício privado de função pública é o dos arrecadadores de tributos do direito romano (os pubblicani e os conductores vectigalium) (ob. cit., p. 242).

504 “A delegação a particulares de tarefas públicas, de natureza jurisdicional ou administrativa, foi na Roma antiga uma consequência natural das circunstâncias. O tamanho do Estado romano dos primeiros tempos, e cujo crescimento não acompanhou o ritmo da expansão política e comercial da nação, exigia que assim fosse” (Os indivíduos e o Estado na realização de tarefas públicas, 2003, p. 190).

${ }^{505}$ As concessões coloniais consistiam em uma concessão que tinha por objeto o exercício de poderes de soberania. Nas concessões coloniais, transferiam-se a grandes companhias comerciais todos os poderes públicos: cobrança de tributos, conservação da ordem pública, edição de leis, administração da justiça, declaração e condução de guerras. Todas essas competências como causa e conteúdo principal da concessão, seu objeto imediato. Enfim, eram atribuídos todos os poderes necessários para governar e administrar os
} 
No período moderno, determinadas atividades foram reconduzidas para a esfera de competência exclusiva do Estado. Com a afirmação do Estado liberal e da separação entre Estado e sociedade, assentada no monopólio da administração pública pelo Estado, passaram a ser admitidas apenas algumas situações excepcionais de exercício privado de atividades administrativas.

Os exemplos trazidos nas obras precursoras sobre o exercício privado de função pública são relativamente restritos, considerando-se a posterior ampliação da participação privada no desenvolvimento de atividades administrativas. Os doutrinadores pioneiros no exame da matéria referem-se a diversos profissionais, tais como os notários e registradores, os leiloeiros e tradutores oficiais, os comandantes de navios e aeronaves e os concessionários de serviço público.

Logo, o exercício privado de funções públicas consiste em categoria extremamente heterogênea, na qual estão compreendidos particulares, externos à organização administrativa, que desempenham função pública, com prerrogativas de autoridade e amparo nos mais diversos títulos jurídicos. As hipóteses de exercício privado de funções públicas não são agrupáveis em uma única categoria, havendo significativas diferenças entre as suas diversas manifestações.

Considerando-se a grande diversidade entre as figuras compreendidas no exercício privado de funções públicas, Santamaría Pastor extrai duas características que seriam comuns a todos eles ${ }^{506}$.

A primeira delas consiste no fato de a atividade desempenhada consistir em função pública em sentido estrito e não uma simples atribuição de interesse público. Disso decorre que a atuação apresenta eficácia jurídico-pública ou representa a prestação de serviço público em sentido estrito.

A segunda característica reside no exercício dessa função pública pelo particular com meios e em nome próprio, não sendo a sua atividade imputável à Administração. Assim se passa sem prejuízo do controle a ser exercido pelo poder público sobre os atos do particular.

Portanto, o “exercício privado de funções públicas” reporta-se a particulares que agem em nome próprio, executando funções ou ofícios públicos que lhes são imputados como próprios. A sua relevância reside na atividade que desenvolvem, que é uma função pública propriamente dita.

territórios concedidos, poderes estes exercidos sob o controle do Estado colonizador (Guido Zanobini. L'esercizio privato delle funzioni e dei servizi pubblici, 1935, p. 557 e s.).

${ }^{506}$ Principios de derecho administrativo, v. I, 1998, p. 431. 
Porém, diante da grande diversidade das atividades englobadas nessa categoria, não há como se estabelecer um regime jurídico uniforme que lhe seja aplicável.

Passa-se, assim, a tecer considerações aplicáveis mais especificamente às atividades de polícia administrativa.

\section{4. $\underline{\text { A execução }} \underline{\text { de }} \underline{\text { atividades }} \underline{\text { materiais, }} \underline{\text { instrumentais }} \underline{\text { ou }}$ acessórias por entidades privadas}

São usuais as manifestações no sentido da possibilidade de desenvolvimento por entidades privadas de atividades instrumentais ou acessórias ao exercício das atividades de polícia administrativa.

Esse é o entendimento, por exemplo, de Celso Antônio Bandeira de Mello. Ao discorrer acerca da execução de atos de polícia administrativa, o autor conclui que, por serem atos de autoridade, não podem ser atribuídos a particulares, em princípio. Porém, apresenta a seguinte ressalva: "Daí não se segue, entretanto, que certos atos materiais que precedem atos jurídicos de polícia não possam ser praticados por particulares, mediante delegação, propriamente dita, ou em decorrência de um simples contrato de prestação” ${ }^{\text {„507. }}$.

Mas a dificuldade reside em se estabelecer com precisão quais seriam os limites entre atividades de polícia administrativa propriamente ditas e atos acessórios, instrumentais ou materiais. Além disso, muitas das atividades usualmente consideradas como sendo meramente acessórias ou instrumentais acabam sendo decisivas e determinantes para a prática daquele que é considerado como sendo o ato final da função de polícia.

Faz-se necessário analisar os critérios que poderiam ser utilizados para a identificação dessas atividades materiais e acessórias para então se avaliar a utilidade dessa dicotomia para a definição das atividades passíveis de exercício privado.

Cabe ressalvar que os atos materiais preparatórios ou sucessivos da atividade de polícia administrativa que podem ser desempenhados por entidades privadas são apenas aqueles que se relacionam com a propriedade dos administrados, sendo vedados aqueles relativos à sua liberdade ${ }^{508}$. Logo, ainda que não se faça referência expressa, os atos materiais de que se trata nos itens seguintes dizem respeito apenas à propriedade.

\footnotetext{
${ }^{507}$ Curso de direito administrativo, 2013, p. 855 - grifos no original.

${ }^{508}$ Celso Antônio Bandeira de Mello. Curso de direito administrativo, 2013, p. 586.
} 


\subsection{Os atos materiais, os atos jurídicos e a atividade técnica da Administração}

Os atos acessórios e instrumentais da Administração costumam ser equiparados aos atos materiais e à atividade técnica. Faz-se necessária, assim, a diferenciação desses conceitos.

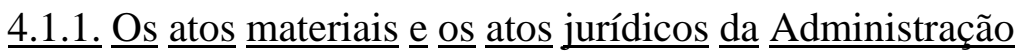

A doutrina propõe a separação entre atividade jurídica e atividade material da Administração, sendo esta considerada não-jurídica.

Os atos jurídicos caracterizam-se pelo fato de consistirem em declaração de vontade. Essa declaração não é necessariamente manifestada formalmente enquanto tal, podendo ser expressa também mediante comportamentos e condutas que revelam determinada posição, vontade ou juízo ${ }^{509}$. Nisso diferenciam-se das atividades puramente materiais.

Para Celso Antônio Bandeira de Mello, os atos materiais da Administração são desprovidos de conteúdo jurídico. Nem sequer consistiriam em atos jurídicos, não havendo sentido em qualificá-los como atos administrativos. Para o autor, essas condutas exclusivamente materiais da Administração poderiam ser consideradas como "fatos administrativos $\$$, 510 .

Cretella Júnior define fato administrativo como "toda atividade material ou todo desempenho de funções práticas do agente público; toda prestação de serviço público com efeitos práticos, no interesse da pessoa jurídica a que se filia o agente; todo ato

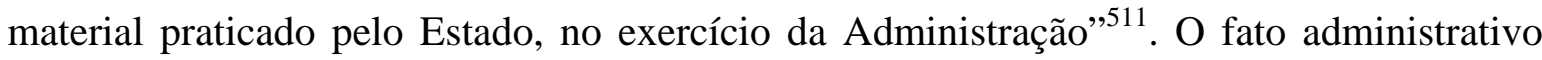
consiste na consequência de ato administrativo anterior. Não pode subsistir por si só, sendo expressão de um ato administrativo.

Segundo Hely Lopes Meirelles, “o fato administrativo, como materialização da vontade administrativa, é dos domínios da técnica" ${ }^{\text {"512 }}$. O fato administrativo seria o resultado de um ato administrativo anterior, que o determina. $\mathrm{O}$ autor ressalva que o fato

\footnotetext{
${ }^{509}$ Eduardo García de Enterría e Tomás-Ramón Fernández. Curso de derecho administrativo, v. I, 2002, p. 545 .

${ }^{510}$ Curso de direito administrativo, 2013, p. 388. O autor assim diferencia os atos jurídicos dos fatos jurídicos: “Atos jurídicos são declarações, vale dizer, são enunciados; são 'falas’ prescritivas. O ato jurídico é uma pronúncia sobre certa coisa ou situação, dizendo como ela deverá ser. Fatos jurídicos não são declarações; portanto, não são prescrições. Não são falas, não pronunciam coisa alguma. O fato não diz nada. Apenas ocorre. A lei é que fala sobre ele.” (ob. cit., p. 378 - grifos no original).

${ }^{511}$ Direito administrativo brasileiro, v. 1, 1983, p. 238. Ainda nas palavras do autor, as operações técnicas e materiais da Administração, denominadas fatos administrativos, não apresentariam nenhum traço de juridicidade (ob. cit., p. 239-240).

${ }^{512}$ Direito administrativo brasileiro, 2012, p. 158.
} 
administrativo pode produzir consequências jurídicas para a Administração e os administrados. A prática de um ato material, por exemplo, pode causar danos a terceiros, dando ensejo à responsabilização civil.

Em sistematização próxima às dos demais autores, Weida Zancaner também propõe a divisão das atividades estatais em atividades materiais e atividades jurídicas ${ }^{513}$. Porém, destaca a existência de uma relação mais profunda entre atos materiais e jurídicos.

Segundo a autora, as atividades materiais seriam o serviço público, os serviços sociais e os serviços técnicos. Já as atividades jurídicas seriam a legislação, a jurisdição e o exercício do poder de polícia. As atividades jurídicas, diferentemente do que se passa em relação às atividades materiais, não poderiam ser exercidas por particulares. Porém, Weida Zancaner ressalva que todas as atividades materiais incluiriam uma parcela de atividade jurídica e vice-versa:

O Estado presta, portanto, atividades materiais e atividades jurídicas e é importante frisar que para prestar atividades jurídicas ele precisa implementar atividades materiais, e que o reverso também é verdadeiro, ou seja, para prestar atividades materiais terá, forçosamente, que implementar, ao menos instrumentalmente, atividades jurídicas ${ }^{514}$.

Adilson Dallari também diferencia estes dois âmbitos de atuação: “uma coisa é expedir uma licença (ato jurídico) para dirigir veículo a motor; outra coisa é verificar em concreto (ato material) se uma pessoa tem ou não habilidade prática para dirigir veículo a motor ${ }^{\text {515. }}$.

Em todas essas formulações, ainda que voltadas a diferenciar a atividade material do ato jurídico, acaba sendo evidenciado o vínculo entre eles, à medida que o segundo geralmente pressupõe a primeira e vice-versa.

Giannini formula a sua crítica à classificação dos atos administrativos em jurídicos e materiais considerando justamente a premissa acima indicada, de que os atos jurídicos demandam uma atuação material. Nas palavras do autor, "todo ato jurídico postula e pressupõe atividade material: é questão apenas de quantidade” ${ }^{516}$. Por isso, conclui que “todos os atos materiais são atos jurídicos”517, ressalvando que importância jurídica tem o ato que qualifica a atividade material e não a atividade material em si.

Concordamos com a crítica de Giannini, no sentido de não ser possível promover-se uma dissociação absoluta entre os atos materiais e os atos jurídicos da

\footnotetext{
513 O perfil jurídico do credenciamento, 2013, p. 790-792.

${ }^{514}$ Ob. cit., p. 792 - grifos no original.

${ }^{515}$ Credenciamento mediante licitação, 1998, p. 100.

${ }^{516}$ Lezioni di diritto amministrativo, v. 1, 1950, p. 109.

${ }^{517}$ Ob. e loc. cit.
} 
Administração. Mais precisamente, reputamos que não se pode retirar a relevância da atividade material da Administração, inclusive para fins de se avaliar a possibilidade de ser desempenhada por entidades privadas.

A atividade material usualmente encontra-se acompanhada de atos jurídicos, que refletem as decisões da Administração e não podem ser simplesmente dissociados da atuação material. São poucos os atos que retratam simplesmente a execução de uma atividade material, tendo sido todos os seus aspectos jurídicos determinados em momento anterior. No momento da execução da atividade material, com frequência, demanda-se também a prática de atos jurídicos, ainda que em menor medida.

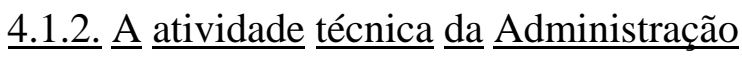

Nesse contexto, cabe analisar também a denominada atividade técnica da Administração. Alguns doutrinadores incluem a atividade técnica na categoria da atuação material da Administração e outros dela tratam em separado, conferindo-lhe características diferenciadas.

Para Giannini, a atividade técnica decorre da aplicação de critérios oriundos da ciência técnica. Estaria mais relacionada à ciência da organização do que ao direito. A rigor, toda a atividade administrativa seria atividade técnica, de aplicação de conceitos técnicos ${ }^{518}$. O autor registra que a atividade técnica adquiriu relevância jurídica porque se passou a utilizar o termo discricionariedade técnica para indicar a margem de liberdade que a norma deixava para o aplicador em se tratando da utilização de noções da disciplina técnica ${ }^{519}$.

Garrido Falla também diferencia a atividade técnica das atividades material e jurídica, ao classificar a atividade administrativa de acordo com o seu conteúdo ${ }^{520}$. Para o autor, a atividade administrativa de natureza técnica consistiria em uma parcela da atividade material da Administração, “aquele tipo de atividade cuja realização supõe a aplicação de critérios proporcionados por disciplinas do tipo técnico” ${ }^{\text {251 }}$. Destaca que uma das principais questões envolvendo as atividades técnicas é o fato de que atos fundados precipuamente

\footnotetext{
${ }^{518}$ Lezioni di diritto amministrativo, v. 1, 1950, p. 110.

519 Para Giannini, a discricionariedade técnica não se confunde com a discricionariedade administrativa. Ao discorrer sobre a denominada discricionariedade técnica, assenta que, "na verdade, essa atividade não é nada discricionária; não é ponderação de interesses, ou juízo de oportunidade: é uma pura e simples aplicação de normas e regras técnicas, que conduzem a solução unívoca enquanto científica” (ob. cit., p. 110). Sobre o tema da discricionariedade técnica, v. item I.7.2.

${ }^{520}$ Tratado de derecho administrativo, v. II, 1992, p. 118.

${ }^{521}$ Ob. e loc. cit. Para diferenciar a atividade material da técnica, em termos bastante práticos, o próprio autor faz a analogia com os funcionários administrativos, que desempenhariam a atividade material, e os funcionários técnicos de uma empresa.
} 
nos conhecimentos técnicos do agente que o pratica são considerados atividade administrativa, imputável à Administração - inclusive para fins de responsabilização ${ }^{522}$.

García de Enterría e Tomás-Ramón Fernández propõem o afastamento da atividade técnica do âmbito da Administração, inclusive tratando-a como uma atividade sujeita a regime jurídico distinto.

Segundo os autores, os atos materiais e técnicos têm fundamento em atos jurídicos, que podem ser antecedentes, subsequentes ou concomitantes aos atos materiais e técnicos. Consistem no exercício de algum direito ou liberdade reconhecida pelo direito. No entanto, não seriam aptos, por si sós, a produzir algum tipo de alteração da situação jurídica existente. Logo, os atos puramente materiais e técnicos da Administração não poderiam implicar nenhuma modificação de situações jurídicas ou a produção de efeitos jurídicos específicos, decorrentes da sua emanação ${ }^{523}$. Caso contrário, devem ser qualificados como atos jurídicos.

Diferentemente de Garrido Falla, García de Enterría e Tomás-Ramón Fernández sustentam que o autor da atividade técnica não seria propriamente a Administração e sim o agente físico que a executa ${ }^{524}$. Os autores ressalvam que isso não implicaria o afastamento da responsabilidade da Administração por esses atos, à medida que a atividade foi ordenada e dirigida por ela, que também se apropria dos seus frutos ${ }^{525}$. Essa responsabilidade é direta, seja pela Administração ser a titular da organização em que esses atos se integram e em nome da qual foram praticados, seja em atenção aos direitos de terceiros.

Como se indicou, é usual sustentar-se que apenas poderiam ser desenvolvidos por entidades privadas os atos materiais, de simples execução, que não implicariam o exercício de poder de decisão.

Pelos apontamentos acima, já é possível identificarem-se algumas das questões problemáticas relativas ao exercício de atividades de polícia administrativa por entidades privadas. Uma delas é a constatação de que o desempenho inclusive de atividades meramente materiais é apto a produzir repercussões jurídicas e influenciar o exercício da função pública em si. Outra questão é a dificuldade de a Administração exercer controle efetivo sobre a atividade técnica, que é fundada principalmente nos conhecimentos

\footnotetext{
522 Ob. e loc. cit.

523 Eduardo García de Enterría e Tomás-Ramón Fernández. Curso de derecho administrativo, v. I, 2002, p. 815.

${ }^{524}$ Curso de derecho administrativo, v. I, 2002, p. 815-818.

${ }^{525}$ Ob. cit., p. 817.
} 
especializados do sujeito que a exerce. Essas questões serão consideradas adiante, ao se analisarem os limites do exercício de atividades de polícia administrativa por entidades privadas.

\subsection{Os atos decisórios e os atos preparatórios ou de mera execução}

São recorrentes também as manifestações no sentido de que poderia ser atribuída a entidades privadas a simples preparação ou execução de atividades de polícia administrativa, à medida que não envolveria a manifestação de poder decisório. O manejo ou não de poder decisório é que consistiria no critério adequado para a identificação das atividades passíveis de delegação.

Na atuação administrativa, podem ser identificados os atos principais, que traduzem o exercício da competência atribuída à Administração. A produção destes atos pressupõe o desenvolvimento de atos preparatórios e de mera execução, que integram o processo administrativo. Para parcela da doutrina, a intervenção de entidades privadas poderia tanto ocorrer na fase de preparação quanto na de implementação de uma atividade pública, desde que não esteja envolvido poder de decisão. Esse tema encontra-se estritamente vinculado ao abordado no item anterior, à medida que os atos instrumentais, acessórios ou materiais consistem geralmente em atos preparatórios ou de mera execução.

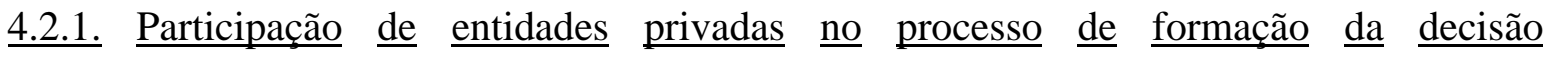 administrativa}

Analisa-se inicialmente a atribuição à iniciativa privada da prática de atos que antecedem o ato decisório da Administração.

A participação de entidades privadas na preparação de decisões públicas pode gerar maiores controvérsias em face do risco de se configurar uma delegação fática de função pública, por não se transferir formalmente, por exemplo, a responsabilidade pela instrução do processo administrativo.

Em princípio, a atribuição a entidades privadas de atividades de preparação de uma decisão administrativa dependeria de expressa autorização legal, por implicar verdadeira delegação de exercício de função pública ${ }^{526}$.

Porém, pode ser demandada a colaboração de entidades privadas no desenvolvimento de atividades específicas, tais como a elaboração de pareceres e laudos técnicos. É o que ocorre, por exemplo, em determinados modelos de delegação utilizados

\footnotetext{
${ }^{526}$ Sobre a exigência de autorização legal, v. item III.6.
} 
para a inspeção de veículos. As entidades responsáveis pela inspeção realizam apenas atos preparatórios da decisão administrativa, sendo que a decisão final acerca da aprovação ou reprovação do veículo cabe a uma autoridade pública. Os atos praticados pelos particulares não são aptos a produzir efeitos jurídicos imediatos na esfera do proprietário do veículo, pois a decisão final apenas poderá ser adotada pela autoridade competente. Em princípio, tal expediente não estaria vedado, considerando-se inclusive que a Administração não dispõe das condições materiais e técnicas necessárias para desempenhar diretamente tais atividades.

Mas o risco envolvido na execução privada de tais atividades, qualificadas como instrumentais ou acessórias, é o de que, como a Administração não teve condições técnicas de produzir tais atos, possivelmente também não tem a possibilidade de recepcionar criticamente os resultados dos trabalhos realizados por entidades privadas e de corrigi-los, se for o caso. Em alguma medida, isso poderia implicar a perda do "controle do procedimento” pela Administração, pois ficaria vinculada de fato às premissas técnicas assentadas na atividade desenvolvida por entidades privadas, podendo fazer apenas a revisão no que se refere ao procedimento observado pela entidade privada.

Em tal hipótese, poderá haver privatização de fato do poder público de decisão porque, em termos práticos, o teor da deliberação acaba dependendo das convicções de entidades privadas - com o risco que isso envolve de que as conclusões técnicas expostas não tenham sido adotadas com a imparcialidade necessária. A Administração encontrar-se-ia vinculada, em termos fáticos, aos resultados apresentados pelas entidades privadas. Em última análise, a decisão pública seria proveniente de convicções formadas por entidades privadas.

Para evitar problemas dessa ordem, uma das soluções a ser considerada consiste na necessidade de autorização legal e de atribuição formal ao particular da responsabilidade pelos atos praticados no processo de formação da decisão administrativa. Os critérios, requisitos e procedimentos a serem observados pelo particular deverão ser detalhadamente previstos no contrato.

Com a formalização de um vínculo contratual com a entidade privada, impondo-lhe deveres e parâmetros obrigatórios a serem observados na sua atividade, apesar de a Administração não ter condições de recepcionar criticamente todos os resultados técnicos, poderia, quando menos, exercer o controle jurídico sobre os resultados produzidos pela entidade privada. Diante da impossibilidade de se realizar o controle efetivo diretamente sobre o resultado, a delegação formal da atividade ao particular permitiria a 
sindicabilidade do procedimento e critérios a partir dos quais os resultados foram produzidos.

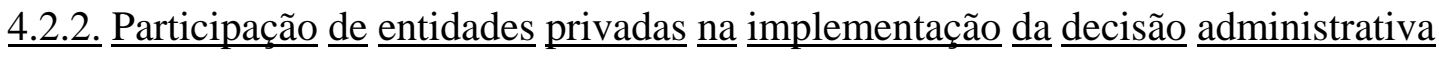

A participação privada estritamente na execução de medidas de polícia administrativa, em tese, é apta a gerar menos polêmicas por envolver precipuamente a realização de atividades materiais. Consistiria na atribuição a entidades privadas da execução de decisões previamente tomadas, com a prática de atividades meramente executivas.

Porém, em termos concretos, nem sempre a fase preparatória e a tomada de decisão podem ser dissociadas com precisão da sua implementação. Atividades de fiscalização do trânsito, por exemplo, podem envolver também, em alguma medida, a aplicação de critérios jurídicos para se identificar a necessidade ou não da atuação material. A definição do momento e do modo de intervenção da entidade privada, para fins de prática de atos materiais, pode demandar a consideração simultânea de aspectos jurídicos.

Em princípio, não há óbices mais relevantes para a atribuição a entidades privadas da realização de atividades materiais, auxiliares da atividade sancionatória, por exemplo, que continuaria sendo de responsabilidade da Administração.

Porém, contratações mais amplas, que impliquem, por exemplo, a atribuição a entidades privadas da execução de um conjunto de atividades públicas de fiscalização pode envolver a delegação do exercício de função pública. Neste caso, deixaria de se tratar de simples execução de atividades instrumentais ou acessórias. Assim se passaria com a atribuição de fiscalização de obras públicas e de controle de trânsito, que não sejam realizados exclusivamente por equipamentos eletrônicos e que demandem alguma intervenção humana. Poderiam implicar então, a delegação do exercício de função pública. Disso não decorre a vedação de tal delegação mas acarreta a necessidade de se observarem determinados requisitos e limites, que são analisados adiante.

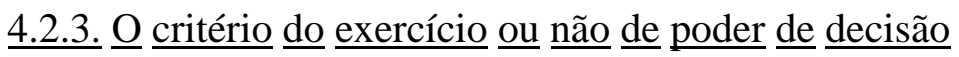

Uma das manifestações de competências da Administração é o poder de decisão unilateral, utilizado para a decisão de casos individuais e concretos.

Esse poder permite que a Administração determine a sua própria conduta bem como a conduta alheia, com a possibilidade de definir unilateralmente a situação, sem 
a necessidade de obter o acordo do interessado ${ }^{527}$. A decisão adotada pela Administração é obrigatória para os particulares.

Como se indicou, alguns sustentam que poderiam ser atribuídas a entidades privadas a simples preparação ou execução de atividades de polícia administrativa. A justificativa para tanto seria a de que tais atos não envolveriam manifestação de poder de decisão.

Em alguma medida, o critério do trespasse ou não de poder de decisão acaba produzindo resultados equivalentes aos da distinção proposta entre atividades materiais e jurídicas. É o que pode ser extraído do posicionamento dos doutrinadores que propõem esse critério e equiparam, em alguma medida, os atos em que o poder de decisão não se faz presente à atividade material da Administração.

Celso Antônio Bandeira de Mello indica especificamente a ausência de exercício de poder decisório, ao lado da não aplicação da coerção, como aspectos a serem considerados para se identificar a possibilidade de delegação. Ao comentar a execução de atividades materiais de fiscalização de trânsito, com a aplicação de critérios objetivos, o autor assenta que

não há nisto atribuição alguma de poder que invista os contratados em qualquer supremacia engendradora de desequilíbrio entre os administrados, pois não está aí envolvida expedição de sanção administrativa e nem mesmo a decisão sobre se houve ou não violação de norma de trânsito, mas mera constatação objetiva de um fato ${ }^{528}$.

Fernando Vernalha Guimarães também propõe a distinção entre as atividades de polícia administrativa passíveis ou não de delegação de acordo com o exercício de poder decisório:

A delimitação do tratamento jurídico das hipóteses, portanto, haverá de passar por uma demarcação entre o exercício decisório que se verifica na atuação exclusiva da Administração Pública em promover a ação de polícia (não só no âmbito abstratonormativo, mas, ainda, quanto a decisões concretas e específicas), e o exercício de mera execução, por particulares, acerca de tarefas (materiais) decorrentes (ou preparatórias) da manifestação decisória da Administração. Uma coisa é decidir acerca do conteúdo jurídico e político da manifestação da polícia administrativa, competência reservada indelegavelmente à Administração, outra é promover a mera execução, preparatória ou sucessiva, acerca do que foi (ou será) deliberado pela autoridade pública. Apanha-se uma distinção quanto à natureza das atividades exercidas: uma, de origem decisória (envolvendo exame de mérito); a outra, de cunho (restritamente) executivo ${ }^{529}$.

No mesmo sentido, Alexandre Jorge Carneiro da Cunha Filho sustenta que os particulares apenas podem praticar determinados atos de polícia administrativa, “desde

\footnotetext{
${ }^{527}$ Diogo Freitas do Amaral. Curso de direito administrativo, v. II, 2006, p. 21-22.

${ }^{528}$ Curso de direito administrativo, 2013, p. 856 - grifos no original

${ }^{529}$ Parceria público-privada, 2013, p. 254-255 - grifos no original.
} 
que não inseridos no que alguns chamam de momentos de poder ou de decisões relevantes no âmbito da competência discricionária da Administração"530.

Reputamos que a aplicação dessa classificação também não é completamente satisfatória para se diferenciarem os atos passíveis de delegação em todas as situações. Caso se repute que os atos preparatórios e sucessivos de decisões administrativas consistem única e exclusivamente em atos materiais, no sentido de fato administrativo acima exposto, acaba-se excluindo uma grande quantidade de atos que, ainda que não retratem uma decisão do poder público propriamente dita, não são irrelevantes em termos jurídicos.

\subsection{A dificuldade de aplicação do critério da delegabilidade de atividades instrumentais, acessórias, materiais e de mera execução}

A aplicação das construções teóricas que diferenciam os atos materiais, instrumentais, acessórios ou de mera execução daqueles atos que manifestam o exercício de atividades de polícia propriamente ditas demandaria a distinção nítida entre essas duas categorias de atividades $^{531}$.

Porém, essas construções teóricas nem sempre encontram fácil aplicação nos casos concretos. A diferenciação entre atos principais e atos preparatórios ou de mera execução é bastante controversa. A possibilidade de distinção de atos preparatórios do ato principal não significa necessariamente que os primeiros sejam despidos de importância jurídica. Os atos preparatórios podem ser determinantes para o conteúdo do ato principal, o que pode dar ensejo a dúvidas relativamente aos limites para a sua delegação.

Dora Maria de Oliveira Ramos adota uma posição restritiva, ao rejeitar a qualquer ato de fiscalização e de verificação de infração a qualificação como ato instrumental da atividade de polícia ${ }^{532}$. Essa interpretação é condizente com a afirmação de

\footnotetext{
${ }^{530}$ Poder de polícia, 2013, p. 178 - grifos no original.

531 Essa proposta de separação encontra-se retratada, por exemplo, na seguinte passagem: "O ato da autoridade de dizer 'sim ou não’, 'defiro ou indefiro', ‘concedo ou não concedo', em suma, a remoção do obstáculo jurídico, que consubstancia a limitação (a restrição, o condicionamento) do exercício de liberdades e do direito de propriedade, não se confunde com as diligências que a Administração Pública é obrigada a oferecer ao administrado, atos estes que culminarão com a edição do ato administrativo de polícia” (Vittorio Constantino Provenza. Parecer, 1997, p. 363).

532 O posicionamento da autora é evidenciado com o seguinte exemplo: "Pode um agente público, no exercício da atividade de fiscalização, constatar a infração de trânsito em decorrência, por exemplo, de estacionamento irregular em local proibido. Em cumprimento à ordem legal, determina, então, a remoção compulsória do veículo da via pública. Emitida a ordem, a execução material dela poderá ser feita por particular previamente qualificado pelo poder público. Uma empresa privada pode, assim, retirar o veículo da via e guardá-lo em local apropriado, até que o proprietário possa retirá-lo. Cuida-se, nesse caso, de permitir ao particular a mera execução de ato material acessório. Não se concebe que um particular, ainda que previamente autorizado pelo Poder Público, constate ele mesmo a ocorrência da infração e remova o veículo compulsoriamente porque, nesse caso, estaria executando ato próprio de autoridade, que o ordenamento
} 
que apenas seriam passíveis de delegação atos materiais, afastando-se qualquer possibilidade de prática de atos jurídicos por entidades privadas.

No entanto, ao se analisar significativa parcela dos atos ditos materiais praticados no exercício da atividade de polícia administrativa, inicialmente reputados como de simples preparação ou execução de decisões de polícia, constata-se que envolvem também, em alguma medida, a prática de atos jurídicos por particulares.

A esse respeito, cabe transcrever a acertada constatação de Fernando Vernalha Guimarães:

em muitas situações será extremamente difícil na prática delimitar e distinguir, no bojo da manifestação estatal, as atividades de decisão daquelas de mera execução. Há por vezes uma dificuldade em se afirmar uma distinção rigorosa (e útil a possibilitar a delimitação de tratamentos jurídicos) entre uma ação de decidir e uma ação de executar materialmente o que fora decidido. O problema fica reconduzido a uma gradação da margem de interferência privada no desempenho das ações de polícia e daquelas de cunho imperativo e coativo. As soluções somente poderão buscar-se nos casos concretos e a partir da modelagem dos arranjos negociais entre a Administração e os privados ${ }^{533}$.

Diante da impossibilidade de se adotar para todos os casos um critério genérico e abstrato, a distinção entre o exercício de atividades meramente materiais e a delegação de exercício da atividade pública em si depende do exame específico das atribuições da entidade privada. A questão passa muita mais por uma diferença gradativa entre as atividades que são puramente materiais até aquelas que comportam essencialmente o exercício de poder de decisão estratégico. Nos graus intermediários, é necessário examinar as competências especificamente implicadas em cada caso para se determinar a sua delegabilidade ou não.

\subsection{Observações finais}

Constata-se que as classificações dos atos de polícia administrativa em instrumentais, acessórios ou materiais e principais, para se admitir o exercício privado apenas dos primeiros, não refletem adequadamente todas as variações que podem se apresentar nos casos concretos.

Em alguns casos, a participação do particular configurará de fato a prática de meros atos materiais. Seria o caso da contratação de guincho para a remoção de veículo, em casos em que a determinação de remoção resulta exclusivamente de atos praticados pelo próprio poder público.

jurídico reserva ao Estado” (A terceirização em matéria de poder de polícia: o caso das vistorias veiculares, 2013, p. 572).

${ }^{533}$ Parceria público-privada, 2013, p. 255. 
Porém, nem todos os atos preparatórios ou sucessivos do ato principal são despidos de importância jurídica ou deixam de refletir uma manifestação de poder. Em muitos casos, os atos praticados por particulares apresentam-se como sendo determinantes ou decisivos para o exercício do ato principal.

Pode-se chegar a cogitar, em termos práticos, da inversão da relevância dos atos, à medida que o ato principal, tal como a lavratura de auto de infração ou a emissão de licenciamento, em alguns casos, acaba sendo ato vinculado aos atos preparatórios praticados por entidades privadas. Por ocasião da prática do ato principal, todo o seu conteúdo já foi previamente determinado, a partir de atos desenvolvidos por entidades privadas. Em termos práticos, o núcleo da atividade de polícia acaba sendo identificado nos atos praticados por entidades privadas e não no ato principal do poder público.

Nesse contexto, parece-nos que a indicação de que seriam passíveis de exercício por entidades privadas apenas os atos instrumentais ou acessórios não seria suficiente para justificar o seu exercício privado. Assim se passa porque, ao se admitir a premissa de que o exercício das atividades de polícia é indelegável, determinados atos, ainda que instrumentais ao ato principal, não poderiam ser desenvolvidos por entidades privadas justamente porque também implicam, em alguma medida, o manejo de poder de autoridade.

Esse aspecto foi percebido pelo Min. Marco Aurélio, no voto proferido na ADI n ${ }^{\circ} 3.338$ :

como excluir o poder de polícia quanto à lavratura de auto de infração, à apreensão do veículo, mas não fazê-lo no tocante ao levantamento de dados para chegar-se a esse ato? Já disse que não passa pela minha cabeça a União, considerada a Receita Federal, vir a delegar inspeções para a lavratura de laudos (...) para servirem de base à imposição de multas. A mesma coisa afirmo quanto ao âmbito da prestação dos serviços, ao direito do trabalho, aos inspetores, aos fiscais do trabalho. Aqui, se placitarmos a lei como ela se encontra, a atividade de polícia vai estar simplesmente respaldada - o elemento essencial é sempre o laudo - em peça elaborada por particulares, por terceiros ${ }^{534}$.

Ou seja, caso se repute que não são passíveis de desempenho por particulares quaisquer atos que impliquem o exercício de poderes públicos, parece-nos que determinados atos, ainda que preparatórios do ato principal, não poderiam ser trespassados a privados à medida que acabam condicionando a prática do ato principal. Por outro lado, caso se admita o exercício privado de tais atos preparatórios, parece-nos ser necessário investigar com maior profundidade quais seriam os limites e possibilidades da delegação de

${ }^{534}$ STF, DJe 21.9.2007. 
atividades de polícia administrativa a particulares, sem se restringir à classificação que distingue os atos instrumentais dos atos principais ${ }^{535}$.

É o que se procura analisar a seguir.

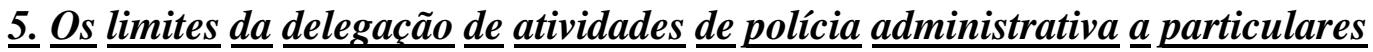

Nessa parte do capítulo, pretende-se enfrentar os principais óbices apresentados para se justificar a tese de que particulares não poderiam desempenhar atividades de polícia administrativa, identificando-se quais são os limites efetivos que decorrem de tais barreiras.

\subsection{Ressalva prévia: possibilidade de se transferir a particulares o exercício de poderes públicos}

Como se analisou anteriormente, a delegação de poderes públicos a particulares não é estranha ao direito nacional. Em várias previsões legais e arranjos contratuais, constata-se a atribuição do exercício de poderes públicos a particulares à medida que são necessários para o cumprimento dos deveres contratuais.

Quando se transfere ao particular a gestão de determinada atividade pública - ou seja, no âmbito dos contratos de delegação -, há o trespasse de um conjunto de direitos e obrigações relacionados ao exercício dessa atividade. A Administração não deixa de ser a titular desses poderes e deveres, mas seus direitos em relação àquela determinada atividade são temporariamente restringidos.

Assim se passa especialmente em relação ao contrato de concessão. A Lei ${ }^{0}$ 8.987/95, por exemplo, já prevê expressamente algumas das prerrogativas que poderão ser exercidas pelo delegatário para desempenhar a atividade pública que lhe é delegada ${ }^{536}$.

Logo, a delegação do exercício de poderes públicos é expressamente admitida no ordenamento jurídico e é utilizada com frequência ${ }^{537}$. A circunstância de a

\footnotetext{
${ }^{535}$ Nesse sentido, Marina Fontão Zago constata que "os limites possíveis de delegação do poder de polícia deverão ser mais consistentes do que a divisão infundada entre atividade-meio e atividade-fim” ( $O$ dogma da indelegabilidade do poder de polícia defrontado com casos do Código de Trânsito Brasileiro, 2010, p. 57).

${ }^{536}$ É o que consta, por exemplo, do art. 29, incs. VIII e IX, e do art. 31, inc. VI.

${ }^{537}$ Como constata Carlos Ari Sundfeld, ao refutar que atos de polícia não poderiam ser delegados por serem imperativos: "No que se refere à edição de atos imperativos, não vejo como sustentar sua indelegabilidade, pela mera circunstância de decorrerem do 'poder de polícia'. Afinal, não se nega a possibilidade dessa delegação, quando embutida na transferência de serviço público, de capacidade tributária ativa ou do poder de promover desapropriações. A propósito, é justamente por editarem atos imperativos, emanados do poder de autoridade pública, que certos agentes de entidades privadas estão legitimados a figurar no polo passivo do mandado de segurança” (Empresa estatal pode exercer o poder de polícia, 1993, p. 101).
} 
atividade de polícia administrativa demandar a prática de atos que impliquem o manejo de poderes de autoridade não é suficiente, por si só, para justificar uma suposta indelegabilidade das atividades de polícia administrativa. O que se deve analisar é se os poderes atribuídos ao particular são passíveis de exercício privado.

\subsection{A desnecessidade de autorização expressa no texto constitucional}

O primeiro questionamento a ser apresentado ao se analisar a delegação de atividades de polícia administrativa seria acerca da própria possibilidade de o Estado exercer indiretamente tais atividades à luz do texto constitucional.

Não se trata ainda de indagação propriamente acerca do conteúdo da atividade mas sim de exame acerca da necessidade ou não de autorização constitucional expressa para o exercício indireto de atividades de polícia administrativa.

O art. 175 da CF/88 trata expressamente da possibilidade de o Estado prestar serviços públicos direta ou indiretamente, nos regimes de concessão ou permissão. O teor do referido dispositivo não deixa dúvidas quanto ao fato de que se refere aos serviços públicos, não podendo ser aplicado de modo automático às demais modalidades de atividades estatais. O seu parágrafo único refere-se a aspectos como direitos dos usuários e política tarifária, que são diretamente relacionados aos serviços públicos.

Indaga-se então se seria possível a delegação de outras atividades estatais, que não sejam serviços públicos, na ausência de disposição constitucional expressamente autorizando.

Uma indicação relevante extrai-se do teor do art. 236 da CF/88. O referido dispositivo prevê expressamente a possibilidade de os serviços notariais e de registro público serem “exercidos em caráter privado, por delegação do Poder Público” ${ }^{\text {538 }}$. Por um lado, esse dispositivo consiste em uma exceção, por dispor expressamente sobre o exercício privado de uma atividade estatal específica. Por outro, não se pode extrair desse destaque para a atividade notarial uma suposta vedação do constituinte para o exercício privado de outras atividades de polícia administrativa ${ }^{539}$.

\footnotetext{
${ }^{538}$ Além do art. 236 da CF/88, podem ser mencionados como exemplos de cláusulas setoriais que autorizam a participação privada no exercício da atividade de polícia administrativa o art. 216, §1º e o art. 225 da CF/88. Ainda que não consistam em hipóteses de delegação, trata-se de previsões específicas que atribuem deveres inclusive a particulares para a tutela do patrimônio histórico cultural e do meio ambiente.

${ }^{539}$ Como constata Flávio Henrique Unes Pereira, o "art. 236, da CR, acolhe interesse de determinada categoria que, no curso do processo constituinte, organizou-se de modo a demonstrar a necessidade de se dar tratamento constitucional a certa atividade. Não pretendeu, portanto, dispor sobre a delegação da atividade notarial visando proibir qualquer outra” (Regulação, fiscalização e sanção, 2013, p. 107).
} 
Aliás, pode-se constatar que o sentido a ser atribuído ao art. 175 da CF/88 não é propriamente o de remover suposta vedação à transferência do exercício de serviços públicos. O seu comando objetiva mais especificamente estabelecer as premissas do regime jurídico da prestação indireta dos serviços, a ser desenvolvidas pela lei regulamentadora ${ }^{540}$.

Acrescente-se a isso o fato de outras atividades estatais serem usualmente objeto de descentralização, apesar da ausência de expressa autorização no texto constitucional. É o que se verifica, por exemplo, com a atividade de fomento. É recorrente o seu exercício pelas denominadas agências estatais de fomento, usualmente constituídas como entes de direito privado.

Outra indicação pode ser extraída do art. 37, inc. XXI, da CF/88, que permite a contratação de "serviços”, mediante processo de licitação pública, “nos termos da lei”. O administrador pode então se utilizar da contratação administrativa na forma disposta pelo legislador ordinário, a quem compete a definição dos "serviços" que poderão ser contratados $^{541}$. Esse argumento deve ser conjugado com o que se expôs anteriormente acerca da ausência de delimitação no texto constitucional do que pode ser objeto de contrato de concessão ${ }^{542}$. Ou seja, para as diversas modalidades de contratação administrativa, não se encontra no texto constitucional elenco exaustivo dos objetos passíveis de contratação.

Deve ser considerado ainda que a delegação do exercício da atividade não implica alteração da sua titularidade. Não há transferência da titularidade, que continua sendo pública, atribuindo-se apenas o seu exercício a entidades privadas. Por esse motivo, Pedro Gonçalves conclui pela desnecessidade de autorização constitucional expressa:

A decisão legislativa de delegação (ou de previsão da possibilidade de delegação) tem, por isso, implicações ao mero nível da organização administrativa e dos sistemas ou modelos de execução de funções e de poderes públicos, desconhecendo, quanto a esse aspecto, um impacto político-constitucional que reclame a previsão constitucional expressa.

\footnotetext{
${ }^{540}$ Esse propósito era evidenciado, por exemplo, no art. 167 da EC/69, que desempenhava função similar à do art. 175 da CF/88: “A lei disporá sobre o regime das empresas concessionárias de serviços públicos federais, estaduais e municipais, estabelecendo: I - obrigação de manter serviço adequado; II - tarifas que permitam a justa remuneração do capital, o melhoramento e a expansão dos serviços e assegurem o equilíbrio econômico e financeiro do contrato; e III - fiscalização permanente e revisão periódica das tarifas, ainda que estipuladas em contrato anterior”. Ainda que a EC/69 não contivesse cláusula geral prevendo o dever do Estado de prestar serviços públicos, seja direta ou indiretamente, sob a sua égide promoveu-se a delegação da prestação de diversos serviços. Não se reputava necessária, portanto, cláusula geral no texto constitucional prevendo a prestação indireta de serviços públicos.

${ }^{541}$ Lembre-se que a definição de "serviço" contida na Lei no 8.666/93 é bastante ampla: "toda atividade destinada a obter determinada utilidade de interesse para a Administração, tais como: demolição, conserto, instalação, montagem, operação, conservação, reparação, adaptação, manutenção, transporte, locação de bens, publicidade, seguro ou trabalhos técnico-profissionais” (art. $6^{\circ}$, inc. II).

${ }^{542}$ V. item II.3.5.
} 
O silêncio constitucional sobre a possibilidade de delegação não pode, por si só, ser interpretado como um obstáculo à legitimidade constitucional da figura: é isso que resulta de a delegação de poderes públicos em entidades particulares não carecer, na nossa interpretação, de uma legitimação constitucional expressa ${ }^{543}$.

Em face desses aspectos, concorda-se com a conclusão de Flávio Henrique Unes pereira, no sentido de que

inexiste fundamento constitucional que obrigue disciplina no próprio texto constitucional acerca da possibilidade de delegar o exercício de determinada função estatal. Em outras palavras, a ausência de regra constitucional expressa sobre a delegação do poder de polícia administrativa não pode ser interpretada como proibição a tal delegação ${ }^{544}$.

Porém, faz-se uma ressalva em relação à delegação com caráter permanente.

Consideramos que as atividades públicas apenas poderão ser atribuídas a particulares com caráter permanente e com exclusão da atuação direta do Estado mediante expressa autorização constitucional. Para esses casos excepcionais, faz-se necessária a previsão constitucional.

Ao analisar os limites da delegação de poderes públicos, especialmente à luz da Constituição Portuguesa de 1976, Paulo Otero conclui que “o exercício de poderes ou funções de soberania com caráter permanente se encontra reservado, por via de regra, a autoridades públicas”545. Disso decorre que o exercício normal ou permanente de prerrogativas de autoridade apenas pode ocorrer em formas jurídico-públicas. Daí que, "salvo perante casos decorrentes de habilitação constitucional expressa, as entidades constituídas ou organizadas sob forma de Direito Privado não podem, a título normal ou sem caráter de precariedade, exercer poderes ou prerrogativas de autoridade como objeto social da respectiva atividade»,546.

Esse seria o sentido, por exemplo, do art. 236 da CF/88, ao estipular que os "serviços notariais e de registro são exercidos em caráter privado, por delegação do Poder Público”. Nesse caso, afastou-se a prestação desses serviços sob o regime de direito público. Entende-se que a regra constitucional vedou o exercício direto de tais atividades pelo poder público, que deve, necessariamente, delegá-las.

Assim, reputamos que apenas o legislador constitucional poderá determinar que certa atividade de polícia administrativa será necessariamente prestada em regime privado, mediante delegação estatal. A atividade de polícia administrativa apenas poderá

\footnotetext{
${ }^{543}$ Entidades privadas com poderes públicos, 2008, p. 949.

${ }^{544}$ Regulação, fiscalização e sanção, 2013, p. 107 - grifos no original.

${ }^{545}$ Vinculação e liberdade de conformação jurídica do setor empresarial do Estado, 1998, p. 237.

${ }^{546}$ Ob. e loc. cit.
} 
ser o objeto principal da delegação, em caráter permanente, mediante autorização constitucional $^{547}$.

Com essa ressalva, adota-se a premissa no sentido da possibilidade de participação privada no exercício de atividades de polícia administrativa independentemente de autorização constitucional expressa. Como se examina adiante, sustentamos a necessidade de previsão legal para a delegação destas atividades - inclusive porque não há autorização legal genérica, tal como se pode extrair do art. 175 da CF/88 em relação aos serviços públicos.

No entanto, disso não decorre que a lei posa autorizar o exercício privado de toda e qualquer atividade de polícia administrativa. Há limites a serem observados, que são analisados a seguir.

\subsection{A delimitação da parcela da função estatal indelegável}

O argumento recorrentemente apresentado como suporte para a afirmação da suposta indelegabilidade é o de que a atividade de polícia seria uma função exclusiva do Estado. As razões invocadas para tanto dizem respeito à coerção que o seu exercício pode envolver, por implicar o manejo de poder autoritário.

O exercício legítimo da força é objeto de monopólio estatal, sendo indisponível e apenas podendo ser exercido pelos representantes do povo. Assim, o princípio republicano também seria vulnerado com a delegação do exercício de atividades de polícia administrativa a particulares.

Diretamente vinculado a esse argumento, pode também ser aduzido o princípio da isonomia. Ao se delegar o exercício de atividades de polícia a particulares, estar-se-ia admitindo a imposição de tratamento jurídico diferenciado aos cidadãos. Alguns particulares exerceriam poder de autoridade sobre outros, violando-se o princípio da isonomia.

Por tais motivos, que serão examinados adiante, alguns concluem que as atividades de polícia apenas poderiam ser exercidas por pessoas jurídicas de direito público. Costuma-se afirmar que entidades de personalidade privada, integrantes ou não da estrutura do Estado, não poderiam praticar atos de autoridade.

\footnotetext{
${ }^{547}$ Foi nesse sentido que se manifestou o Min. Sepúlveda Pertence, no julgamento da medida liminar na ADI $n^{\circ}$ 1.717, que é objeto de comentários específicos no item III.6.5.1. Nos termos do voto, para se assegurar o exercício permanente da atividade notarial em caráter privado mediante delegação estatal, fez-se necessária a expressa previsão no texto constitucional nesse sentido.
} 
O primeiro aspecto a examinar é se existe relação necessária entre a personalidade de direito público e o exercício de autoridade pública, em qualquer caso. Cabe identificar a presença de algum aspecto no exercício da função de autoridade que determine a obrigatoriedade de ser desempenhado exclusivamente por pessoas jurídicas de direito público.

Para tanto, é necessário analisar os critérios que determinam o núcleo de atividades que apenas poderiam ser desempenhadas diretamente pelo Estado, com exclusividade. Como possíveis limites para se delinearem as atividades passíveis ou não de delegação, serão considerados especialmente o monopólio estatal do uso da força e os princípios da soberania, republicano e da isonomia.

Alguns dos aspectos fundamentais a serem analisados dizem respeito à definição de atividades públicas, à possibilidade destas serem exercidas por entidades privadas e à existência ou não de atividades essencialmente públicas, que comportam apenas desempenho direto pelo Estado.

\subsubsection{Definição de atividades públicas}

Entre outros, podem ser utilizados os critérios formal e material para a qualificação de determinada atividade como tendo natureza pública.

Em sentido formal, pode-se definir atividade pública como sendo toda aquela atribuída ao Estado. Porém, essa noção é insuficiente pois não estabelece qualquer restrição para a assunção de atividades pelo Estado. Desconsidera a existência de limites para a publicização ou estatização, que impedem que o Estado assuma, de modo permanente, atividades desprovidas de relevância pública ou social.

A insuficiência do critério formal é evidenciada por Tomas-Ramon Fernández Rodríguez. O autor destaca que não é possível afirmar-se que exista identificação entre a ação administrativa e a ação de satisfação de necessidades coletivas justamente porque as atividades que foram objeto de apropriação pública, ao longo da história do direito administrativo, não revelam essa equiparação ${ }^{548}$.

Ao longo dos anos, verificou-se uma crescente assunção pelo Estado de novas responsabilidades e novas funções, que antes eram de incumbência dos particulares. No entanto, essa publicização de atividades não observou critérios previamente definidos. O processo ocorreu "de forma essencialmente oportunista na medida em que as circunstâncias econômicas, sociais e políticas de cada momento o permitem”549.

\footnotetext{
${ }^{548}$ Derecho administrativo, sindicatos y autoadministración, 1972, p. 21-28.

549 Ob. cit., p. 22.
} 
Não existe um mecanismo que assegure automaticamente que toda atividade que se mostre relevante para a satisfação de interesses coletivos seja objeto de apropriação estatal. A apropriação pública ou não de determinada atividade não decorre propriamente da sua relevância ou não para a satisfação de interesses coletivos e sim da interação de fatores circunstanciais de um dado momento.

Outro aspecto é que a apropriação estatal da atividade pode ser manifestada de várias formas.

Em alguns casos, essa apropriação é bastante evidente. O texto constitucional indica expressamente caber ao Estado exercer determinada atividade, não deixando dúvidas em relação à sua apropriação pública. Note-se que essa apropriação pode ser tanto com ou sem exclusividade. Ou seja, pode tanto ser estabelecido monopólio estatal sobre a atividade quanto o Estado pode assumir a sua execução como sendo responsabilidade sua, sem excluir a possibilidade de atuação de particulares, no regime de direito privado.

Já em outras hipóteses, a apropriação pública pode ser mais controversa. Manuel Izquierdo Carrasco propõe uma aferição mais ampla da titularidade pública da atividade, extraindo-a, por exemplo, dos direitos assegurados aos cidadãos e das previsões constitucionais acerca dos fins a serem perseguidos com o manejo dos poderes públicos ${ }^{550}$.

Ou seja, não haveria apropriação pública apenas nas hipóteses em que o texto legal indicar expressamente ser de responsabilidade do Estado a execução de determinada atividade.

Por esses aspectos, evidencia-se a limitação do critério formal. Não contempla limites nem critérios para a apropriação pública, remetendo-a apenas a critérios de conveniência circunstancial do poder público.

Vital Moreira apresenta o critério material para a definição das atividades públicas, do qual resulta que nem todas as atividades públicas são assumidas pelo Estado: "é comum a afirmação de que as tarefas que o Estado toma diretamente a seu cargo não esgotam as tarefas públicas, ou seja, aquelas que hajam de ser publicamente prosseguidas para satisfação das necessidades coletivas”551. Cabe ao Estado decidir, dentro dos limites determinados pela Constituição, as tarefas que realizará diretamente através da estrutura estatal:

\footnotetext{
${ }^{550}$ Algunas cuestiones generales a propósito del ejercicio privado en el ámbito de la seguridad industrial, 2001, p. 374-379. A partir dessas indicações, o autor conclui que a garantia de segurança industrial consiste em uma atividade pública, apesar de assim não constar expressamente do texto constitucional.

${ }^{551}$ Administração autónoma e associações públicas, 2003, p. 88-89.
} 
Existem tarefas 'essenciais’, 'necessárias', 'originárias’, correspondentes a 'interesses públicos absolutos', e tarefas 'eventuais', correspondentes a 'interesses públicos relativos'. Só a realização das primeiras (defesa externa, segurança pública, justiça, etc.) tem de ser necessariamente assegurada pelo Estado. Todas as demais tarefas públicas - as que não sejam avocadas pelo Estado - podem ser deixadas ao cuidado de entidades privadas ou de entidades públicas representativas de interesses sociais ${ }^{552}$.

Diante disso, conclui que “o Estado perde o monopólio do 'público”,553 e enuncia a inserção de uma zona intermédia entre Estado e sociedade, que corresponde às tarefas públicas não-estatais.

Reputamos ser relevante construir um conceito que considere também a legitimidade da intervenção do Estado ao assumir determinada atividade. Esse seria o conceito material de atividade pública, que revelaria as atividades que o Estado legitimamente pode assumir como suas.

Porém, há de se considerar que o emprego de critérios materiais para a definição de tarefas públicas é apto a acarretar maiores incertezas, diante da impossibilidade de se estabeleceram, a priori e de modo exaustivo, os aspectos a serem considerados para a definição da natureza pública ou não de determinada atividade. Além disso, ao se dispensar o critério formal, abre-se espaço para significativas controvérsias acerca da qualificação de cada atividade ${ }^{554}$.

Por isso, não é possível adotar-se exclusivamente o critério material, da relevância da matéria, para se definir o caráter público ou não de determinada atividade. Apresenta-se como sendo mais adequada a conjugação dos critérios formal e material. A atividade pública seria aquela objeto de apropriação pública formal e de relevância coletiva. O interesse ou a utilidade pública não seriam suficientes para qualificar como sendo pública a tarefa exercida pelo particular. Não basta o reconhecimento da utilidade pública de determinada atividade para que ela se torne pública.

Logo, o critério formal é relevante e acaba prevalecendo. Se não houver apropriação pública expressa, trata-se de atividade privada, mesmo se a sua realização for de alta relevância para o interesse público. O critério material deve ser considerado especialmente no processo legislativo, para se definir pela apropriação pública ou não de determinada atividade.

\footnotetext{
552 Ob. cit., p. 89.

553 Ob. cit., p. 89.

${ }^{554}$ Como se examina adiante, parcela da doutrina espanhola sustenta que as entidades privadas de controle e certificação exercem funções públicas de autoridade apesar de suas atividades não serem objeto de formal apropriação pública - v. item III.7.7.4.
} 
A consideração do aspecto formal é especialmente importante para se diferenciar o exercício privado de atividade pública do exercício de poderes privados. O primeiro ocorre apenas em relação a atividades que foram objeto de apropriação pública expressa. Já o segundo se verifica quanto a atividades que não foram assumidas pelo Estado, ainda que possam apresentar grande relevância coletiva.

5.3.2. Identificação da apropriação pública das atividades desempenhadas por entidades privadas

Uma vez apontados os critérios a serem utilizados para a caracterização das atividades públicas, cabe analisar como se procede à identificação da natureza pública de determinadas atividades desempenhadas por entidades privadas.

Para tanto, o direito francês aplica o conceito de "rattachement organique", que se refere à necessária demonstração de que a atividade foi delegada ao particular por uma entidade pública. A premissa é de que a atividade tenha tido sua execução previamente assumida pelo Estado e que tenha sido transferida ao particular por delegação ou outro mecanismo de atribuição - o que determina o caráter derivado do título de execução privada da atividade.

Adota-se, assim, o conceito de Vital Moreira para a definição das hipóteses em que se verifica o exercício de atividades públicas por particulares:

só existe exercício privado de funções administrativas quando estas são confiadas, enquanto tais, a uma entidade privada. Isso implica ou uma expressa qualificação legal, ou a existência de elementos que nesse sentido seguramente apontem (v.g. a entrega de parte de uma tarefa que cabe integralmente ao Estado, a utilização de poderes de autoridade administrativa $)^{555}$.

Porém, nem sempre é nítida a transferência do exercício da atividade pública a entidades privadas, por meio de um título formal. Para as hipóteses em que a qualificação não for expressa, Pedro Gonçalves apresenta alguns indícios de publicização, a serem analisados conjugadamente: a) conexão inseparável da atividade em questão com uma atividade claramente pública, detectando-se evidências de contato e vínculo de continuidade entre atividades públicas e privadas de modo que o particular exerça uma parte não autônoma de uma atividade unitária pública; b) exercício de poderes de autoridade na execução da atividade; c) atividades essenciais à realização de direitos de exercício condicionado por lei ou ao cumprimento de deveres legalmente impostos aos cidadãos, desde que tais atividades não sejam exercidas livremente pelo próprio mercado e sim por particulares indicados pelo Estado; d) outros fatores, tais como a identificação, pela

${ }^{555}$ Administração autónoma e associações públicas, 2003, p. 289. 
lei, da contrapartida ao serviço prestado como tendo natureza pública, ainda que arrecadada pelo particular ${ }^{556}$.

Pode se verificar também a apropriação pública sem que a execução da atividade tenha sido originariamente atribuída à Administração. Seria a hipótese de substituição originária da Administração por particulares, em que a atividade não chega a ser exercida por uma entidade pública. Há coincidência entre a apropriação pública da atividade e a sua delegação a particulares. Isso apenas se configura se a lei declarar expressamente ou não deixar dúvidas de que aquela atividade foi assumida pelo Estado como sendo de sua responsabilidade.

Outra hipótese é a de atividade exercida por particulares, como incumbência privada, sob a forma de autorregulação ou autodisciplina, que posteriormente é assumida pelo Estado, publicizando-a. Foi o que se verificou, em alguns ordenamentos jurídicos, em relação à regulação de determinados setores da economia e à disciplina desportiva.

Para resumir e seguindo a sistematização exposta por Vital Moreira, assim podem ser apresentados os três processos distintos de delegação do exercício de funções públicas a particulares, a serem considerados para a identificação do exercício privado de atividades públicas: a) a privatização de funções anteriormente confiadas a entidades públicas, b) a administrativização de funções anteriormente confiadas à autorregulação ou autodisciplina privada, e c) a criação de atividades administrativas e sua simultânea atribuição a entidades privadas ${ }^{557}$.

\subsubsection{Atividades essencialmente públicas}

Indo adiante, é relevante examinar se, no conjunto de atividades públicas, existem atividades essencialmente públicas, no sentido de que não poderiam deixar de ser desempenhadas diretamente pelo Estado.

Identifica-se a existência de certas missões irrenunciáveis do Estado, que não podem ser transferidas aos particulares. Comportam apenas o exercício direto pelo Estado. É no âmbito dessas atividades essencialmente públicas que se encontram as atividades não passíveis de delegação.

\footnotetext{
${ }^{556}$ Entidades privadas com poderes públicos, 2008, p. 480-488.

${ }^{557}$ Administração autónoma e associações públicas, 2003, p. 288.
} 


\subsubsection{A definição de atividades essencialmente públicas}

Pode-se afirmar haver unanimidade na doutrina quanto ao fato de que há determinadas atividades que necessariamente deverão ser prestadas diretamente pelo Estado.

No entanto, não há uniformidade quanto à identificação desse núcleo de atividades estatais que não comportariam delegação.

A doutrina usualmente apresenta como sendo funções exclusivas do Estado. que envolveriam o exercício de autoridade, a legislação, a jurisdição e o exercício do poder de polícia ${ }^{558}$.

Arnoldo Wald, Luiza Rangel de Moraes e Alexandre Wald assim definem esse núcleo: "Nem todos os serviços públicos são passíveis de delegação. Alguns deles só podem ser executados diretamente pelo Estado, porque inerentes à sua soberania e à sobrevivência da nação - são principalmente os que dizem respeito à defesa nacional, à segurança e à saúde públicas”,559.

Floriano de Azevedo Marques Neto apresenta a seguinte caracterização dos atos que seriam indelegáveis: "Esse poder [o poder extroverso estatal] coincide com o exercício da autoridade (parcela da soberania estatal) que enseja a prática de atos (jurídicos, normativos ou materiais) aptos a, de forma incontrastável, constranger, condicionar ou limitar direitos dos indivíduos”560.

Para Vera Monteiro, existem “determinados serviços que somente o Estado pode executar diretamente, porque são inerentes à sua soberania, à defesa nacional, à segurança e à saúde públicas. São atividades cuja execução envolve atos de autoridade, e com relação a esses atos não é possível cogitar de delegação" ${ }^{561}$.

A definição do núcleo exclusivo do Estado é lançada por Marcos Juruena Villela Souto de modo a abranger as atividades “que exigem manifestação de poder de império (polícia, fiscalização, controle, justiça)" ${ }^{562}$.

Gaspar Ariño Ortiz apresenta um rol mais amplo de atividades que integrariam o núcleo exclusivo do Estado. Segundo o autor, haveria vedação de utilização do direito privado "em todas as atividades que suponham exercício de autoridade ou disposição da riqueza pública (função arrecadatória, regulatória, de autorização,

\footnotetext{
${ }_{558}^{558}$ Weida Zancaner. O perfil jurídico do credenciamento, 2013, p. 792.

${ }^{559}$ O direito de parceria e a lei de concessões, 2004, p. 143.

${ }^{560}$ A concessão como instituto do direito administrativo, 2013, p. 232.

${ }^{561}$ Concessão, 2010, p. 123.

${ }^{562}$ Desestatização, 2001, p. 371.
} 
expropriatória etc.) ${ }^{\text {563 }}$. Ainda seguindo os ensinamentos de Ariño Ortiz, haveria impedimento para a utilização de formas de direito privado para "todas as atividades que suponham reconhecimento de direitos, ajudas, subvenções, exclusivas de exploração ou adjudicação de bens e serviços”564.

No ordenamento jurídico, não há uma previsão clara e expressa acerca daquele que seria o núcleo de atividades estatais indelegáveis.

Não constam do texto constitucional, por exemplo, regras específicas delimitando as atividades que comportariam ou não a transferência do seu exercício a particulares. Determinadas atividades foram previstas como monopólio estatal, mas isso não impede que a sua execução seja transferida à iniciativa privada por mecanismos contratuais. Logo, o "que se extrai implicitamente da Constituição, fruto do acolhimento do princípio republicano e do cariz democrático do Estado nacional, é a reserva estatal de certas competências envolvidas com o uso da violência e o poder de império, instrumentais à satisfação de valores prezados pelo Estado Democrático de Direito"565.

$\mathrm{Na}$ Lei $\mathrm{n}^{\circ}$ 11.079/04, procurou-se apresentar uma especificação das atividades típicas estatais, estipulando a indelegabilidade "das funções de regulação, jurisdicional, do exercício do poder de polícia e de outras atividades exclusivas do Estado” (art. $4^{\circ}$, inc. III) ${ }^{566}$.

O fato de não ter sido apresentado um rol exaustivo, determinado, encerrando-se com a expressão aberta “outras atividades exclusivas do Estado”, evidencia a

\footnotetext{
${ }^{563}$ El ámbito privado del sector público, 2002, p. 597.

${ }^{564}$ Ob. e loc. cit.

${ }^{565}$ Fernando Vernalha Guimarães. Atividades estatais indelegáveis, 2013, p. 3 (versão digital).

${ }^{566}$ Aplicando esse dispositivo da Lei ${ }^{\circ}$ 11.079/04, em resposta a consulta formulada pelo Tribunal de Justiça do Estado do Maranhão, a maioria dos integrantes do Conselho Nacional de Justiça (CNJ) votou pela vedação da contratação de parcerias público-privadas pelo Judiciário. O voto condutor foi proferido pelo Conselheiro Carlos Ayres Brito e foi assentado em três fundamentos principais: a) a Lei 11.079 permitiria o emprego de contratos de PPP apenas para a administração pública direta; b) as atividades-meio do Judiciário não seriam compatíveis com nenhuma das modalidades de PPP; e c) a composição do Comitê Gestor de PPP Federal seria incompatível com o princípio da separação de poderes, pois teria sido instituído por ato regulamentar do Executivo. O caso concreto objeto da discussão foi a contratação de PPPs, da espécie concessão administrativa, cujo objeto seria a construção de prédios em que seriam instalados fóruns da Justiça estadual, a informatização de serventias extrajudiciais e a disponibilização de veículos. Em síntese, o objeto das PPPs cogitadas diria respeito à infraestrutura utilizada pelo Poder Judiciário. Porém, cabe ressalvar que ainda não se trata de posicionamento definitivo do CNJ acerca do tema. O julgamento foi suspenso e foi criada comissão para analisar o tema. Em junho de 2012, o CNJ realizou audiência para debater a possibilidade de realização de PPPs pelo Judiciário, como ato preparatório da resposta final à consulta. Apesar de a questão ainda não ter sido decidida, os Tribunais cogitam da utilização da concessão administrativa para a construção e operação dos seus edifícios. Não foi possível identificar se já foi concluída a apreciação da questão pelo CNJ. Ainda a esse respeito, o TCU sugeriu a adoção de parcerias público-privadas para o atendimento das necessidades imobiliárias do Judiciário, em resposta a consulta formulada pelo Conselho Superior da Justiça do Trabalho (Acórdão nº 1301/2013 - Plenário).
} 
dificuldade em se determinar, em abstrato, quais são as atividades que não podem ter o seu exercício transferido a particulares.

Diante da inviabilidade de se atingir uma definição conclusiva do elenco das atividades que não são passíveis de delegação, cabe a apresentação de algumas diretrizes a serem consideradas para a determinação, em concreto, da presença ou não de uma atividade que comporta apenas execução direta pelo próprio poder público.

\subsubsection{Os princípios da soberania e republicano}

Pode-se indagar se existiriam determinadas atividades que seriam naturais, genuínas do Estado, de modo que não se conceberia a existência de Estado que não assumisse tais tarefas. Isso poderia implicar inclusive a consideração de elementos de natureza pré-constitucional.

Nesse contexto, o exercício da soberania é o elemento mais relevante que se identifica como tendo natureza essencialmente estatal. O desempenho pelo Estado de atividades que consistem em manifestação direta da soberania funda-se no art. $1^{\circ}$, parágrafo único, da CF/88, nos termos do qual “Todo o poder emana do povo, que o exerce por meio de representantes eleitos ou diretamente”.

A adoção de um sistema republicano implica a reserva de poderes nas mãos do Estado. O exercício desses poderes é manifestação do poder político atribuído aos representantes do povo.

O texto constitucional atribui o exercício do poder ao povo, através de seus representantes eleitos. Posteriormente, os representantes do povo não podem transferir a particulares parcelas desse poder. Em uma ordem republicana, a concretização de restrições a direitos individuais apenas pode ser realizada por quem é titular da função estatal.

Como instrumentos imprescindíveis para a atuação do Estado e manifestação de seu poder de império, tais poderes são intransferíveis e inalienáveis e devem ser exercidos diretamente pelo Estado.

Reputamos que isso corresponde a um núcleo restrito das atividades estatais, correspondente, em linhas gerais, às manifestações coercitivas e políticas do poder estatal. São essas funções cujo exercício privado implicaria alienação dos poderes estatais, violando-se os princípios da soberania e republicano. 


\subsubsection{O monopólio estatal da violência}

Um dos poderes reconhecidos ao Estado como indispensáveis à sua atuação é o monopólio do uso da força. Pode-se afirmar que o monopólio estatal da violência legítima é um dos fundamentos do Estado Democrático de Direito.

\subsection{O monopólio da violência como fundamento do Estado Moderno}

O Estado Moderno funda-se no monopólio estatal dos mecanismos de constrangimento. Após o período medieval, com a centralização do poder político, o Estado assumiu o monopólio da violência para afirmar a sua soberania.

Como anota Marçal Justen Filho, uma das “características do chamado Estado Moderno, instaurado no Ocidente a partir do Tratado de Westfalia, de 1648, consistiu no monopólio da violência" ${ }^{\text {567 }}$. O Estado moderno afirma a sua soberania, tanto no âmbito externo quanto interno, com a detenção exclusiva dos meios de coerção física. $\mathrm{O}$ Estado, como "representante do povo”, tornou-se o único titular do exercício da força coativa.

Assim, o monopólio estatal da força, ainda que não conste expressamente do texto constitucional, pode ser considerado implícito ao Estado Moderno, por ser essencial a este $^{568}$.

\subsection{A instrumentalidade do emprego da violência legítima}

A detenção do monopólio do uso da violência legítima não significa que esse poder possa ser livremente utilizado pelo Estado. Não se trata de manter o poder com o emprego da força bruta. O monopólio estatal da violência significa que ela apenas poderá ser utilizada quando for estritamente necessária para a preservação e restauração da ordem. Trata-se de poder jurídico, submetido aos limites previstos no ordenamento. Como destaca Chevallier, um dos aspectos essenciais do monopólio estatal da violência consiste no fato de se tratar de um poder jurídico, que se expressa por normas jurídicas ${ }^{569}$. A atuação do Estado dá-se através do direito, com a estipulação de normas obrigatórias.

\footnotetext{
${ }^{567}$ Curso de direito administrativo, 2013, p. 95 - grifos no original.

${ }^{568}$ Essa afirmação aplica-se especialmente ao Estado brasileiro. Em relação a outros Estados, ainda que sejam Estados de Direito, a questão deve ser analisada com cautela, considerando-se as especificidades de cada caso. Em relação aos Estados Unidos, por exemplo, Pedro Gonçalves faz a seguinte observação: “pelo fato de não consagrar um monopólio estadual do emprego da força, o sistema jurídico norte-americano revela-se bastante generoso quer quanto à delegação de funções policiais em entidades privadas, quer quanto à extensão da segurança privada” (Entidades privadas com poderes públicos, 2008, p. 959, nota 96).

${ }^{569}$ Science administrative, 2007, p. 87. Ainda segundo o autor, os outros aspectos essenciais do monopólio estatal da violência são a força material, que pertence essencialmente ao Estado mas que se manifesta de forma mediatizada pelo direito, e a situação de monopólio em si, pela qual o Estado dispõe de um poder de constrangimento incondicionado e irresistível, do qual não se pode escapar (ob. cit., p. 88-92).
} 
A execução coerciva implica a prática de atos materiais com o uso de força sobre pessoas e coisas. Com o emprego da coação, o poder público manifesta a sua autoridade em grau máximo, do que decorre o nível mais intenso de intervenção estatal na esfera privada dos cidadãos. Outro aspecto a ser considerado é que o emprego da força produz resultados imediatos, não passíveis de reversão ou correção em termos fáticos. Com isso, são mais graves as consequências de possíveis erros e abusos cometidos ao se adotarem as decisões concretas.

Outro aspecto do monopólio estatal da violência é o dever dele decorrente de o Estado utilizar a força sempre que for necessário para a proteção dos direitos fundamentais. Por deter o monopólio, o Estado tem o dever de empregar a força quando for imprescindível para a defesa dos cidadãos.

\subsection{A decisão acerca da utilização da violência legítima}

O monopólio da violência é instrumental para a realização das finalidades atribuídas ao Estado. O Estado detém o monopólio do exercício da coerção sobre os cidadãos por ser meio necessário para o atendimento de princípios e valores fundamentais. Apenas o Estado é legitimado para fazer essa escolha acerca da manifestação coativa do seu poder.

A violência apenas poderá ser legitimamente utilizada pelo Estado se for necessária. Atribuiu-se ao Estado a competência para decidir quando o emprego da coerção é indispensável.

Portanto, o Estado não apenas detém o monopólio da utilização legítima da violência mas também da decisão acerca do momento e modo em que a coerção será empregada.

No que diz respeito à atividade administrativa, isso significa que o Estado detém o monopólio da decisão acerca das razões que determinam a imposição de restrições à propriedade e à liberdade dos cidadãos. Apenas o Estado poderá decidir em quais circunstâncias poderá haver interferência na autonomia privada dos cidadãos e quais medidas poderão ser adotadas.

A indelegabilidade da coação decorre não apenas da intensidade da ingerência que implica, por atingir a integridade física e a liberdade das pessoas, mas também da impossibilidade de programação prévia do seu exercício, a partir de critérios 
objetivos $^{570}$. Ainda que o exercício da coação seja limitado pelas normas, comporta uma grande quantidade de atos que não são passíveis de determinação antecipada.

Logo, não se pode atribuir o exercício de poderes públicos coercitivos a entidades privadas. A atribuição de poderes públicos a alguns dos cidadãos romperia o equilíbrio próprio das relações entre particulares, à medida que alguns passariam a deter o poder de decisão acerca da utilização de violência legítima sobre outros.

\subsection{O monopólio da violência e as atividades de polícia administrativa}

Note-se que a vinculação entre a atividade de polícia administrativa e o monopólio estatal da violência diz respeito aos meios e instrumentos utilizados na execução de algumas das atividades de polícia.

Daí que o monopólio não é propriamente da atividade de polícia e sim dos meios utilizados para executar determinadas atividades. Além de serem de titularidade pública, atividades que demandem o emprego da força são de execução exclusiva pelo Estado. Este aspecto é relevante para se diferenciarem as atividades que são passíveis de delegação a particulares daquelas que não o são.

Reitere-se que não são todas as atividades compreendidas no ciclo de polícia administrativa que envolvem a utilização de meios coercitivos propriamente ditos.

\subsection{Conclusão parcial: indelegabilidade do poder de coerção}

Reputamos, assim, não ser admissível a dissociação entre a titularidade do poder de coação e a sua execução. Apenas poderá exercê-lo aquele que é o seu titular, que é o Estado. Trata-se do núcleo duro, intangível ${ }^{571}$ do exercício de poderes públicos pelo Estado, a ser desempenhado apenas por aqueles que perseguem exclusivamente os interesses coletivos.

\subsubsection{O princípio da isonomia}

Outro princípio a ser considerado é o da isonomia, sob a perspectiva de que seria vedado o exercício de poderes públicos por particulares porque isso supostamente propiciaria uma situação de desigualdade entre os indivíduos.

Como alerta Tomas-Ramon Fernandez Rodriguez, um dos perigos da delegação do exercício de poderes públicos é a "ruptura do princípio da igualdade, a

\footnotetext{
${ }^{570}$ Como pondera Pedro Gonçalves, "em princípio, o emprego da força tem lugar em circunstâncias que reclamam a tomada de decisões - quanto ao se e quanto ao como da utilização de meios coativos - cujo conteúdo depende, em grande medida, do contexto e do grau de ameaça ou de perigo concreto em que se encontram determinados bens jurídicos” (Entidades privadas com poderes públicos, 2008, p. 961).

${ }^{571}$ Pedro Gonçalves. Entidades privadas com poderes públicos, 2008, p. 962.
} 
reaparição de um sistema de privilégios, a consagração, em definitivo, dos grupos de pressão e a conversão de seu poder de fato em um poder jurídico"572.

O possível rompimento da isonomia entre os administrados também é o argumento invocado por Celso Antônio Bandeira de Mello para justificar a inviabilidade da delegação de atos de polícia administrativa, como regra geral:

A restrição à atribuição de atos de polícia a particulares funda-se no corretíssimo entendimento de que não se lhes pode, ao menos em princípio, cometer o encargo de praticar atos que envolvem o exercício de misteres tipicamente públicos quando em causa liberdade e propriedade, porque ofenderiam o equilíbrio entre os particulares em geral, ensejando que uns oficialmente exercessem supremacia sobre outros ${ }^{573}$.

É o fato de estarem presentes também interesses particulares, legitimamente perseguidos, ao lado dos interesses coletivos que evidenciaria o risco de atuação com desvios no exercício de poderes públicos. Nas palavras de Rui Guerra da Fonseca:

Dada a inevitável e inequívoca presença de interesses particulares no contexto da realização do interesse público quando este é entregue a esses mesmos particulares, há boas razões para, antecipadamente e em regra, suscitar uma desconfiança de preterição deste último em relação aos primeiros, sendo o mesmo dizer que a suspeição do desvio de poder é uma sombra constantemente pairante sobre a atividade de particulares no exercício de poderes de autotutela executiva, como de poderes de autoridade em geral $^{574}$.

Porém, em seguida o autor pondera que “o problema dos interesses ou do risco do desvio de poder seria apenas uma questão de grau: pois também a administração pública é ocupada por pessoas, em termos de titularidade, que transportam consigo os seus interesses, o que é suscetível de afetar o exercício das competências dos órgãos que ocupam enquanto titulares ${ }^{\text {,575 }}$

Outro aspecto diretamente vinculado ao da possível violação da isonomia pelo exercício privado de poderes públicos seria o da ausência de representatividade dessas entidades. Isso se aplicaria especialmente aos particulares, à medida que as entidades da administração indireta, ainda que detenham personalidade privada, encontram-se em alguma medida subordinadas à vontade política dos representantes eleitos. Para tanto, basta considerar que a sua criação depende de autorização legal e que se submetem ao controle da Administração direta.

No entanto, cabe observar que o exercício de determinadas prerrogativas e privilégios por alguns particulares não é violador, por si só, do princípio da isonomia, caso seja necessário para o exercício de atividade pública atribuída a particulares.

\footnotetext{
${ }^{572}$ Tomas-Ramon Fernández Rodrígues. Derecho administrativo, sindicatos y autoadministración, 1972, p. 220 - grifo no original.

${ }^{573}$ Curso de direito administrativo, 2013, p. 855.

${ }^{574}$ O fundamento da autotutela executiva da Administração Pública, 2012, p. 733.

${ }^{575}$ Ob. cit., p. 734.
} 
A delegação do exercício de uma atividade pública, por si só, determina a desigualação do contratado em relação aos demais particulares, sem que isso implique o exercício de supremacia de um particular sobre outro. Essa é precisamente a situação em que se encontra o concessionário de atividade pública. Como destaca Floriano de Azevedo Marques Neto, “a delegação concessória opera uma desequiparação entre os particulares, de tal sorte que o delegatário (concessionário no âmbito do que aqui se estuda) recebe, sim, por meio de mecanismos isonômicos (licitação) e por prazo certo, prerrogativas para exercer, em nome do poder público, atribuições inclusive de natureza ordenadora”576. O trespasse de prerrogativas e privilégios "potencializa o status diferenciado do concessionário em relação aos demais particulares e reforça a necessidade de que o pacto concessório trate e delimite o exercício desses direitos e sua interface com o direito de terceiros ${ } 577$

O princípio da isonomia seria vulnerado se fosse atribuído amplo poder decisório a particulares no desempenho de atividades públicas, com largo espectro de escolha quanto à medida concreta a ser adotada. Por outro lado, a situação diferenciada de alguns particulares em relação a outros não configura ilegalidade se tal circunstância for estritamente necessária ao desempenho de uma missão pública e se o exercício de tais prerrogativas for devidamente disciplinado e delimitado.

Portanto, em relação ao princípio da isonomia, reputamos que não implica a definição como sendo atividade essencialmente pública aquela cuja delegação acarretaria uma desigualação entre os particulares, com fundamento na lei e no contrato.

O princípio da isonomia não demanda a oposição de óbice absoluto à delegação de atividades de polícia a particulares. Exige, sim, a observância de determinados requisitos e procedimentos para se assegurar a objetividade no exercício privado dessas atividades. Isso se dá especialmente com a programação das atividades a serem desempenhadas, estipulando-se previamente as atribuições do contratado, de modo minucioso. Essa regulação do desempenho privado permite também o controle rigoroso da atuação privada. Esses temas são analisados a seguir.

\footnotetext{
${ }^{576}$ A concessão como instituto do direito administrativo, 2013, p. 571.

${ }^{577}$ Ob. cit., p. 233. Diante dessa distinção conferida ao delegatário em relação aos demais particulares, o autor sustenta que a decisão de conceder deve submeter-se aos critérios da subsidiariedade e da relação custobenefício. A subsidiariedade implica que o Estado apenas deve assumir o exercício direto de determinada atividade essencial à realização de interesses coletivos se a iniciativa privada não for capaz de provê-la ou, em sendo capaz, não consegue fazê-lo de modo a atingir os fins visados com a sua execução. No que diz respeito à avaliação de custo-benefício, a decisão de conceder deve ser antecedida da avaliação e comparação das diversas alternativas disponíveis para a satisfação daquela necessidade, justificando-se, ao fim, a opção pela delegação (ob. cit., p. 563).
} 


\subsection{Os critérios e requisitos para a delegação de atividades de polícia administrativa}

Como se analisou acima, os óbices à aplicação de mecanismos de privatização decorrem do caráter de exclusividade de determinadas atividades determinado especialmente pelos princípios da soberania e republicano e o monopólio estatal do uso da força. Analisa-se, assim, a aplicação específica destes critérios para a identificação dos limites incidentes sobre a delegação de atividades públicas, especialmente no que diz respeito à polícia administrativa.

5.4.1. A suposta maior aptidão do regime de direito de direito público para a prática de atos de autoridade

Cabe ponderar inicialmente que, de uma suposta maior aptidão do regime de direito público para o exercício de atividades de polícia administrativa, não se extrai a incompatibilidade do desempenho de tais funções por entidades de direito privado ${ }^{578}$.

Aduzir que o regime de direito público seria mais compatível com a realização de atividades de polícia não é suficiente para justificar eventual conclusão no sentido de que tais atividades não comportariam qualquer tipo de exercício por entidades privadas.

\subsubsection{Advertência necessária: os riscos do argumento da busca da eficiência}

Por outro lado, deve-se ter cautela com argumentos tais como o de que o regime jurídico de direito privado propiciaria maior eficiência ao exercício das atividades de polícia.

O princípio da eficiência apenas poderá ser empregado como motivo apto a justificar o exercício de atividades de polícia por entidades privadas à medida que for compatível com os demais princípios constitucionais.

De todo modo, não se pode deixar de considerar que o desempenho de atividades de polícia por entidades privadas, ainda que despidas de algumas prerrogativas e poderes, que não podem ser manejados por particulares, apresentam alguns benefícios em razão da maior agilidade e eficiência que podem ser obtidas. Além disso, como já se observou, a significativa ampliação do campo de atuação da polícia administrativa na

\footnotetext{
${ }^{578}$ José Vicente Santos de Mendonça refuta a existência de alguma razão intrínseca a justificar a necessidade de a atividade de polícia ser exercida exclusivamente por entidades sujeitas ao regime de direito público: "a ligação entre regime de direito público e poder de polícia é vínculo contingente, baseado na maior aptidão institucional das entidades com personalidade jurídica de direito público para o exercício dessa espécie de atividade administrativa. Nada mais.” (Estatais com poder de polícia: por que não?, 2009, p. 102)
} 
atualidade aliada à complexidade técnica demandada inviabilizaram o desenvolvimento direto pelo Estado de todas as atividades de polícia administrativa.

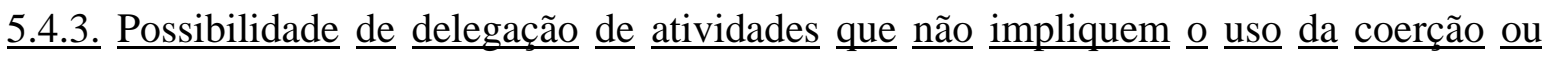
manifestação de amplo poder decisório

A partir dos critérios apontados acima, identificam-se como limites intransponíveis para a delegação de atividades de polícia o emprego da violência e o exercício de amplo poder decisório pelo particular.

\subsubsection{Primeiro limite necessário: impossibilidade de delegação do uso da força}

Em primeiro lugar, devem ser excluídos dos atos passíveis de delegação aqueles que demandarem o emprego da força. Trata-se de decorrência direta do monopólio estatal do emprego da violência legítima, nos termos analisados acima.

Isso não exclui a possibilidade de se atribuir a particulares a mera execução de atos materiais de constrição da propriedade privada, em cumprimento a decisões prévias do poder público.

\subsubsection{Segundo limite necessário: impossibilidade de delegação ampla de poder decisório}

As atividades passíveis de delegação podem consistir em atos de aplicação e execução de atos normativos e atos administrativos propriamente ditos, desde que não impliquem exercício de amplo poder decisório pelo particular.

Poder de decisão consiste em manifestação de poder de império, cujo exercício demanda a legitimação democrática do agente.

Reputamos que não é possível a atribuição a particulares da plena capacidade decisória envolvida no exercício da função pública.

Em primeiro lugar, a delegação a particulares não pode ter por conteúdo a adoção de decisões estratégicas, de cunho político, que apenas podem ser tomadas pelos representantes do povo democraticamente legitimados. Essas decisões estratégicas e nucleares, em alguma medida, correspondem à “função política” ou aos “atos de governo",579.

A função política relaciona-se com a própria existência do Estado e é a tradução mais direta da soberania estatal. Trata da adoção de escolhas essenciais para a condução das atividades do Estado. Consiste no direcionamento da função governamental, com a definição do modo de persecução dos objetivos do Estado, definindo as metas a

\footnotetext{
${ }^{579}$ Atos de governo "são aqueles em que os exercentes da função governativa imprimem fins à gestão pública, em face dos fins do Estado, as opções de políticas públicas e orçamentárias e a direção geral da política estatal” (Oswaldo Luiz Palu. Controle dos atos de governo pela jurisdição, 2004, p. 164).
} 
serem atingidas e os meios a serem utilizados ${ }^{580}$. Não há como se cogitar da sua delegação a entidades privadas.

Depois, também não pode ser atribuída ampla margem de liberdade para o particular determinar os critérios do desempenho da atividade de polícia administrativa no caso concreto. Assim se passa pela necessidade de se assegurar a objetividade e a imparcialidade no exercício privado de poderes públicos.

Isso não significa que os atos passíveis de delegação sejam necessariamente instrumentais ou acessórios ou materiais ${ }^{581}$. Eventualmente, o ato material praticado pelo delegatário consistirá no ato determinante do conteúdo da atividade de polícia no caso concreto. É o que se verifica, por exemplo, com a aprovação ou não do administrado em determinado exame ou vistoria realizados por particulares e necessários para a obtenção da licença ou autorização para o exercício de determinada atividade.

À medida que o resultado do exame ou vistoria realizado por um particular é determinante para a Administração conceder ou não determinada licença, por exemplo, parece-nos que tal atividade não pode ser qualificada como sendo simplesmente instrumental ou acessória. Há de se reconhecer que a atividade desempenhada pelo particular envolve, em alguma medida, o exercício de poder.

Nesse sentido, pode-se mencionar a delegação a particulares das atividades de inspeção veicular. Na sistemática adotada no Rio Grande do Sul, por exemplo, cabe ao delegatário não apenas realizar a inspeção em si mas também, ao final, emitir o atestado de inspeção técnica contendo os resultados obtidos ${ }^{582}$. É com base nesse relatório que a autoridade competente concederá ou não o licenciamento do veículo. Há de se reconhecer que o conteúdo do relatório de inspeção será determinante para o posterior licenciamento do veículo.

Porém, há limites a serem observados na delegação da prática de determinados atos jurídicos por particulares. Reputa-se que não é passível de ser atribuído a

\footnotetext{
${ }^{580}$ Como pondera a doutrina, a definição do ato de governo não é uma operação objetiva, de modo que os atos de governo e os atos administrativos consistam em categorias apartadas. A esse respeito, Cristina M. M. Queiroz conclui que o “'ato de governo’ como categoria jurídica autônoma, pura e simplesmente, não existe” (Os actos políticos no Estado de Direito, p. 127). O que há é uma diferença de grau entre eles, sendo que os atos de governo apresentam uma maior abertura para conteúdos estratégicos e escolhas políticas.

${ }^{581}$ Sobre a insuficiência da classificação em atos instrumentais e atos finais, v. item III.4.

${ }^{582}$ Lei estadual $\mathrm{n}^{\circ} 10.848 / 96$, art. 15 . Os efeitos da referida lei encontram-se suspensos por medida liminar concedida pelo STF no julgamento da ADI n ${ }^{\circ}$ 1.666-2. O fundamento para a concessão da liminar foi a ausência de competência do Estado para legislar sobre trânsito, que seria de competência exclusiva da União. Em relação ao art. $2^{\circ}, \S^{\circ}$, da Lei estadual $n^{\circ} 10.847 / 96$, também objeto da ADI ${ }^{\circ} 1.666-2$, o STF aplicou interpretação conforme para vedar a delegação de atividades de polícia. Nos termos do voto do Min. Nelson Jobim, ressalvou-se que poderão ser delegadas atividades tais como a realização de exames físicos e de inspeção veicular.
} 
particulares o poder de conformar a conduta alheia de modo inovador, com a escolha dos critérios a serem empregados na decisão administrativa. Apenas poderiam ser delegadas ao particular atividades cujo modo de execução tenha sido previamente definido pelo legislador e pela Administração.

Não pode ser atribuída ao particular a escolha acerca do momento e do modo de realização de determinada inspeção, por exemplo. Os critérios a serem observados em exame de verificação do preenchimento ou não dos requisitos para os administrados desempenharem determinada atividade devem ser objeto de prévia definição em ato normativo ou contratual, em termos objetivos.

Por esse motivo, exclui-se do espectro de atividades passíveis de delegação o exercício de poder normativo originário, por implicar o exercício amplo de poder decisório. Já o poder normativo infralegal, desde que tenha a sua abrangência e objeto previamente delimitados e esteja expressamente previsto em ato normativo e/ou no instrumento contratual, pode ter o seu exercício delegado a particulares ${ }^{583}$.

Portanto, a atribuição da prática de atos que propiciem alguma margem para a avaliação concreta pelo particular depende de previsão em ato normativo ou contratual, que determine os seus critérios e limites. É necessária a prévia programação das atividades a serem desempenhadas pelos particulares de modo objetivo, não podendo a própria Administração delegar integralmente as suas atribuições. A definição antecipada dos requisitos e procedimentos a serem observados no desempenho das atividades delegadas é imprescindível também para que a Administração possa exercer efetivo controle sobre a atuação dos particulares.

\subsubsection{A necessidade de proteção adequada dos direitos e garantias fundamentais dos cidadãos}

Em qualquer caso, a possibilidade de ser delegada a particulares a prática de atividades de polícia administrativa não pode implicar qualquer violação a direitos e garantias fundamentais dos cidadãos.

Um dos principais desafios que se apresenta ao exercício privado de atividades públicas mediante delegação estatal é o risco de os interesses coletivos e dos cidadãos, diretamente vinculados àquela atividade, não serem adequadamente tutelados.

A esse respeito, Jean-Bernard Auby destaca que o grande debate na atualidade diz respeito aos mecanismos adequados para se assegurar que o contratado da

\footnotetext{
583 A diferença entre poder normativo originário e derivado e os limites e possibilidades de delegação do segundo são analisados no item III.7.5.
} 
Administração respeite "valores públicos”, isto é, os princípios que os entes públicos devem observar quando desempenham diretamente as suas atribuições. Isso propicia duas perspectivas de análise $e^{584}$.

A primeira delas diz respeito à aplicabilidade ou extensão do dever de tutela dos valores públicos pelo contratado. Isso pode ocorrer mediante previsão contratual, na legislação, pela atuação do Judiciário ou pelo direito privado e autorregulação. Outra vertente do problema diz respeito ao procedimento a ser observado para reivindicar que parceiros privados tutelem os valores públicos. Auby propõe que são legitimados para provocar essa tutela, em primeiro lugar, o ente público contratante, depois as autoridades públicas em geral, os usuários da atividade delegada e os cidadãos que tiverem os seus direitos fundamentais atingidos pela atuação do delegatário.

A necessidade de se assegurar a adequada execução da atividade delegada e de se tutelarem os direitos e garantias fundamentais está vinculada diretamente ao fato de que as atividades desempenhadas por particulares podem produzir efeitos relevantes na esfera dos administrados que se submetem às atividades de polícia. Do fato de não poderem envolver o exercício de coerção e de amplo poder decisório não decorre que tais atividades sejam necessariamente irrelevantes ou despidas de aptidão para atingir a esfera jurídica de terceiros.

O exame ou a vistoria realizada por um particular, por exemplo, poderá ser decisiva para a obtenção ou não de determinada licença. A questão assume contornos mais problemáticos ao se constatar que, na ampla maioria dos casos, a Administração não tem condições de efetuar a recepção controlada dos resultados das avaliações técnicas informados pelos delegatários.

As entidades privadas que desempenham atividades de controle, inspeção, certificação e fiscalização, por exemplo, apresentam-se perante os cidadãos como autênticas autoridades públicas. Como constata Dolors Ametller, em linhas gerais, os papéis são invertidos, cabendo aos particulares a tomada de decisões, pelo conhecimento técnico especializado que detêm, e ao poder público, a sua execução. A actoritas fica com os agentes privados e a potestas, faculdade de execução material, permanece, em grande parte, com o poder público ${ }^{585}$.

Reputa-se ser a adequada proteção dos direitos e garantias dos cidadãos um aspecto essencial na delegação do exercício das atividades de polícia administrativa. Não

\footnotetext{
${ }^{584}$ Contracting out and "public values".

${ }^{585}$ El ejercicio por particulares de funciones de autoridade, 2003, p. 291.
} 
podem ser admitidas soluções meramente formais, com o objetivo de se validar todos os atos praticados por particulares nas etapas anteriores.

É o que se verifica em algumas apurações de infrações de trânsito, por exemplo. Delegam-se a particulares todos os atos de fiscalização e de apuração da infração. Ao final, o auto de infração é lavrado por um servidor público, para dar atendimento ao disposto no art. $280, \S 4^{\circ}$, do CTB. No entanto, a autoridade que lavrou o auto de infração não tem nenhuma condição de verificar a correção da fiscalização e a veracidade dos fatos reportados pelo particular. Em tais circunstâncias, não se pode reputar ser despida de importância a atividade desempenhada pelo particular.

Daí ser imprescindível que todos os critérios e procedimentos a serem observados pelos delegatários tenham sido objeto de prévia definição no âmbito normativo e contratual. Caso o particular que se submete ao exercício da atividade de polícia tenha seus direitos e garantias violados por atos praticados pelo delegatário, deve ser-lhe garantida a manifestação de impugnações e recursos, nas esferas administrativa e judicial $^{586}$.

5.4.4. Necessidade de identificação expressa dos poderes públicos cujo exercício é objeto de delegação

Os eventuais poderes atribuídos a particulares devem ser objeto de expressa numeração e delimitação no ato de delegação. Não é possível a conferência ampla e genérica do exercício de poderes públicos a particulares, devendo haver a enumeração das competências públicas atribuídas. Trata-se de regra aplicável a toda e qualquer delegação, inclusive aquelas realizadas entre órgãos administrativos ${ }^{587}$.

Como ressalva Ana Raquel Gonçalves Moniz, ao se referir à delegação de poderes normativos: “os princípios da determinação dos poderes delegados e da enumeração das competências públicas apontam no sentido de uma identificação precisa dos poderes regulamentares atribuídos às entidades privadas”,588.

Não será válida, portanto, a atribuição genérica e ilimitada de competências públicas a particulares.

\footnotetext{
${ }^{586}$ O tema é analisado adiante, no item IV.4.

${ }^{587}$ Lei n ${ }^{\circ} 9.784 / 99$, art. 14: " $§ 1^{\circ} \mathrm{O}$ ato de delegação especificará as matérias e poderes transferidos, os limites da atuação do delegado, a duração e os objetivos da delegação e o recurso cabível, podendo conter ressalva de exercício da atribuição delegada”.

${ }^{588}$ A delegação administrativa do poder regulamentar em entidades privadas, 2010, p. 235.
} 
Uma das consequências da identificação expressa dos poderes delegados é a de que não existe a possibilidade de serem considerados como manifestações de exercício de poder público os atos praticados fora dos limites da delegação.

O delegatário encontra-se habilitado para exercer prerrogativas e privilégios públicos apenas nos exatos limites da delegação. A não observância desses parâmetros não conduz à invalidade dos atos praticados mas à própria exclusão da sua natureza pública. Não poderão ser considerados, portanto, atos administrativos. Quando muito serão atos privados, produzindo apenas os efeitos a estes reconhecidos.

Em relação a entidades privadas, não existem, portanto, atos administrativos ilegais por vício de competência. O único fundamento possível para o exercício de competências públicas por entidades privadas é a delegação. Fora de seus limites, não há competências públicas a serem exercidas. A ausência de competência para a prática de determinado ato endereça-o ao direito privado, produzindo apenas os efeitos permitidos no exercício da capacidade jurídica de direito privado, se o ato apresentar os requisitos exigidos para a produção de tais efeitos. Vale transcrever a lição de Pedro Gonçalves sobre o tema:

"não existem atos administrativos ilegais por falta de atribuições, por falta de base legal ou por incompetência da entidade privada que assume a respectiva autoria. A falta de competência pública da entidade privada remete para o direito privado a resposta às questões da legalidade e da possibilidade da produção dos efeitos jurídicos pretendidos; ou seja, o ato em causa deve ser qualificado como ato de direito privado, praticado no âmbito de uma capacidade de direito privado"589.

5.4.5. Necessidade de prévia programação dos critérios $\underline{\text { e procedimentos } \underline{\text { a }} \text { serem }}$ $\underline{\text { observados na execução das atividades delegadas }}$

A prévia programação da atividade objeto da delegação é um dos aspectos a serem avaliados para se definir a possibilidade ou não de serem exercidas por particulares.

Considerando esse requisito, por exemplo, Celso Antônio Bandeira de Mello defende a possibilidade de exercício privado também de atos jurídicos, mas apenas se forem inteiramente vinculados ${ }^{590}$.

\footnotetext{
${ }^{589}$ Entidades privadas com poderes públicos, 2008, p. 1.062 - grifo no original.

590 "Existe, finalmente, a hipótese - que na atualidade ainda se pode considerar peculiar - na qual ato jurídico de polícia inteiramente vinculado pode ser expedido por máquina que sirva de veículo de formação e transmissão de decisão do próprio Poder Público (caso de parquímetros que expeçam auto de infração), inobstante o equipamento pertença a um contratado e esteja sob sua guarda e manutenção. Em nosso entender, o fenômeno aí ocorrente explica-se pela preposição do bem do particular ao jugo da 'relação de administração', nos termos em que a configura Ruy Cirne Lima, de tal sorte que, por força dela, o bem privado opera como veículo de expressão do Poder Público (não sendo, pois, de se cogitar de uma 'delegação')”' (Curso de direito administrativo, 2013, p. 856-857).
} 
Reputamos que não se faz imprescindível que se trate de ato completamente vinculado, de modo que não exista qualquer interferência humana no seu exercício. Porém, é necessário que exista disciplina prévia, em termos objetivos, de todos os aspectos das atribuições a serem desempenhadas pelo particular.

Sobre o tema, vale recorrer à formulação do caráter eminentemente contratual da concessão, proposta por Floriano de Azevedo Marques Neto ${ }^{591}$.

O autor enuncia que a concessão é uma fonte de normatividade, no sentido de que normatiza as relações em torno do objeto concedido, envolvendo concedente, concessionário e demais particulares envolvidos. Cabe ao contrato de concessão disciplinar as diversas relações emergentes da delegação e não apenas aquela existente entre concedente e concessionário ${ }^{592}$.

O autor enfatiza a relevância da disciplina a ser estabelecida no contrato de concessão inclusive por ser inadequado que as concessões tenham o seu regime jurídico detalhado em lei. Para o autor, em relação ao objeto concedido, o contrato estabelece "a normatividade própria a disciplinar todos os aspectos da relação jurídica que se estabelece entre concedente, concessionário e terceiros" ${ }^{\text {593 }}$.

Por isso, seria um contrato regulatório, que não deve ser indevidamente restringido por previsões legais uniformes e genéricas, deixando espaço para a normatividade dentro do contrato, de acordo com o objeto.

O conceito de “contrato regulatório", inspirado na experiência norteamericana, foi bastante difundido por Pedro Gonçalves.

Trata-se de "contrato que tem como objeto a regulação administrativa, revelando-se portanto como um instrumento ou meio de efetuar toda ou uma parte da regulação pública administrativa que orienta as condutas das empresas reguladas de um determinado mercado"

A estrutura normativa do contrato de delegação é complexa, conjugando comandos legais e contratuais. Floriano de Azevedo Marques Neto destaca a inviabilidade de a concessão ser disciplinada exclusivamente ou predominantemente por comandos legais. A regulação da concessão envolve múltiplos interesses, depende das características

\footnotetext{
${ }^{591}$ A concessão como instituto do direito administrativo, 2013, passim.

592 "De um verdadeiro ato unilateral disciplinado por um contrato de direito público (...), a hodierna concessão se converteu em um instrumento consensual de articulação de interesses entre o poder público e diversos polos de interesses de particulares com vistas a disciplinar (de forma mais processual que material e para o longo prazo) múltiplos, complexos e diversificados direitos, durante longo prazo. Daí a caracterização que damos aos contratos de concessão como contratos relacionais” (ob. cit., p. 574).

593 Ob. cit., p. 229.

594 Pedro Gonçalves. Regulação administrativa e contrato, 2010, p. 1.017.
} 
específicas do objeto delegado e é necessariamente dinâmica, o que é incompatível com uma regulação legal estática ${ }^{595}$.

Disso decorre inclusive a possibilidade de os contratos criarem efeitos normativos sobre terceiros, desde que suas disposições não sejam contrárias a prescrições de maior densidade normativa ${ }^{596}$. O conteúdo dos contratos, estipulado dentro dos limites legais, passa a integrar o bloco de legalidade e a orientar a conduta de todos os envolvidos $^{597}$.

Portanto, todos os aspectos e procedimentos a serem observados no exercício das atividades delegadas devem ser objeto da regulação mais detalhada possível. O contrato é a sede adequada para a regulação minuciosa dos critérios e procedimentos a serem observados na execução das atividades delegadas. Além de constituir um padrão de conduta vinculante para todas as partes envolvidas, a prévia programação das atividades a serem desenvolvidas propicia a previsibilidade, objetividade e imparcialidade da atuação bem como o seu amplo controle ${ }^{598}$.

Na inviabilidade de programação prévia exaustiva, prevendo-se a conduta a ser adotada diante de todas as circunstâncias possíveis, deverá ser conferida a menor margem possível para o exercício de avaliações pelo delegatário. Deverão também ser expressamente previstos os seus limites, de modo a se identificar o momento a partir do qual será imprescindível a intervenção da Administração para decidir a conduta a ser adotada.

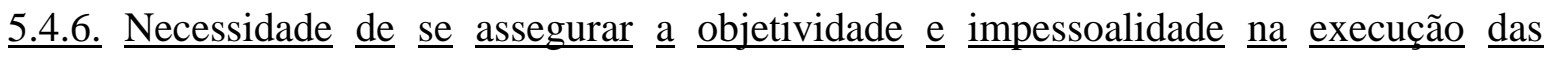
atividades delegadas

Um dos principais objetivos a serem atingidos com a prévia programação dos critérios e procedimentos a serem observados na execução das atividades delegadas é assegurar a objetividade e impessoalidade na atuação dos particulares.

\footnotetext{
${ }^{595}$ A concessão como instituto do direito administrativo, 2013, p. 580.

${ }^{596}$ Ob. cit., p. 582. Paulo Otero também enfatiza a expansividade do contrato, no sentido de produzir efeitos sobre terceiros: "É precisamente no domínio da autonomia de estipulação que os contratos da Administração Pública, regulando direta e imediatamente as relações entre esta e o respectivo co-contratante, se mostram também passíveis de integrar regras definidoras da organização, gestão e utilização de um serviço público, incluindo a produção de efeitos face a terceiros, criando-lhes direitos através da imposição de deveres ao concessionário ou gestor do serviço público” (Legalidade e Administração Pública, 2003, p. 523-524).

${ }^{597}$ Paulo Otero. Legalidade e administração pública, 2003, p. 525; Floriano de Azevedo Marques Neto. A concessão como instituto do direito administrativo, 2013, p. 582-583.

598 Fernando Vernalha Guimarães ressalta a necessidade de "previsão de cláusulas específicas e regulamentares que prescrevam atribuições suficientes à garantia de um desempenho seguro e satisfatório do objeto pelo parceiro privado, delineando, ainda, um suficiente controle por parte do Poder Público" (As parcerias público-privadas e a transferência de atividades de suporte ao poder de polícia, 2007, p. 402).
} 
A necessidade de objetividade na execução de atividades delegadas encontra-se diretamente vinculada ao princípio da impessoalidade. O risco de que elementos subjetivos influenciem o desempenho da atividade pública consiste em um dos óbices opostos ao exercício privado de atividades de polícia. É o que se extrai, por exemplo, da lição de Celso Antônio Bandeira de Mello:

Para execução desta atividade material, objetiva, precisa por excelência, e desde que retentora de dados para controle governamental e dos interessados, nada importa que os equipamentos pertençam e sejam geridos por particulares, aos quais tenha sido delegada ou com os quais tenha sido meramente contratada. É que as constatações efetuadas por tal meio caracterizam-se pela impessoalidade (daí por que não interfere o tema do sujeito, da pessoa) e asseguram, além de exatidão, uma igualdade completa no tratamento dos administrados, o que não seria possível obter com o concurso da intervenção humana ${ }^{599}$.

Reputamos que é possível assegurar-se a objetividade e impessoalidade no exercício das atividades delegadas, mediante a previsão adequada das atribuições do particular. Ou seja, a delegação do exercício de atividades de polícia administrativa apenas não implicará infringência ao dever de se observar a objetividade no desempenho das atividades públicas caso as atribuições do particular encontrem-se minuciosamente previstas em ato normativo ou contratual.

Um dos aspectos aptos a comprometer a objetividade no desenvolvimento das atividades de política delegadas é a vinculação da remuneração do particular aos resultados da atividade que exerce.

Faz-se necessário determinar a forma de remuneração do particular de modo que não incentive desvios de conduta. Como pondera Rafael Wallbach Schwind, "a remuneração do particular deverá ser concebida de tal forma que não crie conflitos objetivos de interesse. Ou seja, a remuneração do ente privado não deverá ser fixada de modo a afetar a sua atuação e, consequentemente, a decisão do Poder Público tomada com base na atividade do particular" ${ }^{\prime 600}$.

Disso não decorre que sejam absolutamente vedadas formas de remuneração atreladas, de alguma forma, ao desempenho dos particulares. É sempre desejável a atuação eficiente do particular, o que pode ser incentivado por mecanismos de remuneração proporcionais aos resultados obtidos com a realização da atividade. Essa questão deve ser especialmente analisada em face das circunstâncias concretas.

Se os diversos aspectos de execução da atividade forem determinados previamente de modo minucioso e objetivo, serão coibidos os eventuais desvios em que o

\footnotetext{
${ }^{599}$ Curso de direito administrativo, 2013, p. 856 - grifos no original.

${ }^{600}$ Particulares em colaboração com o exercício do poder de polícia, p. 153.
} 
particular poderia incorrer e ampliadas as possibilidades de controle efetivo da atuação do particular. Nessas hipóteses, a percepção de remuneração que se encontre, de alguma forma, vinculada aos resultados tende a não comprometer a objetividade na execução da atividade. Já em contratações em que se confiram margens ampliadas para escolhas pelo particular, sistemáticas inadequadas de remuneração poderão ampliar os riscos de desvios $^{601}$.

Portanto, a contratação deverá ser estruturada de modo a assegurar a objetividade e impessoalidade na realização da atividade pública e evitar conflitos de interesses que possam comprometer esse propósito.

5.4.7. Necessidade de retenção $\underline{\text { dos dados para posterior controle pelo concedente }}$

Outro aspecto a ser considerado é que deve ser prevista a retenção dos dados pelo delegatário, de modo a propiciar o efetivo controle pelo poder público das atividades exercidas.

A preservação dos dados é necessária também para que não sejam violados direitos e garantias fundamentais dos administrados. Os direitos de defesa e de impugnação apenas poderão ser exercidos satisfatoriamente com a manutenção e disponibilização de todos os dados relacionados ao exercício das atividades delegadas ${ }^{602}$.

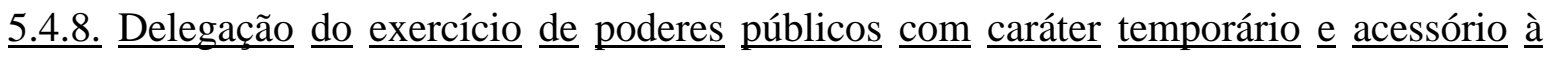
delegação da atividade principal

O exercício de poderes públicos por particulares, mediante delegação, em regra geral, deve apresentar-se como temporário e acessório ao exercício da atividade principal objeto da delegação ${ }^{603}$.

O desempenho da atividade administrativa, acompanhada das prerrogativas e privilégios que lhe são inerentes, cabe, em princípio, à Administração Pública. Diante disso, a investidura de entidades privadas no exercício de poderes públicos “deve ser uma

\footnotetext{
${ }^{601}$ Pode-se ilustrar a constatação com o seguinte exemplo: se o contrato permitir que o particular escolha os locais de instalação dos radares fotográficos para controle de tráfego de veículos, a atribuição de remuneração proporcional à quantidade de infrações detectadas pelos equipamentos que opera ampliará significativamente os riscos de a atuação do particular não observar os princípios da impessoalidade, objetividade e moralidade. Poderão ser escolhidos locais em que exista maior possibilidade de identificação de infrações em detrimentos dos locais em que a instalação dos equipamentos poderia reduzir a quantidade e a gravidade de acidentes. Já se o contrato não atribuir essa margem de liberdade para a atuação do particular e for verificado um aumento da quantidade de infrações constatadas, atribuível, por exemplo, às boas condições de funcionamento e manutenção dos radares, a percepção pelo particular de remuneração atrelada, em alguma medida, ao seu desempenho não estará associada a desvios no desempenho da atividade.

${ }^{602}$ Nesse sentido, a Lei n ${ }^{\circ}$ 8.987/95 prevê, entre os direitos dos usuários, o de "receber do poder concedente e da concessionária informações para a defesa de interesses individuais ou coletivos” (art. $7^{\circ}$, inc. II).

${ }_{603}$ Paulo Otero. Vinculação e liberdade de conformação jurídica do setor empresarial do Estado, 1998, p. 237-238.
} 
situação excepcional ou pelo menos quantitativamente menor no contexto global”604 da Administração Pública.

Note-se que o caráter acessório e temporário aplica-se apenas aos poderes públicos a serem manejados pelo delegatário e não à atividade pública em si. À medida que a atividade delegada, inclusive se for de polícia administrativa, não implicar o uso de poderes públicos com caráter permanente e a título principal da delegação, não incidirá a vedação ora enunciada. Ou seja, não há impeditivo para que a missão atribuída aos particulares esteja compreendida na função de polícia e que o objeto principal da delegação seja uma atividade de polícia administrativa. O exercício de poderes de autoridade pelo delegatário é que deve ser acessório em qualquer caso, seja o objeto principal da delegação a prestação de serviço público ou o desempenho de atividade de polícia administrativa.

Reputamos, assim, que a delegação de poderes e prerrogativas públicas deve ser sempre instrumental ao desempenho de atividades públicas. Cabe a delegação apenas dos poderes e prerrogativas estritamente necessárias ao adequado desempenho da atividade atribuída ao particular.

5.4.9. Vedação de delegação de poderes públicos desvinculada do exercício de atividades públicas

Questão diversa é se seria possível transferir a particulares o exercício de poderes públicos de modo dissociado da execução de atividades públicas. Um exemplo disso é apresentado por Pedro Gonçalves. Trata-se da eventual delegação de poder tributário às associações religiosas ${ }^{605}$.

À luz do direito francês, Pedro Gonçalves registra que não se admite a delegação de poderes públicos de modo desvinculado do exercício de atividades públicas. A doutrina majoritária francesa aceita a prática de atos de autoridade por particulares desde que o façam no desempenho de uma atividade pública e no exercício de prerrogativa de autoridade pública. Se não estiverem presentes os dois elementos - atividade pública e prerrogativa de autoridade -, os atos praticados caracterizam-se como atos privados ${ }^{606}$.

Parece-nos que este é o entendimento a ser aplicado também no direito nacional. À medida que poderes públicos apenas podem ter o seu exercício delegado a particulares por serem estritamente necessários ao desempenho de atividades públicas, não se pode admitir o seu trespasse de modo isolado e desvinculado do desempenho de

\footnotetext{
${ }^{604}$ Vital Moreira. Administração autónoma e associações públicas, 1997, 545-546.

${ }^{605}$ Entidades privadas com poderes públicos, 2008, p. 50, nota 158.

${ }^{606}$ Ob. cit., p. 62.
} 
atividades públicas. O objeto principal da delegação é o desenvolvimento de uma atividade pública, para o exercício da qual podem ser necessários determinados poderes e prerrogativas. Especificamente por este motivo é que pode ser delegado o exercício de poderes públicos a particulares.

\subsection{Conclusões parciais}

Constata-se que um dos limites mais evidentes à delegação das atividades de polícia administrativa é o monopólio estatal da violência legítima.

Porém, não deixa de ser viável o particular implementar decisões de polícia administrativa de modo legítimo, com o emprego de meios de direito privado, sem que lhe seja atribuído o exercício de poderes públicos de coerção sobre os particulares que se submetem à medida de polícia. Esta seria a hipótese da entidade privada que acata a ordem da autoridade pública para demolir um edifício ou remover um veículo. A entidade privada executa a ordem empregando exclusivamente meios de direito privado e o seu vínculo direto é com a Administração, não podendo decidir acerca do modo de execução da atividade ou os meios a serem empregados.

Outro critério relevante para a definição dos limites da delegação é a avaliação da extensão das funções atribuídas aos particulares. Exclui-se a possibilidade de se atribuir o exercício de amplo poder decisório aos particulares. Os atos a serem praticados pelos particulares no exercício da atividade pública que lhes foi delegada devem ser objeto de prévia programação, estabelecendo-se em ato normativo ou contratual os critérios, requisitos e procedimentos a serem observados.

Por esse motivo, afasta-se também da esfera de atividades passíveis de delegação a entidades privadas o exercício de poder normativo originário. Trata-se de poder de exercício exclusivo pelo Parlamento, que admite hipóteses bastante restritas e limitadas de delegação para o Poder Executivo.

As demais atividades compreendidas no denominado ciclo de polícia, que não impliquem o exercício de coerção nem de amplo poder decisório, poderiam comportar, em princípio, a sua delegação a entidades privadas.

Além dos atos materiais, trata-se de atividades nas quais predominam os aspectos cognitivo e informativo e que são necessárias para o exercício da atividade de polícia administrativa. Podem até mesmo compreender a integralidade de uma das etapas do ciclo de poder de polícia, tal como a fiscalização. 
No entanto, quanto mais amplas forem as atribuições compreendidas nas atividades delegadas ao particular, com maior rigor impor-se-á a exigência de regulação precisa e minuciosa dos direitos e obrigações do contratado bem como dos procedimentos a serem observados no exercício da atividade delegada.

Apenas podem ser delegadas atividades que apresentem uma dimensão programável e determinável por antecipação, para se evitar a ocorrência de erros ou abusos por parte do delegatário. Faz-se necessária a prévia definição das medidas a serem adotadas diante de cada situação concreta, de modo que não seja atribuída ao particular a ampla definição do "se” e “como” da atuação.

Logo, nos casos em que for possível determinar antecipadamente, em termos objetivos, o âmbito da intervenção sobre os administrados, excetuando-se o emprego da coação, apresenta-se possível a delegação.

Exatamente pela possibilidade de prévia enumeração e delimitação das atividades a serem executadas pelo particular é que é possível, por exemplo, a delegação de atividades tais como o controle de pessoas e bagagens em aeroportos e outros locais públicos. Nestes casos, a atuação do delegatário tem seus contornos previamente definidos, não se lhe atribuindo a possibilidade de tomada de decisões quanto ao "se" e "como" do desempenho da atividade. Diante da ocorrência de circunstâncias excepcionais, tal como a resistência de um cidadão em ter a sua bagagem revistada, será necessária a intervenção de agente público com competência para o exercício de coerção.

Após a análise dos critérios e requisitos a serem observados para a definição das atividades de polícia administrativa passíveis de delegação a particulares e considerando-se as premissas acima adotadas, as conclusões atingidas acerca dos limites e condições a serem observados na atribuição de tais atividades a particulares podem ser assim sistematizadas:

a) em qualquer caso, veda-se a delegação do exercício da coerção sobre particulares;

b) na hipótese de se transferir o exercício de alguma parcela de poder de autoridade ao particular, deve haver a prévia programação e delimitação das suas atribuições, estipulando-se em ato normativo ou contratual os critérios, requisitos e procedimentos a serem observados;

c) não é possível delegar atos cuja prática demande a formulação de escolhas amplas pelo delegatário, tal como a determinação do "se” e “como” do desempenho da atividade de polícia administrativa; 
d) há a necessidade de se assegurar a objetividade e impessoalidade na execução das atividades delegadas;

e) para fins de posterior controle, deverão ser retidos os dados relativos à execução da atividade objeto da delegação;

f) os eventuais poderes atribuídos a particulares devem ser objeto de expressa numeração e delimitação no ato de delegação;

g) a delegação do exercício de poderes de autoridade deve ser excepcional e temporária; e

h) os eventuais poderes de autoridade delegados devem estar relacionados ao exercício de uma função pública e apenas podem ser delegados os poderes estritamente necessários ao exercício da função atribuída ao particular (proporcionalidade).

\section{6. $\underline{\text { A exigência }} \underline{\text { de }} \underline{\text { autorização }} \underline{\text { legislativa para a }} \underline{\text { delegação }}$}

Acima, identificou-se a desnecessidade de autorização expressa no texto constitucional para o exercício indireto de atividades de polícia administrativa pelo Estado $^{607}$.

Nesse ponto, analisa-se a exigência de autorização legislativa específica para se delegar o exercício de atividades de polícia administrativa a particulares.

O requisito da autorização legislativa prévia encontra-se vinculado à natureza das funções atribuídas aos particulares.

No caso dos contratos de colaboração, nos quais os particulares atuam como auxiliares da Administração, no exercício de atividades acessórias, sem que lhes seja transferida a responsabilidade pela gestão de tais atividades, seria possível sustentar que não se faz necessária autorização legal específica para se adotar tal modalidade de parceria.

Já na hipótese dos contratos de delegação, em que se atribui ao particular a responsabilidade pela gestão da atividade, verificam-se reflexos mais sérios na organização administrativa e há verdadeira delegação de funções públicas. Como se demonstra a seguir, a adoção de tal forma de parceria depende de autorização legal.

Nesses casos, incidirá o denominado mecanismo bifásico da delegação. A delegação em si não é realizada diretamente pela norma. A norma legal autoriza formalmente o titular da competência a delegá-la. A delegação propriamente dita ocorre através de um ato concreto do titular da competência.

${ }^{607}$ V. item III.5.2. 


\subsection{Necessidade de autorização legislativa para a delegação}

A opção pela delegação a particulares do exercício de atividades de polícia administrativa produz importantes repercussões na organização administrativa. Também é passível de atingir os direitos dos cidadãos, que se sujeitarão à prática de atos de polícia administrativa por particulares. Diante da relevância da matéria e da transcendência dos interesses envolvidos, sustenta-se que a decisão a seu respeito não se restringe às competências puramente administrativas. Faz-se necessária também a intervenção do legislador.

Tais poderes são atribuídos pelo ordenamento jurídico à Administração como competências, submetendo-se ao princípio da irrenunciabilidade. Por isso, apenas a lei pode autorizar a atribuição de tais funções, competências e prerrogativas a entidades privadas $^{608}$.

Note-se que, em relação às atividades de polícia administrativa, não existe autorização constitucional genérica para a delegação, tal como se passa em relação aos serviços públicos, nos termos do art. 175 da CF/88. Como já se demonstrou, disso não decorre a impossibilidade de delegação. No entanto, a ausência de permissivo constitucional genérico confirma a necessidade de autorização legislativa específica.

Assim, para que se promova a delegação, faz-se necessária a autorização do legislador. A delegação pode decorrer diretamente da previsão legal ou de decisão administrativa habilitada por lei. Em relação à atribuição da atividade à entidade privada pela própria lei, importa ressaltar que "não constitui uma delegação administrativa a habilitação para o exercício de poderes públicos por entidades privadas constante de ato legislativo (...) estes casos não correspondem a uma delegação (hoc sensu), mas antes à atribuição legal de um poder público"609.

A autorização legislativa pode ser genérica ou específica. O tipo de autorização legislativa a ser dada em cada caso insere-se na esfera de competência do ente federativo titular da atividade de polícia a ser delegada. De todo modo, a habilitação legal para a delegação deverá apresentar, quando menos, uma densidade relativa, de modo que possam ser precisamente identificadas a autorização para se promover a delegação e as competências que poderão ser delegadas.

\footnotetext{
${ }^{608}$ Como constata Laurent Richer, a lei pode tornar uma atividade delegável desde que sejam respeitadas as normas constitucionais (Droit des contrats administratifs, 2002, p. 464).

${ }^{609}$ Ana Raquel Gonçalves Moniz. A delegação administrativa do poder regulamentar em entidades privadas, 2010, p. 217.
} 
Em relação a algumas atividades específicas, pode-se dizer já existir autorização legislativa genérica para a delegação. Assim se passaria, por exemplo, com os serviços notariais e de registro. O art. 236 da CF/88 estabelece que tais serviços serão sempre exercidos por delegação do poder público e remete à regulação das atividades em lei específica.

Em qualquer caso, a autorização legislativa deve ser prévia à delegação das funções a particulares.

\subsection{Autorização legislativa como mecanismo de legitimação}

Pode-se sustentar ser a autorização legislativa elemento essencial para a legitimação do exercício da função pública por particulares.

Seria até possível cogitar-se da legitimação dos particulares para o exercício de determinadas funções em razão do seu conhecimento especializado.

Atualmente, os particulares encontram-se mais capacitados e detêm os meios necessários para o exercício de diversas atividades que apresentam complexidade técnica. Mas a autoridade técnica dos particulares não é suficiente, por si só, para justificar que lhes sejam atribuídas funções públicas, podendo até mesmo proferir decisões vinculantes, com os mesmos efeitos das decisões administrativas. Essa autoridade técnica dos particulares é uma autoridade efetiva, de fato, e não se impõe juridicamente.

Já a autoridade inerente aos poderes públicos é de caráter jurídico, reconhecida pelo ordenamento, sendo dotada das prerrogativas que lhe são próprias. A legitimidade da transferência de funções públicas não pode se apoiar na presumível autoridade técnica dos particulares. É imprescindível a legitimação democrática de tal processo, o que ocorre com a autorização legal.

\subsection{A disposição do art. $2^{\circ}$ da Lei $n^{\circ} 9.074 / 95$}

O art. $2^{\circ}$ da Lei ${ }^{\circ}$ 9.074/95 prevê, como regra, a exigência de autorização legislativa para a outorga de concessão de obras e serviços públicos.

A constitucionalidade do dispositivo é bastante discutida.

Para Maria Sylvia Zanella Di Pietro, o dispositivo seria inconstitucional:

ao exigir autorização legislativa para outorga da concessão; a autorização legislativa para que o Executivo pratique atos ou celebre contratos que se inserem dentro das funções tipicamente administrativas constitui ato de controle (prévio) de um Poder sobre o outro e, por isso mesmo, exceção ao princípio da separação de poderes, somente cabível nos casos expressos na Constituição Federal, na estadual ou na lei orgânica municipal; note-se que a Constituição Federal elenca, nos arts. 49, 51 e 52 os 
atos que devem ser autorizados pelo Congresso Nacional, Câmara dos Deputados e Senado Federal, entre eles não se incluindo a autorização para concessão ou permissão de serviço público, mesmo porque o art. 175 já diz expressamente que a execução de serviços públicos pode ser feita diretamente ou mediante concessão ou permissão ${ }^{610}$.

Marçal Justen Filho extrai a obrigatoriedade de autorização legislativa para a outorga de concessões e permissões do próprio texto constitucional ${ }^{611}$.

O autor atinge essa conclusão a partir da interpretação da regra do art. 175 da CF/88, ao se referir à edição de lei, e a reforça com os princípios republicano e da soberania popular:

A decisão de transferir a gestão do serviço para particulares envolve, portanto, interesses muito relevantes e de natureza transcendente. Não se trata de decisão inserida na órbita de competência do Poder Executivo. Depende do exame, aprovação e regulamentação do Poder Legislativo, por meio de cuja manifestação retrata-se a concordância do povo à alternativa adotada ${ }^{612}$.

Com isso, constata que as disposições do art. $2^{\circ}$ da Lei $n^{\circ}$ 9.074/95 são inconstitucionais à medida que preveem hipóteses de dispensa da autorização legislativa, para os casos de saneamento básico e de limpeza urbana. A lei infraconstitucional não poderia restringir a incidência da regra constitucional.

De todo modo, como se apontou acima, reputamos que o art. 175 da CF/88 não se aplica diretamente à delegação das atividades de polícia administrativa. Por isso, não supre a necessidade de autorização legal para a delegação de tais atividades. Cabe ressalvar as hipóteses em que o objeto principal da delegação é a prestação de serviço público, sendo o exercício de atividades de polícia administrativa meramente acessório e instrumental ao desempenho do serviço público atribuído ao particular. Para tais hipóteses, consideramos ser suficiente a autorização legal já constante do art. 175 da CF/88, não sendo imprescindível a edição de lei contendo autorização específica para a delegação.

\subsection{A autorização legislativa para as entidades da Administração indireta}

Seria possível aduzir que, para os órgãos da Administração direta e as autarquias, não seria necessária disposição legal específica atribuindo-lhes expressamente o exercício de atividades de polícia. No entanto, isso não significa que não seria necessário observar critérios para a distribuição de competências entre os diversos entes políticos e

${ }^{610}$ Parcerias na Administração Pública, 2012, p. 73 - grifos no original. Registre-se que, para Adilson Dallari, o art. $2^{\circ}$ da Lei $n^{\circ}$ 9.074/95 não consiste em norma geral, não sendo aplicável a Estados e Municípios (Inspeção de segurança veicular - Credenciamento - Desnecessidade de autorização legislativa, 1996, p. 435-439).

611 Teoria geral das concessões, 2003, p. 174-177 O autor ressalva que, caso não se extraísse do texto constitucional a obrigatoriedade da autorização legislativa, tal condicionamento não poderia ser imposto por lei ordinária, mesmo em se tratando de norma geral.

${ }^{612}$ Ob. cit., p. 176. 
para a utilização de entidades da administração indireta, ainda que dotadas de personalidade jurídica de direito público.

Em relação às entidades da administração indireta dotadas de personalidade jurídica de direito privado, faz-se necessária a autorização legal para o exercício de atividades de polícia administrativa ${ }^{613}$.

José dos Santos Carvalho Filho admite que entidades da Administração indireta desempenhem atividades de polícia administrativa desde que tal missão lhes seja conferida por lei formal: “a existência da lei é o pressuposto de validade da polícia administrativa exercida pela própria Administração Direta e, desse modo, nada obstaria que servisse também como respaldo da atuação de entidades paraestatais, mesmo que sejam elas dotadas de personalidade jurídica de direito privado”ø14.

A autorização legal pode ser veiculada na própria lei que autorizar a constituição da empresa estatal, conferindo-lhe expressamente competência para o exercício de determinadas atividades de polícia. A autorização poderá constar também de outros diplomas legais, desde que atribuam expressamente a uma empresa estatal específica o exercício de competências de polícia. Ou seja, não é imprescindível que a autorização para o desempenho de atividades de polícia administrativa conste originariamente da lei que autorizou a criação da empresa estatal ${ }^{615}$.

À medida que a criação da empresa estatal depende de autorização legal, seria possível sustentar também que a referida autorização para a sua constituição compreenderia o exercício de atividades de polícia, estritamente no que diz respeito ao seu objeto social, na hipótese de tais competências serem imprescindíveis para o adequado desenvolvimento das funções que lhe foram atribuídas. Nesses casos, será necessário

\footnotetext{
${ }^{613}$ Nesse sentido, José Afonso da Silva defende que empresas estatais apenas podem exercer atividades de polícia se tal competência lhes tiver sido atribuída expressamente no ato legal que autorizou a sua instituição: o direito brasileiro "admite, mediante norma legal expressa, a atribuição de competência para o exercício de atividade de polícia até mesmo a pessoas privadas” (Poder de polícia, 1978, p. 247). Em seguida, esclarece que essa conclusão aplica-se tanto a empresas públicas quanto a sociedades de economia mista. $\mathrm{O}$ autor analisou especificamente o caso da EMPLASA, uma empresa pública do Estado de São Paulo, e concluiu que não havia nenhum dispositivo legal que lhe conferisse competência para a prática de atos de polícia. Por isso, não poderia fiscalizar nem impor sanções. $\mathrm{O}$ autor ressalvou, porém, que poderia ser editada uma lei atribuindo-lhe tais competências.

${ }^{614}$ Manual de direito administrativo, 2012, p. 78.

${ }^{615}$ A esse respeito, José Afonso da Silva recorda o exemplo da DERSA, empresa pública do Estado de São Paulo criada para a exploração, mediante concessão, do uso das rodovias Anchieta e Imigrantes. $\mathrm{O}$ ato de sua criação - Decreto-Lei n ${ }^{\circ}$ 5/69 - não previa expressamente o exercício de atividades de polícia. A Lei no 95/72 alterou-o para conferir expressamente à DERSA competência para "exercer, nas rodovias abrangidas pela concessão, além de outras atividades úteis ou necessárias ao cumprimento de suas finalidades, todos os poderes implícitos e explícitos, com os respectivos direitos e obrigações, inclusive o poder de polícia administrativa, inerente e por isso necessário ao bom desempenho dos serviços concedidos” (Poder de polícia, 1978, p. 247-248).
} 
proceder-se à interpretação com cautela das disposições legais, para se concluir pela inequívoca atribuição de competências de polícia à empresa estatal, ainda que isso não conste expressamente da lei.

O mesmo raciocínio poderia ser aplicado aos empregados das empresas estatais. As unidades de atribuições nas empresas estatais não são criadas por lei, cabendo à própria entidade deliberar a esse respeito. Ao criar tais unidades e atribuir-lhes determinado plexo de atribuições, o ente está conferindo o exercício de parcela de sua competência aos seus empregados. Por sua vez, as atribuições da empresa estatal foram-lhe outorgadas pela lei que autorizou a sua criação. Logo, em última análise, as competências exercidas pelos empregados das empresas estatais também decorrem da lei, ainda que indiretamente.

\subsection{Atribuição do exercício de atividades de polícia administrativa diretamente pelo ordenamento jurídico}

Em determinadas hipóteses, o texto constitucional ou a lei já atribuem diretamente a determinadas entidades, não integrantes da estrutura estatal, e a particulares o exercício de atividades de polícia administrativa.

Nesses casos, diz-se haver delegação legal, por se revestir da forma legal o ato jurídico de delegação. A delegação dita administrativa depende de um ato administrativo ou de um contrato para a concretização da delegação, praticados com fundamento em autorização legal.

Alguns dos exemplos, que são analisados abaixo, consistem nas disposições legais que disciplinam as atividades das corporações profissionais e a atribuição do desempenho excepcional de atividades de polícia a particulares que exercem determinadas profissões.

\subsubsection{Conselhos de fiscalização profissional}

Os conselhos de fiscalização profissional desempenham função de titularidade pública, cujo exercício lhes é delegado pelo Estado. A atividade desempenhada pelos conselhos pode ser identificada como "polícia das profissões”,616, um dos setores abrangidos pela polícia administrativa.

A natureza e o regime jurídico dos organismos de regulação profissional não são temas pacíficos no direito brasileiro. Desde a criação dos primeiros conselhos

\footnotetext{
${ }^{616}$ Diogo de Figueiredo Moreira Neto. Curso de direito administrativo, 2009, p. 454.
} 
profissionais, houve significativas mudanças na legislação bem como divergências no entendimento dos tribunais sobre o tema, inclusive no âmbito do STF.

Os conselhos de fiscalização profissional situam-se em uma zona fronteiriça entre o direito público e o privado, com disputas em relação ao regime jurídico incidente sobre os vários aspectos da sua instituição e funcionamento.

\subsubsection{Os diversos modelos de regulação profissional}

Nos diversos sistemas jurídicos, podem ser identificados três grandes modelos de regulação profissional ${ }^{617}$.

O primeiro deles consiste na regulação estatal das profissões (ou heterorregulação). A regulação é assumida pelo Estado e exercida por entes que integram a estrutura estatal, sem que exista qualquer parcela de autorregulação desempenhada pelos profissionais interessados.

Outro modelo é a autorregulação privada ou regulação endógena. Trata-se da instituição de entidades privadas de autorregulação, sem interferência estatal na sua atividade. A autorregulação privada é uma regulação de origem não estatal, na qual uma entidade coletiva estabelece, impõe e fiscaliza o cumprimento de determinadas regras por seus membros.

A adesão dos profissionais é voluntária. Prevalece a liberdade de associação e os profissionais autovinculam-se espontaneamente às normas por eles mesmos produzidas. Nesse contexto, prevalecem os mecanismos de soft regulation, com a adoção de códigos de conduta e de boas práticas entre outros.

Por fim, há a autorregulação pública. A regulação é exercida pelos próprios interessados mas em organizações impostas ou reconhecidas pelo Estado. Essas entidades são dotadas de instrumentos de direito público, cujo exercício lhes é delegado pelo Estado. Exercem poderes públicos, tais como normativo e sancionatório, e o seu funcionamento observa diretrizes do regime público. Em regra, a filiação é obrigatória para o exercício da profissão $^{618}$.

\footnotetext{
${ }^{617}$ Como ensina Vital Moreira, a regulação profissional é uma forma de regulação pública da economia, em sentido amplo. A regulação profissional pode assumir diversas formas, diretamente vinculadas às relações existentes entre o Estado e a economia em um dado momento (Auto-regulação profissional e Administração Pública, 1997, p. 14). Além disso, as "razões para a regulação profissional são no fundamental as mesmas (...) para a regulação económica em geral: falhas de mercado, direitos dos consumidores, razões sociais” (Vital Moreira; Luís Vale Lima. Autorregulação profissional oficial, 2012).

${ }^{618}$ A outra face da obrigatoriedade de filiação é a vedação da recusa discricionária da inscrição: "Uma consequência necessária do exercício de funções administrativas está em que todos os interessados adquirem um direito à filiação, salvo havendo legalmente numerus clausus (quando lícito), não tendo a associação
} 
Ao se analisarem os modelos concretos de regulação profissional de cada país, há significativas variações nestes grupos. Especialmente entre os extremos da regulação exclusivamente estatal e da autorregulação exclusivamente privada, há várias soluções de regulação que podem combinar, em maior ou menor grau, traços da regulação estatal e da autorregulação privada. Essas variações tendem a ser agrupadas na autorregulação pública que apresenta, assim, significativa variação interna ${ }^{619}$.

Na Europa continental e nos países influenciados mais diretamente pelo seu regime jurídico, prevalecem as configurações de regulação estatal e de autorregulação regulada, usualmente designadas como ordens, colégios ou câmaras profissionais. Consistem em entidades com personalidade de direito público ou privado, que exercem amplos poderes públicos e são de filiação obrigatória para os profissionais.

Em medidas diversas, há o entrelaçamento de aspectos de autorregulação na regulação estatal das profissões. Instituições de autorregulação foram publicamente reconhecidas ou oficializadas, sendo-lhes atribuídos determinados poderes e funções estatais. Nesse modelo, o Estado procura aproveitar determinados benefícios da autorregulação, tais como a maior eficiência e cooperação dos interessados. Essa sistemática reduz também a necessidade de intervenção direta do Estado, implicando menores custos ao dispensar a utilização das estruturas estatais para as atividades normativas e disciplinares, por exemplo, que são desenvolvidas diretamente pelas corporações. Por sua vez, ao estarem diretamente envolvidos os próprios interessados, ampliam-se as possibilidades de se obter um nível de regulação adequado para o exercício da profissão, que assegure a prestação adequada dos serviços sem que a liberdade de profissão sofra restrições excessivas.

poder discricionário para recusar a inscrição" (Vital Moreira. Administração autónoma e associações públicas, 2003, p. 561).

${ }^{619}$ No âmbito da autorregulação pública, Vital Moreira identifica, pelo menos, três grupos de gradação: "podemos autonomizar três degraus intermédios significativos: um modelo central em que as duas formas de regulação se equilibram, que por isso se pode dizer de co-regulação (a definição e a implementação da regulação são compartilhadas de modo equilibrado pelo Estado e pela organização profissional); e depois, de um lado, uma forma de auto-regulação privada com apoio do Estado ou auto-regulação quase-privada (regulação estabelecida e implementada direta ou indiretamente pela organização profissional, mas com base em devolução de poderes pela lei e no controle estadual) e de outro lado uma regulação estadual com participação privada ou regulação quase-estadual (regulação pública, mas em certa medida implementada e aplicada pela organização profissional ou por um órgão público de que ela participe)" (Auto-regulação profissional e Administração Pública, 1997, p. 75-76 - grifos no original). 
Considerando o modelo de autorregulação regulada, para alguns autores a regulação profissional estaria mais próxima da autoadministração ${ }^{620}$ do que da autorregulação $^{621}$.

Nesse contexto, os colégios profissionais seriam exemplos de autoadministração e não de autorregulação. A sua capacidade para regular determinados aspectos da atividade profissional dos seus membros decorre de habilitação legal expressa. As entidades de autoadministração exercem determinados poderes disciplinares por delegação legal - atuam, portanto, como Administração Pública.

A aplicação do direito administrativo a significativa parcela da atuação das corporações profissionais confirmaria não se tratar de autorregulação social. A autoadministração pode até envolver alguns aspectos de autorregulação mas os fins a serem perseguidos devem ser necessariamente públicos, extrapolando os interesses dos associados.

Em relação à sua configuração jurídica, no direito europeu continental prevalece a forma de corporação pública de base associativa - as denominadas associações de direito público. As associações públicas são pessoas públicas

que a lei cria ou reconhece com o objetivo de assegurar a prossecução de certos interesses coletivos, chegando mesmo a atribuir-lhes para o efeito um conjunto de poderes públicos - que exercem relativamente aos seus membros e, nalguns casos, mesmo em relação a terceiros -, ao mesmo tempo que as sujeita a especiais restrições de caráter público ${ }^{622}$.

As associações públicas podem consistir em associações de entidades privadas às quais o Estado atribui a missão de perseguir uma finalidade pública, coincidente com os interesses particulares desses sujeitos privados. O Estado cria uma associação pública a partir de uma associação privada pré-existente. Assim se passou em relação às corporações profissionais em Portugal, Itália, Alemanha e Espanha. Optou-se pelo reconhecimento das organizações próprias dos profissionais como sendo associações

\footnotetext{
${ }^{620}$ No direito europeu, há a noção de autoadministração de direito público, denominada administração autônoma, que consiste em uma forma de administração pública não-estatal. Na definição de Diogo Freitas de Amaral, administração autônoma é "aquela que prossegue interesses públicos próprios das pessoas que a constituem e por isso se dirige a si mesma, definindo com independência a orientação das suas atividades, sem sujeição a hierarquia ou a superintendência do Governo" (Curso de direito administrativo, v. 1, 2006, p. 419-420). Persegue, assim, interesses públicos próprios e não alheios. Apresenta-se como manifestação de autoadministração, pois ela própria define suas atividades, sem subordinar-se às orientações da Administração direta. Submetem-se ao poder de tutela pela Administração, com poder de fiscalização e controle mas não de direção ou orientação (ob. cit., p. 421). Ainda no direito português, são espécies da administração autônoma as associações públicas, as autarquias locais e as regiões autônomas de Açores e Madeira.

${ }^{621}$ Marc Tarrés Vives. Normas técnicas y ordenamiento jurídico, 2003, p. 172-175.

${ }^{622}$ Diogo Freitas do Amaral. Curso de direito administrativo, v. 1, 2006, p. 423.
} 
públicas, atribuindo-lhes essa missão e transferindo-lhes poderes de autoridade originalmente pertencentes ao Estado.

No direito francês, ainda que existam as corporações profissionais com características próximas às dos outros países $^{623}$, não há o conceito de corporação pública profissional. Procurou-se, então, enquadrar essas corporações nas categorias já existentes. Prevalece a qualificação das ordens profissionais como estabelecimento público corporativo, como modalidade de descentralização por serviços. São dotadas de personalidade de direito público, cabendo à jurisdição administrativa o conhecimento dos litígios que as envolvem. No entanto, isso não é pacífico. Em alguns casos, são qualificadas como associações privadas com funções administrativas ${ }^{624}$.

Nos países anglo-saxões, costuma-se reconhecer a organização profissional dos interessados, preservando a sua personalidade privada e atribuindo-lhes o exercício de certos poderes públicos.

\subsubsection{O objeto da regulação profissional}

A regulação pelas corporações profissionais abrange aspectos relacionados tanto aos requisitos de acesso à profissão quanto ao comportamento a ser adotado pelos profissionais no exercício da atividade.

Vital Moreira identifica algumas funções como sendo o núcleo comum das corporações profissionais que disciplinam as profissões que exigem título acadêmico para o seu exercício (usualmente denominadas “ordens”) ${ }^{625}$ : funções de representação e defesa

\footnotetext{
${ }^{623}$ O comissário Daniel Labetoulle, nas conclusões apresentadas no "arrêt" do Tribunal de Conflitos de 13 de fevereiro de 1984 Cordier c/ Compagnie régionale des commissaires aux comptes de Paris, apresentou as seguintes características das ordens profissionais no regime francês: obrigação de adesão à ordem para exercício da profissão, exercício pela ordem de poder regulamentar para editar as regras de exercício da profissão, o controle pela ordem do acesso à profissão e a detenção pela ordem de poder disciplinar de caráter jurisdicional (Michel Degoffe. Droit de la sanction non pénale, 2000, p. 108).

${ }^{624}$ Vale transcrever os comentários de Vital Moreira acerca das controvérsias do direito francês: “A noção de estabelecimento público, enquanto serviço público personalizado, estava mal adaptada para enquadrar essas figuras de entidades públicas de base corporativa. Com efeito, elas não prestavam serviços públicos nem estavam enquadradas na administração pública do Estado, dada a sua autonomia de gestão e de designação de dirigentes. E no entanto o fato incontornável de elas desempenharem tarefas públicas com prerrogativas de autoridade (poder regulamentar, definição unilateral de posições jurídicas, poder disciplinar) - o que fazia das suas decisões atos materialmente administrativos - dificilmente podia concebê-las no quadro das entidades privadas” (Auto-regulação profissional e Administração Pública, 1997, p. 207). Essa relativa indefinição da qualificação jurídica das corporações profissionais no direito francês deu ensejo a uma crítica contundente a essas entidades, propugnando pela sua extinção, especialmente em face da Convenção Europeia dos Direitos do Homem, que assegura a liberdade de associação (Michel Degoffe. Droit de la sanction non pénale, 2000, p. 107). Essa crítica é fundada especialmente no entendimento de parcela da doutrina francesa de que os conselhos de fiscalização profissional seriam entidades privadas. A Corte europeia já decidiu que as ordens profissionais não consistem em associações privadas. Qualificou-as como associações de direito público, às quais não se aplica o princípio da liberdade de associação (“arrêt” Le Compte, Van Leuven et De Meyere, Strasbourg 23 de junho de 1981).

${ }^{625}$ Auto-regulação profissional e Administração Pública, 1997, p. 264-272.
} 
profissional, regulação do acesso à profissão, regulação do exercício da profissão, funções disciplinares e exercício de poderes públicos, tais como poder regulamentar, de decisão unilateral, sancionatório e disciplinar.

Para o exercício dessas funções, usualmente atribuem-se às corporações profissionais a autorregulamentação, com o estabelecimento de regras próprias, a implementação e fiscalização do cumprimento dessas regras e a autodisciplina, com a imposição de sanções pelas infrações constatadas.

\subsubsection{A regulação profissional no Brasil}

No Brasil, por clara influência do modelo europeu, adota-se o modelo de autorregulação regulada, com a criação de ordens e conselhos reguladores de profissões.

Os conselhos profissionais foram instituídos no Brasil por legislação específica, editada sob a égide de regimes constitucionais distintos. Daí não ser possível constatar a uniformidade da natureza jurídica de tais entidades. A regulação profissional assumiu diversas feições, de acordo com a profissão de que se tratava. Pode-se identificar uma diversidade maior da $\mathrm{OAB}$, cuja situação diferenciada em relação às demais entidades de fiscalização profissional foi expressamente confirmada pelo STF no julgamento da ADI $3.026^{626}$.

Os primeiros conselhos profissionais no Brasil foram instituídos na década de 30 do século passado ${ }^{627}$. Os conselhos profissionais recebiam usualmente o tratamento de autarquias corporativas. Algumas das leis específicas de criação de tais entidades já lhes atribuíam expressamente a natureza jurídica de autarquia ${ }^{628}$. Em outros casos, a lei qualificou-os expressamente como tendo personalidade jurídica de direito público, sem mencionar expressamente a natureza autárquica ${ }^{629}$.

Diante, disso, em um momento inicial, pretendeu-se dar às entidades profissionais um tratamento próximo àquele reservado às autarquias administrativas ${ }^{630}$. Em

\footnotetext{
${ }^{626}$ Rel. Min. Eros Grau, Pleno, j. 8.6.2006, maioria, DJ 29.9.2006.

${ }^{627}$ Para um exame do histórico da criação das corporações profissionais no Brasil, podem ser consultadas, entre outras, as obras de Ricardo Teixeira do Valle Pereira. Histórico dos conselhos de fiscalização do exercício profissional, 2008, p. 17-25 e de Durval Carneiro Neto. Os conselhos de fiscalização profissional, 2010, p. 275-320.

${ }^{628}$ Exemplos disso são o Conselho de Odontologia (Lei $\left.n^{\circ} 4.324 / 64\right)$ e o Conselho de Psicologia (Lei $n^{\circ}$ 5.766/71)

${ }^{629}$ São exemplos a Ordem dos Músicos (Lei n ${ }^{\circ}$ 3.857/60), o Conselho de Biblioteconomia (Lei no 4.084/62) e o Conselho de Farmácia (Lei nº 3.820/1960).

${ }^{630}$ Não se tratava, no entanto, de tratamento equivalente ao das autarquias. O Decreto-lei $\mathrm{n}^{\circ}$ 968/69, por exemplo, continha a seguinte disposição: “Art. $1^{\circ}$ - As entidades criadas por lei com atribuições de fiscalização do exercício de profissões liberais que sejam mantidas com recursos próprios e não recebam subvenções ou transferências à conta do orçamento da União, regular-se-ão pela respectiva legislação
} 
diversos casos, eram identificadas como “autarquias corporativas”, figura esta não existente na estrutura administrativa proposta pelo Decreto-lei $n^{\circ} 200$.

\subsubsection{A natureza jurídica das corporações profissionais}

A natureza jurídica das corporações profissionais no direito nacional não encontra unanimidade na doutrina e na jurisprudência. Determinados aspectos indicam a sua natureza pública, enquanto outros são característicos de entidades privadas.

Por um lado, seria possível sustentar que as corporações têm natureza jurídica autárquica e integram, portanto, a estrutura da Administração Pública. Esse enquadramento vai ao encontro da qualificação como autarquias dada pela lei para algumas corporações. Determinadas características das corporações são utilizadas para invocar esse enquadramento, tais como a sua criação por lei, a obrigatoriedade de filiação imposta aos profissionais e o exercício de poderes públicos, inclusive sancionatório ${ }^{631}$.

Por outro lado, é possível encontrar traços de entidades privadas nas corporações profissionais. As justificativas para esse enquadramento consistem na inaplicabilidade de diversas regras do regime jurídico de direito público às corporações profissionais. A ausência de emprego de recursos orçamentários, a não indicação dos dirigentes pelo poder público e a não incidência de controle estatal sobre as decisões dessas entidades são alguns dos aspectos utilizados para justificar a sua possível natureza privada.

Como constatam Carlos Ari Sundfeld e Jacintho Arruda Câmara, os “argumentos lançados de lado a lado são verdadeiros. Existem características nas entidades de fiscalização profissional que as aproximam do regime jurídico de direito público, bem como existem elementos que as diferenciam das demais entidades que integram a Administração"632.

Ou seja, não há como enquadrar adequadamente as corporações profissionais como entidades públicas ou privadas. Ao considerá-las como tendo uma natureza ou outra, acabam sendo privilegiadas algumas das suas características em detrimento de outras, que são igualmente relevantes para a definição dessas entidades.

específica, não se lhes aplicando as normas legais sobre pessoal e demais disposições de caráter-geral, relativas à administração interna das autarquias federais.”

631 "Apesar de as leis brasileiras nem sempre serem claras a respeito da natureza jurídica dos conselhos e ordens, de acordo com a doutrina e com a jurisprudência dominantes, e especialmente considerando a decisão proferida pelo Supremo Tribunal Federal, ao declarar a inconstitucionalidade da Lei $n^{\circ}$ 9649/98, tais entidades têm sido consideradas autárquicas, embora possuam algumas peculiaridades em relação às demais autarquias. Poder-se-ia falar, então, em autarquias especiais ou sui generis.” (Leila Cuéllar. Auto-regulação profissional, 2006).

632 Conselhos de fiscalização profissional, 2006, p. 322. 
Carlos Ari Sundfeld e Jacintho Arruda Câmara classificam expressamente as corporações profissionais como entes públicos não estatais, por apresentarem, concomitantemente, a natureza pública e não-estatal ${ }^{633}$.

Os autores identificam na sistemática das corporações profissionais nacionais o propósito de sua exclusão da estrutura estatal, apesar de exercerem prerrogativas públicas. Foram-lhes atribuídas características incompatíveis com suposto vínculo com a estrutura burocrática do Estado. Algumas destas características seriam a ausência de participação do Estado na escolha dos dirigentes das corporações, que é realizada pela própria categoria, a não percepção de recursos estatais, sustentando-se integralmente com a contribuição (compulsória) dos associados e a desnecessidade de lei para a criação dos postos de trabalho.

\subsubsection{O regime jurídico das corporações profissionais}

O casuísmo da legislação específica de cada entidade e as diversas decisões judiciais imprimiram características diferenciadas ao regime jurídico das corporações profissionais.

As entidades são criadas por lei, com a atribuição de poderes públicos para a regulação do exercício da profissão. Em geral, exercem apenas a função reguladora, não lhes cabendo a defesa dos interesses profissionais - com exceção da OAB. A inscrição nas entidades é obrigatória em relação aos profissionais da categoria a que se referem.

Apesar de várias das entidades serem expressamente qualificadas como autarquias, diferenciam-se do regime destas por vários aspectos. Alguns deles são a escolha dos seus dirigentes pelos próprios associados, a origem própria de todos os seus recursos, oriundos da contribuição compulsória dos associados, e a não submissão ao controle estatal.

Vários debates surgiram acerca das exigências e restrições do regime jurídico de direito público que seriam aplicadas às corporações profissionais.

Uma questão que se destacou foi a sujeição ou não à fiscalização dos Tribunais de Contas ${ }^{634}$. Para a ampla maioria dos organismos de fiscalização profissional, reconhece-se que se submetem à fiscalização pelo Tribunal de Contas competente, pela

\footnotetext{
633 Ob. cit., p. 325-327.

${ }^{634} \mathrm{Na}$ jurisprudência do STF, identifica-se o posicionamento no sentido de que os conselhos profissionais submetem-se ao controle do TCU especialmente em razão da sua natureza autárquica e das prerrogativas públicas que exercem. Assim já decidiu expressamente, por exemplo, em relação ao Conselho Federal de Medicina (MS $n^{\circ}$ 10.272/DF, Rel. Min. Victor Nunes Leal) e ao Conselho Federal de Odontologia (MS $n^{\circ}$ 21.797-9/RJ, Rel. Min. Carlos Velloso, julg. 9.3.2000, DJ 18.5.2001). Nesses casos, reputou-se ser determinante a natureza pública dos recursos geridos pelos conselhos, oriundos de contribuições compulsórias dos associados, pouco importando a sua natureza não orçamentária.
} 
natureza pública dos recursos que administram. Exige-se, assim, que prestem contas. Esse entendimento não se aplica à $\mathrm{OAB}^{635}$.

No que diz respeito a eventual controle interno, a ser exercido pela Administração ${ }^{636}$, o Decreto $n^{\circ} 93.617 / 86$ veda a incidência de qualquer tipo de supervisão ministerial sobre os conselhos profissionais ${ }^{637}$. No que diz respeito à OAB, a Lei $n^{0}$ 8.906/1994, art. 44, $\S 1^{\circ}$, estipula que “a OAB não mantém com órgãos da Administração Pública qualquer vínculo funcional ou hierárquico”.

Quanto às contribuições arrecadadas pelas entidades de fiscalização das profissões, trata-se de contribuições parafiscais. Têm, portanto, natureza tributária. Também em relação a esse aspecto excepciona-se a situação da OAB. A Lei nº 8.906/94 estabelece que as contribuições serão fixadas pela própria entidade.

No que diz respeito ao regime de pessoal, há voto proferido pelo Min. Carlos Velloso, em relação ao Conselho Federal e os Conselhos Regionais de Odontologia ${ }^{638}$, reconhecendo que ao seu pessoal deveria ser aplicado o regime jurídico instituído pela Lei $\mathrm{n}^{\circ} 8.112 / 1990^{639}$. No entanto, por maioria de votos dos integrantes do Tribunal Pleno, a ação não foi conhecida em relação a esse ponto.

Com o advento da EC $n^{\circ} 19 / 98$, que extinguiu a obrigatoriedade do regime único, passou-se a admitir a aplicação do regime trabalhista ao pessoal dos conselhos profissionais $^{640}$. No entanto, a divergência ressurgiu com a retomada da obrigatoriedade do regime jurídico único, mediante a suspensão, pelo STF, da vigência do art. 39 da CF/88, de

\footnotetext{
${ }^{635}$ Em relação à OAB, o TFR dispensou-a de prestar contas ao TCU. Reconheceu que a Ordem não integrava a administração indireta e não recebia recursos orçamentários. Por isso, não deveria se submeter à fiscalização do TCU (RMS $n^{\circ}$ 797, de 25.9.51). Até hoje, invoca-se a força de coisa julgada desse precedente sobre o tema. Esse entendimento foi confirmado, por exemplo, no Acórdão no 1.765/2003 - Plenário do TCU.

${ }^{636}$ A sujeição das corporações profissionais a controle ministerial foi prevista expressamente, por exemplo, no Decreto n ${ }^{\circ}$ 60.900/67 e no Decreto-lei n ${ }^{\circ}$ 968/69, disposições estas que foram revogadas.

${ }^{637}$ A não submissão à supervisão ministerial foi confirmada pelo STF, por exemplo, no julgamento do MS $\mathrm{n}^{\circ}$ 26.150, em 19.9.2006 (Rel. Min. Eros Grau). Porém, não se trata de questão completamente pacificada. Em decisão monocrática, o Min. Joaquim Barbosa invocou o julgamento da ADI nº 641/DF (DJ 12.3.1993) e afirmou que "os conselhos de fiscalização profissional não são entidades autônomas, mas sim autarquias inseridas na estrutura do Poder Executivo Federal, dotadas de competências administrativas específicas e submetidas ao controle ou supervisão de altos órgãos da Administração Pública direta, quais sejam, dos Ministérios de Estado" (MI n ${ }^{\circ}$ 1.952/DF, DJe 21.10.2009). Note-se que o dispositivo da ADI ${ }^{\circ}$ 641/DF reconhece que os conselhos profissionais são espécies de autarquias e não se enquadram no rol do art. 103 da $\mathrm{CF} / 88$, entre os legitimados para a propositura de ação direta, sem haver decisão específica acerca do controle a que essas entidades se submetem.

${ }_{638}$ Lembre-se que a Lei $n^{\circ} 4.324 / 64$ menciona expressamente a natureza autárquica desses conselhos de fiscalização profissional.

${ }^{639} \mathrm{MS}^{\circ}{ }^{\circ}$ 21.797-9/RJ, Rel. Min. Carlos Velloso, julg. 9.3.2000, DJ 18.5.2001.

${ }^{640}$ Esse entendimento foi confirmado pelo STF ao reputar ter havido perda de objeto da ADI $\mathrm{n}^{\circ} 1.717 \mathrm{em}$ relação ao art. 58, $\S 3^{\circ}$, da Lei n ${ }^{\circ}$ 9.649/98, que prevê a aplicação do regime trabalhista para os empregados dos conselhos profissionais.
} 
acordo com a redação dada pela EC $\mathrm{n}^{\mathrm{o}} 19 / 98^{641}$. Tem prevalecido o entendimento de que o regime jurídico de pessoal dos conselhos profissionais deve ser o estatutário mas há significativa divergência, inclusive com precedentes da Justiça do Trabalho que reconhecem a natureza privada das contratações. Em relação à OAB, a questão foi definida também no julgamento da $\mathrm{ADI} \mathrm{n}^{\circ}$ 3.026, que assentou a possibilidade de opção pelo regime celetista.

A exigência de concurso público para a contratação de pessoal também é objeto de vários impasses. Há divergências especialmente no que diz respeito à atuação do TCU, que expediu recomendações a essas entidades para que realizassem concursos públicos para a admissão de servidores ${ }^{642}$.

Em relação à OAB, o STF decidiu expressamente que não se lhe aplica a exigência de realização de concurso público para a contratação de pessoal ${ }^{643}$.

Posteriormente a esse julgamento, o STF proferiu decisões divergentes quanto à aplicação desse mesmo entendimento a outras corporações profissionais. Ao julgar o $n^{\circ} \mathrm{MS} \mathrm{n}^{0}$ 26.150, dispensou o Conselho Regional de Odontologia do Mato Grosso do Sul da realização de concurso para admissão de pessoal ${ }^{644}$. Já no MS no 26.149, impetrado contra ato similar ao que é objeto do MS n 26.150, o STF decidiu que o Conselho Federal de Odontologia submetia-se à exigência de realização de concurso público para seleção de pessoal $^{645}$. Este é o entendimento que tem prevalecido no $\mathrm{STF}^{646}$.

Pelos aspectos utilizados acima apenas para exemplificar a diversidade de entendimentos acerca do regime jurídico dos conselhos de fiscalização profissional, evidenciam-se as profundas divergências. Pode-se apontar a ausência de legislação uniforme para essas entidades como sendo um dos principais motivos para as discussões.

Permite identificar também que o regime jurídico da OAB difere substancialmente dos demais. Essa diferenciação foi expressamente justificada pelo STF, no julgamento da $\mathrm{ADI} \mathrm{n}^{0}$ 3.026. Consta do voto do Min. Relator Eros Grau que, à medida

\footnotetext{
${ }^{641}$ Medida cautelar deferida na ADI $\mathrm{n}^{\circ}$ 2.135/DF (julg. 2.8.2007, DJe 7.3.2008), por possível ocorrência de vício formal no processo legislativo da emenda constitucional.

${ }^{642}$ Determinações nesse sentido constaram, por exemplo, dos Acórdãos nº 1.212/2004, 814/2003, 1.720/2003, 156/2005 e 943/2010, da 2 ${ }^{\text {a }}$ Câmara do TCU.

${ }^{643}$ ADI n ${ }^{\circ}$ 3.026/DF, Rel. Min. Eros Grau, julg. 8.6.2006, DJ 29.9.2006.

${ }^{644}$ Rel. Min. Eros Grau, decisão de 19.9.2006. Nesse caso, adotou-se como fundamento o que foi decidido pelo STF na $\mathrm{ADI} \mathrm{n}^{\circ}$ 3.026, em relação à $\mathrm{OAB}$.

${ }^{645}$ Rel. Min. Celso de Mello, decisão de 7.3.2007. Nesse caso, indicou-se que os fundamentos acolhidos na ADI ${ }^{\circ} 3.026$ aplicam-se exclusivamente à OAB.

${ }_{646}$ V.g. RE $\mathrm{n}^{\circ}$ 368.917, Rel. Min. Ricardo Lewandowski, j. 21.10.2009; MI ${ }^{\circ}$ 1.952, Rel. Min. Joaquim Barbosa, j. 14.10.2009; RE nº 559.814, Rel. Min. Cármen Lúcia, j. 17.9.2009.
} 
que a $\mathrm{OAB}$ não se encontra voltada exclusivamente para finalidades corporativas ${ }^{647}$, "não pode ser tida como congênere dos demais órgãos de fiscalização profissional”“448.

Por não integrar a estrutura administrativa do Estado, a OAB não se submete às regras de direito público cuja incidência apenas se justifica em se tratando de órgão administrativo. As regras de direito público que lhe são aplicáveis consistem naquelas que são demandadas pelo caráter público das suas atividades ${ }^{649}$.

\subsubsection{O entendimento do STF acerca do exercício de atividade de polícia administrativa}

Ao analisar a natureza jurídica das corporações profissionais, o STF já afirmou diversas vezes a impossibilidade de delegação da atividade de polícia administrativa a entidades privadas.

Como se indicou acima, o regime jurídico dos conselhos de fiscalização profissional aproximavam-se ao das autarquias, ainda que não se equiparavam ${ }^{650}$. Em muitos casos, a própria lei de criação dos conselhos já lhes atribuía expressamente a natureza jurídica de autarquia e/ou a personalidade jurídica de direito público.

Em 1998, foi editada a Lei $n^{\circ} 9.649$, que estabeleceu que todos os conselhos de fiscalização profissional teriam personalidade jurídica de direito privado ${ }^{651}$.

Logo em seguida, foi ajuizada a ADI $n^{\circ} 1.717-6$, que tinha por objeto o questionamento da constitucionalidade do caput e parágrafos do art. 58 da Lei $\mathrm{n}^{\circ}$ 9.649/1998. O STF deferiu a medida cautelar, para suspender os efeitos dos dispositivos legais questionados, por se reputar não ser possível, "em face do ordenamento constitucional, mediante a interpretação conjugada dos artigos 5º XIII, 22, XVI, 21, XXIV,

\footnotetext{
647 "A Constituição do Brasil confere atribuições de extrema relevância à OAB, bastando para ratificar a assertiva ressaltar o disposto no inciso VIII do artigo 103 da Constituição, que confere legitimidade ao Conselho Federal da Ordem dos Advogados do Brasil para a propositura da ação direta de inconstitucionalidade, bem assim a definição do advogado como essencial à promoção da Justiça, ao qual é assegurada inviolabilidade no que tange aos seus atos e manifestação no exercício da profissão" (voto do Min. Relator na ADI no 3.026/DF, Rel. Min. Eros Grau, julg. 8.6.2006, DJ 29.9.2006).

${ }^{648} \mathrm{ADI} \mathrm{n}^{\circ}$ 3.026/DF, Rel. Min. Eros Grau, julg. 8.6.2006, DJ 29.9.2006.

${ }^{649}$ Carla Osmo. Os conselhos profissionais integram a estrutura orgânica do Estado?, 2008, p. 64.

${ }^{650}$ Por exemplo, no julgamento do MS n ${ }^{\circ}$ 22.643-9, em 6.8.1998 (Rel. Min. Moreira Alves), o STF afirmou que os Conselhos Regionais de Medicina consistem em autarquias. Ao julgar o MS no 21.797-9, o STF confirmou a natureza autárquica do Conselho de Odontologia, afirmando que as funções que exerce são tipicamente públicas (j. 9.3.2000, Rel. Min. Carlos Velloso).

${ }^{651}$ A locução do caput do art. 58 da Lei no 9.649/98 é a seguinte: “Os serviços de fiscalização de profissões regulamentadas serão exercidos em caráter privado, por delegação do poder público, mediante autorização legislativa”. Note-se que são empregados termos próximos àqueles utilizados pela CF/88, no seu art. 236, para definir a atividade exercida pelos notários e registradores.
} 
70, parágrafo único, 149 e 175 da C.F., a delegação, a uma entidade privada, de atividade típica de Estado, no que tange ao exercício de atividades profissionais”652.

No julgamento de mérito da ADI $\mathrm{n}^{0}$ 1.717-6, foi confirmada a inconstitucionalidade dos dispositivos legais questionados. O STF concluiu pela “indelegabilidade, a uma entidade privada, de atividade típica de Estado, que abrange até poder de polícia, de tributar e de punir, no que concerne ao exercício de atividades profissionais regulamentadas"653.

Ou seja, o STF decidiu que a personalidade de direito público é requisito essencial para que uma entidade possa exercer poderes de autoridade.

Já no julgamento da ADI no $3.026^{654}$, o STF reconheceu que a OAB não integra a organização administrativa estatal, direta ou indireta. Nos termos do voto do Min. Eros Grau, a OAB constitui um serviço público independente. Decidiu-se que a OAB encontra-se apenas parcialmente sujeita ao regime jurídico administrativo, apesar de ser dotada de personalidade jurídica de direito público e de exercer atividade de polícia em relação aos seus membros.

Ao assim decidir, o STF rejeitou a natureza autárquica da OAB e a afastou do tratamento conferido aos demais conselhos profissionais. Como já se indicou, a justificativa para tanto foi o fato de a $\mathrm{OAB}$ não ter apenas finalidade corporativa mas também finalidade institucional, sendo necessário garantir sua independência e autonomia.

Assim, no que diz respeito especificamente à OAB, o STF reconheceu a possibilidade de serem exercidos poderes estatais por entidades não integrantes da organização estatal, desde que sejam dotadas de personalidade jurídica de direito público. Ou seja, o STF decidiu que a OAB dispõe de prerrogativas próprias dos entes públicos mas que não se submete a todos os controles que incidem sobre estes, gozando de maior autonomia. Seria equiparável a uma autarquia quanto à sua atuação mas não se submeteria aos típicos controles administrativos.

\footnotetext{
${ }^{652}$ MC na ADI no 1.717-6/DF, Rel. Min. Sydney Sanches, j. 22.9.1999, DJ 25.2.2000. Nesse julgamento, cabe destacar o voto divergente do Min. Maurício Correa, que invocou a previsão do art. 236 da CF/88, que admite o exercício privado, por delegação estatal, de função pública, para respaldar a conclusão pela possibilidade de as corporações profissionais terem personalidade jurídica privada.

${ }^{653}$ ADI no 1.717-6/DF, Rel. Min. Sydney Sanches, j. 7.11.2002, DJ 28.3.2003. Apesar de a ementa destacar a indelegabilidade de atividades típicas de Estado a entidades privadas, o voto condutor do julgamento não tratou especificamente da incompatibilidade entre a personalidade jurídica de direito privado e o exercício de poderes públicos delegados. Os aspectos mencionados dizem respeito precipuamente à natureza jurídica autárquica - dos conselhos profissionais e à necessidade de se submeterem a controles no exercício das suas atividades.

${ }^{654}$ Rel. Min. Eros Grau, Pleno, j. 8.6.2006, maioria, DJ 29.9.2006.
} 
6.5.1.7. O entendimento do STF acerca do enquadramento dos conselhos de fiscalização profissional na organização administrativa

O julgamento da ADI n 3.026 representou importante marco na definição do lugar ocupado pelos conselhos de fiscalização profissional na organização administrativa. Em relação à $\mathrm{OAB}$, definiu-se expressamente que não integra a estrutura estatal, apesar de ser dotada de personalidade jurídica de direito público. Já no que diz respeito aos demais conselhos, mesmo após o julgamento da ADI $n^{0} 3.026$, prevalece o entendimento de que são equiparados a autarquias ${ }^{655}$ - ainda que o regime jurídico não seja idêntico ao destas em todos os aspectos.

Redefiniram-se os contornos do setor “público não-estatal” dentro da organização administrativa brasileira. Pode ser extraída desse julgamento a afirmação da existência de um setor público não-estatal não apenas em sentido funcional, mediante delegação de funções públicas a particulares, mas também na acepção orgânica ${ }^{656}$. Admitiuse a existência de entidades de direito público que não integram o aparato estatal e gozam de prerrogativas públicas, mas não se submetem às restrições do regime jurídico de direito público.

Ao que parece, procurou-se aplicar no direito nacional a noção de “administração autônoma”, existente em alguns sistemas europeus continentais. Naqueles regimes, os conselhos de fiscalização profissional são considerados associações públicas, que consistem em espécie de administração autônoma.

No entanto, não há previsão expressa no ordenamento nacional de figura similar à administração autônoma.

Outro ponto a ser destacado é que, no direito continental europeu, a noção de administração autônoma é aplicada à ampla maioria das corporações profissionais são qualificadas como administração autônoma. Não se aplica entendimento no sentido de que apenas aquelas que exerceriam funções que extrapolam os interesses corporativos - tal como decidiu o STF em relação à OAB - exerceriam administração autônoma. Logo, não se extraem dos subsídios de direito comparado fundamentos suficientes para se diferenciar a OAB em relação aos demais conselhos de fiscalização profissional.

Maria Sylvia Zanella Di Pietro formula sua crítica acertada e bastante contundente ao posicionamento adotado pelo STF:

\footnotetext{
${ }^{655}$ Uma exceção foi a decisão do Min. Eros Grau no julgamento do MS n ${ }^{\circ}$ 26.150. Em diversos outros precedentes, afirmou-se a natureza autárquica dessas entidades. Foi o que se decidiu, por exemplo, no MS $n^{\circ}$ 26.149, Rel. Min. Celso de Mello, julg. 7.3.2007; RE ${ }^{\circ}$ 368.917, Rel. Min. Ricardo Lewandowski, julg. 21.10.2009 e MS n 27.670, Rel. Min. Ellen Gracie, julg. 19.12.2008.

${ }^{656}$ Durval Carneiro Neto. Os conselhos de fiscalização profissional, 2010, p. 306.
} 
Com essa decisão, a OAB passa a ser considerada como pessoa jurídica de direito público no que esta tem de vantagens (com todos os privilégios da Fazenda Pública, como imunidade tributária, prazos em dobro, prescrição quinquenal etc.), mas não é considerada pessoa jurídica de direito público no que diz respeito às restrições impostas aos entes da Administração Pública direta e indireta (como licitação, concurso público, controle). A decisão é absolutamente inaceitável quando se considera que a OAB, da mesma forma que as demais entidades profissionais, desempenha atividade típica do Estado (poder de polícia, no qual se insere o poder disciplinar) e, portanto, função administrativa descentralizada pelo Estado ${ }^{657}$.

Outro aspecto a ser destacado em relação ao regime jurídico da OAB é o de que, nos votos de alguns dos julgadores da ADI $n^{0} 3.026$, mencionam-se as funções diferenciadas pela $\mathrm{OAB}$, que extrapolariam a defesa dos interesses corporativos, como justificativa para a submissão a um regime jurídico diferenciado em relação aos demais conselhos de fiscalização. No entanto, parece-nos que não foi apresentada a justificativa específica para a diferenciação, com a demonstração da efetiva necessidade de afastamento de diversos controles e restrições que incidem sobre as demais corporações. Não há a identificação do possível comprometimento que a OAB sofreria na realização das suas atividades na hipótese de se submeter a determinados aspectos do regime jurídico de direito público que se aplicam às demais entidades.

O entendimento exposto pelo STF no julgamento da ADI $n^{0} 3.026$ foi acolhido no Anteprojeto de Lei Orgânica da Administração Pública Federal ${ }^{658}$. As corporações profissionais ${ }^{659}$ foram incluídas entre as entidades paraestatais, que abrangem as pessoas jurídicas criadas por iniciativa do Estado mas que não integram a Administração direta nem indireta. Foi-lhes atribuída personalidade jurídica de direito público, por exercerem prerrogativas estatais, especialmente o poder disciplinar sobre os profissionais. Já o regime jurídico previsto é híbrido, de direito público e de direito privado conforme tratar-se de ato de fiscalização profissional ${ }^{660}$ ou de gestão $^{661}$.

\subsubsection{Comandantes de embarcações e aeronaves}

A lei atribui diretamente a determinados particulares o exercício de atividades de polícia administrativa, em razão das suas atividades profissionais. Trata-se

\footnotetext{
${ }^{657}$ Direito administrativo, 2013, p. 493.

${ }^{658}$ Anteprojeto elaborado pela Comissão constituída pela Portaria 426, de 6.12.2007, alterada pela Portaria 84, de 23.4.2008.

659 Note-se que foi proposta solução uniforme para todas as corporações profissionais, estendendo-lhes, em linhas gerais, o entendimento assentado pelo STF em relação à OAB, no julgamento da ADI n ${ }^{0} 3.026$.

${ }^{660}$ Nos termos do projeto, são regidas pelo regime jurídico de direito público as atividades de regulação, fiscalização e sancionadora.

${ }^{661}$ Propôs-se a incidência do regime privado para a gestão financeira, contratação e seleção de pessoal, por exemplo, ainda que devam observar os princípios da eficiência e probidade na aplicação dos recursos e prestar contas aos Tribunais de Contas.
} 
das funções de que são incumbidos pela lei os comandantes de embarcações ${ }^{662}$ e aeronaves $^{663}$, autorizando-os a praticar atos coercitivos, exercer funções disciplinares e emitir provimentos jurídicos, tendo em vista a preservação dos direitos fundamentais dos passageiros e dos tripulantes ${ }^{664}$. Trata-se do designado “poder de bordo”, que consiste na exteriorização do poder público de polícia e recai sobre aqueles que se encontram a bordo de embarcações e aeronaves.

Nesses casos, atribuem-se amplos poderes de autoridade àqueles que exercem tais profissões, inclusive autorizando-os a exercer a coação direta sobre outros particulares. O que justifica essa delegação é a necessidade, à medida que o poder público não pode se fazer presente em tais situações. São conferidos poderes aos comandantes de navios e aeronaves pela impossibilidade de intervenção de agentes públicos naquelas circunstâncias. Por isso, atribui-se temporariamente o exercício de poderes de autoridade a tais particulares, até que seja possível a apreciação da situação pelo próprio poder público até o pouso da aeronave, por exemplo.

\section{$\underline{\text { 7. As }} \underline{\text { atividades }} \underline{\text { de polícia }} \underline{\text { administrativa }} \underline{\text { e a possibilidade }} \underline{\text { de }} \underline{\text { deleqação a }} \underline{\text { particulares }}$}

Considerando as diversas atividades que integram a função administrativa de polícia, passa-se a analisar especificamente as possibilidades de delegação em relação a algumas delas. Nesse ponto, serão analisadas apenas as limitações incidentes sobre a delegação a particulares. No que diz respeito ao desempenho de atividades de polícia por empresas estatais, os limites e condicionamentos serão examinados especificamente abaixo $^{665}$.

\footnotetext{
${ }^{662}$ Lei $\mathrm{n}^{\circ}$ 9.537/97, arts. $8^{\circ}$ a 10 . Todos os que se encontram a bordo submetem-se à autoridade do comandante (art. $9^{\circ}$ ), a quem compete manter a disciplina na embarcação (art. $8^{\circ}$, inc. III). No desempenho das suas funções e para garantir a segurança das pessoas, o comandante pode impor sanções disciplinares previstas na legislação pertinente (art. 10, inc. I), ordenar o desembarque de qualquer pessoa (art. 10, inc. II), ordenar a detenção de pessoa em camarote ou alojamento, se necessário com algemas, quando imprescindível para a manutenção da integridade física de terceiros, da embarcação ou da carga (art. 10, inc. III) e determinar o alijamento de carga (art. 10, inc. IV).

${ }^{663}$ Lei $^{0} 7.565 / 86$, art. 168. Durante o período de voo, o comandante exerce autoridade sobre as pessoas e coisas que se encontrem a bordo da aeronave e pode desembarcar qualquer delas, desde que comprometa a boa ordem, a disciplina, ponha em risco a segurança da aeronave ou das pessoas e bens a bordo (inc. I), tomar as medidas necessárias à proteção da aeronave e das pessoas ou bens transportados (inc. II) e alijar a carga ou parte dela, quando indispensável à segurança de voo (inc. III).

664 Entre outros, manifestam-se nesse sentido Celso Antônio Bandeira de Mello. Curso de direito administrativo, 2013, p. 839 e José Roberto Pimenta Oliveira. Parcerias público-privadas, 2007, p. 419-420).

${ }^{665}$ Sobre o tema, consulte-se o item III.8.
} 
A maior problemática da delegação de atividades de polícia administrativa a particulares diz respeito ao trespasse de funções que envolvem o exercício de poderes de autoridade.

\subsection{Primeira ressalva: necessidade de delegação formal das atividades de polícia administrativa a particulares}

Uma das premissas adotadas no presente estudo é a de que os particulares apenas podem exercer atividades de polícia administrativa mediante delegação formal pelo Estado. Nas hipóteses em que particulares desenvolvem atividades aparentemente similares às de polícia mas não se verifica a existência de um ato formal praticado pelo Estado delegando o desempenho de tais atividades, está-se diante do exercício de poderes privados ou de delegação “de fato”, 666 .

\subsection{Segunda ressalva: natureza pública das atividades objeto de delegação}

Ao se tratar da delegação de atividades de polícia administrativa, pressupõese tratar-se de atividades públicas, que foram objeto de apropriação pública formal. Assim se passa porque reputamos que uma atividade não pode ser considerada pública apenas por se destinar à satisfação de interesses da coletividade, por ter relevância pública. Faz-se necessária a presença de um fator de natureza formal.

\subsection{O poder de coerção}

No momento, analisa-se a coerção como manifestação da Administração, exteriorizada por atos materiais, de imposição forçada do cumprimento de determinada medida prévia ou da modificação de certa situação de fato. É o uso da coerção legítima da Administração que, por sua própria autoridade, pode impor a execução forçada de seus direitos ou a modificação de uma situação de fato. Para tanto, pode fazer uso da força e da coerção física sobre pessoas e coisas.

A coerção direta na polícia administrativa consiste em uma atuação material, agressiva em relação à esfera jurídica dos cidadãos.

${ }^{666}$ Sobre a delegação “de fato”, v. item II.5. 


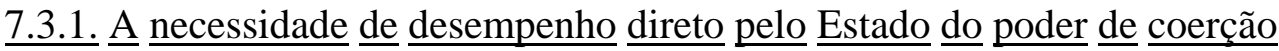

Não foi conferida à Administração a livre utilização de meios de coerção.

Nem sempre a Administração dispõe da competência para executar materialmente os seus próprios atos, sem a necessidade de recorrer previamente ao Judiciário.

A legitimação da atuação material coerciva encontra-se fundada em um ato administrativo prévio ${ }^{667}$. A fundamentação jurídica do ato de coerção deve constar de uma decisão adotada anteriormente, no encerramento de um processo administrativo.

Porém, nem sempre existe um ato administrativo formal prévio. Como se procurou demonstrar anteriormente, a Administração pode satisfazer diretamente um direito, sem autorização prévia do Judiciário, nas hipóteses expressamente previstas em lei e, excepcionalmente, em situações emergenciais, apenas se não houver alternativa que cause prejuízos menores ${ }^{668}$. Nestas hipóteses, a fundamentação jurídica deverá ser apresentada posteriormente e será considerada para fins de controle da legitimidade do emprego dos meios de coerção.

Em qualquer caso, os poderes de execução coerciva devem ser exercidos diretamente pelo Estado, não sendo passíveis de delegação. O monopólio estatal da violência legítima impede que essas atividades sejam desempenhadas por entidades privadas $^{669}$.

Com a utilização dos denominados meios diretos de coação, mediante o emprego de coação absoluta, pode ser obtida a própria prestação que é exigida do administrado ou, na impossibilidade desta, prestação equivalente. Há três modos de exercício da coerção direta: a) a realização da própria prestação pelo obrigado ou por terceiro ${ }^{670}$; b) a conversão da prestação em outra; e c) a apreensão da coisa, em se tratando de obrigação de $\operatorname{dar}^{671}$.

\footnotetext{
${ }^{667}$ Fernando Garrido Falla. Los medios de la policia y la teoria de las sanciones administrativas, 1959, p. 32.

${ }^{668}$ Sobre o tema, reportamo-nos aos limites da autoexecutoriedade dos atos de polícia administrativos expostos anteriormente (v. item I.8).

${ }_{669}$ Nesse sentido, colhem-se os ensinamentos de Floriano de Azevedo Marques Neto: "Por fim, há a etapa que poderíamos denominar genericamente de 'coercitiva', na qual se manifesta o poder extroverso, a capacidade do Estado de exercer a violência legítima. Nesta está em baila o poder exclusivo de exercer a coerção, de aplicar sanções e de adotar medidas de caráter autoexecutório. Aqui, efetivamente, estamos diante do exercício intrínseco da autoridade, o que impede que tais atribuições sejam delegadas aos particulares, sob pena de descaracterizar o Estado de Direito. Apenas devemos notar que as atribuições indelegáveis são aquelas que decorrem direta e intrinsecamente do exercício da autoridade, do poder extroverso, do monopólio da violência legítima pelo Estado. A indelegabilidade não alcança atividades que, malgrado necessárias ao exercício da autoridade, são instrumentais e de suporte à manifestação do poder coercitivo" (A concessão como instituto do direito administrativo, 2013, p. 568).

${ }^{670}$ Pode ser utilizada a prestação de terceiro apenas em relação às obrigações de fazer, de caráter não personalíssimo.

${ }^{671}$ Como anota Seabra Fagundes, “o alcance da execução forçada excede os limites em que o circunscreve o direito privado”. Enquanto que neste aceita-se mais amplamente a conversão em perdas e danos, ainda que se
} 
Ao lado da execução forçada, há também os meios indiretos de coerção administrativa que objetivam forçar indiretamente o cumprimento da prestação. No entanto, não propiciam a obtenção da prestação específica sem o consentimento do devedor. Implicam o acréscimo de ônus sobre o devedor, procurando induzi-lo ao cumprimento da prestação. Os meios indiretos são bastante variáveis, apresentando graus diversos de indução. Um dos mecanismos mais utilizados é a multa. Consiste também em meio indireto, por exemplo, a suspensão do exercício de determinados direitos até que a obrigação seja satisfeita.

É relevante diferenciar os casos em que se verifica o manejo do poder público de coação direta daqueles em que são utilizados poderes privados de emprego da força. O monopólio estatal da força não elimina completamente a utilização da força nas relações entre particulares, admitindo-a em situações excepcionais ${ }^{672}$.

O emprego da força por particulares, expressamente previsto no ordenamento jurídico, pode ocorrer subsidiariamente à intervenção das forças públicas para fins de autodefesa, defesa provisória de bens ou ainda a legítima defesa do agredido ${ }^{673}$. No entanto, o manejo de poderes privados de força deve observar os estritos limites previstos na lei.

Para alguns doutrinadores, como Zanobini ${ }^{674}$ e Sandulli ${ }^{675}$, os poderes privados de uso da força teriam sido conferidos pelo Estado a particulares, não existindo um direito originário para tanto. Identificariam neste caso ou uma delegação de poderes públicos de uso da força a particulares ou uma autorização do Estado para o emprego da força.

privilegie a tutela específica, no direito público emprega-se mais amplamente a coação direta porque, em vários casos, apenas a prestação originariamente imposta é apta a satisfazer os fins visados com a medida $(O$ controle dos atos administrativos pelo Poder Judiciário, 2010, p. 270, nota 32).

${ }^{672} \mathrm{Na}$ concepção de Hobbes para o contrato social, por exemplo, o homem não pode renunciar ao direito de se defender a si mesmo. Tal renúncia não seria válida: "Um pacto em que eu me comprometa a não me defender da força pela força é sempre nulo. Porque (...) ninguém pode transferir ou renunciar a seu direito de evitar a morte, os ferimentos ou o cárcere (o que é o único fim da renúncia ao direito), e portanto a promessa de não resistir à força não transfere nenhum direito em pacto algum, nem é obrigatória.” (Leviatã, 2003, p. 121).

673 Trata-se dos atos previstos no art. 188 do Código Civil, em relação aos quais a lei afasta a ilicitude. No caso de atos de "deterioração ou destruição da coisa alheia, ou a lesão a pessoa, a fim de remover perigo iminente”, o parágrafo único do referido dispositivo ressalva que "o ato será legítimo somente quando as circunstâncias o tornarem absolutamente necessário, não excedendo os limites do indispensável para a remoção do perigo”.

${ }^{674}$ Para Guido Zanobini, a necessidade e a urgência da atuação justificam a atribuição do exercício de poderes públicos a particulares em determinadas circunstâncias (Corso di diritto amministrativo, v. III, 1946, p. 320322).

675 Para Aldo Sandulli, a possibilidade de particulares exercerem poderes em certas situações retrata a atribuição de munus publicum pelo ordenamento jurídico (Manuale di diritto amministrativo, v. I, 1989.p. 566-567). 
Outros defendem que haveria apenas uma tolerância do Estado, que optaria por não punir determinadas condutas em face de certas condições que as tornam legítimas ou respeitaria direitos pré-existentes dos particulares, que teriam permanecido na esfera privada diante da passagem do estado de natureza e transferência de poderes para o Estado. Em qualquer caso, consistiriam em direitos privados de uso da força.

O uso da força por particulares assume especial relevância ao se analisarem as atividades de segurança privada. Como se examinou anteriormente, são basicamente os poderes privados de uso da força, admitidos em circunstâncias excepcionais, que podem ser utilizados na segurança privada.

Em relação ao poder de coerção, admite-se apenas a delegação de atividades instrumentais ou acessórias, que não envolvam o exercício do poder coercivo propriamente dito. Os limites diferenciais entre a vedação de delegação dos poderes coercivos e a possibilidade de delegação de atividades instrumentais e acessórias ao exercício da coerção são evidenciados ao se analisar a possibilidade de gestão privada de presídios.

\subsubsection{A participação privada na gestão de estabelecimentos prisionais}

A concessão administrativa, prevista na Lei das Parcerias Público-Privadas (Lei $\mathrm{n}^{\circ}$ 11.079/04), permite a modelagem de contratos em que o particular investe na infraestrutura necessária à prestação dos serviços e depois é remunerado pela Administração pelos serviços desenvolvidos, utilizando-se daquela infraestrutura, por determinado período. A Administração é a usuária desses serviços, direta ou indireta, e responsável pela remuneração do parceiro privado.

Uma das possibilidades de emprego da concessão administrativa é verificada em arranjos contratuais que objetivam a participação privada na gestão de presídios. Por isso, o debate acerca da gestão privada de estabelecimentos prisionais foi intensificado após a edição da Lei $\mathrm{n}^{\circ}$ 11.079/04. O exemplo do sistema penitenciário é bastante marcante, por se cogitar da atuação de particulares na gestão de atividade que implica uma das manifestações mais intensas do poder de coerção estatal.

\subsubsection{Os modelos de gestão privada de presídios}

A participação privada nas prisões é uma realidade histórica de longa data, tendo a ingerência dos particulares assumido diversas formas. Há registros, por exemplo, de prisões privadas, que funcionavam com objetivos lucrativos, na época medieval. Utilizouse também amplamente a exploração do trabalho dos presos. 
Os modelos atuais de gestão privada de presídios aplicados nos diversos países apresentam significativas variações. No entanto, para fins de estudo, podem ser agrupados em dois modelos principais, o do sistema norte-americano ${ }^{676}$ e o do sistema francês ${ }^{677}$.

A presença de particulares na gestão do sistema carcerário norte-americano é admitida há bastante tempo ${ }^{678}$. Até o início da década de oitenta, o sistema que prevalecia era o de "hands off", segundo o qual a execução da pena era considerada uma atividade administrativa. A atividade judicial encerrava-se com a condenação. Diante da crise de superpopulação carcerária e da grande quantidade de denúncias de violação aos direitos dos presos, o Judiciário passou a intervir na execução da pena, exercendo o controle sobre as atividades penitenciárias ${ }^{679}$. Mesmo assim, continuou a se admitir a privatização dos estabelecimentos prisionais, em maior ou menor grau.

No modelo norte-americano, grupos particulares administram principalmente estabelecimentos nos quais se encontram presos condenados a penas mínimas ou médias ou, ainda, a penas altas, caso estejam na fase de cumprimento dos dois últimos da sanção. A gestão privada ocorre também em estabelecimentos destinados a imigrantes ilegais e delinquentes juvenis. A seleção desses estabelecimentos prisionais está diretamente vinculada ao grau de coerção necessário. A coerção está presente em todas as prisões mas, naquelas de segurança máxima, faz-se necessário o seu exercício em grau máximo, que se reputa não ser compatível com a administração privada de presídios.

Podem variar as funções atribuídas ao particular. Os modelos diversificam-se do simples arrendamento de estabelecimentos particulares, passam pela contratação de serviços específicos dos particulares e podem chegar à atribuição ao particular do gerenciamento completo do presídio, inclusive do sistema de segurança. Neste caso, o Estado exerce apenas a fiscalização da atividade desempenhada pelo particular, mediante

\footnotetext{
${ }^{676}$ Encontram-se exemplos de aplicação do sistema norte-americano no Canadá, Inglaterra, Austrália e Japão, entre outros países.

677 Adotam sistema próximo ao francês, entre outros países, a Bélgica, a Holanda e a Itália. Apesar da diversidade de modelos, algumas poucas empresas privadas concentram a gestão privada de prisões nos diversos países que adotam esse sistema. Conforme dados apresentados por Laurindo Dias Minhoto, relativos à metade da década de 1990, as duas maiores empresas do setor - a Wackenhut Corrections Corporations e a Corrections Corporation of America (CCA) administravam estabelecimentos nos Estados Unidos, Canadá, Inglaterra, França, Alemanha, Austrália e Porto Rico e detinham três quartos do mercado global de prisões (Privatização de presídios e criminalidade, 2000, p. 25-26).

${ }^{678}$ Edmundo Oliveira anota que o sistema conta com a chancela da Suprema Corte dos Estados Unidos, que editou Súmula em 1981 com o seguinte teor: "Não há obstáculo constitucional para impedir a implantação de prisões privadas, cabendo a cada Estado avaliar as vantagens advindas dessas experiências, em termos de qualidade e segurança, nos domínios da execução penal” (O futuro alternativo das prisões, 2002, p. 326).

${ }^{679}$ Marcelo de Figueiredo Freire. Privatização de presídios, 1995, p. 94-95.
} 
funcionário do Estado que exerce controle diário. Há também o modelo de prisão-indústria, em que o trabalho do preso é explorado economicamente ${ }^{680}$.

O modelo francês funda-se na dupla responsabilidade, do Estado e do particular, de modo que devem exercer conjuntamente o gerenciamento e a administração do estabelecimento. As obrigações das partes são definidas contratualmente, com base nas diretrizes previstas na Lei $n^{\circ}$ 87.432, de 22 de junho de 1987.

Em 24 de novembro de 2009, foi aprovada a nova lei penitenciária, que autoriza a França a aproximar o seu sistema dos padrões comunitários europeus. No seu art. $3^{\circ}$, prevê a possibilidade de participação privada na gestão dos presídios e reserva ao Estado as funções de direção, vigilância e registros cartoriais dos estabelecimentos penitenciários. Manteve-se, assim, a possibilidade de gestão compartilhada, com a indicação das matérias que não podem ser objeto de trespasse a particulares.

Em linhas gerais, cabe ao Estado a indicação do Diretor-Geral do estabelecimento, reportar-se ao juízo da execução penal e ser responsável pela segurança externa. O Estado exerce controle intenso e tem a faculdade de vetar a admissão de determinada pessoa indicada para trabalhar no estabelecimento. Já à empresa privada cabem as atividades de guarda e segurança interna bem como de assistência aos presos, tais como a alimentação, saúde, educação, lazer, assistência jurídica e espiritual ${ }^{681}$.

Na França, questionaram-se vários aspectos relacionados à privatização das prisões. Em decisão de 1978, o Conselho Constitucional reconheceu ser da competência do legislador ordinário dispor acerca do serviço penitenciário ${ }^{682}$. Permitiu, com isso, a edição de lei de 1987 que consagrou a participação privada na gestão de presídios. Em 2012, o Conselho Constitucional aprovou novamente o sistema ao reputar ser constitucional o art. $2^{\circ}$ da lei de programação da execução das penas, que prevê a possibilidade de o Estado

\footnotetext{
${ }^{680}$ Como sistematiza Laurindo Dias Minhoto, é possível diferenciar quatro modalidades de intervenção privada nas prisões: “a. o financiamento da construção de novos estabelecimentos; b. a administração do trabalho prisional (prisões industriais); c. a provisão de serviços penitenciários, tais como educação, saúde, profissionalização, alimentação, vestuário, etc.; d. a administração total de estabelecimentos penitenciários, que pode ser contratada somente para a gestão de presídios já existentes, ou, combinando as várias modalidades, para o financiamento, construção e operação de novos estabelecimentos (esta modalidade é conhecida como 'DFCM contracts', isto é, contratos para design, construção, financiamento e administração” (Privatização de presídios e criminalidade, 2000, p. 70).

${ }^{681}$ Edmundo Oliveira. O futuro alternativo das prisões, 2002, p. 326-329. O Tribunal de Conflitos francês decidiu ser de direito público a relação existente entre o detento e o gestor privado da prisão, ao analisar a responsabilidade por erro médico de que o detento foi vítima (Decisão $\mathrm{n}^{\circ}$ 3849, de 11 de junho de 2012; AJDA 2012, p. 1192).

${ }^{682}$ Decisão n ${ }^{\circ}$ 78-97, de 27 de julho de 1978.
} 
contratar particulares para a concepção, construção, organização, exploração e manutenção de estabelecimentos penitenciários ${ }^{683}$.

No Brasil, o modelo de gestão privada de presídios ainda não se disseminou e desperta bastante controvérsia.

Existem algumas experiências, adotadas principalmente por iniciativa dos Estados-membros, que utilizam o modelo de gestão compartilhada, em termos similares aos do sistema francês. Em geral, cabe ao Estado o exercício das funções de direção e de segurança externa do estabelecimento. A empresa contratada é responsável pelos demais serviços necessários ao funcionamento do presídio, incluindo a segurança interna e as diversas assistências prestadas aos internos.

Encontra-se em trâmite no Congresso Nacional o Projeto de Lei no 513/11, que tem por objeto estabelecer "normas gerais para a contratação de parceria públicoprivada para a construção e administração de estabelecimentos penais”. Visa regulamentar a utilização de parcerias público-privadas, na modalidade de concessão administrativa, para a gestão de presídios. Entre as suas principais disposições, destaca-se a previsão de “indelegabilidade das funções jurisdicionais e disciplinares, exclusivas do Estado” (art. 4º, inc. VII). Prevê que apenas os cargos de diretor e vice-diretor do estabelecimento penal deverão ser ocupados por servidores públicos de carreira (art. $5^{\circ}$ ). Os ocupantes de todos os demais cargos serão fornecidos pelo parceiro privado. Ou seja, a atividade de vigilância interna também deverá ser desenvolvida pela empresa privada.

\subsubsection{As distintas estruturações de privatização}

São possíveis diversas estruturações de privatização, com a atribuição de uma quantidade maior ou menor de atividades ao particular.

Há o exemplo menos passível de gerar controvérsias, que implica o trespasse apenas das atividades de alimentação e hotelaria no estabelecimento prisional. Outros modelos podem envolver desde a construção do estabelecimento até a sua Administração pelo particular. Pode-se cogitar também da organização da utilização da mão-de-obra dos encarcerados, no modelo dos chamados presídios “industriais”.

A atividade de execução da pena, que é de natureza complexa, envolve o exercício de funções distintas: função jurisdicional, função administrativo-jurisdicional e função administrativa ${ }^{684}$. A atividade jurisdicional é desempenhada pelo juiz e implica o

\footnotetext{
683 Decisão de 6 de março de 2012, AJDA 2012, p. 409.

${ }^{684}$ Fernando Vernalha Guimarães. Parceria público-privada, 2013, p. 258; Edmundo Oliveira. O futuro alternativo das prisões, 2002, p. 335-336.
} 
controle da execução da pena ${ }^{685}$. As atividades que envolvem função jurisdicional e administrativa são aquelas relacionadas à concretização da função jurisdicional, tais como as atribuições de caráter disciplinar. São atribuições desempenhadas pelo Ministério Público, pelo Conselho Penitenciário e pelo Departamento Penitenciário ${ }^{686}$. Por fim, as atividades administrativas dizem respeito ao provimento da estrutura necessária para a manutenção da custódia física, envolvendo a infraestrutura, o fornecimento de materiais, a prestação de serviços e a assistência dos presos ${ }^{687}$.

As atividades de natureza jurisdicional e jurisdicional-administrativas não são passíveis de ter o seu exercício transferido para particulares.

Em relação às atividades administrativas, é necessário verificar se guardam alguma relação com o exercício da coação.

\subsubsection{Os limites da delegabilidade na gestão prisional}

Como já se indicou anteriormente, um dos limites para o exercício de atividades de polícia administrativa por entidades privadas diz respeito ao manejo de coerção sobre outros particulares. O Estado é o único legitimado para manifestar a coerção sob pena da quebra do equilíbrio das relações privadas, estabelecendo-se a supremacia irresistível de uns perante outros. Em princípio, isso inviabilizaria a transferência da integralidade da gestão prisional a particulares. Determinadas funções teriam que ser necessariamente exercidas diretamente pelo Estado, através de seus agentes.

Portanto, o limite a ser considerado é a impossibilidade de particulares exercerem poderes coercitivos sobre os encarcerados. Considerando-se essa restrição, cabe analisar quais atividades poderiam ser delegadas.

Há atividades que são meramente instrumentais à execução da pena e não envolvem qualquer exercício de coação. Trata-se das atividades eminentemente assistenciais, tais como o fornecimento de alimentação, limpeza e lavanderia. Estes serviços podem ser perfeitamente objeto de trespasse a particulares. A sua execução não demanda a aplicação de coação por particulares sobre os presos.

Serviços como os de saúde e educação também podem ser considerados atividades meramente administrativas se não guardarem relação direta com as condições da execução da pena. Uma avaliação médica que poderá embasar a progressão de regime do

\footnotetext{
685 Trata-se das competências previstas no art. 66 da Lei de Execução Penal (Lei no 7.210/84).

${ }^{686}$ São as atividades previstas nos arts. 67 a 72 da Lei de Execução Penal.

${ }^{687}$ As diversas assistências a serem prestadas aos presos estão previstas nos arts. 10 a 27 da Lei de Execução Penal.
} 
preso, por exemplo, adquire relevância diferenciada e deixa de ser uma atividade meramente instrumental à execução da pena.

Já as funções desempenhadas pelos diretores de presídio e pelos guardas no exercício da função disciplinar, em contato direto com os presos, não seria passível de delegação a particulares diante do forte poder coercitivo envolvido e da impossibilidade de prévia programação de todos os atos a serem praticados. Tais atividades estariam inseridas naquele que seria considerado o núcleo duro das atividades estatais, não sendo passíveis de delegação.

A segurança interna e o monitoramento dos presídios consistem em serviços administrativos que apresentam pontos de conexão com o exercício da coação pelo Estado. Em relação a estes serviços, é necessário avaliar as suas condições específicas de prestação para se identificar se implicam a transferência do exercício de poderes de coerção para particulares.

Adotando-se o exemplo da segurança interna, há determinadas atividades que não geram dúvidas quanto à possibilidade de privatização, tal como o fornecimento dos equipamentos. Porém, ingerência mais significativa de particulares na segurança interna, mediante gestão e operação do próprio sistema de segurança, poderá dar ensejo a maiores questionamentos.

Parece-nos que a delegabilidade dessas atividades dependerá da avaliação do grau de programação prévia a que se sujeitam e da margem de autonomia conferida ao particular na sua operação.

Programas tais como os de monitoramento eletrônico de presos devem ser objeto de ampla programação prévia pela Administração, com a indicação precisa dos equipamentos a serem utilizados e do perímetro de movimentação permitida para o detento. A operação desse sistema implica reduzida interferência humana. Se os requisitos de funcionamento foram previamente determinados, o particular não dispõe de margem de autonomia para alterar as condições de operação do sistema.

A instalação e operação do sistema interno de vigilância do presídio também deve ser objeto de programação prévia pela Administração. Cabe à Administração determinar antecipadamente os equipamentos que serão utilizados, os locais onde serão instalados e o modo de funcionamento. Nesse caso, a instalação e operação desses sistemas pela iniciativa privada também parece possível, por não se atribuir margem de autonomia para o particular que implique amplo poder de decisão ou exercício de coerção. 
A esse respeito, cabe apontar que a evolução tecnológica tem permitido a disponibilização de sistemas de segurança interna que permitem o acompanhamento constante dos presos e minimizam o contato entre os detentos e os agentes penitenciários. É necessário, assim, avaliar cada caso específico para se identificar se a atividade desempenhada pelo particular na segurança interna permite ou não o uso de coerção sobre os detentos.

Portanto, não está afastada toda e qualquer participação privada nas atividades de segurança dos presídios. Atividades passíveis de prévia programação e sujeitas a critérios objetivos previamente determinados poderiam ser delegadas a particulares desde que não lhes sejam atribuídas decisões acerca do modo e do momento de realização da vigilância nem o exercício de coerção.

Já a apuração e aplicação de sanções disciplinares não podem ser submetidas à gestão privada. Ainda que o particular possa auxiliar na instrução do processo, com o fornecimento, por exemplo, de evidências da prática da infração, a decisão acerca da sua ocorrência e a aplicação de eventual sanção disciplinar apenas poderão ser feitas pelo Estado. Assim se passa porque essas atividades implicam manifestamente o emprego de coerção e demandam a avaliação discricionária do agente em determinada medida, não sendo passíveis de ampla programação prévia ${ }^{688}$.

\subsection{O poder sancionatório}

Uma das atividades incluídas no denominado ciclo de polícia administrativa é a sancionatória. Cabe avaliar, portanto, se esta atividade comporta delegação.

\subsection{1. $\underline{\text { A sanção administrativa }}$}

A sanção administrativa pode ser definida como “a direta e imediata consequência jurídica, restritiva de direitos, de caráter repressivo, a ser imposta no exercício da função administrativa, em virtude de um comportamento juridicamente proibido, comissivo ou omissivo" ${ }^{689}$.

\footnotetext{
${ }^{688}$ No sistema norte-americano, há casos em que as empresas privadas são encarregadas da aplicação de sanções disciplinares: "Tradicionalmente, certa margem de discricionariedade tem sido conferida ao corpo de funcionários dos estabelecimentos penitenciários norte-americanos para a tomada de decisões importantes, tais como julgamento e apenação de infrações internas, bem como a instrução de requerimentos de livramento condicional” (Laurindo Dias Minhoto. Privatização de presídios e criminalidade, 2000, p. 88).

${ }^{689}$ Daniel Ferreira. Sanções administrativas, 2001, p. 34.
} 
A sanção é instituída por um ato jurídico, que consiste na determinação de que a não observância de determinada conduta devida implica a execução compulsória ${ }^{690}$. A partir do ato jurídico, há a execução da sanção, com a prática de atos materiais.

Parcela da doutrina recusa a existência de uma diferença ontológica entre a sanção administrativa e a sanção penal ${ }^{691}$. Já para outros, haveria uma diferença material entre essas competências ${ }^{692}$. De todo modo, a figura da sanção apresenta vários tipos, vinculados a diferentes ramos do direito, que se submetem a regimes jurídicos distintos. No entanto, há ampla margem de liberdade para o legislador conformar os ilícitos, observando os limites constitucionais e legais, para atribuir-lhes natureza penal ou administrativa ${ }^{693}$.

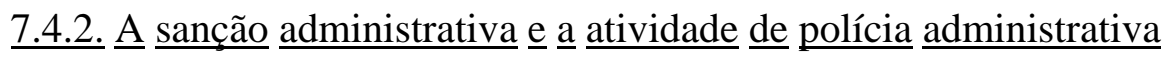

As sanções têm finalidade eminentemente repressiva, punitiva, produzindo efeito aflitivo como reação a um ato ou omissão definido como infração ${ }^{694}$. O seu objeto principal é expressar a desaprovação em relação a determinado comportamento. As sanções apresentam também, em maior ou menor medida, a finalidade de prevenção. Mas este não é o seu objetivo primordial.

\footnotetext{
${ }^{690}$ Carlos Ari Sundfeld. Direito administrativo ordenador, 1997, p. 79.

691 Como constata Rafael Munhoz de Mello, a "sanção é a consequência de um ilícito. É assim no campo do direito civil, do direito penal e do direito administrativo. Ontologicamente não há diferença entre umas e outras. Seja na esfera do direito civil, seja na esfera do direito penal, sanção é a consequência negativa atribuída à ocorrência de um ilícito. E ilícito, por sua vez, é a inobservância de um dever jurídico, tenha ele natureza civil, penal ou administrativa” (Princípios constitucionais de direito administrativo sancionador, 2007, p. 43).

${ }^{692}$ Entre aqueles que sustentam haver diferenças materiais entre a sanção penal e a administrativa, podem ser separados os que defendem que o diferencial é qualitativo dos que entendem ser quantitativo. Para a primeira corrente, os ilícitos penais atingiriam interesses mais relevantes da sociedade. Já os ilícitos administrativos violariam interesses de menor relevância, muitas vezes identificados como sendo interesses apenas da própria Administração Pública. Essa tese foi desenvolvida especialmente pela doutrina alemã, por autores como Feuerbach e Max Ernest Mayer, e influenciou também autores italianos, tais como Ottaviano e Tesauro. Uma análise profunda sobre o tema pode ser encontrada na obra de Rafael Munhoz de Mello. Princípios constitucionais de direito administrativo sancionador, 2007, p. 47-54. Para exemplificar o entendimento daqueles que sustentam haver diferença quantitativa entre os institutos, recorre-se aos ensinamentos de Nelson Hungria. O doutrinador indica que a única diferença entre os ilícitos penal e administrativo seria de quantidade ou de grau, na maior ou menor intensidade lesiva - sendo o ilícito administrativo de menor intensidade em relação ao penal. Não haveria diferença qualitativa ou essencial entre eles: “A punição de certos ilícitos na esfera do direito administrativo, ao invés de o ser na órbita do direito penal comum, não obedece (...) senão a razões de conveniência política: para o direito penal comum é transportado apenas o ilícito administrativo de maior gravidade objetiva ou que afeta mais direta e intensamente o interesse público ou social, passando, assim, a ilícito penal” (Comentários ao Código Penal, v. I, tomo II, 1983, p. 28).

${ }^{693}$ Fábio Medina Osório. O conceito de sanção administrativa no direito brasileiro, 2003, p. 328. O autor pondera que há limites para a atuação do legislador, que não poderia descriminalizar determinados condutas, correspondentes aos crimes de maior gravidade, não por uma questão ontológica mas sim em respeito aos direitos fundamentais das vítimas. A liberdade de configuração legislativa dos ilícitos seria então delimitada pelo texto constitucional (ob. cit., p. 328-329).

"Ex4 Excluem-se dessa análise as sanções premiais. Sobre o tema, consulte-se Norberto Bobbio. Verbete "Sanzione" - Novissimo Digesto Italiano, 1969, p. 531-532.
} 
Mas as sanções não têm por finalidade principal a imposição de restrições e limitações à liberdade e propriedade individuais, tal como se passa em relação às medidas de polícia administrativa. A polícia administrativa compreende providências para a prevenção e o restabelecimento de violações à ordem pública ${ }^{695}$.

Considerando especialmente que tanto as sanções administrativas quanto as medidas de polícia podem ter por finalidade a prevenção, ainda que não a título principal no que diz respeito às sanções, por vezes não há como diferenciar uma e outra a partir do objeto das decisões adotadas ${ }^{696}$.

Determinadas medidas podem tanto consistir na aplicação de uma sanção quanto na execução de ordens de polícia. A interdição do funcionamento de um estabelecimento, por exemplo, pode tanto ser uma medida de polícia quanto uma sanção. Cabe diferenciar, assim, as situações em que se trata da aplicação de sanção propriamente dita dos casos em que há a simples execução de ordens de polícia, suprindo-se o ato que o administrado deixou de praticar.

A esse respeito, Carlos Ari Sundfeld diferencia os vários instrumentos disponíveis para a repressão da inobservância das normas de polícia: a ordem para correção de irregularidade, a medida cautelar e a sanção ${ }^{697}$. A primeira consiste na prática de determinado ato pela Administração, determinando a correção da irregularidade. Não se trata de medida sancionadora. Pressupõe a preexistência de um condicionamento, que não foi observado, e tem por finalidade “exigir formalmente a eliminação da violação produzida"698. As medidas cautelares são utilizadas para impedir a continuidade de ilegalidades que provoquem grave risco ao interesse coletivo. A medida cautelar não tem finalidade sancionatória, objetivando apenas eliminar o perigo de forma imediata. Por fim, há a sanção, que inflige um castigo pela não observância dos condicionamentos de polícia.

\subsubsection{A finalidade das medidas de polícia administrativa e a da sanção administrativa}

A finalidade das medidas é que consiste no critério usualmente aceito pela doutrina para diferenciar as sanções administrativas das medidas de polícia administrativa:

A jurisprudência e a doutrina ( $v g$ francesa, italiana e espanhola) tem adotado como traço essencial-substancial do ato sancionatório a sua finalidade punitiva (elemento teleológico). A finalidade é completada pelo seu caráter individual decorrente da ilicitude de um comportamento que lhe dá causa (elemento subjetivo); pelo conteúdo

\footnotetext{
695 José dos Santos Carvalho Filho apresenta como exemplo da distinção entre sanções e medidas de polícia as disposições do Código de Trânsito Brasileiro. São previstas penalidades (art. 265, I a VII) e medidas administrativas (art. 269, I a X) (Manual de direito administrativo, 2012, p. 92).

${ }^{696}$ Michel Pâques. Police administrative et sanction administrative, 2007, p. 688.

${ }^{697}$ Direito administrativo ordenador, 1997, p. 77.

${ }^{698}$ Ob. e loc. cit.
} 
negativo ou penoso (um "mal" concreto (elemento objetivo); pela sua natureza administrativa e não judicial (elemento orgânico); e pela observância de um procedimento administrativo especial (elemento formal ou procedimental). ${ }^{699}$

Michel Pâques exemplifica que é a finalidade repressiva que permite diferenciar uma sanção administrativa de um ato que recusa a outorga de determinada licença por não estarem presentes os requisitos necessários ${ }^{700}$.

Em determinadas hipóteses, pode-se recorrer à coerção para se obter o cumprimento de determinada sanção administrativa. No entanto, isso não permite equiparar a sanção às medidas de polícia administrativa que demandam o uso da coerção. Com a coerção, procura-se obter o cumprimento da obrigação, ainda que contra a vontade do obrigado, de modo a se promover a reparação da situação fática. Não tem por objeto infligir um mal a alguém ${ }^{701}$. Já a sanção consiste em meio repressivo, imposto em razão do não cumprimento da obrigação ${ }^{702}$.

Em alguns casos, a ausência de finalidade intimidatória e repressiva na atividade de polícia é de fácil identificação ${ }^{703}$.

Porém, em outros casos, constata-se haver maior proximidade entre a atividade de polícia coercitiva e a sancionatória. Uma destas hipóteses consiste na atuação da medida de polícia administrativa com natureza cautelar-sancionadora. Trata-se da adoção de medidas de polícia com finalidade acautelatória, para assegurar a eficácia da sanção correspondente ao ilícito praticado ${ }^{704}$. Consistem em medidas preventivas, com natureza de atividade de polícia, que objetivam "impedir a ocorrência ou a continuidade de um evento causador de danos ao interesse público”705.

Note-se que a adoção de medidas cautelares não significa a aplicação imediata da sanção. As medidas preventivas, praticadas sem o prévio desenvolvimento de processo administrativo no qual sejam assegurados o contraditório e a ampla defesa, devem

\footnotetext{
${ }^{699}$ Luís Guilherme Catarino. Regulação e supervisão dos mercados de instrumentos financeiros, 2010, p. 591-592.

${ }_{700}$ Police administrative et sanction administrative, 2007, p. 681.

${ }^{701}$ Iñaki Agirreazkuenaga Zigorraga. La coacción administrativa directa en el ámbito de la inspección de consumo, 1991, p. 44.

${ }^{702}$ Fernando Garrido Falla. Los medios de la policia y la teoria de las sanciones administrativas, 1959, p. 34.

${ }^{703}$ Como exemplifica Fábio Medina Osório, "quando o Estado veda ao indivíduo um exercício de um direito para o qual não estava habilitado, não há falar-se propriamente em sanção administrativa. Nessa linha de raciocínio, o fechamento ou a interdição de uma atividade iniciada pelo particular sem a necessária autorização do Poder Público não constitui sanção administrativa, pois em realidade se trata de uma medida adotada para o restabelecimento da legalidade, como poder legítimo da Administração" (Direito administrativo sancionador, 2011, p. 102).

${ }^{704}$ Enquadra-se nessa categoria, por exemplo, a apreensão de documento em relação ao qual há suspeita de adulteração e de alimentos supostamente deteriorados, antes da comprovação dos ilícitos em definitivo (Daniel Ferreira. Sanções administrativas, 2001, p. 26-27, nota 51).

${ }^{705}$ Rafael Munhoz de Mello. Princípios constitucionais de direito administrativo sancionador, 2007, p. 82.
} 
ser adotadas excepcionalmente, apenas se forem imprescindíveis e na medida para a cessação do perigo.

De todo modo, como assenta Fábio Medina Osório, “[q]uando uma medida é aplicada com objetivo acautelatório, para preservar direitos ou provas, certamente estaremos diante do poder de polícia”706.

Outro aspecto diferencial entre as sanções administrativas e as medidas de polícia administrativa coercitiva é mencionado por García de Enterría e Fernández, a partir dos ensinamentos de Otto Mayer ${ }^{707}$. Trata-se da noção de que a medida de polícia, especialmente no que diz respeito à sua execução, encontra-se em "linha direta de continuidade” com o ato administrativo. Consiste no cumprimento exatamente daquilo que o ato ordenava ao devedor, sem nenhuma imposição de obrigação adicional ou transformação do conteúdo original do ato. Já a sanção acrescenta algo de novo à obrigação original do devedor, seja para inová-la ou substituí-la ${ }^{708}$. Daí o seu caráter punitivo.

Isso é relevante especialmente porque, no direito administrativo, as sanções administrativas são usualmente vinculadas às atividades de polícia administrativa. A atividade de polícia em si não tem natureza ou finalidade sancionatória. Porém, na hipótese de infração a deveres administrativos previstos em lei, a consequência poderá ser a aplicação de sanção administrativa.

\subsubsection{Algumas repercussões da diferenciação}

Em termos práticos, a distinção entre sanção administrativa e atividade de polícia coercitiva poderia ter algumas repercussões, por exemplo, em relação ao processo administrativo que deve anteceder a adoção das medidas ${ }^{709}$.

\footnotetext{
${ }^{706}$ Direito administrativo sancionador, 2011, p. 103.

${ }^{707}$ Curso de derecho administrativo, v. I, 2002, p. 778-779.

${ }^{708}$ No entanto, há algumas medidas de execução forçada que, sob esse aspecto, acabam se aproximando das sanções. Esse é o caso, por exemplo, da multa coercitiva. É imposta na tentativa de se vencer a resistência do devedor no cumprimento da obrigação original. Porém, a multa em si implica um acréscimo das obrigações do devedor.

709 No direito francês, as medidas de polícia são diferenciadas das sanções administrativas quanto à possibilidade de aplicação retroativa de lei mais rigorosa. Georges Dupuis, Marie-José Guédon e Patrice Chrétien apontam que determinadas medidas têm finalidade preventiva e repressiva simultaneamente, tal como a suspensão administrativa do direito de dirigir. Mas o Conselho de Estado reputa que essas medidas visam assegurar a ordem e não consistem em sanções. A consequência disso é o reconhecimento da possibilidade de as autoridades aplicarem leis mais rigorosas com efeitos retroativos, o que não é possível com as sanções, em relação às quais se aplica a garantia da irretroatividade (Droit administratif, 2009, p. 532533). Chapus também assinala que uma das consequências práticas da distinção entre medidas de polícia e sanções é a de que a fundamentação da aplicação da medida de polícia deve considerar a legislação em vigor na data da decisão, ainda que consistam em textos mais severos e impliquem medidas mais restritivas aos particulares em relação aos textos vigentes na época dos fatos (Droit administratif général, t. 1, 1999, p. 691). Note-se que essa diferenciação parece não ser acolhida no direito nacional, como decorrência dos princípios da segurança jurídica, da legalidade e da isonomia. Reconhece-se que a exigência da anterioridade da lei
} 
A CF/88 assegura, em termos amplos, o exercício de direitos e garantias por todos os administrados, seja em face da possível imposição de sanção ou de adoção de medida de polícia administrativa. Isso impede a existência de diferenças relevantes em relação aos processos a serem desenvolvidos, especialmente no que diz respeito à participação do administrado e ao exercício do contraditório e da ampla defesa.

A sanção pressupõe o desenvolvimento de regular processo administrativo prévio, do qual o administrado poderá participar ativamente. Já a coerção administrativa pode ser, excepcionalmente, manifestada de modo imediato, diante da necessidade de alteração instantânea de uma situação de fato. Isso não significa propriamente que o emprego da coerção dispense a sua prévia autorização, mediante a prolação de decisão fundamentada pela autoridade competente. Como se procurou demonstrar anteriormente, apenas em casos excepcionais autoriza-se o emprego da coerção direta pela Administração, sem o prévio desenvolvimento de processo administrativo e sem autorização judicial.

De todo modo, o processo de aplicação de sanção administrativa, usualmente, é objeto de regulação mais intensa, consagrando-se legislativamente as diversas etapas a serem observadas ${ }^{710}$. Além disso, determinadas medidas de polícia devem ser aplicadas imediatamente, para evitar a ocorrência de danos graves ou interromper a sua produção. Trata-se de hipóteses excepcionais, que demandam a atuação sem a prévia realização de processo administrativo ${ }^{711}$.

Cabe diferenciar também a sanção administrativa do ato sancionador. A sanção constitui o próprio conteúdo do ato sancionador, como consequência de uma conduta não conforme às disposições legais ${ }^{712}$.

As providências materiais relacionadas à aplicação de sanção administrativa consistem em manifestação de atividade de polícia administrativa. A apuração do ilícito administrativo e os atos materiais de aplicação da sanção também podem ser considerados

instituidora, bem como a retroação benigna do art. $5^{\circ}$, inc. XL, da CF/88, aplicam-se tanto para sanções quanto para infrações administrativas (ilícitos). Sobre o tema, podem ser conferidas as lições de Regis Fernandes de Oliveira. Infrações e sanções administrativas, 2012, p. 86; Rafael Munhoz de Mello. Princípios constitucionais de direito administrativo sancionador, 2007, p. 150-151; Daniel Ferreira. Sanções administrativas, 2001, p. 137.

${ }_{710}$ Por exemplo, o procedimento sancionatório é objeto de regulação específica na Lei de Processo Administrativo de São Paulo (Lei no 10.177/98), nos arts. 62 a 64.

711 "Sanção administrativa é imposta sempre após o curso de processo administrativo, no qual é assegurado ao acusado o exercício de todas as garantias inerentes ao due process of law. Já medida preventiva, aplicada justamente para evitar a ocorrência de fato danoso ao interesse público, exige pronta e imediata atuação da Administração Pública, que pode agir sem realizar prévio processo administrativo, sob pena de não atender ao interesse público" (Rafael Munhoz de Mello. Princípios constitucionais de direito administrativo sancionador, 2007, p. 83-84).

${ }^{712}$ Daniel Ferreira. Sanções administrativas, 2001, p. 25-26. 
manifestação do exercício da competência de polícia administrativa. Também se diferenciam, portanto, da sanção propriamente dita.

\subsubsection{A inclusão da aplicação de sanção no ciclo das atividades de polícia administrativa}

Apesar de ser possível traçar distinções entre a sanção administrativa e a atividade de polícia administrativa, é usual considerar-se que a primeira integra a segunda.

Aquele que pode impor medidas de restrição e limitação da propriedade e liberdade privadas, com a possibilidade de emprego da coerção, usualmente também detêm poderes repressivos, para aplicar as sanções pela prática de atos ilícitos ${ }^{713}$. Diante do não cumprimento de uma ordem, imposta no exercício da polícia administrativa, existe a possibilidade de aplicação de uma sanção. É bastante evidente a associação entre as duas atividades.

Daí ser recorrente a integração do direito administrativo sancionador à atividade de polícia. Como já se indicou, Diogo de Figueiredo Moreira Netto inclui a atividade sancionatória no ciclo da atividade de polícia ${ }^{714}$. Vários dos precedentes jurisprudenciais citados ao longo do presente estudo, que analisaram o tema da delegabilidade da atividade de polícia administrativa, consideraram especificamente a aplicação de sanções.

Por esse motivo, também analisamos a atividade sancionatória no âmbito do presente estudo, especificamente quanto à (im)possibilidade da sua delegação. No entanto, reconhecemos a especificidade do regime jurídico a que o direito administrativo sancionador se submete ${ }^{715}$.

\subsubsection{O poder disciplinar}

A capacidade sancionatória pode também ser diferenciada do poder disciplinar que a Administração emprega nas relações que mantém com determinados administrados. O regime disciplinar é aquele a que se submetem os que se relacionam cm a

\footnotetext{
${ }^{713}$ Fábio Medina Osório. Direito administrativo sancionador, 2011, p. 103.

${ }^{714}$ Sobre o tema, v. item I.9.

${ }^{715}$ Fábio Medina Osório apoia-se nos princípios e regras específicos do direito administrativo sancionador para sustentar a sua autonomia, sem deixar de reconhecer a grande proximidade com a atividade de polícia: "não prospera, em sua globalidade, a teoria de que o poder sancionador estaria integrado no poder de polícia, diante das peculiaridades do direito administrativo sancionador, suas garantias, sua generalidade, tipicidade, legalidade, incompatibilidade com a flexível e extremamente elástica natureza que deveria ostentar para ser considerado integrante do poder de polícia” (Direito administrativo sancionador, 2011, p. 104).
} 
Administração mediante vínculos especiais, tais como os agentes públicos, os alunos de escolas públicas, os detentos etc. ${ }^{716}$

O poder disciplinar é inerente a todas as instituições sociais, públicas ou privadas. Todo agrupamento detém um poder disciplinar próprio, destinado a manter a ordem interna ${ }^{717}$. O poder disciplinar verificado no âmbito das entidades privadas já foi analisado no item I.12.7.2.

Na esfera administrativa, o poder disciplinar "é o que cabe à Administração Pública para apurar infrações e aplicar penalidades aos servidores públicos e demais pessoas sujeitas à disciplina administrativa"718. O poder disciplinar relaciona-se com o poder hierárquico à medida que se destina ao controle do desempenho das atribuições e da conduta interna daqueles que exercem a função administrativa, cujas atribuições foram distribuídas e escalonadas no exercício do poder hierárquico ${ }^{719}$.

Para os fins do presente estudo, cabe destacar que o poder disciplinar pode tanto envolver o manejo de poderes privados quanto públicos. Isso não significa equiparar, para todos os fins, o poder disciplinar exercido por uma associação privada sobre os seus associados àquele desempenhado pelo Estado sobre os seus servidores. Há muitas diferenças entre eles, especialmente no tocante ao regime jurídico.

O exercício do poder disciplinar pela Administração pode dar ensejo à aplicação de sanções àqueles que se encontram na escala hierárquica. Esta sanção, denominada disciplinar, pode ser diferenciada da sanção administrativa.

Para Guido Zanobini, a aplicação de uma sanção administrativa e de uma sanção disciplinar, apesar de terem a mesma função, representam manifestação e manuseio de duas ordens de poderes distintas. A primeira representaria a incidência da soberania geral do Estado, que recai indistintamente sobre todos os cidadãos. Já a sanção disciplinar representaria a existência de poderes especiais de supremacia, decorrentes de relações jurídicas especiais que o Estado mantém com determinados particulares ${ }^{720}$.

\footnotetext{
716 Há quem sustente que os administrados em relação aos quais a Administração pode exercer poder disciplinar encontram-se em relação de sujeição especial. Sobre a teoria da supremacia especial e a recusa das suas consequências no âmbito do presente estudo, v. item I.4.

${ }^{717}$ Michel Degoffe. Droit de la sanction non pénale, 2000, p. 82.

${ }^{718}$ Maria Sylvia Zanella Di Pietro. Direito administrativo, 2013, p. 95.

${ }^{719}$ Hely Lopes Meirelles. Direito administrativo brasileiro, 2012, p. 130.

${ }^{720}$ Corso di diritto amministrativo, v. III, 1946, p. 52-53.
} 
Logo, as sanções disciplinares ${ }^{721}$ terão por fundamento esse poder específico, vinculado a relações especiais mantidas pela Administração com determinados sujeitos e não propriamente à capacidade sancionatória da Administração.

No que diz respeito ao exercício de poder disciplinar pela Administração, verifica-se uma tendência de integração dos poderes disciplinares nos poderes sancionatórios gerais ${ }^{722}$. Assim se passa especialmente pela quase identificação do regime jurídico aplicável a um e a outro tipo de sanção. A aplicação do poder disciplinar deve observar as diversas garantias dos administrados que são reconhecidas no processo

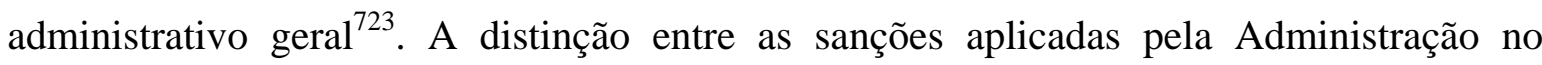
exercício do poder disciplinar e no exercício de poder sancionatório não implica diferenças substanciais em termos de regime jurídico.

Portanto, ainda que os dois tipos de sanção possam ser agrupados genericamente na categoria "sanções administrativas", o importante a ser destacado é que as relações jurídicas que dão ensejo à aplicação de um tipo de sanção e outro são distintas. Ademais, essa diferenciação é relevante para o objeto do presente estudo à medida que o exercício de poder disciplinar não implica necessariamente o manejo de poderes públicos. Uma associação privada exerce poder disciplinar sobre os seus associados, no exercício de poderes privados. Esse exercício de poder disciplinar, em princípio, não consiste no exercício delegado de poderes públicos - ressalvando-se apenas as associações de filiação obrigatória para os interessados, o que determina o caráter público dos poderes que exercem.

\subsubsection{Indelegabilidade do exercício da capacidade sancionatória a particulares}

O direito de punir (jus puniendi), que está presente tanto nas sanções administrativas quanto penais, é vinculado diretamente ao Estado, como atributo da sua soberania $^{724}$.

No entanto, nem sempre a capacidade sancionatória é exercida diretamente pelo Estado. Há exemplos de exercício de poderes sancionatórios por entidades específicas,

\footnotetext{
${ }^{721}$ Diogo de Figueiredo Moreira Neto identifica as sanções aplicáveis aos servidores públicos como sanções internas ou introversas, diferenciando-as das sanções aplicadas, no desempenho de atividades de polícia, aos administrados em geral, que são as sanções externas ou extroversas (Curso de direito administrativo, 2009, p. 447).

${ }^{722}$ Eduardo García de Enterría e Tomás-Ramón Fernández. Curso de derecho administrativo, v. II, 2008, p. 170. Nas palavras de Fábio Medina Osório, “as sanções disciplinares são, evidentemente, espécies de sanções administrativas, embora possuam suas peculiaridades, seja porque não há outro lugar adequado para abrigálas, seja porque o regime jurídico advém do Direito Administrativo em sua vertente sancionadora ou punitiva" (Direito administrativo sancionador, 2011, p. 140).

${ }_{723}$ Romeu Felipe Bacellar Filho. Processo administrativo disciplinar, 2003, p. 76-77.

${ }^{724}$ Franck Moderne. Sanctions administratives et justice constitutionnelle, 1993, p. 134.
} 
vinculados ao seu objeto de atuação. Usualmente, consistem em entidades que exercem poderes públicos de diversas ordens, tais como normativo, fiscalizatório e sancionatório em relação a determinadas áreas específicas - tais como a regulação de determinada profissão ou setor da atividade econômica.

Note-se que não há necessidade de haver correspondência exata em relação à abrangência dos diversos poderes exercidos por essas entidades. Por exemplo, o poder normativo deve ser de natureza derivada, limitado e condicionado às disposições legais. Já os poderes fiscalizatório e sancionatório não se restringem necessariamente às normas editadas pela própria entidade. É perfeitamente possível que estes poderes sejam mais amplos, de modo a abranger a fiscalização e o sancionamento em relação não apenas às próprias normas editadas pela entidade mas também no que diz respeito ao cumprimento de disposições legais e regulamentares aplicáveis à atividade objeto de fiscalização. Sob essa perspectiva, pode-se afirmar ser usual que o poder sancionatório seja mais amplo do que o poder normativo.

Em relação às entidades de direito público, não existem questionamentos mais significativos em relação à possibilidade de exercício de capacidade sancionatória.

Como já se analisou, as corporações profissionais no direito nacional têm natureza jurídica de direito público. Uma das justificativas para a atribuição da personalidade jurídica pública é justamente o desempenho da função sancionatória em relação aos seus associados. Considerando-se que a filiação é obrigatória para o exercício da profissão, os poderes sancionatórios têm origem pública e são objeto de delegação a essas entidades pela lei.

Já no que diz respeito às entidades com personalidade jurídica privada, os questionamentos são mais intensos. Cabe indagar se a lei, ao atribuir determinada atividade de interesse público a uma entidade privada, conferindo-lhe determinadas prerrogativas para o seu exercício, poderia transferir igualmente o exercício de poder sancionatório.

A sanção é uma consequência negativa, punitiva. Pelo seu caráter repressivo e a imediata restrição de direitos que implica, reputamos não ser delegável o poder sancionatório a particulares. Em relação à aplicação de sanções, o exercício de poderes de autoridade não é apenas acessório à atividade e sim o seu conteúdo principal. Não é admissível a delegação pelo Estado de poderes a um particular para que imponha sanções sobre outro particular.

A questão adquire contornos mais complexos em se tratando de particulares que apresentam várias características que os aproximam dos entes públicos. 
Para ilustrar o debate, pode-se aludir ao exemplo da Câmara de Comercialização de Energia Elétrica - CCEE.

Trata-se de pessoa jurídica de direito privado, sem fins lucrativos, que tem por finalidade a viabilização da comercialização de energia elétrica. Sua criação foi autorizada no art. $4^{\circ}$ da Lei $n^{0} 10.848 / 04$. De acordo com o Decreto $n^{0} 5.177 / 04$, entre as atribuições da CCEE, encontra-se a de "apurar o descumprimento de limites de contratação de energia elétrica e outras infrações e, quando for o caso, por delegação da ANEEL, nos termos da convenção de comercialização, aplicar as respectivas penalidades”725.

Devem participar da CCEE os titulares de concessão, permissão ou autorização e consumidores que se enquadrem nos critérios estipulados no art. $4^{\circ}, \S 1^{\circ}$ do Decreto $n^{0} 5.177 / 04$.

As penalidades aplicáveis encontram-se previstas na regulação da ANEEL, especialmente nas convenções e nas regras de comercialização. Assim, não cabe à CCEE a criação de regras sobre infrações e penalidades. No entanto, foi-lhe atribuída competência para apuração de infrações e aplicação de penalidades.

Ainda que não caiba à CCEE a produção de normas sobre infrações e penalidades, a aplicação de normas sancionadoras não pode ser resumida a uma atividade de mera execução. Apesar de a aplicação de penalidades não consistir em atividade discricionária $^{726}$, parece-nos não ser possível afirmar-se que consistiria em atividade material, meramente executória. Não seria possível afastar-se, a priori, a realização de algum tipo de juízo acerca das circunstâncias concretas por ocasião da apuração das infrações e da aplicação de penalidades. Ainda que as hipóteses encontrem-se previstas na regulação da ANEEL, pode haver a necessidade de realização de avaliações concretas por parte do aplicador das regras.

Portanto, caso se repute que a filiação na CCEE é de caráter cogente, ainda que restrita aos agentes do setor, haveria de se reconhecer que os poderes que exerce são de natureza pública, atribuídos pelo Estado. Tratar-se-ia, assim, em princípio, de hipótese de delegação de poder sancionatório em favor de entidade privada.

\footnotetext{
725 Art. 2º inc. VII. A convenção de comercialização deverá prever as "penalidades e sanções a serem impostas aos agentes participantes, na hipótese de descumprimento das normas aplicáveis à comercialização, sem prejuízo da imposição, pela ANEEL, das penalidades administrativas cabíveis” (Decreto nº 5.177/04, art. $3^{\circ}$, inc. III).

726 “Ao aplicar as penalidades, a CCEE não se utiliza de elementos externos à Convenção, às Regras ou Procedimentos de Comercialização, nem aos sistemas computacionais, e, por isso, não tem discricionariedade quanto à sua aplicação. Daí que a CCEE não exerce juízo de valor quando aplica uma penalidade.” (Luiz Eduardo Diniz Araújo. Delegação do poder de sanção a associação privada com viés público, 2012, p. 299).
} 
Ponderamos, no entanto, que a caracterização da CCEE como associação civil sem fins lucrativos e o seu forte vínculo com a Administração aproximam-na significativamente do setor público ${ }^{727}$. A CCEE é integrada por agentes do setor de energia elétrica e custeada majoritariamente pela contribuição dos seus associados. Um dos membros do Conselho de Administração da CCEE deve ser indicado pelo Ministério de Minas e Energia ${ }^{728}$. Outro aspecto a ser considerado é que as receitas resultantes da aplicação de penalidades devem ser revertidas à modicidade tarifária ${ }^{729}$, não implicando benefício para os seus associados.

Esses aspectos minimizam o risco de desvios no exercício desse poder sancionatório que lhe foi delegado. Portanto, reputamos que o caso da CCEE não reflete propriamente um exemplo de delegação de poderes sancionatórios a entidade privada.

Podem ser encontradas situações de exercício de poderes sancionatórios por entidades privadas no direito comparado.

Um deles é o das federações desportivas. No direito francês e no espanhol, por exemplo, consistem em associações de natureza privada que exercem determinadas prerrogativas públicas, que lhes foram atribuídas diretamente pela lei. Entre essas prerrogativas, encontra-se a capacidade sancionatória em relação a infrações abrangidas na sua esfera de atuação. Já no direito nacional, a atividade disciplinar em relação aos esportes é de competência exclusiva da Justiça Desportiva.

Ainda em termos exemplificativos, Rocco Galli reporta-se aos amplos poderes conferidos aos concessionários de determinadas atividades no direito italiano. Aos concessionários de rodovias e de ferrovias, por exemplo, são conferidos poderes para aplicar sanções de interdição e pecuniárias para os usuários que violarem os regulamentos do serviço, sejam estes atos editados pelo poder público concedente ou pelos concessionários $^{730}$.

Porém, à luz do sistema jurídico nacional, concluímos pela indelegabilidade do poder sancionatório em favor de particulares.

\footnotetext{
${ }^{727}$ No seu voto na Medida Cautelar na Ação Direta de Inconstitucionalidade n ${ }^{\circ}$ 3.090-6, o Min. Gilmar Mendes assim se manifestou sobre o Mercado Atacadista de Energia Elétrica - MAE, que foi sucedido pela CCEE: "evidencia-se que o MAE caracteriza-se como uma pessoa jurídica de direito privado 'atípica', com forte coloração pública. É uma instituição peculiar que desempenha uma função de eminente interesse público" (DJe 26.10.2007). Tal como a CCEE, o MAE também consistia em pessoa jurídica de direito privado, constituído sob a forma de associação civil sem fins lucrativos e integrado por agentes do setor elétrico.

${ }^{728}$ Decreto ${ }^{\circ} 5.177 / 04$, art. $9^{\circ}, \S 1^{\circ}$, inc. I.

${ }^{729}$ Decreto $n^{\circ} 5.163 / 04$, art. $3^{\circ}, \S 4^{\circ}$.

${ }^{730}$ Corso di diritto amministrativo, 1996, p. 560.
} 
7.4.5. Delegabilidade do exercício da capacidade sancionatória $\underline{\text { a }}$ entidades $\underline{\text { da }}$ Administração indireta

Já no que diz respeito às entidades da Administração indireta, reputamos ser viável a delegação do exercício de poder sancionatório desde que seja afastado o risco de conflito de interesses entre os titulares do capital e os objetivos coletivos visados com o exercício da função pública. O tema será analisado adiante ${ }^{731}$.

\subsection{A atividade normativa derivada}

A atividade de polícia administrativa pode se manifestar também mediante a edição de normas jurídicas, necessárias à preservação da ordem pública. Logo, no âmbito da delegação de atividades de polícia administrativa, pode-se cogitar também da delegação de atividade normativa a particulares.

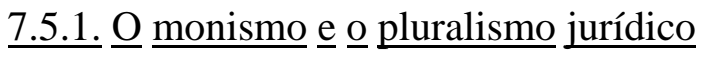

A formação do Estado Moderno caracterizou-se pela monopolização do direito pelo Estado, com a substituição do sistema medieval das corporações.

Uma das principais representações do monopólio estatal é a teoria kelseniana do direito, do monismo jurídico, que considera que apenas a norma jurídica é direito. A norma jurídica caracteriza-se pela sua força obrigatória e produção no âmbito de um sistema jurídico. Nessa acepção, uma norma não é jurídica se não tiver sido produzida pelo Estado.

A análise da possibilidade da edição de normas por particulares remete, em um primeiro momento, ao pluralismo jurídico, no sentido da existência de regulações paralelas que poderiam ameaçar a premissa de que o direito apenas pode ser produzido por aqueles que exercem soberania estatal.

Nesse contexto, é relevante mencionar-se a concepção institucional do direito $^{732}$. A proposta da teoria do direito como instituição, de Santi Romano, tem como alvo a teoria normativa do direito. Expandiu os limites do direito para além da esfera estatal, expondo o debate entre monistas e pluralistas acerca da produção do direito.

Na teoria formulada por Santi Romano, por exemplo, há direito quando houver uma sociedade organizada e ordenada, identificada como instituição. Cada instituição produz então o seu ordenamento jurídico. Logo, sustenta que a produção de

\footnotetext{
${ }^{731}$ V. item III.8.

${ }^{732}$ A teoria institucional não foi a única desenvolvida para o pluralismo jurídico. A sua exposição é feita apenas para ilustrar os fundamentos adotados para se sustentar a coexistência de vários ordenamentos jurídicos.
} 
normas não é privativa do Estado ${ }^{733}$. A teoria institucional permite a proliferação de ordenamentos jurídicos ao conceber a possibilidade de haver direito fora do Estado ${ }^{734}$.

A teoria estatista do Estado surgiu com a formação dos Estados modernos, que sucederam a sociedade medieval. Os poderes normativo e coativo foram centralizados no Estado. Para Bobbio, o debate diria mais respeito a uma disputa de palavras, empregando-se o termo “direito” em sentido amplo ou restrito ${ }^{735}$. Reconhecendo-se ou não o caráter jurídico desses conjuntos de regras produzidos pelas instituições, é necessário analisar a relação dessas entidades com o direito estatal.

Giannini desenvolveu a teoria de Santi Romano para aplicá-la aos regulamentos setoriais ${ }^{736}$. Com a especialização técnica das atividades do Estado e a setorização interna, fez-se necessário conferir certo poder decisório a essas instâncias na esfera de sua competência. Isso não se verifica apenas dentro do aparato estatal mas também nos diversos setores sociais, que são dotados de certa autonomia e atuam de forma paralela ao Estado. Assim, denominam-se ordenamentos setoriais aqueles produzidos por entidades responsáveis pela regulação de determinado setor social ou econômico ${ }^{737}$.

Em alguns casos, as entidades privadas podem aplicar exclusivamente o que está previsto no ordenamento estatal, sem produzir um ordenamento próprio. Outros grupos podem produzir normas próprias, cuja relevância depende de seu reconhecimento pelo Estado, atribuindo efeitos jurídicos à atuação normativa daquela instituição - seria o caso de federações desportivas, sindicatos e organismos de normalização. Há ainda as organizações de âmbito supraestatal, que podem produzir normas ultra ou contra legem em relação às leis estatais - exemplos são as federações desportivas internacionais, sendo que a observância destes ordenamentos é voluntária ${ }^{738}$.

Giannini, ao conceber o pluralismo jurídico, entende que essas diversas manifestações organizativas têm a sua independência reconhecida frente ao Estado ${ }^{739}$. O

\footnotetext{
${ }_{733}$ O ordenamento jurídico, 2008, p. 92.

734 Sobre as várias aplicações da teoria de Santi Romano especificamente para o direito administrativo, consulte-se Sebastían Martín-Retortillo. La doctrina del ordenamiento jurídico de Santi Romano y algunas de sus aplicaciones en el campo del derecho administrativo, 1962, p. 39-78.

${ }^{735}$ Teoria geral do direito, 2010, p. 24-28.

${ }^{736}$ Diritto amministrativo, v. I, 1993, p. 171-175.

737 “Neste ponto, convém alertar que não se deve encarar os ordenamentos setoriais dentro do tradicional esquema de 'norma especial versus norma geral'. Os ordenamentos setoriais envolvem aspectos muito mais amplos e complexos, atinentes à própria concepção e estruturação do Estado e do Direito, sendo possível, inclusive, concebê-los como subsistemas integrantes do sistema jurídico total, envolvendo questões de grande importância, teórica prática, concernentes às interpenetrações e reenvios entre os diversos subsistemas jurídicos parciais e destes com o sistema jurídico central” (Alexandre Santos de Aragão. Agências reguladoras e a evolução do direito administrativo econômico, 2002, p. 195).

${ }^{738}$ Marc Tarrés Vives. Normas técnicas y ordenamiento jurídico, 2003, p. 229.

${ }^{739}$ Istitutiozi di diritto amministrativo, 2000, p. 16-24.
} 
controle feito pelo Estado é apenas para evitar o conflito de interesses entre o ordenamento estatal e esses outros ordenamentos jurídicos. O pluralismo jurídico retrata a multiplicidade de fontes de regulação jurídica, com a existência de vários subsistemas dentro de um mesmo sistema jurídico.

\subsection{2. $\underline{\text { O poder normativo }}$}

O poder normativo diz respeito à edição de atos gerais e abstratos. Seguindo os ensinamentos de Maria Sylvia Zanella Di Pietro, referimo-nos à competência normativa e não ao poder regulamentar da Administração, à medida que aquela competência não se esgota com a edição de regulamentos ${ }^{740}$. Existem outras formas de expressão da competência normativa além dos decretos editados pelo Chefe do Executivo, tais como as resoluções, portarias e instruções emitidas por outros órgãos da Administração.

O poder legiferante é denominado atividade normativa originária, porque a sua origem é a própria Constituição. É a competência reservada constitucionalmente ao Poder Legislativo, no exercício do qual são produzidas as leis em sentido amplo. Destina-se a "instaurar, modificar ou extinguir direitos"741.

A competência normativa da Administração corresponde à atividade normativa derivada, porque a sua fonte são os atos produzidos no exercício do poder legiferante. A competência de editar normas acessórias e complementares à lei retrata o exercício de poder de segundo grau ${ }^{742}$. Compreende a edição de atos normativos derivados, consistentes na "explicitação ou especificação de um conteúdo normativo preexistente, visando à sua execução no plano da praxis" ${ }^{, 74}$.

No exercício da competência normativa, produzem-se os atos administrativos em sentido amplo. Por ocuparem posição inferior à lei, os atos administrativos devem observar os limites e competências estabelecidos pelo legislador.

Uma das decorrências usualmente atribuídas ao princípio da legalidade é o não reconhecimento de poder normativo à Administração para a instituição de norma

\footnotetext{
${ }^{740}$ Direito administrativo, 2013, p. 91.

${ }^{741}$ Miguel Reale. Revogação e anulamento do ato administrativo, 1980, p. 15.

${ }^{742}$ Marçal Justen Filho. Curso de direito administrativo, 2013, p. 255. Extrapola os limites do presente estudo o exame do cabimento de regulamentos autônomos no direito nacional. De acordo com a doutrina majoritária, haveria uma única hipótese de regulamento autônomo, consistente na previsão do art. 84, inc. VI, al. "a”, da CF/88, com a redação dada pela EC 32. A ampla maioria dos atos normativos da Administração consiste em regulamentos de execução, subordinados a uma lei prévia. Sobre o tema, confira-se Maria Sylvia Zanella Di Pietro. Direito administrativo, 2013, p. 92-93.

${ }^{743}$ Miguel Reale. Revogação e anulamento do ato administrativo, 1980, p. 13-14.
} 
jurídica que não tenha sido prevista legislativamente ${ }^{744}$. Os principais aspectos da norma jurídica devem ser previamente determinados por uma lei, cabendo à Administração complementar o espaço normativo deixado pelo legislador.

\subsubsection{Os atos normativos originários}

Consideramos que as normas jurídicas como padrão de conduta vinculante, cuja incidência independe da concordância do destinatário, devem ser de natureza pública. As normas produzidas no exercício de poder normativo de natureza privada não se caracterizam como jurídicas se não forem reconhecidas pelo Estado ${ }^{745}$.

Portanto, adota-se a concepção de que os atos normativos originários são de produção exclusiva pelo Estado, como manifestação do Poder Legislativo. Não se adotam as teorias que reconhecem outras fontes de normatividade jurídica além do Estado, tal como a teoria institucionalista de Santi Romano, mencionada acima. Assim se passa porque os comandos restritivos dos direitos dos indivíduos devem ser necessariamente previstos em lei, cuja elaboração não pode ser objeto de delegação a entidades privadas (CF/88, art. 5, inc. II, e art. 44).

\subsubsection{Os atos normativos derivados}

A possibilidade de delegação do exercício de poder normativo restringe-se aos atos normativos derivados.

Ao se analisar o possível exercício de atividade normativa por particulares, interessam os atos normativos passíveis de modificar a situação jurídica de terceiros independentemente do seu consentimento. Para os fins do presente estudo, adota-se como conceito de ato normativo derivado como sendo ato unilateral, geral e executório, praticados com fundamento na lei ${ }^{746}$. São atos dotados de normatividade, no sentido de se aplicarem de forma generalizada, impessoal e abstrata.

\footnotetext{
744 Nos limites do presente estudo, não se fará a análise do significado do princípio da legalidade administrativa, questão que ainda desperta intensos debates doutrinários.

${ }^{745}$ Para Tercio Sampaio Ferraz Jr., a juridicidade da norma está vinculada ao grau de institucionalização da relação existente entre emissor e receptor da mensagem. Mais especificamente, depende da institucionalização da autoridade do emissor da norma sobre o receptor, que é confirmada por terceiros. A institucionalização decorre de um consenso geral presumido no sentido da prevalência da norma. (Introdução ao estudo do direito, 1994, p. 108-115). O autor reconhece que a institucionalização de normas em grau elevado “depende da inserção delas em grandes sistemas disciplinares, em termos desta poderosa instituição chamada de Estado" (ob. cit., p. 111). Aplicando os ensinamentos do autor, parece-nos que, ainda que nem todas as normas jurídicas tenham que ser produzidas pelo Estado, a sua primazia, decorrente da institucionalização em grau mais elevado, dependeria do reconhecimento ou da validação pelo Estado.

${ }^{746}$ Não se alude especificamente ao conteúdo “inovador” passível ou não de constar de ato regulamentar em face das previsões legais diante da grande controvérsia doutrinária acerca do tema, cujo exame extrapola os limites do presente estudo. Como constata José dos Santos Carvalho Filho, ao expor suas conclusões: " $1^{\circ}$ ) é incontestável a diferença entre a lei e o regulamento sob o aspecto da hierarquia dos atos normativos; $2^{\circ}$ ) nem
} 
Para Diogo de Figueiredo Moreira Neto, a normatividade derivada ou secundária seria passível de delegação, mediante previsão legal ${ }^{747}$. Esse seria o caso, por exemplo, dos conselhos profissionais no Brasil, aos quais a lei conferiu autonomia para elaborarem seus estatutos dispondo sobre sua organização, estrutura e funcionamento.

\subsubsection{Ausência de delegação legislativa}

O exercício de poder normativo pela Administração não consiste em delegação de poder legislativo. Aplica-se, ao caso, a diferenciação existente entre atividade normativa originária e derivada, que envolvem o exercício de poderes distintos.

Logo, a produção de atos normativos derivados não é equiparada à delegação legislativa prevista no art. 68 da CF/88. Também não se trata de poder de legislar que a Constituição atribui ao Executivo em determinadas hipóteses, autorizando-o a editar normas com força de lei (tal como a medida provisória).

Na delegação legislativa “própria”, expressamente prevista no texto constitucional, o exercício da competência legislativa é objeto de delegação ao Executivo. Essa delegação é necessariamente parcial e limitada, transferindo-se apenas esses poderes específicos para o Executivo editar a lei delegada. Os atos produzidos pelo Executivo no exercício dessa delegação têm natureza legislativa.

A edição de atos normativos derivados não implica o exercício de poderes normativos amplos. Portanto, em relação à edição de atos normativos derivados, não se cogita de delegação de poder legislativo.

\subsubsection{Possibilidade de delegação de poder normativo derivado a entidades privadas}

Cabe assim analisar a possibilidade de delegação de poder normativo derivado a particulares.

Em Portugal, por exemplo, a lei processual administrativa admite expressamente a edição de normas administrativas por particulares ${ }^{748}$. Permite, assim, a edição por particulares de regulamentos administrativos que produzem efeitos sobre terceiros e se destinam a regular relações não fundadas no consenso e na livre adesão.

sempre é fácil distinguir o que deve constituir matéria de cada um desses atos” (Agências reguladoras e poder normativo, 2006, p. 77).

${ }^{747}$ Mutações do direito administrativo, 2001, p. 134.

748 Estatuto dos Tribunais Administrativos e Fiscais - ETAF, aprovado pela Lei no 13/02, art. 4": “ 1 Compete aos tribunais da jurisdição administrativa e fiscal a apreciação de litígios que tenham nomeadamente por objeto: (...) d) Fiscalização da legalidade das normas e demais atos jurídicos praticados por sujeitos privados, designadamente concessionários, no exercício de poderes administrativos”. 
No direito nacional, reputamos também ser possível a delegação de atividade infralegal.

É a atividade desempenhada pelo particular ao fixar os parâmetros técnicos ou normas de funcionamento ou de utilização do bem público que the foi concedido, por exemplo $^{749}$. Também consiste nessa atividade normativa derivada a disciplina, pelo concessionário, da fruição de determinada utilidade pública, tal como se encontra expressamente previsto em relação às concessões florestais ${ }^{750}$. Note-se que o exercício dessa atividade infralegal pode nem mesmo ser necessário no caso concreto, caso se opte pela exaustão da regulação na esfera legislativa.

Trata-se de atividade de caráter secundário ou derivada, no sentido de se tratar de atribuição permitida pela lei e conferida pelo contrato. Porém, o caráter não originário não retira a caracterização da atividade de edição de normas derivadas como sendo o exercício de poder normativo ${ }^{751}$.

Note-se que apenas nos casos em que houver expressa delegação de atividade infralegal é que haverá o exercício de poder normativo derivado por particulares. Há mecanismos de atribuição de efeitos públicos a normas produzidas por particulares, que são analisados adiante. Porém, reputamos que a juridicidade eventualmente atribuída a normas de origem privada que não foram produzidas a partir de delegação expressa de poder normativo derivado não decorre da transferência do exercício de poderes públicos a particulares e sim de um ato estatal posterior que reconhece e valida a norma de origem privada, conferindo-lhe obrigatoriedade.

\subsubsection{Necessidade de estabelecimento de padrões mínimos para o exercício da atividade normativa delegada}

O exercício da atividade normativa derivada não poderá ser delegado de forma aberta e ampla. Não é viável atribuir ao delegatário o exercício amplo do poder normativo derivado. Isso implicaria verdadeira renúncia ao exercício de tal poder pelo Executivo, abdicando da sua competência. A delegação do exercício do poder normativo derivado não poderá implicar renúncia ao poder-dever de regulamentar, atribuído ao Poder Executivo.

O poder público não poderá evadir-se da sua responsabilidade pela atividade normativa atribuindo-a a entidades privadas. O delegante não poderá dar um “cheque em

\footnotetext{
${ }^{749}$ Floriano de Azevedo Marques Neto. A concessão como instituto do direito administrativo, 2013, p. 566567. O autor posiciona-se pela possibilidade de delegação de atividade infralegal (ob. e loc. cit.).

${ }^{750}$ Lei $\mathrm{n}^{\circ} 11.284 / 06$, art. 31, inc. V.

${ }^{751}$ Luigi Ferri. La autonomía privada, 2001, p. 45.
} 
branco"752 para o exercício da competência normativa pelo delegatário. Devem ser estabelecidos standards, padrões mínimos para orientar e delimitar o exercício da atribuição, bem como fixadas as matérias sobre as quais poderá versar. Por isso, diz-se que o poder regulamentar que pode ser atribuído a particulares é um poder limitado ${ }^{753}$.

Além da fixação de parâmetros mínimos a serem observados, o poder público deverá preservar a sua prerrogativa de exercer o poder regulamentar, com a possibilidade de reverter a delegação e controlar o seu exercício pelo delegatário. É conveniente que o emprego desses mecanismos esteja previsto no ato ou contrato que contemplar a delegação ${ }^{754}$.

7.5.5. $\underline{\text { A atribuição }} \underline{\text { de efeitos jurídicos a normas privadas }}$

Um dos principais vetores do surgimento de normas privadas é a incapacidade de o direito regular todas as áreas da sociedade. A produção de normas de conteúdo técnico assume grande relevância no contexto da sociedade industrial e de risco, em que se procura conjugar a vida industrial com a segurança e a proteção de bens jurídicos mediante a regulação técnica das atividades.

A problemática do exercício privado de competências normativas pode se apresentar especialmente no que diz respeito aos denominados organismos de normatização. Examinaremos mais detidamente a produção normativa privada no que diz respeito aos denominados documentos normativos, por se tratar da atividade que tem assumido maior relevância e ainda desperta controvérsias acerca da sua natureza jurídica.

\footnotetext{
${ }^{752}$ A expressão é usualmente utilizada ao se analisar o exercício do poder normativo pelo Executivo, nos espaços conferidos pelo Legislativo, para se referir à circunstância de que o legislador não pode renunciar ao estabelecimento das regras de direito de caráter primário, necessárias para a fixação das balizas a serem observadas pela atividade normativa secundária. Estas mesmas diretrizes aplicam-se à delegação do exercício do poder normativo derivado a entidades privadas.

753 "Da Constituição resulta claramente o princípio de que o exercício de poderes de autoridade (onde se inclui o poder regulamentar) cabe a pessoas coletivas públicas; em consequência da excepcionalidade que singulariza a atribuição de poderes de autoridade a entidades privadas, estas deverão ser titulares um poder regulamentar limitado e legalmente individualizado (e não um poder regulamentar 'normal'), sob pena de se subverter, em termos normativos, aquele princípio em todas as áreas do exercício privado de funções públicas” (Ana Raquel Gonçalves Moniz. A delegação administrativa do poder regulamentar em entidades privadas, 2010, p. 235).

${ }^{754}$ Assim se passa porque a avocação dessa competência pelo delegante apenas pode ocorrer nos limites previstos nas disposições legais e contratuais aplicáveis ou com a extinção da relação de delegação. Por isso, a avocação da competência não significa necessariamente a extinção do contrato em si. A exclusão da delegação do exercício de poder normativo (ou de outros poderes públicos) implicará a extinção do próprio contrato se essa delegação for essencial para a execução do objeto principal do contrato.
} 


\subsubsection{A atividade de normatização}

A industrialização, a produção em série e a intensificação da comercialização de mercadorias demandaram a criação de organismos de normalização. Em princípio, existem dois grandes grupos de atividades de normatização.

Há aquele em que a atividade é desempenhada por entes públicos, que editam normas técnicas de caráter coercitivo.

A função de normatização no âmbito do próprio Estado é desenvolvida especialmente pelas agências reguladoras independentes no Brasil e pelas entidades similares instituídas em outros países. Essas entidades foram criadas para a regulação setorial da economia com independência, mediante a intervenção de técnicos especializados. As normas produzidas por tais entidades consistem em normas jurídicas de conteúdo técnico, em relação às quais não há necessidade de maiores digressões no que diz respeito ao exercício de poder normativo no âmbito do presente estudo ${ }^{755}$.

O outro grupo de atividades de normatização consiste na elaboração de normas técnicas por entidades privadas.

As normas técnicas produzidas no exercício de atividade privada, sem delegação estatal, não são vinculantes por si sós. Elas adquirem relevância social pelo consenso e não pela obrigatoriedade da sua observância ${ }^{756}$. O cumprimento das disposições previstas nas normas técnicas implica uma presunção ${ }^{757}$ de regularidade do produto ou serviço $^{758}$.

Em princípio, cabe a entidades privadas a elaboração de normas técnicas de caráter consensual e o desenvolvimento de mecanismos próprios para garantir a observância de tais normas. Essas atividades são desempenhadas com a utilização dos instrumentos próprios de direito privado, em mecanismos de autorregulação.

\footnotetext{
${ }^{755}$ Isso não significa que o tema do exercício do poder normativo pelas agências reguladoras seja pacífico. Há diversas obras que analisaram amplamente os diversos aspectos do debate. Podem ser consultadas, entre outras: Alexandre Santos de Aragão (Coord.). O poder normativo das agências reguladoras, 2006; Maria Sylvia Zanella Di Pietro (Org.). Direito regulatório, 2003; Marçal Justen Filho. O direito das agências reguladoras independentes, 2002; Leila Cuéllar. As agências reguladoras e seu poder normativo, 2001.

756 “As Normas Técnicas tendem a ser obrigatórias, na medida em que a experiência confirma sua utilidade; elas se consagram na medida da sua utilidade e da conscientização coletiva da sua necessidade" (Thomaz Marcello d'Avila, A normalização técnica e o direito, 1990, p. 365).

${ }^{757}$ Presunção esta que é relativa, sujeita a prova em sentido contrário.

758 "A bem da verdade, não existe, em termos jurídicos, norma inteiramente facultativa, pois mesmo aquelas assim denominadas podem ser utilizadas pelo administrador e pelo magistrado no julgamento da adequação técnica do comportamento do fornecedor. Se é certo que a norma dita facultativa indica uma meta a ser alcançada, nem por isso deixa de afirmar um patamar de qualidade que, no estado da arte do momento, é considerado alcançável e adequado. Negar-se o fornecedor a acompanhar e acolher aquilo que é tecnicamente viável ou até praticado, de forma cotidiana, em outros países constitui forte indício de abusividade de sua conduta” (Ada Pellegrini Grinover. Código de defesa do consumidor comentado pelos autores do anteprojeto, 2005, p. 377).
} 
No entanto, essas normas de origem privada podem vir a ser objeto de apropriação estatal. Foram desenvolvidos instrumentos para a introdução dessas normas técnicas no sistema jurídico. Essa atuação privada pode ir além da colaboração, implicando até mesmo a substituição de normas públicas por normas de origem privada. Isso se insere no contexto de regulação pública que leva em consideração elementos de autorregulação, pelos mecanismos que serão analisados adiante.

\subsubsection{Os documentos normativos}

No direito nacional, “documento normativo” é um termo genérico utilizado para designar normas, especificações técnicas, códigos de prática e regulamentos. O seu conteúdo, de caráter técnico, são regras, diretrizes ou características para atividades ou seus resultados $^{759}$.

É relevante diferenciar especialmente as normas dos regulamentos, por serem dotados de eficácia distinta.

As normas, para fins do Sistema Brasileiro de Normalização, encontram-se definidas no anexo à Resolução nº 6, de 2.12.2002, do CONMETRO. A definição de norma apresentada no item 3.1. é a seguinte: “documento, estabelecido por consenso e aprovado por um organismo reconhecido, que fornece, para uso comum e repetitivo, regras, diretrizes ou características para atividades ou seus resultados, visando à obtenção de um grau ótimo de ordenação em um dado contexto". Em seguida, registra-se que, "no âmbito do SINMETRO, norma é considerada de caráter voluntário”.

Já o regulamento consiste no "documento que contém regras de caráter obrigatório e que é adotado por uma autoridade"760. O regulamento pode estipular requisitos técnicos diretamente ou mediante a incorporação do conteúdo de uma norma, especificação técnica ou código de prática.

Portanto, as normas técnicas têm caráter voluntário. Em princípio, não há obrigatoriedade de sua observância nem de submissão às inspeções ou obtenção de certificações previstas nas normas. No direito nacional, apenas os regulamentos técnicos são de observância compulsória. No entanto, as normas podem ser dotadas de obrigatoriedade na hipótese de assim ser previsto em lei ou se a norma for objeto de expressa referência em um regulamento.

No direito comunitário europeu, emprega-se o termo "norma técnica” para se referir à produção normativa técnica de entidades privadas. A locução “norma técnica”

\footnotetext{
${ }^{759}$ Anexo à Resolução n ${ }^{\circ}$ 6, de 2.12.2002, do CONMETRO, item 3.6.

${ }^{760}$ Anexo à Resolução n ${ }^{\circ}$ 6, de 2.12.2002, do CONMETRO, item 3.3.
} 
designa exclusivamente as normas produzidas por entidades privadas de normatização ${ }^{761}$. Normas privadas produzidas por outras entidades não poderão receber essa denominação ${ }^{762}$. Em alguns sistemas jurídicos, tal como o espanhol, em muitos casos tais normas técnicas são incorporadas pelo ordenamento jurídico e passam a ser de observância obrigatória.

\subsubsection{A produção de normas técnicas no ambiente de autorregulação}

As normas técnicas são usualmente produzidas em contexto de autorregulação. A possível relação existente entre a autorregulação e o exercício privado de atividades de polícia administrativa foi analisada acima ${ }^{763}$. No momento, cabe pontuar a conexão que pode existir entre a atividade de autorregulação e o poder normativo estatal.

A regulação estatal desenvolve-se em ambiente de heterroregulação, por se tratar de regulação proveniente do Estado a incidir sobre os agentes privados. Há diferenciação entre reguladores e regulados. Já na autorregulação, há identidade entre os que produzem a regulação e os que a ela se submetem.

Utilizando-nos da diferenciação apresentada por Marcos Juruena Villela Souto, a regulação seria um efeito econômico e a regulamentação teria natureza jurídica ${ }^{764}$. A regulação, em sentido amplo, desenvolve-se nos diversos ambientes sociais mas apenas passa a integrar o sistema jurídico quando já é produzida nesse sistema ou quando o direito reconhece e recepciona essas normas. A partir desse momento, pode-se identificar a possibilidade de serem atribuídos efeitos de regulamentação ao produto da autorregulação.

Uma das principais manifestações de consideração de elementos de autorregulação pela regulação estatal consiste na assunção pelo Estado de determinadas normas elaboradas por segmentos da sociedade. Há a integração da autorregulação na regulação estatal. Apesar de não terem sido elaboradas por instâncias democráticas, essas normas acabam produzindo efeitos que extrapolam a esfera dos sujeitos autorregulados e são vinculantes para todos os envolvidos na atividade regulada.

\footnotetext{
${ }^{761} \mathrm{O}$ artigo $1^{\circ}$, item 6, da Diretiva 98/34/CE, de 22.6.1998, define norma como sendo “a especificação técnica aprovada por um organismo reconhecido com atividade normativa para aplicação repetida ou contínua, cujo cumprimento não é obrigatório”.

${ }^{762}$ Foi o que decidiu o Tribunal Supremo Espanhol nas sentenças de 5 de abril de 1999 (Ar. 3847) e de 2 de junho de 2003 (Ar. 6090).

${ }_{763}$ V. item II.4.

${ }^{764}$ Direito administrativo regulatório, 2002, p. 43. Isso não significa que a regulação teria efeitos apenas econômicos. Há evidentes finalidades sociais e de interesse comum que são perseguidas com o emprego da regulação econômica. Nas palavras de Marçal Justen Filho, "a ideia de um Estado Regulador não envolve abraçar concepções economicamente reducionistas. Se a ideia de regulação se desenvolveu nesse âmbito, a tanto não pode ser limitada. As finalidades regulatórias relacionam-se à realização dos valores fundamentais consagrados pela Nação, sejam eles de natureza econômica ou não" ( $O$ direito das agências reguladoras independentes, 2002, p. 40).
} 


\subsubsection{A organização dos ordenamentos da técnica}

A tendência é de se verificar uma diversidade de grupos e associações que participam da elaboração de documentos normativos, em sistema de autorregulação ${ }^{765}$.

A voluntariedade que caracteriza originalmente esses documentos propicia a coexistência de normas conflitantes entre si. Mas a impossibilidade de convivência de várias normas sobre um mesmo tema, dispondo de modo diverso, conduziu à necessidade de organização de um ordenamento da técnica. Deve prevalecer uma das normas regulando determinado objeto, ainda que esteja sujeita à correção ou emenda por outra norma técnica.

Para a formação do ordenamento da técnica, com a organização e instituição de processos normativos, faz-se necessária a institucionalização de critérios de recepção das normas privadas pelo Estado.

Alguns sustentam que a regulação da técnica adquiriu tal autonomia frente ao direito e ao Estado que permite falar-se em ordenamento da técnica ${ }^{766}$. A relação entre direito e técnica seria uma relação entre ordenamentos, na forma proposta pela teoria institucional de Santi Romano. Uma das consequências do reconhecimento de que a técnica seria um ordenamento jurídico consistiria na aceitação da limitação da soberania estatal frente às normas editadas pelas organizações e corporações supranacionais.

$\mathrm{Na}$ concepção monista do direito, de monopólio jurídico do Estado, as normas técnicas carecem de natureza jurídica. As associações que as produzem não detêm poder para editar normas cujas disposições sejam de observância obrigatória ou cujo cumprimento possa ser exigido dos destinatários. O Estado detém o monopólio da produção jurídica, o que impede o reconhecimento da natureza jurídica de normas produzidas por instituições privadas, que não tenham sido editadas no exercício de poder delegado ou recebidas pelo sistema jurídico.

\footnotetext{
${ }^{765}$ Marc Tarrés Vives apresenta um apanhado histórico detalhado da normatização. Identifica como sendo o exemplo mais significativo da regulação social da técnica os grêmios da Idade Média. As ordenanças gremiais não deixam de representar um verdadeiro exemplo de autorregulação social. Os estatutos disciplinavam o exercício dos ofícios bem como estabeleciam um conjunto de valores religiosos. Além de regular o acesso à profissão, as normas dos grêmios preocupavam-se em assegurar que os produtos gozassem de boa reputação, estabelecendo padrões mínimos de qualidade - o que pode ser identificado como um antecedente da atividade de certificação. Com a Revolução industrial e o absolutismo, os grêmios foram substituídos pelas academias, que eram totalmente institucionalizadas e sujeitas aos interesses do Estado. A função normativa passou a ser exercida pelo Estado, única instância legitimada para a produção da regulamentação. Esse foi o cenário em países como a França e a Espanha. O modelo inglês de revolução industrial preservou a autorregulação e o autocontrole da técnica, desenvolvidas exclusivamente na esfera privada. Na Alemanha, desenvolveu-se um modelo intermediário, da regulação privada com efeitos públicos. Os particulares que desempenhavam essas funções recebiam uma habilitação do Estado (Belehiung) (Normas técnicas y ordenamiento jurídico, 2003, p. 35-112).

${ }^{766}$ Marc Tarrés Vives. Normas técnicas y ordenamiento jurídico, 2003, p. 230.
} 


\subsubsection{A recepção das normas privadas pelo Estado}

Foram desenvolvidos mecanismos para que as normas técnicas, que foram produzidas na esfera estritamente privada, sejam trazidas para o ambiente da regulação jurídica.

Trata-se de incorporação ou remissão, por normas jurídicas, ao conteúdo de normas editadas por entidades privadas, atribuindo-lhes validade e eficácia jurídica. As normas privadas são incorporadas à esfera pública, submetendo-se às mesmas regras de vigência, modificação e derrogação das normas jurídicas. Aplicam-se estas técnicas aos casos em que as normas não foram produzidas mediante delegação de poder normativo estatal.

A questão foi objeto de grande interesse nos países comunitários europeus, diante da política de harmonização técnica. Ao se adaptarem às diretrizes comunitárias, as normas nacionais deixaram de conter amplas prescrições técnicas para se limitar à previsão de cláusulas gerais, que remetem a normas técnicas privadas.

Os principais meios de integração de normas técnicas de origem privada nos ordenamentos estatais são: (a) incorporação, na qual o legislador reproduz o conteúdo da norma técnica na norma jurídica editada; e (b) reenvio, em que o legislador determina a observância de normas técnicas sem transcrever o seu conteúdo.

A incorporação não apresenta desafios significativos para a sua aceitação. À medida que todo o conteúdo da norma técnica que foi recepcionado pelo sistema jurídico encontra-se expressamente transcrito na norma jurídica, não há dúvidas acerca do teor da referida norma. Há a expressa identificação do conteúdo técnico ao qual foi atribuída eficácia jurídica.

Já as técnicas de reenvio, pela ausência de definição tão precisa do conteúdo técnico na norma jurídica, propiciam algumas controvérsias.

Podem ser identificados mecanismos de reenvio direto e indireto a normas técnicas ${ }^{767}$.

Há dois tipos de técnica de reenvio direto: (a) reenvio material ou receptício e (b) reenvio formal ou remissão.

No primeiro, a norma reenviada passa a integrar a norma que a ela se refere tal como se fosse uma só norma. É considerado reenvio estático ou nominado, porque abrange apenas uma dada versão da norma técnica, não adotando alterações posteriores do

\footnotetext{
${ }^{767}$ Marc Tarrés Vives. Normas técnicas y ordenamiento jurídico, 2003, p. 254-276.
} 
conteúdo da norma reenviada. As alterações supervenientes da norma técnica não integrarão automaticamente a norma jurídica.

Já no reenvio formal, a remissão é a uma norma já existente e é feito de forma a assumir não apenas o seu conteúdo atual mas também o conteúdo que possa vir a ter no futuro. Trata-se de reenvio dinâmico. Esse reenvio pode ser completamente aberto, aceitando o conteúdo posterior da norma técnica seja qual for, ou pode estabelecer alguns requisitos gerais, a serem concretizados pelas normas técnicas para que seja mantido o reenvio.

O reenvio material contém elementos que facilitam o reconhecimento da legitimidade dessa técnica ${ }^{768}$. O conteúdo da norma incorporada já se encontra previamente definido e é de conhecimento do legislador. Porém, não assegura a atualidade da norma jurídica diante da possível obsolescência da norma técnica reenviada. Outro problema seria a ausência de publicação integral da norma técnica em veículo de publicidade oficial, o que não é incomum em se tratando de norma técnica. A norma jurídica faria referência apenas aos dados de identificação da norma técnica, tais como número e título ${ }^{769}$.

No reenvio dinâmico, há a vantagem da atualização constante do conteúdo da norma técnica incorporada à norma jurídica. Porém, isso dá ensejo a questionamentos mais significativos quanto à validade jurídica desse mecanismo. O principal óbice estaria no fato de que o ordenamento jurídico deixa de ter o domínio sobre a norma incorporada.

Em razão disso, o reenvio dinâmico pode até mesmo ser caracterizado como uma espécie de delegação fática de competência normativa a um ente privado, ao autorizarlhe, em última instância, a alteração do conteúdo de uma lei ${ }^{770}$.

Além disso, há o reenvio indireto, que é a remissão mediante a previsão de cláusulas gerais na norma jurídica.

\footnotetext{
${ }^{768}$ A esse respeito, há sentença do Tribunal Supremo espanhol, de 14.6.2001 (Ar. 435/2002), que admitiu a remissão pela lei a regulamentos técnicos, determinando a sua observância obrigatória, considerando especialmente tratar-se de envio estático, pois consistiria em simples substituição da transcrição integral e literal do conteúdo da norma técnica na norma jurídica.

${ }_{769}$ A ausência de publicação integral da norma técnica poderia configurar infração ao princípio da publicidade. Mas esse parece não ser o problema jurídico mais relevante envolvido no caso. Ainda que não sejam publicadas na íntegra, as normas técnicas devem ser de livre acesso ao público, ainda que mediante o pagamento do custo das cópias.

${ }_{770}$ Esse risco de perda do controle do conteúdo da norma legal pode ser reduzido com previsões tais como a que consta do Regulamento da Infraestrutura para a Qualidade e a Segurança Industrial - RICSI do direito espanhol (Real Decreto no 2200/1995), no artigo 11, "h", no sentido de que os organismos de normalização devem comunicar a Administração do início do processo de revisão ou anulação de normas técnicas. A Administração poderia intervir ou não nesses trabalhos e, diante do resultado final, decidir pela manutenção ou não da remissão.
} 
No reenvio indireto, não há remissão expressa à norma técnica. Estipula-se uma cláusula técnica, que se reporta genericamente ao estado da técnica e aos conhecimentos científicos mediante o emprego de conceitos jurídicos indeterminados - tais como "melhor técnica disponível” ou "estado da técnica" -, que consistem na denominada “cláusula técnica”771. Para a concreção desse conceito, pode-se recorrer ao conteúdo de normas técnicas, mas elas não são vinculantes. O conteúdo da norma jurídica acaba sendo determinado por aquele que é responsável por sua aplicação, mediante a adoção dos critérios admitidos para a concretização de conceitos jurídicos indeterminados.

\subsubsection{A natureza da atividade desempenhada pelas entidades privadas na produção de normas técnicas}

Diante disso, é necessário investigar a natureza pública ou privada da atividade desempenhada pelos organismos de normatização. Trata-se de analisar se, na produção de normas técnicas que são objeto de posterior recepção e apropriação pelo Estado, essas entidades encontram-se no exercício de poder normativo estatal.

Parcela da doutrina reputa que a assunção pública de normas técnicas privadas consiste na delegação de poder normativo. Sustentam que a validade dessa delegação dependeria de autorização expressa do legislador. Na ausência da referida autorização, a remissão de regulamentos ao conteúdo de normas técnicas seria ilegal ${ }^{772}$.

Para outros, não se trata de exercício privado de poder normativo. Assim se passa porque a atividade desenvolvida propriamente pelas entidades privadas é de caráter voluntário. O elemento obrigatoriedade em relação às normas por elas produzidas surge apenas após a intervenção do Estado, mediante o emprego das técnicas de reenvio ${ }^{773}$.

Como já se indicou, reputamos que a produção normativa privada, na ausência de delegação formal de poder normativo estatal, não implica o exercício de poderes públicos por entidades privadas. Com o reenvio, o Estado atribui valor jurídico às normas produzidas por entidades privadas, no contexto de autorregulação, exercendo competências puramente privadas.

\footnotetext{
771 A cláusula técnica opera uma relação entre sistemas, o do direito e o da técnica. Vincula-se ao reconhecimento de que os sistemas elaboram referências que não são apenas de uso interno, podendo interagir com códigos e critérios de outros sistemas (José Esteve Pardo. Autorregulación, 2002, p. 89-91).

772 É o que sustenta, por exemplo, Juan Antonio Carrillo Donaire. Segundo o autor, a aplicação de mecanismos de reenvio a normas técnicas implica o exercício de função normativa por entidades privadas. Por isso, o autor questiona a legalidade e a legitimidade dessa prática "em face da concepção constitucional do poder regulamentar, a instrumentalização do princípio democrático e a irrenunciabilidade da competência administrativa” (Seguridad y calidad productiva, 2009, p. 113).

${ }^{773}$ Dolors Canals I Ametller. El ejercicio por particulares de funciones de autoridad, 2003, p. 89-90.
} 
No entanto, tanto a delegação de poderes normativos a particulares quanto a utilização de mecanismos de reenvio demandam cautelas na produção das normas técnicas.

Assim se passa porque uma questão subjacente à natureza da atividade desempenhada pelas entidades privadas na elaboração de normas técnicas é a da sua legitimidade.

\subsubsection{A legitimação da produção de normas técnicas por entidades privadas}

O desenvolvimento da técnica implica desafios para o Estado não apenas pela complexidade da sua regulação, que demanda a concorrência dos conhecimentos especializados da iniciativa privada, mas também por implicar um possível problema de legitimidade. Deixou de existir o monopólio do Estado na prevenção, controle e redução dos riscos.

Cabe averiguar se a legitimação pelo conhecimento especializado seria suficiente para justificar a recepção pelo sistema jurídico das normas produzidas no ambiente técnico. A questão que se coloca é o risco de existência de eventual conflito que possa ocorrer entre a legitimação dos especialistas para atuarem em campos extracientíficos ou extratécnicos e a ordem jurídica, que conta com a legitimação das instâncias democráticas.

Note-se que a constatação da inviabilidade de o Executivo e Legislativo controlarem todos os riscos em razão da complexidade técnica não seria uma razão suficiente para justificar a atribuição de efeitos jurídicos a normas privadas ${ }^{774}$. Afinal, não se trata de uma colaboração excepcional e sim da recepção de normas privadas de modo contínuo e sistematizado.

Portanto, a legitimidade da transferência de poderes não pode se apoiar na presumível autoridade técnica desses particulares. Reputamos ser necessária, em alguma medida, a legitimação democrática de tal processo, o que ocorre mediante a edição de lei autorizando a delegação de poder normativo derivado ou a atribuição de efeitos públicos a essas normas de origem privada ${ }^{775}$.

No entanto, a autorização legal para a edição de normas técnicas por entidades privadas, conferindo-lhes legitimidade jurídica, não é apta para resolver todo o possível problema de legitimidade dessas normas. Referimo-nos especificamente ao possível déficit democrático das entidades privadas de normatização. Em alguma medida,

\footnotetext{
774 Dolors Canals I Ametller. El ejercicio por particulares de funciones de autoridad, 2003, p. 75.

${ }^{775}$ Nesse sentido, Dolors Canals I Ametller. El ejercicio por particulares de funciones de autoridade, 2003, p. 75. Como afirma a autora, a legitimação das entidades privadas, em princípio, é apenas técnica e não jurídica, a não ser que a lei lhes confira esta legitimação expressamente (ob. cit., p. 77-78).
} 
trata-se de problemática similar àquela que surgiu em torno da atividade normativa das agências reguladoras.

A questão está diretamente relacionada à concepção de que apenas o povo, diretamente ou por seus representantes, teria legitimidade para decidir e elaborar as normas sobre questões essenciais. Daí a afirmação de que o parlamento deteria o monopólio jurídico. As suas competências não poderiam ser simplesmente esvaziadas, com a ilimitada transferência de poder normativo a entidades não integradas por representantes eleitos pelo povo, sob pena de violação do princípio da democracia.

Deve, assim, ser observada a existência de uma reserva ao parlamento. Nas palavras de Marçal Justen Filho, “a Democracia exige a manutenção no parlamento e no governo das competências essenciais e mais relevantes, que envolvam a avaliação e determinação do destino do Estado e da Sociedade»776.

A competência decisória não pode ser transferida de forma ampla e ilimitada. Porém, isso não impede que sejam transferidos a outras entidades poderes de natureza secundária, limitados e condicionados.

Um argumento invocado para justificar a produção de normas por entidades não integradas por representantes escolhidos pela vontade popular é o caráter técnicocientífico dos critérios adotados para essa atividade normativa. Por isso, essa atividade técnica deveria permanecer afastada do ambiente de discussão política representado pelo parlamento.

A confirmação desse argumento apresenta diversas dificuldades. Em termos práticos, é bastante difícil isolar as decisões de critérios políticos de escolha, de modo que sejam considerados exclusivamente critérios técnicos. Pode se fazer necessária, por exemplo, a escolha entre diversos critérios técnicos disponíveis, decisão essa que possivelmente levará em consideração também determinados aspectos de oportunidade. Nem sempre a adoção de critérios técnico-científicos eliminará completamente qualquer margem de autonomia em relação à decisão a ser adotada ${ }^{777}$.

Portanto, a alegada legitimidade técnica não pode ser utilizada em substituição à legitimidade democrática. Dentro desse contexto, uma das possibilidades que se apresenta é o controle da produção normativa fora do parlamento, mediante a observância do devido processo.

\footnotetext{
${ }^{776}$ Agências reguladoras e democracia, 2006, p. 320.

777 A questão está relacionada com a discricionariedade técnica, sobre a qual já foram tecidas algumas ponderações anteriormente (v. item I.7.2).
} 
O processo administrativo deixou de ter o papel principal de instrumento para a composição de conflitos para viabilizar a efetiva participação dos interessados na atividade administrativa.

Um dos mecanismos utilizados para minimizar o déficit democrático na atuação das agências reguladoras consistiu na participação dos interessados no processo de elaboração de normas pelas agências ${ }^{778}$. A observância de um processo previamente definido reduz também o risco de prevalecerem concepções meramente subjetivas no processo de formação de vontade que antecede a tomada de decisão.

Trata-se da denominada legitimação pelo procedimento, com a efetiva participação dos interessados na elaboração de instrumentos normativos que possivelmente os afetarão ${ }^{779}$. A legitimação das normas decorreria não da sua vinculação à vontade popular e sim pelo modo como são produzidas.

A experiência brasileira das agências reguladoras evidencia os limites da tese da legitimação pelo procedimento. Os processos de audiência e consulta pública, na ampla maioria das vezes, não refletem uma efetiva democratização da atividade normativa. A participação acaba sendo restringida a um grupo seleto de interessados. E essa participação acaba se limitando à apresentação de colaborações ou contribuições espontâneas dos interessados, que serão posteriormente aproveitadas ou rejeitadas em processo desenvolvido exclusivamente no âmbito da agência.

De todo o modo, tanto a delegação de poderes normativos a particulares quanto a recepção de normas privadas de caráter técnico deverão ser acompanhadas de determinadas cautelas acerca do procedimento de edição de tais normas ${ }^{780}$. O controle a ser desenvolvido sobre o ato normativo produzido implicará a verificação não apenas do

\footnotetext{
${ }^{778}$ Egon Bockmann Moreira. Os limites à competência normativa das agências reguladoras, 2006, p. 191.

${ }^{779}$ O processo de produção de normas da ABNT retrata a participação de particulares em várias etapas. O processo poderá ser desencadeado por solicitação dos interessados em geral. O pedido tem a sua pertinência avaliada pela ABNT. Se for aceito, é submetido ao Comitê Técnico do setor, para inserção no Plano de Normalização Setorial da Comissão de Estudo relacionada ao tema. Se esta já não existir, é criada uma Comissão de Estudo especial. Cabe às Comissões de Estudo o debate do tema e a elaboração do projeto da norma. O referido projeto é submetido pela ABNT a consulta nacional, na qual é oportunizada a manifestação e apresentação de contribuições pelos interessados. Após a análise dos resultados da consulta nacional e das contribuições recebidas, se não houver alterações no projeto de norma, a Comissão de Estudo o encaminha para homologação pela ABNT, na qualidade de Foro Nacional de Normalização. Se forem realizadas modificações no projeto, ele deve ser submetido a nova consulta nacional (informações extraídas do sítio eletrônico da ABNT: http://www.abnt.org.br/m2.asp?cod_pagina=963\#, acesso em 14.9.2013.

${ }^{780}$ Luis Arroyo Jiménez enumera alguns princípios de organização e funcionamento das entidades de autorregulação que seriam necessários para assegurar a sua legitimidade democrática: (i) garantir que todos os interesses privados afetados tenham possibilidades reais de ter acesso à estrutura de regulação; (ii) garantir que os titulares de todos os interesses privados tenham razoável capacidade de tutelá-los, impondo-os frente aos outros em condições equitativas; (iii) garantir que os procedimentos de tomada de decisão e o regime de funcionamento satisfaçam os critérios de transparência e visibilidade, que são pressupostos essenciais dos processos de controle e de prestação de contas (Introducción a la autorregulación, 2008, p. 34-35).
} 
conteúdo do próprio ato mas também do seu processo de produção, para se aferir se foi devidamente oportunizada a participação dos potenciais interessados e se houve a efetiva consideração e debate das possíveis contribuições apresentadas ${ }^{781}$.

Aplicam-se, em linhas gerais, os requisitos do regime jurídico do exercício privado de atividades de polícia administrativa expostos no Capítulo IV. O diferencial nesse caso é que se faz necessário assegurar determinadas garantias no processo de elaboração de normas não apenas quando isso se faz mediante delegação do poder público mas também quando se trata de atividade desenvolvida inicialmente na esfera estritamente privada, cujos resultados são objeto de posterior recepção pelo poder público.

\subsubsection{A produção de normas técnicas no direito nacional}

O Sistema Nacional de Metrologia, Normalização e Qualidade Industrial (SINMETRO) foi instituído pela Lei n 5.966/73, com a finalidade de "formular e executar a política nacional de metrologia, normalização industrial e certificação de qualidade de produtos industriais” (art. $1^{\circ}$ ). O referido sistema é integrado por entidades públicas e privadas que exercem atividades de metrologia, normalização industrial e certificação de qualidade de produtos industriais.

O CONMETRO ${ }^{782}$ consiste no órgão normativo do SINMETRO. Competelhe a formulação da política nacional do setor bem como o estabelecimento de normas, procedimentos e critérios para a uniformização e racionalização de processos e serviços.

O CONMETRO poderá atribuir parcela das suas atribuições ao INMETRO, que é o órgão executivo do SINMETRO. O INMETRO é uma autarquia vinculada ao Ministério do Desenvolvimento, Indústria e Comércio Exterior. O INMETRO exerce o poder de polícia no setor bem como é responsável pela edição de regulamentos técnicos de diversas áreas.

A obrigatoriedade de observância das previsões legais e dos atos normativos expedidos pelo CONMETRO e pelo INMETRO, inclusive regulamentos técnicos e administrativos, atinge todos os agentes, público e privados, que atuam nas diversas etapas da cadeia produtiva de bens e serviços e consta expressamente do art. $5^{0}$ da Lei $n^{0}$ $9.933 / 99^{783}$.

\footnotetext{
781, Flávio Henrique Unes Pereira. Regulação, fiscalização e sanção, 2013, p. 147.

${ }^{782}$ O CONMETRO é um órgão colegiado que integra a estrutura do Ministério do Desenvolvimento, Indústria e Comércio Exterior (Lei n ${ }^{\circ} 9.933 / 99$, art. $2^{\circ}$ ).

${ }^{783}$ A jurisprudência reconhece a obrigatoriedade de observância das normas técnicas produzidas pelo CONMETRO e o INMETRO. Como já decidiu o STJ: “(...) 2. Estão revestidas de legalidade as normas expedidas pelo CONMETRO e INMETRO, e suas respectivas infrações, com o objetivo de regulamentar a qualidade industrial e a conformidade de produtos colocados no mercado de consumo, seja porque estão esses
} 
A Associação Brasileira de Normas Técnicas foi designada como Foro Nacional de Normalização ${ }^{784}$. A ABNT é uma entidade privada, constituída na forma de associação civil sem fins lucrativos. O seu quadro social é integrado por "pessoas físicas e jurídicas, ligadas direta ou indiretamente à causa da normalização"785.

Cabe à ABNT tanto a elaboração e edição de normas técnicas bem como a coordenação, orientação e supervisão da elaboração de normas por outros entes. Essas atribuições foram repassadas à ABNT mediante a celebração de "termo de compromisso" com o governo brasileiro ${ }^{786}$.

Portanto, as normas técnicas são produzidas em sistema de autorregulação, especialmente pela ABNT. Essas normas técnicas são, em princípio, de observância facultativa.

Já a elaboração de regulamentos técnicos é da competência do CONMETRO. Aos regulamentos foi atribuída a característica da obrigatoriedade pela Lei $n^{\circ}$ 9.933/99, art. $1^{\circ}$. No entanto, os regulamentos não são propriamente independentes das normas produzidas pela ABNT. Os referidos regulamentos “deverão considerar, quando couber, o conteúdo das normas técnicas adotadas pela Associação Brasileira de Normas Técnicas” (Lei ${ }^{\circ}$ 9.933/99, art. $2^{\circ}$, §2º ). Logo, os regulamentos poderão adotar as técnicas de reenvio em relação às normas técnicas, tornando o seu conteúdo vinculante.

Vale registrar que o Código de Defesa do Consumidor determina aos fornecedores de produtos ou serviços a obrigatoriedade de observância das normas expedidas pela $\mathrm{ABNT}^{787}$. Porém, reputamos que, nesse caso, não se tornou obrigatória a observância de todas as normas produzidas pela ABNT mas apenas daquelas que já eram de uso compulsório ${ }^{788}$.

órgãos dotados da competência legal atribuída pelas Leis 5.966/1973 e 9.933/1999, seja porque seus atos tratam de interesse público e agregam proteção aos consumidores finais. Precedentes do STJ. (...) 4. Recurso especial conhecido e provido. Acórdão sujeito às disposições previstas no art. 543-C do CPC e na Resolução

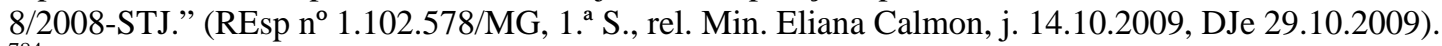

${ }^{784}$ CONMETRO, Resolução n ${ }^{\circ}$ 7, de 24.8.1992.

${ }^{785}$ Art. $3^{\circ}$ do Estatuto social, disponível em http://www.abnt.org.br/IMAGENS/Estatuto.pdf, acesso em 14.2.2014.

${ }^{786}$ O referido "termo de compromisso" consta como anexo da Resolução CONMETRO/No 07/92, publicado no D.O.U. de 27/ 08 /92- Seção 1- página 11728.

${ }^{787}$ Lei no 8.078/90, art. 39: "É vedado ao fornecedor de produtos ou serviços, dentre outras práticas abusivas: (...)VIII - colocar, no mercado de consumo, qualquer produto ou serviço em desacordo com as normas expedidas pelos órgãos oficiais competentes ou, se normas específicas não existirem, pela Associação Brasileira de Normas Técnicas ou outra entidade credenciada pelo Conselho Nacional de Metrologia, Normalização e Qualidade Industrial (Conmetro)".

${ }^{788}$ Nesse sentido é o comentário de Antônio Herman de Vasconcellos e Benjamin ao art. 39 do CDC (Ada Pellegrini Grinover e outros. Código de defesa do consumidor comentado pelos autores do anteprojeto, 2005, p. 373). 
À medida que o dispositivo legal não foi específico em relação às "normas técnicas”, reportando-se em termos mais genéricos às “normas expedidas pelos órgãos oficiais competentes”, entre eles a ABNT, reputamos que a disposição aplica-se apenas às normas técnicas da ABNT que são de observância obrigatória, quais sejam, aquelas que foram aprovadas pelo CONMETRO ${ }^{789}$.

As normas produzidas pela ABNT foram objeto de expressa recepção também em relação às contratações do governo federal. A Lei no 4.150/62 determina ser de observância obrigatória as normas técnicas produzidas pela ABNT nos serviços públicos federais e nos contratos de obras, serviços e compras dos entes da Administração federal direta e indireta ${ }^{790}$. Também nesse caso reputamos que o dispositivo legal não alterou o sistema nacional de normalização, aplicando-se apenas às normas obrigatórias.

Há precedentes do TCU que reputam que a comprovação de cumprimento de normas da ABNT que pode ser exigida para fins de licitação não atinge todas as normas aplicáveis ao objeto licitado mas apenas “aquelas de natureza procedimental, cujo objetivo seja o detalhamento das etapas a serem seguidas na execução de obras e serviços de

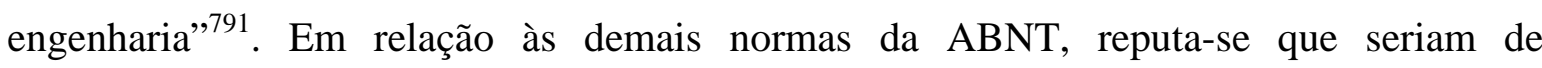
cumprimento facultativo. Caso o administrador pretenda exigir o seu cumprimento, a decisão deverá ser fundamentada com a demonstração da necessidade de se assegurar a observância dessas normas no caso concreto.

\subsection{A atividade de fiscalização}

Integra também o ciclo das atividades de polícia administrativa a fiscalização do cumprimento das normas de polícia.

\footnotetext{
789 As normas técnicas produzidas pela ABNT classificam-se em quatro níveis: NBR 1 - normas compulsórias, aprovadas pelo CONMETRO, de uso obrigatório; NBR 2 - normas referenciais, aprovadas pelo CONMETRO e de uso obrigatório pelo poder público e serviços públicos delegados; NBR 3 - normas de caráter voluntário, registradas pelo INMETRO; e NBR 4 - normas probatórias, registradas no INMETRO, em fase experimental e de vigência limitada. As normas de observância obrigatória são apenas a NBR 1 e a NBR 2. A existência de normas tais como as o tipo NBR 4, as normas probatórias, registradas em fase experimental e de vigência limitada, evidenciam não ser razoável supor-se que a disposição do art. 39 do CDC tornou compulsória a aplicação de todas as normas da ABNT, mesmo daquelas que não dispõem de caráter obrigatório originariamente.

${ }^{790}$ A redação do art. $1^{\circ}$ da Lei no ${ }^{\circ} .150 / 62$ é a seguinte: "Nos serviços públicos concedidos pelo Governo Federal, assim como nos de natureza estadual e municipal por ele subvencionados ou executados em regime de convênio, nas obras e serviços executados, dirigidos ou fiscalizados por quaisquer repartições federais ou órgãos paraestatais, em todas as compras de materiais por eles feitas, bem como nos respectivos editais de concorrência, contratos ajustes e pedidos de preços será obrigatória a exigência e aplicação dos requisitos mínimos de qualidade, utilidade, resistência e segurança usualmente chamados "normas técnicas" e elaboradas pela Associação Brasileira de Normas Técnicas, nesta lei mencionada pela sua sigla 'ABNT'”.

${ }^{791}$ Processo $n^{\circ}$ 017.812/2006-0; Acórdão nº 2392/2006 - Plenário; Rel. Min. Benjamin Zymler, DOU 13.12.2006.
} 


\subsubsection{A fiscalização das normas de polícia}

A fiscalização do respeito às normas de polícia verifica a regularidade da sua observância e do exercício dos direitos pelos administrados, tanto no sentido de não se estar praticando um comportamento vedado quanto no de não haver abuso no uso de um bem ou no exercício de uma atividade.

Carlos Ari Sundfeld ressalva não haver um poder geral implícito para a Administração fiscalizar os mais diversos aspectos da vida dos administrados. O poder de fiscalização depende de previsão legal: “Há poder de fiscalização para a Administração quando previsto expressamente pela lei, ou quando decorrer logicamente da competência administrativa para impor condicionamentos ou reprimir sua infração,792.

A atividade de fiscalização, por consistir principalmente na constatação de fatos e na aplicação de normas previamente estabelecidas, comporta reduzida margem para o exercício de competências discricionárias. Em geral, implica a avaliação da incidência do quadro normativo a fatos já ocorridos, para se verificar a correção ou não da atuação daqueles que se submetem às normas de polícia administrativa ${ }^{793}$. Disso decorre também o amplo controle incidente sobre a atividade de fiscalização, que pode ser realizado com a aplicação de critérios objetivos ${ }^{794}$.

Sob uma perspectiva, essas atividades de fiscalização consistem em aspecto acessório da atividade de polícia administrativa. O objetivo final da atividade de polícia não é o exercício de controle sobre os administrados. A fiscalização e as demais atividades conexas são instrumentais à persecução dos objetivos visados com as atividades de polícia.

No entanto, isso não significa que essas atividades sejam irrelevantes. As atividades de fiscalização podem compreender tanto atos materiais quanto jurídicos. Dependendo da extensão das missões conferidas aos particulares, as atividades de controle podem implicar o exercício de poderes públicos.

\footnotetext{
792 Direito administrativo ordenador, 1997, p. 76.

${ }^{793}$ Flávio Henrique Unes Pereira. Regulação, fiscalização e sanção, 2013, p. 77.

${ }^{794}$ Mas nem por isso afasta-se por completo a possibilidade de haver alguma margem de discricionariedade na atividade de fiscalização, expressamente atribuída pela lei. Como constata Floriano de Azevedo Marques Neto, "temos que reconhecer que a conferência, pelo legislador, de margens de discricionariedade para o administrador, é algo contumaz, frequente, em qualquer atividade administrativa. O fiscal municipal a quem compete exercer o poder de polícia sobre edificações possui margens de discricionariedade para interditar ou não uma obra” (Discricionariedade e regulação setorial, 2006, p. 580).
} 


\subsection{2. $\underline{\text { A participação privada na atividade de fiscalização }}$}

Reputamos ser possível a participação privada nas atividades de fiscalização, desde que possam ser exercidas com a aplicação de critérios objetivos e previamente determinados.

A contratação de particulares para o exercício de atividades de fiscalização não é estranha ao direito administrativo. Consta expressamente, por exemplo, do art. 67 da Lei 8.666/93 ${ }^{795}$.

Com frequência, a atividade de fiscalização não se restringe à prática de meros atos materiais. Os atos praticados por particulares são passíveis de exercer forte influência sobre os atos da Administração, desenvolvidos com base nos dados colhidos na etapa de fiscalização. Como constata Flávio Henrique Pereira Unes, “as informações captadas e selecionadas pelo parceiro privado são determinantes para a conclusão ou conteúdo do ato administrativo, a revelar a administração de prerrogativas públicas de extrema relevância no contexto do exercício de poderes públicos»”796.

Portanto, essa participação do particular usualmente não é irrelevante.

Um dos resultados possíveis de serem obtidos com o exercício da fiscalização consiste na preparação da repressão de infrações, com a constatação formal de atos infratores $^{797}$. A documentação produzida e o registro da possível infração por ele informada à Administração têm poder probatório reforçado. Em se tratando da apuração de atos ilícitos, a documentação dos fatos é de extrema relevância pela necessidade de certeza da prática do ato, sob pena de comprometimento do processo sancionatório. Não se pode impor ao particular a produção de prova negativa, que é impossível, em seu favor.

Mas não se pode confundir a documentação da possível infração e a sua comunicação à Administração com a aplicação de sanção ${ }^{798}$. A aplicação da sanção em si é desencadeada a partir da documentação da possível infração pelo particular e demanda o desenvolvimento de um processo administrativo específico, com a notificação do possível infrator, apresentação de defesa e instrução probatória.

\footnotetext{
795 “A execução do contrato deverá ser acompanhada e fiscalizada por um representante da Administração especialmente designado, permitida a contratação de terceiros para assisti-lo e subsidiá-lo de informações pertinentes a essa atribuição”.

${ }^{796}$ Regulação, fiscalização e sanção, 2013, p. 102.

${ }^{797}$ Diogo de Figueiredo Moreira Neto. Curso de direito administrativo, 2009, p. 447.

${ }^{798}$ O STJ já decidiu o seguinte: "Nada obsta, nesse procedimento, que certos atos antecedentes do poder de polícia sejam exercidos por particulares, mediante contrato de prestação. O registro fotográfico da infração serve como base para a lavratura do auto de infração, cuja competência é exclusiva da autoridade de trânsito" (voto da Min. Eliana Calmon no REsp n ${ }^{\circ}$ 880.549/DF, 2 ${ }^{\mathrm{a}}$ T., j. 21.10.2008, DJe 18.11.2008).
} 
A instauração do processo sancionatório pode ser fundada na documentação da possível infração realizada por um particular. É por meio do seu contratado e não diretamente que a Administração constata a ocorrência dos fatos passíveis de caracterizar uma infração e produz a sua documentação ${ }^{799}$. Essa aferição e avaliação do contexto fático realizados pelo contratado tendem a prevalecer no processo sancionatório.

Pela relevância dos atos, o exercício das atividades de fiscalização pode ser realizado por particulares desde que sejam previamente determinados os seus aspectos, estipulando-se os critérios e procedimentos a serem observados. Tal se faz necessário para que sejam asseguradas a objetividade e a isonomia no exercício destas atividades por particulares. Não poderá ser atribuída a um particular ampla margem de discricionariedade, com a faculdade de determinar, por exemplo, o "se" e o "como" do exercício da fiscalização.

Logo, admite-se a delegação do exercício de atividades de fiscalização, desde que não seja atribuída ao particular ampla margem de decisão ${ }^{800}$.

Para o exercício das atividades de fiscalização, pode ser necessária a sujeição e a colaboração dos administrados ${ }^{801}$. Cabe-lhes, por exemplo, fornecer toda a documentação necessária acerca das instalações, produtos e serviços. Deverão permitir também a coleta de amostras e o acesso aos locais em que a fiscalização deve ser exercida.

\footnotetext{
${ }^{799}$ Como pondera Pedro Gonçalves, "é a documentação da infração que dá por oficialmente verificada a situação que está na origem imediata da instauração do processo sancionatório; por outro lado, há um manifesto momento de poder na atuação das entidades fiscalizadoras, que, no terreno, têm, afinal, uma palavra decisiva sobre o funcionamento da máquina sancionatória do Estado, podendo, por ex., 'abrir os olhos' para certas infrações e ‘fechá-los' para outras” (Entidades privadas com poderes públicos, 2008, p. 767 - grifos no original).

${ }^{800}$ Floriano de Azevedo Marques Neto defende a possibilidade de delegação das atividades de fiscalização, bem como das atividades adjudicatórias: "As atividades adjudicatórias e de acompanhamento ou fiscalização são atribuições de ordenação que a nosso ver podem ser, em si, objeto de delegação. Não apenas no tocante às atividades de apoio ao exercício dessas atribuições, como já sustentamos em outra oportunidade, mas também no tocante à própria delegação da realização dessas etapas. É o que ocorre, por exemplo, com a delegação do exercício de certificação de elevadores ou equipamentos de segurança contra incêndio, ou com a certificação de equipamentos no âmbito do controle de pesos e medidas. Nessas hipóteses, parece-nos perfeitamente possível a delegação, por via de concessão do exercício de tais atividades a um ou a vários postulantes. Outro exemplo de concessão possível dessas atividades diz com a implantação e a operação de equipamentos de fiscalização de trânsito, seja para suportar a aplicação de sanções, seja para monitorar o tráfego" (A concessão como instituto do direito administrativo, 2013, p. 567). Em obra anterior, o doutrinador já havia se posicionado no sentido da possibilidade de contratação de empresas privadas de engenharia consultiva para a prestação de serviços de gerenciamento, acompanhamento e apoio à fiscalização das concessionárias de sistemas rodoviários. Conclui pela sua legitimidade por não se tratar de atividades próprias do Estado, não sendo revestidas de imperatividade nem implicando o exercício de coerção estatal (A contratação de empresas para suporte da função reguladora e a "indelegabilidade do poder de polícia", 2000, p. 74).

801 "Ao poder de fiscalizar corresponde a obrigação de o administrado suportar a verificação administrativa e de colaborar com ela (...) Opor óbices a ela traduz comportamento ilícito, como tal passível de sanção" (Carlos Ari Sundfeld. Direito administrativo ordenador, 1997, p. 76).
} 
Na ausência da colaboração dos administrados sujeitos à fiscalização, poderá ser necessário o emprego de coerção direta. Por exemplo, se houver negativa de acesso ao local ou às informações e documentos a serem fiscalizados, será necessária a prática de atos materiais de coerção física, objetivando possibilitar o efetivo exercício da fiscalização. Como já se indicou, apenas excepcionalmente poderá ser exercida a coerção direta sem prévia autorização judicial $^{802}$.

Em qualquer caso, se a atividade de fiscalização estiver sendo exercida por particular mediante delegação estatal, tais atos de coerção direta não poderão ser exercidos pelo delegatário. Este poderá apenas informar à Administração a constatação da resistência do administrado em colaborar com a atividade de fiscalização, para que então sejam adotadas as providências cabíveis.

Eventualmente, uma entidade privada poderá praticar os atos meramente materiais necessários para remover os obstáculos opostos à fiscalização. Essa atividade será exercida sob comando direto da Administração, que deverá determinar previamente todos os aspectos dos atos materiais a serem praticados.

7.6.3. Exemplos de deveres $\underline{\text { de fiscalização atribuídos pela lei a particulares }}$

Há disposições legais que atribuem expressamente a determinados particulares a fiscalização da atividade de outros particulares. Isso implica, em alguma medida, o exercício de poderes de um particular sobre outro, ao cumprir o dever que lhe foi atribuído pela lei de fiscalizar a conduta de outrem.

A Lei no 13.541, de 7.5.2009, do Estado de São Paulo, proíbe o consumo de cigarros, cigarrilhas, charutos, cachimbos ou de qualquer outro produto fumígeno, derivado ou não do tabaco, na forma que especifica, em ambientes de uso coletivo, públicos ou privados. A referida lei atribuiu expressamente ao proprietário do recinto o dever de fiscalização do seu cumprimento.

O proprietário tem o dever de advertir o frequentador que estiver infringindo a lei, ressalvando-se apenas a prática do ato de coação consistente na retirada do local ${ }^{803}$. O

\footnotetext{
${ }^{802}$ Se o local em que a fiscalização tiver que ser exercida for qualificado como "casa" para fins constitucionais, o acesso apenas poderá ocorrer nas hipóteses expressamente previstas no texto constitucional. Terceiros apenas poderão adentrar no recinto sem o consentimento do morador em caso de flagrante delito ou desastre, para prestar socorro ou, durante o dia, por determinação judicial (CF/88, art. 5º inc. XI). São também invioláveis a correspondência e as comunicações telegráficas, de dados e das comunicações telefônicas $\left(\mathrm{CF} / 88\right.$, art. $5^{\circ}$, inc. XII). A sua interceptação depende de autorização judicial, não podendo ser acessadas em mera fiscalização administrativa.

803 “Artigo $3^{\circ}$ - O responsável pelos recintos de que trata esta lei deverá advertir os eventuais infratores sobre a proibição nela contida, bem como sobre a obrigatoriedade, caso persista na conduta coibida, de imediata retirada do local, se necessário mediante o auxílio de força policial”.
} 
particular responsável pelo fornecimento de produtos e serviços sujeita-se inclusive a penalidades na hipótese de não exercer a atividade de fiscalização apropriadamente ${ }^{804}$.

Constata-se que a simples advertência daquele que está consumindo tabaco e produtos similares já implica uma restrição à liberdade individual. Assim se caracteriza ainda que tenha amparo legal, seja realizada com grau mínimo de constrangimento sobre a integridade física e deva ser aplicada de modo generalizado e padronizado, a todos os que se encontrem na mesma situação.

Outro exemplo de dever de fiscalização a particular conferido pela lei é o imposto ao transportador de carga ou passageiros, em relação a mercadorias sobre as quais recai a suspeita de prática de infração fiscal.

Exige-se do transportador a identificação das bagagens pertencentes aos passageiros e o controle dos volumes transportados. Há previsão de aplicação de multa ao transportador para a hipótese de se constatar o transporte de mercadoria com características ou quantidades que evidenciem que se trata de produto sujeito a pena de perdimento ${ }^{805}$.

Atribui-se ao transportador o dever de fiscalizar as bagagens e cargas transportadas e recusar o transporte na hipótese de não estarem identificadas ou se houver suspeita de se tratar de mercadoria sujeita a pena de perdimento. Em se tratando de transporte rodoviário, o veículo ficará retido até o recolhimento da multa ou o acolhimento de recurso administrativo, ainda que o infrator não seja o proprietário do veículo ${ }^{806}$.

Nesses dois exemplos, pela impossibilidade de o poder público fazer-se presente de modo permanente, o legislador atribuiu poderes de fiscalização a determinados particulares, habilitando-os a praticar determinados atos aptos a determinar a conduta de terceiros e de se fazer obedecer. Trata-se do exercício de significativos poderes públicos, que não se restringem à constatação de fatos. Esses poderes podem ser equiparados àqueles envolvidos no instituto da responsabilidade tributária, que confere poderes para um particular fiscalizar a conduta de outro, bem como determina o dever de exercitar tais poderes $^{807}$.

\footnotetext{
804 “Artigo $4^{\circ}$ - Tratando-se de fornecimento de produtos e serviços, o empresário deverá cuidar, proteger e vigiar para que no local de funcionamento de sua empresa não seja praticada infração ao disposto nesta lei. Parágrafo único - O empresário omisso ficará sujeito às sanções previstas no artigo 56 da Lei federal n. ${ }^{\circ}$ 8.078, de 11 de setembro de 1990 - Código de Defesa do Consumidor, aplicáveis na forma de seus artigos 57 a 60, sem prejuízo das sanções previstas na legislação sanitária.”

${ }^{805}$ Lei no $10.833 / 03$, art. 75 , incs. I e II.

${ }^{806}$ Lei $^{\circ} 10.833 / 03$, art. $75, \S \S 1^{\circ}$ e $2^{\circ}$.

${ }^{807}$ Como esclarece Marçal Justen Filho, há uma relação de poder entre o responsável tributário e a conduta de outrem, quanto ao cumprimento do dever tributário deste: “o destinatário da responsabilidade encontra-se em situação de poder sobre o sujeito passivo tributário, de molde a ser-lhe dado exigir ou verificar o cumprimento da prestação devida” (Sujeição passiva tributária, 1986, p. 295). A norma de responsabilidade tributária
} 
Nesses exemplos, como a lei delineou os requisitos e procedimentos a serem observados pelos particulares e foram excluídos os atos que demandem o emprego de coação, reputamos ser legítima a atribuição de tais poderes de fiscalização. Outro aspecto a ser considerado é que se trata de atividade de particulares que se realiza de modo complementar à do poder público. Consiste em hipótese de atuação conjunta, em que uma não exclui a outra.

\subsection{4. $\underline{\text { A fiscalização }} \underline{\text { de trânsito }}$}

Constata-se a ampla participação de particulares nas diversas etapas de fiscalização e controle do trânsito de veículos. Atuam na execução de tais atividades tanto entidades da Administração indireta quanto particulares.

A fiscalização de trânsito envolve a prática de diversos atos materiais, que implicam o registro de fatos. O monitoramento do trânsito, com a detecção de possíveis atos infracionais, pode demandar a prática de meras atividades materiais, caso todas as suas condições estejam previamente programadas e não demandem a intervenção humana.

A utilização de equipamentos eletrônicos de propriedade privada para aferição de velocidade, por exemplo, sem qualquer interferência privada na sua operação, revela a transferência de incumbências bastante restritas à entidade privada. Porém, isso não afasta a caracterização do ato final como sendo ato administrativo, dotado de autoridade. Hartmut Maurer alude à decisão administrativa automaticamente adotada, mediante a introdução e processamento de dados eletrônicos, que não deixa de ser um ato administrativo. É a Administração que conduz e prejulga a tomada de decisão, mediante a programação do sistema e fixação dos seus critérios e, posteriormente, torna vinculante a decisão adotada $^{808}$.

A instalação, operação e manutenção dos equipamentos utilizados para o registro dos fatos, desde que tenham sido objeto de prévia programação, não implicam o exercício de poderes públicos por entidades privadas ${ }^{809}$. Os fatos registrados serão

coloca o responsável "em uma situação jurídica especial que lhe assegura, se o desejar, compelir o sujeito passivo a adimplir o dever tributário" (ob. e loc. cit.). Em contrapartida, a norma tributária impõe ao responsável o dever de se valer desse poder para verificar o cumprimento da prestação devida pelo sujeito passivo, exigindo a comprovação do recolhimento dos tributos devidos. O responsável pode (deve) constranger o sujeito passivo a adimplir as suas obrigações, sem emprego de meios coercitivos.

${ }^{808}$ Direito administrativo geral, 2006, p. 522.

${ }^{809}$ José dos Santos Carvalho Filho identifica esses atos de fiscalização como sendo passíveis de delegação, ressalvando que não podem ser aplicadas quaisquer restrições a particulares: "Em determinadas situações em que se faz necessário o exercício do poder de polícia fiscalizatório (normalmente de caráter preventivo), o Poder Público atribui a pessoas privadas, por meio de contrato, a operacionalização material da fiscalização através de máquinas especiais, como ocorre, por exemplo, na triagem em aeroportos para detectar eventual porte de objetos ilícitos ou proibidos. Aqui o Estado não se despe do poder de polícia nem procede a qualquer 
utilizados pela autoridade policial como elementos de prova, a serem avaliados no processo de formação da convicção acerca da ocorrência ou não do ato ilícito. Há uma valoração posterior dos dados coletados, dando-se início ao processo sancionatório na hipótese de ser constatada possível infração.

Em algumas hipóteses, não é necessária uma avaliação mais específica para se identificar a ocorrência da infração. Por exemplo, em se tratando da utilização de equipamentos que aferem a velocidade dos veículos, sem qualquer intervenção humana, não há a necessidade de se desenvolver posteriormente um processo próprio para se constatar a possível ocorrência ou não da infração.

Porém, nos casos em que a infração não puder ser constatada a partir de critérios puramente objetivos, previamente definidos, será necessária a intervenção de autoridade administrativa para avaliar os fatos registrados e identificar a possível ocorrência ou não de uma infração.

Se a entidade privada puder exercer alguma influência quanto ao modo como a fiscalização é exercida, definindo, por exemplo, o local, o momento, os meios a serem empregados ou a duração do controle, há o exercício de atividades que envolvem o manejo de poderes públicos. Não há como se considerar que tais atividades envolvem apenas a prática de simples atos materiais.

O grau de programação ou de definição prévia dos termos de execução da atividade pública são relevantes para se determinar a extensão das atribuições delegadas e, consequentemente, a legitimidade da delegação. O exercício de atividades de fiscalização não demanda, muitas vezes, o emprego da coerção direta e o exercício de amplo poder de decisão. Porém, isso não implica a sua delegabilidade irrestrita. Reputamos ser possível a delegação de atividades de fiscalização apenas se houver prévia especificação, em ato normativo ou no contrato, do momento, condições, critérios, meios e modo de seu exercício.

Assim se passa pela necessidade de se assegurar que a entidade privada desempenhará a fiscalização com objetividade e impessoalidade. Não seria possível atribuírem-se poderes amplos a entidades privadas, conferindo-lhes a possibilidade, por

delegação, mas apenas atribui ao executor a tarefa de operacionalizar máquinas e equipamentos, sendo-lhe incabível, por conseguinte, instituir qualquer tipo de restrição; sua atividade limita-se, com efeito, à constatação de fatos. O mesmo ocorre, aliás, com a fixação de equipamentos de fiscalização de restrições de polícia, como os aparelhos eletrônicos utilizados pelos órgãos de trânsito para a identificação de infrações por excesso de velocidade: ainda que a fixação e a manutenção de tais aparelhos possam ser atribuídos a pessoas privadas, o poder de polícia continua sendo da titularidade do ente federativo constitucionalmente competente. Nada há de ilícito em semelhante atribuição operacional” (Manual de direito administrativo, 2012, p. 80 - grifos no original) 
exemplo, de escolher o momento e os meios a serem utilizados em determinada ação de fiscalização ${ }^{810}$.

Outro aspecto relacionado à fiscalização de trânsito diz respeito à extensão das funções que podem ser atribuídas a particulares.

$\mathrm{O}$ art. 280, §4", da Lei $\mathrm{n}^{\circ}$ 9.503/97, prevê que "O agente da autoridade de trânsito competente para lavrar o auto de infração poderá ser servidor civil, estatutário ou celetista ou, ainda, policial militar designado pela autoridade de trânsito com jurisdição sobre a via no âmbito de sua competência”. Já no $\S 2^{\circ}$ do mesmo dispositivo estipula-se que a infração poderá ser comprovada, entre outras formas, "por aparelho eletrônico ou por equipamento audiovisual”.

O primeiro ponto a ser destacado é que o dispositivo legal não restringe a lavratura de auto de infração aos servidores estatutários. Admite que essa atribuição seja desempenhada também por servidor celetista. Logo, quando menos, admite a lavratura de autos de infração por agentes de entidades da Administração indireta com personalidade jurídica privada.

Depois, cabe investigar se, na hipótese de a infração ser comprovada por aparelho eletrônico ou equipamento audiovisual, faz-se necessário que o auto de infração seja lavrado por agente detentor de autoridade.

O problema que se coloca é que, se a infração tiver sido detectada por meios eletrônicos e o auto de infração for lavrado por agente de autoridade de trânsito, esse agente não terá presenciado a infração ${ }^{811}$. Por esse motivo, reputamos não ser necessária a lavratura do auto de infração por agente de trânsito nos casos em que a apuração da infração é realizada sem qualquer interferência humana.

Note-se que a lavratura do auto de infração não consiste em ato de natureza sancionatória. A imposição da sanção ocorre apenas no término do processo administrativo, que tem início com a notificação do condutor. A partir da ciência da imputação, o condutor poderá apresentar a sua defesa perante a autoridade competente, instaurando o contraditório. Ao final do processo, se o auto de infração for julgado consistente, poderá ser aplicada a penalidade cabível (Lei $\mathrm{n}^{\circ}$ 9.503/97, art. 281). Diante desse julgamento, o

\footnotetext{
${ }^{810}$ Como se examina adiante, o STJ reconheceu a possibilidade de se delegarem as atividades de fiscalização do trânsito em geral, vedando apenas a imposição de sanções por entidades privadas (Resp nº 817.534/MG).

${ }^{811}$ Consta o seguinte do item 4 do volume I do Manual Brasileiro de Fiscalização de Trânsito, aprovado pela Resolução n 371/2010, do CONTRAN: "O agente de trânsito, ao presenciar o cometimento da infração, lavrará o respectivo auto e aplicará as medidas administrativas cabíveis, sendo vedada a lavratura do AIT por solicitação de terceiros” (grifo no original).
} 
condutor deve ser novamente notificado, agora para cientificá-lo da aplicação da penalidade (Lei $n^{\circ}$ 9.503/97, art. 282).

Logo, o auto de infração consiste apenas em meio de prova da infração. Não retrata propriamente a aplicação de uma penalidade.

Cabe examinar também a qualificação a ser dada aos exames exigidos para fins de obtenção e renovação de licença para condução de veículos, quando algumas das verificações necessárias são realizadas por particulares.

Para Pedro Gonçalves, a realização de tais exames consiste em atividade pública e o resultado das verificações é externado em ato administrativo, inclusive quando são realizados por particulares, pois o seu resultado é vinculante e produz efeitos diretamente na esfera jurídica do condutor $^{812}$. Concordamos com o posicionamento do autor, à medida que os referidos exames não consistem em meros atos materiais.

A grande quantidade de aspectos eminentemente técnicos inviabiliza o recebimento controlado dos resultados dos exames pela Administração. Por isso, faz-se necessária a prévia programação da atividade, com a descrição dos requisitos e critérios a serem observados da forma mais objetiva e minuciosa possível, de modo a se reduzir ao máximo eventual margem de livre apreciação do examinador ao decidir pela aprovação ou não de determinado candidato. Deverá ser assegurado aos administrados o direito de questionar e recorrer especificamente em relação ao procedimento adotado no exame e ao seu resultado, especialmente perante o poder público. Todas essas garantias são necessárias porque a atividade desempenhada por particulares é apta a atingir diretamente a esfera jurídica dos administrados que a ela se submetem.

É importante mencionar que é na área da fiscalização do trânsito que têm sido travados os debates mais recentes acerca da participação de entidades privadas da Administração indireta no exercício da atividade de polícia. Vários municípios atribuíram a empresas públicas e a sociedades de economia mista as diversas atividades relacionadas com o controle de tráfego, incluindo a aplicação de penalidades. Porém, as atividades atribuídas a essas entidades vão além da fiscalização.

O STJ reputou inviável o exercício das funções de fixação de normas e de aplicação de penalidades pela BHTRANS, que é sociedade de economia mista, ressalvando a possibilidade de exercício das atividades de fiscalização ${ }^{813}$. Já o TJPR declarou a inconstitucionalidade do dispositivo da Lei Orgânica do Município de Curitiba que atribuiu

\footnotetext{
${ }^{812}$ Entidades privadas com poderes públicos, 2008, p. 885-887.

${ }^{813}$ REsp n ${ }^{\circ}$ 817.534/MG, Rel. Min. Mauro Campbell Marques, $2^{\mathrm{a}}$ T., j. 10.11.2009, v.u., DJ 10.12.2009.
} 
à URBS, constituída como sociedade de economia mista, a função de policiamento das vias urbanas $^{814}$. O fundamento invocado também foi o da inadmissibilidade da delegação de atividade típica do Estado a uma entidade com personalidade privada. Porém, em caso similar, o TJRJ reconheceu a constitucionalidade de lei municipal que atribuiu a empresa pública a função de exercer a fiscalização de trânsito, inclusive aplicando penalidades aos motoristas infratores ${ }^{815}$.

Os critérios a serem observados especificamente no que diz respeito ao exercício das atividades de polícia administrativa por entidades da Administração indireta com personalidade jurídica privada são analisados adiante.

\subsection{A atividade de avaliação da conformidade}

As atividades de certificação, inspeção, vistorias e outras similares, que designamos genericamente como atividades de avaliação de conformidade, integram o ciclo das atividades de polícia administrativa. Interessam-nos especialmente as atividades de natureza pública, que são assumidas pelo Estado e podem ter o seu exercício delegado a particulares.

\subsection{1. $\underline{\text { A }}$ avaliação da conformidade}

Emprega-se o termo avaliação da conformidade para indicar a utilização de procedimentos para a verificação do cumprimento de determinados regulamentos técnicos ou normas ${ }^{816}$. Abrange todo o tipo de avaliação para se aferir se determinado objeto ${ }^{817}$ atende a requisitos mínimos previamente estabelecidos. Trata-se de atividade com caráter declaratório, que atesta a conformidade de determinado produto ou instalação com as normas setoriais aplicáveis.

Há significativas variações na terminologia empregada para designar as atividades de avaliação da conformidade. No direito espanhol, por exemplo, as inspeções abrangem todas as atuações que possibilitam à Administração o exercício de funções de

\footnotetext{
${ }^{814}$ ADI n ${ }^{\circ}$ 052.764-2, Rel. Des. Antônio Martelozzo, Órgão Especial, j. 16.9.2011, DJ 28.9.2011.

${ }^{815}$ Representações de Inconstitucionalidade n $\mathrm{n}^{\circ}$ 2003.007.00146 e n 2003.007.00109, Relator p/ acórdão Des. Nagib Slaibi, Órgão Especial, j. 12.3.2007.

${ }_{816}$ De acordo com a norma ABNT NBR ISO/IEC 17000:2005, avaliação da conformidade consiste na "demonstração de que os requisitos especificados relativos a um produto, processo, sistema, pessoa ou organismo são atendidos".

${ }^{817}$ Para fins de avaliação da conformidade, o termo objeto é utilizado "para abranger qualquer material, produto, instalação, processo, sistema, pessoa ou organismo particulares aos quais a avaliação da conformidade é aplicada. Um serviço é coberto pela definição de um produto” (ABNT ISO/IEC 17000:2005).
} 
comprovação ou constatação do cumprimento das normas vigentes, inclusive de requisitos de ordem técnica ${ }^{818}$.

No Brasil, há o Sistema Brasileiro de Avaliação da Conformidade - SBAC, gerido pelo Instituto Nacional de Metrologia, Normalização e Qualidade Industrial INMETRO. O INMETRO é uma agência executiva vinculada ao governo federal e consiste no único acreditador oficial do país.

A International Organization for Standardization (ISO) é a principal entidade internacional de normalização. Têm bastante destaque as séries de normas da ISO.

Os principais processos de avaliação da conformidade consistem em certificação, auditoria, inspeção, ensaios e acreditação de organismos de avaliação da conformidade. Os documentos que comprovam o atendimento aos requisitos podem consistir, entre outros, em certificados, atestados, relatórios técnicos e pareceres técnicos.

No âmbito de exercício de poderes públicos, estão incluídas apenas as avaliações de conformidade que são impostas pela lei e desenvolvidas em um sistema criado e regulado de modo a se obterem resultados confiáveis. Somente os resultados dessas avaliações são dotados de força probatória especial.

As atividades de certificação são usualmente antecedidas de inspeções e vistorias, inseridas nas atividades de controle. Em algumas hipóteses, atribui-se a particulares apenas a primeira etapa, de verificação das condições fáticas e técnicas. Já em outros casos, faz-se a delegação global, atribuindo-se a entidades privadas não apenas a realização da inspeção técnica mas também a certificação oficial da inspeção e da conformidade do produto ou serviço com as normas aplicáveis.

A circunstância de se atestar a autenticidade de determinados dados ou de produzir declarações que consistem em elemento qualificado de prova revela que a sua produção implica repercussões imediatas na esfera jurídica de terceiros ${ }^{819}$.

Não se reconhece que os atos de certificação caracterizam-se pela estabilização e vinculação. É possível, por exemplo, produzirem-se novos laudos ou verificações, passíveis de conduzir à alteração da declaração inicialmente fornecida.

\footnotetext{
${ }^{818}$ José Bermejo Vera. La administración inspectora, 1998, p. 40-41.

${ }^{819}$ No direito espanhol, por exemplo, as atividades de avaliação de conformidade são desenvolvidas por entidades privadas, as denominadas entidades colaboradoras. Ao analisar a atuação destas entidades, José Bermejo Vera constata que as funções que desempenham são, em princípio, de caráter material-técnico e desprovidas de imperium. No entanto, incidem sobre direitos e interesses dos administrados, o que determina a necessidade de se considerar com atenção os parâmetros sobre os quais se desenvolvem e assegurar a adequada garantia dos direitos dos administrados que se submetem a tais atividades (Privatización y el nuevo ejercicio de función pública por particulares, p. 423).
} 
No entanto, a autoridade de tais atos decorre também do fato de a obtenção da certificação ou de outras declarações ser imposta pela lei, que estipula para a produção de tais atos um sistema específico de avaliação de conformidade. Apenas as declarações produzidas por entidades que integram esse sistema é que são aptas a satisfazer a exigência legal e produzir os efeitos previstos em lei.

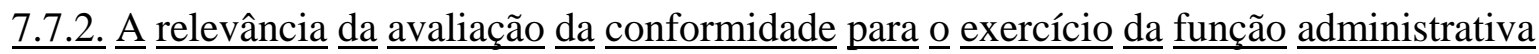

O principal objetivo visado com as atividades de avaliação da conformidade é a segurança.

As atividades de controle podem se encontrar vinculadas à atividade sancionatória, destinando-se a assegurar a observância das normas de polícia administrativa e prevenir transgressões. Há hipóteses em que se atribui ao particular a fiscalização do cumprimento das normas, a documentação de eventuais infrações e a sua comunicação à autoridade competente, a quem cabe avaliar os dados e aplicar a possível penalidade cabível. Como se analisou acima, reputamos que o poder sancionatório em si não é passível de delegação.

É possível também que as atividades de controle consistam em mecanismos preparatórios para a adoção de decisões administrativas necessárias para a realização de determinadas atividades privadas, tais como a expedição de certificados, alvarás e autorizações, por exemplo.

A delegação da realização da inspeção não implica a atribuição da prática de atos sancionatórios em face dos particulares inspecionados. No entanto, os particulares devem se submeter à atividade de inspeção, ainda que realizada por outros particulares, e os resultados obtidos na inspeção e informados ao poder público tendem a prevalecer no processo de decisão da Administração.

\subsubsection{A delegabilidade da atividade de avaliação da conformidade}

A avaliação da conformidade implica o desempenho de diversas atividades que podem ser consideradas prévias ao exercício da atividade de polícia propriamente dita.

Nas palavras de Vittorio Constantino Provenza, “Os exames, vistorias, perícias, verificações, avaliações, confrontos, estimativas e outras atividades correlatas são, na verdade, condição ou preparo do ato propriamente de polícia, consistente em autorizar, licenciar, homologar, permitir, etc." ${ }^{820}$.

${ }^{820}$ Parecer, 1997, p. 361. 
Essas atividades de vistoria, avaliação, verificação etc. antecedem a prática de atos que retratam o exercício de poder de polícia propriamente dito. No entanto, esses atos materiais preparatórios não podem ser completamente dissociados dos atos subsequentes - de autorização, licenciamento etc. As funções de inspeção e controle que são exercidas por agentes privados, na maioria das vezes, não podem ser autonomizadas em relação às funções decisórias e de certificação a elas vinculadas. São funções indissociáveis agregadas nessas atividades ${ }^{821}$.

Reputamos ser possível a delegação a particulares do exercício das atividades de declaração que produzem efeito de certeza pública ou que são dotadas de força probatória especial. Um forte indício da possibilidade de delegação dessas atividades a particulares consiste na disposição do art. 236 do texto constitucional, que prevê que as atividades notariais e de registro serão desempenhadas em caráter privado, por delegação estatal.

Em relação às atividades de avaliação de conformidade ou de certificação, como se analisa adiante, a Lei $n^{\circ} 9.933 / 99$, de acordo com a redação dada pela Lei $n^{\circ}$ 12.545/11, veda expressamente a delegação das atividades que impliquem o exercício de poder de polícia. Autorizou apenas a delegação de atividades materiais e acessórias, de caráter técnico. Assim, diante da expressa vedação legal, em relação às atividades de certificação de natureza pública, que se impõem compulsoriamente aos interessados, as atividades finais não podem ser delegadas.

No entanto, consideramos que seria possível que a lei consagrasse a possibilidade de delegação a entidades privadas inclusive das atividades de avaliação compulsória. Tais atos não envolvem o exercício de coerção, produzindo efeitos de natureza declaratória (e, em casos excepcionais, alguns efeitos constitutivos associados aos declaratórios) ${ }^{822}$.

\footnotetext{
${ }^{821}$ Dolors Canals I Ametller. El ejercicio por particulares de funciones de autoridad, 2003, p. 288.

${ }^{822}$ A doutrina espanhola consigna a necessidade de a transferência da atividade para as entidades colaboradoras, que desempenham as funções de controle e certificação, ser acompanhada de garantias suficientes: "é imprescindível que a normativa reguladora das entidades colaboradoras determine de forma rigorosa os requisitos e as garantias que devem cumprir estas entidades. Em particular, é fundamental garantir sua independência, objetividade e imparcialidade, sua solvência, sua capacidade técnica; os direitos dos afetados; e o seguro de possíveis responsabilidades. Por essa perspectiva, também é fundamental regular o procedimento a seguir no exercício das funções de controle, inspeção e certificação por parte das entidades colaboradoras” (Lucía Casado Casado e outros. La externalización de las funciones de control e inspección en materia de protección del medio ambiente, p. 175-176).
} 
7.7.4. $\underline{\text { A natureza jurídica da atividade de controle exercida por particulares }}$

A identificação da natureza jurídica da atividade de controle exercida por particulares depende da existência ou não de apropriação pública dessa atividade.

Nos casos em que as atividades de controle foram expressamente assumidas pelo Estado, os particulares apenas podem exercê-las caso o seu exercício lhes seja formalmente atribuído. Trata-se das hipóteses de inspeções, vistorias e fiscalizações obrigatórias, às quais os administrados são obrigados a se submeter.

Nesse caso, em tese, poderia ser atribuída aos particulares desde a execução de atividades meramente materiais até o ato de aprovação ou reprovação do bem ou serviço vistoriado. Caso seja transferido ao particular o exercício de atividades aptas a produzir efeitos imediatos na esfera jurídica daqueles que se submetem às inspeções e fiscalizações, independentemente da intervenção da Administração, estará configurado o exercício de poderes públicos de controle pelo particular.

Tal como se passa em relação às atividades de fiscalização, as atividades de inspeção e controle também implicam obrigações que restringem a liberdade dos cidadãos, ao imporem um conjunto de deveres públicos de colaborar com a realização desses atos ${ }^{823}$.

Para Manuel Izquierdo Carrasco, a qualificação da atividade como sendo de natureza pública é evidente quando o controle desempenhado por particulares não consiste em mero complemento técnico de uma decisão administrativa posterior e sim uma resolução pelo próprio particular, com plenos efeitos, quanto à observância das regras aplicáveis por determinado produto, equipamento ou instalação ${ }^{824}$. Da decisão a ser adotada pelo particular é que resulta a possibilidade ou não de determinado produto ser comercializado no mercado, sem prejuízo de posterior revisão pela Administração.

Portanto, quando se encontram no exercício de atividades de controle que lhes foram atribuídas pelo Estado, dependendo da extensão das atribuições que lhes foram conferidas, os particulares podem exercer poderes públicos. Trata-se de atividades de natureza imperativa, à medida que os administrados devem suportar essa atividade de controle, bem como têm o dever de colaborar ${ }^{825}$.

\footnotetext{
823 Dolors Canals I Ametller. El ejercicio por particulares de funciones de autoridad, 2003, p. 227.

${ }^{824}$ Algunas cuestiones generales a propósito del ejercicio privado en el ámbito de la seguridad industrial, 2001, p. 382-383.

${ }^{825}$ Nesse sentido, confira-se a lição de Dora Maria de Oliveira Ramos: “A atividade de certificação do preenchimento dos requisitos legais para exercício do direito que culmina com a expedição de um alvará, bem como os atos necessários à fiscalização do comportamento dos administrados, também encerram, em maior ou menor grau, o exercício de atividade de império, em que o poder público exerce ao de soberania” ( $A$ terceirização em matéria de poder de polícia: o caso das vistorias veiculares, 2013, p. 571).
} 
As hipóteses de controles públicos, assumidos pelo Estado, devem ser diferenciadas daqueles que têm natureza privada e são exercidos mediante relações jurídicas regidas pelo direito privado.

Trata-se dos controles voluntários, aos quais os administrados se submetem por sua livre e espontânea vontade. As entidades que exercem esses controles não atuam por delegação do Estado e sim por atribuição do próprio particular interessado em se submeter ao controle.

Essas atividades podem ser enquadradas como hipóteses de devolução de atividades de controle à iniciativa privada ${ }^{826}$. O Estado teria renunciado ao exercício de tais poderes, que passam a ser exercidos por particulares na forma de atividade privada. Essa “renúncia” do Estado é configurada pelo controle e regulação que o Estado exerce sobre essas atividades, que não são integralmente privadas. Ao Estado cabe o exercício do papel de garante, assegurando, por exemplo, a capacidade técnica, a independência e a imparcialidade dos organismos acreditados bem como incrementando os controles sucessivos.

Em se tratando de controles públicos, a intervenção estatal é muito mais ampla do que aquela representada quando o Estado se encontra na posição de garante. A regulação do exercício das atividades, realizada por via normativa e contratual, deverá dispor detalhadamente acerca das obrigações e direitos do contratado bem como sobre os critérios, requisitos e procedimentos a serem observados na prestação dos serviços.

\subsubsection{As diversas formas de participação privada na atividade de controle}

Como se analisa adiante, no direito nacional, os controles obrigatórios foram assumidos pelo Estado. No entanto, ao se analisar os sistemas vigentes em outros países, constata-se a existência de uma tendência de substituição ampla dos controles públicos, mesmo que de caráter obrigatório, por controles privados.

No direito europeu, especialmente na área da segurança técnica, constata-se a orientação pela substituição dos controles públicos por controles privados, com o reforço das responsabilidades privadas de controle ${ }^{827}$. É possível constatar haver uma tendência pela simplificação ou substituição do processo administrativo de controle em diversos setores técnicos, atribuindo-se maior relevância à atividade desenvolvida por particulares.

Isso ocorre mediante a atribuição pelo Estado ao próprio particular que deve se submeter ao controle o dever de providenciá-lo junto a entidades acreditadas. Em outros

\footnotetext{
${ }^{826}$ Pedro Gonçalves. Entidades privadas com poderes públicos, 2008, p. 187 e 196-199.

${ }^{827}$ Sobre o tema, confira-se Pedro Gonçalves. Entidades privadas com poderes públicos, 2008, p. 185 e ss.
} 
casos, o Estado simplesmente renunciou ao exercício de controle, abolindo a exigência de determinados licenciamentos. Incrementou-se também a participação privada no processo administrativo de realização do controle.

Ou seja, vários dos controles públicos foram parcial ou integralmente substituídos por controles privados. O controle deixou de ser uma atividade estatal e passou a ser diretamente desempenhado por entidades privadas, cabendo ao Estado o exercício da função de regulação e de garante. Por vezes, o Estado instituiu mecanismos de controle público a incidir sobre os controles privados. É o que ocorre ao se exigir que o controle seja desempenhado por entidades particulares, independentes, oficialmente acreditadas, reconhecidas ou credenciadas para exercerem tais funções ${ }^{828}$.

${ }^{828}$ Para ilustrar a maior participação privada na atividade de controle, apresentam-se alguns mecanismos de controles preventivos, que foram inseridos na esfera de responsabilidade própria dos particulares. Adota-se a sistematização apresentada por Pedro Gonçalves. Entidades privadas com poderes públicos, 2008, p. 191211:

a) controles que substituem controles públicos preventivos:

Aplicam-se às hipóteses em que houve abolição de procedimentos administrativos de autorização (certificação, homologação, aprovação). Exemplo que pode ser mencionado é o do modelo comunitário de certificação da conformidade de produtos industriais com normas de segurança, de proteção à saúde, ao ambiente etc. Tal modelo abrange as atividades de normalização, certificação e acreditação. No modelo da “nova abordagem em matéria de harmonização técnica e de normalização” adotada em 1985 pela CE, os Estados fixam apenas "exigências essenciais” de segurança, saúde etc. que os produtos devem atender. A fixação das normas e dos detalhes técnicos cabe a organismos europeus de normalização, que são entidades privadas. Tais normas não são de observância obrigatória. Se o produto atender a tais normas, presume-se que cumpre as exigências essenciais. Se não observar as normas, o fabricante deverá comprovar que atende às exigências essenciais previstas na legislação. Por um meio ou por outro, os fabricantes poderão apor a sigla “CE” na embalagem do produto, que é condição para o produto entrar no mercado. O procedimento para verificar a conformidade dos produtos é a atividade de certificação, também confiado a organismos privados, oficialmente acreditados pelo Estado. Por fim, há a atividade de acreditação, que cabe ao Estado ou a entes privados que exercem funções públicas delegadas. É “o procedimento através do qual se reconhece formalmente que uma entidade é competente para efetuar determinada função específica, de acordo com normas internacionais, europeias ou nacionais” (Pedro Gonçalves. Entidades privadas com poderes públicos, 2008, p. 194). O ato de acreditação é ato administrativo constitutivo de estatuto de entidade acreditada, pelo qual o Estado reconhece e garante a competência dessa entidade. Nesse modelo, o Estado abandona os controles preventivos e passa a controlar o controlador, mediante a acreditação, e exerce controles sucessivos (retirando de circulação produtos que apresentem desconformidades, proibindo sua venda etc.). O controle prévio passou a ser privado, de responsabilidade dos próprios fabricantes (autocontrole), que são obrigados a contratar os entes privados de controle e certificação.

b) controles que substituem controles públicos preventivos por procedimentos de comunicação de início de atividade:

Trata-se das hipóteses de substituição de procedimentos administrativos de autorização por procedimentos de comunicação de início de atividade. Também nesse caso a Administração renuncia à decisão de controle preventivo e transfere sua responsabilidade aos particulares, que exercem tal controle sob a forma de atividade privada. Usualmente, estipula-se que os particulares não podem dar início às atividades sujeitas a controle sem comunicarem esse fato previamente à Administração e sem que decorra determinado lapso temporal após tal comunicação. O particular assume a responsabilidade pela conformidade da sua atividade com as normas aplicáveis, mediante a intervenção de peritos e organismos acreditados. O procedimento de autorização é então substituído por um procedimento de comunicação de início de atividade. Cabe ao administrado que pretende exercer determinada atividade obter a certificação técnica necessária. É de responsabilidade do técnico ou da entidade que fornece a certificação verificar a adequação daquela atividade às normas em vigor. Pode ser qualificado como um sistema de autorresponsabilidade pelo cumprimento da legislação em vigor (Dolors Canals I Ametller. El ejercicio por particulares de funciones de autoridade, 2003, p. 68). Ainda que o Estado tenha renunciado a essa atividade, o seu exercício por particulares submete-se a intenso controle 


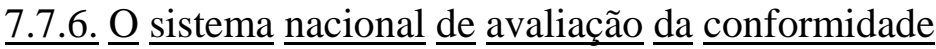

No Brasil, há o Sistema Brasileiro de Avaliação da Conformidade - SBAC.

A atividade de avaliação da conformidade é conduzida pelo INMETRO - Instituto Nacional de Metrologia, Normalização e Qualidade Industrial e pelas entidades a ele vinculadas e consiste na "demonstração de que requisitos especificados relativos a um produto, processo, sistema, pessoa ou organismo são atendidos”, ${ }^{\text {„29 }}$. O INMETRO pode “credenciar entidades públicas ou privadas para a execução de atividades de sua competência” (Lei nº 5.966/73, art. 5º).

O $\S 1^{\circ}$ do art. $4^{\circ}$ da Lei $n^{\circ} 9.933 / 99$, incluído pela Lei $n^{\circ} 12.545 / 11$, especifica que o INMETRO apenas poderá delegar “as atividades materiais e acessórias da metrologia legal e da avaliação da conformidade compulsória, de caráter técnico, que não impliquem o exercício de poder de polícia administrativa”.

Em seguida, no $\S 2^{\circ}$, especifica as atividades que não são passíveis de delegação:

As atividades que abrangem o controle metrológico legal, a aprovação de modelos de instrumentos de medição, fiscalização, verificação, supervisão, registro administrativo e avaliação da conformidade compulsória que impliquem o exercício de poder de polícia administrativa somente poderão ser delegadas a órgãos ou entidades de direito público.

Portanto, no que diz respeito às atividades relacionadas à avaliação da conformidade compulsória, apenas poderão ser delegadas a particulares as atividades materiais e acessórias, de caráter técnico. O ato final de aprovação, registro, fiscalização ficou restrito à Administração.

As atividades de avaliação são realizadas por Organismos Acreditados, que podem ser tanto entidades públicas quanto privadas. Caso constatada a regularidade do

público. Esse procedimento é aplicável, por exemplo, ao direito de construção na Alemanha e na Itália. Insere-se num contexto de liberalização e simplificação do processo administrativo, que deixa de observar as tradicionais fases (requerimento, instrução, decisão etc.). Há a obrigação de informar do particular e o dever da Administração de verificar a regularidade da informação apresentada pelo particular. Porém, nesse procedimento simplificado, não há propriamente decisão da Administração. O particular não tem um ato de autoridade chancelando a sua atividade. Já os terceiros interessados não dispõem propriamente de um ato de autoridade contra o qual possam eventualmente se voltar. Verifica-se, assim, eventual risco de degradação da proteção dos administrados nesse procedimento simplificado.

c) controles que substituem controles públicos preventivos cujos resultados são relevantes num procedimento administrativo de autorização:

Trata-se de transferir aos particulares a execução de determinadas tarefas de controle preventivo que são empregadas para instruir determinada decisão administrativa, proferida após a Administração ter conhecimento dos resultados do controle realizado previamente. Consiste em uma forma de privatização de uma parcela da instrução do processo administrativo. Pode haver a transferência a particulares também de controles sucessivos: instituições acreditadas emitem um certificado de conformidade da atividade em funcionamento, o qual deve ser entregue às entidades públicas periodicamente. Em qualquer caso, a responsabilidade pela fiscalização não deixa de ser da Administração.

${ }^{829}$ Norma Brasileira ABNT NBR ISO/IEC 17000, de 31.10.2005. 
produto, processo ou serviço, é assinado um termo contratual entre a empresa interessada e o Organismo Acreditado, pelo qual se concede a licença para uso do selo de identificação da conformidade. Durante o período de vigência do instrumento contratual que concede a licença de uso, são desenvolvidas ações de acompanhamento e controle do preenchimento dos requisitos necessários para a certificação.

No caso de inspeção, uma vez comprovada a regularidade do bem ou da instalação, o Organismo Acreditado fornece um certificado ao proprietário. A detenção de tal certificado é obrigatória nas hipóteses de inspeção compulsória. Nesse caso, de acordo com art. $4^{\circ}$ da Lei n ${ }^{\circ}$ 9.933/99, a certificação deverá ser emitida por entidade pública.

Todos os Organismos que participam das atividades de avaliação devem ser acreditados pelo INMETRO, que é o único ente acreditador reconhecido pelo Sistema Nacional de Metrologia, Normalização e Qualidade Industrial (SINMETRO).

Reputamos que seria possível o desenvolvimento de atividades mais amplas pelos particulares em relação à metrologia e à avaliação da conformidade compulsória, não se restringindo às atividades acessórias. Existe a possibilidade de prévia programação dos atos de avaliação da conformidade com elevado grau de objetividade, estabelecendo-se critérios e procedimentos a serem observados. Porém, houve a expressa opção do legislador no sentido de que diversas das atividades poderão ser exercidas apenas por entidades com personalidade jurídica de direito público.

\subsubsection{A prévia acreditação das entidades privadas que exercem a função de controle}

Em diversos ordenamentos jurídicos, tal como o brasileiro, exige-se a prévia acreditação $^{830}$ da entidade privada que desempenha funções de avaliação da conformidade com independência em relação ao fornecedor e ao cliente ${ }^{831}$.

As entidades que solicitam a obtenção da acreditação para atuar como organismos de controle devem demonstrar o preenchimento de uma série de requisitos para o seu deferimento. Com a acreditação, uma entidade reconhece a competência técnica de um agente para desempenhar as atividades de avaliação da conformidade ${ }^{832}$.

\footnotetext{
830 “A acreditação é o reconhecimento formal, concedido por um organismo autorizado, de que a entidade foi avaliada, segundo guias e normas nacionais e internacionais e tem competência técnica e gerencial para realizar tarefas específicas de avaliação da conformidade de terceira parte” (INMETRO, Livreto de Avaliação da Conformidade, Diretoria da Qualidade, 5. ed., maio de 2007, p. 39).

${ }^{831}$ É a denominada avaliação da conformidade por "terceira parte".

${ }^{832}$ Anteriormente, utilizava-se o termo "credenciamento" para expressar o reconhecimento de competência de organismos de avaliação da conformidade no âmbito do Sistema Brasileiro de Avaliação da Conformidade. A Resolução CONMETRO n ${ }^{\circ}$ 5, de 10.12.2003, determinou a sua substituição pelo termo acreditação, tendo em vista que o credenciamento é utilizado para diversas outras finalidades (sobre o credenciamento, v. item II.3.8).
} 
No direito comunitário europeu, por exemplo, para obter a autorização administrativa para desempenhar funções de controle, os organismos privados devem providenciar previamente a acreditação, que é expedida por outra entidade privada. As entidades de acreditação não têm fins lucrativos e atestam formalmente, de acordo com as regras nacionais e internacionais, a competência técnica da entidade que pretende atuar como organismo de controle.

Outro mecanismo que vem sendo amplamente utilizado na Europa é a designação de organismos. Trata-se de indicar determinado organismo para a realização da atividade de avaliação da conformidade, considerando o seu notório saber e competência, que o diferenciam dos demais. A designação é utilizada quando não há tempo hábil para a acreditação de entidades e há urgência na implantação do programa de avaliação da conformidade. Pode ser o mecanismo adequado também para as hipóteses em que se faz necessário restringir a quantidade de organismos que atuam em determinado programa de avaliação da conformidade, em razão das especificidades do produto, processo ou serviço.

No direito nacional, o único organismo acreditador oficial é o Instituto Nacional de Metrologia, Qualidade e Tecnologia - INMETRO ${ }^{833}$, de natureza autárquica. Portanto, a atividade de acreditação é desenvolvida exclusivamente por uma entidade pública.

No entanto, há debates acerca da natureza essencialmente pública da acreditação.

Para uma corrente doutrinária, trata-se de função pública. A valoração técnica de uma entidade para exercer atividade de controle consistiria no exercício de uma função pública. É o que sustenta, por exemplo, Manuel Izquierdo Carrasco ${ }^{834}$. No que diz respeito à competência técnica, é a entidade de acreditação que decidirá se foram preenchidos ou não os requisitos para o exercício da atividade de controle. A Administração encontra-se vinculada à decisão da entidade de acreditação.

Já para Dolors Canals I Ametller, se a acreditação tiver por objetivo apenas atestar a capacidade técnica da entidade, sendo necessário ainda um ato de autorização ou de delegação, emitido pela Administração, para conferir efeitos jurídicos à atuação da entidade acreditada, tratar-se-ia de atividade privada. Assim se passa porque a validade e

\footnotetext{
${ }^{833}$ Lei $n^{\circ} 9.933 / 99$, art. $3^{\circ}$, inc. VI.

${ }^{834}$ Algunas cuestiones generales a propósito del ejercicio privado en el ámbito de la seguridad industrial, 2001, p. 383.
} 
eficácia dos atos da entidade acreditada decorreriam da autorização ou delegação pública e não da acreditação. A acreditação por si só teria efeitos estritamente privados ${ }^{835}$.

De acordo com esse entendimento, a acreditação privada, realizada por uma entidade de acreditação sem substituir integralmente as funções da Administração, não consistiria no exercício privado de função pública e não implicaria o exercício de autoridade pública. Continuaria sendo necessária a intervenção da Administração para o organismo acreditado exercer as funções de controle, mediante a verificação do preenchimento de outros requisitos. Nesse contexto, a acreditação tratar-se-ia de atividade privada, de cunho técnico.

No entanto, reputamos que a acreditação tem natureza pública à medida que consiste no mecanismo utilizado para a comprovação do preenchimento de determinados requisitos para que uma entidade exerça uma função pública. Cabe exclusivamente à Administração delegar o exercício de poderes públicos, mediante a constatação do preenchimento dos requisitos pela entidade privada que pretende desempenhar essa função. Essa atividade de verificação da presença dos requisitos - que se aproxima da "habilitação" ou “qualificação” nos processos de contratações administrativas - têm natureza pública.

7.7.8. Os programas de avaliação da conformidade compulsórios

Determinados produtos ou atividades submetem-se a programas de avaliação da conformidade compulsória. A submissão compulsória à avaliação da conformidade aplica-se aos casos em que o produto, processo ou serviço oferecem riscos ou quando o seu desempenho inadequado é apto a acarretar prejuízos à sociedade ${ }^{836}$.

Os programas compulsórios são regidos por regulamentos técnicos. Como já se analisou, os regulamentos técnicos consistem em normas técnicas de observância obrigatória, incorporadas pelo direito estatal.

\subsubsection{Os programas de avaliação da conformidade voluntários}

Todos os produtos e serviços que não estão incluídos em programas de avaliação da conformidade compulsórios podem se submeter a programas voluntários.

\footnotetext{
${ }^{835}$ El ejercicio por particulares de funciones de autoridad, 2003, p. 149. A autora ressalva que, quando os efeitos da atuação privada implicam a substituição da certificação ou homologação administrativa e produzem os mesmos efeitos destas, há o exercício privado de funções públicas (ob. cit., p. 155).

${ }^{836}$ São exemplos de produtos que se submetem a programas de avaliação da conformidade compulsória: botijão de GLP, extintor de incêndio, brinquedo, fios e cabos elétricos de até $750 \mathrm{~V}$ e dispositivo de retenção para crianças.
} 
A avaliação voluntária é realizada por iniciativa do fornecedor. O que motiva a realização da avaliação nesse caso é o valor agregado ao produto avaliado, representando uma importante vantagem competitiva no mercado ${ }^{837}$.

Os programas voluntários têm como documentos de referência normas técnicas estabelecidas de modo consensual, pelos próprios interessados, em sistema de autorregulação.

Há vários exemplos de programas de avaliação de conformidade voluntários, que contam com significativo reconhecimento social.

Um dos exemplos de programas de avaliação de conformidade voluntários consiste na certificação ambiental. Ainda que seja desenvolvida de modo voluntário, atribui-se grande relevância a essa certificação ${ }^{838}$.

A certificação ambiental atesta que determinado produto ou processo produtivo causa menor impacto ao ambiente em relação a produtos similares. Há várias certificações ambientais, com diversos níveis de adequação em termos de qualidade ambiental. A comprovação mais usual da certificação ocorre com o uso de um selo ou rótulo nos produtos e serviços.

Trata-se de certificação voluntária, cabendo ao produtor decidir livremente pela sua obtenção ou não. No entanto, a sua não obtenção pode implicar sérias barreiras e restrições para o comércio, especialmente no âmbito internacional. Por exemplo, é comum que para a exportação de determinados produtos, tal como a madeira, os compradores de países da Europa e dos Estados Unidos exijam a certificação de origem da matéria-prima, emitidas por entidades reconhecidas internacionalmente.

As normas ambientais voluntárias de âmbito internacional encontram-se previstas especialmente na Série ISO 14000. Para a obtenção desse certificado, a empresa deve implantar um Sistema de Gestão Ambiental, para reduzir o impacto ambiental durante todo o processo de produção.

\subsubsection{A atividade de certificação}

A certificação consiste em um ato declaratório que atesta determinadas qualidades de produtos, serviços, sistemas de gestão e pessoas ${ }^{839}$.

\footnotetext{
837 São exemplos de produtos que se submetem a programas de avaliação da conformidade voluntária: produtos de origem florestal, auditoria de sistema de gestão de qualidade e produtos orgânicos.

${ }^{838}$ Por exemplo, o art. $7^{\circ}$, inc. III, da Lei $\mathrm{n}^{\circ} 12.462 / 11$ ressalvou expressamente a possibilidade de se exigir a certificação da qualidade do produto ou do processo de fabricação sob o aspecto ambiental nas licitações para aquisição de bens realizadas no Regime Diferenciado de Contratações Públicas - RDC.

${ }^{839}$ Encontram-se na doutrina estrangeira referências à atividade de certificação realizada por terceira parte ou independente, pela qual se afirma a conformidade de produtos e serviços às normas técnicas, como sendo a
} 
Extraem-se da Norma ABNT ISO/IEC 17000:2005 várias definições acerca da avaliação da conformidade.

A atestação é a "emissão de uma afirmação, baseada numa decisão feita após a análise crítica, de que o atendimento aos requisitos especificados foi demonstrado”. A certificação consiste em "atestação relativa a produtos, processos, sistemas ou pessoas por terceira parte”, ou seja, por pessoa ou organização independente daquele que fornece o objeto bem como do usuário do objeto.

A função de certificação tem assumido uma relevância cada vez maior. Basta constatar a grande quantidade de produtos e serviços que apresentam selos ou certificados, sendo que muitos deles devem ser obrigatoriamente apresentados pelo produtor ou prestador do serviço. Pode-se mencionar ainda a certificação digital, necessária para o reconhecimento da autenticidade daquele que pratica determinados atos através da rede mundial de computadores, que tem adquirido relevância cada vez maior diante da substituição dos meios físicos pelos eletrônicos para os mais diversos procedimentos.

\subsubsection{Objeto da atividade de certificação}

O objeto da certificação pode tanto consistir em produtos, processos ou serviços, sistemas de gestão e pessoal.

A certificação de um produto ou processo produtivo aplica-se apenas a esse objeto específico, não englobando outras atividades exercidas por aquela empresa.

Já a certificação de sistemas de gestão afere a conformidade do sistema adotado pela empresa em face de requisitos normativos. Essa certificação não tem por objeto aferir como determinado produto deve ser fabricado mas sim se os sistemas de gestão da organização propiciam a repetição de determinados resultados, que atendem a parâmetros previamente estabelecidos de qualidade, ambiental etc.

Uma das certificações mais conhecidas em termos de sistemas de gestão refere-se ao atendimento das exigências da ISO (International Organization for Standardization). Os critérios de avaliação mais utilizados são os aplicáveis aos sistemas de gestão da qualidade, certificados com base nas normas da série ISO 9001, e os sistemas de gestão ambiental, cerificados com base nas normas da série ISO 14001.

produção de “certezas privadas”, de modo a diferenciá-las da “certeza pública”, que corresponde àquela que resulta da atividade dos notários e registradores. O ponto em comum entre as duas atividades seria o objetivo de produção de “certezas”, para propiciar a segurança e confiança necessárias para as relações jurídicas entre particulares. O tema é amplamente analisado na obra de Auretta Benedetti. Certezza pubblica e "certezze" private: poteri pubblici e certificazioni di mercato, 2010. 
Há outros sistemas de gestão passíveis de certificação, estabelecidos a partir da iniciativa de determinados setores, tais como o automobilístico e o de telecomunicações.

Por fim, a certificação de pessoal afere a formação e a experiência profissional, contrastando-as com determinados requisitos previamente estabelecidos. Há certificação voluntária de profissionais tais como agente de viagem, sommelier e chefe executivo de cozinha.

\subsubsection{Natureza da atividade de certificação}

A certificação não consiste necessariamente em uma atividade pública. O Estado pode assumir a certificação, organizando os sistemas e definindo as suas regras. Mas a atividade pode também ser desenvolvida na esfera privada, em sistema de autorregulação, pelos próprios interessados. Ainda que a atividade não seja assumida pelo Estado, usualmente submete-se à regulação estatal diante da relevância conferida às certificações privadas.

Pedro Gonçalves aponta que existem dois grandes tipos de sistemas de certificação $^{840}$.

Há os sistemas públicos, organizados e geridos pelo Estado ou pela entidade a quem delegar poderes para tanto. Em tais sistemas, há o exercício de funções públicas de certificação ou a delegação de funções ou poderes públicos a entidades privadas.

Existem também os sistemas privados, organizados e regulados pelo Estado mas que prestam atividades de certificação livremente, no sistema de mercado. Nos sistemas privados, os serviços são exercidos por entidades privadas, reconhecidas ou acreditadas pelo Estado para prestar tais serviços privados a terceiros, em regime de livre concorrência e sob regulação estatal. Com a intervenção estatal, assegura-se a objetividade das normas a serem observadas na atividade e a respeitabilidade das entidades responsáveis pela certificação.

No direito nacional, como já se indicou, convivem os dois sistemas de certificação, com a existência tanto de programas de avaliação compulsória quanto facultativa.

\subsubsection{Efeitos das certificações}

Os certificados emitidos no exercício de função pública, no âmbito dos programas de avaliação de conformidade compulsória, consistem em atos administrativos $^{841}$.

\footnotetext{
${ }^{840}$ Entidades privadas com poderes públicos, 2008, p. 212-213.
} 
As certificações são relevantes meios de prova, consistindo em documentos públicos que declaram conhecimentos de fatos. Disso decorre também que são passíveis dos mesmos meios de impugnação aplicáveis aos atos administrativos.

Isso não significa que o conteúdo das certificações deva sempre ser aceito. Se for constatada a inexatidão do seu conteúdo, cabe a declaração de nulidade. Pode haver também a retificação da certificação.

7.7.10.4. Exigência de certificação de produtos e serviços para fins de participação em licitações públicas

A lei pode também exigir a certificação para que sejam verificados determinados efeitos jurídicos. Passa-se a falar então na adesão à certificação como sendo um ônus do particular.

No regime da lei geral de licitações, é controvertida a legalidade da exigência de certificação de qualidade para que o licitante possa ofertar determinado produto à Administração.

Entre os argumentos contrários elencados, destaca-se a ausência de previsão expressa da exigência de certificação de produto ou processo de fabricação entre os requisitos de habilitação estipulados na Lei $n^{\circ}$ 8.666/93 $3^{842}$. Além disso, há o possível comprometimento da competitividade, à medida que o prazo para obter determinada certificação pode ser superior ao lapso temporal existente entre a publicação do edital e a data de entrega das propostas. A obtenção da certificação pode envolver também custos significativos, tanto para a certificação em si quanto para a adaptação necessária no processo produtivo, para dar atendimento aos requisitos. Não apresenta, portanto, amplo acesso a todos os interessados.

Por esses motivos, é perfeitamente plausível que exista uma grande quantidade de potenciais licitantes que não detêm a certificação mas que preenchem todos os requisitos necessários para a sua obtenção. Não seria possível, assim, restringir a

\footnotetext{
${ }^{841}$ Bartoméu Colom I Pastor. El certificado como acto y documento público, 1984, p. $233-238$.

${ }^{842} \mathrm{O}$ TCU tem reconhecido a ilegalidade de exigências de certificação estipuladas como requisitos de habilitação, pela ausência de previsão na Lei ${ }^{\circ}$ 8.666/93. Foi o que se decidiu, por exemplo, nos Acórdãos $n^{0}$ 1.292/2003 - Plenário, Rel. Min. Augusto Sherman Cavalcanti; $n^{\circ}$ 1.107/2006 - Plenário, Rel. Min. Marcos Vinicios Vilaça; e no 1.265/2009 - Plenário, rel. Min. Benjamin Zymler. Em alguns casos, o TCU admite a utilização de certificações não como exigência de habilitação mas como critério de pontuação da proposta técnica. Exemplos dessa orientação são as determinações do Acórdão nº 479/2004 - Plenário, e da Decisão n 351/2002 - Plenário.
} 
comprovação da sua habilitação para participar do certame a apenas um meio específico, a certificação ${ }^{843}$.

É o que consta, por exemplo, da Instrução Normativa no 1/2010 da Secretaria de Tecnologia e Logística da Informação - STLI, que dispõe sobre os critérios de sustentabilidade ambiental em contratações públicas. O seu art. $5^{\circ}, \S 1^{\circ}$, prevê que a comprovação do atendimento dos critérios de sustentabilidade ambiental poderá ser feita mediante a apresentação de certificação "ou por qualquer outro meio de prova que ateste que o bem fornecido cumpre com as exigências do edital”.

Cabe registrar ser possível detectar-se certa tendência de diplomas legais mais recentes de prever expressamente a possibilidade de se exigirem certificações de qualidade como requisito de habilitação dos licitantes. Com isso, possibilita-se a superação da falta de amparo legal para a exigência de certificação.

É o que se verifica em relação à Lei ${ }^{0} 12.232 / 10$, que trata das licitações para contratação de serviço de publicidade, que no seu art. $4^{\circ}$ dispõe que apenas poderão ser contratadas as empresas às quais tenha sido concedido o "certificado de qualificação técnica de funcionamento”. O Decreto $n^{\circ} 7.174 / 10$, que dispõe sobre a licitação de bens e serviços de informática, também prevê a exigência de certificações como requisito de habilitação (art. $3^{\circ}$, inc. II). O Decreto $n^{\circ} 7.746 / 12$, que regulamenta o art. $3^{\circ}$ da Lei $n^{\circ}$ 8.666/93 e estabelece critérios, práticas e diretrizes para a promoção do desenvolvimento nacional sustentável nas contratações realizadas pela Administração, prevê que a comprovação da adoção de práticas de sustentabilidade poderá ser feita mediante a apresentação de certificação (art. $8^{\circ}$ ).

A Lei $\mathrm{n}^{0}$ 12.462/11, que dispõe sobre o Regime Diferenciado de Contratações Públicas (RDC), no seu art. $7^{\circ}$, III, também permite que se exija nas licitações para compras “a certificação da qualidade do produto ou do processo de fabricação, inclusive sob o aspecto ambiental, por qualquer instituição oficial competente ou por entidade credenciada".

Importa destacar que requisitos no sentido de apresentação de certificações apresentam possível efeito restritivo à competição. São aptos a reduzir o universo de potenciais interessados em participar do certame. Por esse motivo, a despeito da existência

\footnotetext{
${ }^{843}$ Marçal Justen Filho, por exemplo, reputa que, na sistemática da Lei ${ }^{\circ}$ 8.666/93, é possível que o instrumento convocatório preveja a apresentação de certificações para fins de habilitação. No entanto, aqueles que não detêm a certificação não podem ser proibidos de participar do certame. Deve ser-lhes facultada a comprovação da habilitação por outros meios (Comentários à lei de licitações e contratos administrativos, 2012, p. 534).
} 
de previsão legal específica nesses casos, o requisito de certificação do objeto proposto pelo licitante não pode ser estipulado pela Administração em qualquer caso.

A obtenção de certificações usualmente implica gastos significativos, sejam os custos diretos da certificação em si sejam aqueles necessários para a observância dos requisitos exigidos para a atividade produtiva para a obtenção da certificação. Há também a necessidade de determinado lapso temporal para obter a certificação, quase sempre superior ao interregno entre a publicação do edital e a data para apresentação das propostas.

A exigência de apresentação de certificação apresenta também algumas vantagens. Uma delas consiste na dispensa da apresentação de amostras e realização de exames, à medida que a “certificação gera presunção absoluta de satisfatoriedade do produto" ${ }^{844}$. Propicia também a simplificação dos atos licitatórios, abreviando a fase de verificação da aceitabilidade do objeto proposto pelo licitante.

Por isso, deve-se considerar que esses diplomas legais autorizam a exigência de certificações pela Administração apenas em caráter excepcional. Somente uma quantidade reduzida de produtos e processos detém a certificação. A sua exigência implica a restrição do universo de potenciais licitantes.

$\mathrm{Na}$ fase interna da licitação, deve ser demonstrado o benefício que o requisito propicia para a Administração em termos de segurança para a futura contratação $^{845}$. Como ensina Marçal Justen Filho, “a exigência da certificação é admissível nos casos em que as características da contratação impõem requisitos diferenciados e exacerbados relativamente à qualidade do objeto ou do processo de fabricação" ${ }^{846}$. Em casos de produtos que apresentam maior complexidade técnica e cujo mau funcionamento é passível de acarretar graves danos, a certificação consiste em um dos mecanismos mais adequados para a Administração assegurar-se da sua qualidade e aptidão para a satisfação das necessidades coletivas.

\subsubsection{Proteção das indicações geográficas}

Uma das aplicações das atividades de certificação de produtos e serviços vincula-se às indicações geográficas. Consistem em indicações utilizadas para distinguir produtos ou serviços.

Trata-se de sistema voluntário de certificação, que tem recebido significativo estímulo estatal para a adesão pelos interessados. É interessante analisar mais detidamente o

\footnotetext{
${ }^{844}$ Marçal Justen Filho. Comentários ao RDC, 2013, p. 143-144.

${ }^{845}$ Em relação ao RDC, a necessidade de justificativa para a exigência de certificação de qualidade do produto ou do processo de fabricação consta expressamente do Decreto n ${ }^{\circ} 7.581 / 11$, art. $4^{\circ}$, inc. IV, “d”.

${ }^{846}$ Comentários ao RDC, 2013, p. 145.
} 
sistema de proteção das indicações geográficas por evidenciar a relevância das funções atribuídas à autorregulação para fins de certificação. Ainda que a utilização da certificação dependa da intervenção estatal, que realiza o registro de propriedade industrial, os próprios interessados, organizados em entidades representativas, desempenham papel fundamental nessas certificações.

O sistema comunitário europeu de proteção das referências geográficas de produtos agrícolas e de gêneros alimentícios é bastante desenvolvido.

No âmbito da União Europeia, foi organizado um sistema para a proteção das referências geográficas, o Registro das Denominações de Origem e das Indicações Geográficas Protegidas, que é gerido pela Comissão. Para se beneficiar de tais indicações, os produtos devem atender a determinadas especificações. O agrupamento de produtores deve apresentar um pedido de registro e, se estiverem presentes os requisitos, será deferido pela Comissão ${ }^{847}$.

Trata-se de mecanismo bastante utilizado especialmente em países europeus para a identificação e individualização de determinados produtos, tais como vinhos e queijos. Apresentam elevada importância sócio-econômica, conferindo maior valor agregado aos produtos e serviços certificados. Incentiva também a realização de investimentos na área delimitada pela indicação geográfica.

Em relação à indicação geográfica, apesar de a certificação ser voluntária, constatou-se, especialmente nos países europeus, que ela acabou se tornando “obrigatória de fato” em relação a determinados produtos. Assim se passa quando o mercado e os consumidores passam a exigir a certificação e dão preferência aos produtos que a detêm.

No direito nacional, as indicações geográficas consistem em certificações protegidas como propriedade industrial, nos termos previstos na Lei $n^{\circ}$ 9.279/96, arts. 176 a $182^{848}$.

As indicações geográficas (IGs) de produtos são divididas em duas categorias, a indicação de procedência e a denominação de origem.

A indicação de procedência (IP) consiste em um nome geográfico de país, cidade, região ou localidade, que seja reconhecido como centro de produção, extração ou

\footnotetext{
${ }^{847}$ Sobre o tema, consulte-se Martina Conticelli. Il procedimento europeo di registrazione dele denominazioni di origine protetta, 2004, p. 317-345.

${ }^{848}$ A proteção das indicações geográficas é amparada também nos arts. 22 a 24 do Acordo sobre Aspectos dos Direitos de Propriedade Intelectual Relacionados ao Comércio - TRIPS, Anexo 1C do Acordo Constitutivo da Organização Mundial do Comércio - OMC. Esse acordo foi ratificado pelo Brasil através do Decreto $\mathrm{n}^{\circ}$ 1.355/94, que promulgou a Ata final que incorpora os resultados da Rodada Uruguai das Negociações Comerciais Multilaterais do GATT.
} 
fabricação de determinado produto ou prestação de certo serviço. Diz respeito à reputação ou notoriedade do local em relação àquele produto ou serviço.

A denominação de origem (DO) consiste em um nome geográfico de país, cidade, região ou localidade que identifica determinado produto ou serviço que apresentem determinados aspectos qualitativos ou características que sejam devidos exclusiva ou essencialmente ao meio geográfico, abrangendo fatores naturais e humanos.

As denominações de origem diferenciam-se das simples indicações de procedência geográficas protegidas, à medida que apenas as primeiras comprovam o atendimento a características especiais de produção, observando procedimentos de elaboração e criação específicos, típicos e diferenciados ${ }^{849}$. Para a obtenção da denominação de origem, além de se encontrar estabelecido no local, é necessário comprovar o atendimento de determinados requisitos qualitativos ${ }^{850}$.

Portanto, a denominação de origem representa também uma garantia acerca da qualidade do produto. A sua produção deve observar determinadas práticas, que o tornam qualitativamente diferenciado em relação a outros produtos.

Com a utilização da denominação de origem, procura-se evitar práticas de concorrência desleal, tais como de imitação fraudulenta ou de aproveitamento indevido da reputação de uma marca coletiva geográfica. Insere-se nos mecanismos de proteção à propriedade industrial.

No direito nacional, a indicação geográfica consiste em um registro de propriedade industrial. Cabe à Administração realizar esse registro, através do INPI, mediante apresentação de requerimento pelo interessado.

No entanto, a proteção da indicação geográfica encontra-se estritamente vinculada à autorregulação de produtores ou prestadores de serviços. Uma importante etapa do processo de registro depende da atuação de particulares, que exercem o controle sobre a utilização de indicações geográficas pelos produtores locais.

O registro é de uso coletivo e restrito aos produtores e prestadores de serviços locais, devendo ser solicitado pela entidade representativa do setor. Essa entidade representativa deve elaborar as normas de produção e controlar a sua aplicação (geralmente por meio de um órgão denominado “conselho regulador”), de modo que sejam autorizados

\footnotetext{
${ }^{849}$ Carlos Coello Martín e Fernando González Botija. Sobre el carácter declarativo del reconocimiento de una denominación de origen, 2008, p. 250.

${ }^{850}$ É o que consta do art. 182 da Lei $n^{\circ}$ 9.279/96: “O uso da indicação geográfica é restrito aos produtores e prestadores de serviço estabelecidos no local, exigindo-se, ainda, em relação às denominações de origem, o atendimento de requisitos de qualidade".
} 
a utilizar a certificação apenas aqueles que comprovem efetivamente observar as normas aplicáveis à indicação geográfica regulamentada. O produtor que pretender utilizar a certificação de indicação geográfica deverá observar as regras da entidade de produtores que obteve o registro e regula o seu uso. Trata-se de certificação de caráter voluntário, não havendo imposição do seu uso aos produtores de determinada região.

Um dos requisitos a serem observados no requerimento de registro da indicação geográfica a ser submetido ao INPI consiste na comprovação da existência de normas de produção e de uma estrutura de controle sobre os produtores ou prestadores de serviços que tenham o direito ao uso exclusivo da indicação de procedência ou da denominação de origem, bem como sobre o produto ou serviço distinguido com a indicação de procedência ou denominação de origem ${ }^{851}$. Deve também comprovar encontrar-se estabelecido na área geográfica demarcada, exercendo efetivamente as atividades de produção ou prestação de serviços.

Logo, para a solicitação do registro da indicação geográfica, os produtores devem previamente se organizar em entidades específicas. A organização dos produtores em sistema de autorregulação consiste em um dos principais fatores para a obtenção do registro e a utilização de uma indicação geográfica.

\subsubsection{Inspeção e vistoria veicular}

A inspeção e a vistoria veicular também consistem em instrumentos de avaliação da conformidade em sentido amplo, ainda que não sejam propriamente desenvolvidas no âmbito do Sistema Brasileiro de Avaliação da Conformidade. Trata-se da verificação e julgamento do cumprimento de determinados requisitos, com o emprego de medições, ensaios ou calibres.

\subsubsection{A inspeção veicular}

Para circular na via pública, o veículo deve ter sido aprovado em inspeção veicular $^{852}$. O art. 104 do CTB disciplina a inspeção, prevendo a medida de retenção aos veículos que não forem aprovados.

Apesar da previsão legal, o Brasil ainda dispõe de poucos programas de controle de segurança veicular e de emissão de poluentes.

Nos termos da Resolução CONAMA n ${ }^{0}$ 256/99, a implementação dos Programas de Inspeção e Manutenção para Veículos Automotores em Uso é de

\footnotetext{
${ }^{851}$ Instrução normativa n ${ }^{\circ}$ 25/13 do INPI, art. 8 , "b” e “c”, e art. 9 , “c” e “d”.

${ }^{852}$ Lei n $^{\circ} 9.503 / 97$ - CTB, art. 131, §3º.
} 
responsabilidade dos órgãos ambientais estaduais e municipais. A Lei $n^{0}$ 10.203/01 facultou aos municípios com frota total igual ou superior a três milhões de veículos a implantação de programas próprios de inspeção periódica de emissões, a serem alinhados com os futuros programas de inspeção de segurança veicular ${ }^{853}$.

Faz-se necessária, assim, a edição de leis específicas pelos Municípios que pretendam implantar seus programas de inspeção veicular ${ }^{854}$.

\subsubsection{A vistoria veicular}

A vistoria de veículos encontra-se prevista no art. 22, inc. III, do CTB e é regulamentada por atos dos órgãos de trânsito. O referido dispositivo atribui a sua execução aos órgãos ou entidades executivos de trânsito dos Estados e do Distrito Federal, no âmbito de sua circunscrição.

A Resolução nº 005/98, do CONTRAN, dispõe sobre a vistoria de veículos. Prevê que "serão realizadas por ocasião da transferência de propriedade ou de domicilio intermunicipal ou interestadual do proprietário do veículo, ou qualquer alteração de suas caraterísticas” (art. $1^{\circ}$ ). Os objetivos visados com a realização das vistorias são os de constatação da autenticidade da identificação do veículo e da documentação, legitimidade da propriedade, disponibilização dos equipamentos obrigatórios e eventuais alterações das características originais dos veículos.

A Resolução $n^{\circ}$ 282/08, do CONTRAN, especifica os dados a serem coletados por ocasião da realização de vistorias de regularização e transferência de veículos.

\subsubsection{Os mecanismos de delegação}

Para a prestação dos serviços de implantação e operação dos centros de inspeção, os modelos utilizados com maior frequência são o de concessão e o de credenciamento de empresas ${ }^{855}$.

\footnotetext{
${ }^{853}$ É importante registrar haver divergências quanto à competência para regulação e implantação da inspeção veicular. Para uma corrente, a competência para editar normas gerais (de titularidade da União - CF/88, art. 22, inc. XI) poderia ser dissociada da competência para edição de outros atos regulatórios necessários e implementação dos programas. Em sentido contrário, Floriano de Azevedo Marques Neto sustenta o seguinte: "Se compete à União legislar exclusivamente sobre trânsito e transporte, deve competir-lhe também adotar as medidas consistentes em regulamentar (editar normas infralegais, outorgar, planejar, fixar metas e tarifas bem como fiscalizar a execução do programa, podendo, em alguns casos, delegar atividades aos Estados e Municípios)" (Aspectos jurídicos enredados na implantação do programa de inspeção veicular, 2001, p. 184). Em alguma medida, a Lei ${ }^{\circ} 10.203 / 01$ reconheceu a competência da União ao autorizar expressamente que Estados e Municípios estabeleçam os seus programas de inspeção, os quais deverão ser harmonizados com o futuro programa de inspeção de segurança veicular a ser implementado pelo Governo Federal.

${ }^{854}$ No Município de São Paulo, o Programa de Inspeção Ambiental Veicular foi instituído pela Lei municipal $\mathrm{n}^{\circ} 11.733 / 95$ e regulamentado pelo Decreto municipal $n^{\circ}$ 50.232/08.
} 
A Portaria $n^{0}$ 131/08 do DENATRAN estabelece os requisitos para credenciamento, instalação e funcionamento de Empresas Credenciadas em Vistoria de Veículos - ECV, para a prestação de serviços de vistoria. Para a obtenção do credenciamento, o interessado deverá comprovar a habilitação jurídica, regularidade fiscal e qualificação técnica, de acordo com os requisitos previstos no regulamento.

Há previsão específica quanto à exigência de que as empresas credenciadas atuem com exclusividade no mercado de vistorias, de modo a evitar possíveis conflitos de interesse no desenvolvimento das atividades ${ }^{856}$.

\subsubsection{A admissibilidade da delegação da atividade de inspeção e vistoria veicular}

A identificação do exercício de poderes públicos por particulares que prestam os serviços de inspeção e vistoria veicular depende das atividades que são efetivamente desempenhadas. Existe a possibilidade de haver participação privada nas atividades de inspeção e vistoria veicular, com atribuições variadas.

O veículo poderá ser aprovado ou reprovado na inspeção e vistoria. Na hipótese de aprovação, são expedidos o selo, de uso obrigatório ${ }^{857}$, e o Certificado de Aprovação do Veículo, do qual constam os itens inspecionados e os respectivos resultados.

No caso de rejeição, o veículo deverá ser reparado nos itens rejeitados e submeter-se a nova inspeção e vistoria. Os veículos que não se submeterem à inspeção e vistoria ou que forem reprovados sujeitam-se à retenção ${ }^{858}$ e não poderão obter o licenciamento anual ${ }^{859}$.

As empresas de inspeção e vistoria são responsáveis pelas informações constantes do laudo de inspeção por elas emitido, com exceção das informações oriundas dos bancos de dados oficiais ${ }^{860}$.

Se a aprovação ou reprovação do veículo for realizada diretamente pelo particular delegatário, produzindo efeitos imediatos na esfera jurídica do proprietário do veículo, há de se reconhecer o exercício privado de poderes públicos. O resultado da

${ }^{855}$ Esses são os modelos previstos, por exemplo, para o Município de São Paulo (Lei municipal nº 11.733/95, arts. $3^{\circ}$ e $\left.3^{\circ} \mathrm{A}\right)$.

${ }_{856}^{8}$ Resolução CONTRAN n ${ }^{\circ} 282 / 08$, art. $1^{\circ}, \S 2^{\circ}$.

${ }^{857}$ Lei n ${ }^{\circ} 9.503 / 97$, art. 230, inc. I; Resolução CONTRAN n $22 / 98$, art. $1^{\circ}$.

${ }^{858}$ Lei $n^{\circ} 9.503 / 97$, art. 104, $\S 5^{\circ}$.

${ }^{859}$ Lei $n^{\circ}$ 9.503/97, art. 124, inc. XI; Resolução CONAMA n ${ }^{\circ}$ 256/99, art. $1^{\text {o }}$; Resolução CONAMA $n^{\circ}$ 418/09, art. 20.

${ }^{860}$ Portaria ${ }^{\circ}$ 131/08 do DENATRAN, art. $3^{\circ}$. O art. 12, inc. V, da Portaria estipula, entre os requisitos para a obtenção do credenciamento, a apresentação de "prova de regular contratação de seguro de responsabilidade civil em razão da atividade desenvolvida, com importância segurada de no mínimo R\$ 300.000,00 (trezentos mil reais), para eventual cobertura de danos causados a terceiros, devendo a ECV promover a recomposição do valor, sistematicamente”. 
inspeção produz efeitos vinculantes. Nesse caso, todo o processo de inspeção, até a aprovação ou reprovação do veículo, é conduzido no âmbito do próprio centro de inspeção, sem influência externa ${ }^{861}$.

Nesses casos, a inspeção técnica de veículos não se resume a uma simples verificação de um produto industrial. A inspeção objetiva a obtenção pelo particular proprietário do veículo de certificado de exibição obrigatória, que o habilita a utilizar o veículo. Logo, essa atividade tem natureza autorizativa, no sentido de autorizar a circulação de determinado veículo, e vincula a própria Administração. Por um lado, os agentes de fiscalização deverão aceitar a regularidade do veículo se o certificado for exibido e, por outro, se o condutor não exibir o certificado, o veículo deverá ser retido. Trata-se então de exercício de função pública por particulares ${ }^{862}$.

Já na hipótese de o ato de aprovação ou reprovação do veículo e da emissão dos respectivos certificado e selo ser realizada pela própria Administração, as atividades exercidas pelo particular consistem em atos preparatórios, de conteúdo técnico, de decisão a ser adotada pela Administração ${ }^{863}$.

No entanto, é relevante analisar se a Administração procede a uma recepção controlada dos dados das vistorias e inspeções realizadas pelos particulares, de modo a conferir os resultados para então proferir a decisão quanto à aprovação ou reprovação do veículo. Se houver uma vinculação, em termos fáticos, do resultado da inspeção à decisão a ser adotada pela Administração, de modo que seja sempre acatada a conclusão do laudo produzido pelo particular ${ }^{864}$, há de se reconhecer que as atividades realizadas pelos particulares não consistem apenas em simples atividades materiais. Ainda que essa circunstância não implique a atribuição da decisão de aprovação ou reprovação do veículo ao particular, isso demanda o reforço do controle a ser exercido sobre as atividades dos particulares.

\footnotetext{
${ }^{861}$ Isso não impede que essa decisão seja objeto de posterior controle pela Administração mediante, por exemplo, a interposição de recurso administrativo pelo usuário prejudicado.

${ }^{862}$ Dolors Canals I Ametller. El ejercicio por particulares de funciones de autoridad, 2003, p. 167-169.

${ }^{863}$ No sistema de inspeção veicular adotado no Município de São Paulo, a certificação é emitida pela Administração e fornecida pelo concessionário do serviço. É o que prevê o art. $5^{\circ}$ do Decreto municipal $\mathrm{n}^{\circ}$ 50.232/08: “A aprovação na inspeção realizada no âmbito do Programa I/M-SP será atestada por meio de certificado e de selo emitidos pela Secretaria Municipal do Verde e do Meio Ambiente e fornecidos pela concessionária dos serviços de inspeção.”

${ }^{864}$ Por exemplo, se o certificado de inspeção for automaticamente emitido pela Administração, a partir da informação enviada pelo centro de inspeção de que o veículo foi aprovado na vistoria.
} 


\subsubsection{O entendimento do STF}

Há precedente do STF acerca da possibilidade de delegação das atividades de inspeção veicular, proferido ao julgar ADI ajuizada contra dispositivos de lei do Rio Grande do Sul. Na sistemática prevista na legislação daquele estado, cabe ao delegatário não apenas realizar a inspeção em si mas também, ao final, emitir o atestado de inspeção técnica contendo os resultados obtidos ${ }^{865}$. É com base nesse relatório que a autoridade competente concederá ou não o licenciamento do veículo. Há de se reconhecer que o conteúdo do relatório de inspeção será determinante para o posterior licenciamento do veículo.

No julgamento da ADI $n^{0} 1.666-2^{866}$, o STF deferiu cautelar adotando a premissa de que o DETRAN não poderia delegar o exercício do poder de polícia. No entanto, autorizou expressamente a transferência de determinadas atividades, tal como a inspeção veicular.

\subsection{A atividade de registro e de declaração que produz efeito de certeza pública ou que é dotada de força probatória especial}

No contexto do exercício de atividades de polícia administrativa, podem ser analisadas também as atividades de registro e de declaração que produzem efeito de certeza pública ou que são dotadas de força probatória especial. Ainda que a integração dessas atividades na polícia administrativa possa ser questionada, a sua proximidade com o tema do presente estudo, especialmente no que diz respeito ao exercício de poderes públicos por particulares, recomenda o seu exame conjunto.

Um documento privado não faz plena prova por si só. A força probatória especial é própria apenas do ato público ${ }^{867}$.

Os atos declaratórios com a função de dar certeza de fatos juridicamente relevantes consistem em instrumentos de verificação de certeza propiciados pelo ordenamento jurídico, diante da impossibilidade de o homem ter conhecimento da verdade absoluta em todo e qualquer caso.

Diz-se que o ato é de certeza legal quando contém uma declaração de certeza que deve ser recebida por todos como tal ${ }^{868}$. Todos têm o dever jurídico de assumir como verdadeiro o fato declarado, até que se produza prova contrária. A certeza legal apenas

\footnotetext{
${ }^{865}$ Lei estadual 10.848/96, art. 15.

${ }^{866}$ Rel. Min. Carlos Velloso, Pleno, j. 16.6.1999, v.u., DJ 27.2.2004.

${ }^{867}$ Guido Zanobini. Corso di diritto amministrativo, v. V, 1952, p. 180.

${ }^{868}$ Rocco Galli. Corso di diritto amministrativo, 1996, p. 667.
} 
pode ser produzida por autoridades, nos casos expressamente previstos em lei. São espécies de atos de certeza legal, entre outras, as certificações, notificações e registros realizados por ofícios públicos.

Está compreendida nessa atividade a redação de atos que são dotados de força probatória especial, em relação aos quais recai a presunção de veracidade até prova em contrário, em razão da fé pública reconhecida aos atos praticados por determinados sujeitos. Por essa razão, esses documentos são dotados de força probatória reforçada. Em acréscimo a isso, o ato público desempenha outra função, que é a de controle acerca da legitimidade do ato jurídico. Como se analisa adiante, cabe ao notário verificar o preenchimento pelo ato dos requisitos legais.

A publicidade de atos jurídicos é um dos serviços mais importantes prestados pela Administração aos particulares para a regular constituição e o desenvolvimento pacífico das suas relações. Procura, assim, propiciar a máxima certeza e garantia aos direitos privados. Trata-se de “garantir a segurança jurídica no tráfego jurídico ordinário”869.

O registro não tem apenas função probatória. Em alguns casos, pode ser constitutivo. Quando a lei impõe o registro como requisito para a própria existência do negócio, serve para dar existência ao negócio apresentando, portanto, efeito constitutivo ${ }^{870}$.

No direito nacional, essas atividades que produzem efeito de certeza pública ou são dotadas de força probatória especial correspondem especialmente àqueles desempenhadas por notários e registradores.

As certificações, analisadas anteriormente, também são dotadas de força probatória especial. No entanto, apresentam uma estabilidade mais frágil em relação aos atos produzidos por notários e registradores. Há constante verificação da manutenção dos requisitos necessários para a obtenção das certificações. Podem ser realizados novos ensaios e verificações, cujo resultado é passível de infirmar o teor expresso na certificação anteriormente expedida. Já em relação às atividades de notários e registradores, como se analisa adiante, a desconstituição dos registros, como regra geral, depende da intervenção do Judiciário. Por esse motivo, optou-se pelo exame em separado dessas duas categorias de atos que são dotados de força probatória especial.

\footnotetext{
${ }^{869}$ Dolors Canals I Ametller. El ejercicio por particulares de funciones de autoridad, 2003, p. 238.

${ }^{870}$ Guido Zanobini. Corso di diritto amministrativo, v. V, 1952, p. 182-183.
} 


\subsubsection{Atividade notarial e de registro}

O art. 236 da CF/88 estabelece no seu caput que "os serviços notariais e de registro são exercidos em caráter privado, por delegação do Poder Público”. O $\S 3^{\circ}$ do mesmo dispositivo determina que "o ingresso na atividade notarial e de registro depende de concurso público de provas e títulos”.

A delegação para o exercício das atividades notariais e de registro é concretizada por ato administrativo, praticado com fundamento na disposição constitucional. É necessária a investidura na função pública após a aprovação no concurso público.

As atividades notariais e de registro objetivam propiciar especial proteção às relações entre particulares, conferindo publicidade, autenticidade, segurança e eficácia a atos jurídicos. Com a intervenção dos notários e registradores, as relações entre os particulares revestem-se da forma jurídica adequada, de modo que possam produzir os efeitos desejados.

Os serviços notariais consistem na redação, formalização e autenticação, com fé pública, de instrumentos contendo declarações de interesse dos solicitantes. Atribui certeza jurídica a atos de interesse dos particulares. Os serviços de registro destinam-se ao assentamento de títulos, públicos ou privados, para fins de publicidade e oponibilidade a terceiros.

A fé pública é da essência da função dos notários e registradores ${ }^{871}$. Produz a presunção legal de autenticidade e veracidade dos atos praticados por aqueles que exercem função pública.

A atribuição de certeza e segurança a determinados atos corresponde a uma exigência das relações entre particulares. Para o desenvolvimento das relações sociais e comerciais, fez-se necessária a instituição de mecanismos que propiciem a confiança e segurança em relação a determinado ato ou fato. A certeza propiciada pela intervenção dos notários e registradores prevalece até prova em contrário. Trata-se de presunção de veracidade relativa (iuris tantum), havendo a possibilidade de invalidação dos registros, uma vez constatada a sua nulidade, por pronunciamento judicial.

Outro aspecto da atividade notarial e de registro é a incumbência atribuída pela lei de fiscalização do recolhimento de tributos. Os titulares desses serviços respondem

\footnotetext{
${ }^{871}$ Alexandre Rezende Pellegrini. Algumas linhas sobre a atividade notarial, 2003, p. 155. O autor aponta que a fé pública notarial encontra a sua origem nos juízes germânicos, que exerciam inclusive funções notariais. Com a separação das funções notariais daquelas desempenhadas pelos juízes, aos particulares que passaram a exercer essas funções foi atribuída a fé pública anteriormente conferida ao Judiciário (ob. e loc. cit.).
} 
solidariamente pelos tributos devidos sobre os atos praticados por eles, ou perante eles, em razão do seu ofício ${ }^{872}$. Devem, portanto, fiscalizar o recolhimento dos tributos, relacionados aos atos que praticam, por aqueles que contratam os seus serviços. Trata-se de um dos principais exemplos de responsabilidade tributária.

\subsubsection{A natureza jurídica da atividade}

Os serviços notariais e de registro consistem em função pública que é exercida por particulares, em caráter privado, mediante delegação. É o que está expressamente previsto no art. 236 da $\mathrm{CF} / 88^{873}$.

Nos termos do art. $1^{\circ}$ da Lei $n^{\circ} 8.935 / 94$, que regulamenta o art. 236 da CF/88, os serviços notariais e de registro "são os de organização técnica e administrativa destinados a garantir a publicidade, autenticidade, segurança e eficácia dos atos jurídicos”. Como destaca Celso Antônio Bandeira de Mello, trata-se de atividade de natureza jurídica e não material ${ }^{874}$.

As atividades notariais e de registro implicam o exercício de poderes públicos. Ainda que as decisões sejam definitivas apenas com a intervenção do Judiciário, os notários e registradores desempenham importante função na verificação da regularidade e do preenchimento dos requisitos legais dos atos e documentos a serem objeto de registro. A fé pública em si, conferida aos atos desempenhados por notários e registradores, consiste em um poder conferido pelo Estado. Esse exercício de poderes públicos é evidenciado nos vários aspectos da atividade notarial e de registros.

Por exemplo, cabe ao titular da serventia conferir se os documentos e declarações que lhe são apresentados preenchem os requisitos legais, podendo recusar o registro caso constate irregularidades ${ }^{875}$. O oficial de registro deve indicar, por escrito, as exigências a serem satisfeitas para o registro. Se o interessado no registro não concordar com a exigência ou não puder satisfazê-la, a controvérsia deve ser dirimida pelo Judiciário $^{876}$. Alguns erros de registros, que não exigem qualquer indagação para a

\footnotetext{
${ }^{872}$ CTN, art. 134, inc. VI.

${ }^{873}$ A esse respeito, o STF já assentou que "a atividade notarial e registral (...) constitui, em decorrência de sua própria natureza, função revestida de estatalidade, sujeitando-se, por isso mesmo, a um regime estrito de direito público. A possibilidade constitucional de a execução dos serviços notariais e de registro ser efetivada 'em caráter privado, por delegação do poder público' (CF, art. 236), não descaracteriza a natureza essencialmente estatal dessas atividades de índole administrativa” (Pleno, ADI n ${ }^{\circ}$ 1.378-MC, Rel. Min. Celso de Mello, j. 30.11.1995).

${ }^{874}$ A competência para criação e extinção de serviços notariais e de registros e para delegação para provimento desses serviços, 1999, p. 199.

${ }^{875}$ Lei no 6.015/73: "Art. 156. O oficial deverá recusar registro a título e a documento que não se revistam das formalidades legais”.

${ }^{876}$ Lei n $^{\circ} 6.015 / 73$, art. 198.
} 
constatação imediata de necessidade de sua retificação, podem ser corrigidos pelo próprio oficial, sem intervenção do Poder Judiciário, mediante requerimento do interessado e após manifestação conclusiva do Ministério Público ${ }^{877}$.

Diante da previsão constitucional, há a delegação do exercício da atividade. A atividade em si continua sendo pública. Uma peculiaridade das funções notariais e de registro consiste no fato de que, por imperativo constitucional, devem ser desempenhadas por particulares ${ }^{878}$. Os sujeitos que exercem tais funções mantêm a qualidade de particulares, ainda que se encontrem investidos de poderes públicos.

Cumpre ressalvar ser discutível a natureza da função pública exercida pelos notários e registradores, se é função administrativa ou não. Defendem a sua natureza administrativa, por exemplo, Guido Zanobini ${ }^{879}$ e Celso Antônio Bandeira de Mello ${ }^{880}$. Já outros consideram ser a função notarial uma função pública autônoma, não se enquadrando nas funções administrativa, legislativa ou jurisdicional. É o que sustenta, por exemplo, Pedro Gonçalves ${ }^{881}$.

De todo modo, há de se reconhecer a proximidade entre as atividades notariais e as competências de polícia administrativa ${ }^{882}$. A imposição do registro público para a prática de determinados atos consiste em inequívoca intervenção da autonomia

\footnotetext{
${ }^{877}$ Lei ${ }^{\circ}$ 6.015/73, art. 110.

${ }^{878}$ Celso Antônio Bandeira de Mello. A competência para criação e extinção de serviços notariais e de registros e para delegação para provimento desses serviços, 1999, p. 198. Luís Roberto Barroso afirma a inviabilidade de os serviços notariais e de registro serem exercidos diretamente pelo Estado. Para tanto, o autor destaca a diferença entre a redação do caput do art. 236 e a dos arts. 175, 21, inc. XI e XII, 25, §2 e 30, inc. $\mathrm{V}$, do texto constitucional. Estes dispositivos mencionam expressamente que os serviços indicados poderão ser prestados diretamente ou mediante delegação. Já o art. 236 refere-se exclusivamente à possibilidade de exercício privado, mediante delegação pública (Invalidade de exercício direto pelo Estado dos serviços notariais e de registros).

${ }^{879}$ L'amministrazione pubblica del diritto privato, 1955, p. 19 e ss.

${ }^{880}$ A competência para criação e extinção de serviços notariais e de registros e para delegação para provimento desses serviços, 1999, p. 202.

${ }^{881}$ Entidades privadas com poderes públicos, 2008, p. 586. Ao afirmar não se tratar de serviço público, o STF aproximou-se de uma definição das atividades notariais e de registro como uma função pública autônoma: "Numa frase, então, serviços notariais e de registro são típicas atividades estatais, mas não são serviços públicos, propriamente. Inscrevem-se, isto sim, entre as atividades tidas como função pública lato sensu, a exemplo das funções de legislação, diplomacia, defesa nacional, segurança pública, trânsito, controle externo e tantos outros cometimentos que, nem por ser de exclusivo domínio estatal, passam a se confundir com serviço público.” (ADI n 3.643, voto do Rel. Min. Ayres Britto, julgamento em 8.11.2006, Plenário, DJ de 16.2.2007).

${ }^{882}$ Adilson Abreu Dallari propõe uma classificação das atividades administrativas que agrega os atos voltados a conferir segurança à atuação dos particulares em categoria distinta da polícia administrativa: “O conjunto das atividades desenvolvidas pela Administração Pública comporta uma divisão em grupos que apresentam certo grau de homogeneidade e que seriam os seguintes: prestação de serviços públicos, poder de polícia, fomento às atividades dos particulares de interesse público, intervenção nos fatos e atos dos particulares para lhes dar segurança jurídica e, por último, atividades instrumentais, internas, necessárias para viabilizar as demais" (Credenciamento mediante licitação, 1998, p. 98). Essa também é a proposta de Lúcia Valle Figueiredo, que apresenta a classificação das atividades administrativas contemplando para os atos e fatos de particulares para conferir-lhes certeza e segurança jurídicas uma categoria distinta à do condicionamento do exercício da liberdade e da propriedade (Curso de direito administrativo, 2008, p. 77).
} 
privada. Além disso, a atividade notarial envolve a prática de atos dotados de fé pública, aos quais se reconhece força probatória especial, o que implica o exercício de poder de autoridade. Caracterizando-se ou não como atividade de polícia, ao ser exercida "em caráter privado”, como determina o texto constitucional, a atividade notarial consiste em hipótese de delegação a particulares do exercício de poderes de autoridade.

\subsubsection{A relevância da previsão constitucional do exercício privado}

Cabe analisar se o fato de o art. 236 da CF/88 prever expressamente que o exercício das funções públicas notariais e de registro ocorre em caráter privado apresenta alguma relevância específica no que diz respeito ao exercício privado das demais atividades públicas.

Parece-nos que o art. 236 da CF/88 representa uma exceção na sistemática adotada no texto constitucional à medida que prevê que as atividades notariais e de registro deverão ser desempenhadas em caráter privado. Atribui-se integralmente o exercício dessas atividades a particulares. Não existe a previsão de desempenho direto pelo Estado. Trata-se de disciplina diversa da que se verifica, por exemplo, nos art. 21, incs. XI e XII, e art. 175 da CF/88.

Outro aspecto diferencial diz respeito ao fato de a CF/88 prever que a delegação será disciplinada por lei, sem mencionar o emprego de mecanismos contratuais tal como a concessão. Assim se passa por ser da essência das atividades notariais e de registro a uniformidade de critérios em todo o território nacional. Diante da previsão de que o acesso à atividade dá-se mediante a realização de concurso público e da impossibilidade de haver variação nas regras de funcionamento de cada serviço específico, não haveria maior utilidade no emprego de um instrumento contratual para disciplinar aspectos específicos da atividade.

Já para Weida Zancaner, a previsão constitucional seria de extrema relevância por refletir a única hipótese em que uma atividade-fim do Estado poderá ser desempenhada por particulares: “a única atividade-fim que pode ser repassada aos particulares é a notarial e registral, por força da dicção constitucional, ex-vi do art. 236”,883. Ou seja, para a autora, na ausência de expressa autorização constitucional, apenas poderiam ser transferidas aos particulares atividades-meio.

Como já procuramos demonstrar acima, reputamos que a distinção entre atividades-meio e atividades-fim não é suficiente para se diferenciar adequadamente as

${ }^{883}$ O perfil jurídico do credenciamento, 2013, p. 792. 
atividades estatais que podem ter o seu exercício atribuído a entidades privadas. De todo modo, o art. 236 da CF/88 consagra um regime jurídico diferenciado para o exercício privado de funções públicas.

\subsubsection{Alguns aspectos do regime jurídico}

Encontra-se assente a noção, na doutrina e na jurisprudência, de que os notários e registradores não são servidores públicos e sim delegatários de serviços de natureza pública, exercidos em caráter privado ${ }^{884}$. A doutrina usualmente os insere entre os agentes públicos, na categoria dos particulares em colaboração com a Administração ${ }^{885}$. Os notários e oficiais de registro percebem emolumentos pelos atos praticados, não sendo remunerados pelos cofres públicos.

O ingresso nas atividades notariais depende de concurso público de provas e títulos $^{886}$. Cabe ao Judiciário exercer a fiscalização dos atos praticados por esses agentes públicos no exercício da função delegada ${ }^{887}$.

Os notários e oficiais de registros respondem civil e criminalmente pelos danos que causarem a terceiros, no exercício da função pública delegada.

Quanto à natureza dessa responsabilidade, da redação do art. 22 da Lei $n^{0}$ 8.935/94 pode-se extrair o entendimento de que se trata de responsabilidade objetiva. Notese que esse dispositivo emprega termos similares aos do art. $37, \S 6^{\circ}$, da CF/88. No entanto, há disposições legais que preveem a responsabilidade subjetiva dos notários e registradores. Esse é o caso, por exemplo, do art. 28 da Lei $n^{\circ} 6.015 / 73$. Ainda que se possa alegar que esse dispositivo não mais seria aplicável diante das previsões do art. 37, §6º da CF/88 e do art. 22 da Lei $\mathrm{n}^{\circ} 8.935 / 94^{888}$, há disposições mais recentes que preveem a responsabilidade

\footnotetext{
${ }^{884}$ Nos termos do art. $3^{\circ}$ da Lei $n^{\circ} 8.935 / 94$, “notário, ou tabelião, e oficial de registro, ou registrador, são profissionais do direito, dotados de fé pública, a quem é delegado o exercício da atividade notarial e de registro". Almiro do Couto e Silva, a propósito das decisões judiciais que insistiam na qualificação dos notários e registradores como servidores públicos já sob a égide da $\mathrm{CF} / 88$, agudamente registra que "constitui um dos grandes paradoxos do direito brasileiro um caso de força de inércia do direito antigo, que o faz sobrepor-se ao novo. Apesar de o atual preceito constitucional declarar que os notários e registradores exercem atividade pública delegada, em caráter privado o que logicamente os exclui da execução direta daqueles serviços públicos - diferentemente da situação existente na vigência da Constituição anterior, em que as funções notariais e registrais eram estatais e indelegáveis - a jurisprudência, inclusive a dos tribunais superiores, STF e STJ, tem inexplicavelmente persistido no entendimento de que notários e registradores são servidores públicos” (Privatização no Brasil e o novo exercício de funções públicas por particulares, 2003, p. 230).

${ }^{885}$ Nesse sentido, entre outros, podem ser conferidos: Maria Sylvia Zanella Di Pietro. Direito administrativo, 2013, p. 592; Celso Antônio Bandeira de Mello. Curso de direito administrativo, 2013, p. 256-258.

${ }^{886} \mathrm{CF} / 88$, art. 236, $\S 3^{\circ}$.

${ }^{887} \mathrm{CF} / 88$, art. 236, $\S 1^{\circ}$.

${ }^{888}$ Por exemplo, Jairo Vasconcelos Rodrigues Carmo considera que o art. 28 da Lei n ${ }^{\circ}$ 6.015/73 encontra-se revogado (Responsabilidade civil do delegatário notarial e de registros públicos, 2006, p. 173).
} 
subjetiva para algumas atividades. Esse é o caso do art. 38 da Lei n 9.492/97, aplicável exclusivamente aos tabeliães de protesto de títulos.

O entendimento que tem prevalecido no STF é o de que o Estado seria objetivamente responsável pelos atos praticados pelos notários e registradores, que responderiam pessoalmente apenas caso tenha concorrido com culpa ou dolo para a ocorrência do dano ${ }^{889}$. Essa tem sido a interpretação majoritariamente aplicada, na tentativa de se compatibilizarem as diversas disposições legais que versam sobre o tema ${ }^{890}$. No entanto, considerando-se que o atual regime jurídico dos notários e registradores afasta a sua caracterização como servidores públicos e lhes atribui o caráter de agentes em colaboração com a Administração, tal como se passa em relação aos concessionários de serviço público, reputamos que a sua responsabilização submete-se ao disposto no art. 37, $\S 6^{\circ}$, da CF/88, ou seja, que respondem objetivamente pelos danos causados a terceiros, com a possibilidade de haver responsabilidade subsidiária do Estado ${ }^{891}$.

O STF também já teve oportunidade de se manifestar sobre várias outras peculiaridades do regime jurídico de tais serviços. Assentou que os notários e registradores

${ }^{889}$ O STF tem decidido que há responsabilidade direta do Estado pelos atos praticados por notários e registradores: "Agravo regimental em recurso extraordinário. Responsabilidade civil do Estado. Danos causados a terceiros em decorrência de atividade notarial. Precedentes. 1. Nos termos da jurisprudência do Supremo Tribunal Federal, "o Estado responde, objetivamente, pelos atos dos notários que causem dano a terceiros, assegurado o direito de regresso contra o responsável, nos casos de dolo ou culpa (C.F., art. 37, § 6)" (RE 209.354-AgR, da relatoria do ministro Carlos Velloso). 2. Agravo regimental desprovido.” (AgR no RE 518.894/SP, $2^{\mathrm{a}}$ T., Rel. Min. Ayres Britto, DJe 23.9.2011). De todo modo, não se trata de questão pacífica. Para alguns, o regime de responsabilidade civil mais adequado seria o de responsabilização direta do titular da serventia, com a possibilidade de o Estado responder subsidiariamente, nos moldes previstos no art. $37, \S 6^{\circ}$, da $\mathrm{CF} / 88$. Tal como se passa com os concessionários de serviços públicos, os notários e registradores são particulares em colaboração com a Administração. Não haveria, assim, justificativa para submeterem-se a regime jurídico distinto. Nesse sentido, Rodrigo Gerent Mattos. Responsabilidade civil dos notários e registradores públicos, 2010, p. 6474.

${ }^{890}$ Para tanto, invoca-se o entendimento de que o art. 37, §6 ${ }^{\circ}$, da CF/88 não seria aplicável a pessoas físicas, tais como os notários e registradores. Outro dado a ser considerado é o fato de o Estado não exigir a prestação de garantias por aqueles que exercem as atividades notariais e registrais, diferentemente do que se passa em relação a concessionários de serviço público, por exemplo.

${ }^{891}$ Nesse sentido, pode-se aludir aos ensinamentos de Yussef Said Cahali: "na linha do princípio inovador inserto no art. $37, \S 6^{\circ}$, da Constituição e da legislação ordinária ajustada aos seus enunciados, a responsabilidade civil dos notários e oficiais de registro define-se como sendo igualmente objetiva, a prescindir de qualquer perquirição a respeito do elemento subjetivo do dolo ou culpa sua ou de seus prepostos, bastando para o seu reconhecimento a demonstração do nexo de causalidade entre o ato (ou omissão) cartorário e o dano sofrido pelo particular" (Responsabilidade civil do Estado, 2007, p. 264). Romeu Felipe Bacellar Filho também sustenta a responsabilização direta e objetiva dos notários e registradores, desde que presente o nexo causal entre o dano e a sua atividade (Reflexões sobre direito administrativo, 2009, p. 157). Pode ser localizado um precedente do STF nesse sentido, que retrata corrente minoritária naquele Tribunal sobre o tema: "Responsabilidade objetiva - Estado - Reconhecimento de firma - Cartório oficializado. Responde o Estado pelos danos causados em razão de reconhecimento de firma considerada assinatura falsa. Em se tratando de atividade cartorária exercida à luz do artigo 236 da Constituição Federal, a responsabilidade objetiva é do notário, no que assume posição semelhante à das pessoas jurídicas de direito privado prestadoras de serviços públicos - $\S 6^{\circ}$ do artigo 37 também da Carta da República” (RE $\mathrm{n}^{\circ}$ 201.595/SP, Rel. Min. Marco Aurélio, 2ª T., unânime, j. 28.11.2000, DJ 20.4.2001, p. 138). 
exercem atividade própria do poder público, de titularidade estatal, em caráter privado, mediante delegação ${ }^{892}$. O titular de serviços notariais não ocupa cargo público efetivo e não se sujeita ao regime jurídico dos servidores públicos, tratando-se de função estatal não vinculada a um cargo público ${ }^{893}$.

No que diz respeito à organização e à gerência da serventia, aplica-se o regime jurídico privado ${ }^{894}$. Isso se traduz, inclusive, na liberdade de contratação dos empregados que auxiliam no desempenho das funções delegadas ${ }^{895}$. Sobre as atividades de natureza privada, não incide a fiscalização do Poder Judiciário.

\subsection{A privatização de parcela do procedimento administrativo}

Em tese, pode-se cogitar da participação privada no desenvolvimento do procedimento administrativo.

Tal privatização pode ser da integralidade do procedimento administrativo, hipótese em que este é integralmente substituído por um procedimento privado. Seria a situação em que determinada autorização é solicitada a um particular no exercício de função pública, que desenvolve o procedimento e, ao final, concede ou não a autorização pleiteada. Como já se analisou anteriormente, cogita-se da possibilidade de delegação das atividades de consentimento de polícia apenas se o seu desempenho for objeto de prévia definição em atos normativos, com a anterior programação dos requisitos e etapas a serem observadas, de modo que não se atribua ampla margem de decisão ao particular.

Schmidt-Assmann apresenta um exemplo de privatização do procedimento no que se refere à auditoria ecológica no âmbito do direito comunitário ${ }^{896}$. Trata-se do desenvolvimento de mecanismos de autoavaliação pelas empresas, de modo que os próprios particulares considerem o impacto ambiental da sua atuação. A declaração ambiental emitida pela empresa é verificada por especialistas privados. A acreditação destes

\footnotetext{
${ }^{892}$ ADI no 2.602, Pleno, Rel. p/ acórdão Min. Eros Grau, maioria, j. 21.11.2005. Este julgamento sinalizou a mudança do entendimento do STF, que até então, especialmente considerando o texto constitucional anterior, reputava ser o titular de serviços notariais servidor público. A partir de então, até o presente momento, o STF tem aplicado o posicionamento adotado no julgamento da ADI ${ }^{\circ} 2.602$.

${ }^{893}$ Nesse sentido, entre outros: ADI no 4.178/GO, Pleno, Rel. Min. Cezar Peluso, DJe 7.5.2010; AgRg no RE $n^{\circ}$ 385.667-7/PE, $1^{\text {a }}$ T., v.u., Rel. Min. Cármen Lúcia, j. 17.10.2006; AgRg no AI no 655.378-6, $2^{\mathrm{a}}$ T., v.u., Rel. Min. Gilmar Mendes, j. 26.2.2008.

${ }^{894}$ Lei no ${ }^{\circ} 8.935 / 94$, arts. 21 e 41.

${ }^{895} \mathrm{O}$ CNJ reconheceu, por maioria, a inaplicabilidade da vedação ao nepotismo às serventias extrajudiciais (pedido de providências $n^{\circ}$ 200910000000060, voto convergente do Conselheiro Ministro João Oreste Dalazen, 9.6.2009).

${ }^{896}$ La teoría general del derecho administrativo como sistema, 2003, p. 370.
} 
especialistas também se faz na esfera privada. Reduz-se, com isso, a necessidade de intervenção estatal direta.

Como anota Schmidt-Assmann, a rigor, não se trataria propriamente de privatização do procedimento administrativo pois o que se atribui aos particulares é a utilização de um mecanismo independente e neutro para a aferição do impacto ambiental ${ }^{897}$. Logo, quando se menciona a privatização do procedimento administrativo está-se tratando mais especificamente de uma substituição do procedimento administrativo por um procedimento privado publicamente regulado e controlado.

A privatização do procedimento administrativo pode também ser apenas parcial, atribuindo-se somente uma ou algumas das suas etapas a particulares. É o que pode ocorrer, por exemplo, com a fase de instrução. Seria possível a participação de particulares na fase de preparação de decisões públicas, sendo que a decisão final continuaria sendo proferida por uma autoridade pública.

As atividades de avaliação de conformidade podem também ter que ser praticadas para fins de instrução de determinado procedimento administrativo. $\mathrm{O}$ ente encarregado da decisão pode solicitar a entidades especializadas determinadas contribuições que o auxiliem na instrução, tais como vistorias, pareceres e estudos.

Nesse ponto, assume grande relevância a participação de entidades de autorregulação. Consiste na atribuição de algumas fases centrais ou relevantes do procedimento administrativo a entidades de autorregulação, sendo os resultados por estas produzidos integrados ao procedimento ${ }^{898}$. Por exemplo, uma parcela do trâmite poderia ser substituída por um informe ou inspeção produzidos por autorregulação privada. A decisão final do procedimento continua cabendo à Administração, que pode intervir inclusive para contradizer esses resultados apresentados pelas instâncias de autorregulação.

A questão que se apresenta é se a Administração, que não teve capacidade técnica para realizar tais atos, teria condições de recepcionar criticamente as contribuições apresentadas pelas entidades privadas. O risco verificado é o de perda do controle do processo pela Administração e privatização de fato deste, uma vez que o conteúdo da decisão acabaria ficando nas mãos de particulares.

Dora Maria de Oliveira Ramos opõe-se à possibilidade de se impor à Administração a obrigatoriedade de aceitação de laudos elaborados por particulares. A autora manifestou seu entendimento ao analisar se poderia ser prevista a obrigatoriedade de

\footnotetext{
${ }^{897}$ Ob. e loc. cit.

898 José Esteve Pardo define como “efeito integrador” da autorregulação essa possibilidade de substituição de parcelas do processo administrativo (Autorregulación, 2002, p. 139-142).
} 
os Departamentos de Trânsito aceitarem compulsoriamente os laudos de vistoria veicular elaborados por empresas credenciadas pelo DENATRAN:

não se extrai da contestada Resolução CONTRAN nº 282/2008 nenhuma ordem para que os Departamentos Estaduais aceitem os laudos das empresas credenciadas. O ato normativo em exame admite o credenciamento de empresas privadas para realização das vistorias. Não obriga, no entanto, e nem existiria qualquer fundamento para fazê-lo, que os órgãos estaduais, compulsoriamente, abdiquem, total ou parcialmente, da execução da atividade que lhes foi atribuída por lei. Qualquer exigência que se pretenda fazer nesse sentido, portanto, carece de substrato de validade ${ }^{899}$.

A autora menciona também que, para a aceitação automática de laudos elaborados por particulares, deve-se ponderar se a Administração dispõe de condições de fiscalizar efetivamente a atividade realizada por essas empresas, se a Administração tem acesso a toda a documentação analisada e se a empresa dispõe efetivamente de condições de identificar possíveis irregularidades nos veículos ${ }^{900}$.

O risco de perda do controle do procedimento pela Administração é real e deve ser considerado ao se atribuírem determinados atos processuais a particulares.

Portanto, a delegação do exercício de atos que venham a integrar parcela ou a totalidade de procedimento administrativo desenvolvido para fins de exercício da atividade de polícia administrativa deve ser adotada com cautela. Apenas poderá ocorrer nas hipóteses em que for possível a prévia definição dos critérios a serem adotados pelo particular no desempenho dessas atividades e se for viável o efetivo controle pelo poder público das atividades delegadas.

\subsection{A capacidade tributária ativa}

A delegação das funções de arrecadação e fiscalização de tributos, inclusive a entidades privadas, é expressamente prevista na legislação.

\subsubsection{Capacidade tributária ativa e atividade de polícia}

A arrecadação e a fiscalização tributárias guardam relação com a atividade de polícia à medida que podem demandar o exercício de atos de autoridade. Por isso, podese considerar que a arrecadação e fiscalização tributárias, como atividades de natureza administrativa, integram as atividades de polícia administrativa ${ }^{901}$.

\footnotetext{
${ }^{899}$ A terceirização em matéria de poder de polícia, 2013, p. 578.

900 Ob. cit., p. 577-578.

901 Aliomar Baleeiro registra que a doutrina norte-americana propôs a distinção entre os tributos que eram cobrados com base no "poder de tributar" e aqueles que tinham por fundamento o "poder de polícia". Com isso, pretendeu-se sustentar que os tributos cobrados com fundamento no poder de polícia não precisariam submeter-se ao regime tributário em sua integralidade (Uma introdução à ciência das finanças, 1981, p. 177). Note-se que não é disso que se está tratando ao se indicarem os pontos de conexão entre a arrecadação
} 


\subsubsection{Competência tributária e capacidade tributária ativa}

A competência tributária consiste na aptidão, conferida pelo texto constitucional, aos entes federados para a criação de tributos, observando os limites da sua competência. É o texto constitucional que delineia a competência legislativa tributária das pessoas políticas, autorizando-lhes a editar leis que criem tributos descrevendo hipótese de incidência, base de cálculo, sujeitos ativo e passivo e alíquota.

A indelegabilidade é uma das características da competência tributária. A pessoa política pode não exercer os poderes que recebeu para legislar. No entanto, não pode transferi-los para outra pessoa.

A criação de tributos é função legislativa, que se esgota com a edição da lei. Depois de criado o tributo, o que se desempenha é a capacidade tributária ativa, que implica o direito de arrecadar os tributos. A arrecadação tributária consiste em função administrativa.

A capacidade tributária ativa é a competência do ente federado de exercer a arrecadação e a fiscalização em relação aos tributos de sua competência É o direito de integrar a relação jurídica de cunho tributário como sujeito ativo e postular o cumprimento da prestação. A capacidade tributária decorre da competência tributária, encontrando-se nela compreendida, e tem natureza administrativa ${ }^{902}$.

Apenas a capacidade tributária é passível de delegação, especialmente no que diz respeito à arrecadação de tributos. É o que consta expressamente do art. $7^{\circ}$ do CTN. Ao mesmo tempo em que estipula a indelegabilidade da competência tributária, autoriza a atribuição da função de arrecadação de tributos a entidades de direito privado porque "não constitui delegação de competência”.

Como ensina Roque Antonio Carrazza, “[e]mbora a competência tributária aptidão para criar o tributo - seja indelegável, a capacidade tributária ativa - aptidão para arrecadar o tributo - é delegável por lei (lei, é claro, da pessoa política competente)”903.

tributária e as atividades de polícia administrativa. Nos termos da CF/88, pelo exercício das atividades de polícia administrativa podem ser cobradas as taxas, que têm inequívoca natureza tributária e submetem-se integralmente ao mesmo regime jurídico dos demais tributos (art. 145, inc. II).

902 "Uma coisa é poder legislar, desenhando o perfil jurídico de um gravame ou regulando os expedientes necessários à sua funcionalidade; outra é reunir credenciais para integrar a relação jurídica, no tópico de sujeito ativo" (Paulo de Barros Carvalho. Curso de direito tributário, 1998, p. 156).

${ }^{903}$ Curso de direito constitucional tributário, 1998, p. 160. Assim já decidiu o STF: é "legítima, outrossim, a delegação da capacidade tributária ativa, que não se confunde com a competência tributária” (Agrg no AI n⿳亠丷⿵冂丶 133.645-5, 2ª Turma, Rel. Min. Carlos Velloso, j. 13.11.1990, DJ 14.12.1990). 
7.10.3. A “sujeição ativa auxiliar”

A pessoa política que institui o tributo pode optar por delegar a terceiros a realização da atividade de cobrança. O particular desempenha apenas a função de arrecadação, que é feita em nome e por conta da pessoa tributante. O produto obtido é entregue ao ente político tributante.

Não se trata de manifestação de parafiscalidade, que é analisada adiante. Consiste apenas na autorização para que terceiros procedam à cobrança tributária, sem que o sujeito ativo tenha disponibilidade sobre os valores arrecadados. Roque Antonio Carrazza qualifica essa situação como “sujeição ativa auxiliar"904.

\subsubsection{A delegação de capacidade tributária ativa no contexto da parafiscalidade}

O termo "parafiscalité” foi utilizado pela primeira vez em 1946, no Inventário Schuman, na França, para refletir a existência de contribuições que ficavam alheias ao Fisco $^{905}$. Sob a rubrica parafiscalidade, esse relatório agrupou aportes distintos, tais como as taxas arrecadadas por repartições e estabelecimentos públicos financeiramente autônomos, os encargos sociais e os encargos profissionais ${ }^{906}$.

Designaram-se, assim, como parafiscais os pagamentos exigidos dos indivíduos por entidades públicas e privadas, consistentes em grupos profissionais, religiosos ou de outra natureza. Os sujeitos passivos eram, em maior ou menor medida, representados por aquelas instituições ou beneficiados pelas suas atividades.

A parafiscalidade caracteriza-se pelo fato de terceiros serem autorizados a procederem à cobrança tributária, sendo que o produto permanece na entidade que fez a arrecadação, que o aplica no desenvolvimento das suas atividades ${ }^{907}$. Caracteriza-se,

\footnotetext{
${ }^{904}$ Curso de direito constitucional tributário, 1998, p. 160, nota 41.

905 Apesar de a designação do fenômeno como parafiscalidade ser relativamente recente, há registros de atribuição a grupos profissionais da cobrança de tributos ainda nas corporações medievais, nos denominados direitos de "maitrise et jurande". Podiam também ser verificados exemplos de delegação de capacidade tributária a câmaras de comércio, consórcios agrários e industriais e outras entidades (Aliomar Baleeiro. Uma introdução à ciência das finanças, 1981, p. 270, nota 4).

${ }^{906}$ Nicolau Konkel Junior. Contribuições sociais, 2005, p. 65.

907 Antes da CF/88, travaram-se intensos debates acerca da natureza jurídica das contribuições parafiscais. Para alguns, consistiria em categoria tributária nova, que não se submeteria ao regime jurídico dos tributos nem aos controles sobre estes incidentes. Procurava-se, assim, estabelecer a existência de recursos públicos paralelos ao Fisco, que não integravam o orçamento geral nem se submetiam à fiscalização dos Tribunais de Contas e dos órgãos de controle da execução orçamentária. Com esse sentido, a parafiscalidade é usualmente associada a formas arbitrárias de governo, tendo sido usada com intensidade na era fascista na Itália e durante o regime de Vichy na França. Sobre o debate existente acerca da natureza jurídica das contribuições parafiscais, podem ser consultados, entre outros: Julien Laferrière e Marcel Waline. Traité élémentaire de science et de législation financières, 1952, p. 247-250; Aliomar Baleeiro. Limitações constitucionais ao poder de tributar, 1997, p. 585-591; A. Theodoro Nascimento. Preços, taxas e parafiscalidade, 1977, p. 405-423. O art. 149 da CF/88 afastou qualquer dúvida que pudesse existir sobre a natureza jurídica. Afirma que as contribuições parafiscais têm natureza tributária e, como qualquer tributo, sujeitam-se ao regime jurídico
} 
portanto, pela afetação dos recursos aos fins específicos da entidade encarregada da arrecadação $^{908}$.

Na definição de Roque Antonio Carrazza, “a parafiscalidade é apenas a atribuição, mediante lei, da capacidade tributária ativa que a pessoa política faz a outra pessoa (pública ou privada), que, por vontade desta mesma lei, passa a dispor do produto arrecadado, para a consecução de suas finalidades”909.

Logo, a parafiscalidade abrange a generalidade dos casos em que há cobrança de tributos por terceiros, em seu próprio benefício.

No art. 149 da CF/88, são previstas três espécies de contribuições parafiscais: sociais, de intervenção no domínio econômico e corporativas.

As contribuições sociais destinam-se a assegurar o financiamento das prestações previstas na Ordem Social do texto constitucional. Abrangem direitos como a seguridade social, a educação e acultura. As contribuições interventivas voltam-se ao atendimento da intervenção estatal no domínio econômico, tendo em vista a concretização dos objetivos constitucionais para a atividade econômica. Nas contribuições corporativas, enquadram-se aquelas arrecadadas pelas entidades de regulação do exercício de profissões ou de atividades econômicas e os sindicatos de representação de categorias profissionais.

7.10.5. A cobrança de tarifas dos usuários de serviços concedidos: inocorrência de delegação de capacidade tributária

Os custos do exercício da atividade de polícia podem autorizar a instituição de tributo, as taxas (CF/88, art. 145, inc. II). O fato gerador da taxa de polícia é o exercício da fiscalização, efetiva ou potencial, sobre as atividades do particular. O sujeito passivo é aquele que exerce a atividade que é objeto da fiscalização.

tributário. A CF/88 não apenas inseriu essas contribuições no capítulo do Sistema Tributário Nacional, tal como tinham feito as Constituições anteriores, mas também determinou que lhes sejam aplicados os princípios constitucionais tributários da legalidade, da irretroatividade e da anterioridade.

${ }^{908}$ Para alguns autores, a parafiscalidade seria caracterizada apenas pela destinação específica dos recursos arrecadados, sem que ingressem no orçamento geral do ente político que instituiu o tributo. Ou seja, se o próprio ente político ocupasse a posição de sujeito ativo na relação jurídica para a arrecadação de contribuições com receita afetada a fins específicos, não restaria descaracterizada a parafiscalidade. A delegação das funções de fiscalização e arrecadação a terceiro não seria imprescindível para a configuração do instituto da parafiscalidade. A figura do sujeito ativo seria irrelevante, sendo suficiente que os recursos arrecadados fossem destinados e geridos pelos entes e entidades a que se destinam. Esse é o entendimento, por exemplo, de Nicolau Konkel Junior. Contribuições sociais, 2005, p. 76-83, que foi adotado pelo STF no julgamento da $A D C n^{\circ} 1-1 / D F$, ao reconhecer que a arrecadação e fiscalização da COFINS pela Receita federal não a descaracteriza como contribuição (Rel. Min. Moreira Alves, DJ 16.6.1995).

${ }^{909}$ Curso de direito constitucional tributário, 1998, p. 161, nota 41. 
A taxa consiste em tributo vinculado, com destinação orçamentária específica. O valor da taxa de polícia deve ser proporcional ao custeio da atividade de fiscalização em si ${ }^{910}$.

Porém, note-se que a cobrança de tarifa pela realização de atividades de polícia administrativa por particulares não decorre da suposta delegação de capacidade tributária. O mesmo se passa no âmbito de um contrato de concessão de serviço público. Os valores arrecadados pelo concessionário consistem em tarifa, que não tem natureza tributária. Portanto, a cobrança de tarifa dos usuários de serviço público pelo concessionário não consiste em manifestação de parafiscalidade ${ }^{911}$.

Com frequência, atividades de inspeção e vistoria realizadas por particulares, mediante delegação, são remuneradas pela cobrança de tarifas dos usuários. É o que se passa, por exemplo, com a tarifa paga pela inspeção veicular desenvolvida por particulares.

\subsubsection{A exigência de autorização legal}

É necessária autorização legal para a delegação de capacidade tributária ativa. Esse é o entendimento pacífico da doutrina ${ }^{912}$.

Diante disso, reconhece-se que o exercício da capacidade tributária envolve o manejo de poder de autoridade. $\mathrm{O}$ ato de arrecadação do tributo não deixa de consistir na exteriorização de um ato de autoridade. Faz-se necessária, assim, que a lei expressamente atribua a determinada entidade privada o exercício de tal autoridade.

A esse respeito, há controvérsias na doutrina acerca da possibilidade de os próprios sindicatos imporem a contribuição confederativa, prevista no art. $8^{\circ}$, inc. IV, da CF/88, “independentemente da contribuição prevista em lei”, que é a contribuição sindical.

\footnotetext{
${ }^{910}$ Segundo Roque Antônio Carrazza, o "valor da taxa, seja de serviço, seja de polícia, deve corresponder ao custo, ainda que aproximado, da atuação estatal específica. É claro que, neste campo, não precisa haver uma precisão matemática; deve, no entanto, existir uma razoabilidade entre a quantia cobrada e o gasto que o Poder Público teve para prestar aquele serviço público ou praticar aquele ato de polícia” (Curso de direito constitucional tributário, 1998, p. 339).

${ }^{911}$ Pode-se conceber a possibilidade de, entre as atribuições do concessionário, estar previsto o recolhimento de eventual tributo e repasse do valor arrecadado à Administração. O produto arrecadado não integra a remuneração do concessionário. Nesse caso, tem-se a "sujeição ativa auxiliar", nos termos acima examinados, e não a parafiscalidade. Nesse sentido, da doutrina francesa vem o exemplo da transferência da cobrança de taxas municipais devidas pela realização de feiras e mercados (Pierre Delvolvé. Les contradictions de la délégation de service public). No âmbito de contratos de "affermage”, pelos quais se transfere ao particular a exploração de determinado empreendimento, entre as cobranças que o concessionário realiza dos usuários encontra-se a arrecadação das taxas municipais.

912 Confiram-se, entre outros: Geraldo Ataliba. Hipótese de incidência tributária, 1997, p. 76-77 e 166; Roque Antonio Carrazza. Curso de direito constitucional tributário, 1998, p. 160. Paulo de Barros Carvalho especifica que a lei a indicar um sujeito ativo diverso daquele que detém a competência tributária deve ser a lei instituidora da exação (Curso de direito tributário, 1998, p. 163).
} 
Nos termos do dispositivo constitucional, a contribuição confederativa será fixada pela assembleia geral.

Em defesa da legitimidade da contribuição, sustenta-se que não teria natureza tributária ${ }^{913}$ e poderia ser imposta diretamente pelos sindicatos, independentemente de previsão legal, porque o seu fundamento seria o consentimento do obrigado, atingindo apenas os associados do sindicato ${ }^{914}$. Logo, o seu caráter facultativo, diretamente vinculado à liberdade de associação sindical assegurada pelo texto constitucional, autoriza a sua instituição pela assembleia geral.

\subsection{Observações finais}

Procurou-se demonstrar acima que o "dogma” da indelegabilidade das atividades de polícia administrativa não se sustenta ao se analisarem as diversas atividades compreendidas na função de polícia administrativa na atualidade.

O exercício de poderes de coerção e o exercício amplo de poder decisório apresentam-se como limites intransponíveis à delegação. Por um lado, há o monopólio estatal da violência legítima, que determina o exercício direto pelo poder público das atividades de coerção. Por outro, não se pode transferir ao particular a "capacidade de dar a última palavra”915, ou seja, de exercer amplo poder decisório no que diz respeito ao exercício de atividades públicas.

Considerando-se estes limites, há uma grande quantidade de atividades passíveis de delegação. Cabe ressalvar que a possibilidade concreta da delegação depende da previsão bastante clara dos limites das atividades delegadas e dos critérios e procedimentos a serem adotados na sua execução. Na ausência destes pressupostos, há o

\footnotetext{
${ }^{913}$ Nesse sentido, posiciona-se Sergio Pinto Martins: “a natureza jurídica da contribuição confederativa não é tributária” (Direito do trabalho, 2010, p. 764). Note-se que o autor ressalva que, apesar de não ter natureza tributária, a contribuição confederativa deve ser instituída em lei, em decorrência do princípio da legalidade (CF, art. $5^{\circ}$, inc. II). $\mathrm{O}$ art. $8^{\circ}$, inc. IV, da $\mathrm{CF} / 88$ não seria autoaplicável e haveria necessidade de lei estabelecendo, por exemplo, o quórum de aprovação da contribuição, a sua alíquota e base de cálculo, a destinação dos recursos arrecadados etc. (ob. cit., p. 765-766). Cabe registrar que o STF já decidiu ser autoaplicável o inc. IV do art. $8^{\circ}$ da CF/88 (v.g. Agrg no AI no 657.096/RS, $2^{a}$ T., Rel. Min. Celso de Mello, j. 26.6.2007, DJ 23.8.2007).

${ }^{914} \mathrm{Em}$ alguma medida, trata-se do entendimento adotado pelo STF, que deu ensejo à edição da Súmula $\mathrm{n}^{\circ}$ 666: "A contribuição confederativa de que trata o art. $8^{\circ}$, IV, da Constituição, só é exigível dos filiados ao sindicato respectivo". Em relação às demais contribuições sindicais, que são compulsórias e se aplicam a todos que pertencem à categoria, independentemente de serem sindicalizados, o entendimento do STF confirma a exigência de instituição em lei: "Contribuições - Categorias profissionais - Regência - Portaria Inconstitucionalidade formal. A regência das contribuições sindicais há de se fazer mediante lei no sentido formal e material, conflitando com a Carta da República, considerada a forma, portaria do Ministro de Estado do Trabalho e Emprego, disciplinando o tema” (ADI 3.353/DF, Pleno, Rel. Min. Marco Aurélio, j. 14.4.2005, DJ 26.8.2005).

${ }^{915}$ Floriano de Azevedo Marques Neto. A concessão como instituto do direito administrativo, 2013, p. 570.
} 
risco de se acabar permitindo o exercício de amplo poder decisório pelo particular. Isso não pode ser admitido, inclusive por configurar, em alguma medida, a renúncia do poder público ao exercício da função administrativa.

Adotam-se as advertências precisas de Floriano de Azevedo Marques Neto acerca das cautelas a serem observadas na delegação de atividades públicas:

Certo deve estar que, ao transferir essas prerrogativas, o poder concedente deve ter duas cautelas fundamentais: (i) delimitar de forma clara no contrato quais são essas prerrogativas delegadas, seus limites e as finalidades para as quais elas serão exercidas e (ii) prever também no contrato o processo pelo qual tais prerrogativas ou funções serão exercidas pelo concessionário inclusive - e especialmente - assegurando os direitos dos demais particulares de resistir juridicamente e de recorrer ao regulador caso entendam que o concessionário exorbita dos limites dos poderes trespassados ${ }^{916}$.

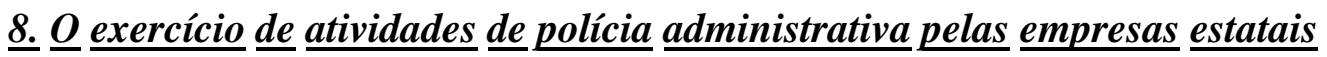

Após o exame dos limites e possibilidades do exercício das atividades de polícia administrativa por particulares, cabe analisar se esses mesmos limites se aplicam quando tais atividades forem desempenhadas por empresas estatais.

\subsection{A possível reserva do exercício de prerrogativas públicas a entidades com personalidade jurídica pública}

O primeiro passo da investigação consiste na identificação da existência ou não de reserva do exercício de prerrogativas públicas a entidades com personalidade jurídica pública.

A personalidade jurídica pública denota a possibilidade de exercício de diversos direitos e prerrogativas, por serem instrumentos necessários à persecução das finalidades atribuídas a estes entes. Essas características diferenciadas da capacidade de direito público são bastante evidentes ao se comparar com as possibilidades de ação muito mais restritas dos particulares. A liberdade de ação, ainda que não seja absoluta, e a ausência de controles mais rígidos sobre as atividades dos particulares impedem que lhes seja atribuído, em caráter permanente, o exercício de poderes sobre outros particulares.

Porém, no que diz respeito às entidades da Administração indireta com personalidade jurídica privada, a situação é distinta em relação ao que se passa com os particulares. Tais entidades submetem-se a um regime jurídico bastante rígido, especialmente aquelas que desempenham atividades públicas. Os controles e restrições que

\footnotetext{
${ }^{916}$ A concessão como instituto do direito administrativo, 2013, p. 571-572.
} 
lhes são aplicáveis aproximam-se mais daqueles incidentes sobre os entes dotados de personalidade jurídica pública do que daqueles aplicáveis aos particulares.

Parece-nos, portanto, que o aspecto mais relevante consiste na integração ou não da entidade na estrutura estatal e não a sua personalidade jurídica. O controle que recai sobre as entidades que integram a estrutura estatal é muito mais rigoroso, mesmo em relação àquelas dotadas de personalidade privada.

Para exemplificar, isso resulta bastante claro ao se comparar o regime jurídico a que se submetem as empresas estatais, especialmente aquelas que exercem atividade pública, com o regramento aplicável à Ordem dos Advogados do Brasil que, segundo o STF, consiste em entidade de personalidade jurídica de direito público que não integra a estrutura estatal ${ }^{917}$. Pode-se constatar que o regime jurídico das empresas estatais é muito mais rigoroso, apesar da sua personalidade jurídica privada. Ou seja, há uma incidência muito mais significativa do direito administrativo em relação às empresas estatais do que em relação à OAB.

A constatação de que as empresas estatais encontram-se mais próximas dos entes da Administração direta do que dos particulares também deve se aplicar no que diz respeito ao exercício de poderes e prerrogativas públicas.

Portanto, ao se afirmar a incidência de limites e restrições para o exercício de atividades de polícia administrativa por entidades privadas, pode-se identificar que essa questão está mais relacionada à incidência do regime jurídico de direito público do que à personalidade jurídica da entidade que exerce a atividade. O regime jurídico em que a atividade é exercida, com as injunções disso decorrentes, é o dado que propicia uma maior quantidade de elementos úteis para a identificação da possibilidade ou não de exercício de prerrogativas públicas por entidades privadas.

Cabe, assim, analisar os aspectos do regime jurídico das empresas estatais que se apresentam como sendo mais relevantes para a identificação da possibilidade ou não de exercerem atividades de polícia administrativa.

\subsection{O monopólio estatal do uso da força e as entidades privadas da Administração indireta}

Cabe questionar inicialmente se o argumento do monopólio estatal do uso legítimo da força seria válido em se tratando de pessoas com personalidade de direito privado que integram a estrutura do Estado, como entes da administração indireta.

${ }^{917}$ Sobre o tema, v. item III.6.5.1.7. 
Carlos Ari Sundfeld apresenta uma interpretação bastante ampla para a questão $^{918}$. Segundo o doutrinador, o art. $144, \S 5^{\circ}$, do texto constitucional, atribui às polícias militares “a polícia ostensiva e a preservação da ordem pública”. Disso decorre que apenas as atividades de coerção vinculadas à polícia ostensiva e à preservação da ordem pública é que devem ser exercidas com exclusividade pelo aparato policial. Não há vedação no texto constitucional para que outros órgãos e entidades exerçam o uso da força quando necessária para a defesa de outros valores, tais como o trânsito, a saúde e o meio ambiente. Assim, ainda segundo o doutrinador, não há vedação para que empresas estatais exerçam a coerção em outras situações, não vinculadas à defesa da ordem pública, se estiverem previamente autorizadas pela lei para tanto.

Em alguma medida, o posicionamento do autor reporta-se à distinção, adotada expressamente em outros sistemas jurídicos, entre a polícia geral e as polícias especiais.

Parece-nos que a coerção física, por integrar o núcleo das funções estatais irrenunciáveis, apenas pode ser exercida por servidores públicos. Trata-se de atividade exclusiva do Estado a que se refere o art. 247 da CF/88 que, como se examina adiante, determina a reserva do exercício de determinadas funções estatais a servidores públicos que se submetem ao regime estatutário.

Logo, a coerção física sobre outros cidadãos não pode ser exercida por entidades da Administração indireta com personalidade jurídica privada. Note-se que a vedação, no que diz respeito ao exercício da coerção, aplica-se também aos que ocupam empregos públicos e se submetem ao regime celetista, seja de entes da Administração direta seja de entidades da Administração indireta com personalidade jurídica pública.

No entanto, isso não impede que as entidades privadas da Administração indireta desenvolvam outras atividades de polícia administrativa. Para identificar quais atividades de polícia podem ser atribuídas a tais entidades, cabe avaliar alguns aspectos do controle a que se submetem e as garantias que este propicia para o exercício das atividades de polícia.

\subsection{O controle a que se submetem as entidades privadas da Administração indireta}

É importante examinar a qual tipo de controle submetem-se as entidades privadas da Administração indireta que desenvolvem atividades de natureza pública.

${ }^{918}$ Empresa estatal pode exercer o poder de polícia, 1993, p. 102-103. 
Como destaca Maria Sylvia Zanella Di Pietro, ao serem incumbidas do exercício de uma atividade pública, as entidades da Administração indireta detêm, por um lado, “o direito de exercer, com independência, o serviço que lhe foi outorgado por lei” e, por outro, "o dever de desempenhar esse serviço" ${ }^{19}$, de modo que se submetem ao controle da Administração direta justamente para se assegurar que a atividade que lhes foi atribuída seja desempenhada adequadamente.

São justamente esses os limites a serem observados pelo controle: ao mesmo tempo em que não pode infringir a autonomia assegurada por lei a essas entidades, deve ser suficiente para propiciar a persecução das finalidades para as quais foram constituídas.

Por integrarem a Administração Pública, as empresas estatais submetem-se a mecanismos de controle interno e externo. O controle interno é exercido pelo Poder Executivo. Já o controle externo é desempenhado pelo Poder Legislativo, com o auxílio do Tribunal de Contas.

\subsection{1. $\underline{\text { O controle interno }}$}

As empresas estatais apresentam vínculo permanente com o ente responsável pela sua criação e estão sujeitas ao seu controle, mediante o exercício da tutela estatal.

Na definição de Celso Antônio Bandeira de Mello, a tutela exercida sobre as entidades da Administração indireta "é o poder que assiste à Administração Central de influir sobre elas com o propósito de conformá-las ao cumprimento dos objetivos públicos em vista dos quais foram criadas, harmonizando-as com a atuação administrativa global do Estado",920.

\subsubsection{Não ocorrência de relação de subordinação}

Esse controle não significa que a empresa estatal encontra-se subordinada à Administração direta.

A sujeição à tutela estatal não significa que a validade dos atos da empresa estatal ficará condicionada à aprovação do supervisor. Cabe aos administradores da empresa tomarem todas as decisões relacionadas à sua gestão. Se os administradores adotarem conduta inadequada, poderão ser destituídos. Mas o supervisor não tem legitimidade para praticar diretamente atos que são de competência dos administradores, nos termos da legislação societária.

\footnotetext{
${ }^{919}$ Direito administrativo, 2013, p. 547 - grifos no original.

${ }^{920}$ Curso de direito administrativo, 2013, p. 166.
} 
Como decorrência da ausência de subordinação, a Administração direta não é competente para o conhecimento de recursos contra atos praticados pela entidade da Administração indireta. Apenas será cabível o denominado recurso hierárquico impróprio, se houver expressa previsão legal do seu cabimento.

Além disso, a Administração direta poderá ser provocada a exercer a tutela mediante o exercício de direito de petição pelos administrados ${ }^{921}$. Caberá à Administração direta verificar se estão presentes os requisitos previstos em lei para o exercício da supervisão e, em caso positivo, adotar as providências necessárias em relação ao ato impugnado pelo administrado.

\subsubsection{Necessidade de previsão legal}

A doutrina é unânime ao apontar que a tutela da Administração direta sobre as entidades da Administração indireta não se presume e somente existe na medida, forma e limites determinados pela lei ${ }^{922}$. Não há exercício de tutela sem que as competências de controle a serem exercidas pela Administração direta tenham sido expressamente previstas em lei.

O controle deve ser compatibilizado com a liberdade reconhecida à entidade descentralizada. Em relação a esta, a liberdade é a regra, sendo o controle a exceção. Para além das prescrições legais, não há tutela e vigora a liberdade. Aplica-se a fórmula clássica do direito francês: "Pas de tutelle sans texte, pas de tutelle au delà des textes",923.

Depende também de previsão legal a definição dos mecanismos de tutela a serem utilizados.

Eles poderão abranger tanto uma verificação de conformidade quanto de mérito dos atos praticados pelas empresas estatais. O controle de conformidade objetiva verificar se os atos praticados pela empresa estatal atendem aos requisitos previstos em lei. Trata-se de contrapor o ato em face da moldura legal prevista. O controle de mérito implica uma intensidade maior da tutela, com a avaliação da conveniência e da oportunidade dos atos praticados.

A tutela poderá também ser exercida tanto de forma preventiva quanto repressiva, também a depender das previsões legais. O controle preventivo é manifestado sob a forma de exigência de aprovação prévia pelo controlador para que determinado ato do

\footnotetext{
${ }^{921} \mathrm{CF} / 88$, art. $5^{\circ}$, inc. XXXIV, “a”.

${ }^{922}$ Nesse sentido, entre outros, Maria Sylvia Zanella Di Pietro. Direito administrativo, 2013, p. 547; Celso Antônio Bandeira de Mello. Curso de direito administrativo, 2013, p. 168; Edmir Netto de Araújo. Curso de direito administrativo, 2010, p. 264.

${ }^{923}$ Jean Rivero. Droit administratif, 1960, p. 267.
} 
controlado possa ser praticado ou para que ele tenha eficácia. Já o controle repressivo incide após a prática do ato.

\subsubsection{Controle mediante os mecanismos societários}

Um dos principais aspectos da tutela exercida pela Administração direta diz respeito ao controle das finalidades perseguidas pelas empresas estatais.

Como já se indicou, a lei que autoriza a criação da entidade da Administração indireta já deve especificar as suas finalidades. No seu funcionamento, a entidade apenas poderá perseguir aqueles fins.

Esse controle das finalidades ocorre não apenas por meio dos mecanismos de tutela previstos em lei. A própria participação do Estado nos atos de gestão societária da empresa, como acionista controlador, deverá conduzir à persecução dos objetivos para os quais a entidade foi criada.

Além disso, o controle a ser exercido sobre as empresas estatais pelo ente que a criou também deverá observar as orientações políticas setoriais, de modo a dirigi-las para a satisfação dos interesses coletivos para os quais foram criadas. A tutela faz-se necessária também para que a Administração proteja a unidade da sua orientação política.

Essa orientação da Administração direta quanto ao destino da companhia encontra manifestação nos atos societários praticados pelo ente estatal como acionista. Trata-se de determinar como os diretores da companhia deverão decidir o seu rumo de atuação, sempre em conformidade com as finalidades previstas na lei que autorizou a criação da empresa estatal.

Em relação às sociedades de economia mista, isso consta expressamente do art. 238 da Lei das S.A.

\subsection{2. $\underline{\text { O controle externo }}$}

As empresas estatais também se submetem ao controle externo desempenhado pelo Poder Legislativo, inclusive com o auxílio pelos Tribunais de Contas.

A fiscalização e controle a serem exercidos pelo Congresso Nacional sobre os atos do Executivo incluem as entidades da administração indireta, por expressa disposição constitucional (CF/88, art. 49, inc. X). O controle externo abrange "a fiscalização contábil, financeira, orçamentária, operacional e patrimonial” das entidades da administração indireta "quanto à legalidade, legitimidade, economicidade, aplicação das subvenções e renúncia de receitas” (CF/88, art. 70). Cabe ao Tribunal de Contas o 
julgamento das contas dos administradores e responsáveis por dinheiros, bens e valores públicos inclusive da administração indireta (CF/88, art. 71, inc. II).

\subsubsection{A relevância do controle}

Há a previsão de incidência de controle sobre as empresas estatais com o objetivo de assegurar o adequado desempenho das atividades que lhes foram atribuídas. Ainda que os mecanismos de controle encontrem limites na autonomia assegurada pela lei a essas entidades, consistem em instrumentos importantes para se evitarem eventuais desvios no desempenho de atividades públicas. Cabe à lei prever mecanismos de tutela $\operatorname{adequados}^{924}$.

Ainda que esteja descartada a subordinação em face da Administração direta, a possibilidade de instituição de controles que impliquem inclusive a verificação dos atos praticados pelas estatais e das finalidades perseguidas, incluindo o emprego de mecanismos societários, permite que o desenvolvimento das atividades de polícia administrativa submetam-se a um controle mais intenso em relação àquele possível em relação às atividades desenvolvidas por particulares mediante delegação. Com isso, minimizam-se os riscos de a personalidade jurídica privada vir a comprometer a persecução das finalidades públicas.

A submissão das estatais ao controle público foi um dos argumentos utilizados pelos tribunais para atenuar a vedação do exercício de atividades de polícia administrativa. Por exemplo, o TJRJ reconheceu a legitimidade do exercício da polícia administrativa de trânsito por empresa pública com fundamento na autonomia de que dispõe a Administração para escolher os meios a serem utilizados para o desempenho das suas funções e no fato de as empresas estatais estarem sujeitas à supervisão ${ }^{925}$.

\footnotetext{
${ }^{924}$ A possibilidade de haver intervenção e controle pela Administração direta para assegurar o atingimento das finalidades visadas com a atividade pública consiste em requisito para a atribuição de tal missão a entidades privadas: "a possiblidade de opção do decisor público pela criação ou participação em formas jurídicoprivadas de organização empresarial apenas será constitucionalmente admissível se a sua utilização preservar sempre a existência de mecanismos de intervenção e controle do Estado, podendo aqui formular-se o seguinte princípio geral: se não for possível a utilização pelo Estado de quaisquer meios de direção ou de fiscalização tendentes a assegurar os fins públicos da atividade empresarial desenvolvida, não será admissível em termos constitucionais a liberdade de opção por formas jurídico-privadas de intervenção empresarial” (Paulo Otero. Vinculação e liberdade de conformação jurídica do setor empresarial do Estado, 1998, p. 247-248).

${ }_{925}$ Representação de Inconstitucionalidade n ${ }^{\circ}$ 2003.007.00146, Rel. p/ acórdão Des. Nagib Slaibi, Órgão Especial, j. 12.3.2007.
} 


\subsection{A possível incompatibilidade entre a execução de atividades de polícia administrativa e a presença de recursos privados no capital da empresa estatal}

A utilização de entidades com capital misto, com sócios públicos e privados, é apta a gerar controvérsias adicionais no que diz respeito ao exercício de funções de autoridade.

Trata-se de analisar o potencial conflito entre os fins públicos a serem perseguidos e os interesses (legítimos) do capital privado. Existe a possibilidade de haver divergência entre o exercício de atividades de polícia administrativa pela pessoa jurídica de direito privado e os interesses dos titulares do seu capital social, especialmente os titulares dos recursos privados.

Esse argumento tem sido invocado com bastante frequência, especialmente no que diz respeito ao exercício do atividades de polícia pelas estatais de capital misto.

\subsubsection{Afastamento do conflito em relação às empresas públicas}

O risco de conflito entre os interesses perseguidos pelos titulares dos capitais públicos e privados não se verifica em relação às empresas públicas, que são constituídas exclusivamente por capitais públicos.

Por esse motivo, alguns doutrinadores sustentam que apenas empresas públicas poderiam desempenhar atividades de polícia administrativa.

Para afastar qualquer possibilidade de conflito de interesses entre os sócios da empresa estatal, José Vicente Santos de Mendonça propõe que "na estatal que for exercer poder de polícia só pode existir capital público, jamais privado”`26. Daí que sociedades de economia mista jamais poderiam exercer atividades de polícia. O autor admite excepcionalmente a hipótese de sociedade de economia mista que tenha como acionistas privados exclusivamente os membros do Conselho de Administração ${ }^{927}$.

Note-se que, até 2011, a Lei das Sociedades Anônimas (Lei nº 6.404/76) exigia que os membros do Conselho de Administração fossem acionistas da empresa ${ }^{928}$. Assim, em diversos casos, o Estado atribuía determinadas ações aos seus dirigentes para cumprir o requisito exigido pela Lei $n^{0}$ 6.404/76. Essa participação privada no capital social, por si só, não representava a configuração de uma sociedade de economia mista de verdade e não era apta a dar ensejo ao potencial conflito de interesses na gestão da

\footnotetext{
${ }^{926}$ Estatais com poder de polícia: por que não?, 2009, p. 111.

927 Ob. e loc. cit.

${ }^{928}$ A Lei $n^{\circ} 12.431 / 11$ alterou a redação do caput do art. 146 da Lei $n^{\circ}$ 6.404/76 para excluir a referida exigência.
} 
atividade pública. Não implicava verdadeira participação privada no capital social da empresa.

No mesmo sentido é a conclusão de Vitor Rhein Schirato, que sustenta a "total e absoluta impossibilidade do ingresso de capitais privados nas empresas estatais que exercem função pública”929.

Parece-nos ser necessária a avaliação específica, em cada caso, para se identificar se há eventual incompatibilidade entre os interesses dos titulares do capital privado e o exercício das atividades de polícia.

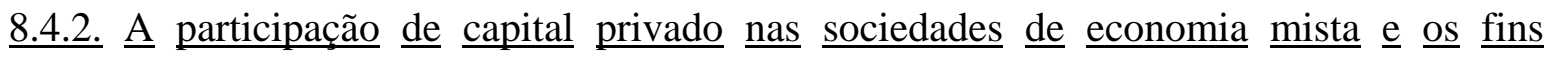
lucrativos

Em se tratando de sociedade de economia mista com sócios privados, é inafastável a acentuação do seu cunho empresarial ${ }^{930}$.

Os sócios investem recursos em uma sociedade de economia mista visando a lucratividade. Trata-se de interesse legítimo, próprio da iniciativa privada. Do mesmo modo, ao aportar recursos em uma sociedade de capital misto, o Estado objetiva uma atuação eficiente, adotando parâmetros próprios da atividade empresarial privada. Ao recorrer a recursos privados para o exercício das suas atividades, a atuação da empresa de capital misto deverá ser atrativa para esses investidores. Os particulares apenas investem recursos em uma sociedade de economia mista diante da perspectiva de percepção de lucros.

Ainda que o controle da sociedade de economia mista tenha que ser exercido por uma entidade estatal, a participação societária de sócios privados repercute no seu funcionamento. Os direitos dos sócios minoritários também terão que ser respeitados. Isso significa, inclusive, orientar a atividade empresarial de modo a propiciar a percepção de lucros pelos seus acionistas.

Portanto, não há como afastar a característica da lucratividade de uma sociedade de economia mista ${ }^{931}$.

\footnotetext{
${ }^{929}$ Novas anotações sobre as empresas estatais, 2005, p. 227-228. Essa é também a conclusão de Alexandre Jorge Carneiro da Cunha Filho. Poder de polícia, 2013, p. 173.

930 Marçal Justen Filho. Curso de direito administrativo, 2013, p. 307-308.

931 Sobre o tema, vale fazer referência ao estudo de Jacintho Arruda Câmara, em que o autor conclui que "é plenamente possível e, nalguns casos mostra-se até mesmo como necessário, que a estatal busque resultados econômico-financeiros positivos em suas operações, pois será essa uma das maneiras de atender aos objetivos que lhe foram constitucional e legalmente atribuídos” (O lucro nas empresas estatais, 2012, p. 18).
} 
8.4.3. A necessidade de observância dos critérios legais no exercício da atividade pública

É recorrente o argumento de que empresas com participação de capitais privados poderiam desenvolver as atividades públicas de modo a obter maior “lucratividade”, por exemplo, com a aplicação excessiva de multas.

Ocorre que esse argumento não é de natureza jurídica, no sentido de que o regime jurídico autorizaria tal prática em relação às sociedades de economia mista.

A empresa estatal deverá necessariamente os critérios legais para o desempenho da atividade de polícia administrativa, mesmo se houver a participação de capitais privados. Ainda que a empresa apresente a característica da lucratividade, isso não afasta o imperativo de que as atividades públicas que lhe foram atribuídas sejam desempenhadas em estrito acordo com a legalidade.

Todos os que exercem atividades de polícia administrativa, com personalidade jurídica pública ou privada, poderão adotar determinados mecanismos que propiciem a apuração de infrações e a aplicação de penalidades de modo mais eficiente. Caso tais mecanismos não sejam legítimos e evidenciem desvio de finalidade no exercício da atividade pública, o problema reside na estratégia em si e não na personalidade jurídica daquele que a aplica. Como pondera Rodrigo Pagani de Souza, isso poderá ocorrer tanto em relação a entidades com natureza jurídica de direito público quanto privado:

Veja-se o caso da empresa estatal constituída para o exercício de poder de polícia. Observe-se que, se porventura enveredar para uma estratégia de se tornar uma "indústria de multas”, dando ensejo a controvérsias sobre a existência de desvio de finalidade na sua atuação, ela não estará fazendo nada diferente do que poderia fazer, na prática, uma autarquia ou uma secretaria de Estado. Estas, no exercício de poder de polícia, também poderiam enveredar por estratégia semelhante, produzindo os mesmos resultados $^{932}$.

Portanto, o risco de desvios, por si só, não é apto a justificar uma suposta impossibilidade de exercício de atividades de polícia por entidades com personalidade jurídica privada. Na hipótese de serem constatados eventuais desvios no exercício da atividade de polícia, há meios específicos para se coibir e sancionar a conduta abusiva. Não há necessidade de se vedar o exercício de toda e qualquer atividade de polícia

\footnotetext{
${ }^{932}$ Empresas estatais constituídas para o exercício de poder de polícia, 2014, p. 167. Ponderação similar acerca de possíveis abusos na aplicação de multas é formulada por José dos Santos Carvalho Filho: "Cuida-se de abuso de poder, que precisa ser severamente reprimido pelas autoridades competentes. Tal abuso, todavia, tanto pode vir de pessoas privadas quanto de pessoas públicas incumbidas da função fiscalizadora. Portanto, esse aspecto não serve para solucionar juridicamente a questão posta sob enfoque. O que se exige é o controle e a exemplar punição pelo cometimento de abusos, o que, infelizmente, quase nunca acontece” (Manual de direito administrativo, 2012, p. 79).
} 
administrativa por sociedades de economia mista por se temer a ocorrência de eventuais $\operatorname{desvios}^{933}$.

O mesmo se aplica à eventual estipulação de remuneração dos empregados de acordo com o seu desempenho, de modo que haveria estímulo para o incremento da arrecadação de multas. O recebimento de bônus e incentivos pode ser previsto também no regime estatutário.

Logo, também em relação a essa questão não se trata propriamente de uma decorrência que seria exclusiva do regime jurídico privado. Em qualquer caso de instituição de benefícios de remuneração aos agentes desempenhem atividades de polícia administrativa, deve-se verificar se existe o risco de comprometimento da necessária isenção.

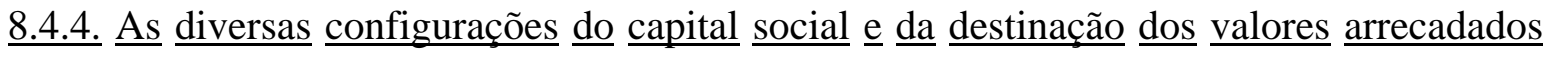
pelas sociedades de economia mista

A questão da "lucratividade" das empresas estatais e o eventual comprometimento da persecução das finalidades coletivas é evidenciada pela destinação dada aos recursos arrecadados com a cobrança de multas. Com frequência alega-se que empresas estatais não poderiam desempenhar atividades de polícia administrativa porque poderiam ser movidas exclusivamente pelo objetivo de arrecadação.

Para o exame do efetivo risco que esse fato representa, é necessário analisar as configurações que a participação privada adota efetivamente na sociedade de economia mista que desempenha atividades de polícia administrativa. Trata-se de avaliar as circunstâncias concretas acerca da distribuição de dividendos aos acionistas para se verificar se haveria algum conflito de interesses que conduziria à intensificação da aplicação de multas com propósitos ilegítimos.

A questão da BHTrans teve grande repercussão nacional. Ao decidir pela ilegalidade de parcela das atribuições que foram conferidas à sociedade de economia mista, o STJ $^{934}$ invocou a possível maior lucratividade da estatal à medida que uma maior quantidade de multas fosse por ela aplicada. Disso se extraiu suposto comprometimento da persecução do interesse coletivo pela busca pelo lucro.

Porém, cabe fazer uma avaliação mais específica do capital social da BHTrans. O seu acionista majoritário é o Município de Belo Horizonte, que detém 98\% do capital. A parcela restante do capital social é titularizada por duas outras acionistas, que

\footnotetext{
${ }^{933}$ Rodrigo Pagani de Souza. Ob. cit., p. 178.

${ }^{934}$ Resp n ${ }^{\circ}$ 817.534/MG, Rel. Min. Mauro Campbell Marques, 2 ${ }^{\mathrm{a}}$ T., j. 10.11.2009, v.u., DJ 10.12.2009.
} 
detêm 1\% do capital social cada. Trata-se da SUDECAP - Superintendência de Desenvolvimento da Capital, que é uma autarquia municipal, e da PRODABEL - Empresa de Informática e Informação do Município de Belo Horizonte S/A, que é uma sociedade de economia mista dependente e de capital fechado ${ }^{935}$.

Por sua vez, os acionistas da PRODABEL são o Município de Belo Horizonte, a Superintendência de Desenvolvimento da Capital - SUDECAP, o Hospital Municipal Odilon Behrens - HOB, a Superintendência de Limpeza Urbana - SLU e a Companhia Urbanizadora de Belo Horizonte - URBEL. Além do Município de Belo Horizonte, esses três outros acionistas titulares do capital social da PRODABEL são autarquias municipais.

Ou seja, não há recursos propriamente privados no capital social da BHTrans.

Considerações dessa ordem conduziram o TJRS a reconhecer a legalidade da atuação da Empresa Pública de Transporte e Circulação - EPTC de Porto Alegre, que tem por atribuição a regulação e fiscalização das atividades de trânsito e transporte do município. O TJRS destacou que se tratava de sociedade de economia mista formada com capitais exclusivamente públicos, tendo como acionistas o Município de Porto Alegre e o DMLU, autarquia municipal. Isso reforçaria a sua natureza pública e a habilitaria para o exercício de atividade estatal ${ }^{936}$.

Além disso, cabe avaliar a destinação do valor das multas arrecadadas pela BHTrans. Segundo Marcos Augusto Perez ${ }^{937}$, a destinação do valor arrecadado observaria as regras da Lei $n^{\circ}$ 9.503/97 (Código de Trânsito Brasileiro). Aplicando o art. 320 da referida lei ${ }^{938}$, 5\% do valor total arrecadado devem ser destinados ao Fundo Nacional de Segurança e Educação de Trânsito (FUNSET). O restante deve ser aplicado em implantação e manutenção de sinalização, engenharia de tráfego, de campo, policiamento, fiscalização e educação de trânsito.

Em Belo Horizonte, tais atividades seriam realizadas através do Fundo de Transportes Urbanos - FTU, para o qual seriam destinados os 95\% restantes da arrecadação.

\footnotetext{
${ }^{935}$ Informações extraídas do sítio eletrônico da BHTrans: http://www.bhtrans.pbh.gov.br/portal/page/portal/ portalpublico/Temas/BHTRANS/BHTRANS-2013, acesso em 17.9.2013.

${ }_{936}$ Incidente de inconstitucionalidade $n^{\circ}$ 70049790009, Órgão Especial, Rel. Des. Carlos Eduardo Zietlow Duro, jul. 13.8.2012.

${ }_{937}^{938}$ Delegação das atividades chamadas de polícia administrativa ou poder de policía, 2010, p. 45.

938 "Art. 320. A receita arrecadada com a cobrança das multas de trânsito será aplicada, exclusivamente, em sinalização, engenharia de tráfego, de campo, policiamento, fiscalização e educação de trânsito. Parágrafo único. O percentual de cinco por cento do valor das multas de trânsito arrecadadas será depositado, mensalmente, na conta de fundo de âmbito nacional destinado à segurança e educação de trânsito.”
} 
O FTU, por sua vez, subsidia o funcionamento da BHTrans. Com isso, não se poderia cogitar de obtenção de lucro pela BHTrans de acordo com a maior ou menor arrecadação de multas.

Diante de tais características, não se identifica a existência de uma participação de capital privado apta a gerar conflito de interesses. Aliás, o art. 320 da Lei $n^{0}$ 9.503/97 veda que a receita obtida com a cobrança de multas reverta para a entidade responsável pela sua arrecadação. A aplicação desse dispositivo já permitiria afastar o argumento de que fins lucrativos moveriam entidades de personalidade jurídica privada, de modo que a atividade fiscalizatória e sancionatória fosse desenvolvida com desvio de finalidade.

Cabe, assim, avaliar as circunstâncias concretas para se identificar se existe a possibilidade de o objetivo da participação privada, que é a obtenção do lucro, comprometer a execução das atividades de polícia com isenção. Faz-se necessário identificar se a participação privada no capital social é significante ou não, inclusive em termos de condução da gestão. Se a participação privada não tiver o condão de, por si só, adotar decisões estratégicas e definir os rumos da empresa, mantendo-se essas decisões nas mãos dos titulares do capital público, não se identifica, em princípio, o conflito de interesses.

\subsubsection{Os mecanismos passíveis de mitigar os potenciais conflitos}

A realização do interesse coletivo visado com a atividade de polícia administrativa não pode ser comprometida com o desempenho da atividade por uma entidade privada. O risco potencial de conflito de interesses deve ser afastado com a adoção de cautelas na atribuição, acompanhamento e controle do desenvolvimento da atividade pública, de modo a se garantir a atuação desinteressada da entidade privada. Faz-se necessária a adoção de mecanismos aptos a garantir a imparcialidade e a neutralidade no exercício das atividades de polícia administrativa por entidades privadas.

Pode-se cogitar, por exemplo, da definição de hipóteses que implicariam a suspeição de determinado particular para exercer as atividades, mediante participação no capital de empresa de economia mista. Trata-se de casos, por exemplo, em que o particular, ao ocupar posição de autoridade em face de outros sujeitos, poderia obter outros benefícios de modo a comprometer a imparcialidade e a independência no exercício da atividade de polícia administrativa. Em qualquer caso, o exercício da atividade de polícia apenas poderá estar vinculada à persecução das finalidades de interesse coletivo para as quais foi 
estipulada. Não se pode admitir a contaminação e o comprometimento do exercício da atividade administrativa com a persecução de interesses privados de particulares.

Outra questão a ser considerada diz respeito à escolha do parceiro da Administração.

Nas hipóteses de utilização de empresas estatais para a execução de obrigações públicas, seria recomendável a adoção de critérios isonômicos para o acesso de particulares a essas entidades e, consequentemente, ao desempenho dessas atividades. Pode-se cogitar da fixação de requisitos e da realização de um processo público concorrencial para a escolha dos parceiros privados ${ }^{939}$.

Cabe verificar também se a sociedade de economia mista desempenha outras atividades que possam comprometer a imparcialidade no exercício da atividade pública. A estatal não poderá, por exemplo, exercer atividade de polícia administrativa e, simultaneamente, explorar atividade econômica, de algum modo vinculado às atividades públicas que exerce, que possa colocar em risco a imparcialidade no desenvolvimento da atividade pública.

Não se trata de vedação a que uma empresa estatal exerça atividade pública e explore atividade econômica ao mesmo tempo. Como se indicou acima, a heterogeneidade do objeto das empresas estatais tem sido verificada cada vez com mais frequência ${ }^{940}$. O que se procura destacar é que, no caso específico das estatais que desempenham função pública, não poderá ser admitido que explorem atividades econômicas, subsidiariamente à sua atividade principal, que possam comprometer o exercício da função pública que lhes foi atribuída.

\subsection{O regime de pessoal das entidades regidas pelo direito privado e o exercício de atividades de polícia administrativa}

Nas empresas estatais, como regra geral, o regime de pessoal é o da legislação trabalhista, em relação de emprego público. As entidades da Administração dotadas de personalidade jurídica de direito privado devem constituir seus agentes sob o regime de direito privado.

\footnotetext{
${ }^{939}$ Por exemplo, Pedro Gonçalves registra, à luz do direito português, que a ausência de regra específica para a escolha dos particulares parceiros do Estado não significa que ela possa ser feita livremente. Os princípios de direito constitucional e de direito comunitário determinariam a exigência de observância de concorrência e de publicidade em tais processos (Entidades privadas com poderes públicos, 2008, p. 410, nota 944).

940 V. item II.2.7.1.
} 
Diante disso, faz-se necessário avaliar o argumento segundo o qual poderes autoritativos apenas poderiam ser exercidos por ocupantes de cargos públicos, aos quais se reconhecem determinadas garantias no exercício das suas funções.

Em alguma medida, trata-se de analisar a validade do argumento segundo o qual haveria uma reserva da função pública aos servidores estatutários. A atribuição do exercício de funções públicas a particulares seria apta a frustrar o regime de cargo público $^{941}$. A regra geral é que a investidura em cargo público sujeita-se à prévia aprovação em concurso público. O exercício privado de funções públicas não poderia transformar o cargo público em posições privadas, de modo generalizado.

8.5.1. Os requisitos constitucionais para o provimento de cargos públicos e empregos públicos nas empresas estatais

A CF/88 estabeleceu diversos requisitos a serem preenchidos para a investidura em cargos públicos, sendo a regra geral a prévia aprovação em concurso público. O exercício de função pública por particulares não ocupantes de cargos públicos não pode frustrar as regras constitucionais acerca da seleção de pessoal pela Administração.

Disso decorre que o exercício de funções públicas por particulares não pode ser empregado de modo generalizado pela Administração. Faz-se necessário justificar a necessidade e a adequação da adoção da medida em cada caso concreto, apresentando-se fundamentos suficientes para excepcionar o exercício da função pública por ocupantes de cargos públicos.

O art. 37, inc. II, da CF/88, em regra aplicável tanto para a Administração direta quanto indireta, determina que a investidura em cargos e empregos públicos depende da prévia aprovação em concurso público.

Logo após a promulgação do texto constitucional, debateu-se acerca da aplicabilidade desse dispositivo em face das empresas estatais. O questionamento embasava-se em outra regra constitucional, a do art. 173, que determina que as empresas estatais devem se sujeitar ao regime próprio das empresas privadas.

\footnotetext{
${ }^{941}$ Trata-se da diretriz exposta no Decreto federal $n^{\circ}$ 2.271/97, que dispõe acerca da execução indireta de atividades materiais acessórias, instrumentais ou complementares no âmbito da Administração Pública federal. Nos termos do art. $1^{\circ}$, $\S 2^{\circ}$, do referido Decreto: "Não poderão ser objeto de execução indireta as atividades inerentes às categorias funcionais abrangidas pelo plano de cargos do órgão ou entidade, salvo expressa disposição legal em contrário ou quando se tratar de cargo extinto, total ou parcialmente, no âmbito do quadro geral de pessoal”. Cabe ponderar a eficácia normativa restrita do dispositivo, por integrar um ato normativo secundário, restrito ao âmbito da Administração federal, e a necessidade de interpretá-lo como vedando a terceirização de atividades de desempenho privativo dos ocupantes de cargos públicos. Reputamos que o caráter privativo ou não do desempenho de determinadas funções apenas poderia ser determinado no nível constitucional-legal.
} 
O STF manifestou-se acerca da questão e assentou que se exige, também das empresas estatais, a observância da regra de contratação de pessoal mediante a realização de concurso público ${ }^{942}$.

Uma hipótese de dispensa de realização de concurso público, expressamente prevista no texto constitucional, consiste nas nomeações para cargos em comissão declarados em lei de livre nomeação e exoneração (art. 37, inc. II, parte final).

Cabe destacar a situação diferenciada dos dirigentes das empresas estatais, investidos em decorrência do exercício da supervisão ministerial pela entidade que exerce o controle. São ao mesmo tempo agentes da empresa estatal e representantes da entidade que exerce a sua supervisão. No exercício de mandato de dirigente da empresa estatal, manterão o vínculo que já detinham com a entidade responsável pela supervisão, seja este estatutário ou celetista.

8.5.2. Os requisitos para a dispensa de servidores estatutários e empregados públicos das empresas estatais

Nos termos do art. $41, \S 1^{\circ}$, da $C F / 88$, consagrou-se como regra geral a vedação à livre exoneração dos servidores estatutários, salvo se configurada uma das hipóteses expressamente previstas.

Em relação aos empregados das empresas estatais, não se reconhece a estabilidade conferida aos servidores estatutários, nos termos previstos no art. 41 do texto constitucional.

No entanto, reconhece-se que os empregados das empresas estatais apenas podem ser admitidos mediante prévio concurso público. A ausência de vedação à livre exoneração não significa ser possível a conclusão de que os empregados públicos seriam livremente demissíveis.

Há diversas manifestações doutrinárias propugnando a necessidade de motivação do ato de demissão do empregado público e que lhe sejam asseguradas as garantias do devido processo, do contraditório e da ampla defesa.

Ao comentar que a acessibilidade tanto aos cargos quanto aos empregos públicos, como regra geral, ocorre mediante concurso público, Celso Antônio Bandeira de Mello constata o seguinte: “Assim como a contratação de pessoal nas empresas públicas e

\footnotetext{
${ }^{942}$ O julgamento do MS $\mathrm{n}^{\circ}$ 21.322, em 3.12.1992, é considerado o leading case sobre o tema: "Se a Constituição na exigência de concurso público para provimento de cargos e empregos públicos, não fez qualquer restrição às entidades da administração pública indireta, é de se concluir que a exigência se aplica a toda empresa estatal, seja ela prestadora de serviço público, seja ela prestadora de atividade econômica de natureza privada” (voto do Min. Relator Paulo Brossard).
} 
sociedades de economia mista sofre o condicionamento aludido, também não é livre o desligamento de seus empregados. Cumpre que haja razões prestantes e demonstráveis para efetuá-lo (...)"943.

Assim se passa porque os desligamentos devem observar os princípios da isonomia e da motivação. Cabe a prévia apuração de eventuais faltas ou insuficiências imputadas ao empregado público, com o desenvolvimento de regular processo no qual lhe seja assegurado o exercício do contraditório e da ampla defesa. Se a dispensa tiver sido causada por motivos não imputáveis à conduta específica do empregado público, tal como a necessidade de redução de despesas com pessoal, devem ser adotadas determinadas cautelas para se assegurar a impessoalidade da medida adotada.

Na jurisprudência, prevalece o entendimento no sentido da necessidade de motivação da dispensa de empregados públicos ${ }^{944}$. Em relação aos empregados públicos federais, o art. $3^{\circ}$ da Lei $n^{\circ}$ 9.962/00 traz o elenco restritivo das hipóteses em que poderá haver rescisão do contrato de trabalho por decisão unilateral da Administração ${ }^{945}$.

Não se olvida que a submissão de toda e qualquer dispensa de empregados de empresas estatais a prévio processo administrativo, com a incidência de todos os direitos e garantias que lhe são inerentes e a prolação de decisão final devidamente motivada, pode vir a comprometer o atingimento de determinados objetivos das empresas estatais.

\footnotetext{
${ }^{943}$ Curso de direito administrativo, 2013, p. 289. No mesmo sentido, Raquel Urbano de Carvalho sustenta o seguinte: "Conclui-se, portanto, que, além de se considerar necessária a motivação do ato demissório de empregado público de uma paraestatal, entende-se necessário sejam asseguradas as garantias da ampla defesa e do contraditório, o que não implica reconhecimento de estabilidade aos servidores celetistas, nem mesmo supressão da discricionariedade da sociedade de economia mista ou empresa pública quando do ato de dispensa" (Curso de direito administrativo, 2009, p. 740).

${ }_{944}$ No julgamento do RE 589.998/PI, com repercussão geral reconhecida, o Pleno do STF proferiu a seguinte decisão: "Empresa brasileira de correios e telégrafos - ECT. Demissão imotivada de seus empregados. Impossibilidade. Necessidade de motivação da dispensa. RE parcialmente provido. I - Os empregados públicos não fazem jus à estabilidade prevista no art. 41 da CF, salvo aqueles admitidos em período anterior ao advento da EC n ${ }^{\circ}$ 19/1998. Precedentes. II - Em atenção, no entanto, aos princípios da impessoalidade e isonomia, que regem a admissão por concurso público, a dispensa do empregado de empresas públicas e sociedades de economia mista que prestam serviços públicos deve ser motivada, assegurando-se, assim, que tais princípios, observados no momento daquela admissão, sejam também respeitados por ocasião da dispensa. III - A motivação do ato de dispensa, assim, visa a resguardar o empregado de uma possível quebra do postulado da impessoalidade por parte do agente estatal investido do poder de demitir” (Rel. Min. Ricardo Lewandowski, j. 20.3.2013, DJe 12.9.2013).

${ }^{945} \mathrm{O}$ dispositivo legal tem a seguinte redação:

"Art. $3^{0} \mathrm{O}$ contrato de trabalho por prazo indeterminado somente será rescindido por ato unilateral da Administração pública nas seguintes hipóteses: I - prática de falta grave, dentre as enumeradas no art. 482 da Consolidação das Leis do Trabalho - CLT; II - acumulação ilegal de cargos, empregos ou funções públicas; III - necessidade de redução de quadro de pessoal, por excesso de despesa, nos termos da lei complementar a que se refere o art. 169 da Constituição Federal; IV - insuficiência de desempenho, apurada em procedimento no qual se assegurem pelo menos um recurso hierárquico dotado de efeito suspensivo, que será apreciado em trinta dias, e o prévio conhecimento dos padrões mínimos exigidos para continuidade da relação de emprego, obrigatoriamente estabelecidos de acordo com as peculiaridades das atividades exercidas. Parágrafo único. Excluem-se da obrigatoriedade dos procedimentos previstos no caput as contratações de pessoal decorrentes da autonomia de gestão de que trata o $\S 8^{\circ}$ do art. 37 da Constituição Federal."
} 
Referimo-nos especificamente às empresas estatais que atuam em competição com as empresas privadas.

Em tais casos poderá ser dispensada, excepcionalmente, a incidência de determinadas regras, inclusive no que diz respeito à necessidade de submissão a concurso público. Trata-se de hipóteses excepcionais, cuja aplicação depende da avaliação das circunstâncias concretas. Importa destacar que esse argumento não poderá ser utilizado para se admitir a demissão imotivada de empregados de empresas estatais em todo e em qualquer caso.

Constata-se, assim, que é possível extrair do regime jurídico dos empregados das empresas estatais determinadas garantias contra a extinção do contrato de trabalho com desvio de finalidade.

É inequívoca a aproximação entre os regimes jurídicos de cargo e emprego públicos nas empresas estatais. Ainda que as situações não tenham sido equiparadas, não se pode afirmar que os servidores estatutários estariam significativamente mais garantidos contra os referidos desvios em relação aos empregados das empresas estatais.

\subsubsection{A reserva do exercício de funções públicas por servidores estatutários}

Outra questão a ser examinada é se o texto constitucional reservou com exclusividade a servidores estatutários o exercício de funções públicas. Trata-se de analisar se haveria no texto constitucional brasileiro a consagração explícita ou implícita da reserva do exercício da função pública a servidores estatutários.

Constata-se que, à luz do texto constitucional, há determinadas competências que apenas podem ser exercidas por agentes submetidos ao regime jurídico de direito público.

Na lição de Maria Sylvia Zanella Di Pietro, o fundamento para tanto encontra-se no art. 247 da CF/88:

ocupam necessariamente cargos públicos, sob regime estatutário, os servidores que “desenvolvem atividades exclusivas de Estado"; isto porque o artigo 247 da Constituição, acrescentado pelo artigo 32 da Emenda Constitucional $n^{\circ}$ 19/98, exige sejam fixados, por lei, "critérios e garantias especiais para a perda do cargo pelo servidor público estável que, em decorrência das atribuições de seu cargo efetivo, desenvolva atividades exclusivas de Estado ${ }^{946}$.

Em sentido próximo, encontra-se o posicionamento de Marçal Justen Filho:

\footnotetext{
${ }^{946}$ Direito administrativo, 2013, p. 591. A autora complementa o seguinte: “Ainda não foram definidas as carreiras de Estado, mas, com certeza, pode-se afirmar que abrangem, além dos membros da Magistratura, Ministério Público, Tribunal de Contas, Advocacia Pública e Defensoria Pública (os quais exercem atribuições constitucionais), os servidores que atuam nas áreas de polícia civil ou militar, controle, fiscalização, diplomacia e regulação” (ob. e loc. cit.).
} 
Uma democracia republicana exige que as competências estatais fundamentais sejam exercitadas por indivíduos submetidos a vínculo jurídico apropriado. A condição de órgão do Estado impõe um regime jurídico diferenciado, próprio do direito público. Por isso, todas as atividades que materializem as competências essenciais do Estado devem ser exercitadas segundo o regime estatutário ${ }^{947}$.

Portanto, apenas servidores estatutários poderiam exercer funções estatais reputadas essenciais, cujo exercício demanda garantias específicas para a atuação impessoal do agente ${ }^{948}$.

A questão relaciona-se diretamente com a constatação de que os servidores estatutários agiriam com maior imparcialidade e objetividade no exercício da função pública.

Um dos principais precedentes jurisprudenciais sobre a matéria consiste no julgamento pelo STF da ADI $n^{0}$ 2.310/DF, que versou sobre o regime de pessoal das agências reguladoras. A ação foi proposta em face de determinadas disposições da Lei $\mathrm{n}^{\circ}$ 9.986/00, que estipulavam que os agentes públicos integrantes dos quadros das agências reguladoras deveriam submeter-se ao regime da CLT. Os autores da ação direta sustentaram que apenas o regime jurídico dos servidores estatutários é que seria compatível com o exercício das funções atribuídas às agências, em especial no que diz respeito às tarefas nas áreas de regulação e fiscalização, que seriam exclusivas do Estado.

Ao deferir a medida cautelar na ADI, houve expressa alusão à necessidade de serem reconhecidas determinadas garantias aos agentes que exercem atividades de polícia. Nos termos da decisão do Min. Marco Aurélio:

Inegavelmente, as agências reguladoras atuam com poder de polícia, fiscalizando, cada qual em sua área, atividades reveladoras de serviço público, a serem desenvolvidas pela iniciativa privada. (...) Está-se diante de atividade na qual o poder de fiscalização, o poder de polícia fazem-se com envergadura ímpar, exigindo, por isso mesmo, que aquele que a desempenhe sinta-se seguro, atue sem receios outros, e isso pressupõe a ocupação de cargo público, a estabilidade prevista no artigo 41 da Constituição Federal $^{949}$.

Ou seja, de acordo com o entendimento adotado pelo STF naquela oportunidade, o regime do emprego público não seria compatível com o desempenho de

\footnotetext{
${ }^{947}$ Curso de direito administrativo, 2013, p. 1.027.

948 Registre-se que Celso Antônio Bandeira de Mello adota um posicionamento mais restritivo, reputando que as atividades que poderiam ser exercidas no regime de emprego seriam aquelas "correspondentes à prestação de serviços materiais subalternos, próprios dos serventes, motoristas, artífices, jardineiros ou mesmo de mecanógrafos, digitadores etc., pois o modesto âmbito da atuação destes agentes não introduz riscos para a impessoalidade da ação do Estado em relação aos administrados caso lhes faltem as garantias inerentes ao regime de cargo” (Curso de direito administrativo, 2013, p. 269 - grifos no original).

${ }^{949}$ Decisão do Rel. Min. Marco Aurélio, DJ 1.2.2001. A apreciação da decisão monocrática pelo Plenário do STF não foi concluída. Verificou-se a perda superveniente de objeto e a ADI n ${ }^{\circ}$ 2.310/DF não teve o seu mérito julgado porque os dispositivos da Lei $n^{\circ}$ 9.986/00 que estipularam o regime de emprego público para as agências foram expressamente revogados pela Lei $n^{0}$ 10.871/04. Esta lei criou carreiras e cargos efetivos para as agências reguladoras.
} 
atividades de polícia administrativa. Aludiu-se expressamente às maiores instabilidade e sujeição a pressões externas como sendo os fatores do regime de emprego público que inviabilizariam a sua aplicação para aqueles que exercem atividades de polícia.

No direito brasileiro, a consequência direta dessa conclusão é o reconhecimento de que não apenas particulares, mas também as entidades estatais dotadas de personalidade jurídica de direito privado e os que se submetem ao regime de emprego público não podem praticar atos de autoridade.

Segundo José Vicente Santos de Mendonça, o argumento do STF seria “consequencialista”, uma vez que considerou antecipadamente as possíveis consequências da tese inicial, a aplicação do regime celetista ao pessoal das agências, para então rejeitá-la. Como a adoção do regime de direito privado dos servidores públicos provavelmente os tornaria mais suscetíveis à pressão externa, reconheceu-se que o regime celetista seria incompatível com o exercício das atividades de regulação ou de polícia ${ }^{950}$.

Inicialmente, cabe avaliar a procedência deste argumento em face do regime dos empregados públicos das empresas estatais.

Pode-se indagar se o regime celetista atualmente consagrado no direito brasileiro efetivamente torna o agente público mais sujeito a pressões indevidas em relação ao que se passa com o regime estatutário. Como se analisou acima, apesar das aproximações dos regimes jurídicos de cargo e emprego público, continuam existindo diferenças.

De todo modo, para parcela da doutrina essas diferenças não permitem concluir pela vedação do exercício de atividades de polícia administrativa pelas empresas estatais.

Como destaca Carlos Ari Sundfeld, as diferenças existentes entre os regimes jurídicos dos agentes não são suficientes para justificar suposta inviabilidade de os empregados das empresas estatais executarem atividades de polícia administrativa:

Não há vínculo necessário entre o regime estatutário e o poder de autoridade. Não nego que o funcionário público, pelas garantias que tem - especialmente a estabilidade, quando a tem - esteja em melhores condições para exercer imparcialmente seu mister. Mas daí a negar a viabilidade de os empregados públicos praticarem atos administrativos vai enorme distância ${ }^{951}$.

O mesmo entendimento é adotado por Vitor Rhein Schirato, para concluir pela viabilidade de exercício de atividades de polícia por empresas estatais:

\footnotetext{
${ }^{950}$ Estatais com poder de polícia: por que não?, 2009, p. 105-106.

${ }^{951}$ Empresa estatal pode exercer o poder de polícia, 1993, p. 101.
} 
com o advento da Constituição Federal de 1988, os regimes de cargo e emprego público foram consideravelmente aproximados. Tal aproximação, em primeiro lugar, decorre da necessidade de concurso público para a investidura, tanto nos cargos públicos, quanto nos empregos públicos, consoante previsão expressa do inciso II do artigo 37 da Constituição Federal. Em segundo lugar, referida aproximação decorre da impossibilidade de exoneração a qualquer tempo e sem motivação de servidores e empregados públicos ${ }^{952}$.

Outro problema do argumento de que apenas servidores estatutários poderiam exercer atos de polícia administrativa é destacado por doutrinadores como Carlos Ari Sundfeld ${ }^{953}$, José Vicente Santos de Mendonça ${ }^{954}$ e Rodrigo Pagani de Souza ${ }^{955}$. Tratase do fato de se aceitar que servidores estatutários efetivos, mas ainda não estáveis, tais como os que se encontram em estágio probatório, pratiquem atos de autoridade. O mesmo se aplica aos que ocupam cargos em comissão. As principais decisões políticas e administrativas são adotadas por agentes que ocupam cargos em comissão. O requisito da estabilidade haveria de incidir também nestes casos, para determinar a impossibilidade de tais servidores exercerem atividades de polícia.

Cabe destacar também que, para fins da legislação penal, há equiparação entre os agentes da Administração direta e indireta. $\mathrm{O}$ art. 327, §1 ${ }^{\circ}$, do Código Penal prevê o seguinte: “Equipara-se a funcionário público quem exerce cargo, emprego ou função em entidade paraestatal”. Há equiparação dos agentes também para fins de aplicação da Lei de Improbidade Administrativa (arts. $1^{\circ}$ e $2^{\circ}$ da Lei $n^{\circ}$ 8.429/92).

Parece-nos que a reserva de funções estatais exclusivas aplica-se especificamente ao exercício da coação. O monopólio estatal da violência constitui função exclusiva do Estado e integra o núcleo de funções estatais que apenas podem ser exercidas por aqueles que ocupam cargos públicos, sujeitos ao regime estatutário.

Já no que diz respeito a outras atividades compreendidas no ciclo da polícia administrativa, parece-nos que não se aplica a reserva de exercício de função estatal por servidores estatutários. O regime jurídico a que se submetem os empregados públicos, por exemplo, propiciaria garantias suficientes para se assegurar a objetividade no exercício das atividades de polícia administrativa - excluindo-se apenas aquelas que implicam o emprego da coação, que são atividades exclusivas do Estado.

Ainda que se possa presumir que os servidores estatutários atuem com maior imparcialidade no desempenho da função pública, toda e qualquer atividade está sujeita a

\footnotetext{
${ }^{952}$ Novas anotações sobre as empresas estatais, 2005, p. 224-225.

${ }^{953}$ Empresa estatal pode exercer o poder de polícia, 1993, p. 101.

${ }^{954}$ Estatais com poder de polícia: por que não?, 2009, p. 108.

${ }^{955}$ Empresas estatais constituídas para o exercício de poder de polícia, 2014, p. 169.
} 
desvios. Os controles e garantias aplicáveis aos servidores estatutários são aptos a reduzir a ocorrência de desvios em maior grau em relação ao que se verifica com os empregados públicos e com mais nitidez ainda no que diz respeito aos trabalhadores da iniciativa privada. No entanto, isso não parece ser suficiente para afastar a possibilidade do exercício de função pública por entidades privadas, ao menos no tocante às atividades não exclusivas do Estado. Ainda que possa existir uma preferência pelo exercício de função pública por servidores estatutários, não se poderia afastar por completo a possibilidade de sua atribuição a entidades privadas.

Nesse ponto, adquire relevância o regime jurídico a que deve se submeter o exercício privado de funções públicas. Referido regime jurídico deve ser adequado para afastar ou minimizar os riscos do exercício de funções públicas por entidades privadas.

Faz-se necessário o estabelecimento de procedimentos e controles rígidos de modo a se garantir que não ocorrerão desvios na persecução do interesse coletivo. A imparcialidade e a isenção deverão ser asseguradas em qualquer caso, sejam as atividades desempenhadas por servidores estatutários ou por empregados sujeitos a regime jurídico distinto. Os mecanismos de controle deverão ser proporcionais à extensão das atividades transferidas aos que se submetem ao regime da legislação trabalhista.

\subsubsection{Observações finais}

Para se assegurar o atingimento de determinadas finalidades, não basta a sua atribuição a determinados sujeitos. É necessário oferecer-lhes um regime jurídico que garanta de modo eficaz o desenvolvimento das atividades e o atingimento das finalidades visadas.

Não há dúvidas de que a relação de emprego público nas empresas estatais apresenta características bastante diversas daquelas verificadas nas relações de trabalho privadas. Aspectos tais como a livre escolha do empregado, a liberdade de estipulação da remuneração e os requisitos para a formação e a extinção da relação de trabalho são bastante distintas ao se comparar a relação de emprego público nas empresas estatais com uma relação trabalhista da iniciativa privada.

De todo modo, não existe equiparação entre os servidores estatutários e os empregados públicos das empresas estatais. Determinados aspectos dos seus regimes jurídicos são diferenciados. Ainda que a relação de emprego nas empresas estatais esteja cercada de diversas garantias, que não existem na relação de trabalho privada e propiciam maior segurança para a atuação imparcial, não estão presentes todas as garantias de que 
dispõem os servidores estatutários. Por esse motivo, não se reputa cabível que empregados públicos exerçam funções exclusivas do Estado, tais como as que implicam o exercício da coação.

\subsection{A necessidade de autorização legal para a criação das empresas estatais}

Outro aspecto a ser considerado é que, por expressa determinação no texto constitucional $^{956}$, as empresas estatais devem ser criadas mediante prévia autorização legal. É necessária a edição de lei específica, na qual deverá ser previsto o objeto social da empresa a ser criada e sua forma de atuação.

A necessidade de que a lei de autorização da criação da estatal especifique as atividades a serem por ela desempenhadas decorre diretamente da competência legislativa. Não haveria sentido em se determinar a prévia aprovação pelo legislativo se este pudesse autorizar a criação de entidades com área de atuação indeterminada. Assim, a autorização legislativa não é genérica, para a criação de qualquer entidade da Administração indireta, e sim para a criação de uma entidade específica, para o desempenho de atividades previamente determinadas.

Essa autorização legal para a sua criação é vinculante para a atuação da empresa estatal. Ela apenas poderá perseguir as finalidades previstas na lei que autorizou a sua criação. Não poderá ser utilizada para fins diversos, ainda que consistam em finalidades públicas. Em relação às sociedades de economia mista, a vedação de exploração do empreendimento para fins diversos consta expressamente do art. 237 da Lei $n^{\circ}$ 6.404/76.

Assim, haverá autorização legal específica para que a empresa estatal exerça atividades de polícia administrativa. A empresa estatal estará autorizada expressamente pelo legislador para desempenhar determinadas finalidades, inclusive no que diz respeito ao exercício de atividades de polícia administrativa.

\subsection{Conclusões parciais}

Uma primeira questão que se coloca é se seria possível cogitar-se de fungibilidade entre as formas públicas e privadas como suporte para o exercício de atividades de polícia.

A partir das considerações apresentadas acima, pode-se concluir que diversos dos argumentos usualmente empregados para justificar a suposta indelegabilidade

${ }^{956}$ CF/88, art. 37, inc. XIX. 
das atividades de polícia a entidades privadas aplicam-se apenas a particulares que não integram o aparato estatal ou se aplicam com menor intensidade às empresas estatais. Daí que as diversas limitações expostas para a delegação de atividades de polícia administrativa a particulares ou não incidem ou incidem com menor intensidade no caso de exercício de atividades de polícia por empresas estatais.

Afigura-se-nos que a personalidade jurídica de direito privado não é suficiente para afastar a possibilidade de tais entidades desenvolverem atividades de polícia administrativa. Como adverte Carlos Ari Sundfeld: “não se confundem o regime da pessoa com o regime da atividade. Empresa que executa atividade pública sujeita-se ao direito público, no que respeita a essa atividade ${ }^{\text {957. }}$.

Outro aspecto constatado é o de que diversos dos argumentos apresentados para justificar a suposta impossibilidade do exercício de atividades de polícia por empresas estatais fundam-se na alegação de prováveis consequências negativas, desacompanhadas da comprovação concreta de que comprometem o atingimento das finalidades visadas com o desempenho da função pública ${ }^{958}$. É o que se passa, por exemplo, com as justificativas relacionadas ao regime jurídico dos empregados públicos.

Ainda que o argumento do monopólio estatal da força não impeça a delegação de toda e qualquer atividade de polícia, há de se reconhecer que incidem maiores restrições quando tais atividades são desempenhadas por entidades com personalidade jurídica privada.

Em primeiro lugar, o exercício de coação física sobre os cidadãos não é passível de delegação e apenas pode ser exercida por servidores estatutários, que ocupam cargos públicos, por se tratar de função exclusiva do Estado. Sobre o tema, deve ser observada também a reserva constitucional de exercício da segurança pública a determinados órgãos. A prestação exclusiva de atividades de segurança pública pelas Forças Armadas e pelos diversos órgãos policiais pode ser extraída dos arts. 142 e 144 da $\mathrm{CF} / 88$.

\footnotetext{
${ }^{957}$ Empresa estatal pode exercer o poder de polícia, 1993, p. 101 - grifo no original.

${ }^{958}$ Vale transcrever a precisa crítica de Rodrigo Pagani de Souza em relação a tais argumentos, ao comentar as decisões judiciais que os acolhem para afirmar a suposta impossibilidade de exercício de atividades de polícia por empresas estatais: "Essas decisões são problemáticas. Reafirmam o dogma apoiando-se em interpretações normativas que apontam “prováveis” consequências negativas da delegação do poder de polícia a entidades de direito privado e seus agentes, sem atentar para a circunstância de que estas consequências, abstratamente cogitadas, carecem de firme comprovação na experiência concreta. Decisões que afirmem a indelegabilidade de poderes de polícia a empresas estatais com base na invocação de riscos, em abstrato, dessa delegação, e que, no entanto, ignorem a experiência jurídica acumulada por empresas estatais constituídas para exercê-los, devem ser rechaçadas. São, nitidamente, decisões que padecem de insuficiência de motivação” (Empresas estatais constituídas para o exercício de poder de polícia, 2014, p. 157-158).
} 
Em segundo lugar, em relação às atividades que não envolvam o manejo de poder de coerção, o seu exercício por entidades de personalidade privada determina a incidência de determinadas restrições e controles.

Logo, não existe perfeita fungibilidade, no âmbito do aparato estatal, entre as formas pública e privada como suporte para o exercício de atividades de polícia. Não seria possível afirmar existir completa fungibilidade nem mesmo entre as diversas formas privadas passíveis de utilização para a delegação de atividades de polícia administrativa.

Porém, disso não decorre que os limites incidentes sobre a delegação de atividades de polícia administrativa a particulares sejam idênticos àqueles incidentes sobre o desempenho de tais atividades pelas empresas estatais.

As diversas restrições e garantias incidentes sobre as atividades das empresas estatais, que determinam que se aproximem muito mais do regime jurídico dos entes da Administração direta do que aquele aplicável aos particulares, permite a execução de atividades de polícia administrativa com maior amplitude. Assim se passa porque o exercício de atividades de polícia administrativa por entidades administrativas de natureza privada e por particulares não é idêntico. O regime jurídico a que se submetem as empresas estatais é significativamente mais rigoroso.

Disso decorre que o risco de conflito de interesses e a consequente necessidade de determinadas salvaguardas especiais apresenta-se com maior evidência quando as atividades de polícia admnistrativa são desempenhadas por particulares. Algumas das cautelas podem ser dispensadas quando se trata de entidade integrante da própria Administração que exerce as atividades de polícia.

Esses aspectos permitem a delegação mais ampla de atividades de polícia administrativa a empresas estatais. Atividades como a sancionatória ${ }^{959}$, cuja delegação reputamos encontrar-se vedada a particulares, seria possível no que diz respeito às empresas estatais desde que sejam adotadas as cautelas necessárias ${ }^{960}$.

\footnotetext{
${ }^{959}$ Luiz Felipe Hadlich Miguel defende a possibilidade de sociedades de economia mista exercerem inclusive atividades sancionatórias ao tecer os seus comentários ao julgamento do STJ no caso BHTRANS (REsp $\mathrm{n}^{\circ}$ 817.534): “o Superior Tribunal de Justiça já chancelou a delegação da fiscalização; contudo, vetou a prática de atos de sanção por particulares. Assim, o agente de trânsito de sociedade de economia mista criada especificamente para gerenciar o trânsito de dado município poderia constatar que um dado veículo está estacionado em cima da faixa de pedestre. Poderia este agente por a termo esta constatação. Este termo poderia dar origem a um auto de infração. Contudo, não poderia ser por ele assinado, pois não lhe foi delegado atos de sanção! Ora, foi o agente de trânsito da sociedade de economia mista que declarou o veículo estar em dado dia e horário estacionado em local inadequado. O que muda, na prática, se ele ou a autoridade quem irá lavrar e assinar o auto de infração? Se houve irregularidade na sanção foi a constatação da infração, e não na efetivação da autuação! (Limites à delegação do poder de polícia, p. 197).

${ }_{960}$ Exemplo de empresa estatal que exerce competências sancionatórias é a CETESB - Companhia de Tecnologia de Saneamento Ambiental, do Estado de São Paulo. Nos termos da Lei ${ }^{\circ} 13.542 / 09$, art. $2^{\circ}$, que
} 
Tais cautelas dizem respeito especialmente à necessidade de se assegurar a objetividade, impessoalidade e isonomia no exercício das atividades de polícia administrativa. A problemática refere-se especialmente às sociedades de economia mista, no tocante à atividade sancionatória. O exercício de poderes sancionatórios por entidades da Administração indireta apenas será possível caso se afaste o risco de tais poderes serem utilizados para fins meramente arrecadatórios, por exemplo.

Essa questão deverá ser aferida nos casos concretos, avaliando-se a destinação dada aos valores arrecadados para se identificar se implicam estímulo ou não para a utilização dos poderes sancionatórios para finalidades privadas. Caso se identifique o risco de conflito de interesses entre as finalidades visadas com o exercício da função pública e os objetivos perseguidos pelos titulares do capital social, as atividades passíveis de desenvolvimento pela entidade privada serão apenas aquelas em relação às quais é possível assegurar-se a objetividade na sua execução.

alterou a redação da Lei $n^{\circ}$ 118/73, estão previstas entre as suas atribuições as de "V - fiscalizar e impor penalidades: a) a quem instale ou opere as atividades de que trata o inciso I deste artigo, sem licença ou autorização ambiental ou descumpra as exigências e condições nelas impostas; b) a quem cause poluição ou degradação do meio ambiente; c) aos infratores da legislação sobre o uso e ocupação do solo em áreas de proteção de mananciais; d) aos infratores da legislação sobre o zoneamento industrial metropolitano”. 


\section{CAPÍTULO IV - REGIME JURÍDICO DO EXERCÍCIO DE ATIVIDADES DE POLÍCIA ADMINISTRATIVA POR ENTIDADES PRIVADAS}

A premissa inicial a ser adotada é a de que a escolha por uma entidade privada para o exercício de determinadas atividades de polícia administrativa não pode conduzir à redução do nível de garantia ou de proteção dos direitos dos administrados.

O estudo das diferentes técnicas ou operações através das quais se atribui o exercício de prerrogativas públicas de polícia administrativa por entidades privadas é relevante diante do grande risco de, através desses expedientes, acabar-se promovendo uma fuga do direito público ${ }^{961}$.

Faz-se necessário, assim, estabelecer as balizas mínimas a ser observadas pelo regime jurídico de execução de tais atividades, para se evitar que a opção por formas jurídico-privadas acabe configurando expediente para a incidência do direito privado de forma indevida. Os particulares no exercício de função pública devem se submeter a um regime jurídico que assegure o atendimento do interesse coletivo visado bem como dos direitos dos cidadãos ${ }^{962}$.

Isso significa que os administrados que estabelecem relações com os particulares no exercício de função pública não podem ter os seus direitos e garantias reduzidos. A atividade pública em si deve ser desempenhada, sob os aspectos material e procedimental, tal como se estivesse sendo conduzida por uma entidade pública. Significa também que deverão ser preservados mecanismos de intervenção e controle do Estado sobre o exercício de tais atividades, de modo a assegurar a persecução dos fins públicos envolvidos e a tutela das posições subjetivas dos particulares.

Outra face relevante da questão é a de que, ao ter-lhes conferido o exercício de prerrogativas e privilégios públicos, os particulares têm não apenas o direito mas também o dever de exercê-los ${ }^{963}$. Os particulares não dispõem da livre escolha quanto à

\footnotetext{
${ }^{961}$ Maria Sylvia Zanella Di Pietro alerta para a indevida fuga do direito público mediante a privatização do regime jurídico de institutos tradicionais de direito administrativo ( $O$ direito administrativo brasileiro sob influência dos sistemas de base romanística e da common law, 2007, p. 28-29).

962 José Bermejo Vera constata que a legislação teria sido incapaz de tratar adequadamente do fenômeno da privatização de tarefas públicas, ao não dispor sobre as suas consequências, em especial no que diz respeito à submissão de particulares ao direito administrativo. Identifica, assim, a "falta de instrumentos jurídicos preparados para responder a este fenômeno ou, ao menos, procurar que tais técnicas alcancem as mesmas cotas de controle e garantia que se vinham exigindo das atuações das Administrações públicas no passado próximo” (Privatización y el nuevo ejercicio de función pública por particulares, p. 405).

${ }^{963}$ Vital Moreira. Administração autónoma e associações públicas, 1997, p. 547.
} 
submissão ao regime jurídico correspondente às prerrogativas que lhes foram conferidas, sujeitando-se ao controle e à responsabilidade decorrentes.

\section{1. $\underline{\text { A submissão das }} \underline{\text { entidades privadas ao direito administrativo }}$}

Ao se avaliar o regime jurídico das entidades privadas que exercem atividades de polícia administrativa, um dos temas a ser analisado é o da sua submissão ou não ao regime jurídico de direito público.

Faz-se necessário analisar os critérios propostos pela doutrina para definir a quais entidades o direito administrativo é aplicável.

De acordo com o critério subjetivo, apenas se submeteriam ao direito administrativo as entidades dotadas de personalidade jurídica de direito público. Já o critério funcional consideraria as funções exercidas, de modo a abranger todas as entidades que exercem função administrativa, pelos mais diversos títulos. Pelo critério funcional, são abarcadas todas as entidades encarregadas da execução da função administrativa, inclusive as privadas.

Constata-se a prevalência da aplicação do critério funcional, no sentido de que a atividade desempenhada pela entidade é que determina o regime jurídico a que se submete, independentemente da personalidade jurídica privada ${ }^{964}$.

Logo, quando uma entidade privada exerce função pública mediante delegação, tem que se submeter, ao menos em alguma medida, ao direito administrativo ${ }^{965}$. É uma consequência necessária do exercício de funções públicas. Como pondera Paulo Otero, “não é a aplicação do Direito Administrativo que atribui a tais entidades poderes de autoridade, antes é a atribuição destes por um título precário do poder público que justifica a aplicação do Direito Administrativo",966.

\footnotetext{
964 Eduardo García de Enterría e Tomás-Ramón Fernández apresentam um exemplo que evidencia a relevância do critério funcional. Os autores narram que a jurisprudência do contencioso administrativo espanhol aplicou a teoria da desconsideração da personalidade jurídica para relevar a personalidade jurídica privada de entidades criadas para própria Administração e qualificar como sendo de natureza administrativa os atos por elas praticados na gestão de serviços públicos. Procurou-se evitar que a personalidade privada fosse utilizada para fraudar a incidência do regime jurídico-administrativo, inclusive em termos de responsabilidade civil, e prejudicar aqueles que se travaram relações com essas entidades (Curso de derecho administrativo, v. I, 2002, p. 46).

${ }_{965}$ Pedro Gonçalves chega a afirmar que as entidades privadas que exercem função administrativa integram a Administração Pública, à medida que são instrumentos de que o poder público se utiliza para realizar os fins que lhe foram atribuídos. Seriam integrantes da Administração Pública em sentido funcional (Entidades privadas com poderes públicos, 2008, p. 287). O tema é analisado mais detidamente adiante.

${ }^{966}$ Legalidade e Administração Pública, 2003, p. 828, nota 308.
} 
O exercício de prerrogativas e privilégios públicos é o critério principal para a aplicação do direito administrativo às atividades de entidades privadas ${ }^{967}$. A Administração pode recorrer ao direito privado para o desempenho das suas funções, mas o limite é que deve sujeitar ao direito administrativo toda e qualquer atuação que suponha o exercício de autoridade pública.

Assente a possibilidade de entidades privadas submeterem-se ao direito administrativo, faz-se necessário examinar em qual medida isso ocorre.

\subsection{Aplicação parcial do direito administrativo às entidades privadas}

É perfeitamente possível conceber-se que as entidades privadas utilizem poderes ou prerrogativas públicas para a gestão de atividades de titularidade pública, formalmente assumidas pela Administração, mas que também pratiquem outros atos, ainda que relacionados de algum modo com a atividade pública, com os seus mecanismos de direito privado.

Assim se passa porque o regime publicístico abrange apenas a atividade pública exercida pela entidade privada e não a sua estrutura empresarial ${ }^{968}$. Por isso, o direito administrativo apenas pode ser aplicado às atividades públicas cuja execução foi atribuída à entidade privada.

As entidades privadas que exercem funções públicas preservam o seu caráter privado. As suas relações jurídicas referentes a aspectos da sua atuação que não se relacionam diretamente com a atividade administrativa são regidas pelo direito privado. Por esse motivo, Jean-Paul Négrin sustenta que o regime jurídico das entidades privadas que participam do exercício da função administrativa não pode ser homogêneo ${ }^{969}$. O autor identifica a existência de uma “tensão” entre a personalidade privada, a demandar a

\footnotetext{
967 “O exercício de autoridade é o único legalmente reservado com exclusividade ao Direito administrativo, sem ser um elemento decisivo a natureza pública ou privada da personificação jurídica que pratica tal exercício. O elemento subjetivo resta, por conseguinte, relegado a um segundo plano no estado atual da nossa disciplina jurídica. O relevante na nova ordem social não é tanto o sujeito concreto que atua senão o Direito que se aplica à sua atuação, atendendo não apenas aos interesses individuais afetados, senão, principalmente, aos interesses públicos em jogo" (Dolors Canals I Ametller. El ejercicio por particulares de funciones de autoridad, 2003, p. 253). Importa ressalvar que não é necessária a presença de prerrogativas de direito público em todas as relações regidas pelo direito administrativo. A atividade de fomento, por exemplo, se desenvolve, em princípio, sem o manejo de prerrogativas públicas (Eduardo García de Enterría e Tomás-Ramón Fernández. Curso de derecho administrativo, v. I, 2002, p. 53).

${ }_{968}$ Essa constatação aplica-se especialmente aos particulares que exercem atividades públicas mediante delegação. Em relação às entidades da Administração indireta com personalidade jurídica privada, determinados aspectos do regime publicístico atingem também a sua estrutura empresarial. O tema já foi analisado no item II.2.7.

${ }_{969}$ L'intervention des personnes morales de droit prive dans l'action administrative, 1971, p. 139.
} 
incidência do regime jurídico privado, e as funções por ela exercidas, que exigem a submissão, ainda que parcial, ao direito administrativo.

Outro aspecto a ser considerado é o de que o direito administrativo não deve incidir em bloco, com todas as suas regras e princípios. Deve ser avaliada a aplicação de cada regra específica do direito administrativo. Assim se passa porque determinadas regras são criadas para vincular a atuação de qualquer entidade à qual tenha sido atribuído o exercício de função pública. Já em relação a outras regras, a sua aplicação apenas se justifica se o ente for integrante da estrutura estatal. A aplicação destas regras não propicia qualquer benefício ou serventia para o exercício da função pública por particulares ${ }^{970}$.

Deve-se ter em mente essa separação para não se incorrer em equívocos na indicação do regime jurídico a que se submetem os atos dessas entidades.

Especialmente na doutrina e jurisprudência da Europa continental, encontram-se referências à incidência da teoria dos atos separáveis ou destacáveis ${ }^{971}$. De acordo com essa teoria, em determinado ato ou contrato, devem ser diferenciados, entre os atos de sua formação e as suas estipulações, aqueles que são regidos pelo direito administrativo daqueles que decorrem do exercício de poderes e instrumentos próprios dos particulares e que são, portanto, regidos pelo direito privado.

Portanto, a natureza privada indica que, em princípio, as entidades privadas são regidas pelo direito privado ${ }^{972}$. Porém, a natureza da atividade por elas exercida pode determinar a incidência do regime de direito público especialmente no que se refere ao vínculo com a entidade pública e, em menor grau, às suas relações com terceiros. Já a sua configuração organizativa é regida precipuamente pelo direito privado.

\footnotetext{
${ }^{970}$ Para ilustrar a colocação, vale recorrer ao exemplo apresentado por Carlos Ari Sundfeld e Jacintho Arruda Câmara. Para os autores, o dever de realizar concurso público para a contratação de pessoal (CF/88, art. 37, inc. II) tem por objetivo atingir apenas os entes integrantes da estrutura estatal. O critério decisivo para a incidência da regra é o fato de o ente integrar a estrutura estatal. Para tanto, em linhas gerais, pouco importa a sua natureza jurídica e a atividade por ele desempenhada - a comprovação disso estaria no fato de a regra ser aplicável inclusive às empresas estatais que exploram atividade econômica (Conselhos de fiscalização profissional, 2006, p. 328-329).

971 J. García Trevijano Fos. Contratos y actos ante el Tribunal Supremo, 1959, p. 147-165.

${ }^{972}$ Nesse ponto, rejeita-se o entendimento que pode ser extraído de alguns julgados do STF, mencionados no item II.2.7.3, segundo o qual as empresas estatais que prestam serviço público seriam equiparadas às autarquias. A natureza privada das empresas estatais não deixa de produzir consequências em relação ao seu regime jurídico, ainda que este sofra as modificações necessárias em razão do caráter público da atividade exercida por tais entidades.
} 


\subsection{A vinculação ao direito administrativo de acordo com a extensão das atividades atribuídas ao particular}

Importa destacar não ser possível aplicar-se de modo homogêneo o direito administrativo, com as modulações adiante expostas, a toda e qualquer hipótese em que for atribuído ao particular o exercício de atividades de polícia administrativa. A vinculação ao direito administrativo depende da natureza das atividades a serem desempenhadas pelo particular.

No âmbito do presente estudo, será destacada especialmente a aplicação do direito administrativo verificada no exercício de atividades de polícia administrativa mediante vínculos contratuais firmados com o Estado. Como se indicou anteriormente, há hipóteses de exercício privado de atividades de polícia também por determinados profissionais, que desempenham atividades de polícia administrativa como objeto principal ou em caráter acessório à atividade profissional. A grande diversidade do regime jurídico aplicável a esses profissionais, geralmente disciplinado em legislação específica, inviabiliza o seu exame conjunto. Em termos exemplificativos, analisou-se anteriormente o regime jurídico aplicável à atividade dos notários e registradores e dos comandantes de navios e aeronaves. De todo modo, vale também para a atividade desses profissionais a constatação de que se submete ao regime jurídico de direito público em diversos aspectos, mas não integralmente ${ }^{973}$.

No âmbito dos contratos de colaboração, transfere-se ao particular a preparação ou a implementação de determinada atividade mas não se lhe atribui a responsabilidade em si pela execução da atividade. O particular apenas produz um resultado que atende às necessidades da Administração mas o faz no exercício de uma atividade privada. Há o auxílio de particulares na execução de atividades públicas mas a gestão e a responsabilidade em relação a tais atividades continuam sendo exclusivas do Estado. O particular atua como representante do Estado, em nome e por conta do Estado.

Diante disso, nas hipóteses em que o particular atua como mero auxiliar da Administração, sem assumir a responsabilidade pela gestão das atividades que lhe foram atribuídas, a sua atuação ocorre, em princípio, sob o regime de direito privado. Porém, ele não deixa de se submeter ao direito administrativo em alguma medida, em decorrência do vínculo contratual que detém com a Administração, decorrente de contrato administrativo.

${ }^{973}$ Como consignou Celso Antônio Bandeira de Mello, ao se referir aos titulares de serviços notariais e de registro: “A contrapartida dos poderes inerentes a uma função considerada pelo Estado como sendo pública é a sujeição aos métodos e critérios peculiares de atrelamento do comportamento deste aos objetivos legais” (Regime constitucional dos servidores da Administração direta e indireta, 1991, p. 10). 
Já nos contratos de delegação, atribui-se ao particular a gestão de uma atividade pública a ser desenvolvida com certa autonomia, transferindo-lhe inclusive a responsabilidade pela sua execução. Nessa hipótese, o particular ocupa a posição do Estado nas suas relações com terceiros e pode inclusive exercer poderes públicos vinculados à missão que lhe foi atribuída, caso estes estejam compreendidos no objeto da delegação.

Tais características dos contratos de delegação demandam a incidência de um regime jurídico mais rigoroso e uma vinculação mais intensa do particular ao direito público. A atuação do particular, seja nas relações com a Administração seja nas relações com terceiros, deverá ser pautada, em ampla medida, pelo direito administrativo ${ }^{974}$. Mas determinadas aspectos, principalmente relacionados à estrutura empresarial, são regidos pelo direito privado.

\subsubsection{Relações com a Administração}

Nas relações entre o particular que exerce função pública e o ente da Administração que lhe atribuiu tal função, a regra geral é a incidência do regime de direito administrativo. Trata-se de relação especial, regulada pela lei e pelo ato ou contrato.

Já no que diz respeito a outras relações com a Administração não vinculadas diretamente à execução do ato ou contrato de atribuição da atividade pública, a regra geral é a incidência do direito privado, considerando-se que o particular preserva a sua natureza privada.

\subsubsection{Relações com outros particulares}

Em se tratando de contrato de delegação, no âmbito externo, devem ser diferenciadas as relações travadas pelo particular como delegatário de função pública das suas outras atividades.

No que diz respeito ao exercício da função que lhe foi delegada, aplicam-se as regras de direito público. Nas relações da entidade privada com terceiros, existe a possibilidade de incidência do direito administrativo justamente porque uma das partes da relação está ocupando determinada posição por exercer funções públicas.

\footnotetext{
974 Almiro do Couto e Silva aponta com precisão, ao identificar os múltiplos interesses envolvidos no desempenho das tarefas administrativas, que a "relação de Direito Administrativo tornou-se, pois, muito frequentemente, uma relação pluripessoal, mudança que está obviamente ligada à democratização da defesa dos interesses públicos, difusos e coletivos perante o Poder Judiciário e a novas formas de democracia participativa na tomada de decisões pelo Estado, quando no exercício da função administrativa, como ocorre, sobretudo, nas matérias relacionadas com o meio ambiente” (Os indivíduos e o Estado na realização de tarefas públicas, 2003, p. 207).
} 
Em se tratando de relação de delegação, o delegatário atua tal como se fosse o próprio delegante - no caso, a Administração. Ainda que atue em nome próprio, o delegatário apresenta-se perante terceiros tal como se integrasse a própria Administração.

Disso decorre que as relações jurídicas travadas pelo delegatário com outros particulares, no exercício da função pública de que foi incumbido, terão natureza administrativa $^{975}$.

Trata-se da aplicação do direito administrativo a relações entre particulares, quais sejam, o particular delegatário da função pública e outros particulares. Justifica-se nas hipóteses em que ao menos um dos particulares envolvidos encontra-se em situação jurídica diferenciada, no exercício de função pública delegada.

Além disso, constata-se a expansão dos valores do direito administrativo às relações entre particulares. Consiste em fenômeno diverso da vinculação dos particulares aos direitos fundamentais ${ }^{976}$. Em alguma medida, a vinculação aos valores do direito administrativo consiste em um fenômeno mais amplo, pois determina a incidência de restrições e exigências aos particulares que não decorreriam apenas da vinculação aos direitos fundamentais. Com a incidência dos valores do direito administrativo às relações privadas, procura-se garantir que serão obtidos os mesmos resultados visados com exercício de atividades públicas que seriam propiciados pela atuação direta do Estado.

Segundo Pedro Gonçalves, as técnicas de que o legislador pode se utilizar para a expansão dos valores do direito administrativo são as seguintes: (a) incorporação, com a reprodução do conteúdo de normas administrativas em normas privadas; (b) inclusão de destinatários particulares na extensão de normas administrativas, mediante a qual a norma será então de direito público e de direito privado ao mesmo tempo; e (c) estipulação, pelas próprias regras de direito privado, de que determinados atos de particulares serão regulados por regras de direito administrativo ${ }^{977}$.

Já em relação às outras relações do delegatário, que não integram a execução das atividades públicas que lhe foram atribuídas, aplica-se o regime privado. Assim, no que diz respeito às relações com terceiros decorrentes da gestão empresarial, os delegatários sujeitam-se ao regime de direito privado. A delegação não faz com que o delegatário passe a ser integrante da Administração Pública.

\footnotetext{
${ }^{975}$ Eduardo García de Enterría e Tomás-Ramón Fernández. Curso de derecho administrativo, v. I, 2002, p. 45.

${ }_{976}$ O tema é objeto de exame específico no item IV.2.

${ }^{977}$ Entidades privadas com poderes públicos, 2008, p. 318-319.
} 
A Lei $\mathrm{n}^{0}$ 8.987/95, por exemplo, confirma a sujeição da gestão da concessionária de serviço público ao regime privado ao dispor sobre os seus contratos com terceiros (art. 25, $\S 2^{\circ}$ ) e o seu regime de pessoal (art. 31, parágrafo único). Ainda que os recursos humanos e materiais sejam utilizados para a execução da atividade pública delegada, não integram o objeto da delegação propriamente dito e, por isso, não se submetem ao regime jurídico de direito público.

É especialmente nesses espaços de atividades desempenhadas no regime jurídico de direito privado que o delegatário poderá atuar com maior flexibilidade. A margem de autonomia conferida ao delegatário para organizar os instrumentos e meios de execução da atividade delegada deve ser exercida dentro desse espaço, que não sofre as restrições do regime público. Como já se indicou, a legislação e, especialmente, o contrato deverá delinear com precisão os limites dessa margem de autonomia conferida ao delegatário.

Já no que diz respeito aos contratos de colaboração, o particular atua como representante do Estado, em nome e por conta do Estado.

No que se refere à execução do contrato, o particular mantém uma relação jurídica apenas com o poder público, não se apresentando perante os usuários como titular de posição jurídica própria. Ainda que o contratado atue diretamente perante terceiros, a sua atuação será atribuída à Administração, tal como se ela estivesse exercendo diretamente as atividades. Não são travadas relações jurídicas autônomas entre o contratado da Administração e os usuários dos serviços por ele prestados.

\subsubsection{Configuração organizativa}

Na organização interna do particular que exerce função pública, a regra geral é a incidência do direito privado, com exceção dos aspectos do regime jurídico de direito público que forem cogentes em razão do exercício da atividade pública. Eventuais deveres específicos a que se submetam os particulares que exercem funções públicas, tais como normas sobre organização interna, eleição de dirigentes etc., devem constar expressamente da lei ou do ato ou contrato de atribuição da missão pública.

Analisam-se adiante os principais aspectos do regime jurídico de direito público que se aplicam às entidades privadas que exercem atividades de polícia administrativa. 
Cabe ressalvar que tais apontamentos aplicam-se especialmente às hipóteses de contratos de delegação, nas quais o particular assume a responsabilidade pela execução da função que lhe foi atribuída. Como se indicou anteriormente, nos casos em que o particular atua como mero colaborador da Administração, sem assumir a responsabilidade pelo desempenho da atividade perante terceiros, os seus atos são regidos precipuamente pelo direito privado, aplicando-se o direito administrativo apenas na relação contratual que trava com a Administração.

\section{2. $\underline{\text { A vinculação }} \underline{\text { dos particulares }} \underline{\text { aos }} \underline{\text { direitos fundamentais }}$}

A vinculação dos particulares aos direitos fundamentais consiste em assunto amplamente debatido na doutrina e na jurisprudência.

A afirmação da vinculação dos particulares aos direitos fundamentais apresenta-se com maior relevância ainda quando se trata do exercício privado de poderes públicos.

Cabe analisar se os particulares que exercem funções públicas encontram-se vinculados aos direitos fundamentais tal como se do próprio Estado se tratasse ou se seria possível cogitar-se de modulações nessa incidência.

\subsection{Aplicação dos direitos fundamentais às relações privadas}

$\mathrm{Na}$ atual etapa de desenvolvimento da teoria dos direitos fundamentais, reconhece-se que estes não são apenas direitos oponíveis ao Estado e que também se aplicam às relações entre particulares.

\subsubsection{Eficácia horizontal dos direitos privados}

A vinculação dos direitos fundamentais a particulares consiste na denominada eficácia horizontal ou efeito externo dos direitos fundamentais.

A questão é objeto de disposição expressa na Constituição de Portugal. O art. $18^{\circ}$, n. 1 , determina que as disposições constitucionais sobre direitos, liberdades e garantias são vinculantes inclusive para as entidades privadas ${ }^{978}$.

\footnotetext{
${ }^{978}$ A redação do dispositivo é a seguinte: “Os preceitos constitucionais respeitantes aos direitos, liberdades e garantias são diretamente aplicáveis e vinculam as entidades públicas e privadas”.
} 
2.1.2. Modo de aplicação dos direitos fundamentais às $\underline{\text { relações privadas: eficácia mediata }}$ ou imediata

A respeito da incidência dos direitos fundamentais às relações privadas, os debates mais acirrados concernem ao modo como ocorre a sua aplicação.

Por um lado, há a corrente que defende a aplicação direta e imediata dos direitos fundamentais. Segundo essa teoria, "os direitos, liberdades e garantias e direitos de natureza análoga aplicam-se obrigatória e diretamente no comércio jurídico entre entidades privadas (individuais ou coletivas) ${ }^{\text {„779 }}$. Isso significa que os indivíduos podem apelar a tais direitos "sem qualquer necessidade de mediação concretizadora dos poderes públicos"980.

No direito português, por exemplo, a doutrina extrai do acima referido art. $18^{\circ}, \mathrm{n}^{\mathrm{o}} 1$ da Constituição Portuguesa a eficácia preceptiva imediata das normas constitucionais que dispõem sobre direitos, liberdades e garantias ${ }^{981}$. A liberdade individual é protegida não apenas dos ataques do Estado, mas também de qualquer outro ente que possa ofender e até suprimir tais direitos.

Segundo Ana Prata, “desta direta eficácia resulta o óbvio limite negativo à autonomia privada que se traduz na nulidade dos negócios contrários aos direitos fundamentais” ${ }^{982}$, com aplicação especialmente nas situações em que os particulares se encontrem em situações de poder desiguais e um deles possa ditar unilateralmente o regulamento a que o outro tem que se submeter.

No entanto, diante da possibilidade de restrições excessivas à autonomia individual provocadas pelos direitos fundamentais, procura-se "circunscrever a sua operatividade aos casos em que a regulamentação legal imponha no domínio privado a sua específica observância - integrada pelo recurso às cláusulas gerais do direito privado (ordem pública, bons costumes etc.)”983.

Outra decorrência problemática da aplicação direta dos direitos fundamentais às relações privadas consiste em se atribuir um papel maior ao juiz, na concretização dos direitos fundamentais, em detrimento daquele conferido ao legislador. O maior encargo do Judiciário repercutiria também na ampliação das questões submetidas às Cortes constitucionais, que acabariam atuando amplamente também em conflitos civis.

\footnotetext{
${ }_{979}$ J. J. Gomes Canotilho. Direito constitucional e teoria da Constituição, 2000, p. 1243.

980 Ob. e loc. cit.

981 Nesse sentido, por exemplo, posiciona-se Gomes Canotilho. Direito constitucional e teoria da Constituição, 2000, p. 1245.

${ }^{982}$ A tutela constitucional da autonomia privada, 1982, p. 138.

${ }^{983}$ Ana Prata. A tutela constitucional da autonomia privada, 1982, p. 138.
} 
Por outro lado, há os que reconhecem que a vinculação não deve ser igual àquela verificada em relação aos poderes públicos. Trata-se da aplicação mediata ou eficácia indireta dos direitos fundamentais.

Há duas modalidades de efeito mediato ou eficácia indireta dos direitos fundamentais. Na primeira, a aplicação mediata pode ocorrer pela atividade legislativa. O legislador deverá buscar a realização e a concretização dos direitos fundamentais ao disciplinar as relações privadas. Na segunda, verifica-se a incidência dos direitos fundamentais ao impor-se ao intérprete o exame das normas que disciplinam as relações privadas em conformidade com os direitos fundamentais.

Como conclui Gilmar Ferreira Mendes, “ainda que não se possa cogitar de vinculação direta do cidadão aos direitos fundamentais, podem esses direitos legitimar limitações à autonomia privada seja no plano da legislação, seja no plano da interpretação"984. Nesses dois domínios, verifica-se o exercício do dever de proteção que cabe ao Estado.

Nesse ponto, Virgílio Afonso da Silva destaca a necessidade de se diferenciar a incidência dos direitos fundamentais na legislação de direito privado da eficácia dos direitos fundamentais nas relações jurídicas privadas ${ }^{985}$. Negar-se qualquer eficácia direta dos direitos fundamentais significa também afastar a vinculação do legislador aos direitos fundamentais. Ocorre que a aplicação imediata dos direitos fundamentais está expressamente prevista em diversos textos constitucionais, inclusive no brasileiro (art. $5^{\circ}, \S 1^{\circ}$ ). Daí, como conclui o autor:

a constitucionalidade da atividade do legislador ordinário, incluindo-se aí sua atividade como criador de dispositivos de direito privado, depende diretamente da compatibilidade dessa atividade com os direitos fundamentais previstos na constituição. Nesse sentido, a vinculação do legislador - ainda que no campo do direito privado - aos direitos fundamentais é, e somente pode ser, direta. ${ }^{986}$

Canaris também rejeita as teses que sustentam que a vinculação do legislador aos direitos fundamentais seria mediata. Não se faz necessária a intermediação de qualquer previsão no ordenamento para que se possa aferir se determinada norma de direito ordinário guarda ou não conformidade com os direitos fundamentais ${ }^{987}$.

\footnotetext{
${ }^{984}$ Direitos fundamentais e controle de constitucionalidade, 2007, p. 127.

${ }^{985}$ A constitucionalização do direito, 2008, p. 68-70.

${ }^{986}$ Ob. cit., p. 70. Segundo o autor, após a mediação legislativa da matéria, não haveria mais espaço para aplicação direta dos direitos fundamentais às relações privadas. A partir daí, os direitos fundamentais teriam apenas efeitos indiretos, à medida que devem ser levados em consideração na interpretação do direito infraconstitutional. O autor ressalva que é o caso de aplicação direta dos direitos fundamentais quando não há mediação legislativa sobre a matéria ou quando a atividade legislativa se apresenta insuficiente (ob. cit., p. 147-148).

${ }^{987}$ Direitos fundamentais e direito privado, 2009, p. 28-32.
} 
Segundo o autor, questão diversa da vigência imediata dos direitos fundamentais é a eficácia em relação a terceiros, da sua incidência imediata nas relações privadas. Para Canaris, são destinatários das normas de direitos fundamentais, em princípio, o Estado e seus órgãos. Os atos dos particulares, agindo enquanto tais, não se submetem ao controle direto sob a perspectiva dos direitos fundamentais ${ }^{988}$.

Indo além da distinção entre eficácia imediata e mediata, Canotilho propõe a superação da referida dicotomia e a busca de "soluções diferenciadas", que sejam adequadas à aplicação do direito fundamental no caso concreto ${ }^{989}$.

Para Canotilho, os direitos fundamentais têm eficácia nas relações privadas como direitos subjetivos públicos que são e não apenas como direitos privados, resultantes da sua recepção pelo direito civil ${ }^{990}$.

O autor destaca que os direitos fundamentais têm especial relevância nas relações privadas nos casos de colisão entre direitos. A definição de qual direito vai prevalecer e qual será sacrificado implica o reconhecimento de que determinados interesses prevalecem sobre outros. A justificação dessa relação de prevalência deverá considerar os direitos fundamentais.

Porém, não se pode pretender, com a aplicação dos direitos fundamentais às relações privadas, o aniquilamento da autonomia individual e a estipulação de situações de absoluta igualdade.

A incidência dos direitos fundamentais no exercício da autonomia privada pode resultar em limites negativos, que determinam a abstenção por outrem, resguardando o espaço de liberdade individual. Porém, pode ter também uma eficácia limitadora positiva, para determinar a adoção de certa conduta ou a inserção de dada cláusula no regulamento negocial $^{991}$.

Uma das principais aplicações da eficácia horizontal dos direitos fundamentais ocorre em relação aos poderes privados. A violação a direitos e garantias individuais não provem exclusivamente do poder público. O exercício dos denominados poderes privados representam um significativo risco aos direitos individuais. Como já se

\footnotetext{
${ }^{988}$ Ob. cit., p. 53-56.

${ }^{989}$ Direito constitucional e teoria da Constituição, 2000, p. 1246. De acordo com o autor, as soluções diferenciadas são necessárias mas não podem dar amparo a uma "dupla ética no seio da sociedade" com relação a temas nucleares: "Essa 'dupla ética' existe quando, por exemplo, se considera como violação da integridade física e moral a exigência de 'testes de gravidez' às mulheres que procuram emprego na função pública, e, ao mesmo, tempo, se toleram e aceitam esses mesmos testes quando o pedido de emprego é feito a entidades privadas, em nome da 'produtividade das empresas' e da 'autonomia contratual e empresarial'” (ob. cit., p. 1251).

${ }^{990}$ Ob. cit., p. 1251-1252.

991 Ana Prata. A tutela constitucional da autonomia privada, 1982, p. 140.
} 
observou, há exercício de poderes privados nos diversos agrupamentos privados de interesses organizados, que representam complexos de poderes sociais.

Constata-se a inviabilidade de se formular uma resposta genérica e abstrata quanto à existência ou não de eficácia direta dos direitos fundamentais nas relações privadas. É necessário analisar-se cada caso concreto, avaliando-se a relação jurídica em questão e os direitos fundamentais que se pretende aplicar.

Pode-se afirmar que a caracterização da relação privada concreta pelo exercício de poderes privados e por sua relevância social implica uma carga de argumentação em favor da aplicação dos direitos fundamentais. No entanto, isso não dispensa a ponderação a ser realizada no caso concreto.

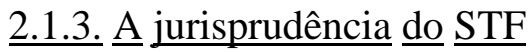

Por diversas vezes, o STF apreciou a problemática da aplicação dos direitos fundamentais às relações privadas para reconhecer a sua aplicabilidade imediata. No entanto, fê-lo de modo implícito, sem enunciar expressamente a argumentação nesse sentido $^{992}$.

A primeira vez em que reconheceu expressamente a eficácia direta dos direitos fundamentais nas relações entre particulares, consignando-a inclusive na ementa, foi no julgamento do RE $\mathrm{n}^{\circ}$ 201.819/RJ, conhecido como “caso UBC"993. O referido precedente consiste em recurso vinculado a medida judicial ajuizada por ex-associado à União Brasileira de Compositores - UBC, objetivando o reconhecimento da nulidade do processo que culminou com a sua exclusão da associação. Postulou o reconhecimento da incidência das garantias de ampla defesa e do contraditório no processo da associação, de modo que pudesse se defender das imputações que lhe foram feitas e produzir provas.

A tese que prevaleceu foi exposta pelo Min. Gilmar Mendes. Nos termos do voto, o processo de exclusão não poderia ser livremente definido pela associação e deveriam ser observadas as garantias constitucionais do devido processo legal, do contraditório e da ampla defesa.

Cabe destacar que o STF levou em consideração especialmente dois aspectos para enfatizar a relevância social e econômica da questão que estava sendo discutida, extrapolando os aspectos eminentemente individuais.

${ }^{992}$ RE $n^{\circ}$ 158.215/RS, Rel. Min. Marco Aurélio, 2 $2^{\mathrm{a}}$ T., j. 30.4.1996, DJ 7.6.1996; RE $n^{\circ}$ 161.243/DF, Rel. Min. Carlos Velloso, $2^{\text {a }}$ T., j. 29.10.1996, DJ 19.12.1997.

993 Para uma análise do "caso UBC", pode-se consultar o texto de Paula Gorzoni. A vinculação dos particulares a direitos fundamentais no STF, 2009, p. 514-527. 
O primeiro deles foi o reconhecimento de que a associação em questão, a UBC, integra o sistema ECAD e desempenha relevante papel na cobrança de direitos autorais. Nas palavras do Min. Gilmar Mendes, a UBC “consistiria em uma entidade de natureza pública, ainda que não-estatal” e a sua atividade "poderia até configurar um serviço público por delegação legislativa” ${ }^{994}$.

O outro aspecto consiste nas consequências da exclusão do associado da UBC. Ao ser afastado, o músico fica impossibilitado de receber os direitos autorais que lhe cabem pela execução das suas obras. Assim, no caso dos músicos profissionais, o processo de exclusão da associação repercute diretamente na liberdade de exercício profissional. Essa relevância social e econômica do objeto social da associação determina uma margem de liberdade mais restrita para definir os seus procedimentos com relação à liberdade conferida a outras associações que tem por objetivo apenas expressar determinado ponto de vista (que poderiam ser identificadas como associações ideológicas), tal como as entidades religiosas $^{995}$.

\subsection{Vinculação direta aos direitos fundamentais dos particulares que exercem atividades de polícia administrativa}

No caso do exercício das atividades de polícia administrativa por particulares, é essencial que estes estejam também vinculados aos direitos fundamentais ${ }^{996}$. Essa constatação vincula-se diretamente à impossibilidade de o exercício privado de tais atividades implicar a diminuição das garantias dos administrados.

Daí a vinculação direta aos direitos fundamentais dos particulares que desempenham atividades de polícia administrativa.

Para Daniel Sarmento, os particulares que exercem função pública devem ser tratados tal como se fosse o próprio poder público atuando, para fins de submissão a um regime estrito de vinculação aos direitos fundamentais:

\footnotetext{
${ }^{994}$ Ou seja, não se trata propriamente de um precedente de aplicação dos direitos fundamentais a relações privadas, tendo em vista que se invocaram aspectos da entidade que a aproximariam do setor público para justificar o resultado do julgamento.

${ }_{995}$ Nos termos do voto, "as associações que detêm posição dominante na vida social ou econômica ou que exercem funções de representação de interesses gozam de uma liberdade mais restrita na fixação das causas de sanção e na imposição das mesmas".

${ }^{996}$ A relevância do tema é evidenciada ao se constatar que a doutrina indica como sendo um dos principais fundamentos pelos quais poderes públicos não poderiam ser exercidos por particulares "a construção dos direitos fundamentais como garantias frente à atuação dos poderes públicos, não frente aos sujeitos privados” (Ricardo Rivero Ortega. Administraciones públicas y derecho privado, 1998, p. 143). Eventual fragilidade da garantia dos direitos fundamentais em tais relações implicaria maior risco aos direitos fundamentais dos cidadãos, concebidos precipuamente para controlar as ingerências do poder público e não do poder exercido por outros particulares.
} 
A submissão irrestrita e incondicional aos direitos fundamentais se estende também, sem sombra de dúvida, para os particulares que desempenham funções de natureza pública, exercendo parcela da autoridade estatal, como os concessionários e permissionários de serviços públicos, no que diz respeito à execução destas funções ${ }^{997}$.

Assim se passa porque, ao optar por delegar a gestão de determinada atividade pública à iniciativa privada, o Estado não pode desfavorecer a proteção em relação aos direitos fundamentais de que dispõem os administrados.

A vinculação direta das entidades privadas aos direitos fundamentais consiste em medida necessária para se evitar a "fuga” do direito público. A utilização de formas privadas para o exercício de atividades estatais não pode frustrar a eficácia imediata dos direitos fundamentais em relação aos entes públicos:

"a escolha da forma de organização do setor empresarial do Estado, em especial a opção por formas jurídico-privadas, não pode ser determinada, nem conduzir, a uma diminuição do nível de garantia ou de proteção das posições jurídico-subjetivas dos particulares, designadamente em termos de vinculação de tais entidades empresariais aos direitos fundamentais"998.

Nos Estados Unidos, aplica-se a "public function theory” para justificar a sujeição de particulares às limitações constitucionais quando se encontrarem no exercício de atividades de natureza estatal ${ }^{999}$. Reputa-se que essa teoria não incide apenas nos casos em que há delegação do exercício de atividade estatal. Aplica-se a todas as hipóteses em que particulares encontrarem-se no exercício de atividade de natureza estatal, independentemente do título de habilitação ${ }^{1000}$.

A aplicabilidade imediata dos direitos fundamentais nas relações entre particulares que exercem função pública e os administrados encontra-se também diretamente vinculada ao regime de responsabilidade civil previsto para estas entidades, nos termos do art. 37, § $6^{\circ}$ da CF/88. Em linhas gerais, os delegatários de atividades públicas e o Estado submetem-se ao mesmo regime jurídico de responsabilização civil. O mesmo deve ser observado em relação à incidência dos direitos fundamentais. A inviabilidade de se

\footnotetext{
997 Direitos fundamentais e relações privadas, 2006, p. 274.

998 Paulo Otero. Vinculação e liberdade de conformação jurídica do setor empresarial do Estado, 1998, p. 244.

999 "Esta teoria impede, em primeiro lugar, que o Estado se livre da sua vinculação aos direitos constitucionais pela constituição de empresas privadas, ou pela delegação das suas funções típicas para particulares, pois estes, quando assumem funções de caráter essencialmente público, passam a sujeitar-se aos mesmos condicionamentos constitucionais impostos aos Poderes Públicos” (Daniel Sarmento. A vinculação dos particulares aos direitos fundamentais, 2011, p. 135).

${ }^{1000}$ A esse respeito, é relevante o precedente Marsh v. Alabama, de 1946. Tratava-se de uma empresa que mantinha uma "cidade privada" no interior da sua propriedade, com ruas, casas etc. Decidiu-se que a proprietária não poderia proibir a pregação por fieis de determinada religião no local, reputando-se que, tal como o Estado, também deveria respeitar a garantia constitucional de liberdade de culto.
} 
reduzirem as garantias dos administrados é a diretriz que orienta a equiparação do regime jurídico em relação a esses dois aspectos.

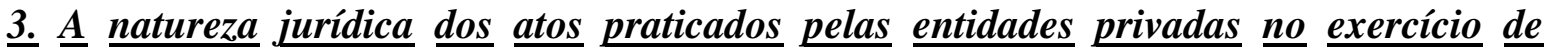 poderes públicos}

A definição da natureza jurídica dos atos praticados pelas entidades privadas que exercem poderes públicos é relevante para se determinar a qual regime jurídico se submetem.

\subsection{A produção de efeitos públicos por atos de particulares}

Cabe analisar inicialmente a possibilidade e, caso positivo, a extensão, da produção de efeitos públicos por atos de particulares.

Trata-se de atos praticados por particulares, no exercício de atividade privada. Posteriormente, os resultados de atos privados são considerados e recebidos pela Administração, podendo até mesmo ser empregados como pressupostos para a prática de atos públicos.

A recepção de atos privados e a atribuição de efeitos públicos podem ocorrer de diversas formas. Em alguns casos, pode existir até mesmo o dever de a Administração receber tais resultados, sem a possibilidade de realizar uma recepção crítica ou controlada. Isso se verifica, por exemplo, quando tais atividades privadas são exercidas mediante prévia acreditação pública dos profissionais ou entidades que praticam os atos. Em outros casos, a lei determina que a eficácia ou a validade de atos privados depende de atos públicos de controle.

Em qualquer caso, a atividade desenvolvida pelo particular é relevante para o exercício da função pública, existindo ou não a recepção controlada pela Administração. O poder público confere eficácia aos atos praticados por particulares. O desempenho da função de polícia pela Administração passa a depender, em maior ou em menor medida, dos atos de particulares praticados no exercício de função privada.

\subsection{A qualificação de atos de particulares como atos administrativos}

Questão diversa da atribuição de efeitos públicos a atos de particulares é o reconhecimento da natureza de ato administrativo a determinados atos praticados por particulares. 
Diferentemente da atribuição posterior de efeitos públicos a atos privados, analisada acima, trata-se da hipótese de os atos praticados por particulares possuírem desde logo a mesma eficácia dos atos da Administração, independentemente de recepção e reconhecimento pelos entes e órgãos administrativos.

Em relação às entidades dotadas de personalidade de direito público, reconhece-se que se encontram naturalmente investidas da capacidade de empregar a forma ato administrativo ${ }^{1001}$. Seria uma consequência natural do reconhecimento da sua personalidade de direito público. Por isso, diz-se que os atos por elas praticados são atos administrativos por sua origem $^{1002}$.

3.2.1. A possibilidade de equiparação de atos $\underline{\text { de particulares a atos administrativos }}$

No que diz respeito aos atos praticados por particulares, reconhece-se que determinados atos seus podem ser equiparados a atos administrativos.

Ainda que não sejam atos administrativos propriamente por sua origem, consideram-se atos materialmente administrativos. Os atos praticados por entidades privadas no exercício de uma atividade pública são atos administrativos porque traduzem o manejo de prerrogativas públicas, ou seja, de um poder destinado à satisfação de necessidades de interesse geral $^{1003}$.

Como destaca Seabra Fagundes, os atos praticados por entidades privadas, no exercício de função pública que lhes foi delegada, não são considerados atos administrativos pela sua origem. Essas entidades exercem essas atividades em nome próprio e os atos por elas praticados são, em princípio, atos privados. No entanto, por se encontrarem no manejo de determinadas prerrogativas públicas, os atos dessas entidades “transcendem do âmbito de ação estritamente privado” e “elas se consideram, quando assim agem, como se autoridades fossem”1004.

Considerando-se que a Administração assume determinados atos praticados por particulares tal como se fossem seus atos próprios e determina a sua execução, reconhecendo-lhes autoridade, esses atos devem se submeter ao regime próprio dos atos

${ }^{1001}$ Importa ressalvar que não é só no exercício de competências públicas delegadas que os particulares podem praticar atos jurídicos de direito público. Almiro do Couto e Silva aponta que, em diversas situações, os particulares podem criar, modificar ou extinguir uma relação jurídica de direito administrativo. Como exemplo, o autor cita a manifestação de vontade por parte do particular que é necessária para que o ato de sua nomeação para cargo público tenha eficácia. $\mathrm{O}$ autor caracteriza esses poderes dos particulares como sendo direitos subjetivos, do tipo formativo. Direitos formativos são direitos que têm por conteúdo o poder de formar relações jurídicas concretas (Atos jurídicos de direito administrativo praticados por particulares e direitos formativos, 2003, p. 79).

${ }^{1002}$ Miguel Seabra Fagundes. O controle dos atos administrativos pelo Poder Judiciário, 2010, p. 38.

1003 René Chapus. Droit administratif général, t. 1, 1999, p. 512.

${ }^{1004}$ O controle dos atos administrativos pelo Poder Judiciário, 2010, p. 39. 
administrativos. A Administração reconhece que os atos praticados por particulares no exercício de atividade pública são verdadeiros e corretos, se não houver prova em contrário. Ou seja, beneficiam-se da presunção de veracidade, tal como se tivessem sido praticados pela Administração ${ }^{1005}$.

A consequência disso é o reconhecimento de que sujeitos privados também podem praticar atos administrativos ${ }^{1006}$.

A esse respeito, Eduardo García de Enterría e Tomás-Ramón Fernández tratam especificamente do exercício de atividades de polícia administrativa por particulares mediante delegação do poder público. Qualificam essa manifestação como sendo “atividade administrativa dos particulares”1007.

Essa atuação privada é traduzida em atos que possuem "virtude e eficácia” igual a que teriam caso tivessem sido praticados diretamente pela Administração. Por isso, concluem os autores, trata-se de verdadeiros atos administrativos, com o concessionário atuando no lugar da Administração, na condição de seu delegado ${ }^{1008}$.

A doutrina começou a tratar mais detidamente dos atos administrativos de origem privada ao analisar alguns precedentes do Conselho de Estado francês, a partir dos quais se enunciou a decadência da definição de direito administrativo sob o ponto de vista orgânico $^{1009}$.

O mesmo se passou em relação aos contratos. A jurisprudência do Conselho de Estado francês admitiu a qualificação como contrato administrativo de avença celebrada

\footnotetext{
${ }^{1005}$ Adilson Abreu Dallari expõe a relevância dos atos praticados pelos particulares ao analisar um dos mecanismos de atribuição de atividades de polícia administrativa, o credenciamento: "Os atos praticados pelo particular credenciado são tidos ou havidos pelo credenciante como verdadeiros, corretos, confiáveis, salvo prova em contrário, da mesma forma pela qual os atos administrativos são beneficiados pela presunção de veracidade. O efeito fundamental dessa credibilidade é ensejar a prática do ato jurídico do qual depende a atividade material ou técnica desenvolvida instrumentalmente pelo credenciado" (Credenciamento, 1997, p. 53).

${ }^{1006}$ No direito alemão, reconhece-se que os sujeitos privados que exercem função pública a título privado integram a Administração. Seria o caso dos "beliehene" que, a partir de uma habilitação - a "Beleihung" exercem funções públicas sob responsabilidade própria. Reputa-se que os "belihene" integram a Administração indireta (José Esteve Pardo. Autorregulación, 2002, p. 109-110), ainda que se trate de sujeitos que, sob sua própria responsabilidade, produzem atos administrativos que podem ser executados como tais pela Administração. A concepção dos particulares que desempenham atividade pública como sendo órgãos impróprios da Administração está presente também na lição de Guido Zanobini. Nessa linha, o autor desenvolveu a teoria orgânica da concessão, na qual considerava o concessionário como sendo órgão indireto da Administração (L'esercizio privato delle funzioni e dei servizi pubblici, 1935, p. 436-437). No entanto, não reputamos ser necessário traçar uma vinculação orgânica entre o particular que exerce função pública em caráter privado e a estrutura administrativa para que os atos por ele praticados possam ser qualificados como atos administrativos.

${ }^{1007}$ Curso de derecho administrativo, v. I, 2002, p. 44-46.

1008 Ob. cit., p. 45.

${ }^{1009}$ Foi o que sustentou, por exemplo, Franck Moderne. Decadencia del punto de vista orgánico en la definición del acto administrativo en derecho francés, 1975, p. 3-15.
} 
entre pessoas privadas, à medida que uma das pessoas teria agido em lugar da Administração ${ }^{1010}$.

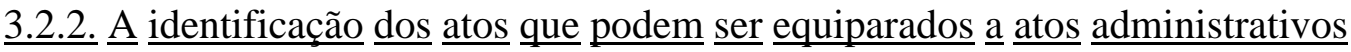

Disso decorre que apenas alguns dos atos praticados por particulares no exercício de função pública são equiparados a atos administrativos.

O reconhecimento da natureza de ato administrativo aos atos praticados por particulares abrange apenas os atos que impliquem manifestação de atividade típica do Estado. Consistirão, precipuamente, nos atos que refletem o exercício de atividade jurídica e não de simples atividade material pelo particular.

Portanto, não se trata de atribuir a natureza de ato administrativo a todos os atos praticados pelo particular. Muito menos trata-se de equiparar a entidade privada a uma autarquia, submetendo-a ao mesmo regime jurídico. Deverão ser considerados atos administrativos apenas aqueles que envolvem o exercício de poderes de autoridade.

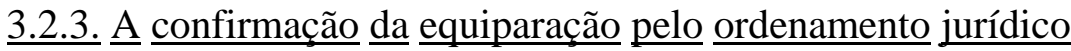

Cabe destacar que o ordenamento jurídico confirma o reconhecimento de que determinados atos praticados por particulares consistem em atos administrativos ao prever o cabimento contra eles de mandado de segurança ${ }^{1011}$.

\subsubsection{Cabimento de mandado de segurança contra agentes de entidades privadas}

Uma das consequências da submissão a controles próprios das atividades públicas é a aceitação do cabimento de mandado de segurança contra atos praticados por entidades privadas no exercício de atividades de polícia administrativa.

O cabimento de mandado de segurança contra dirigentes de entidades privadas não é tema novo. A noção geral é a de que, em se tratando de exercício de

\footnotetext{
${ }^{1010}$ Em relação a contratos, um dos principais precedentes do direito francês seria o arrêt Entreprise Peyrot, de 8 de julho de 1963, no qual o Tribunal de Conflitos reconheceu a natureza administrativa de contrato de obras celebrado com um particular por empresa concessionária de rodovia. Esse mesmo entendimento foi aplicado em outros precedentes, tais como o arrêt Société des Autorutes de la Région Rhône-Alpes, do Conselho de Estado, julgado em 3 de março de 1989. Laurent Richer ressalva que essa solução não se explica pela concepção civilista de mandato, de alguém celebrar um contato "por conta" de outrem, e sim pelo objeto do contrato ser uma atividade de natureza estatal. A concessionária não figura como representante do Estado mas os contratos por ela celebrados submetem-se às mesmas regras que observariam caso tivessem sido firmados pelo próprio Estado (Droit des contrats administratifs, 2002, p. 117-118).

${ }^{1011}$ Seabra Fagundes aponta que é a lei que equipara os atos de particulares, praticados no uso de poderes próprios do Estado, a atos administrativos e menciona como fundamento legal específico a previsão de cabimento de mandado de segurança inclusive contra atos de particulares - na época da redação da obra, o dispositivo que promovia a equiparação era a Lei $\mathrm{n}^{\circ} 1.533 / 51$, art. $1^{\circ}$, $\S 1^{\circ}$. Esse aspecto não foi substancialmente alterado pela legislação em vigor ( $O$ controle dos atos administrativos pelo Poder Judiciário, 2010, p. 39).
} 
atividade pública delegada, o dirigente da entidade privada é equiparado a agente público inclusive no que diz respeito à possível caracterização como autoridade coatora.

\subsection{A qualificação do ato de entidade privada como "ato coator"}

Há expressa previsão legal de cabimento de mandado de segurança contra atos praticados por delegatários de função pública. Trata-se de interpretar o "ato de autoridade” de forma ampla, de modo a abranger inclusive atos praticados por particulares no exercício de função delegada. Nos termos do art. 5º inc. LXIX, da CF/88, cabe mandado de segurança, para proteção de direito líquido e certo, “quando o responsável pela ilegalidade ou abuso de poder for autoridade pública ou agente de pessoa jurídica no exercício de atribuições do Poder Público” ${ }^{1012}$.

Isso também consta expressamente da Lei $\mathrm{n}^{0}$ 12.016/09. O seu art. $1^{\circ}$ prevê o cabimento de mandado de segurança contra atos praticados por autoridades, "seja de que categoria for e sejam quais forem as funções que exerça”. Em seguida, o $\S 1^{\circ}$ desse mesmo dispositivo legal equipara às autoridades, para os fins daquela lei, "os dirigentes de pessoas jurídicas ou as pessoas naturais no exercício de atribuições do poder público” ${ }^{1013}$.

Logo adiante, o art. $1^{\circ}, \S 1^{\circ}$, ressalva que a equiparação é processada “somente no que disser respeito a essas atribuições”. No $\S 2^{\circ}$, afirma-se não caber mandado de segurança “contra os atos de gestão comercial praticados pelos administradores de empresas públicas, de sociedade de economia mista e de concessionárias de serviço público”.

Ou seja, adotou-se o critério de diferenciação entre atos de autoridade e atos de gestão para identificar os atos passíveis de equiparação a atos administrativos ${ }^{1014}$. Tratase do critério que foi adotado pela jurisprudência, em face do regime jurídico anterior, para identificar os atos que poderiam ser atacados com o manejo de mandado de segurança ${ }^{1015}$.

\footnotetext{
1012 Súmula 510 do STF: "Praticado o ato por autoridade, no exercício de competência delegada, contra ela cabe o mandado de segurança ou a medida judicial”.

${ }^{1013}$ A legislação anterior do mandado de segurança consagrava regras bastante próximas a esse respeito. O art. $1^{\circ}$ da Lei 1.533/51 previa o cabimento de mandado de segurança contra atos praticados por autoridades "seja de que categoria for e sejam quais forem as funções que exerça". $\mathrm{O} \S 1^{\circ}$ desse dispositivo esclarecia que se consideravam autoridades, para os efeitos da lei, "os representantes ou administradores das entidades autárquicas e das pessoas naturais ou jurídicas com funções delegadas do Poder Público”, ressalvando que a equiparação ocorria "somente no que entender com essas funções" (conforme redação dada pela Lei $\mathrm{n}^{0}$ 9.259/96)

${ }^{1014}$ As considerações que seguem acerca do tema foram parcialmente expostas por nós em Mandado de segurança contra omissão e contra ato de gestão, 2009.

${ }^{1015}$ Esse entendimento foi consagrado na Súmula 333 do STJ: “Cabe mandado de segurança contra ato praticado em licitação promovida por sociedade de economia mista ou empresa pública”.
} 
A distinção entre atos de império e atos de gestão, para o fim de se identificar o cabimento de mandado de segurança, foi objeto de intensos debates tanto na doutrina quanto na jurisprudência.

Os atos de império seriam aqueles praticados no exercício de prerrogativas públicas. Já nos atos de gestão, a Administração colocar-se-ia em situação de igualdade com os particulares. Usualmente, consideram-se atos de gestão aqueles praticados para a conservação e desenvolvimento do patrimônio público e na gestão de serviços ${ }^{1016}$. Em linhas gerais, os atos de gestão não retratariam uma situação de superioridade da Administração ou daqueles que se encontrem no exercício de funções públicas. Por isso, não estariam sujeitos ao controle pela via mandamental.

Porém, como registra Maria Sylvia Zanella Di Pietro ${ }^{1017}$, não é possível enquadrar todos os atos praticados pela Administração na gestão do patrimônio público e na gestão dos seus serviços como sendo simples atos de gestão, desprovidos de poder de império. Daí que a referida classificação dos atos administrativos acabou sendo abandonada e substituída por aquela que considera o regime jurídico a que se submetem os atos, classificando-os em atos administrativos, regidos pelo direito público, e atos de direito privado da Administração.

Cabe registrar, ainda, que os atos de gestão não se confundem com os denominados atos de expediente. Estes são aqueles atos praticados rotineiramente, dando seguimento a processos e documentos, sem qualquer apreciação quanto ao mérito da questão que está sendo processada. Porém, caso as condutas praticadas no processamento do requerimento se configurem como sendo ilegais ou abusivas e aptas a lesar ou ameaçar lesionar direito líquido e certo do administrado, não serão simples atos de gestão mas atos administrativos passíveis de ataque através de impetração. É o que se verifica, por exemplo, diante da recusa injustificada em se processar o requerimento do particular.

Por outro lado, há de se observar que a Lei $n^{0}$ 12.016/09 adotou a terminologia “ato de gestão comercial” para afastar o cabimento do writ contra estes. A lei não esclarece em que consistiriam tais atos de "gestão comercial”. Pode-se cogitar de que se trata dos atos praticados pelas empresas públicas, sociedades de economia mista e concessionárias de serviço público no exercício de atividades de gestão, que não envolvem o manejo de poderes públicos.

\footnotetext{
${ }^{1016}$ Maria Sylvia Zanella Di Pietro. Direito administrativo, 2013, p. 227-228.

${ }^{1017}$ Direito administrativo, 2013, p. 228.
} 
O dispositivo legal deve ser interpretado adequadamente, de modo a se afastar o cabimento da impetração exclusivamente nas hipóteses em que a entidade privada pode atuar tal como um particular, submetendo-se exclusivamente ao direito privado. Isso abrange apenas as situações em que $o$ ato praticado inequivocamente não implique 0 exercício de função pública e não se submeta aos princípios da Administração Pública.

A aplicação concreta dessas noções pode apresentar controvérsias, especialmente no que diz respeito à caracterização ou não do exercício de atividade pública por particular mediante delegação.

A jurisprudência dos tribunais nacionais, confirmada pelo $\mathrm{STJ}^{1018}$, adota entendimento no sentido de ser cabível a impetração de mandado de segurança contra ato de dirigente de instituição particular de ensino. O argumento utilizado é o de que o referido dirigente pratica atos de autoridade porque exerceria função delegada pelo poder público.

Em face desse entendimento, é necessário analisar se essa situação consiste efetivamente no exercício de atividade pública por particulares. Ou seja, identificar se os dirigentes de instituições particulares de ensino praticam atos de autoridade por delegação da pessoa política a que se vincula a instituição de ensino que dirigem ou se exercem meros poderes privados, que atingem apenas determinada comunidade acadêmica.

A problemática da jurisprudência acima mencionada diz respeito ao reconhecimento de que tais dirigentes exercem funções de autoridade ao mesmo tempo em que se admite que a atividade desempenhada pela instituição não se desenvolve em regime de delegação. O sistema nacional admite a convivência entre o ensino público e o privado, não existindo monopólio público do ensino. As escolas privadas são constituídas como entidades privadas que exercem atividade publicamente regulada mas que não atuam por delegação do Estado.

O que se verifica é que a legislação atribui aos títulos, às avaliações e aos graus conferidos pelas escolas privadas o mesmo valor reconhecido àqueles emitidos pelas escolas públicas. Porém, ao atribuírem tais títulos aos alunos, as escolas privadas não exercem função pública. Trata-se de exercício de atividade própria, privada, cujos efeitos são reconhecidos pelo Estado. É a atribuição de efeitos públicos a atos privados ${ }^{1019}$.

\footnotetext{
${ }^{1018}$ Nesse sentido, podem ser mencionados os seguintes acórdãos do STJ, entre outros: CC ${ }^{\circ}$ 108.466/RS, Rel. Min. Castro Meira, $1^{\text {a }}$ S., j. 10.2.2010, v.u., DJe 1.3.2010; REsp n ${ }^{\circ}$ 883.497/GO, Rel. Min. Luiz Fux, $1^{\mathrm{a}}$ T., j. 4.11.2008, v.u., DJe 1.12.2008; Resp n ${ }^{\circ}$ 661.404/DF, Rel. Juiz Conv. Carlos Fernando Mathias, $2^{\mathrm{a}}$ T., j. 21.2.2008, v.u., DJe 1.4.2008.

${ }^{1019}$ Cabe destacar que o tema é objeto de controvérsia na doutrina. Paulo Otero, por exemplo, sustenta que os atos de avaliação e de certificação dos alunos realizados pelas escolas privadas submetem-se ao regime
} 
No entanto, parece-nos que, no que diz respeito especificamente às entidades privadas de ensino, elas não exercem atividade pública delegada. Portanto, não haveria justificativa para se admitir o cabimento de impetração de mandado de segurança contra os atos praticados por seus dirigentes.

3.2.3.1.2. O mandado de segurança como instrumento de controle do exercício privado de atividades de polícia administrativa

O cabimento de mandado de segurança contra atos praticados por entidades privadas no exercício de função pública consistem em importante instrumento de controle sob dois aspectos.

O primeiro deles é o que já se mencionou acima. Trata-se do reconhecimento de que os atos que tais entidades privadas praticam consistem em atos de autoridade, tanto que podem ser impugnados com o manejo de mandado de segurança. Como atos de autoridade, devem também preencher os requisitos a serem observados pela Administração ao praticar seus atos.

O outro aspecto diz respeito aos instrumentos de defesa de que dispõe o administrado para se defender perante tais atos de autoridade praticados por entidades privadas. Ao se assegurarem mecanismos de defesa adequados, procura-se afastar o argumento contra a possibilidade de particulares praticarem atos de autoridade no sentido de que os administrados eventualmente atingidos ficariam com a sua defesa fragilizada. Afinal, reconhece-se que tais atos podem ser impugnados inclusive em sede de mandado de segurança.

\subsubsection{Cabimento de habeas data}

Outra decorrência do reconhecimento da natureza pública de determinadas atividades desempenhadas pelo delegatário é o cabimento habeas data.

O habeas data consiste na via processual prevista na Constituição para que o seu autor obtenha o conhecimento ou a retificação de informações relativas à sua pessoa que constem de banco de dados de entidades estatais ou de entidades privadas que armazenem tais informações para o desempenho de função pública (CF/88, art. 5, LXXII).

\subsubsection{As consequências da equiparação}

É importante registrar que, no direito comparado, o debate acerca da qualificação dos atos de particulares praticados no exercício de função pública tem especial 
relevância para se definir a competência da justiça administrativa ou da justiça comum para o conhecimento de litígios acerca de tais atos ${ }^{1020}$. Ainda que no direito nacional não exista essa preocupação diante da unidade de jurisdição, isso não significa que a caracterização como ato administrativo seja irrelevante.

Uma das decorrências relevantes já foi mencionada acima. Trata-se do reconhecimento da possibilidade de impugnação de tais atos pelos mesmos mecanismos empregados em face dos atos praticados pela Administração.

Outro aspecto da questão vincula-se ao fato de a forma ato administrativo constituir um fator suplementar ou aditivo de poder, em razão dos seus atributos. O ato administrativo é dotado de exigibilidade (e eventual autoexecutoridade), tem presunção de legitimidade ${ }^{1021}$, é passível de anulação e revogação unilateral pela Administração. Trata-se de características próprias dos atos administrativos, que estão presentes em toda e qualquer manifestação do poder público.

Note-se que nem todos esses atributos dos atos administrativos verificam-se nos atos praticados por particulares, no exercício de função pública delegada. Apesar de o ato por ele praticado ser exigível e ter presunção de legitimidade, não poderá o particular anulá-lo ou revogá-lo. As decorrências da autoexecutoriedade - que, em regra, implicam o emprego da coerção direta - também não são passíveis de delegação e apenas poderão ser exercidas pela própria Administração.

Importa destacar que a equiparação faz-se necessária inclusive em atenção aos demais particulares que se relacionam com o particular no exercício de função pública. Os cidadãos não podem ter os seus direitos e garantias reduzidos ou vulnerados porque a função pública está sendo exercida por um particular delegatário do poder público. Isso

\footnotetext{
${ }^{1020}$ Na Espanha, a lei reguladora da Jurisdição Contencioso-administrativa (Lei no 29/98, de 13 de julho) dispõe expressamente ser da competência da jurisdição administrativa o conhecimento de questões relacionadas a "atos administrativos de controle ou fiscalização ditados pela Administração concedente, a respeito dos ditados pelos concessionários dos serviços públicos que impliquem o exercício de poderes administrativos conferidos aos mesmos, assim como os atos dos próprios concessionários quando possam ser recorridos diretamente ante esta ordem jurisdicional em conformidade com a legislação setorial correspondente" (art. 2.d).

${ }^{1021}$ O TJSP reconheceu que a CETESB, empresa pública, pode exercer atividades de polícia e que os autos de infração por lavrados, relativos a infrações ambientais, gozam de presunção de legitimidade: "CETESB. Empresa pública. Poder de polícia. Existência, eis que esta tem como objeto exercer as atividades relativas ao controle de poluição das águas e do ar, incumbindo-lhe o efetivo exercício do controle da qualidade do meio ambiente em todo o território estadual além de outras atividades úteis ou necessárias ao cumprimento de suas finalidades, inclusive o poder de polícia administrativa, inerente e indispensável ao bom desempenho de seus serviços (inciso I do artigo $3^{\circ}$ do Decreto n. 5.993/1975). Tal poder está diretamente relacionado à competência comum (inciso VI do artigo 23 da CF). Trata-se de poder conferido à Administração Pública, que pode exercê-lo de forma direta ou indireta. Outrossim, os autos de infração impugnados não apresentam qualquer ilegalidade patente e, bem por isso, gozam de presunção de legitimidade" (Apelação Cível $n^{0}$ 994.03.081217-0, Rel. Des. Eduardo Braga, j. 3.2.2011).
} 
implica a necessidade de os atos praticados pelo delegatário no exercício da função pública preencherem todos os requisitos da atividade administrativa, tal como se estivessem sendo praticados pela própria Administração.

Outra possível decorrência seria o reconhecimento da possibilidade de o particular atingido pelo ato interpor recurso administrativo em face da decisão adotada por outro particular no exercício de função pública. A questão é analisada adiante.

\section{4. $\underline{\text { A incidência }} \underline{\text { da }} \underline{\text { garantia }} \underline{\text { do }} \underline{\text { devido }}$ processo}

Ao exercer atividade pública por delegação, o particular também se submete ao dever constitucional de procedimentalização ${ }^{1022}$.

O dever de observância do devido processo aplica-se, em primeiro plano, ao próprio desenvolvimento da atividade delegada. Trata-se de observar os requisitos e procedimentos previstos na lei e no contrato, que delimitam e delineiam as competências a serem exercidas pelo delegatário.

A garantia do devido processo também se aplica nas relações travadas pelo delegatário com terceiros. À medida que o particular assume a posição do Estado, o dever de se observar a processualidade administrativa passa a incidir também sobre relações privadas $^{1023}$. A concretização da garantia do devido processo nas relações com terceiros também se encontra delineada principalmente na lei e no contrato.

Também esse aspecto do regime jurídico do exercício privado de função pública encontra-se vinculado ao fato de que o recurso a formas privadas não pode significar a possibilidade de a Administração escolher o regime jurídico a que se submete a sua atuação, de modo a vulnerar as garantias dos particulares. O recurso a formas privadas para o exercício de atividades públicas não pode implicar a redução das garantias dos particulares.

\subsection{A aplicação da garantia do devido processo no exercício da atividade delegada}

No que diz respeito à atuação de delegatários no exercício de função pública, a sua atividade deverá ser regida especialmente pelas disposições normativas e contratuais. A conduta do delegatário deverá ser orientada especialmente por tais previsões, que disciplinarão tanto as suas relações com o poder público quanto com os usuários.

\footnotetext{
1022 Eurico Bittencourt Neto. Devido procedimento equitativo e vinculação de serviços públicos delegados no Brasil, 2009, p. 138-139.

${ }^{1023}$ Floriano de Azevedo Marques Neto. A concessão como instituto do direito administrativo, 2013, p. 573.
} 
É a observância do devido processo que permite reduzir os riscos de desvios no exercício das atividades de polícia administrativa. Por envolver a atuação humana, há o risco de a atividade não ser desenvolvida com a impessoalidade e a imparcialidade necessárias, seja o agente integrante da Administração Pública ou não. A condição de servidor público não é suficiente para afastar todo e qualquer risco de arbitrariedade no desempenho da função administrativa.

Nesse contexto, é por meio do devido processo que é possível assegurar-se que a atividade será desenvolvida de acordo com critérios objetivos previamente definidos, delimitadores das prerrogativas públicas que poderão ser exercidas. A peculiaridade em relação ao serviço delegado é que deve haver a prévia programação dos critérios e procedimentos especialmente em sede contratual, vinculando o particular e submetendo-o aos diversos controles aplicáveis.

Ou seja, os riscos de se instalar uma “indústria de multas”, usualmente invocados para se rejeitar a delegação de atividades de polícia administrativa, são coibidos especialmente com a incidência do devido processo.

Cabe à lei a estipulação de previsões mais genéricas e amplas sobre o tema. Como se indicou anteriormente, é o contrato a sede mais adequada para a regulação minuciosa dos diversos requisitos, critérios e procedimentos a serem observados no exercício da atividade delegada.

Essa regulação deve ser minuciosa o suficiente para assegurar a delimitação, enumeração e prévia programação das atividades a serem desenvolvidas pelo particular. Esses são pressupostos imprescindíveis para se assegurar a objetividade e imparcialidade no exercício da atividade pública bem como a sua plena contrastabilidade pelos órgãos de controle.

Assim, a atividade delegada deve ser desenvolvida de acordo pelas disposições legais e contratuais. São essas as principais balizas a delinearem os procedimentos a serem observados pelo delegatário no exercício da atividade pública. Disso decorre que o comportamento que se pode exigir do delegatário apenas pode ser aquele expressamente previsto na legislação ou no contrato.

Não há como se imputar ao delegatário o dever de cumprir requisitos e procedimentos que não tenham sido expressamente previstos nas disposições legais e contratuais aplicáveis ao desenvolvimento da sua atividade. Isso equivaleria à obrigação de cumprimento de deveres “invisíveis”, dos quais o delegatário não tem conhecimento. São 
necessárias as plenas previsibilidade e conhecimento do delegatário em relação aos seus deveres, de modo que possa desempenhar as suas atividades ciente dos seus encargos.

\subsection{A garantia dos direitos dos administrados}

Em relação aos terceiros que travam relações com o delegatário da atividade pública, no exercício da função pública, devem ser assegurados os mesmos direitos e garantias tal como se a atividade estivesse sendo desenvolvida diretamente pelo Estado: "a forma jurídica de organização não deveria desempenhar qualquer influência na proteção dos direitos dos particulares contra atuações da Administração passíveis de lesar a esfera jurídica dos particulares, sendo certo que uma tal proteção jurídica deve sempre adaptar-se às diversas formas de organização administrativa e não o inverso”"1024.

Ao transferir missões públicas e prerrogativas a entidades privadas, o Estado deve estipular a forma de exercício das funções delegadas, estabelecendo seus requisitos, limites e finalidades a serem perseguidas. Com base nessas disposições, os administrados têm o direito subjetivo público de exigir um determinado comportamento, positivo ou negativo, em primeiro lugar do delegatário e depois do poder público ${ }^{1025}$.

Ocupando a posição do Estado no exercício de atividades públicas perante os administrados, o delegatário assume essa posição do poder público também no que diz respeito à necessária observância do devido processo no desenvolvimento das suas atividades, inclusive no tocante à adoção de decisões (audição dos interessados, fundamentação, etc.) ${ }^{1026}$ e à solução de divergências e impasses.

Nessa regulação do desempenho da atividade pública pela entidade privada, é necessário também assegurar os direitos dos demais particulares de resistir ao exercício desses poderes e de recorrer ao poder concedente e à esfera judicial caso reputem que a atuação do delegatário tenha sido incorreta ou abusiva.

\footnotetext{
${ }^{1024}$ Paulo Otero. Vinculação e liberdade de conformação jurídica do setor empresarial do Estado, 1998, p. 246.

1025 Cesar A. Guimarães Pereira. Usuários de serviços públicos, 2008, p. 78; Egon Bockmann Moreira. Direito das concessões de serviço público, 2010, p. 290.

${ }^{1026}$ Vital Moreira. Administração autónoma e associações públicas, 1997, p. 548.
} 


\subsection{A participação dos usuários na gestão da atividade delegada}

As diversas decorrências da aplicação da garantia do devido processo às relações entre o delegatário e os usuários apenas podem ser desencadeadas ao se assegurar a participação ${ }^{1027}$ na gestão da atividade pública delegada.

A participação do usuário na Administração Pública direta e indireta encontra-se expressamente prevista no art. $37, \S 3^{\circ}$, da $\mathrm{CF} / 88^{1028}$. O dispositivo constitucional contempla um conjunto mínimo de regras a serem desenvolvidas e ampliadas por ocasião da edição da lei disciplinando a matéria ${ }^{1029}$. Trata-se de regras exemplificativas de prioridades, que devem ser regulamentadas por lei.

A “Lei de Defesa do Usuário de Serviços Públicos” ainda não foi editada, apesar de expirado o prazo previsto no art. 27 da EC nº 19/98 (de 120 dias contados a partir da promulgação da referida Emenda) ${ }^{1030}$. Em relação aos serviços prestados por concessionários, as Leis $\mathrm{n}^{0}$ 8.987/95 e $\mathrm{n}^{0}$ 9.074/95 já disciplinam a participação dos usuários $^{1031}$, implicitamente prevista no art. 175, inc. II, da CF/88.

O exercício desses direitos pressupõe a existência de um serviço de atendimento ao usuário, tanto para o recebimento quanto para o processamento de

1027 Sobre as diversas formas de participação popular na Administração, consulte-se o texto de Maria Sylvia Zanella Di Pietro. Participação popular na Administração Pública, 1993, p. 128-139.

1028 A redação do dispositivo é a seguinte: “A lei disciplinará as formas de participação do usuário na administração pública direta e indireta, regulando especialmente: I - as reclamações relativas à prestação dos serviços públicos em geral, asseguradas a manutenção de serviços de atendimento ao usuário e a avaliação periódica, externa e interna, da qualidade dos serviços; II - o acesso dos usuários a registros administrativos e a informações sobre atos de governo, observado o disposto no art. 5\%, X e XXXIII; III - a disciplina da representação contra o exercício negligente ou abusivo de cargo, emprego ou função na administração pública.”

${ }^{1029}$ Dinorá Adelaide Musetti Grotti. O serviço público e a Constituição brasileira de 1988, 2003, p. 354.

${ }^{1030}$ O Min. Dias Toffoli deferiu liminar, ad referendum do plenário, na ADO $\mathrm{n}^{\circ}$ 24, ajuizada pelo Conselho federal da OAB, reconhecendo o estado de mora do Congresso Nacional e estabelecendo prazo de 120 dias para que sejam adotadas as providências legislativas necessárias ao cumprimento do dever imposto no art. 27 da EC no 19/98 (DJE 31.7.2013). Até o final de janeiro de 2014, a liminar ainda não havia sido apreciada pelo Plenário. A ação direta pleiteou também, em sede de medida liminar, a aplicação do Código de Defesa do Consumidor enquanto a lei específica não for editada. A liminar não foi deferida em relação a esse pedido.

${ }^{1031} \mathrm{Na}$ Lei no 8.987/95, o art. $3^{\circ}$ prevê a “cooperação dos usuários” na fiscalização da delegação, a ser desenvolvida "por intermédio de órgão técnico do poder concedente ou por entidade com ele conveniada, e, periodicamente, conforme previsto em norma regulamentar, por comissão composta de representantes do poder concedente, da concessionária e dos usuários” (art. 30, parágrafo único). No art. 7º são reconhecidos os direitos dos usuários de "receber do poder concedente e da concessionária informações para a defesa de interesses individuais ou coletivos” (inc. II), "levar ao conhecimento do poder público e da concessionária as irregularidades de que tenham conhecimento, referentes ao serviço prestado" (inc. IV) e "comunicar às autoridades competentes os atos ilícitos praticados pela concessionária na prestação do serviço” (inc. V). Entre as obrigações do poder concedente, encontra-se prevista a de "estimular a formação de associações de usuários para defesa de interesses relativos ao serviço” (art. 29, inc. XII). Já o art. 33 da Lei nº 9.074/95 estipula a edição de regulamento, para cada modalidade de serviço, que "estabeleça forma de participação dos usuários na fiscalização e torne disponível ao público, periodicamente, relatório sobre os serviços prestados”. Diversas leis setoriais disciplinam especificamente a matéria, tais como as Leis $\mathrm{n}^{0}$ 9.472/97, 9.427/96 e 10.233/01, que preveem diversos mecanismos de participação nos processos de regulação. 
reclamações e representações. Ao se assegurar o direito do usuário de denunciar irregularidades, impõe-se ao poder concedente e ao concessionário o dever de investigálas ${ }^{1032}$, com a disponibilização de estrutura destinada à apuração de irregularidades.

Note-se que o dever de a própria concessionária disponibilizar a estrutura necessária para o recebimento e processamento de reclamações de usuários e apuração de irregularidades não implica a necessidade de uma espécie de exaurimento de instância perante a concessionária, antes que as irregularidades possam ser submetidas ao poder público. O particular tem o direito de notificar diretamente o poder público das irregularidades constatadas na prestação dos serviços por concessionária ${ }^{1033}$. É o que se extrai da Lei $n^{\circ} 8.987 / 95$, art. $7^{\circ}$, inc. V.

A efetiva implementação dos diversos mecanismos de participação previstos nas leis gerais e setoriais consistem em condição para o desenvolvimento da garantia de devido processo nas relações entre os delegatários de atividades públicas e os usuários.

\subsection{A abrangência da incidência da garantia do devido processo em relação a terceiros}

A incidência da garantia do devido processo impõe também a observância de diversas providências concretas no desenvolvimento da atividade pública e na recepção e solução de controvérsias com os administrados.

Em relação a alguns aspectos, não há maior dificuldade na aplicação da garantia do devido processo nos atos a serem desenvolvidos no âmbito do delegatário. Assim se passa, por exemplo, em relação às garantias do contraditório e da ampla defesa. O delegatário deverá, por exemplo, manter infraestrutura para receber as eventuais reclamações dos usuários, instruí-las com os dados disponíveis e, caso não sejam atendidas, encaminhá-las para a decisão pelo poder público responsável.

Um aspecto relevante a ser observado é o da necessidade de se assegurar a transparência e o acesso às informações pertinentes aos usuários.

No julgamento da Reclamação $\mathrm{n}^{\mathrm{o}} 14.284 / \mathrm{MC}^{1034}$, o STF apreciou a incidência de garantias processuais em processos administrativos disciplinares desenvolvidos pela CVM e pela BM\&F. Assegurou o direito ao acesso ao inteiro teor de processo administrativo, qualificando como pública a atividade de supervisão e fiscalização

\footnotetext{
1032 Marçal Justen Filho. Teoria geral das concessões de serviço público, 2003, p. 563.

1033 Ob. cit., p. 564-565.

${ }^{1034}$ Rel. Min. Marco Aurélio, j. 22.12.2012, DJe 31.1.2013.
} 
de empresas privadas desenvolvidas tanto pela CVM e quanto pela BM\&F Supervisão de Mercados.

A questão merece destaque especialmente no que diz respeito à $B M \& F$ Bovespa Supervisão de Mercados, que é uma associação civil, pessoa jurídica de direito privado sem finalidade lucrativa ${ }^{1035}$, que atua na fiscalização do mercado de valores mobiliários. Já a CVM é uma agência reguladora, com personalidade jurídica de direito público $^{1036}$, não consistindo em hipótese de exercício de funções públicas por particulares.

Nos termos da decisão do Min. Relator, destacou-se a importância do controle e de se assegurar a observância das garantias do devido processo legal no exercício de funções públicas por particulares. A incidência de tais postulados foi considerada requisito necessário para a legitimação de tal delegação de função pública:

A transferência de funções públicas tipicamente regulatórias, inclusive com poderes de polícia, para entidades privadas é um fenômeno que vem sendo verificado cada vez com maior frequência. A autorregulação não é um problema quando se trata de associações particulares em que o ingresso e submissão às regras por ela impostas dependem da aquiescência do participante. Contudo, a questão ganha complexidade se essas normas se destinam a agentes não associados ou a atividades privadas de interesse público relevante, caso do mercado de valores mobiliários. Tais delegações se tornam legítimas apenas diante da existência de parâmetros de controle e supervisão pelo Poder Público, bem como de instrumentos eficazes para assegurá-los.

A garantia de devido processo concretiza-se também com o estabelecimento de mecanismos de impugnação da atuação dos particulares não apenas perante eles mesmos mas também frente à Administração. Assim se passa porque a garantia de legalidade, objetividade e imparcialidade no desempenho das funções públicas cabe, em última instância, ao poder público. Compete ao Estado, na posição de garante, assegurar o correto desempenho da missão pública atribuída ao particular.

Em princípio, o delegatário exercerá apenas algumas funções de processamento e de instrução em relação aos pleitos formulados por terceiros - sem prejuízo de que tais reclamações sejam apresentadas pelos interessados diretamente ao poder público responsável.

Assim se passa porque a tomada de decisões em processos desenvolvidos por uma entidade privada apresenta contornos mais complexos. O dever de decisão imparcial, por exemplo, exige a adoção de cautelas adicionais para que seja implementado em um processo desenvolvido pelo delegatário. Um empregado da empresa privada não dispõe das garantias reconhecidas aos agentes na Administração Pública, necessárias para

$\overline{1035}$ Estatuto disponível em http://www.bsm-autorregulacao.com.br/InstDownload/BSM-Estatuto-Social.pdf, acesso em 5.9.2013.

${ }^{1036}$ Lei 6.385/76, art. 5º cf. redação dada pela Lei no ${ }^{\circ} 10.411 / 02$. 
assegurar que a decisão seja adotada sem o propósito de obtenção de vantagens pessoais ou de forma conveniente aos superiores hierárquicos.

Uma das possibilidades seria a contratação de sujeito específico para o exercício dessa função, no âmbito da própria entidade privada, atribuindo-lhe autonomia decisória. A esse respeito, Marçal Justen Filho propõe, para a satisfação da garantia do devido processo, que o delegatário deverá "estruturar um corpo decisório que disponha de condições de decidir com imparcialidade, reconhecendo a procedência de pretensões oriundas de usuários sem limitações ou constrangimentos”1037. Trata-se de constituir um órgão julgador com perfil semelhante aos ombudsmen, figura esta já disseminada na iniciativa privada.

Reputamos que o exercício de poder decisório pelo próprio delegatário, no que diz respeito a conflitos com terceiros, deve ser excepcional, podendo ocorrer apenas à medida que possa ser assegurada a objetividade e a isonomia em tais decisões. Isso poderá ocorrer com maior probabilidade nas entidades da Administração indireta, em razão do maior peso dos aspectos do regime jurídico público que sobre elas incide.

Cabe considerar também os critérios a serem adotados na decisão. Caso a disputa diga respeito à aplicação de regras que não demandam margem significativa para variações para sua incidência em face das circunstâncias concretas, há maiores possibilidades de não haver comprometimento da objetividade e da isonomia ao se atribuir essa decisão à entidade privada. De todo modo, sempre que não for possível assegurar-se a isonomia e a objetividade da decisão, essa função não poderá ser desempenhada por entidades privadas.

Em qualquer caso, deverá ser assegurada ao particular a manifestação diretamente perante a Administração, sem necessidade de provocar antes o delegatário.

O particular deve ter assegurado também o direito de interposição de recursos e a manifestação de impugnações perante o poder público, bem como na esfera judicial. O cabimento de recurso administrativo é assim enunciado por Garrido Falla:

as entidades privadas que, por razão dos interesses que perseguem utilizam poderes coativos frente a outros particulares que resultam assim obrigados por suas decisões, têm que observar que tais atuações realizam-se sob controle dos organismos administrativos e que, portanto, sempre cabe recurso do particular afetado pela decisão ante a Administração Pública ${ }^{1038}$.

\footnotetext{
1037 Teoria geral das concessões de serviço público, 2003, p. 518.

1038 Tratado de derecho administrativo, v. I, 1994, p. 50. Na Espanha, há expressa previsão legal quanto ao cabimento de recurso administrativo em face de atos praticados por concessionários no art. 126.3 do Regulamento de Serviços das Corporações Locais, de 17 de junho de 1955 (RSCL): “3. Os atos dos
} 
Faz-se necessário, portanto, reconhecer o cabimento de recurso administrativo contra os atos do delegatário por ser o principal meio para se garantir a recondução à Administração titular dos poderes cujo exercício foi por ela delegado ${ }^{1039}$.

\section{$\underline{5 .} \underline{\text { controle }} \underline{\text { a }} \underline{\text { que }} \underline{\text { se }} \underline{\text { submetem }} \underline{\text { os }} \underline{\text { atos praticados por particulares }} \underline{\text { no }} \underline{\text { exercício }} \underline{\text { de }}$ atividades de polícia administrativa}

Cabe fazer menção também a quais controles submetem-se os atos praticados por particulares ${ }^{1040}$. Aqui não cabe fazer uma longa digressão sobre esse tema por não apresentar diversidades significativas em relação às demais hipóteses de desempenho de atividades públicas.

Importa destacar que a possibilidade de se fazer o controle adequado das atividades desempenhadas pelo particular no exercício de função pública depende da previsão de critérios objetivos para o desenvolvimento da atividade. Como se demonstrou anteriormente, a prévia programação dos critérios, procedimentos e limites da atividade a ser desenvolvida pelo particular não apenas assegura que seja exercida de modo objetivo e impessoal mas também propicia a sindicabilidade pelos diversos órgãos e instâncias de controle $^{1041}$.

\subsection{Os diversos graus de controle}

Nos casos em que não se transfere ao particular a responsabilidade pela gestão da atividade pública que lhe foi atribuída, ele se submete apenas ao controle público decorrente do contrato firmado com a Administração. No que diz respeito a terceiros, os resultados dos atos do particular terão que ser assumidos pela Administração tal como se ela mesma os tivesse praticado.

Nas hipóteses em que o particular assume a responsabilidade pelo exercício da função pública que é objeto da delegação, perante terceiros esta entidade é considerada como se fosse integrante da Administração.

concessionários realizados no exercício das funções delegadas serão recorríveis em reposição ante a Corporação concedente, frente a cuja resolução se admitirá recurso jurisdicional com fundamento na Lei.” 1039 Tomas-Ramon Fernández Rodrígues. Derecho administrativo, sindicatos y autoadministración, 1972, p. 191.

${ }^{1040} \mathrm{O}$ controle a que se submetem as entidades da Administração indireta com personalidade privada foi analisado anteriormente, no item III.8.3.

${ }^{1041}$ José Roberto Pimenta Oliveira. Parcerias público-privadas, 2007, p. 417. 
No último caso, é necessária a incidência de controle mais intenso. Não se poderia admitir que a delegação de função pública a particular, que pode inclusive exercer determinados poderes de autoridade, implique a criação de um centro de poder não sujeito a controle por estar situado fora da esfera estatal.

Logo, a fiscalização deve ser exercida em todo e qualquer caso de atribuição do exercício de funções públicas a particulares. É dever do poder concedente exercer o controle sobre a atividade delegada. Em última análise, o controle decorre da própria posição de garante assumida pela Administração, em razão da qual preserva, em qualquer caso, a responsabilidade última pelos atos praticados pelo particular.

\subsection{A extensão do controle}

A fiscalização deve abranger as atividades do particular relacionadas com o exercício da função pública que lhe foi atribuída. Disso não decorre a incidência de fiscalização sobre todos os atos do particular, de modo a publicizá-los integralmente.

Faz-se necessária a incidência de controle sobre os aspectos relevantes da atuação do particular para se identificar se a função pública está sendo corretamente exercida ou não. Porém, esse controle não abrange a estrutura empresarial, à medida que esta se sujeita ao direito privado ${ }^{1042}$. As relações do particular que são regidas exclusivamente pelo direito privado, tais como a sua gestão interna e a contratação de empregados, não se submetem a controle pelo poder público.

Quanto aos critérios de controle, devem ser estritamente pautados nas disposições normativas e contratuais. A esse respeito, cabe destacar a necessidade de previsão minuciosa de todos os aspectos do exercício das atividades atribuídas ao particular, inclusive para se propiciar o controle efetivo do cumprimento das suas obrigações.

\subsection{Os meios de controle}

Os atos praticados pelas entidades privadas no exercício de função pública podem ser impugnados com a utilização dos mesmos mecanismos empregados em relação

\footnotetext{
1042 “Assim e por exemplo, não apresenta constitucionalidade lei que atribua ao poder concedente poderes de intervenção no âmbito interno da estrutura empresarial do concedente, substituindo-se a ele em escolhas ou decisões de natureza puramente privada. O concessionário sujeita-se ao controle e à fiscalização do poder concedente naquilo em que tal tenha pertinência estrita e direta com o serviço público desempenhado. $\mathrm{O}$ concessionário não se transforma em órgão administrativo nem o poder concedente adquire poder hierárquico sobre a atividade privada propriamente dita” (Marçal Justen Filho. Teoria geral das concessões de serviço público, 2003, p. 430).
} 
aos atos administrativos praticados pela Administração direta, não sendo necessário o seu desenvolvimento específico no âmbito do presente estudo. O cabimento de mandado de segurança e de habeas data já foram mencionados acima.

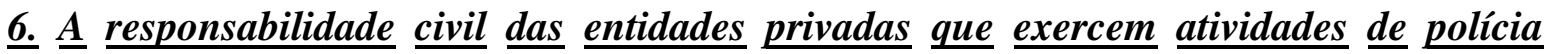 $\underline{\text { administrativa }}$}

É relevante examinar também o regime de responsabilidade civil a que se submetem as entidades privadas no exercício de atividades de polícia administrativa. A questão que se coloca é se os atos praticados pela entidade privada podem ser diretamente opostos ao ente delegante ou se este responde apenas subsidiariamente.

Vale destacar que o regime de responsabilização das entidades privadas que exercem atividades de polícia administrativa não difere substancialmente em relação ao que se passa com os demais contratados da Administração. O fato de se tratar de atividade de polícia administrativa não implica a adoção de um regime de responsabilização diferenciado.

Como se indicou especialmente no Capítulo II, as atividades de polícia administrativa podem ser atribuídas a entidades privadas em diversas modalidades de organização administrativa e de contratação. Algumas dessas modelagens implicam a atribuição de funções mais amplas e, portanto, de maior responsabilidade às entidades privadas.

A divisão principal desses mecanismos diz respeito à configuração das atribuições a serem desempenhadas pelo particular. Nas hipóteses em que atua como mero colaborador da Administração, na execução de atividades precipuamente materiais que são realizadas em nome e por conta da Administração, o particular submete-se a um regime de responsabilização diverso daquele aplicado às situações em que há delegação, com a assunção da responsabilidade pela gestão da atividade pública.

Portanto, o aspecto principal a ser destacado é o de que o regime de responsabilidade civil sofre variações, de acordo com as funções atribuídas ao particular. Antes, no entanto, cabem algumas especificações acerca da responsabilidade estatal pelo exercício de atividade de polícia administrativa. 


\subsection{A responsabilidade civil pelo exercício de atividade de polícia administrativa}

A responsabilidade administrativa no que diz respeito especificamente ao exercício de atividades de polícia adquire contornos mais complexos, diretamente vinculados à amplitude e complexidade assumidas por essa atividade estatal.

Como regra, a responsabilidade civil por danos causados no exercício de atividades estatais pode ser desencadeada pela prática tanto de atos lícitos quanto ilícitos. Nos dois casos, podem ser provocados danos a particulares, a serem indenizados, em princípio, pelo Estado. No entanto, como esclarece Maria Sylvia Zanella Di Pietro, em relação aos atos lícitos, estes são deflagradores da responsabilização civil do Estado se forem causadores de “dano anormal e específico a determinadas pessoas, rompendo o princípio da igualdade de todos perante os encargos sociais”"1043.

Em alguns casos, a própria legislação prevê a responsabilização civil pela prática de atos lícitos. É o que se passa, por exemplo, em relação aos atos praticados em legítima defesa ou no exercício regular de direito. Da conjugação dos arts. 188, 929 e 930 do CC/02, constata-se que a prática desses atos não afasta a responsabilidade civil de quem os praticou, salvo se houver culpa do lesionado ou do dono da coisa. Existe também a possibilidade de direito de regresso contra o causador do dano.

A questão é relevante porque a ocorrência de um dano, material ou moral, produzido por ação ou omissão estatal, que são elementos configuradores da responsabilidade civil do Estado, pode decorrer também do exercício da atividade de polícia administrativa. Ao agir para a remoção de um perigo iminente, por exemplo, a Administração pode causar danos a pessoa ou coisa alheia.

Um dos aspectos a serem considerados é a necessidade de observância do princípio da proporcionalidade no desempenho de atividades de polícia administrativa. Como já se indicou, a medida adotada não pode exceder os limites indispensáveis para o atingimento do objetivo visado. Portanto, a avaliação da responsabilidade civil daquele que exerce a atividade pública demanda aferir se os meios empregados foram necessários, adequados, proporcionais e aplicados de modo correto.

Daí decorre que, no exercício regular de direito, "não haverá responsabilidade civil do Estado se tiverem sido observados todos os limites e deveres pertinentes ao dever de diligência”"1044. Se forem adotadas todas as cautelas exigidas e se as medidas adotadas tiverem sido proporcionais, não haverá dever de indenizar.

\footnotetext{
1043 Direito administrativo, 2013, p. 711-712 - grifos no original.

${ }^{1044}$ Marçal Justen Filho. Curso de direito administrativo, 2013, p. 1.322.
} 


\subsection{A responsabilidade civil na ausência de transferência da gestão da atividade ao particular}

Quando não há transferência ao particular da responsabilidade pela gestão da atividade pública, cabendo-lhe apenas a execução de prestações específicas e previamente determinadas pela Administração, isso repercute na responsabilidade assumida pelo particular na execução desses atos.

\subsubsection{Responsabilidade civil do contratado}

O art. 70 da Lei $n^{\circ}$ 8.666/93 dispõe que o contratado deve responder por danos causados à Administração ou a terceiros, "decorrentes de sua culpa ou dolo na execução do contrato”.

No entanto, no que diz respeito a terceiros, a interpretação desse dispositivo deve ser conjugada com a regra do art. $37, \S 6^{\circ}$, da $C F / 88$, que determina a incidência da responsabilidade objetiva da Administração em face dos administrados. Ou seja, a responsabilidade da Administração perante terceiros é objetiva. A responsabilidade do empreiteiro ou construtor, perante a Administração, é que é definida de acordo com a responsabilidade subjetiva.

A esse respeito, Maria Sylvia Zanella Di Pietro assenta que “[p]erante terceiros, a responsabilidade é do Estado e se rege pelo artigo 37, §6º , da Constituição; o Estado responde objetivamente, mas tem direito de regresso contra aquele a quem transferiu a execução da obra ou serviço, desde que este tenha agido com culpa”"1045.

Ao comentar a previsão do art. 70 da Lei $n^{0}$ 8.666/93, Marçal Justen Filho também se posiciona no sentido de que “[e]ssas regras são aplicáveis no relacionamento entre o particular e a Administração. Não se aplicam, porém, no relacionamento entre o contratado e terceiros, relativamente à execução de serviços públicos”1046 .

Para José dos Santos Carvalho Filho, os contratados que realizam prestações que objetivam apenas instrumentalizar a ação da Administração não podem ser equiparados a concessionários nem podem ser considerados prestadores de serviço público, para os fins previstos no art. $37, \S 6^{\circ}$, da $\mathrm{CF} / 88$. Para o autor, "se a pessoa contratada para obra ou serviço causar danos a terceiros, por força de conduta culposa e exclusiva de um de seus agentes, sua responsabilidade civil será a que prevê o Código Civil, ou seja, a

\footnotetext{
1045 Direito administrativo, 2013, p. 342 - grifo no original.

${ }^{1046}$ Comentários à lei de licitações e contratos administrativos, 2012, p. 938.
} 
responsabilidade subjetiva”1047. Ressalva a possibilidade de haver responsabilidade subsidiária da Administração, na hipótese de insolvência do contratado.

Cabe assim diferenciar os atos em relação aos quais o particular poderá ser demandado, caso tenha atuado culposamente.

Para esse fim, parcela da doutrina propõe, a partir dos ensinamentos de Hely Lopes Meirelles, a diferenciação, para fins de responsabilização do empreiteiro, entre o fato da construção e os atos dos que a executam ${ }^{1048}$. O "fato da construção" diria respeito às consequências da própria existência da obra, tais como àquelas relacionadas ao seu planejamento e localização. Já os atos de construção são aqueles praticados diretamente pelo empreiteiro, na execução da obra.

Caberia à Administração responder exclusivamente pelos danos decorrentes do fato da construção ou fato da obra, de acordo com o seu regime de responsabilidade civil (objetiva), por ter sido o poder público que determinou a sua execução. Assim se passa porque “o dano provém de uma atividade administrativa ordenada pelo Poder Público no interesse da comunidade, colocando-se o executor da obra em posição de preposto da Administração, equiparável, portanto, aos seus agentes” ${ }^{1049}$.

Ainda segundo Hely Lopes Meirelles, os danos causados pelos atos de execução da obra em si seriam de responsabilidade do seu executor, caso ele tenha atuado com imprudência, negligência ou imperícia. Ou seja, a responsabilidade do contratado seria subjetiva, observando o regime privado de responsabilização civil. O autor diferencia os danos causados por defeitos na execução do projeto, em que a responsabilidade é originária da Administração, com direito de regresso em face do executor que atuou culposamente, da situação em que a atuação do construtor era relacionada com a obra mas não estava especificamente prevista no projeto nem imposta pelo contrato ${ }^{1050}$, situação em que a responsabilidade é originariamente do construtor e subsidiária da Administração, caso seja demonstrada a sua culpa in eligendo ${ }^{1051}$.

\footnotetext{
${ }^{1047}$ Responsabilidade civil das pessoas de direito privado prestadoras de serviços públicos, 2006, p. 152.

${ }^{1048}$ Direito de construir, 2011, p. 283.

1049 Hely Lopes Meirelles. Direito de construir, 2011, p. 326. No mesmo sentido, Odete Medauar. Direito administrativo moderno, 2008, p. 369; José dos Santos Carvalho Filho. Responsabilidade civil das pessoas de direito privado prestadoras de serviços públicos, 2006, p. 153.

${ }^{1050}$ Para o autor, essa definição abrangeria atividades tais como o transporte e depósito de materiais e a sinalização do local da obra.

${ }^{1051}$ Ob. cit., p. 327.
} 
Note-se que esse segundo aspecto não é unânime na doutrina. Para Odete Medauar, por exemplo, em relação aos atos de execução da obra, haveria responsabilidade solidária da Administração e do contratado ${ }^{1052}$.

No que diz respeito ao exercício de atividades de polícia administrativa desempenhadas especialmente no âmbito de contratos de prestação de serviços e de credenciamento de particulares, parece-nos ser mais adequada a imputação de responsabilidade ao Estado. Será ele o responsável principal, devendo responder de acordo com o art. 37, $\S 6^{\circ}$, da CF/88.

Nesse sentido é a lição de José dos Santos Carvalho Filho: "Indivíduos credenciados por entes públicos para o exercício de atividades qualificadas como poder de polícia ensejam a responsabilidade direta, objetiva e primária do ente responsável pelo credenciamento" ${ }^{\text {1053 }}$. Discordamos, no entanto, dos motivos pelos quais se atinge essa conclusão. O autor invoca a circunstância de que esses sujeitos credenciados configurariam “agentes do Poder Público” e, por isso, submeter-se-iam à regra do art. 37, §6º da CF/88.

Ocorre que nem sempre a atuação de agentes públicos implica ser a Administração a responsável principal por seus atos. Note-se que os concessionários de serviço público também podem ser considerados agentes públicos, da categoria dos particulares em colaboração com a Administração ${ }^{1054}$ - aliás, a mesma categoria na qual se inserem os particulares credenciados pela Administração. No entanto, em relação aos concessionários, o posicionamento praticamente unânime é o de que, em geral, o próprio particular é o principal responsável pelos atos praticados no exercício da função que lhe foi delegada. Como se indicou acima, a questão é controversa também em relação aos notários e registradores, que igualmente podem ser considerados agentes públicos.

\subsection{2. $\underline{\text { Responsabilidade civil do poder público }}$}

Nas hipóteses em que a entidade privada não assume a responsabilidade pela gestão da atividade pública, isso significa que a sua atuação é imputada à Administração inclusive no que diz respeito à responsabilidade civil perante terceiros. Disso decorre que, em princípio, é a própria Administração que responde por tais atos. Trata-se de decorrência necessária da premissa de que a Administração preserva a responsabilidade direta pela execução daquela atividade para a qual a entidade privada apenas presta auxílio.

\footnotetext{
1052 Direito administrativo moderno, 2008, p. 370.

1053 Responsabilidade civil das pessoas de direito privado prestadoras de serviços públicos, 2006, p. 157.

${ }^{1054}$ Celso Antônio Bandeira de Mello. Curso de direito administrativo, 2013, p. 256.
} 


\subsection{A responsabilidade civil com transferência da gestão da atividade ao particular}

Quando se verifica a delegação do exercício de uma atividade pública, o delegatário coloca-se, nos limites da delegação, em condição similar à do ente delegante. $\mathrm{O}$ delegatário age em nome próprio e não como representante ou por conta do delegante.

Pode-se aplicar ao caso a noção de "presentação”, tal como concebida por Pontes de Miranda ${ }^{1055}$, que retrata melhor a situação do que a expressão “representação” nas hipóteses em que o sujeito que emite a manifestação de vontade corporifica o ente delegante. Um dos principais exemplos de "presentação” é o do administrador da sociedade que, quando se manifesta em nome desta, não é um ente externo e sim um órgão da própria sociedade - e ato de órgão da sociedade ingressa no mundo jurídico como ato da própria pessoa jurídica $^{1056}$.

Isso justifica a responsabilidade direta do delegatário pelos atos praticados no exercício da delegação.

\subsubsection{Responsabilidade civil do delegatário}

Nas hipóteses em que se transfere ao particular a própria responsabilidade pela gestão da atividade, cabe a ele responder também pelos eventuais danos decorrentes do exercício de tais funções públicas. Além da delegação da função, há a transferência também da responsabilidade pelo seu exercício. Aplica-se ao caso o disposto no art. $37, \S 6^{\circ}$, da $\mathrm{CF} / 88^{1057}$.

Assim, a regra geral é de que cabe exclusivamente ao delegatário responder por ações ou omissões, decorrentes do exercício da função delegada e que causem danos a terceiros $^{1058}$.

Aplica-se ao delegatário o mesmo regime da responsabilidade civil do Estado. Como a doutrina usualmente define, a responsabilidade civil do Estado é objetiva

\footnotetext{
1055 Tratado de direito privado: parte geral, t. III, 1983, p. 231-238.

1056 Ob. cit., p. 233.

${ }^{1057}$ Cuja redação é a seguinte: “As pessoas jurídicas de direito público e as de direito privado prestadoras de serviços públicos responderão pelos danos que seus agentes, nessa qualidade, causarem a terceiros, assegurado o direito de regresso contra o responsável nos casos de dolo ou culpa”. Note-se que a expressão “prestadoras de serviços públicos” empregada pelo dispositivo deve ser interpretada em sentido amplo, de modo a abranger as diversidades atividades públicas e não apenas aquelas que prestam serviço público, no sentido técnico do termo. Nesse sentido, confira-se a exposição de Romeu Felipe Bacellar Filho. Responsabilidade civil da Administração Pública, 2006, p. 318-321. Como assevera Flávio Henrique Unes Pereira, "não há, em relação ao tema da responsabilidade civil objetiva, particularidade que justifique a não incidência do mencionado comando constitucional em relação a danos causados a terceiros pelo exercício do poder de polícia administrativa. Tanto o serviço público quanto o poder de polícia são funções de titularidade do Estado e envolvem diretamente a vida dos cidadãos” (Regulação, fiscalização e sanção, 2013. p. 159).

${ }^{1058}$ Em relação ao contrato de concessão comum, a questão encontra-se disciplinada no art. 25, caput, da Lei $\mathrm{n}^{\circ}$ 8.987/95. Esse dispositivo aplica-se também às concessões administrativa e patrocinada (Lei $\mathrm{n}^{\circ}$ 11.079/04, art. $3^{\circ}$, caput e $\left.\S 1^{\circ}\right)$.
} 
em relação aos atos comissivos e subjetiva em relação aos atos omissivos ${ }^{1059}$.Por esse motivo, é usual haver a previsão do dever de contratação de seguros de responsabilidade civil pelo delegatário.

Esse regime de responsabilidade objetiva incide apenas sobre as consequências dos atos praticados no exercício da atividade pública delegada ${ }^{1060}$. Ou seja, apenas nas hipóteses em que o dano decorrer diretamente do exercício da atribuição pública delegada ao particular.

Como empresas privadas, os delegatários de atividades públicas travam relações com terceiros e praticam negócios privados que não retratam o exercício de atividade pública. Essas relações jurídicas de natureza privada podem até mesmo ser instrumentais ao desempenho da atividade pública que lhes foi atribuída. No entanto, são regidas pelo direito privado, não ocupando o delegatário posição equivalente à do Estado. Por isso, em relação a estes atos, não há como submetê-los ao regime de responsabilização do direito público.

\subsection{2. $\underline{\text { Responsabilidade civil do poder público }}$}

A responsabilidade direta do delegatário não afasta a possibilidade de responsabilização do poder público.

Ainda que a entidade privada responda diretamente pelos danos causados por seus atos, existe a possibilidade de a Administração também responder pelas consequências daqueles atos. Essa responsabilização subsidiária eventual diz respeito apenas aos atos praticados no desempenho da atividade pública delegada. Ou seja, incide principalmente nas relações entre os delegatários e os administrados, sejam estes usuários das atividades delegadas ou sujeitos aos seus efeitos (por exemplo, os que se submetem à atividade de fiscalização desenvolvida mediante delegação).

As relações do delegatário com terceiros são, em regra, regidas pelo direito privado. A eventual insolvência do delegatário não justifica, em princípio, a responsabilização civil do Estado. No entanto, pode haver casos em que o inadimplemento do delegatário seja diretamente imputável ao Estado, por sua atuação defeituosa.

\footnotetext{
${ }^{1059}$ Essa noção geral é apta a várias controvérsias na sua aplicação concreta, que já foram debatidas com profundidade em obras doutrinárias específicas. Sobre o tema, podem ser consultados, entre outros, Celso Antônio Bandeira de Mello. Curso de direito administrativo, 2013, p. 1029-1034; Yussef Said Cahali. Responsabilidade civil do Estado, 2007, p. 218-223; José dos Santos Carvalho Filho. Manual de direito administrativo, 2012, p. 560-563.

${ }^{1060}$ Nas palavras de Romeu Felipe Bacellar Filho, "a cogência da determinação constitucional aplica-se aos particulares em colaboração com a Administração Pública, somente quando o dano for constatado em razão do exercício de uma atividade revestidora da característica de serviço público” (Responsabilidade civil da Administração Pública, 2006, p. 335).
} 
Eventualmente, seria possível argumentar que os terceiros contrataram com o delegatário pressupondo o adimplemento do concedente. Mas se trata de circunstância excepcional, cuja configuração depende da comprovação da existência de relação direta entre a conduta do Estado e a inadimplência do delegatário ${ }^{1061}$.

O fato de a entidade privada ser investida da capacidade jurídica de direito público para a prática de determinados atos, exercendo tais atividades em nome próprio, com imputação pessoal, não significa o afastamento de toda e qualquer responsabilidade da Administração. Parece-nos que o Estado não deixa de assumir a responsabilidade última pelos resultados dos atos praticados por entidades privadas no exercício de funções públicas.

Isso decorre do fato de tais funções, de titularidade do Estado, terem sido delegadas à entidade privada por decisão estatal. Ao delegar o exercício de determinadas funções a entidades privadas, o Estado não deixa de ser responsável por que tais funções sejam regularmente desempenhadas. O Estado continua sendo o titular e o responsável pelo exercício de tais funções, na posição de garantidor que assume em todo processo de delegação.

Essa responsabilidade apresenta, em geral, natureza subsidiária e se funda na posição de garante assumida pela Administração, que não deixa de ser a responsável última por todos os atos praticados no exercício da função pública.

No entanto, pode ser configurada a responsabilidade solidária do Estado em determinadas hipóteses. Na lição de Maria Sylvia Zanella Di Pietro, isso pode ocorrer nos casos “em que se verifique a omissão do poder concedente no controle da prestação do

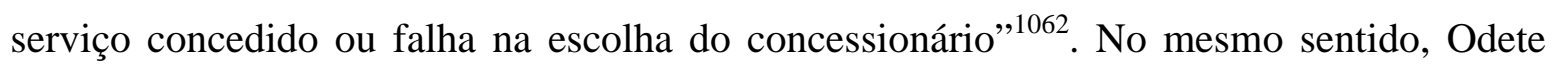
Medauar reputa que as entidades privadas contratadas pela Administração para a prestação de serviços, tais como a coleta de lixo e a limpeza urbana, "também se regem nessas atividades, pela responsabilidade objetiva, com solidariedade da Administração, se comprovada a negligência desta na fiscalização do contrato ou na escolha do contratado" 1063 .

\footnotetext{
${ }^{1061}$ Marçal Justen Filho cogita dessa hipótese de responsabilização do Estado em relação às concessões de serviço público, ressalvando a sua excepcionalidade (Teoria geral das concessões de serviço público, 2003, p. 474-475).

1062 Parcerias na Administração Pública, 2012, p. 95.

1063 Direito administrativo moderno, 2008, p. 369. Ainda no mesmo sentido, Yussef Said Cahali. Responsabilidade civil do Estado, 2007, p. 123-124.
} 
Marçal Justen Filho acrescenta ainda hipóteses de responsabilidade própria do Estado perante os usuários ${ }^{1064}$. Ainda que o delegatário seja acionado, ele terá direito de regresso em face do Estado. Trata-se das situações em que o evento danoso for direta e exclusivamente imputável ao Estado, tais como os danos ocasionados pela adoção de determinada técnica na prestação do serviço, cuja aplicação tenha sido determinada pelo Estado, e por erros de concepção do empreendimento.

Cabe registrar que, em relação às sociedades de economia mista, o art. 242 da Lei $\mathrm{n}^{0}$ 6.404/76 previa expressamente que a pessoa jurídica que a controla respondia subsidiariamente pelas suas obrigações. Esse dispositivo foi revogado pela Lei $\mathrm{n}^{\circ}$ 10.303/01. No entanto, disso não decorre que a responsabilidade subsidiária da Administração direta tenha deixado de ser aplicável às sociedades de economia mista. Trata-se de decorrência direta da sua vinculação ao Estado, de modo que a responsabilidade subsidiária incide independentemente de expressa previsão legal. Como sintetiza Maria Sylvia Zanella Di Pietro, “afinal, é o particular sofrendo prejuízo pela atuação, direta ou indireta, do Estado"1065.

Celso Antônio Bandeira de Mello destaca que a responsabilidade subsidiária da Administração direta incide em qualquer caso de exercício de função pública por entidades outras que não a Administração direta, sejam elas particulares ou entidades da Administração indireta:

para fins de responsabilidade subsidiária do Estado, incluem-se, também, as demais pessoas jurídicas de Direito Público auxiliares do Estado, bem como quaisquer outras, inclusive de Direito Privado, que, inobstante alheias à sua estrutura orgânica central, desempenham cometimentos estatais sob concessão ou delegação explícitas (concessionárias de serviço público e delegados de função pública) ou implícitas (sociedades mistas e empresas do Estado em geral, quando no desempenho de serviço público propriamente dito). Isso porque não faria sentido que o Estado se esquivasse a responder subsidiariamente - ou seja, depois de exaustas as forças da pessoa alheia à sua intimidade estrutural - se a atividade lesiva só foi possível porque o Estado lhe colocou em mãos o desempenho da atividade exclusivamente pública geradora do dano ${ }^{1066}$.

Note-se que regime de responsabilidade diverso poderia resultar em graves prejuízos para os usuários. Como se indicou, o particular que exerce atividades de polícia administrativa sob sua responsabilidade apresenta-se em nome próprio perante terceiros mas pratica atos tal como se fosse o próprio Estado.

\footnotetext{
1064 Teoria geral das concessões de serviço público, 2003, p. 475-476.

1065 Direito administrativo, 2013, p. 521.

${ }^{1066}$ Curso de direito administrativo, 2013, p. 1025 - grifos no original.
} 
Parece-nos, portanto, que o diferencial para a atribuição da responsabilidade principal para a Administração ou para o particular ao qual foi atribuída a execução de uma atividade pública é a extensão das obrigações do particular. Caso este desempenhe estas funções em nome e por conta própria, ou seja, tenha assumido a gestão da atividade, a responsabilidade principal é do contratado e deverá observar o regime público de responsabilização civil. Nos demais casos, em que o particular executa prestações previamente estabelecidas pela Administração e atua em nome desta e não em nome próprio, a responsabilidade principal perante terceiros deverá ser do próprio Estado - ainda que possa ser cabível o direito de regresso em face do contratado.

\section{Observações finais: a publicização $\underline{\text { das }} \underline{\text { atividades privadas }}$}

Ao se analisarem os diversos aspectos do regime jurídico aplicável ao exercício das atividades de polícia administrativa por entidades privadas, constata-se que não há propriamente fuga para o direito privado. Mais precisamente, a delegação de prerrogativas públicas insere-se em um ambiente de expansão do direito público sobre as relações privadas.

Há a publicização de várias perspectivas do regime jurídico aplicável às entidades privadas que exercem atividade pública. Esse forte influxo do regime público é necessário para se assegurar a realização dos fins coletivos visados com essas atividades bem como a observância dos direitos e garantias fundamentais dos cidadãos, em especial daqueles que se submetem a estas atividades. Porém, a publicização encontra limites, aplicando-se apenas aos aspectos relacionados ao desempenho da atividade pública. Não se trata de transformar os particulares que exercem atividade pública em entes integrantes da Admiistração. 


\section{CONCLUSÕES}

Com o presente estudo, objetivou-se demonstrar as diretrizes gerais para a identificação dos limites e possibilidades do exercício de atividades de polícia por entidades privadas.

Nesse ponto, não serão reiteradas as conclusões parciais obtidas e destacadas no corpo do texto. Serão apresentadas, em termos sumários, as conclusões que retratam os principais contornos que podem ser extraídos do estudo em relação ao exercício de atividades de polícia por entidades privadas.

1. Nem todos os atos praticados no exercício da função administrativa envolvem o manejo de poder de autoridade, no sentido de implicar a produção unilateral de efeitos jurídicos que incidem sobre a esfera jurídica de terceiros, independentemente da vontade destes.

2. Para fins operacionais, adota-se a sistemática do "ciclo de polícia”, que divide em quatro grupos as atividades compreendidas no exercício dessa função: ordem de polícia, consentimento de polícia, fiscalização de polícia e sanção de polícia. Isso permite evidenciar que a diversidade das funções compreendidas no exercício da atividade de polícia impede que seja fornecida uma resposta única a respeito da possibilidade ou não de seu exercício por entidades privadas. O principal aspecto a ser identificado é o de que nem todas as atividades envolvem o exercício do poder de coerção.

3. A categoria "poder jurídico" pode ser concebida como um gênero, que tem como espécies os poderes titularizados pelo Estado e os poderes privados. Podem ser semelhantes as manifestações de exercício de poderes públicos e privados que se apresentam, inicialmente, de forma juridicamente neutra. Para diferenciá-las, é necessário analisar qual é o seu fundamento jurídico, qual seja, a natureza da função desempenhada no exercício do referido poder ou a natureza da relação existente entre o titular do poder e aquele que se encontra a ele sujeito.

3.1. A atividade de segurança privada, contratada por particulares, pode envolver apenas o manejo de poderes privados. Trata-se de poderes reconhecidos pelo direito privado e que têm o seu uso por qualquer pessoa tolerado em circunstâncias específicas, tais como os de uso da força no contexto de legítima defesa e de flagrante delito. Já nas hipóteses em que o contratante da segurança privada é a Administração, as atribuições do 
particular podem envolver o desempenho de algumas atividades públicas. Porém, os agentes de segurança privada não podem exercer coerção, mesmo quando lhes for atribuída a vigilância de bens públicos, restringindo-se ao exercício excepcional dos poderes privados de defesa.

3.2. Os poderes que as associações privadas exercem sobre os seus associados consistem em poderes privados. Uma das principais manifestações desses poderes é a aplicação de medidas disciplinares em relação aos associados. Assim, em princípio, as sanções aplicadas por associações privadas não consistem em exercício de poder punitivo do Estado. Mas se a adesão à entidade privada for obrigatória, ainda que se trate de associação civil, os poderes por ela praticados deverão ser de origem estatal, exercidos mediante delegação.

4. Não se verifica ampla liberdade para o Estado decidir acerca do modo de exercício das suas funções. Há limites que impedem a livre atuação da Administração sob o direito privado em relação a determinadas atividades. Além disso, a possível autorização outorgada pelo legislador para a atribuição de missões públicas a entidades privadas não pode ser empregada em qualquer situação, sendo necessário ponderar a adequação da solução em face do caso concreto.

4.1. As autarquias são entidades com natureza jurídica pública que detêm capacidade administrativa específica, reputando-se ser a sua atuação equivalente à própria ação da Administração direta. Por isso, não se opõem óbices ao exercício de atividades de polícia administrativa pelas autarquias.

4.2. As empresas públicas e as sociedades de economia mista são entidades da Administração indireta com personalidade jurídica de direito privado e fins econômicos. Apesar de usualmente mencionar-se que as empresas estatais poderiam ter por objeto a prestação de serviço público ou o desempenho de atividade econômica, reputamos que também podem desenvolver atividades de polícia administrativa. Nesta hipótese, o seu regime jurídico será semelhante ao das empresas estatais que prestam serviço público.

5. Para o exercício indireto de atividades de polícia administrativa por particulares, podem ser utilizados especialmente os contratos de colaboração e os contratos de delegação.

5.1. Os contratos de colaboração destinam-se à satisfação de necessidades instrumentais da Administração. Na execução das obrigações contratuais, o particular exercita as suas próprias competências, de direito privado, para cumprir as obrigações que lhe foram atribuídas, sem assumir obrigações perante terceiros. Esse tipo de contrato não é 
objeto de maiores preocupações em relação ao desempenho de atividades de polícia administrativa por não envolver o trespasse do exercício de poderes e prerrogativas públicas para o particular nem repercutir na responsabilidade do Estado pelo cumprimento de suas missões institucionais.

5.2. A terceirização de atividades administrativas envolve geralmente a transferência a particulares do exercício de determinadas atividades materiais, sob a forma de contrato de prestação de serviços. Constata-se a inadequação do critério que distingue as atividades-meio das atividades-fim para determinar que apenas as primeiras poderiam ser objeto de terceirização. Não há como se distinguir com precisão em que consiste a atividade-meio e a atividade-fim em cada caso. Além disso, o art. 37, inc. XXI, da CF/88 não restringe a aplicação da técnica contratual às atividades-meio da Administração. Logo, os limites à delegação do exercício de funções públicas a particulares não se vinculam ao fato de se tratar de atividade-meio ou atividade-fim e sim aos aspectos intrínsecos da atividade, que revelam a viabilidade ou não de ser objeto de contrato.

5.3. Ainda que o conceito de contrato de concessão tenha sido construído no direito nacional de modo atrelado à concessão de serviços públicos, o seu objeto possível não é apenas este. Entre as modalidades de concessão, destaca-se a concessão administrativa. Pela ampliação do objeto da concessão que determina, apresenta maiores desafios quanto à delimitação dos direitos e prerrogativas transferidos ao concessionário. De todo modo, os limites de delegabilidade do objeto são os mesmos aplicáveis às demais modalidades de concessão.

5.4. A delegação do exercício de poderes públicos é verificada com frequência no âmbito dos contratos de concessão. Atribuem-se ao concessionário poderes à medida que sejam estritamente necessários para o cumprimento efetivo das suas obrigações. Portanto, não há nenhuma anormalidade no desempenho de poderes públicos por particulares mediante atribuição contratual. O fato de a delegação de atividades de polícia administrativa implicar o trespasse do exercício de determinados poderes públicos a particulares não pode ser invocado como óbice absoluto à delegabilidade dessa atividade.

6. A autorregulação comporta várias modalidades, que vão da delegação legislativa de competências, que seria o caso das ordens profissionais, ao exercício de atividade estritamente privada, na esfera associativa, sem conferência de efeitos públicos. Na parcela intermediária, há diversas formas de incentivo estatal à autorregulação e de atribuição de efeitos públicos aos resultados produzidos pelas entidades, no exercício de atividade privada. Os poderes envolvidos no exercício da autorregulação podem tanto ter 
origem pública quanto privada, o que determina também a natureza das atividades que desenvolvem. Nas modalidades de autorregulação impostas pelo Estado, pode-se verificar o desempenho de atividades de polícia administrativa por entidades privadas, mediante delegação estatal.

7. São recorrentes as manifestações doutrinárias e jurisprudenciais no sentido da indelegabilidade das atividades de polícia administrativa. Porém, encontram-se, cada vez com maior frequência, ressalvas e exceções, admitindo a delegação de várias atividades compreendidas na função de polícia. Constata-se, assim, a inviabilidade de se tratar a matéria a partir da enunciação de um princípio geral de indelegabilidade, sendo necessário analisar separadamente os limites e possibilidades de delegação em relação às atividades específicas.

8. São usuais as manifestações no sentido da possibilidade de desenvolvimento por entidades privadas de atividades instrumentais ou acessórias ao exercício das atividades de polícia administrativa. A doutrina propõe a separação entre atividade jurídica e atividade material da Administração, enunciando ser a segunda desprovida de conteúdo jurídico. Para alguns, a atividade técnica consistiria em parcela da atividade material da Administração. Reputamos não ser possível promover-se uma dissociação absoluta entre os atos materiais e os atos jurídicos da Administração, de modo a se retirar a relevância dos primeiros. A atividade material usualmente encontra-se acompanhada de atos jurídicos, que refletem as decisões da Administração e não podem ser simplesmente separados da atuação material. No momento da execução da atividade material, com frequência, demanda-se também a prática de atos jurídicos, ainda que em menor medida. Logo, o desempenho inclusive de atividades meramente materiais pode ser apto a produzir repercussões jurídicas e influenciar o exercício da função pública em si.

9. São recorrentes também as manifestações no sentido de que poderiam ser atribuídas a entidades privadas a simples preparação ou execução de atividades de polícia administrativa.

9.1. Em relação à participação na preparação de decisões, o risco que se apresenta é de delegação fática de poder de decisão, à medida que a Administração acaba ficando vinculada às conclusões atingidas pelos particulares. Esse risco pode ser minimizado com a previsão contratual minuciosa de deveres e parâmetros obrigatórios a serem observados pelo particular. A participação privada estritamente na execução de medidas de polícia administrativa, em tese, é apta a gerar menos polêmicas por envolver precipuamente a realização de atividades materiais. Porém, é necessário identificar se 
também não estão sendo trespassadas atividades jurídicas, para então se avaliar a sua delegabilidade.

9.2. Aqueles que defendem que poderiam ser exercidos por particulares atos de preparação e de execução de atividades de polícia justificam essa possibilidade pelo fato de essas atividades não envolverem manifestação de poder decisório. Consideram então ser o exercício de poder decisório o critério determinante a inviabilizar a delegação. Porém, a identificação da presença ou não de manifestação de poder de decisão muitas vezes não é fácil. Com frequência, atos considerados meramente materiais agregam também a prática de atos jurídicos de cunho decisório pelo delegatário. Por isso, não é possível fornecer respostas genéricas e abstratas, sendo necessário examinar as competências especificamente implicadas em cada caso para se determinar a delegabilidade ou não da atividade.

10. Reputamos que o ordenamento jurídico admite o exercício indireto de atividades de polícia administrativa, não sendo necessária a autorização expressa no texto constitucional. Não há uma definição restritiva dos objetos que são passíveis de contratação administrativa, cabendo ao ente titular da atividade deliberar acerca do modo de seu exercício, observando os limites intransponíveis para o objeto contratado.

11. A definição do núcleo das atividades essencialmente estatais, no sentido de não comportarem qualquer tipo de exercício privado, demanda a consideração de vários critérios. Os princípios da soberania e republicano determinam a reserva de atividades essenciais ao Estado a serem exercidas apenas pelos legítimos representantes do povo. Ao empregar a força, o poder público manifesta a sua autoridade em grau máximo, do que decorre o nível mais intenso de intervenção estatal na esfera privada dos cidadãos. o monopólio do uso da força não é propriamente da atividade de polícia e sim dos meios utilizados para executar determinadas atividades. Disso decorre que as atividades que demandem o emprego da força são de execução exclusiva pelo Estado. Em relação ao argumento relacionado ao princípio da isonomia, no sentido de que seria vedado o exercício de poderes públicos por particulares porque isso supostamente propiciaria uma situação de desigualdade entre os indivíduos, reputamos que não consiste em óbice absoluto. A delegação do exercício de uma atividade pública, por si só, determina a desigualação do contratado em relação aos demais particulares, sem que isso implique o exercício de supremacia de um particular sobre outro se a atividade for desenvolvida observando critérios imparciais e objetivos.

12. A partir desses limites, identificou-se como sendo possível a delegação de atividades de polícia administrativa que não impliquem o uso da coerção ou manifestação 
de amplo poder decisório. O particular não pode fazer uso da força nem ser autorizado a tomar decisões de natureza político-estratégica ou que impliquem ampla margem de liberdade para determinar os critérios do desempenho da atividade de polícia administrativa no caso concreto. Em qualquer caso, a possibilidade de ser delegada a particulares a prática de atividades de polícia administrativa não pode implicar qualquer violação a direitos e garantias fundamentais dos cidadãos.

13. Reputamos que os principais critérios e requisitos para a delegação de atividades de polícia administrativa consistem nos seguintes: a) necessidade de identificação expressa dos poderes públicos cujo exercício é objeto de delegação; b) necessidade de prévia programação dos critérios e procedimentos a serem observados na execução das atividades delegadas; c) necessidade de se assegurar a objetividade e impessoalidade na execução das atividades delegadas; d) necessidade de retenção dos dados para posterior controle pelo concedente; e) delegação do exercício de poderes públicos com caráter temporário e acessório à delegação da atividade principal; f) vedação de delegação de poderes públicos desvinculada do exercício de atividades públicas.

14. Consideramos ser necessária a autorização legislativa para a delegação de atividades de polícia administrativa a entidades privadas, inclusive para a legitimação do exercício da função pública por particulares.

15. Os poderes de execução coerciva devem ser desenvolvidos diretamente pelo Estado, não sendo passíveis de delegação, como decorrência do monopólio estatal do uso da força. Porém, permite-se a delegação de atividades instrumentais e acessórias. Os limites diferenciais entre a vedação de delegação dos poderes coercivos e a possibilidade de delegação de atividades instrumentais e acessórias ao exercício da coerção são evidenciados ao se analisar a possibilidade de gestão privada de presídios. As atividades de natureza jurisdicional e jurisdicional-administrativas não são passíveis de ter o seu exercício transferido para particulares. Em relação às atividades administrativas, seria permitida a delegação de atividades assistenciais, de saúde e educação. O exercício de função disciplinar não poderá ser trespassado a particulares. Em relação à segurança interna e ao monitoramento dos estabelecimentos, reputamos ser possível a sua delegação caso sejam desenvolvidos com a prévia definição dos seus critérios e reduzida interferência humana.

16. O direito de punir que está presente nas sanções administrativas é vinculado diretamente ao Estado, como atributo da sua soberania, e não é passível de exercício por particulares. A sanção é uma consequência negativa, punitiva. Pelo seu caráter repressivo e a imediata restrição de direitos que implica, reputamos não ser delegável o poder 
sancionatório a particulares. Em relação à aplicação de sanções, o exercício de poderes de autoridade não é apenas acessório à atividade e sim o seu conteúdo principal.

17. A possibilidade de delegação do exercício de poder normativo restringe-se aos atos normativos derivados, que têm como fonte os atos produzidos no exercício do poder legiferante. O exercício de poder normativo derivado depende de expressa delegação e da delimitação do seu exercício pelo delegatário, com a indicação das matérias sobre as quais poderá versar e fixação de parâmetros mínimos a serem observados. Fenômeno distinto do exercício de poder normativo derivado por particulares é a atribuição de efeitos públicos a normas de origem privada, que são produzidas no exercício de atividade privada. Os efeitos públicos conferidos a normas privadas não decorrem da transferência do exercício de poderes públicos a particulares e sim de um ato estatal posterior que reconhece e valida a norma de origem privada, conferindo-lhe obrigatoriedade. Consideramos ser necessária a autorização legal também para a recepção de normas técnicas pelo sistema jurídico.

18. A fiscalização do respeito às normas de polícia verifica a regularidade da sua observância e do exercício dos direitos pelos administrados. As atividades de fiscalização podem compreender tanto atos materiais quanto jurídicos. Dependendo da extensão das missões conferidas aos particulares, as atividades de controle podem implicar o exercício de poderes públicos. Reputamos ser possível a participação privada nas diversas atividades de fiscalização compreendidas na função de polícia administrativa, desde que possam ser exercidas com a aplicação de critérios objetivos e previamente determinados.

19. As atividades de certificação, inspeção, vistorias e outras similares, que designamos genericamente como atividades de avaliação de conformidade, apresentam principalmente caráter declaratório, de atestação da conformidade de determinado produto ou instalação com as normas setoriais aplicáveis. No âmbito de exercício de poderes públicos, estão incluídas apenas as avaliações de conformidade que são impostas pela lei, cujos resultados são dotados de força probatória especial. Reputamos ser possível, em tese, a delegação a particulares do exercício das diversas atividades compreendidas na avaliação de conformidade de natureza obrigatória. Porém, a Lei nº 9.933/99 veda expressamente a delegação pelo INMETRO a entidades privadas de atividades de sua competência que impliquem o exercício de poder de polícia. Autorizou a delegação apenas de atividades materiais e acessórias, de caráter técnico. Diante da expressa vedação legal, as atividades exercidas pelo INMETRO que retratam o exercício do controle em si não podem ser delegadas. 
20. As atividades de inspeção e vistoria veicular implicam a realização de testes e verificações que são necessários para a prática de atos tais como o licenciamento e a transferência de veículos. Consideramos ser possível a delegação das atividades de inspeção e vistoria veicular. A identificação do exercício de poderes públicos por particulares que prestam tais serviços depende das atividades que são efetivamente desempenhadas. Se a aprovação ou reprovação do veículo for realizada diretamente pelo particular delegatário, produzindo efeitos imediatos na esfera jurídica do proprietário do veículo, há de se reconhecer o exercício privado de poderes públicos. Já na hipótese de o ato de aprovação ou reprovação do veículo e da emissão dos respectivos certificado e selo ser realizada pela própria Administração, as atividades exercidas pelo particular consistem em atos preparatórios, de conteúdo técnico, de decisão a ser adotada pela Administração.

21. As atividades que produzem efeito de certeza pública ou são dotadas de força probatória especial correspondem especialmente àqueles desempenhadas por notários e registradores. Nos termos do art. 236 da CF/88, essas atividades são desenvolvidas em caráter privado, por delegação do poder público. Consistem no desempenho de atividade jurídica por particulares, de natureza pública, que envolve o exercício de determinados poderes públicos. Ainda que seja discutível o seu enquadramento nas atividades administrativas, constitui-se em importante exemplo de exercício de poderes públicos por particulares.

22. Pode haver também participação privada no desenvolvimento do procedimento administrativo. Quando se trata da atribuição da integralidade do procedimento ao particular, o que se verifica é a substituição do procedimento administrativo por um procedimento privado publicamente regulado e controlado. Já nas hipóteses de atribuição de algumas das etapas do procedimento a particulares, na preparação de decisões públicas, o risco verificado é o de perda do controle do processo pela Administração e privatização de fato deste, uma vez que o conteúdo da decisão acabaria ficando nas mãos de particulares. Por isso, essa atividade apenas poderá ser desenvolvida por particulares se for possível o efetivo controle da Administração sobre o seu desenvolvimento.

23. A delegação das funções de arrecadação e fiscalização de tributos, inclusive a entidades privadas, é expressamente prevista na legislação. A capacidade tributária ativa, que não se confunde com a competência tributária, é passível de delegação a entidades privadas, como consta expressamente do art. $7^{\circ}$ do CTN. Essas atividades são desenvolvidas especialmente no âmbito da parafiscalidade, que demanda autorização legal. 
24. Os controles e restrições que são aplicáveis às entidades da Administração indireta com personalidade privada aproximam-se mais daqueles incidentes sobre os entes dotados de personalidade jurídica pública do que daqueles aplicáveis aos particulares. Por isso, os limites que recaem sobre as empresas estatais para o exercício de atividades de polícia administrativa são distintos em relação aos que incidem sobre os particulares. Diversos dos argumentos usualmente empregados para justificar a suposta indelegabilidade das atividades de polícia a entidades privadas aplicam-se apenas a particulares que não integram o aparato estatal. Consideramos que as empresas estatais não podem exercer a coerção física, por se encontrar reservada a servidores públicos, devendo-se também observar a reserva constitucional dos arts. 142 e 144 da CF/88. Em relação às demais atividades compreendidas na função de polícia administrativa, inclusive a sancionatória, reputamos que podem ser desempenhadas por empresas estatais desde que sejam adotadas as cautelas necessárias para se assegurar a objetividade, impessoalidade e isonomia.

25. A escolha por uma entidade privada para o exercício de determinadas atividades de polícia administrativa não pode conduzir à redução do nível de garantia ou de proteção dos direitos dos administrados.

26. As entidades privadas que desempenham funções públicas submetem-se ao direito administrativo especialmente no que diz respeito ao exercício das funções públicas que lhes foram atribuídas. As suas relações jurídicas referentes a aspectos da sua atuação que não se relacionam diretamente com a atividade administrativa são regidas pelo direito privado. Isso determina a incidência do regime de direito público especialmente no que se refere ao vínculo com a entidade pública e, em menor grau, às suas relações com terceiros, sendo que a sua configuração organizativa é regida precipuamente pelo direito privado. Essa constatação aplica-se especialmente a particulares, considerando que as entidades administrativas com natureza privada submetem-se a determinados aspectos de direito público também no que diz respeito à sua gestão empresarial.

27. Os particulares que desempenham atividades de polícia administrativa mediante delegação estatal vinculam-se diretamente aos direitos fundamentais no que diz respeito ao exercício dessas funções, tal como se o próprio Estado estivesse atuando diretamente.

28. Os atos praticados por entidades privadas no exercício de atividade pública são atos administrativos porque traduzem o manejo de prerrogativas públicas. $\mathrm{O}$ ordenamento jurídico confirma o reconhecimento de que determinados atos praticados por 
particulares consistem em atos administrativos ao prever o cabimento de mandado de segurança contra tais atos.

29. O particular submete-se ao dever de observar o devido processo ao exercer atividade pública por delegação. O dever de observância do devido processo aplica-se ao próprio desenvolvimento da atividade delegada bem como às relações mantidas pelo delegatário com terceiros. A concretização da garantia do devido processo, com todos os seus requisitos e procedimentos, encontra-se delineada principalmente na lei e no contrato.

30. É dever do poder concedente exercer o controle sobre a atividade delegada. Os graus de controle variam de acordo com o tipo de contratação, apresentando-se de modo mais intenso em relação aos contratos de delegação. O controle deve abranger as atividades do particular relacionadas com o exercício da função pública que lhe foi atribuída, não atingindo a estrutura empresarial, à medida que esta se sujeita ao direito privado.

31. O regime de responsabilidade civil sofre variações, de acordo com as funções atribuídas ao particular. Quando não há transferência ao particular da responsabilidade pela gestão da atividade pública, cabendo-lhe apenas a execução de prestações específicas e previamente determinadas pela Administração, a responsabilidade do contratado perante a Administração é subjetiva. Porém, a Administração responde objetivamente perante terceiros, inclusive quanto aos atos praticados pelo contratado. Já nos contratos de delegação, a regra geral é de que cabe exclusivamente ao delegatário responder por ações ou omissões, decorrentes do exercício da função delegada e que causem danos a terceiros, nos termos do art. $37, \S 6^{\circ}$, da $\mathrm{CF} / 88$. 


\section{REFERÊNCIAS}

ALESSI, Renato. Principi di diritto amministrativo. 4. ed., v. I. Milano: Dott. A. Giuffrè, 1978.

ALFONSO, Luciano Parejo. Los actos administrativos consensuales en el derecho español. A\&C Revista de Direito Administrativo e Constitucional. Belo Horizonte: Fórum, a. 3, n. 13, p. 11-43, jul./set. 2003.

ALMEIDA, Mário Aroso de. Anulação de actos administrativos e relações jurídicas emergentes. Coimbra: Almedina, 2002.

ARAGÃO, Alexandre Santos de. A consensualidade no direito administrativo: acordos regulatórios e contratos administrativos. Revista de Direito do Estado - RDE. Rio de Janeiro: Renovar, a. 1, n. 1, p. 155-173, jan./mar. 2006.

ARAGÃO, Alexandre Santos de. Agências reguladoras e a evolução do direito administrativo econômico. Rio de Janeiro: Forense, 2002.

As PPPs e as concessões administrativas. In: MARQUES NETO, Floriano de Azevedo; SCHIRATO, Vitor Rhein (Coord.). Estudos sobre a lei das parcerias públicoprivadas. Belo Horizonte: Fórum, 2011, p. 31-46.

. Curso de direito administrativo. Rio de Janeiro: Forense, 2012.

(Coord.). O poder normativo das agências reguladoras. Rio de Janeiro: Forense, 2006.

ARAÚJO, Edmir Netto de. Curso de direito administrativo. 5. ed. São Paulo: Saraiva, 2010.

ARAÚJO, Luiz Eduardo Diniz. Delegação do poder de sanção a associação privada com viés público: o caso da Câmara de Comercialização de Energia Elétrica. Revista da AGU Advocacia-Geral da União. Brasília: Escola da Advocacia-Geral da União Ministro Victor Nunes Leal, a. XI, n. 33, p. 273-305, jul./set. 2012.

ATALIBA, Geraldo. Hipótese de incidência tributária. 5. ed., 6. tir. São Paulo: Malheiros, 1997.

_. SABESP - Serviço público - Delegação a empresa estatal - Imunidade a impostos - Regime de taxas. Revista de Direito Público. São Paulo: Revista dos Tribunais, n. 92, p. 70-95, out./dez. 1989. 
ATALIBA, Geraldo; FOLGOSI, Rosolea. Saneamento básico - serviço público estadual e municipal - contrato administrativo entre SABESP e município - concessão não ordinária. Revista Trimestral de Direito Público. São Paulo: Malheiros, n. 9, p. 105-122, 1995.

AUBY, Jean-Bernard. Contracting out and "public values": a theoretical and comparative approach. Disponível em: http://www.law.yale.edu/ documents/ pdf/CompAdminLaw/JeanBernard_Auby_CompAdLaw.pdf. Acesso em: 18.2.2014.

BACELLAR FILHO, Romeu Felipe. Processo administrativo disciplinar. São Paulo: Max Limonad, 2003. . Reflexões sobre direito administrativo. Belo Horizonte: Fórum, 2009.

—. Responsabilidade civil da Administração Pública - aspectos relevantes. A Constituição Federal de 1988. A questão da omissão. Uma visão a partir da doutrina e da jurisprudência brasileiras. In: FREITAS, Juarez (Org.). Responsabilidade civil do Estado. São Paulo: Malheiros, 2006, p. 293-336.

BACELLAR FILHO, Romeu Felipe; HACHEM, Daniel Wunder (Coord.). Direito administrativo e interesse público: estudos em homenagem ao Professor Celso Antônio Bandeira de Mello. Belo Horizonte: Fórum, 2010.

BALEEIRO, Aliomar. Limitações constitucionais ao poder de tributar. 7. ed. atual. por Misabel Abreu Machado Derzi. Rio de Janeiro: Forense, 1997.

. Uma introdução à ciência das finanças. 13. ed. rev. e atual. por Flávio Bauer Novelli. Rio de Janeiro: Forense, 1981.

BANDEIRA DE MELLO, Celso Antônio. A competência para criação e extinção de serviços notariais e de registros e para delegação para provimento desses serviços. Parecer jurídico. Revista de Direito Imobiliário. São Paulo: Revista dos Tribunais, a. 22, n. 47, p. 197-212, jul./dez. 1999.

. Curso de direito administrativo. 30. ed. São Paulo: Malheiros, 2013.

. Discricionariedade e controle jurisdicional. 2. ed., 4. tir. São Paulo: Malheiros, 2000.

- Natureza jurídica das bolsas de valores. Revista de Direito Público. São Paulo: Revista dos Tribunais, a. 20, n. 81, p. 217-222, jan./mar. 1987.

. Regime dos servidores da Administração direta e indireta. 2. ed. São Paulo: Malheiros, 1991.

Serviço público e poder de polícia: concessão e delegação. Revista Trimestral de Direito Público. São Paulo: Malheiros, n. 20, p. 21-28, 1997. 
BANDEIRA DE MELLO, Oswaldo Aranha. Natureza jurídica dos corretores oficiais: os corretores oficiais não são funcionários públicos. São comerciantes. Separata da Revista Direito. São Paulo: Prefeitura do Município de São Paulo, v. XIII, 1943.

. Princípios gerais de direito administrativo. 3. ed., 2. tir., v. I. São Paulo: Malheiros, 2010.

BARACHO, José Alfredo de Oliveira. O princípio de subsidiariedade: conceito e evolução. 3. tir. Rio de Janeiro: Forense, 2000.

BARROSO, Luís Roberto. Invalidade de exercício direto pelo Estado dos serviços notariais e de registros. Interpretação conforme a Constituição do art. 1.361, §1º , do novo Código Civil. Parecer. Disponível em: http://www.irtdpjbrasil. com.br/NEWSITE/Barroso.htm. Acesso em: 31.10.2013.

BATTINI, Stefano. Organizzazioni internazionali e soggetti privati: verso un diritto amministrativo globale? Rivista Trimestrale di Diritto Pubblico. Milano: Giuffrè, n. 2, p. 359-388, 2005.

BECK, Ulrich. Sociedade de risco: rumo a uma outra modernidade. 2. ed. Trad. Sebastião Nascimento. São Paulo: 34, 2011.

BENEDETTI, Auretta. Certezza pubblica e “certezze” private: poteri pubblici e certificazioni di mercato. Milano: Giuffrè, 2010.

BÉNOIT, Francis-Paul. Le droit administratif français. Paris: Dalloz, 1968.

BEZNOS, Clóvis. Poder de polícia. São Paulo: Revista dos Tribunais, 1979.

BINENBOJM, Gustavo. Uma teoria do direito administrativo: direitos fundamentais, democracia e constitucionalização. 2. ed. Rio de Janeiro: Renovar, 2008.

BITTENCOURT NETO, Eurico. Devido procedimento equitativo e vinculação de serviços públicos delegados no Brasil. Belo Horizonte: Fórum, 2009.

BOBBIO, Norberto. Teoria geral do direito. Trad. Denise Agostinetti. 3. ed. São Paulo: Martins Fontes, 2010.

. Verbete “Sanzione”. Novissimo Digesto Italiano. v. XVI. Turim: UTET, 1969, p. 531-532.

BOBELA-MOTA KIRKBY, Mark. Contratos sobre o exercício de poderes públicos: o exercício contratualizado do poder administrativo de decisão unilateral. Coimbra: Coimbra, 2011.

BOITEAU, Claudie. Les conventions de délégation de service public. Paris: Éditions locales de Frances - Imprimerie Nationale, 1999. 
BORGES, Alice Maria Gonzalez. O credenciamento de inspeções de segurança veicular na legislação de trânsito: aspectos peculiares. Repertório de Estudos Doutrinários e Jurisprudenciais, out. 2004.

BRESSER-PEREIRA, Luiz Carlos; GRAU, Nuria Cunill (Org.). O público não-estatal na reforma do Estado. Rio de Janeiro: Fundação Getúlio Vargas, 1999.

CAETANO, Marcello. Manual de direito administrativo. 10. ed., 10. reimpr., v. II. Coimbra: Almedina, 2010.

CAHALI, Yussef Said. Responsabilidade civil do Estado. 3. ed. São Paulo: Revista dos Tribunais, 2007.

CALADO, Luiz Roberto. Regulação e autorregulação do mercado financeiro: conceito, evolução e tendências num contexto de crise. São Paulo: Saint Paul, 2009.

CÂMARA, Jacintho Arruda. O lucro nas empresas estatais. Revista Brasileira de Direito Público - RBDP. Belo Horizonte: Fórum, a. 10, n. 37, p. 9-18, abr./jun. 2012.

CANALS I AMETLLER, Dolors. El ejercicio por particulares de funciones de autoridad: control, inspección y certificación. Granada: Comares, 2003.

CANANEA, Giacinto della. I pubblici poteri nello spazio giuridico globale. Rivista Trimestrale di Diritto Pubblico. Milano: Giuffrè, n. 1, p. 1-34, 2003.

CANARIS, Claus-Wilhelm. Direitos fundamentais e direito privado. Trad. Ingo Wolfgang Sarlet e Paulo Mota Pinto. 2. reimp. Coimbra: Almedina, 2009.

CANOTILHO, J. J. Gomes. Direito constitucional e teoria da Constituição. 4. ed. Coimbra: Almedina, 2000.

CARMO, Jairo Vasconcelos Rodrigues. Responsabilidade civil do delegatário notarial e de registros públicos. Revista da EMERJ v. 9, n. 36, p. 169-197, 2006.

CARNEIRO NETO, Durval. Os conselhos de fiscalização profissional: uma trajetória em busca de sua identidade jurídica. In: MODESTO, Paulo (Coord.). Nova organização administrativa brasileira. 2. ed. rev. e ampl. Belo Horizonte: Fórum, 2010, p. 275-320.

CARRASCO, Manuel Izquierdo. Algunas cuestiones generales a propósito del ejercicio privado en el ámbito de la seguridad industrial. In: Studia Iuridica 60: Os caminhos da privatização da administração pública: IV Colóquio Luso-Espanhol de Direito Administrativo. Coimbra: Coimbra, 2001, p. 367-406.

CARRAZZA, Roque Antonio. Curso de direito constitucional tributário. 11. ed. São Paulo: Malheiros, 1998.

CARVAlHO, Paulo de Barros. Curso de direito tributário. 10. ed. São Paulo: Saraiva, 1998. 
CARVALHO, Raquel Urbano de. Curso de direito administrativo. 2. ed. Salvador: JusPodivm, 2009.

CARVALHO FILHO, José dos Santos. Agências reguladoras e poder normativo. In: ARAGÃO, Alexandre Santos de (Coord.). O poder normativo das agências reguladoras. Rio de Janeiro: Forense, 2006, p. 75-89.

. Manual de direito administrativo. 25. ed. São Paulo: Atlas, 2012.

- Responsabilidade civil das pessoas de direito privado prestadoras de serviços públicos. In: FREITAS, Juarez (Org.). Responsabilidade civil do Estado. São Paulo: Malheiros, 2006, p. 136-157.

CASADO, Lucía Casado et al. La externalización de las funciones de control e inspección en materia de protección del medio ambiente. Barcelona: Atelier, 2010.

CASSESE, Sabino. La funzione costituzionale dei giudici non statali. Dallo spazio giuridico globale all'ordine giuridico globale. Rivista Trimestrale di Diritto Pubblico. Milano: Giuffrè, n. 3, p. 609-626, 2007.

. Il diritto amministrativo globale: una introduzione. Rivista Trimestrale di Diritto Pubblico. Milano: Giuffrè, n. 2, p. 331-357, 2005.

CATARINO, Luís Guilherme. Regulação e supervisão dos mercados de instrumentos financeiros: fundamento e limites do governo e jurisdição das autoridades independentes. Coimbra: Almedina, 2010.

CAVALCANTI, Themístocles Brandão. Tratado de direito administrativo brasileiro. 5. ed., v. III. Rio de Janeiro: Freitas Bastos, 1964.

CHAPUS, René. Droit administratif général. 13. ed., t. 1. Paris: Montchrestien, 1999.

CHEVALLIER, Jacques. O Estado pós-moderno. Trad. Marçal Justen Filho. Belo Horizonte: Fórum, 2009.

. Science administrative. 4. ed. Paris: Presses Universitaires de France, 2007.

CIVITARESE, Stefano. Contributo allo studio del principio contrattuale nell'attività amministrativa. Torino: G. Giappichelli, 1997.

COMPARATO, Fabio Konder. Natureza jurídica das bolsas de valores e delimitação do seu objeto. Revista de Direito Mercantil, Industrial, Econômico e Financeiro. São Paulo: Revista dos Tribunais, a. 24, v. 60, out./dez. 1985, p. 45-53.

CONTICELLI, Martina. Il procedimento europeo di registrazione dele denominazioni di origine protetta. Rivista Trimestrale di Diritto Pubblico. Milano: Giuffrè, n. 2, p. 317-345, 2004. 
COUTO E SILVA, Almiro do. Atos jurídicos de direito administrativo praticados por particulares e direitos formativos. Revista da Procuradoria-Geral do Estado do Rio Grande do Sul - Cadernos de Direito Público. Porto Alegre: Procuradoria de Informação, Documentação e Aperfeiçoamento Profissional, v. 27, n. 57 supl., p. 77-94, 2003.

Autoridade pública e mandado de segurança. Revista da Procuradoria-Geral do Estado do Rio Grande do Sul - Cadernos de direito público. Porto Alegre: Procuradoria de Informação, Documentação e Aperfeiçoamento Profissional, v. 27, n. 57 supl., p. 239-260, 2003.

- Os indivíduos e o Estado na realização de tarefas públicas. Revista da Procuradoria-Geral do Estado do Rio Grande do Sul - Cadernos de Direito Público. Porto Alegre: Procuradoria de Informação, Documentação e Aperfeiçoamento Profissional, v. 27, n. 57 supl., p. 181-208, 2003.

Poder discricionário no direito administrativo brasileiro. Revista de Direito Administrativo. Rio de Janeiro: Renovar, n. 179-180, p. 51-67, jan./jun. 1990.

. Privatização no Brasil e o novo exercício de funções públicas por particulares. Serviço público “à brasileira”? Revista da Procuradoria-Geral do Estado do Rio Grande do Sul - Cadernos de Direito Público. Porto Alegre: Procuradoria de Informação, Documentação e Aperfeiçoamento Profissional, v. 27, n. 57 supl., p. 209-237, 2003.

CRETELLA JÚNIOR, José. Direito administrativo brasileiro. v. 1. Rio de Janeiro: Forense, 1983.

. Direito administrativo do Brasil. v. IV. São Paulo: Revista dos Tribunais, 1961.

. Manual de direito administrativo. 2. ed. Rio de Janeiro: Forense, 1979.

CUÉLLAR, Leila. As agências reguladoras e seu poder normativo. São Paulo: Dialética, 2001.

Auto-regulação profissional: exercício de atividade pública. Revista de Direito Público da Economia - RDPE. Belo Horizonte: Fórum, a. 4, n. 15, p. 73/98, jul./set. 2006. Disponível em: <http://www.bidforum.com.br/bid/PDI0006. aspx?pdiCntd=37259>. Acesso em: 11.12.2013.

CUNHA FILHO, Alexandre Jorge Carneiro da. Poder de polícia: delegação a entes privados. São Paulo, 2013, 198 f. Dissertação - Pós-Graduação da Faculdade de Direito da Universidade de São Paulo.

CURY, Maria Fernanda Calado de Aguiar Ribeiro; PEREIRA, Roberto Codorniz Leite. Desafio ao desenvolvimento do mercado de valores mobiliários brasileiro: conflito de interesses na autorregulação. In: CUSCIANO, Dalton Tria e outros. Autorregulação e 
desenvolvimento do mercado de valores mobiliários brasileiro. São Paulo: Saraiva, 2009, p. 37-72.

D’ALTE, Sofia Tomé. A nova configuração do setor empresarial do Estado e a empresarialização dos serviços públicos. Coimbra: Almedina, 2007.

D’AVILA, Thomaz Marcello. A normalização técnica e o direito (alguns comentários e considerações). Anais do Congresso Internacional de Normalização e Qualidade. Rio de Janeiro: ABNT, 1990, p. 359-377.

DALLARI, Adilson Abreu. Credenciamento. In: BANDEIRA DE MELLO, Celso Antônio (Coord.). Estudos em homenagem a Geraldo Ataliba - 2: Direito Administrativo e Constitucional. São Paulo: Malheiros, 1997, p. 38-54.

- Credenciamento mediante licitação. Revista Trimestral de Direito Público. São Paulo: Malheiros, n. 23, p. 97-105, 1998.

Inspeção de segurança veicular - Credenciamento - Desnecessidade de autorização legislativa. Informativo de Licitações e Contratos - ILC. Curitiba: Zênite, n. 28, p. 430-440, jun. 1996.

DARNACULLETA I GARDELLA, M. Mercè. Autorregulación y derecho público: la autorregulación regulada. Madrid: Marcial Pons, 2005.

DEBBASCH, Charles. Droit administratif. 6. ed. Paris: Economica, 2002.

DEGOFFE, Michel. Droit de la sanction non pénale. Paris: Economica, 2000.

DELEUZE, Gilles. Post-scriptum sobre as sociedades de controle In: Conversações. Rio de Janeiro: 34, 1992, p. 219-226.

DELVOLVÉ, Pierre. Le droit administratif. Paris: Dalloz, 1994.

. Les contradictions de la délégation de service public. AJDA p. 675, 1996. Disponível em http://www.dalloz.fr/documentation. Acesso em 20.9.2013.

DI PIETRO, Maria Sylvia Zanella. A participação popular na Administração Pública. Revista Trimestral de Direito Público - RTDP. São Paulo: Malheiros, n. 1, p. 127-139, 1993.

. Direito administrativo. 26. ed. São Paulo: Atlas, 2013.

(Org.). Direito regulatório: temas polêmicos. Belo Horizonte: Fórum, 2003.

. Discricionariedade administrativa na Constituição de 1988. 3. ed. São Paulo: Atlas, 2012.

. Limites do controle externo da Administração Pública: ainda é possível falar em discricionariedade administrativa?. Revista Brasileira de Direito Público - RBDP, Belo Horizonte, ano 11, n. 42, jul./set. 2013. Disponível em: 
$<$ http://www.bidforum.com.br/bid/PDI0006.aspx?pdiCntd=97453>. Acesso em: 31 out. 2013.

. O direito administrativo brasileiro sob influência dos sistemas de base romanística e da commom law. Revista Brasileira de Direito Público. Belo Horizonte: Fórum, v. 5, n.16, p. 9-30, jan./mar., 2007.

Parcerias na Administração Pública: concessão, permissão, franquia, terceirização, parceria público-privada e outras formas. 9. ed. São Paulo: Atlas, 2012.

- Participação popular na Administração Pública. Revista Trimestral de Direito Público. São Paulo, Malheiros, n. 1, p. 128-139, 1993.

. Poder de polícia. Revista de Direito Público. São Paulo: Revista dos Tribunais, a. 24, n. 98, p. 90-93, abr./jun. 1991.

DI PIETRO, Maria Sylvia Zanella; RIBEIRO, Carlos Vinícius Alves (Coord.). Supremacia do interesse público e outros temas relevantes do direito administrativo. São Paulo: Atlas, 2010.

DONAIRE, Juan Antonio Carrillo. Seguridad y calidad productiva: de la intervención policial a la gestión de riesgos. Revista de Administración Pública. Madrid: Centro de Estudios Políticos y Constitucionales, n. 178, p. 89-142, jan./abr. 2009.

DUGUIT, Léon. De la situation des particuliers à l'égard des services publiques. Revue du Droit Publique et de la Science Politique en France et à l'Étranger. Paris: Librairie generale de droit et de jurisprudence, v. 14, n. 24, p. 411-439, 1907.

DUPUIS, Georges; GUEDON, Marie-José; CHRETIEN, Patrice. Droit administratif. 11. ed. Paris: Sirey, 2009.

ENTERRÍA, Eduardo García de; FERNÁNDEZ, Tomás-Ramon. Curso de derecho administrativo. 11. ed., v. I e v. II. Madrid: Civitas, 2002 e 2008.

ESTORNINHO, Maria João. A fuga para o direito privado: contributo para o estudo da actividade de Direito Privado da Administração Pública. Coimbra: Almedina, 1999.

FALLA, Garrido. Las transformaciones del régimen administrativo. 2. ed. Madrid: Instituto de Estudios Políticos, 1962.

. Los medios de la policia y la teoria de las sanciones administrativas. Revista de Administración Pública. Madrid: Centro de Estudios Políticos y Constitucionales, n. 28, p. 11-50, 1959.

. Tratado de derecho administrativo. 12. ed., v. I, 10. ed., v. II. Madrid: Tecnos, 1994 e 1992. 
FERRAZ, Luciano. Contratação de prestadoras de serviço de telefonia pelos órgãos e entidades da Administração à luz da Lei nº 8.666/93: primeiras impressões. ILC. Curitiba: Zênite, n. 75, p. 370, maio 2000.

Termos de ajustamento de gestão (TAG): do sonho à realidade. Revista Brasileira de Direito Público - RBDP. Belo Horizonte: Fórum, a. 8, n. 31, p. 43-50, out./dez. 2010. FERRAZ JUNIOR, Tercio Sampaio. Introdução ao estudo do direito: técnica, decisão, dominação. 2. ed. São Paulo: Atlas, 1994.

FERREIRA, Daniel. Sanções administrativas. São Paulo: Malheiros, 2001.

FERRI, Luigi. La autonomía privada. Trad. José Luis Monereo Pérez. Granada: Comares, 2001.

FIGUEIREDO, Lúcia Valle. Curso de direito administrativo. 9. ed. São Paulo: Malheiros, 2008.

FONSECA, Rui Guerra da. O fundamento da autotutela executiva da Administração Pública: contributo para a sua compreensão como problema jurídico-político. Coimbra: Almedina, 2012.

FOS, J. García Trevijano. Contratos y actos ante el Tribunal Supremo: la explotación del “hotel Andalucia-Palace” de Sevilla. Revista de Administración Pública. Madrid: Centro de Estudios Políticos y Constitucionales, n. 28, p. 147-165, jan./abr. 1959.

FREIRE, Marcelo de Figueiredo. Privatização de presídios: uma análise comparada. In: ARAÚJO JÚNIOR, João Marcello de (Org.). Privatização das prisões. São Paulo: Revista dos Tribunais, 1995, p. 89-115.

FREITAS, Juarez. Parcerias Público-Privadas (PPPs): características, regulação e princípios. Interesse Público - IP. Belo Horizonte, n. 29, a. 7, jan./fev. 2005. Disponível em: <http://www.bidforum.com.br/bid/PDI0006.aspx?pdiCntd=50106>. Acesso em: 1.7.2013.

FREITAS DO AMARAL, Diogo. Curso de direito administrativo. 3. ed., v. 1, 5. reimp., v. II. Coimbra: Almedina, 2006.

FREITAS DO AMARAL, Diogo; TORGAL, Lino. Estudos sobre concessões e outros actos da Administração. Coimbra: Almedina, 2002.

GALLI, Rocco. Corso di diritto amministrativo. 2. ed. Padova: CEDAM, 1996.

GARCIA, Flávio Amaral. A relatividade da distinção atividade-fim e atividade-meio na terceirização aplicada à Administração Pública. Revista Brasileira de Direito Público RBDP. Belo Horizonte: Fórum, a. 7, n. 27, p. 137-160, out./dez. 2009. 
GARRIGOU-LAGRANGE, J. M. Recherches sur les raports des associations avec les pouvoirs publics. Paris: Librairie generale de droit et de jurisprudence, 1970.

GASPARINI, Diogenes. Direito administrativo. 17. ed. São Paulo: Saraiva, 2012.

GENY, Bernard. La collaboration des particuliers avec l'administration. Paris: Sirey, 1930.

GIANNINI, Massimo Severo. Corso di diritto amministrativo. Milano: Dott. A. Giuffrè, 1965.

. Diritto administrativo. 3. ed., v. 1. Milano: Giuffrè, 1993.

. Istitutiozi di diritto amministrativo. 2. ed. Milano: Giuffrè, 2000.

. Lezioni di diritto amministrativo. v. I. Milano: Dott. A. Giuffrè, 1950.

GONÇALVES, Pedro. A concessão de serviços públicos. Coimbra: Almedina, 1999.

- Entidades privadas com poderes públicos: o exercício de poderes públicos de autoridade por entidades privadas com funções administrativas. Reimp. Coimbra: Almedina, 2008.

. Regulação administrativa e contrato. In: Estudos em homenagem ao Prof. Doutor Sérvulo Correia. v. II. Coimbra: Coimbra, 2010.

- Regulação administrativa da internet. Revista de Direito Público da Economia RDPE. Belo Horizonte: Fórum, a. 1, n. 1, p. 177-199, jan./mar. 2003.

GORDILLO, Agustin A. Tratado de derecho administrativo. t. 2 - La defensa del usuario y del administrado. 9. ed. Buenos Aires: Fundación de Derecho Administrativo, 2009.

GORZONI, Paula. A vinculação dos particulares a direitos fundamentais no STF: o julgamento do “Caso UBC” (RE 201.819-RJ) e alteração do modo de decidir do Tribunal. In: COUTINHO, Diogo R.; VOJVODIC, Adriana M. (Coord.). Jurisprudência constitucional: como decide o STF? São Paulo, Malheiros, 2009, p. 514-527.

GRIMM, Dieter. The achievement of constitutionalism and its prospects in a changed world. In: DOBNER, Petra; LOUGHLIN, Martin (eds.). The twilight of constitutionalism? Oxford: Oxford University Press, 2010.

GRINOVER, Ada Pellegrini e outros. Código de defesa do consumidor comentado pelos autores do anteprojeto. 8. ed. Rio de Janeiro: Forense Universitária, 2005.

GROTTI, Dinorá Adelaide Musetti. O serviço público e a Constituição brasileira de 1988. São Paulo: Malheiros, 2003.

Parcerias na Administração Pública. In: FIGUEIREDO, Marcelo e PONTES FILHO, Valmir (Coord.). Estudos de direito público: em homenagem a Celso Antônio Bandeira de Mello. São Paulo: Malheiros, 2006, p. 233-307. 
HOBBES, Thomas. Leviatã: ou matéria, forma e poder de uma república eclesiástica e civil. Organizado por Richard Tuck. São Paulo: Martins Fontes, 2003.

HUNGRIA, Nelson; FRAGOSO, Heleno Cláudio. Comentários ao Código Penal. v. I, t. II. Rio de Janeiro: Forense, 1983.

JELLINEK, G. Teoría general del Estado. 2. ed. Trad. Fernando de los Ríos Urruti. Mexico: Compania Editorial Continental, 1958.

JIMÉNEZ, Luis Arroyo. Introducción a la autorregulación. In: JIMÉNEZ, Luis Arroyo; MARTÍN, Adán Nieto (Org.). Autorregulación y sanciones. Valladolid: Lex Nova, 2008, p. 19-35.

JUSTEN FILHO, Marçal. Agências reguladoras e democracia: existe um déficit democrático na “regulação independente”? In: ARAGÃO, Alexandre Santos de (Coord.). O poder normativo das agências reguladoras. Rio de Janeiro: Forense, 2006, p. 301-332.

. Comentários à lei de licitações e contratos administrativos. 15. ed. São Paulo: Dialética, 2012.

. Comentários ao RDC. São Paulo: Dialética, 2013.

. Conceito de interesse público e a "personalização” do direito administrativo. Revista Trimestral de Direito Público. São Paulo: Malheiros, n. 26, p. 115-136, 1999.

. Curso de direito administrativo. 9. ed. São Paulo: Revista dos Tribunais, 2013.

. O direito das agências reguladoras independentes. São Paulo: Dialética, 2002.

. O regime jurídico das empresas estatais e a distinção entre "serviço público" e “atividade econômica”. Revista de Direito do Estado. Rio de Janeiro: Renovar, a. 1, n. 1, p. 119-135, jan./mar. 2006.

. O regime jurídico dos operadores de terminais portuários no direito brasileiro. Revista de Direito Público da Economia - RDPE. Belo Horizonte: Fórum, a. 4, n. 16, p. 77-124, out./dez. 2006.

. Sujeição passiva tributária. Belém: CEJUP, 1986.

. Teoria geral das concessões de serviço público. São Paulo: Dialética, 2003.

KLEIN, Aline Lícia. Mandado de segurança contra omissão e contra ato de gestão. Informativo Justen, Pereira, Oliveira e Talamini, Curitiba, no 30, ago. 2009. Disponível em http://www.justen.com.br/informativo. Acesso em: 23.02.2014.

KONKEL JUNIOR, Nicolau. Contribuições sociais: doutrina e jurisprudência. São Paulo: Quartier Latin, 2005.

KRELL, Andreas Joachim. As competências administrativas do artigo 23 da CF, sua regulamentação por lei complementar e o "poder-dever” de polícia. Interesse Público - IP. 
Belo Horizonte, n. 20, ano 5, jul./ago. 2003. Disponível em: $<$ http://www.bidforum.com.br/bid/PDI0006.aspx? pdiCntd=50805>. Acesso em: 31 ago. 2013.

LAFERRIÈRE, Julien ; WALINE, Marcel. Traité élémentaire de science et de législation financières. Paris: Librairie generale de droit et de jurisprudence, 1952.

LAUBADÈRE, André de. Direito público económico. Trad. Maria Teresa Costa. Coimbra: Almedina, 1985.

LAUBADERE, André de; VENEZIA, Jean-Claude; GAUDEMET, Yves. Traité de droit administratif. 15. Ed., t. 1. Paris: Librairie generale de droit et de jurisprudence, 1999.

LEMAIRE, Elina. Actualité du principe de prohibition de la privatisation de la police. Revue Française de Droit Administratif - RFDA. Paris: Dalloz, n. 4, p. 767-776, jul./ago. 2009.

LIBERATI, Eugenio Bruti. Consenso e funzione nei contratti do diritto pubblico: tra amministrazioni e privati. Milano: Dott. A. Giuffrè, 1996.

LLORENS, François. La définition actuelle de la concession de service public en droit interne. In: BRÉCHON-MOULÈNES, Christine et. al. La concession de service public face au droit communautaire. Paris: Sirey, 1992, p. 15-58.

LORA, Alejandro Huergo. Los contratos sobre los actos y las potestades administrativas. Madrid: Civitas, 1998.

MAC CRORIE, Benedita Ferreira da Silva. A vinculação dos particulares aos direitos fundamentais. Coimbra: Almedina, 2005.

MAGANO, Octavio Bueno. Do poder diretivo na empresa. São Paulo: Saraiva, 1982.

MARINS, Vinicius. Contratação de serviços de segurança privada pela Administração Pública: uma análise à luz da moderna privatização de poderes administrativos. Revista do Tribunal de Contas do Estado de Minas Gerais. Belo Horizonte, v. 74, n. 1, jan./mar. 2010. MARQUES NETO, Floriano de Azevedo. A concessão como instituto do direito administrativo. São Paulo, 2013. 628 f. Tese (Concurso para provimento de cargo de Professor Titular) - Faculdade de Direito, Universidade de São Paulo.

. A contratação de empresas para suporte da função reguladora e a "indelegabilidade do poder de polícia”. Revista Trimestral de Direito Público. São Paulo: Malheiros, n. 32, p. 65-82, 2000.

A contratação de particulares para suporte de atividade regulatória estatal. Revista trimestral de direito público. São Paulo: Malheiros, n. 25, p. 163-180, 1999. 
Aspectos jurídicos enredados na implantação do programa de inspeção veicular. Revista de Informação Legislativa. Brasília: Senado Federal, a. 38 n. 151, p. 183-189, jul./set. 2001.

Discricionariedade e regulação setorial - o caso do controle dos atos de concentração por regulador setorial. In: ARAGÃO, Alexandre Santos de (Coord.). O poder normativo das agências reguladoras. Rio de Janeiro: Forense, 2006, p. 569-604.

Poderes da Administração Pública. In: FIGUEIREDO, Marcelo (Coord.). Novos rumos para o direito público: reflexões em homenagem à Professora Lúcia Valle Figueiredo. Belo Horizonte: Fórum, 2012, p. 221-236.

. Regulação econômica e suas modulações. Revista de Direito Público da Economia. Belo Horizonte: Fórum, a. 7, n. 28, p. 27-42, out./dez. 2009.

. Regulação estatal e interesses públicos. São Paulo: Malheiros, 2002.

MARQUES NETO, Floriano de Azevedo; CYMBALISTA, Tatiana Matiello. Os acordos substitutivos do procedimento sancionatório e da sanção. Revista Brasileira de Direito Público - RBDP. Belo Horizonte: Fórum, a. 8, n. 31, p. 51-68, out./dez. 2010.

MARTÍN, Carlos Coello; BOTIJA, Fernando González. Sobre el carácter declarativo del reconocimiento de una denominación de origen: el reglamento de la denominación Rueda: comentário a la STS de 3 de octubre de 2006 (Sala de lo Contencioso-Administrativo, Sección 4. Recurso núm. 6828/2003). Revista de Administración Pública. Madrid: Centro de Estudios Políticos y Constitucionales, n. 176, p. 247-271, maio/ago. 2008.

MARTINS, Sérgio Pinto. A terceirização e o direito do trabalho. 3. ed. São Paulo: Malheiros, 1997.

. Direito do trabalho. 26. ed. São Paulo: Atlas, 2010.

MATTOS, Rodrigo Gerent. Responsabilidade civil dos notários e registradores públicos. Fórum Administrativo - FA. Belo Horizonte: Fórum, a. 10, n. 115, p. 6474, set. 2010.

MATTOS FILHO, Ary Oswaldo. Natureza jurídica das atividades das bolsas de valores. Revista de Administração de Empresas. v. 6, p. 5-16, 1986.

MAURER, Hartmut. Direito administrativo geral. Trad. Luís Afonso Heck da 14. ed. alemã. Barueri: Manole, 2006.

MAYER, Otto. Derecho administrativo alemán. 2. ed., t. II - parte especial. Trad. Horacio H. Heredia e Ernesto Krotoschin. Buenos Aires: Depalma, 1982.

MEDAUAR, Odete. Convênios e consórcios administrativos. Revista Jurídica da Procuradoria Geral do Município de São Paulo. São Paulo: CEJUR - Centro de Estudos Jurídicos, 1995. 
Direito administrativo moderno. 12. ed. São Paulo: Revista dos Tribunais, 2008.

O direito administrativo em evolução. 2. ed. São Paulo: Revista dos Tribunais, 2003.

MEIRELLES, Hely Lopes. Direito administrativo brasileiro. 38. ed. atualizada por Délcio Balestero Aleixo e José Emmanuel Burle Filho. São Paulo: Malheiros, 2012.

Direito de construir. 10. ed. atual. por Adilson Abreu Dallari, Daniela Libório Di Sarno, Luiz Guilherme da Costa Wagner Jr. e Mariana Novis. São Paulo: Malheiros, 2011.

MELLO, Rafael Munhoz de. Princípios constitucionais de direito administrativo sancionador: as sanções administrativas à luz da Constituição Federal de 1988. São Paulo: Malheiros, 2007.

MENDES, Gilmar Ferreira. Direitos fundamentais e controle de constitucionalidade: estudos de direito constitucional. 3. ed., 3. tir. São Paulo: Saraiva, 2007.

MENDONÇA, José Vicente Santos de. Estatais com poder de polícia: por que não? Revista de Direito Administrativo. Rio de Janeiro: Fundação Getúlio Vargas, v. 252, p. 97-118, set./dez. 2009.

MENDONÇA, Rafael Aliprandi. A indelegabilidade do poder de polícia às sociedades de economia mista. Fórum Administrativo - FA. Belo Horizonte: a. 11, n. 119, jan. 2011.

MENEZES DE ALMEIDA, Fernando Dias. Contrato administrativo. São Paulo: Quartier Latin, 2012.

MIGUEL, Luiz Felipe Hadlich. Limites à delegação do poder de polícia. In: MEDAUAR, Odete; SCHIRATO, Vitor Rhein (Coord.). Poder de polícia na atualidade. Belo Horizonte: Fórum, 2014, p. 189-204.

MINET, Charles-Édouard. Droit de la police administrative. Paris: Vuibert, 2007.

MINHOTO, Laurindo Dias. Privatização de presídios e criminalidade. São Paulo: Max Limonad, 2000.

MIRANDA, Francisco Cavalcanti Pontes de. Tratado de direito privado: parte geral. 4. ed., t. III. São Paulo: Revista dos Tribunais, 1983.

MODERNE, Franck. Decadencia del punto de vista orgánico en la definición del acto administrativo en derecho francés: los actos administrativos de origen privado. Revista Española de Derecho Administrativo. Madrid: Civitas, n. 4, p. 3-15, jan./mar. 1975.

. Sanctions administratives et justice constitutionnelle: contribution à l'étude du jus puniendi de l’État dans les démocraties contemporaines. Paris: Economica, 1993.

MONCADA, Luís S. Cabral de. As relações especiais de poder no direito português. In: Estudos de direito público. Coimbra: Coimbra, 2001. 
MONIZ, Ana Raquel Gonçalves. A delegação administrativa do poder regulamentar em entidades privadas: algumas questões. Boletim da Faculdade de Direito da Universidade de Coimbra. Coimbra: Coimbra, v. LXXXVI, p. 209-257, 2010.

MONTEIRO, Vera. Concessão. São Paulo: Malheiros, 2010.

MOREIRA, Egon Bockmann. Direito das concessões de serviço público: inteligência da Lei 8.987/1995 (parte geral). São Paulo: Malheiros, 2010.

. Os limites à competência normativa das agências reguladoras. In: ARAGÃO, Alexandre Santos de (Coord.). O poder normativo das agências reguladoras. Rio de Janeiro: Forense, 2006, p. 173-220.

MOREIRA, Vital. Administração autónoma e associações públicas. Reimp. Coimbra: Coimbra, 2003.

. Auto-regulação profissional e Administração Pública. Coimbra: Almedina, 1997.

MOREIRA, Vital; LIMA, Luís Vale. Autorregulação profissional oficial: o caso dos corretores de seguros no Brasil. Revista de Direito Público da Economia - RDPE. Belo Horizonte: Fórum, a. 10, n. 39, jul./set. 2012. Disponível em: $<$ http://www.bidforum.com.br/bid/PDI0006.aspx?pdiCntd=81158>. Acesso em: 30 jun. 2013.

MOREIRA NETO, Diogo de Figueiredo. Curso de direito administrativo. 15. ed. Rio de Janeiro: Forense, 2009.

. Mutações do direito administrativo. 2. ed. Rio de Janeiro: Renovar, 2001.

MOTTA, Carlos Pinto Coelho. Delimitação conceitual e finalidade do instituto do credenciamento. Revista da Procuradoria Geral do Município de Belo Horizonte RPGMBH. Belo Horizonte, a. 1, n. 1, p. 15-25, jan./jun. 2008.

- Terceirização e funcionalização: conflito ou complementariedade. Boletim de Direito Administrativo. São Paulo: NDJ, n. 9, p. 799-807, dez. 1997.

NASCIMENTO, A. Theodoro. Preços, taxas e parafiscalidade. In: BALEEIRO, Aliomar. Tratado de direito tributário brasileiro. v. VII. Rio de Janeiro: Forense, 1977.

NÉGRIN, Jean-Paul. L'intervention des personnes morales de droit prive dans l'action administrative. Paris: Librairie generale de droit et de jurisprudence, 1971.

NICOUD, Florence. La participation des personnes privées à la sécurité publique: actualité et perspectives. Revue du Droit Public et de la Science Politique en France et a l'étranger. Paris: Librairie generale de droit et de jurisprudence, n. 5, t. 122, p. 1247-1273, 2006.

NOHARA, Irene Patrícia. Direito administrativo. 3. ed. São Paulo: Atlas, 2013. 
NOVAIS, Jorge Reis. A intervenção do provedor de Justiça nas relações entre privados. Disponível em www.fd.unl.pt/docentes_docs/ma/JRN_MA_6178.doc. Acesso em 15.8.2013.

OLIVEIRA, Edmundo. O futuro alternativo das prisões. Rio de Janeiro: Forense, 2002. OLIVEIRA, Farlei Martins Riccio de; CAMPOS, Alexandra Cerqueira. Poder de polícia: anotações à margem de Agustín Gordillo. In: OLIVEIRA, Farlei Martins Riccio de (Coord.). Direito administrativo Brasil - Argentina. Belo Horizonte: Del Rey, 2007, p. 151-194.

OLIVEIRA, Regis Fernandes de. Infrações e sanções administrativas. 3. ed. São Paulo: Revista dos Tribunais, 2012.

ORTEGA, Ricardo Rivero. Administraciones públicas y derecho privado. Madrid: Marcial Pons, 1998.

ORTIZ, Gaspar Ariño. El ámbito privado del sector público. In: XXIV Jornadas de Estudio: el ámbito privado del sector público - 11, 12 y 13 de diciembre de 2002. Madrid: Ministerio de Justicia, 2002, p. 577-603.

OSMO, Carla. Os conselhos profissionais integram a estrutura orgânica do Estado? Revista de Direito Público da Economia - RDPE. Belo Horizonte: Fórum, a. 6, n. 21, p. 45-66, jan./mar. 2008.

OSÓRIO, Fábio Medina. Direito administrativo sancionador. 4. ed. São Paulo: Revista dos Tribunais, 2011.

. O conceito de sanção administrativa no direito brasileiro. In: MOREIRA NETO, Diogo de Figueiredo (Coord.). Uma avaliação das tendências contemporâneas do direito administrativo. Rio de Janeiro: Renovar, 2003, p. 315-359.

OTERO, Diego Vigil de Quiñones. Autorregulación y publicidade registral. Madrid: Fundación Registral, 2010.

OTERO, Paulo. Legalidade e Administração Pública: o sentido da vinculação administrativa à juridicidade. Coimbra: Almedina, 2003.

. Vinculação e liberdade de conformação jurídica do setor empresarial do Estado. Coimbra: Coimbra, 1998.

PALMA, Juliana Bonacorsi de. Atuação administrativa consensual: estudos dos acordos substitutivos no processo administrativo sancionador. São Paulo, 2010, 332 f. Dissertação Pós-Graduação da Faculdade de Direito da Universidade de São Paulo.

PALU, Oswaldo Palu. Controle dos atos de governo pela jurisdição. São Paulo: Revista dos Tribunais, 2004. 
PÂQUES, Michel. Police administrative et sanction administrative. In: ANDERSEN, Robert et. al. (Coord.). Les sanctions administratives. Bruxelas: Bruylant, 2007, p. 680-701. PARDO, José Esteve. Autorregulación: génesis y efectos. Navarra: Editorial Aranzadi, 2002.

PASTOR, Bartoméu Colom I. El certificado como acto y documento público. Revista Española de Derecho Administrativo. Madrid: Civitas, n. 41-41, p. 233-238, 1984.

PELLEGRINI, Alexandre Rezende. Algumas linhas sobre a atividade notarial. Revista de Direito Imobiliário. São Paulo: Revista dos Tribunais, v. 54, p. 155, jan. 2003.

PEREIRA, Cesar A. Guimarães. Usuários de serviços públicos: usuários, consumidores e os aspectos econômicos dos serviços públicos. 2. ed. São Paulo: Saraiva, 2008.

PEREIRA, Flávio Henrique Unes. Regulação, fiscalização e sanção: fundamentos e requisitos da delegação do exercício do poder de polícia administrativa a particulares. Belo Horizonte: Fórum, 2013.

PEREIRA, Ricardo Teixeira do Valle. Histórico dos conselhos de fiscalização do exercício profissional. In: FREITAS, Vladimir Passos de (Coord.). Conselhos de fiscalização profissional: doutrina e jurisprudência. 2. ed. São Paulo: Revista dos Tribunais, 2008, p. $17-25$.

PEREZ, Marcos Augusto. Delegação das atividades chamadas de polícia administrativa ou poder de polícia. Fórum Administrativo - Direito Público - FA. Belo Horizonte: Fórum, a. 10, n. 111, p. 39-45, maio 2010.

O risco no contrato de concessão de serviço público. Belo Horizonte: Fórum, 2006.

PICARD, Etienne. La notion de police administrative. t. I e II. Paris: Librairie generale de droit et de jurisprudence, 1984.

PIMENTA OLIVEIRA, José Roberto. Parcerias público-privadas: indelegabilidade no exercício da atividade administrativa de polícia e na atividade administrativa penitenciária. In: SUNDFELD, Carlos Ari (Coord.). Parcerias público-privadas. 2. tir. São Paulo: Malheiros, 2007, p. 406-432.

PRATA, Ana. A tutela constitucional da autonomia privada. Coimbra: Almedina, 1982. PROVENZA, Vittorio Constantino. Parecer. Revista de Direito da Procuradoria Geral do Estado do Rio de Janeiro - RDPGE. v. 50, 1997, p. 359-382.

QUADROS, Fausto de. O princípio da subsidiariedade no direito comunitário após o Tratado da União Europeia. Coimbra: Almedina, 1995.

QUEIROZ, Cristina M. M. Os actos políticos no Estado de Direito: o problema do controle jurídico do poder. Coimbra: Almedina, 1990. 
RAMOS, Dora Maria de Oliveira. A terceirização em matéria de poder de polícia: o caso das vistorias veiculares. In: MARQUES NETO, Floriano de Azevedo [et. al.] (Org.). Direito e Administração Pública: estudos em homenagem a Maria Sylvia Zanella Di Pietro. São Paulo: Atlas, 2013, p. 567-581. . Terceirização na Administração Pública. São Paulo: LTr, 2001.

RANELLETTI, Oreste. La polizia di sicurezza. In: Primo trattato completo di diritto amministrativo (a cura di V. E. Orlando). v. IV, parte 1. Milano: Società Editrice Libraria, 1904.

REALE, Miguel. Lições preliminares de direito. 11. ed. São Paulo: Saraiva, 1984.

Revogação e anulamento do ato administrativo. 2. ed. Rio de Janeiro: Forense, 1980

RETORTILLO, Sebastían Martín. La doctrina del ordenamiento jurídico de Santi Romano y algunas de sus aplicaciones en el campo del derecho administrativo. Revista de Administración Pública. Madrid: Centro de Estudios Políticos y Constitucionales, n. 39, p. 39-78, set./dez. 1962.

RICHER, Laurent. Délégation de service public: le critère du risque financier. AJDA p. 2454, 2008. Disponível em: http://www.dalloz.fr/documentation. Acesso em: 20.9.2013.

Droit des contrats administratifs. 3. ed. Paris: Librairie generale de droit et de jurisprudence, 2002.

RIVERO, Jean. Direito administrativo. Trad. Rogério Ehrhardt Soares. Coimbra: Almedina, 1981.

. Droit administratif. Paris: Dalloz, 1960.

RODRIGUEZ, Tomas-Ramon Fernandez. Derecho administrativo, sindicatos y autoadministración. 2. ed. Madrid: IEAL, 1972.

ROLLAND, Louis. La collaboration des agentes des syndicats à la repression des fraudes. Revue du Droit Public et de la Science Politique en France et à l'Étranger. Paris: Librairie generale de droit et de jurisprudence, n. 29, p. 480-504, 1912.

ROMANO, Santi. Frammenti di un dizionario giuridico. Milano: Dott. A. Giuffrè, 1947. . O ordenamento jurídico. Trad. Arno Dal Ri Júnior. Florianópolis: Fundação Boiteaux, 2008.

SAINZ MORENO, Fernando. Ejercicio privado de funciones públicas. Revista de Administración Pública. Madrid: Centro de Estudios Políticos y Constitucionales, n. 100102, v. III, p. 1699-1783, 1983. 
SANDULLI, Aldo. Manuale di diritto amministrativo. 15. ed., v. I. Napoli: Dott. Eugenio Jovene, 1989.

SANTAMARÍA PASTOR, Juan Alfonso. Principios de derecho administrativo. v. I. Madrid: Editorial Centro de Estudios Ramón Areces, 1998.

SARMENTO, Daniel. A vinculação dos particulares aos direitos fundamentais: o debate teórico e a jurisprudência do STF. In: SARMENTO, Daniel; SARLET, Ingo Wolfgang (Coord.). Direitos fundamentais no Supremo Tribunal Federal: balanço e crítica. Rio de Janeiro: Lumen Juris, 2011.

Direitos fundamentais e relações privadas. 2. ed. Rio de Janeiro: Lumen Juris, 2006

(Coord.). Interesses públicos versus interesses privados: desconstruindo o princípio de supremacia do interesse público. Rio de Janeiro: Lumen Juris, 2007.

SCHMIDT-ASSMANN, Eberhard. La teoría general del derecho administrativo como sistema. Madrid: INAP e Marcial Pons, 2003.

SCHIRATO, Vítor Rhein. Novas anotações sobre as empresas estatais. Revista de Direito Administrativo. Rio de Janeiro: Renovar, v. 239, p. 209-240, jan./mar. 2005.

SCHIRATO, Vitor Rhein; PALMA, Juliana Bonacorsi de. Consenso e legalidade: vinculação da atividade administrativa consensual ao direito. Revista Eletrônica sobre a Reforma do Estado (RERE). Salvador: Instituto Brasileiro de Direito Público, n. 24, dez./jan./fev. 2011. Disponível na $\quad$ Internet: http://www.direitodoestado.com/revista/RERE-24-DEZEMBRO-JANEIRO-FEVEREIRO2011-VITOR-JULIANA.pdf>. Acesso em: 31 de janeiro de 2014.

SCHWIND, Rafael Wallbach. Particulares em colaboração com o exercício do poder de polícia: o "procedimento de polícia”. In: MEDAUAR, Odete; SCHIRATO, Vitor Rhein (Coord.). Poder de polícia na atualidade. Belo Horizonte: Fórum, 2014, p. 131-156.

SEABRA FAGUNDES, Miguel. O controle dos atos administrativos pelo Poder Judiciário. 8. ed. atual. Gustavo Binenbojm. Rio de Janeiro: Forense, 2010.

SÉRVULO CORREIA, José Manuel. Legalidade e autonomia contratual nos contratos administrativos. Reimp. Coimbra: Almedina, 2003.

SHAPLAND, Joanna e VAN OUTRIVE, Lode. Police et securité: contrôle social et interaction public/privé. Paris: L’Harmattan, 1999.

SILVA, José Afonso da. Poder de polícia. Revista de Direito Administrativo. Rio de Janeiro: FGV, n. 132, p. 241-255, abr./jun. 1978. 
SILVA, Vasco Pereira da. Em busca do acto administrativo perdido. Coimbra: Almedina, 1996.

SILVA, Virgílio Afonso da. A constitucionalização do direito: os direitos fundamentais nas relações entre particulares. 3. tir. São Paulo: Malheiros, 2011.

SOLDINI, David. La délégation de service public, sa fonction, ses critères. RFDA p. 1114, 2010. Disponível em http://www.dalloz.fr/documentation. Acesso em 20.9.2013.

SOUTO, Marcos Juruena Villela. Desestatização: privatização, concessões, terceirizações e regulação. 4. ed. Rio de Janeiro: Lumen Juris, 2001.

. Direito administrativo regulatório. Rio de Janeiro: Lumen Juris, 2002.

SOUZA, António Francisco de. “Conceitos indeterminados” no direito administrativo. Coimbra: Almedina, 1994.

SOUZA, Rodrigo Pagani de. Empresas estatais constituídas para o exercício de poder de polícia. In: MEDAUAR, Odete; SCHIRATO, Vitor Rhein (Coord.). Poder de polícia na atualidade. Belo Horizonte: Fórum, 2014, p. 157-187.

STEINMETZ, Wilson. A vinculação dos particulares a direitos fundamentais. São Paulo: Malheiros, 2004.

SUNDFELD, Carlos Ari. Direito administrativo ordenador. 2. tir. São Paulo: Malheiros, 1997.

. Empresa estatal pode exercer o poder de polícia. Boletim de Direito Administrativo. São Paulo: NDJ, v. 2, p. 98-103, fev. 1993.

. Guia jurídico das parcerias público-privadas. In: SUNDFELD, Carlos Ari (Coord.). Parcerias público-privadas. 1. ed., 2. tir. São Paulo: Malheiros, 2007, p. 15-44.

SUNDFELD, Carlos Ari; CÂMARA, Jacintho Arruda. Acordos substitutivos nas sanções regulatórias. Revista de Direito Público da Economia - RDPE. Belo Horizonte: Fórum, a. 9, n. 34, p. 133-151, abr./jun. 2011.

. Conselhos de fiscalização profissional: entidades públicas não-estatais. Revista de Direito do Estado. Rio de Janeiro: Renovar, a. 1, n. 4, p. 321-333, out./dez. 2006.

TÁCITO, Caio. Evolução histórica do direito administrativo. In: Temas de direito público: estudos e pareceres. v. 1. Rio de Janeiro: Renovar, 1997.

. O poder de polícia e seus limites. Revista de direito administrativo. Rio de Janeiro: FGV, vol. 27, p. 1-11, jan./mar. 1952.

TORRES, Silvia Faber. O princípio da subsidiariedade no direito público contemporâneo. Rio de Janeiro: Renovar, 2001. 
UBILLOS, Juan María Bilbao. La eficacia frente a terceros de los derechos fundamentales en el ordenamiento español. In: MONTEIRO, António Pinto [et. al.] (Org.). Direitos fundamentais e direito privado: uma perspectiva de direito comparado. Coimbra: Almedina, 2007, p. 165-212.

VEDEL, Georges; DELVOLVÉ, Pierre. Droit administratif. 9. ed. Paris: Presses Universitaires de France, 1984.

VENEZIA, Jean-Claude. Puissance publique, puissance privée. In: WALINE, Marcel (Org.). Récueil d'études en hommage à Charles Eisenmann. Paris: Cujas, 1975, p. 363-378. VERA, José Bermejo. La administración inspectora. Revista de Administración Pública. Madrid: Centro de Estudios Políticos y Constitucionales, n. 147, p. 39-58, set./dez. 1998.

- Privatización y el nuevo ejercicio de función pública por particulares. In: MOREIRA NETO, Diogo de Figueiredo (Coord.). Uma avaliação das tendências contemporâneas do direito administrativo: obra em homenagem a Eduardo García de Enterría. Rio de Janeiro: Renovar, 2003, p. 403-426.

VERNALHA GUIMARÃES, Fernando. As parcerias público-privadas e a transferência de atividades de suporte ao poder de polícia - em especial, a questão dos contratos de gestão privada de serviços em estabelecimentos prisionais. In: SUNDFELD, Carlos Ari (Coord.). Parcerias público-privadas. 2. tir. São Paulo: Malheiros, 2007, p. 368-405.

Atividades estatais indelegáveis. Revista de Direito Público da Economia-RDPE. Belo Horizonte: Fórum, a. 11, n. 42, abr./jun. 2013. Disponível em: $<$ http://www.bidforum.com.br/bid/PDI0006.aspx?pdiCntd=95966>. Acesso em: 16 jul. 2013.

. Parceria público-privada. 2. ed. São Paulo: Saraiva, 2013.

VILLEY, Michel. O direito e os direitos humanos. Trad. Maria Ermantina de Almeida Prado Galvão. São Paulo: Martins Fontes, 2007.

VIRGA, Pietro. La potestà di polizia. Milano: Giuffrè, 1954.

VITTA, Heraldo Garcia. Poder de polícia. São Paulo: Malheiros, 2010. . Soberania do Estado e poder de polícia. São Paulo: Malheiros, 2011.

VIVES, Marc Tarrés. Normas técnicas y ordenamiento jurídico. Valencia: Tirant lo blanch, 2003.

WALD, Arnoldo; EIZIRIK, Nélson. O regime jurídico das bolsas de valores e sua autonomia frente ao Estado. Revista de Direito Mercantil, Industrial, Econômico e Financeiro. São Paulo: Revista dos Tribunais, a. 25, n. 61, p. 5-21, jan./mar. 1986. 
WALD, Arnoldo; MORAES, Luiza Rangel de; WALD, Alexandre. O direito de parceria e a lei de concessões: análise das leis n. 8.987/95 e n. 9.074/95 e legislação subsequente. São Paulo: Saraiva, 2004.

WEBER, Max. Economia e sociedade. 3. ed., v. 1. Trad. Regis Barbosa e Karen Elsabe Barbosa. Brasília: Universidade de Brasília, 1994.

WEFFORT, Francisco C. (Org.). Os clássicos da política. 14. ed., v. 1. São Paulo: Ática, 2006.

WEIL, Prosper. Derecho administrativo. Reimpr. Madrid: Civitas, 1994.

WERNECK, Bruno Dário. A auto-regulação da atividade econômica no Brasil. In: DI PIETRO, Maria Sylvia Zanella (Org.). Direito regulatório: temas polêmicos. Belo Horizonte: Fórum, 2003, p. 625-641.

ZAGO, Marina Fontão. O dogma da indelegabilidade do poder de polícia defrontado com casos do Código de Trânsito Brasileiro. Fórum Administrativo - FA. Belo Horizonte: Fórum, a. 10, n. 111, p. 46-58, maio 2010.

ZANCANER, Weida. O perfil jurídico do credenciamento. In: MARQUES NETO, Floriano de Azevedo [et. al.] (Org.). Direito e Administração Pública: estudos em homenagem a Maria Sylvia Zanella Di Pietro. São Paulo: Atlas, 2013, p. 787-794.

ZANOBINI, Guido. Corso di diritto amministrativo. 3. ed., v. III, reimp., v. V. Milano: Dott. A. Giuffrè, 1946 e 1952.

L'amministrazione pubblica del diritto privato. In: Scritti vari di Diritto Pubblico. Milano: Giuffrè, 1955, p. 19 e ss.

. L'esercizio privato delle funzioni e dei servizi pubblici. In: Primo trattato completo di diritto amministrativo (a cura di V. E. Orlando). v. II, parte 3. Milano: Società Editrice Libraria, 1935, p. 235-682.

ZIGORRAGA, Iñaki Agirreazkuenaga. La coacción administrativa directa en el ámbito de la inspección de consumo: límites en el acceso a locales a inspecionar. Revista Española de Derecho Administrativo. Madrid: Civitas, n. 69, p. 43-64, 1991. 